Historic, archived document

Do not assume content reflects current scientific knowledge, policies, or practices. 


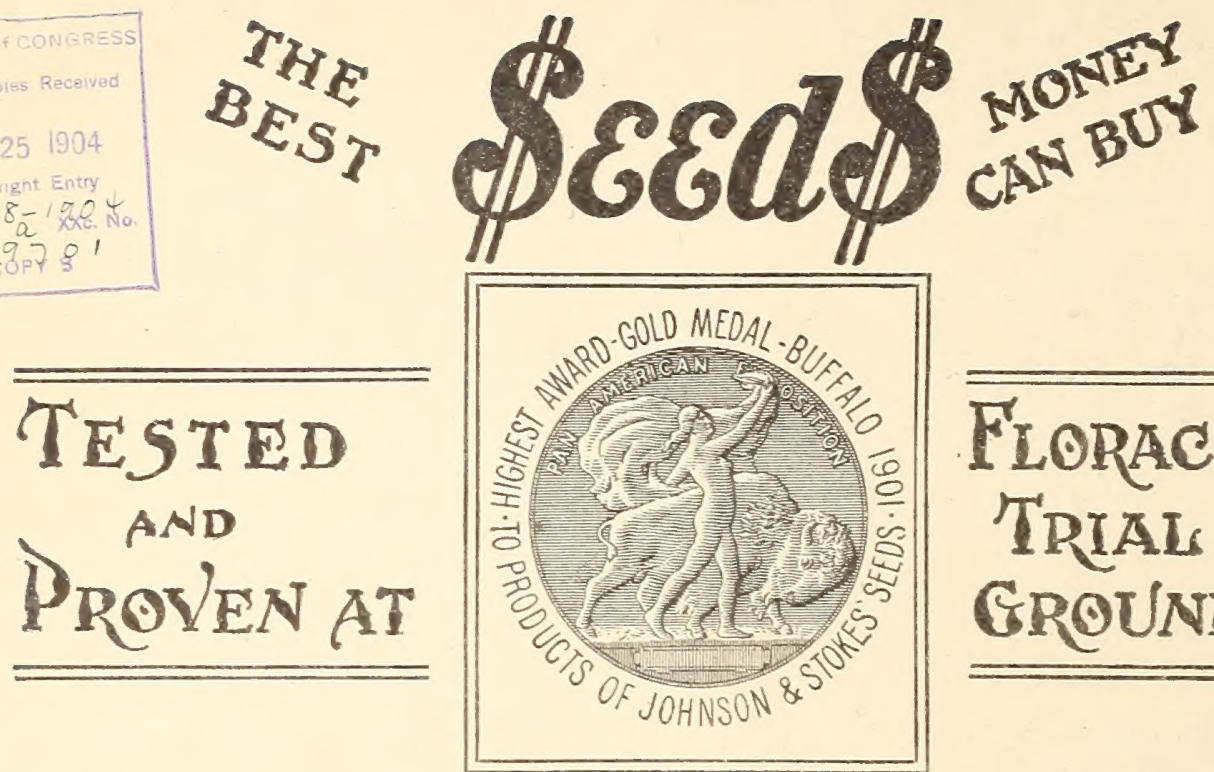

$\overline{\text { FIORACREFT }}$

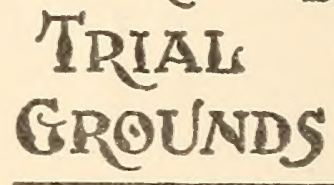

\section{A MODEST CATALOGUE WITH HONEST DESCRIPTIONS AND ILLUSTRATIONS}

We were the first seedsmen in this country to trust entirely to photographic reproduction in illus. trating our catalogues. This has given our MANUAL a deserved reputation for, truthfulness and accuracy. It is for this reason that some things that are much lauded in other catalogues are omitted. Some do not appear as large or extravagant as shown in the overdrawn cuts of other lists. Our pictures have won for us the attention of thousands of seed buyers, and we have held their confidence by meeting the promises of our catalogue, both as to illustrations and descriptions of the various vegetables and flowers which are made during the growing season at FLORACROFT or on our various SEED FARMS where the crops are grown. It is for this reason that our MANUAL is so frequently used by other seedsmen as a reference-book and is frequently found at the agricultural colleges, being used as an auxiliary text-book.

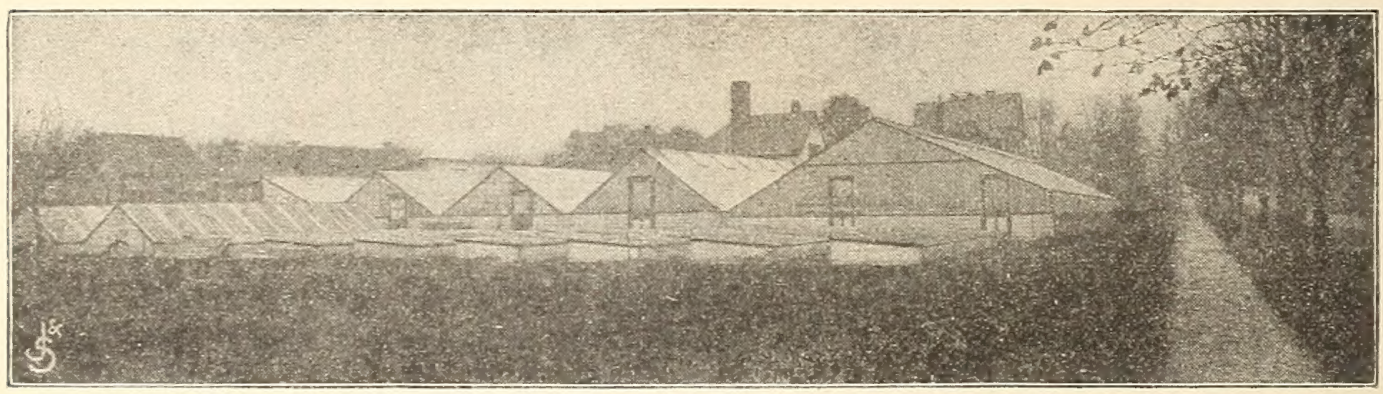

A partial plew at FLORAOROFT SEED GARDExs and Trin Grovwd, showing our seed-testing houses, where all seedi are proven and tested for vitality before being sold. The two large houses on the right were erected the past season.

\section{FLORACROFTSEDE GARENS AND TRIAL GROUNDS Insure to Qux. Customers Tested Seeds of Known Vitality and Purity}

For more than 20 y.rsto thing possible to safeguard his interests, and for this reason conduct every year, at great expense, extensive trials at our Floracroft Seed Gardens and Trial Grounds, located about nine miles from our city warehouses. The cash expended at Floracroft buys knowledge, and the benefit goes to our customers.

Besides making extensive open field trials at FLORACROFT, we also develop there a considerable amount of high-grade pedigree stock seed. Although these grounds are under the direct personal supervision of one of our firm, we have there also experienced and intelligent men who understand the improvement and development of ideal types and high standards. From Floracroft we eend improved seed stocks to our various farms in other States, wherever the conditions of soil and climate are best adapted to their perfect development, for multiplication as to bulk and quantity.

We ask a careful reading of the following pages and solicit the orders of all JOHNSON \& STOKES, 217 and 219 Market Street, 


\section{How to Order Johnson \& Stokes' Seeds}

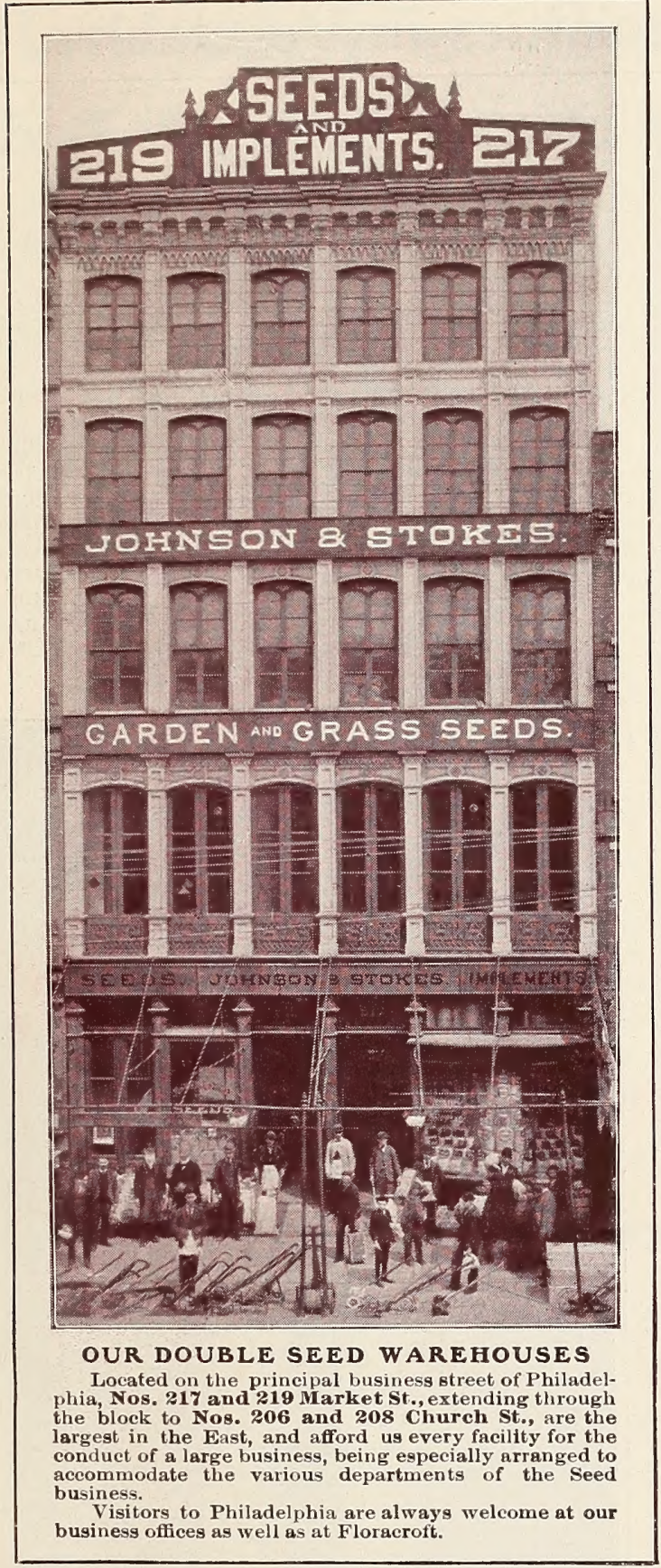

When possible, use order sheet opposite page 12 , which can be easily detached from book at perforated line.

Cash should always accompany the order. We will be responsible for money sent by Post-Office Order, Express Money Order, Bank Draft, Express or by Registered Letter.

Post-Office Orders cost, for any amount up to $\$ 2.50,3$ cents; over $\$ 2.50$ and not exceeding $\$ 5,5$ cents; over $\$ 5$ to $\$ 10,8$ cents; over $\$ 10$ to $\$ 20,10$ cents; over $\$ 20$ to $\$ 30,12$ cents; over $\$ 30$ to $\$ 40,15$ cents; over $\$ 40$ to $\$ 50,18$ cents; over $\$ 50$ to $\$ 60,20$ cents.

Express Money Orders are issued by express companies at their agencies, and cost, for amounts not over $\$ 5,5$ cents; $\$ 10,8$ cents; $\$ 20,10$ cents; $\$ 30,12$ cents; $\$ 40,15$ cents.

Bills, Coin or Stamps (we accept postage stamps the same as cash) can be sent safely by registered letter. Every postmaster is required to register any letter on payment of 8 cents extra postage.

Cost of remitting may, on all orders over $\$ 1.00$, be deducted from the amount sent.

\section{SEEDS BY MAIL}

In ordering Vegetable and Grass Seeds to be sent by mail, 10 cents per pound, 15 cents per quart, or at this rate for the fraction, should be added to cover postage, except where otherwise specified. We will, however, send packets and ounces at catalogue rates free of postage.

\section{Johnson}

\section{\& Stokes}

\section{Garden and Flower Seeds}

are grown exclusively for the most critical market garden and private trade, and are known in every large market of the United States as producers of vegetables and flowers which are the accepted standards of excellence.

WE HAVE NO BRANCH STORES

Look for Our Name and Number Before Entering

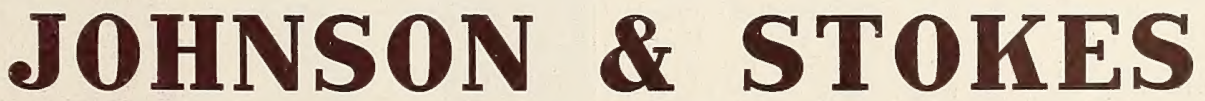

217 and 219 MARKET STREET, Between second and Third streets

For a Complete Index of this Catalogue See Page 124 


\section{JOHNSON \& STOKES' Novelties and Specialties in Vegetables}

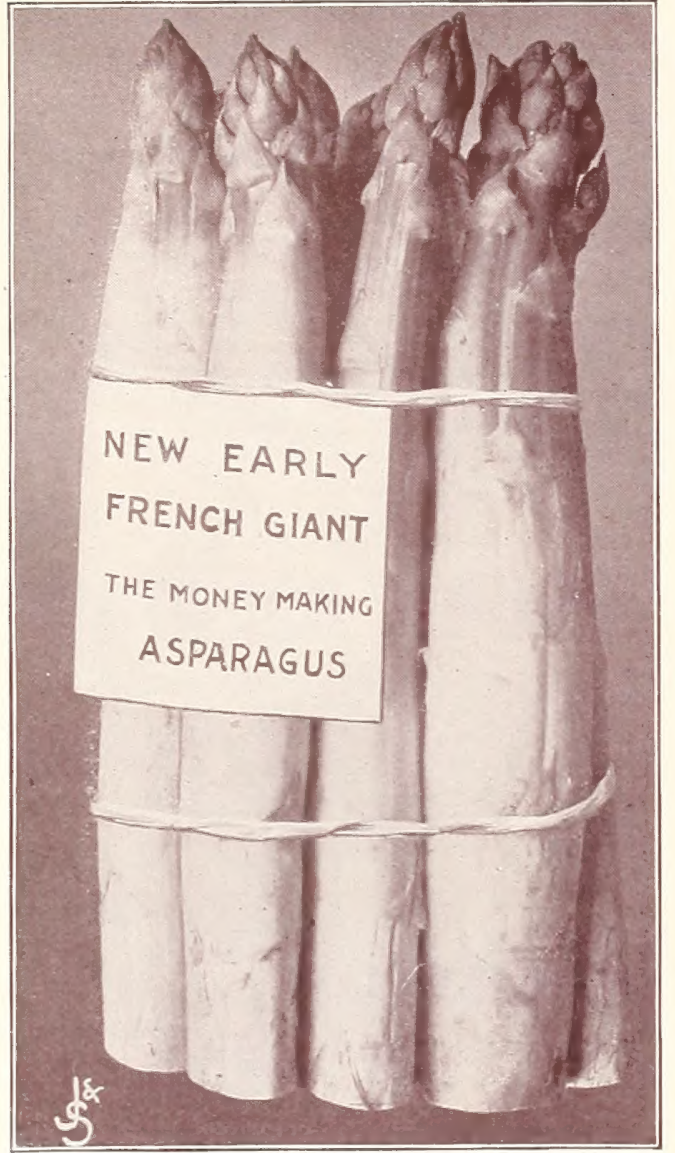

\section{New Asparagus Early French Giant}

THE EARLIEST - LARGE AND PROLIFIC

This new sort, the seed and roots of which we offered for sale for the first time last Spring, is a great improvement on the popular Palmetto or French Argenteuil asparagus, which was first brought to this country by Mr. John Nix, the largest asparagus grower of South Carolina. The roots were imported from Mr. Louis Lérault de Argenteuil, of France, and have proven this new asparagus to be not only 10 days earlier than Palmetto, but of larger size and superior in flavor and color. In New York market, the past two seasons, it sold for $\$ 5.00$ per dozen, while other varieties only brought $\$ 1.50$ to $\$ 2.00$ per dozen. It is by far the most promising asparagus, as a money maker, that can be grown. Our seed and roots are from the original importation that has attracted so much attention and sold so high in New York. Prices of seed: Pkt., 5c.; oz., 15c.; 卉 lb., 35c.; lb., \$1.25. Good, strong 1 year old roots, 50 for $75 \mathrm{c}$.; 100 for $\$ 1.25$, by mail, postage paid; by express or freight, $\$ 1.00$ per $100 ; \$ 7.00$ per 1,000 . Two year old roots, $\$ 1.25$ per 100 ; (by mail, postpaid, 50 roots for $85 \mathrm{c}$.; 100 for $\$ 1.50) ; \$ 7.50$ per 1,000 by freight or express (500 roots at 1,000 rate).

\section{New Round Pod Kidney Wax}

The Best Wax Bean yet Introduced

Since our introduction of this valuable bean in 1901, it has rapidly grown in popularity with market gardeners, who now grow it in preference to all others. It originated with N. B. Keeney \& Sons, the well-known bean experts of New York State, and is the first round-podded Wax Bean we have ever found possessing the excellent market and shipping qualities of the popular Wardwell's Kidney Wax. The plant grows tall, strong and sturdy, with long, round, handsome, stringless pods of large size, very solid and full of meat, crisp, brittle and free from rust; wonderfully early and productive. Seed grown by the originator. Pkt., 10c.; pint, 30c.; qt., 50c., by mail, postage paid. By freight or express, qt., 35c.; peck, \$2.00; bushel, $\$ 7.50$.

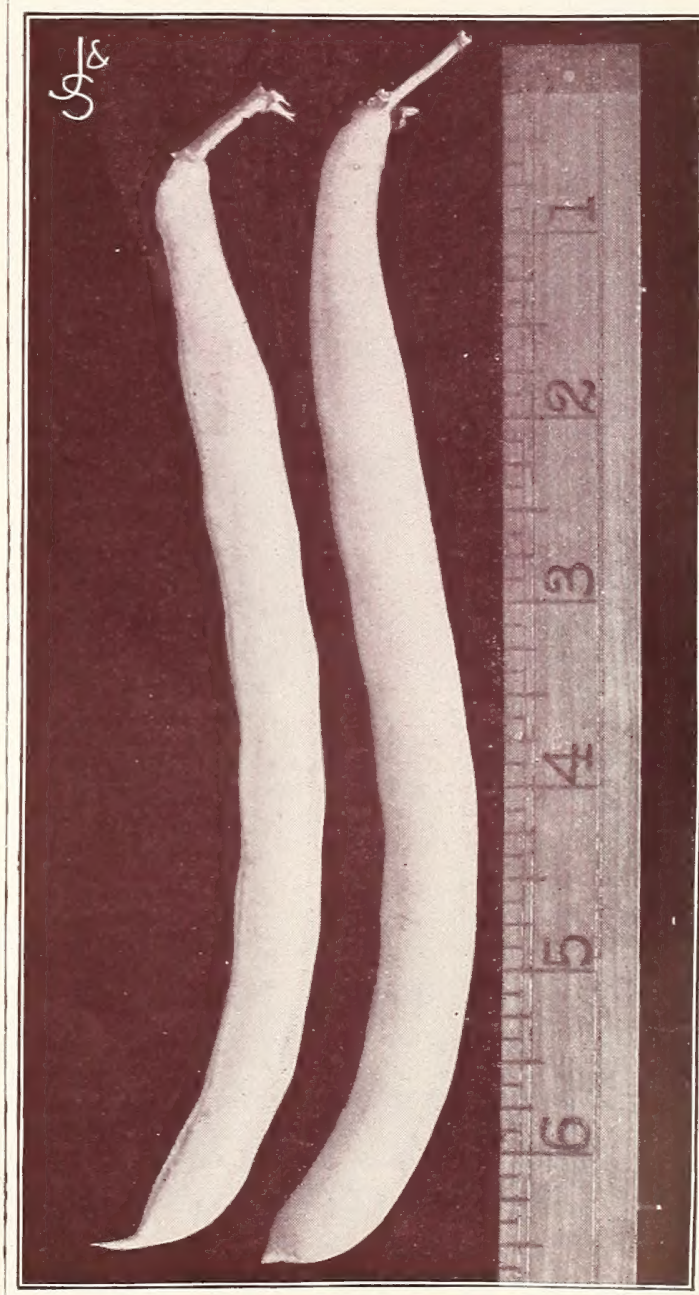

Average pods of New Round Pod Kidney Wax Bean. 


\section{Lannier's Superba Beet}

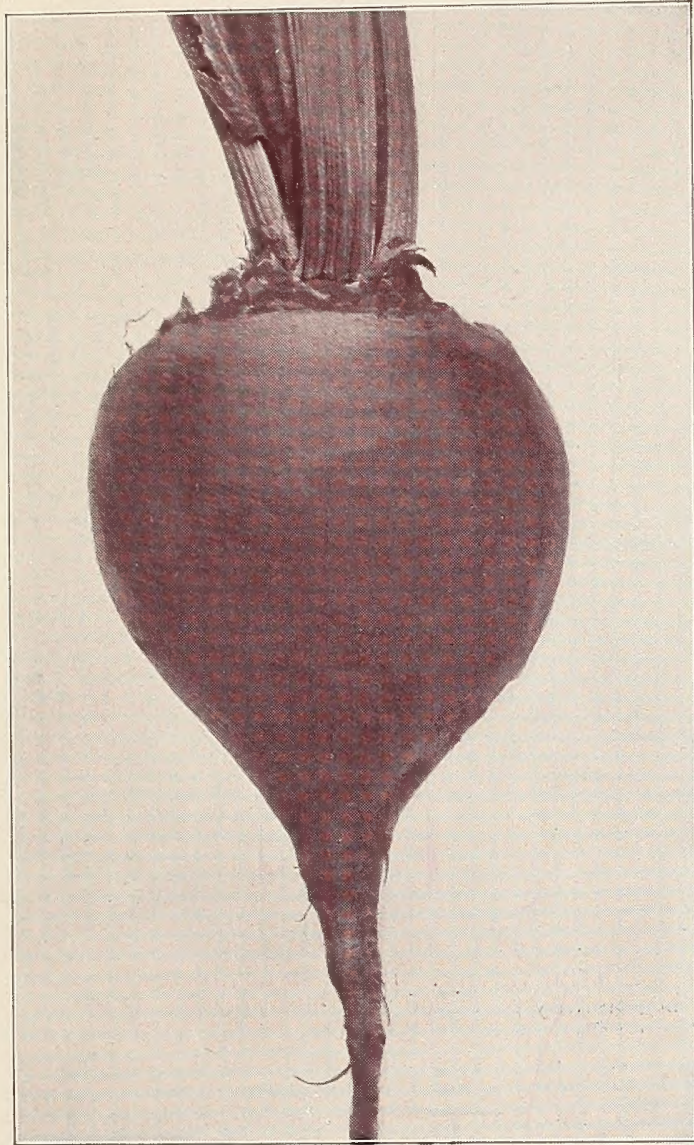

LANNIER'S SUPERBA BEET. See also colored plate on back of

\section{Seed of which is now offered for sale for the first time}

\section{THE MOST PERFECT BEET IN EXISTENCE}

For more than fifty years Mr. Wm. Lannier, one of the oldest and best-known market gardeners near Philadelphia, supplied the early and late markets with the handsomest and most salable beets that could be had, and Lannier's Beets, as they were called, became much sought after by the best commission merchants of New York, Boston, and Philadelphia. During all these years Mr. Lannier selected with a critical eye the most perfect beets from each crop for seed stock to plant for his own use, never allowing himself to purchase seed for planting from any one. This new beet is the result of all these years of such careful and intelligent selection, and in it we believe the acme of perfection has been reached in beet culture.

In sending out sample trial packages last spring, we offered $\$ 100.00$ in cash for the best names suggested for it. These names were referred to a disinterested committee of three, who, after careful consideration of all the names sent in, selected the name of Lannier's Superba as the best, with ten other names as the next best. We immediately sent our checks aggregating $\$ 100$ to the successful competitors, as follows:

First Prize, \$50.00 for Best Name.

Geo. Hichoff, McElhattan, $\mathrm{Pa}$ James Allen, Laurel Springs, N. J.

Next Best 10 Names, \$5.00 each.

Frank Roche, Quincy, California.

Joseph Irving, Salina, Kansas.

Wm. A Smith, Ludlow, Mass.

Wm. H. Torrey, Palouse, Wash.

J. D Staftord, Pineland, Fla

Wa

Tule

Jule Perthuis, Hitchcock, Texas.

C. S. Bassett, Kalamazoo, Mich.

Wilson Turner, Greeley, Colorad.

R. C. Pennington, Willard, Ky.

\section{A Few Extracts from Hundreds of Letters Received}

TWO WEEKS AHEAD OF OTHERS

E. G. SмiтH, Rensselaer, N. Y., July 10, 1903, writes: "Your new beet (Lannier's Superba) is a wonder; it is the earliest and finest I ever had; all other beets planted the same time will not be ready for two weeks yet."

\section{BEAUTIFUL AND DISTINCT IN SHAPE}

CHAS. E. Davis, Cranbury Station, N. J., Aug, 4, 1903 , writes: "Your new beet (Lannier's Superba) is a stronger and quicker grower than any other beet I ever raised. Its beautiful and distinct bell-shape and rich color unequalled.'

\section{AS EARLY AS EGYPTIAN}

R. H. HaRT, Stono, S. C., June 11, 1903, writes: “Your new beet (Lannier's Superba) is just as early as the Extra Early Egyptian, but far surpasses it in size and tender quality, sweetness and beauty of form.'

\section{WILL PLANT NO OTHER}

WM. Perry, Cool Spring, Del July 11, 1903, writes: "For beets next season I shall want only your new one (Lannier's Superba), I am so greatly pleased with it. I shall plant no other for both early and late."

\section{A WEEK EARLIER THAN LENTE}

Jos. Irving, Salina, Kan., Aug. 10, 1903, writes: "I planted your new beet (Lannier's Superba) one week after Lentz and dug them the same time. It is the handsomest and best beet yet introduced."
NE PLUS ULTRA OF BEET FAMULY

LOUIS MEYer, Malvern, Ark., June 13, 1903, writes: "I planted your new beet (Lannier's Superba) the end of March and began using them May 11th. They are the best beet we ever had; rich, sweet and of a splendid dark carmine color. This new variety is surely the ne plus ultra of all."

\section{MOST ATTRACTIVE FOR MARKET}

Chas. G. Addison, Springfield, Md., Aug. 20, 1903, writes: 'In vigorous and rapid growth, beauty of shape and color, attractive appearance on the market stall, as well as delicious flavor and tenderness, your new beets (Lannier's Superba) surpass all others. They were invariably picked out by pursurpass all others. They were invariably picked out by purwhole crop was not of this new variety, but I intend it shall whole crop was not

\section{BEST FROM SIX SEEDSMEN}

Miss MARY E, KIFER, Neri, Md, Aug. 6, 1903, writes: "It is the sweetest and most tender of any beet $I$ ever used. I have had beets from six different seedsmen, and this beautiful new one of yours is the best of them all."

\section{RICHEST RED COLOR}

J. Dumas, Rye Valley, Ore, July 25, 1903, writes: "Your new beet (Lannier's Superba) is the very best of early market beets. It is very handsome, having the richest red color, both inside and out, of any ever seen here."

PRICES FOR 1904: Per pkt., Ioc.; oz., 20c.; 1/4 lb., 6oc.; lb., \$2.00 


\section{Johnson \& Stokes' Quick=Cash Cabbage} The Earliest and Hardiest Flat-Headed Cabbage

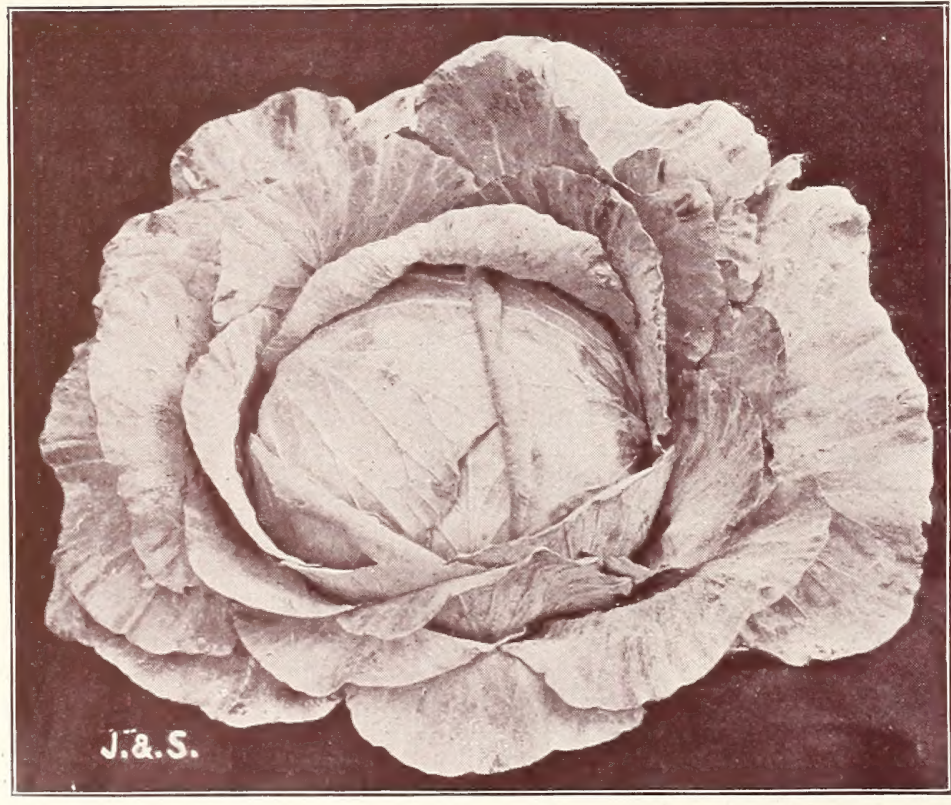

We distributed last Spring several thousand packages of this wonderful new cabbage among our customers for trial, offering $\$ 100$ in cash for the best names suggested for it. Of the numerous names sent in, the committee decided on the name of “Johnson \& Stokes' Quick= Cash" as the most appropriate, and which had been sent in by the first two persons named below, to each of whom we sent our check for first prize of $\$ 50.00$, also check for $\$ 5.00$ each to the ten last-named persons who had sent in what the committee considered the next best ten names.

The Prize Winners :

\section{J. C. Sutton, Blacks, Md., 1st.}

J.W. HuMPHREYS, Guyencourt, Del., 1st. GEO. S. WORCESTER, Thetford, Vt J. W. Ralston, Cedar Hill, N. M. THEO, BOSAN, Edgewater, Col MRS. H. J. BAIRD, Terre Haute, Ind. FRED. SORENSEN, Nephi City, Utah. B. F. PEEPI.ES, Whaley, S. C, C. B. HERRICK, Twinsbury, Ohio W. A. BELL, Hampton, Va WM. W. Foust, Barnegat, N. J.

JOHNSON \& STOKEG' OUICK-CASH CABBAGE, (See also colored plate on back of book.)

Johnson \& Stokes' Quick=Cash Cabbage is a cross between our Johnson \& Stokes' Earliest and Early Spring, made and successfully bred for us by one of the largest cabbage growers of Long Island. It is fully as early as the celebrated Johnson \& Stokes' Earliest. Some growers who tested it the past season claim it is even earlier than that wonderful variety. It has an advantage, however, in being a round or flat-headed cabbage, which type is generally preferred to pointed heads. It grows to good size for so early a variety. The stem is short, leaves finely veined, heads very solid, with few outer leaves. It has the peculiarity of heading firmly at a very early stage of growth, so that cabbage of the finest edible and market quality can be obtained long before it has reached its mature size. These advantages, together with its large yield per acre, make it the most profitable and desirable early cabbage that can be grown for either the market or home garden. Prices for 1904: Per pkt., 15c.; oz., 60c.; t lb., $\$ 2.00 ; 1 b ., \$ 6.50$.

\section{WHAT CABBAGE GROWERS SAY OF JOHNSON \& STOKES' QUICK-CASH}

\section{EARLIEST OF ALI}

W. H. ERARD, Comstock, Mich., July 13, 1903, writes : "Every plant of your new cabbage (J. \& S, Quick-Cash) made a good-sized solid head, as hard as a rock, quality most excellent and earliest of all."

STANDS FOR WEEKS WITHOUT BURSTING

E. S. SHAFFER, Moline, Ill., August 25, 1903, writes: "Your new cabbage (J. \& S. Quick-Cash) grown side by side with four other extra early kinds, has beat them all in earliness and whiteness of fruit and in solidity of head. After apparently being fully matured it stands for weeks without apparently being fully matured it stands for weeks without longer it stands."

\section{EVERY HEAD A PICTURE OF BEAUTY}

WM. WINcoTT, of Suffolk County Horticultural Association, Babylon, N. Y., July 27, 1903, writes: "I hardly know how to describe your new cabbage (J. \& S. Quick-Cash). It and the very best quality. Every head is a perfect picture of beauty."

\section{THE FINEST EARLY SHIPPER}

Witson TURner, Greeley, Col., July 24, 1903, writes: "Your new cabbage (J. \& S. Quick-Cash) is a perfect wonder in earliness, fine quality and solidity. It will be the finest early shipper."

\section{SELLS AT HIGH PRICES}

John Herrman, Groesback, Ohio, August 5, 1903, writes "From the one packet of your new cabbage sent me ( $J_{\text {. \& S }}$ Quick-Cash) I raised 340 fine heads for market, and sold at high prices. I found it earlier and more solid than any other cabbage I ever raised."

\section{A WEEK EARLIER THAN ANY OTHER}

CHAs. G. Andison, Springfield, Md., July 20, 1903, writes: "I have tested your new cabbage (J. \& S. Quick-Cash) impartially with my favorite early varieties, and found that from the start it took the lead of all others and held it to the end. They are at least a week earlier than any other, and are remarkable for their solidity and sure heading qualities."

\section{LARGE HEADS IN TWO MONTHS}

Wr. W. Foust, Barnegat, N. J., August 14, 1903, writes: "Your new cabbage ( J. \& S. Quick-Cash) was the earliest I ever raised. Small plants set out the middle of April produced large solid heads the 15 th of June. I reserved some of the seeds to sow in Fall to Winter over in cold frames, and I believe I can get cabbage middle of next May.

\section{NOT BOTHERED BY WORMS}

B. Marple, Canonsburg, Pa., August 4, 1903, writes: "Your new cabbage (J.\& S. Quick-Cash) came extra early, very closeand compact, and was not bothered any by worms."

\section{EARLIEST OF SIX EXTRA EARLY SORTS}

R. A. CAlvin, Lawrence, Mich., August 12, 1903, writes ' I planted your New Early Cabbage (J. \& S. Quick-Cash) this season at the same time with six other extra early varieties, and I had yours in the market ahead of all the rest. It was very crisp, and more solid at the core than the others."

\section{THE FIRST TO CUT}

George W. Cook, Cable, Pa., July 17, 1903, writes : “I am decidedly pleased with your new cabbage (J. \& S. Quick Cash). It is the earliest of all the early kinds, being the first I cut this year and by far the handsomest." 


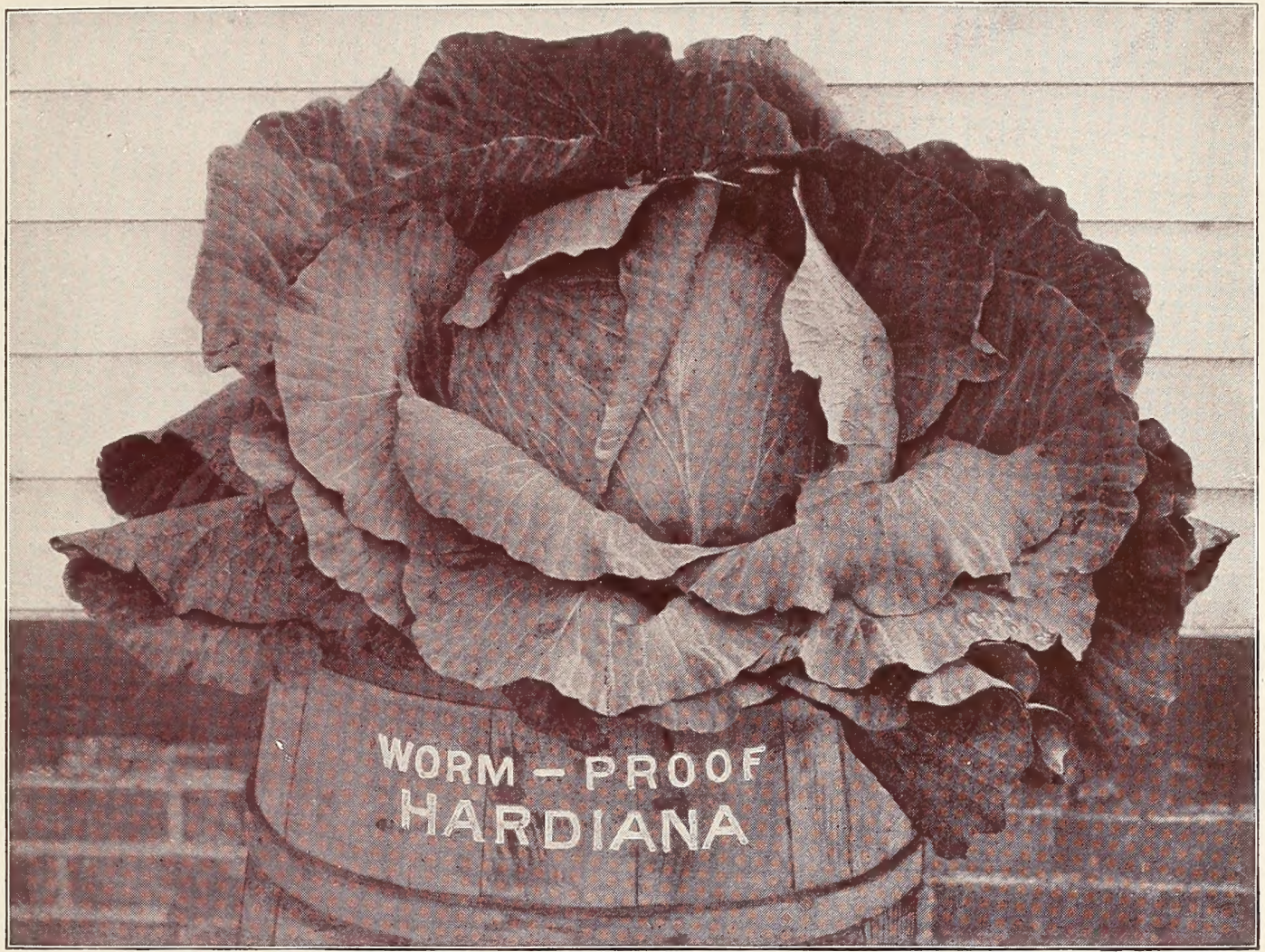

\section{A New Late Cabbage-Worm=proof Hardiana}

Our attention was first attracted to this cabbage in Dock Street Market, Philadelphia, two years ago, on account of its quick sale and handsome appearance, the leaves being entirely free of worm-holes, while all other varieties were more or less eaten by the worms. On close examination we found a slight coating or enameling completely covering the leaves, making it impervious to the worms and without affecting its fine quality. We found the variety was controlled by a few Atlantic County, N. J., growers, who readily sold the seed to their near neighbors at $\$ 3$ to $\$ 5$ per ounce, and it was only after great persuasion and at high cost we were able to get enough to grow our present supply. The heads are very hard and solid, of good size, often showing a slight purplish tinge on top, and as a winter keeper there is nothing superior. Per pkt., 15c.; oz., 70c.; $\frac{1}{4}$ lb., $\$ 2.25 ; 1$ lb., $\$ 8.00$.

\section{A FEW OPINIONS ON NEW WORM= PROOF HARDIANA CABBAGE}

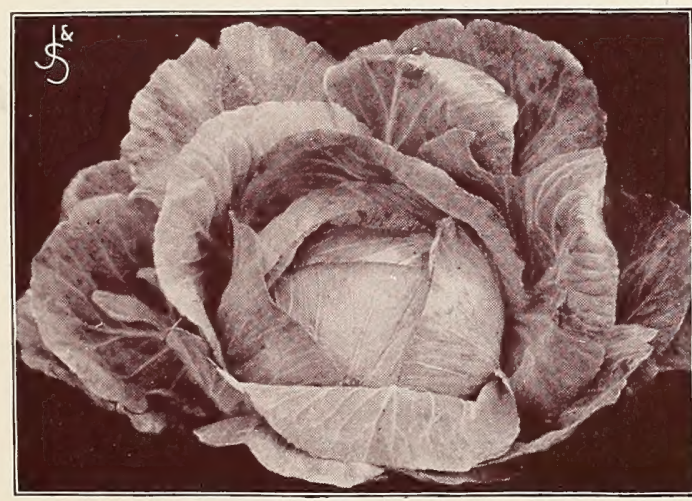

NEW NAMELESS CABBAGE FOR INTRODUOTION IN 1905.
B. F. PEePles, Whaley, S. C., Aug. 15, 1903, writes: "Your new Worm-proof Cabbage, of which you sent me a packet for trial, is most excellent; it stands the heat better than any I have ever grown. Absolutely worm-proof and very Iarge and solid."

F. W. Schatfer, Newburgh, N. Y., Sept. 9, 1903, writes: "Your new Worm-proof Cabbage is all O. K.; not a worm on any of them; beautiful, solid heads of the best quality. I than $\mathrm{k}$ you for sending me the seed for trial."

JaCob S. Knisely, Red Lion, Pa., Sept. 26, 1903, writes: "For the year 19"4 I shall plant nothing but new Worm-proof Cabbage if you have the seed for sale. It is by far the handsomest and most perfect late cabbage I have ever seen."

\section{A New Nameless Cabbage}

Trial Packets Now Free

We have been fortnnate in securing a small quantity of seed from the originator of the beautiful new cabbage shown alongside (not yet named), and which we propose to introduce in 1905 . We shall be glad to add a good-sized trial package free to all orders of $\$ 1.00$ and over, where an interest in our new varieties is indicated. 


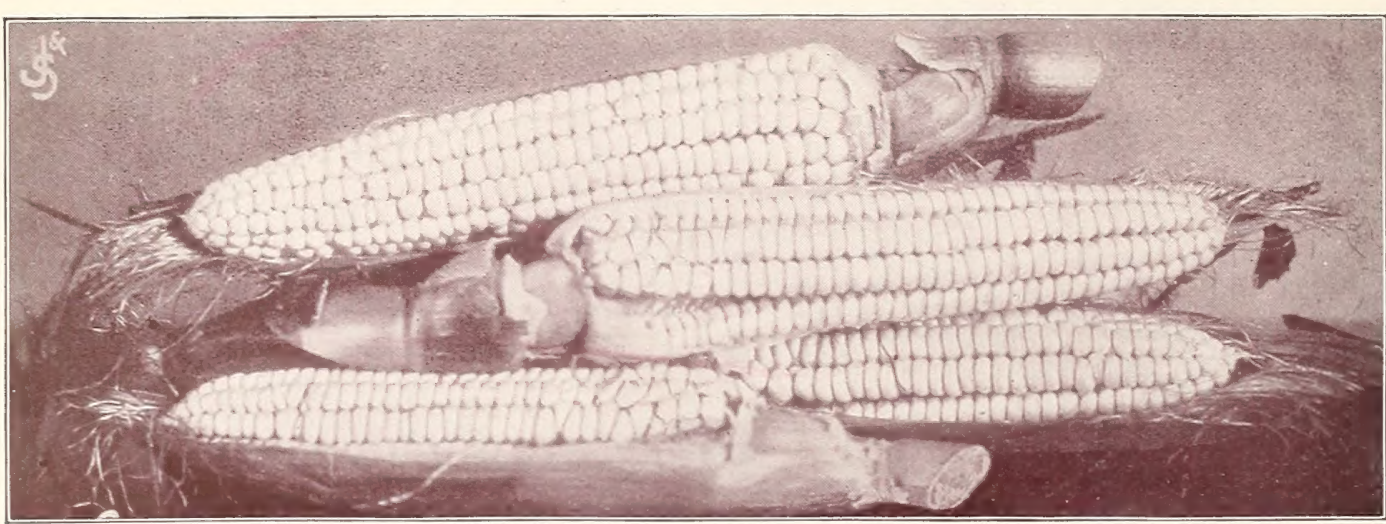

PHOTOGRAPH OF AVERAGE EARS OF HOLMES' PREMO SWEET CORN.

\section{Holmes' Premo 60=Day Sweet Corn}

Mr. C. S. Clark and several other expert corn growers pronounce this new variety from five to even days earlier than any other sweet corn in existence. In our own tests the past season it gave us good boiling ears ahead of all other corn planted, with the single exception of the New Buck Mountain. It combines all the merits of the leading early varieties, and is also really superior to many of them in size, quality and yield. Holmes' Premo can be planted fully as early as the Adams, for the young plants withstand slight frosts, while other varieties are tender and the seed will rot if planted before the soil becomes warm. The stalks grow about five feet high, and are very vigorous, generally bearing two welldeveloped ears to a stalk. Ist., 10c.; pint, 25c.; quart, 40c., postpaid ; by express or freight, qt., 30c.

\section{The Camera is Our Illustrator-What Leading Agricultural Papers Say:}

"The Gardex ard Farm Manual issued by Johnson \& Stokes, Seeds men, of Philadelphia, Pa. is strikingly interesting. It is a decided departure from the ordinary exaggerated seed cat alogue, in that it shows the product of this firm' $\theta$ seeds just as they were seen through the camera. From cover to cover it contains photographic reproductions of vegetable, flower, nursery and farm products that are indisputable evifarm products that are indisputable evialso illustrates the integrity and honesty of this well-known firm, and cannot help but inspire the confidence and patronage of its readers. This method of ehanging doubt into certainty as to reliability and results obtained from their seeds, is a commendable step in seed selling." - American Gardening, New York, February 7, 1903.

'Among the most Interesting Seed Catalogues received is the Garden AND FABM Mand al of Messrs. GahneN AND FABM MANUAL of Messrs. Street, Philadelphia. This catalogue differs from those offered by any other seedsmen in this country, as it is illus trated throughout with handsome photographs taken direct from the vegets- bles and flowers themselves, One of their latest introductions, and which has brought them a very considerable amount of favorable comment, is their 'Sparks' Earliana 'Tomato.' This has proven to be a novelty of very sterling merit, being the finest, large, round, smooth tomato, and coming earlier than any other known sort."-New EngIand Homestead, February, 1903.

\section{Photographing Seed Products.}

Though good seeds are scarce this Spring, we feel assured that any of our readers applying to that old reliable seed house, Johnson \& Stokes, Philadelphia, will be well taken care of. Even if seeds are bought elsewhere, it would be well to write for their GARDEN AND FARM MANUAL, and see what development is regched by different varieties of regetables and fruits from the photoregetables and fruits from the photo rito photored throughout by reproducing photographs of seed products. Whatver is of renl worth is sure to be found with this firm, and by illustration from photograph and accurate description, you kuow exactly before ordering just what its merits are." - Home and Farm, Neiv York and Louisville, Ky.

'JoHNSON \& STOKEs' GARDEN AND Farm ManUaL. This beautiful catalogue is completely illustrated by cute direct from nature. This absence of exaggeration is most refreshing in comparison with some of the wondrous distortions that come to us from other sources,"-Rural New Yorker, New York.

“JOHNSON \& STOKES' GARDEN AND FARM MANUAL is especially interesting for its fine illustrations, which are wholly reproductions from photographs. Such pictures alone must inspire confidence in the integrity of the firm."Farm and Fireside.

'JOHNSON \& 9TOKES' GARDEN AND FARM MANUAL contains only photo engravings of the plants and seeds offered. There can be no deception or exaggeration about these, as they are made directly from photographs." Northwestern Farmer.

We congratulate you on the splendid appearance of your Catalogue The truthful photo-reproductions make known just exactly what you are get ting." - Farm Journal.

\section{We Will Pay $\$ 200.00$ in Cash for Best Photographs}

of products of Johnson \& Stokes' Seeds grown in 1904. \$10.00 each for best 5 photos, \$50.00; $\$ 5.00$ each for best Io photos, $\$ 50.00 ; \$ 2.00$ each for best 50 photos, $\$ 100.00 ;$ total of $\$ \mathbf{2 0 0 . 0 0}$. The awards will be made October $\mathbf{1 , 1 9 0 4}$, by a committee of officers, including the President and Treasurer (who have kindly consented to act) of the Philadelphia Photographic Society.

Photographs can be sent to us any time during the season, and should not be less than 4 inches by 5 inches, with objects as large as possible. Where field crops are taken, photos of single specimens should also be sent, as they are intended for catalogue illustrations. 


\section{Myers' Quick Growing White Plume Celery}

A new strain of White Plume Celery, selected and improved by Myers \& Bowman the well-known Philadelphia market gardeners. It is unquestionably the earliest celery known, being ready for market 10 days to 2 weeks earlier than any other strain. It differs also from the old White Plume in size and habit, somewhat resembling the Paris Golden SelfBlanching, but more stocky and robust, throwing out from 8 to 12 hearts. Leaves are very light in color and entirely fiee from green celery. It has proven to be by far the handsornest, best and most salable early celery that has been offered on Philadelphia markets the past three seasons.

Choice home-grown seed, per pkt., 15c.; oz.; $45 \mathrm{c}$; 京 lb., $\$ 1.25$; lb., $\$ 4.50$.

WHICH IS THE BEST WINTER CELERY?

American Gardening, the leading agricultural paper of New York, in its celery trial ground reports, March 7, 1903, says:

"Winter Queen (Johnson \& Stokes). In the vicinity of New York City the market gardeners have found this variety of green celery to be the one to plant in preference to any other. It is one of the very best for late use ; stands handling and shipping the very best; it was introduced by the firm who annually have sent us the sample of seed for our trials. It is one of the darkest of green celeries; makes an exceedingly strong and robust growth; in fact, the plant, from its very early life, has an appearance of healthfulness; it is of a close and stocky habit, and when blanched is of a cream-white; very solid and of a very good flavor; it does not grow so very tall, but does make an exceedingly large, broad crown, and thus develops a large heart. For profit this is the best variety now grown of the green celeries."

If you want genuine seed of the Winter Queen send to the introducers. Prices for 1904: Pkt., 10c.; oz., 35c.; 交 lb., $\$ 1.00 ;$ lb., $\$ 3.50$.

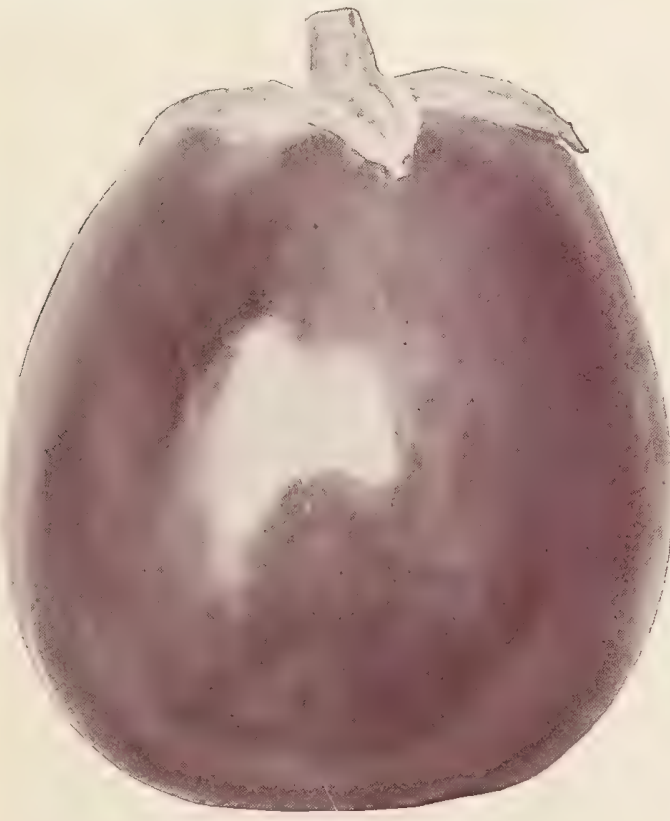

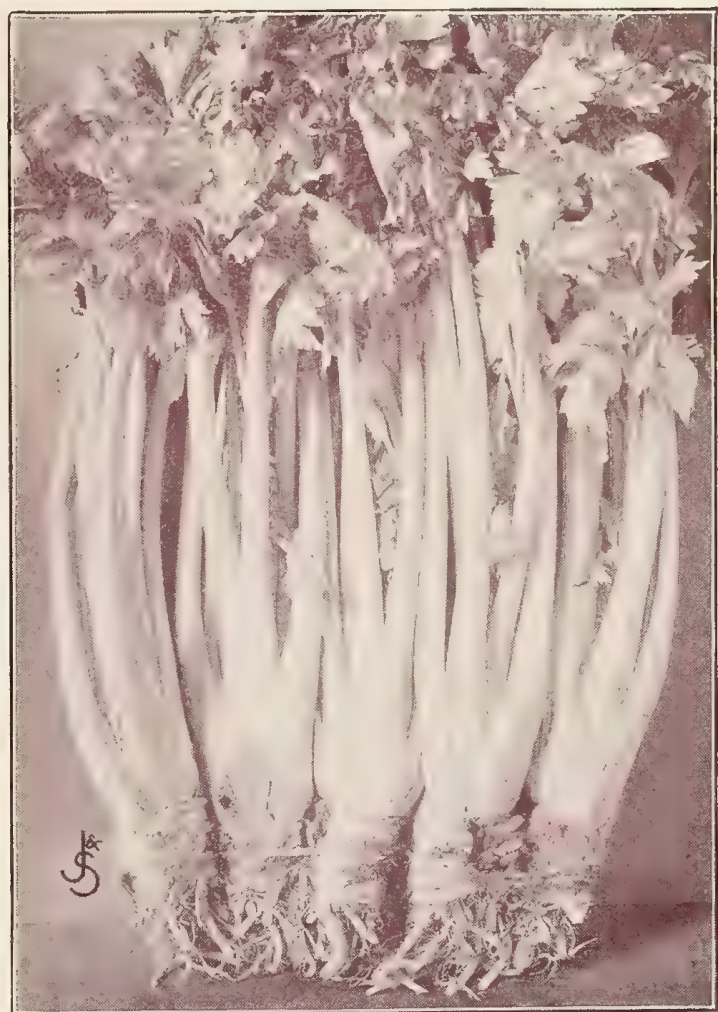

MYER' QUIOK GROWING WHITE PLUME CELERY, as marketed in Philadelphia, September 15th.

\section{New Early Black Beauty Egg Plant}

This new variety was originated by Mr. W. E. Ashcroft, of South Jersey. It is fully ten days earlier than the New York Improved Purple, and fully as large in size. It is remarkably handsome and prolific.

Mr. Howard Russ, of Burlington County, N. J., who is probably the largest egg plant grower in the State, and no better authority could be given, says: "The Early Black Beauty which I obtained first from you proved to be much hardier and thriftier in growth than any other. It is also much better in shape and fuller at the top than the New York Large Purple. It gave me the handsomest patch of egg plants I ever saw. Not a plant with less than 10 and many bore 20 perfect uniform fruits, which never turned gray even after becoming dead ripe."

Seed, per pkt., 15c.; oz., 85c.; $\frac{1}{4}$ lb., $\$ 2.50$. 


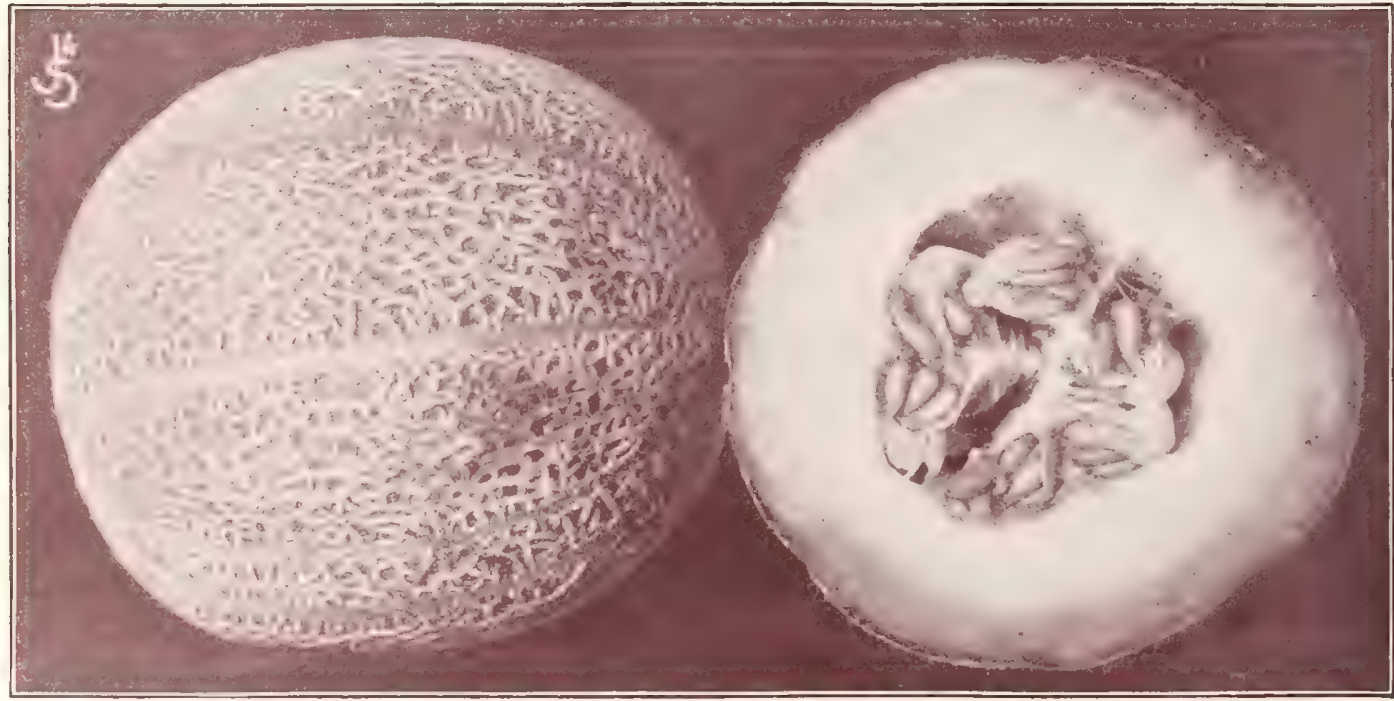

SELECTED ROCKY FORD, THE GREAT OOLORADO SHIPPING MELOY, OELEBRATED FOR ITS REMARKABLY FINE QUALITY.

\section{GENUINE ROCKY FORD MELON \\ JOHNSON \& STOKES' SELECTED STRAIN}

In the past few years Coloralo has developed into a great melon-growing State. It is estimated that over 4,000 acres were planted in 1903, which were shipped, reaching almost every large city in the United States, where they were placed on sale as the choicest fruits in the most fashionable markets, always realizing handsome profits, owing to their fine quality and appearance. They are an improvement on an! differ from the old "Netted Gem" in being a little more oblong in shape and possessing much better shipping and keeping qualities, and are unquestionably one of the best second early green fleshed melons in existence. Owing to the growing popularity of this melon, much spurious seed is being offered at low prices, and wo warn our customers to beware of such. Our selected strain of this celebrated melon is unequalled. In addition to selected seed of our own growing, we also offer thoroughbred seed grown and selected in Colorado, so that our customers can take their choice. Prices of either: Pkt., 5c.; oz., 10c.; ج lb., 30c.; 1b., $\$ 1.00$, postpaid; by expres8, 1b., $90 \mathrm{c}$.; 5 lbs. and over, 80c. per lb.

\section{HALBERT HONEY WATERMELON}

Originated by Mr. H. A. Halbert, of Texas, who claims it to be the best that can be grown for family use and home market. In our trials the past two seasons we have found it fully equal in delicious flavor to the celebrated Kleckley Sweets Watermelon, but better and more uniform in color and shape, being free from any tendency to "neck," The vines also grow stronger and are much more prolific. Notwithstanding its Southern origin, they ripen quite early. Lovers ố fine melons will make no mistake in planting Halbert Honey. Pkt., 10c.; oz., 20c.; $\frac{1}{4} 1 \mathrm{~b}$ 50c.; lb., $\$ 1.50$.

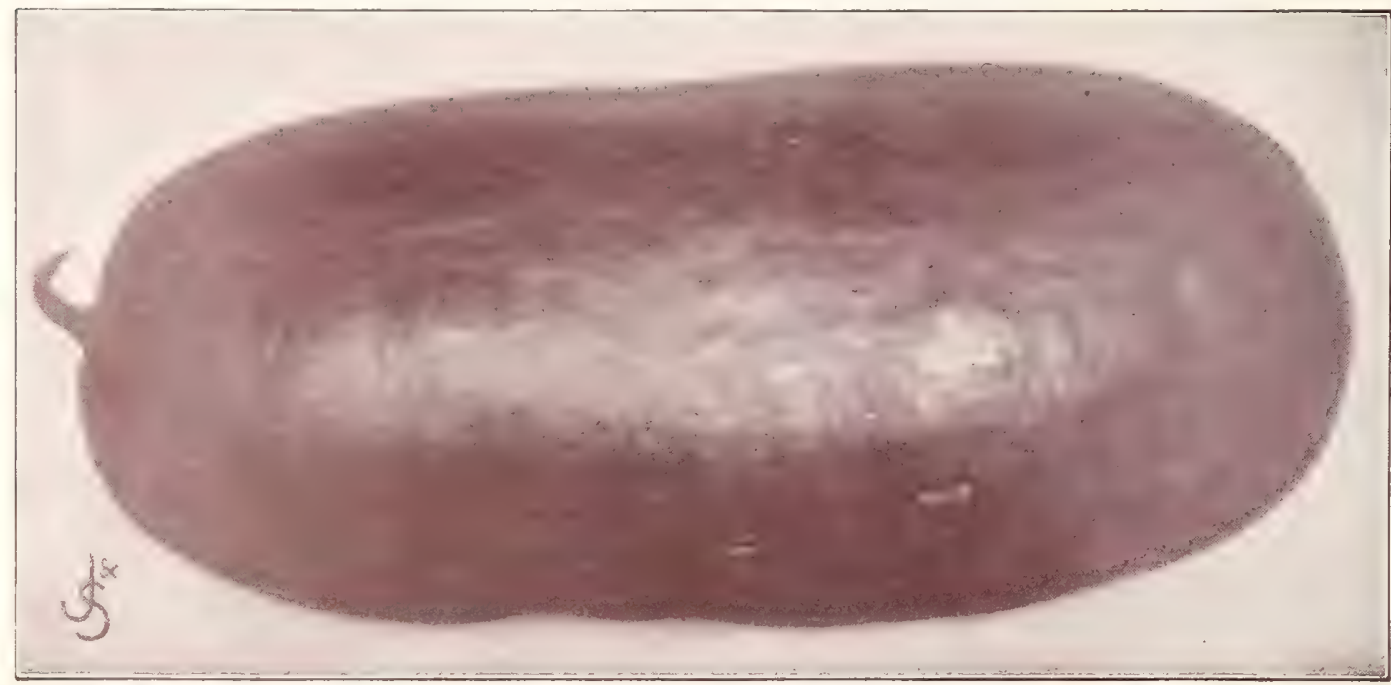

THE NEW HALBERT HONEY WATERYELON, AS SWBET AS KLECKLEY'S, HANDSOMER IN APPEARANCE. 


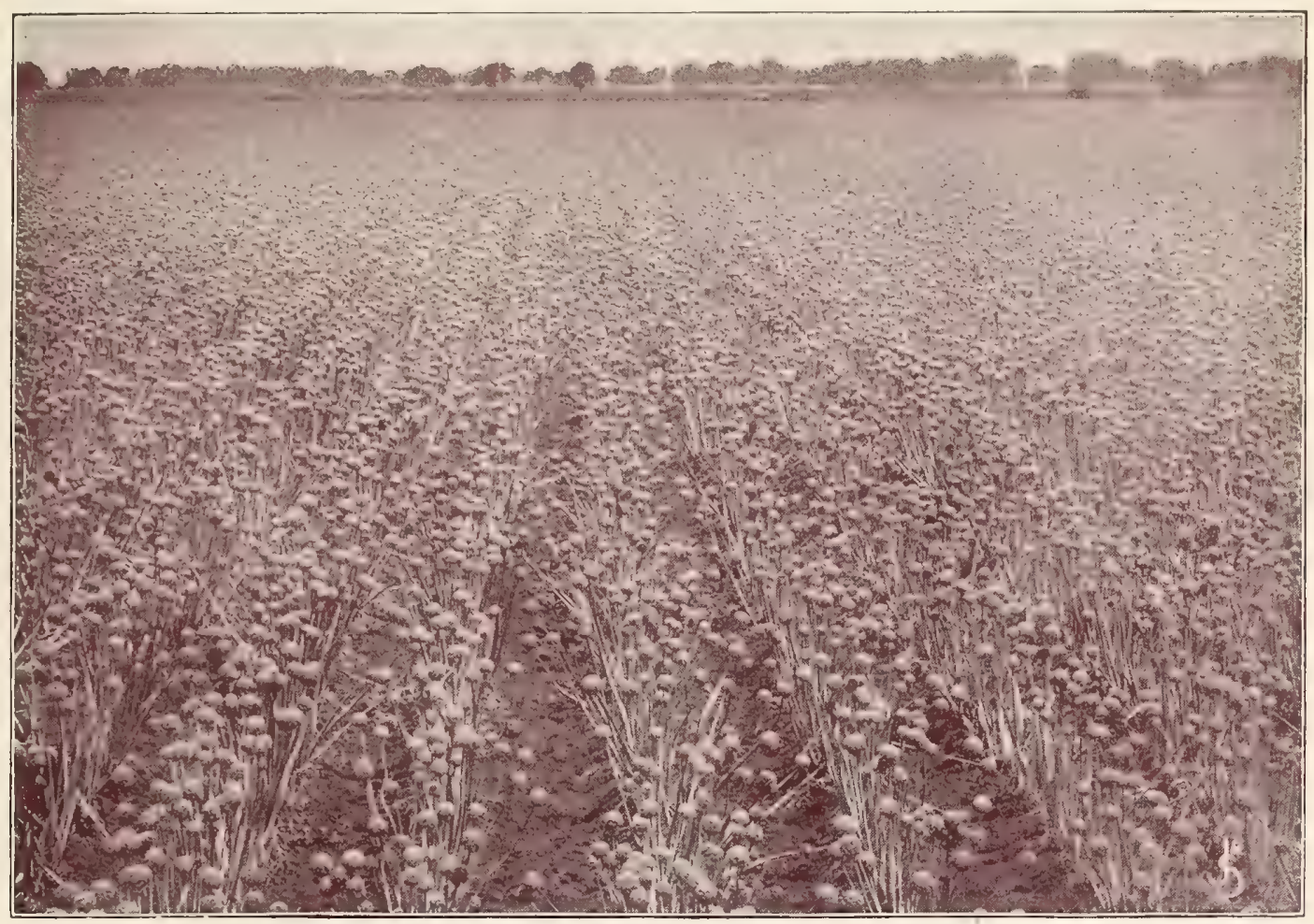

A field of our celebrated Philadelphia Yellow Globe Darvers Onion growing for geed. For illustration and description see page 38. Prices for 1904, new crop pedigree tested seed : Pkt., 5c.; oz., $15 \mathrm{c}$; $\frac{1}{4} 1 \mathrm{~b} ., 35 \mathrm{c}$. ; lb., $\$ 1.25$, postpaid ; by express or freight, lb., $\$ 1.15 ; 5 \mathrm{lbs}$. for $\$ 5.50 ; 10 \mathrm{lbs}$. for $\$ 10.00$; $25 \mathrm{lbs}$. and over, $95 \mathrm{c}$. per $\mathrm{lb}$.

\section{Philadelphia Long-Keeping Yellow Egg Onion}

This is one of the best selling Winter Onions in the retail markets of Philadelphia. It grows to good size, with handsome thin yellow skin. Its fine-grained white flesh is of the most superior quality. It is a large cropper, and as an onion to keep over for Winter and Spring markets or home use there is nothing auperior. Per pkt., 5c.; oz., 15c.; $\frac{1}{4} 1 \mathrm{~b} ., 45 \mathrm{c}, ; 1 \mathrm{~b} ., \$ 1.50$.

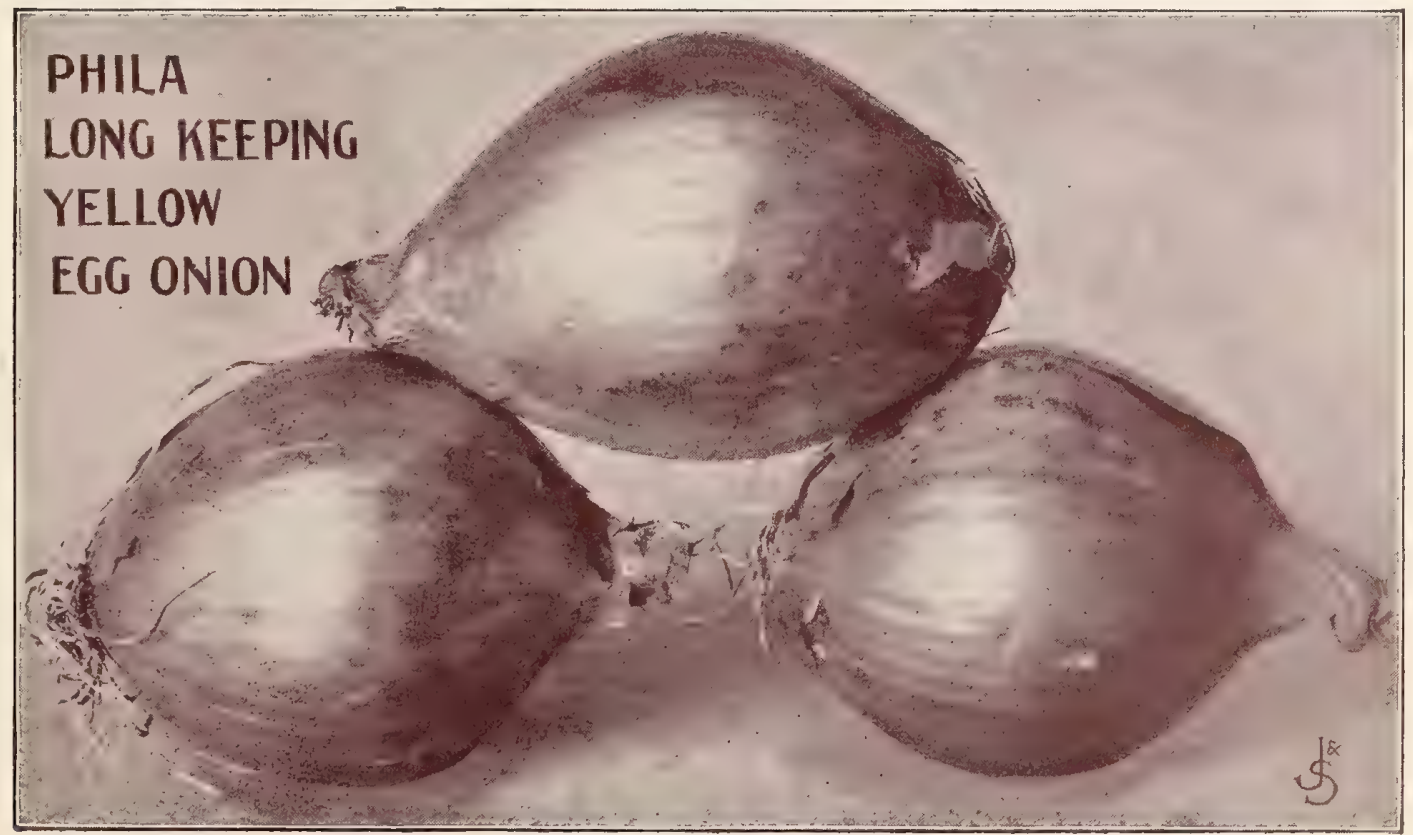




\section{THE LARGEST MILD RED PEPPERS IN CULTIVATION}

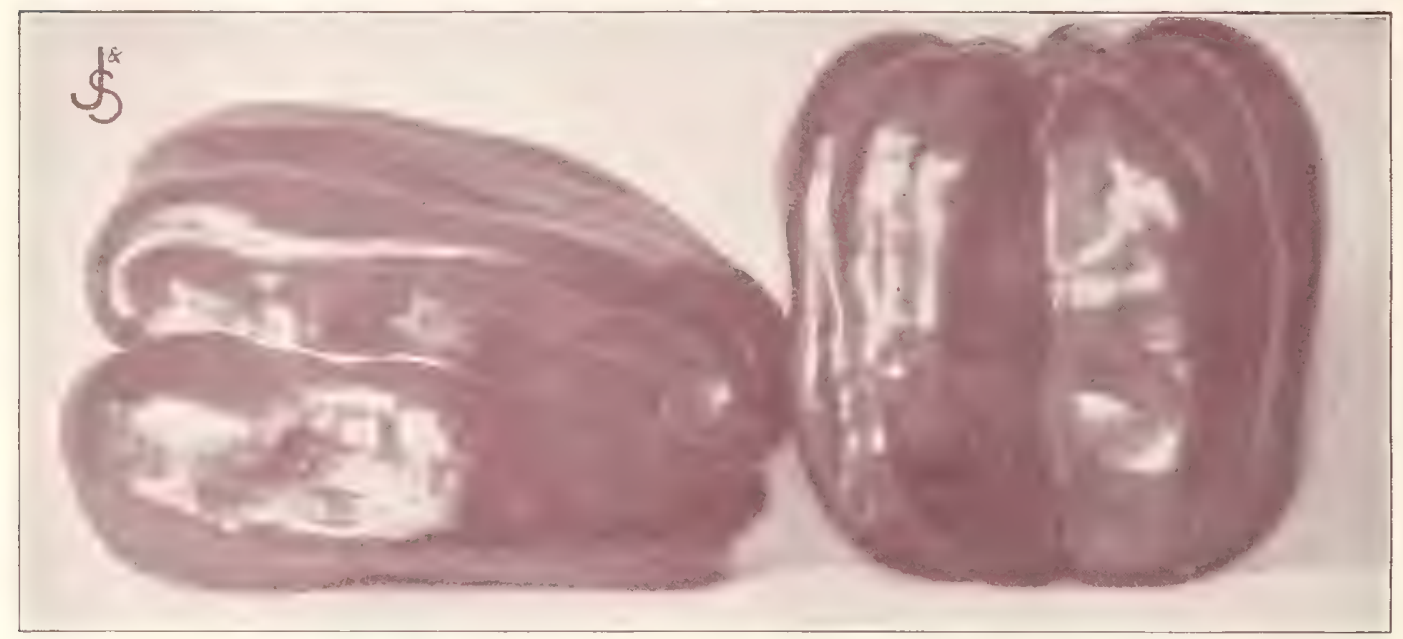

NEW RTBY GIANT PEPPER.

CHINESE GIANT PEPPER.

\section{NEW RUBY GIANT PEPPER}

In Philadelphia and many other markets there is a demand for long-shaped peppers on the style of the Ruby King. To meet this demand a New Jersey grower has successfully crossed the Ruby King and Chinese Giant, retaining the large size of the Chinese Giant with the longer shape of the Ruby King, as shom in onr photouraph above. Supply of seed grown and selected by the originator is so small we can only offer in packets this season. Per pkt., 20 c; 3 pkts., 50 c.; 7 pkts. for $\$ 1.00$.

\section{NEW CHINESE GIANT PEPPER}

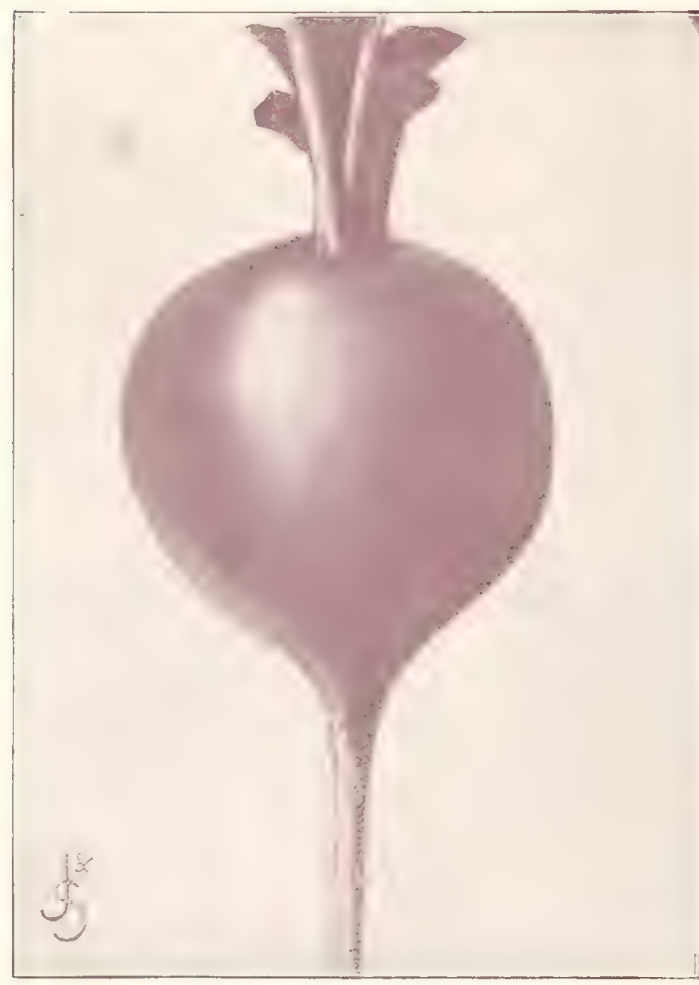

On account of its earliness, productiveness and large size, truckers who grow for market have found this a most profitable variety. Plants grow very vigorous and stocky; flesh unusually thick, mild and sweet. Pkt., 10c.; oz., 60c.; 青 lb., $\$ 1.75$; lb., $\$ 6.50$.

\section{NEW CRIMSON GIANT FORCING RADISH}

FOR FORCING OR OPEN GROUND CULTURE

A new type of Early Turnip Radish of a striking deep crimson color, attaining a size of 6 to 7 inches in circumference, weighing over an ounce, or about four times the weight of Scarlet Turnip sorts; notwithstanding its immense size, it does not get hollow or pithy, the flesh remaining white, solid, crisp and tender, and of the mildest flavor. The shape is well shown in our photograph alongside. Packets of seed, for trial, were distributed last Spring to many experienced market gardeners, who all agree that it is a very valuable acquisition to our list of fine early Radishes. Per pkt., 10c.; $\mathrm{oz}_{\text {. }}, 20 \mathrm{c}$.; $\frac{1}{4} \mathrm{lb}, 50 \mathrm{c}$.; lb., $\$ 1.75$.

\section{NOVELTIES FOR 1905 NOW FREE FOR TRIAL}

In addition to the New Nameless Cabbage and New Extra Early Tomato offered on pages 5 and 11, we have a few other distinct novelties not yet catalogued by any seedsmen, and which we propose to introduce in 1905 . We shall include one or more packets in all orders amounting to $\$ 1.00$ and 


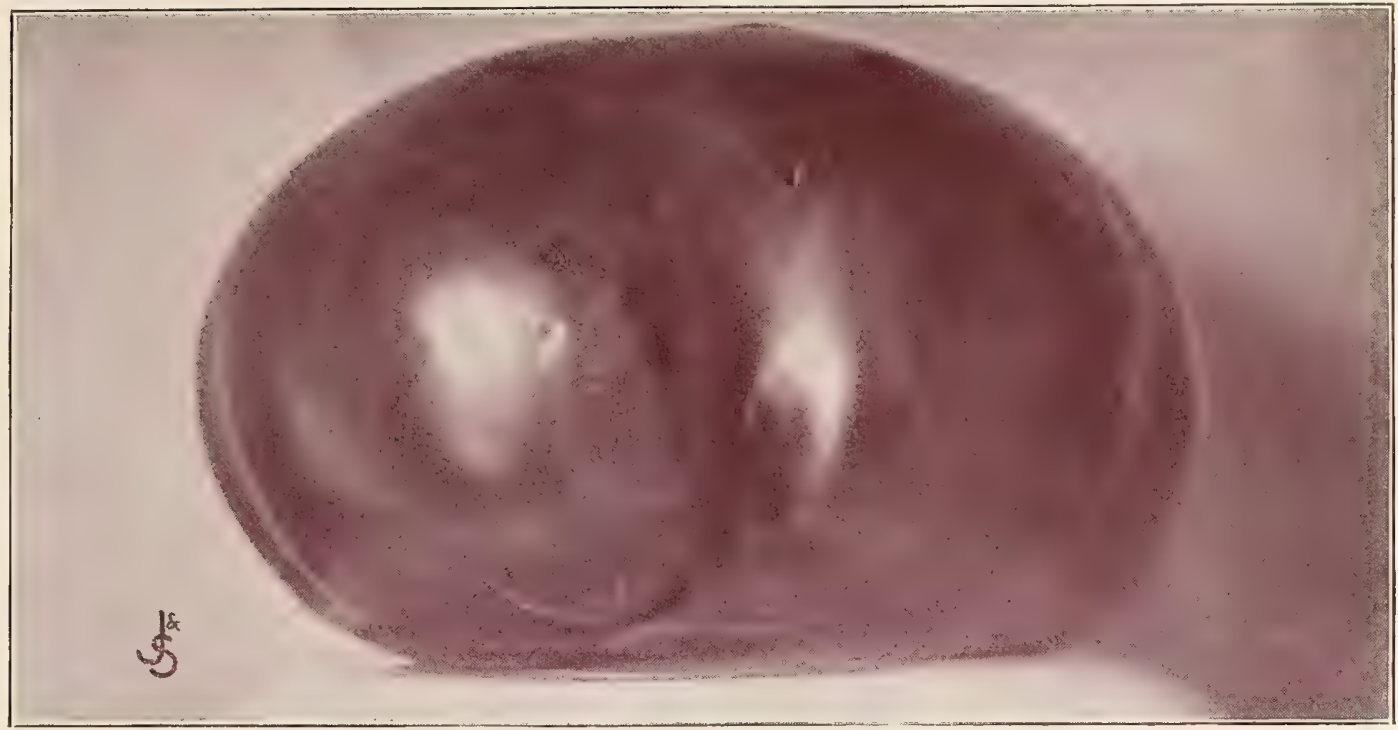

Photograph of new SANTA ROSA TOMATo-specimen weighing 23 ounces, $17 \frac{1}{2}$ inches in circumference.

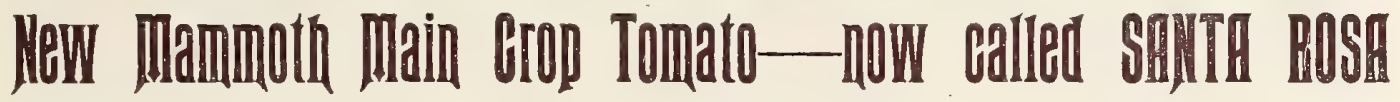

Three years ago one of our customers at Santa Rosa, California, sent us a few seeds of this valuable new tomato for trial. Upon growing we found in it a new race of tomatoes, differing from all others in its brilliant crimson untinged color, thick symmetrical shape, solid, meaty and almost seedless flesh. We were also astonished at its great size, eclipsing all very large tomatoes such as Ponderosa, Enormous and all others we have ever seen, many fruits 5 to 6 inches across and almost as deep through. Desiring that it be given a trial in all sections of the country, before offering the seed for sale, we sent out several thousand trial packages last Spring, and publish below a few extracts from several hundred letters received.

\section{AN OBJECT OF AMAZEMENT}

HoN. BenJ. M. Frisbee, Rideout, Fla., July 7, 1903, writes: "Your new Main Crop Tomato (Santa Rosa) is an object of amazement to all. I have just picked one that measures 16 inches around and weighs $201 / 2$ ounces. Although so large, they are solid and firm. They are smooth and round, and as a main cropper cannot be surpassed; they are about 14 days later than Sparks' Karliana.'

\section{A WONDER IN SIZE AND OUALITY}

J. C. SutToN, Blacks, Ind., Sept. 14, 1903, writes: "Your new tomato (Santa Rosa) is a wonder in size and quality; I never saw its equal. I shall want to buy the seed next season."

\section{A CONTINUOUS BEARER}

R. H. DENNEY, Smyrna, Del., Sept, 14, 1903, writes: "Early in the Spring I sowed in our plant house your New Mammoth Main Crop Tomato Seed (Santa Rosa); they made us very strong, thrifty plants. I set them out in due time and they made excellent vines. The tomatoes were the largest I ever saw. Our crop is now about over; they have been bearing since the early part of July."

\section{BEST FOR CANNING AND MARKET}

P. WEBER, Hamilton, Ohio, Sept. 16, 1903, writes: "Your new California tomato is the finest main crop variety, being very large, firm and solid, with but few seeds. I highly
WHAT A NEWSPAPER SAYS

LELA M. BRADLEY, of Malden, Mo., sends, July 3, 1903, a clipping from The Dunklin News, which reads: "Three mammoth tomatoes were brought to this office yesterday that are fine specimens of that luscious fruit. 'They were raised by J. N. Howard in this city and he says he has great quantities that are nearly as large as these specimens. Two of them that are nearly as large as these specimens. Two of them
measure 14 inches in circumference and weigh over one pound each. The seed (Santa Rosa) came from Johnson \& Stokes. The plants had no particular cultivation more than is usual."

\section{TOMATOES OVER 7 INCHES ACROSS}

J. M. McCrackev, Bucyrus, Ohio, Aug. 9, 1903, writes : "I have plants growing of your large California Main Crop Tomato (Santa Rosa) from seed received last Spring and I now have tomatoes on them measuring over 7 inches across."

\section{VIGOROUS AND WONDERFULLY PROLIFIC}

RoBT. C. MAY, Miamo, Fla, May 2, 1903, writes: "Your new Main Crop California. Tomato (Santa Rosa) is a very fine variety. The plant is a vigorous grower, wonderfully prolific and the fruit solid, very large and excellent in quality."

\section{LARGEST AND BEST HE EVER GREW}

J. M. Murtland, Dawson, Pa, Sept, 22, 1903, writes: "The fruit of your new Main Crop Tomato (Santa Rosa) ripens very evenly. It is the largest and best 1 ever grew."

Prices for 1904 of new Santa Rosa Tomato seed of our own growth and selection: Pkt., 15c.; 2 pkts., 25c.; oz., 70c.; $\frac{1}{4}$ lb., $\$ 2.00 ; 1 b ., \$ 7.00$.

\section{A New Extra Early Tomato Free}

Which We Desire to Have Tested in Comparison with our Famous Sparks' Earliana

Very early tomatoes have of late years been such a profitable crop that almost every grower in Southern New Jersey boasts, with more or less justice, that he has the earliest tomato. This new variety comes from the same trucking section as Sparks' Earliana, and the originator, Mr. E. A. Locke, claims it to be even earlier than that wonderful variety. So strongly was it recommended by Mr. Locke and many of his neighbors that we have secured from him, at high cost, a limited quantity of the seed, so that we may include a liberal trial packet to all customers whose orders amount to $\$ 2.00$ and over. 


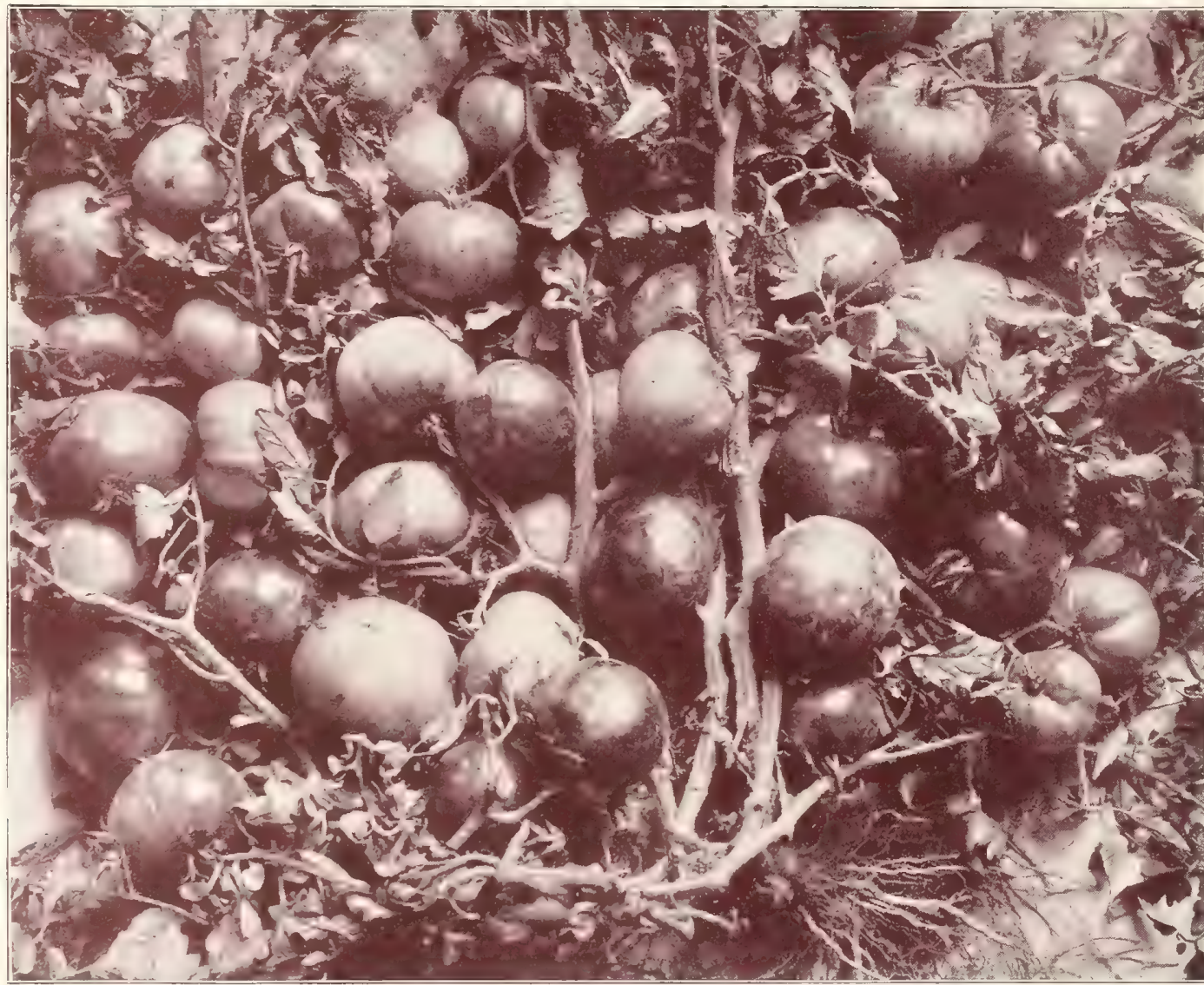

Photograph of a single plant of SPARKS' EARLIANA TOMATO, showing its wonderful productiveness

\section{SPARKS' EARLIANA TOMATO NAMED AND INTRODUCED}

THE EARLIEST LARGE, SMOOTH TOMATO IN THE WORLD

The most perfect of all tomatoes. Of large uniform size and beautiful red color. Quality almost beyond praise. Ripens thoroughly all over, the stem-end coloring up periectly. Almost seedless and as solid as beefsteak. Most vigorous grower. A prodigious bearer, continuing until frost. Succeeds everywhere from Maine to California, and Canada to Mexico.

The above claims may seem strong, but they have been abundantly proven by thousands of planters who have grown this grand tomato in the past 3 years. Nothing we have ever introduced has brought us so many strong unsolicited testimonials. Tomato growers of the United States have realized hundreds of thousands of dollars from this remarkable variety. The demand for the seed was so great in 1903 that we were obliged to refuse all large orders from planters and seedsmen. We have positive knowledge that another and greatly inferior tomato was sold last season, and will again be offered in 1904 as Sparks' Earliana, and warn our customers to beware of such.

Sparks' Earliana is as near seedless as any tomato we ever saw, giving but 12 to 15 pounds

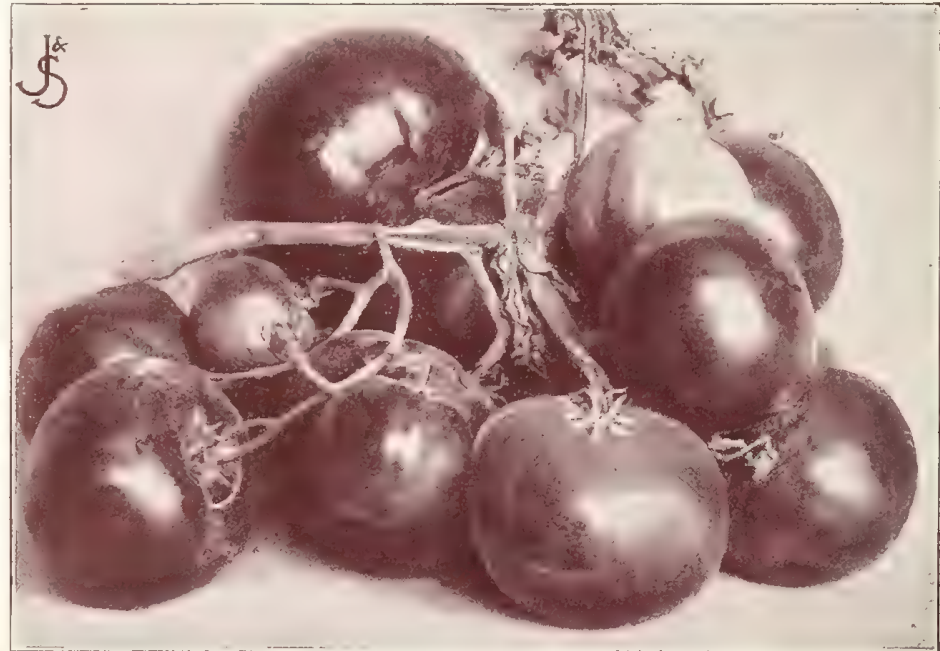

A single cluster of SPARKS' EARLIANA taken from our field, of seed to the acre, while other varieties yield from 75 to 100 pounds per acre. For this reason the genuine seed can never be sold at a low price. We control the entire supply of seed grown direct from the originator's selected stock seed. Per pkt., 15c.; $\frac{1}{2}$ oz., 40 c.; oz., 80 c.; $\frac{1}{4} 1$ b., $\$ 2.50 ; 1 b ., \$ 9.00$. 


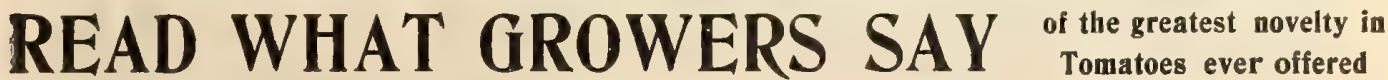

If space would permit, we could print hundreds of letters similar to the following:

THREE TIMES AS PRODUCTIVE AS OTHERS

J. T. MAUZY, Princeton, Ind., Aug. 19, 1908, writes: "I never saw any tomato that would begin to equal Sparks' Earliana in earliness, productiveness and fine quality. I can get more tomatoes off of 300 Sparks' Earliana plants than I could get off 1000 of any other variety."

\section{O VER TWO WEEKS AHEAD}

Gro. M. HARWOOD, Platte, Mich., Sept. 13, 1903, writes: "I had tomatoes over two weeks before any one else here, they were your Earliana. I sold 59 baskets of them at $\$ 1.25$ per basket. Everybody praises them. They are so large and solid and have better flavor than any other tomato."

RIPEN IN CANADA JULX 10th

A. H. Leonard, Prescott, Ont, Canada, July 29, 1903, writes: "Your Sparks' Earliana is the earliest and best tomato I ever saw. I gathered bushels of ripe ones in this northern latitude on the 10th of July."

\section{FINEST FRUITS FROM JULY TO} SEPTEMBER

W. H. Cla RK, New Brunswick, N. J., Sept. 11, 1903, writes: "Your Sparks" Earliana tomatoes are very large, solid and perfect; flavor is excellent; the color perfect; it gave finest fruits from July 4 th to september 12th. An enormous yielder."

\section{S300 FROM $1 / 2$ OUNCE OF SEED}

C. M. EMerory, Knoxville, Tenn., Oct. 17, writes: "The 1/2 ounce Sparks' Earliana 'Tomato Seed purchased from you gave me 1500 plants from which I made over $\$ 300$. I have been growing tomatoes for 18 years and have never seen its equal. Fine large tomatoes more than three weeks ahead of all others on the market."

\section{MOST VALUABLE NOVELTY IN A CENTURY}

JoHN W. MiLLETT, Bismarck, N. Dakota, writes: "I congratulate you on having introduced the most valuable tomato novelty of the past century, which 7aluable tomato novelty of the past century which Bparkg' Earliana surely is. It is earlier than all other varieties ever brought forward; it produces three
times the amount of fruit of any variety I ever grew. This superb tomato not only equals, but far surpasses all you claim for it."

\section{TWO WEEKS AHEAD OF ATLANTIC PRIZE}

Mrs, B. R. Miluer, McKeesport, Pa, July 31, 1903, writes: "Your Snarks' Earlians is the best all-around Tomato we ever had; it is perfectly smooth, very meaty, a good keeper and first of all to ripen, being two weeks ahead of Atlantic Prize."

CAN HAVE TOMATOES BY JUNE 20th

George W. CoRnish, Inwood, I. I., N. Y., Feb. 20, 1903, writes: "I have raised tomatoes 32 years, but have never 'seen any as good as your Sparks' Earliana. I believe by raising these plants in house I can have tomatoes for the table by the 20 th of June."

\section{FIRST PRIZE IN CANADA}

THos. BulmaN, Winnipeg, Canada, Sept. 3, 1903, writes: "Your Sparks' Earliana Tomatoes have given great gatisfaction; they are by far the earliest. At the Horticultural F.xhibiticn I recelved first prize for them. You will find a "great demand for the seed in Manitoba and Canada."

\section{TOMATOES ON ONE PLANT}

WM. H. KIRBY, Chestertown, Md., writes: "Your Sparks' Farliana is the finest tomato I ever saw. It is the earliest and most productive. In the past thirty years I have tried many varieties of tomatoes, but this one beats them all ; yesterday one of my men counted 176 tomatoes on one plant."

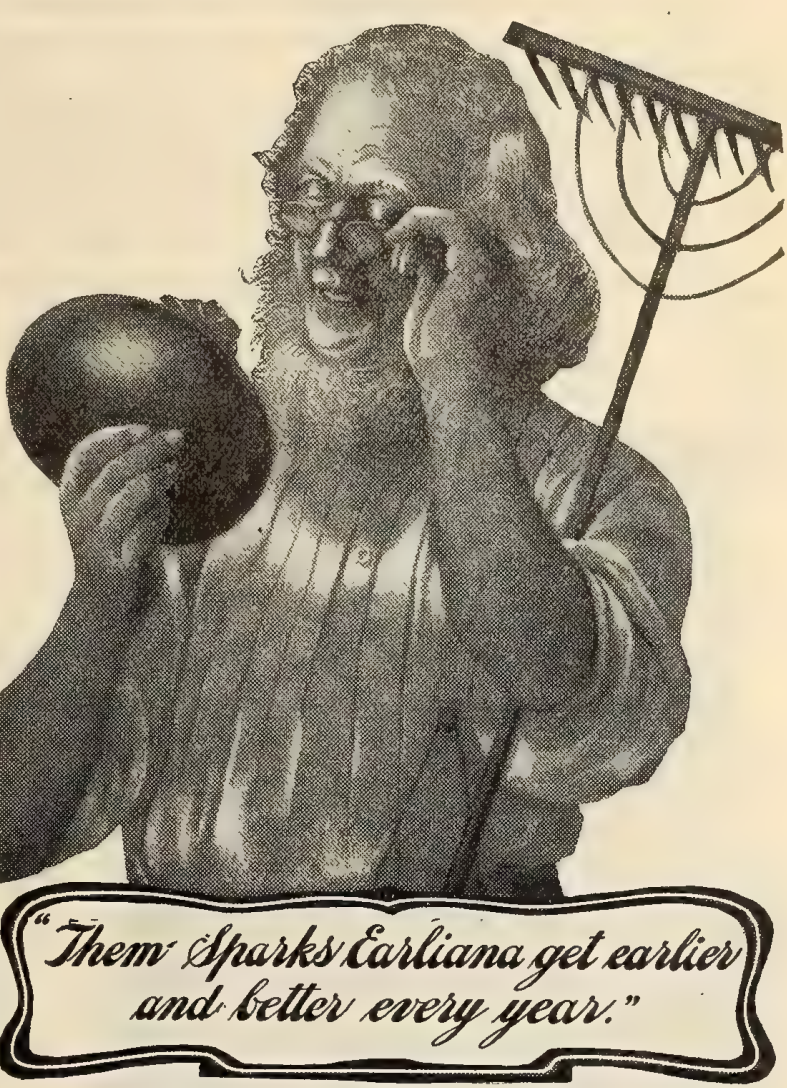

WITESTOOD WET WHEN OTHERS ROTTED

C. W. Macmillan, Savannah, Ga., writes: "I found your Sparks' Earliana everything you claim for them; not only were they heavy bearers and at least ten days earlier than any other varieties planted at same time, but they withstood an exceedingly wet season without damage, whilst other kinds rotted badly."

\section{$\$ 200$ ON LESS THAN ONE-HALF ACRE}

R. E. I. BRADFoRd, Forth Worth, Texas, August 2, 1902 , writes: "I sold $\$ 200$ worth of tomatoes from less than onehalf acre of your Sparks' Earliana. It beats any tomato ever grown for this market in earliness and productiveness. I will plant three acres of them next season."

\section{EARLIEST AND BEST OF 100 VARIETIES}

Alfred Palmer, Salem, N. C., writes: "After forty years" experience in tomato raising I must say that of over 100 varieties I have tried, I found your Sparks' Earliana to be the very earliest and best in every way. Its quality and merits are perfection."

\section{HEAVT CROP WEEN OTHERS FAILED}

GEO. WOLFRUM, JR, Kresson, N. J., writes: "I have grown your Sparks' Earliana Tomato since its introduction, and find it the vers earliest and best. Last vear I had a heavy crop of them while my neighbors had hardly any from other varieties."

Sparks' Earliana Tomato requires intelligent and constant selection for stock seed to keep it at its present high standard. All seed purchased from us (the introducers) insures the highest possible grade saved from selected fruits of the genuine variety. We planted in 1903 in Sparks' Earliana by far the largest acreage we have ever grown in any one variety of tomato and hope to be able to fill all orders that we may receive this season. Prices for 1904 : Per pkt., 15c.; $\frac{1}{2}$ oz., 40c.; oz., 80c.; $\frac{1}{4} 1 \mathrm{lb} ., \$ 2.50 ; 1 \mathrm{~b}, \$ 9.00$. 


\section{JOHNSON \& STOKES' NEW LEAFLET. ESSAYS ON IMPORTANT VEGETABLES, ETC.}

\section{SENT FREE to all purchasers of Johnson \& Stokes'}

Seeds when asked for with their Seed Orders

They give in a concise, practical way complete cultural information gained from long experience on the subjects of which they treat.

No. 1. ASPARAGUS. Making the Bed, Setting Roots, Cultivating, Fertilizing and Marketing.

No. 2. CABBAGE. Planting Uut, Cultivation, Diseases and Insects, Storing and Marketing.

No. 3. CELERY. Soil, Fertilizers, Planting, Cultivating, Blanching, Storing for Winter.

No. 4. MELONS. Musk or Cantaloupe and Watermelons, Cultivation, Manuring, Insect Enemies.

No. 5. MUSHROOMS. How to Prepare Bed, Planting Spawn, Temperature and Marketing.

No. 6. ONIONS. Preparing the Soil, Fertilizers, Planting Seeds and Sets, Cultivating, Harvesting, Storage, Marketing, etc.

No. 7. SWEET POTATOES. Growing Sprouts or Plants, Setting Out, Cultivating, Harvesting, Storing for Winter, etc.

No. 8. GINSENG. History, Possibilities, Cultivation and Marketing of this Wonderful Root.

No. 9. FLOWER CULTURE FROM SEED. Including Sweet Peas, Nasturtiums, Pansies and other Popular Flowers. Complete Cultural Directions.

No. 10. SASHES AND BEDDING PLANTS. Treating Principally on Hot Beds and Cold Frames

No. 11. THE FAMILY VEGETABLE GARDEN. Telling How and What to Grow.

No. 12. HINTS ON LAWN MAKING AND GRASS SEED MIXTURES for Lawns, Golf Grounds, Permanent Pasture and Mowing.

In asking for these essays it is only necessary to mention the number of the essay wanted. They are not for sale and cannot be sent unless the seed of the kind on which they treat is included in the order, exccpt the last three, which will be sent, when requested, with any order of 50 cents or over.

\section{BOOKS FOR THE FARM AND GARDEN}

Standard works, written by acknowledged authorities on the subjects of which they treat. We send them postpaid on receipt of price. To customers who order them sent with seed orders, we allow a discount of 10 per cent. from publishers' prices, here quoted:

ON FARM AND GARDEN TOPICS

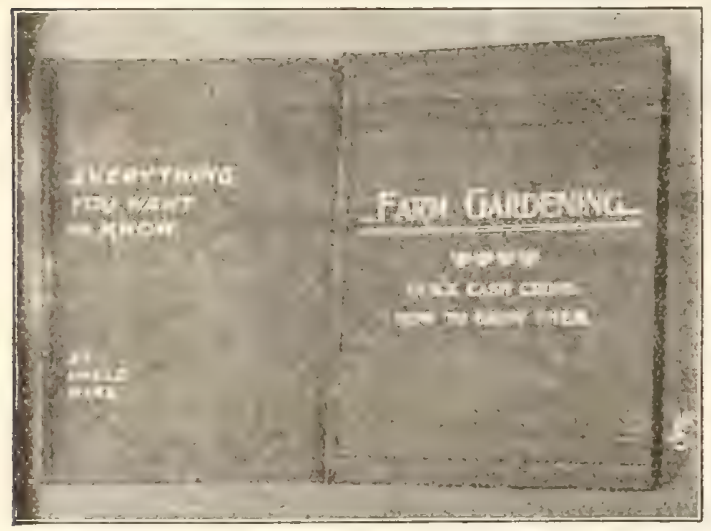

EVERTTHING YOU WANT TO KNoW. By UNCLE MIKE. A complete work for both gardeners and poultry men. Treats in the brief, boiled-down style, characteristic of the author, on vegetables and farm products, together with a complete poultry section.

Farm Gardening, or Quick Cash Crops and Ho to Grow Them. A decided help to both the farmer and market gardener. Tells how and what to grow, how to fertilize and how to treat insect enemies, etc. 128 pages, fully illustrated, bound in

Irrigation by Cheap Modern Methods. A practical work. Johnson \& Stokes.

$\$ 100$ Prize Essays. By practical growers. "How and What to Grow in the Soutl,

Practical Farm Chemistry, T. Greiner

Cardening for Pleasure. Henderson.

The Young Mark et Gardener. A Beginner's Guide,

How the Farm Pays. Henderson and Crozier

How Crops Grow. A treatise on the elemical composition, structure and life of the plant. Johnson

How Crops Feed. A treatise on the atmosphere and soil as related to the nutrition of plants. Jolnnson. Draining for Profit and Health. Waring

\section{ON VEGETABLES AND FRUITS} Asparagus Culture. Barnes and Robinson ...$\$ 050$
Biggle Berry book. (New.) The very latest treatisa on small fruits. Illustrated by colored plates Broom Corn and Brooms. Cloth

Cabbages and Cauliflowers, How to Grow Them Mushroom Culture. J. \& S. Paper Circular... Mushrooms-How to Grow Them. Cloth New Onion Culture. T. Greiner. . . . 50 New Potato Culture. The French System. Carmen, 50 Squashes-Fow to Grow Them. Giegory ..... 30

\section{Sweet Potato Culture, Fitz .......}

\section{ON FLORICULTURE}

Practical Floriculture. For Florists. Henderson , 150 Commercial Violet Culture. Galloway . . . . 150 Success with House Plants. Hillhouse How to Destroy Insects on Plants aud Flowers My Handkerchief Garden. Barnard How to Plant a Place

\section{ON POULTRY AND LIVE STOCK}

Little Chicks. Just out. A treatise on the success ful care of clicks by both natural and artiticial methods. Boyer

Blgele Poultry Book. Finely illustrated Biggle Cow Book. All up-to-date modern methods Higgle Swine Book. concentrated and recorded for Riggle Horse Bnok. the benefit of man. Profitable Poultry Farming. M. K. Boyer Farm-Poultry Doctor, Dr. N. W. Sanborn Low-Cost Poultry Houses. Ilustrated . 500 Questions and Answers on Poultry Topics A Living from Poultry. M. K. Boyer
Broilers for Profit. M. K. Boyer Broilers for Profit. M. K. Boy

Capons for Profit. T, Greiner ..... Winter Eggs. How to get them. John H. Robinson, Egg Record and Account Book Practical Pigeon Keeper. Illustrated. 'Wright : 150 Money in Squabs. Brinton American Standard of Perfection. A complete description of all the recognized Breeds of Fowls . 100 Duck Culture, Rankin....... 50 Training of Shepherd Dogs. Wickham : . 5 The Collie. Its history, points and breeding. Dalziel, An Egg Farm, or the Management of Poultry in 100

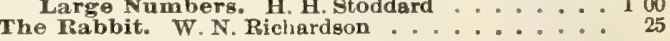
NO BOOK AS USEEUL.

Mrs S. FiIs, Montello, Wis , Aug, 17, 1903, writes: "I have planted your seed many year 3 with greatest success. I never had anything that has been of such use as your book entitled "Everytbing You Want to Know." 


\section{Johnson \& Stokes' Vegetable Seeds}

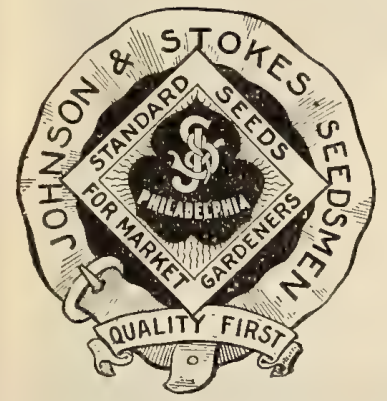

DIRECTIONS FOR ORDERING ON ORDER SHEET TO BE DETACHED, OPPOSITE PAGE 12

$\mathrm{N}$ the following pages we have endeavored to list the cream of all varieties known, weeding out many that are still advertised by other seedsmen, but which our extended tests at Floracroft Trial Grounds have proven to us are unworthy of cultivation. We take great pains each season to inform ourselves fully as to the real merits of everything offered as new or superior, and our customers may rest assured that if any much-lauded variety is not found in our MANUAL, the probability is much greater that we have tested it and found it of little or no value, than that it is unknown to us. It is our constant aim thus to gain and hold the confidence of all customers.

\section{ARTICHOKE}

As a table regetable the Artichoke deserves to be more generally cultivated. The part eaten is the flower head, which is used before it begins to open, and cooked in much the same way as asparagus.

Large Green Globe. Pkt., 10c.; oz., 30c.; lb., \$3.00.

Artichoke Roots for hog feed wili be found under "Farm Seeds," Peck, $\$ 1.00$; bush., $\$ 3.00 ;$ bbl., $\$ 7.50$.

\section{ASPARAGUS}

A sparagus is one of the earliest spring vegetables. No regetable on our list can be produced so cheaply and easily. Directions for planting and culture will be found in our new LEAFLET-ESSAYS, sent free on request. A bed $12 x 40$ feet, requiring about 100 roots, will give an abundant
supply for an ordinary family. One ounce of seed will sow $\$ 0$ feet of row; 7,260 roots will plant an acre.

\section{EARLY FRENCH GIANT THE EARLIEST-LARGE AND PROLIFIC}

For description and illustration, see pare 2.

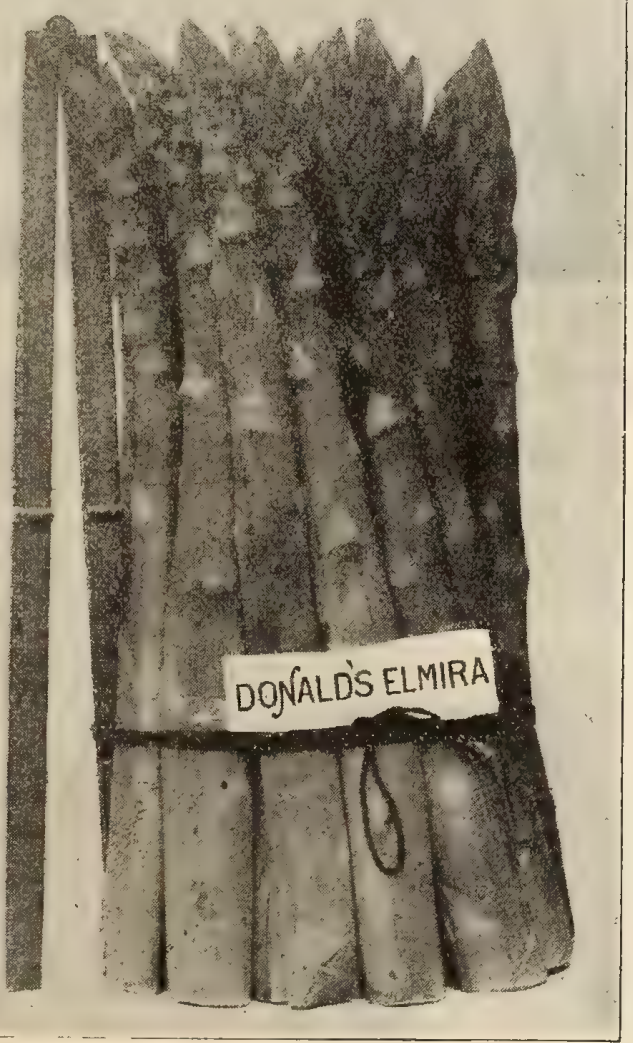

\section{Donald's Elmira Asparagus}

This new asparagus, first introduced by us, has attracted much attention throughout the country. It was originated by Mr. A. Donald, a prominent market gardener of Elmir market gardener of Elmira. He lias always realized handsome prices, and although a large grower was unable to supply half the demand. The delicate green color is notably different from either the fanous Barr's Philadelphia Mam. moth or Palmetto, while the stalks are more tender and succulent. Its mammoth size succulent. Its mammoth size that in whole from the fact that in whole cropg a bunch of twelve stalks will average three to four pounds in weight. It requires much less labor in cutting and bunching, thus lessening the expense of $\mathrm{mnt}$ keting. Price of Seed: Pkt. 5c.; oz., 10c.; $1 / 4$ lb., 30c.; 1b.; year old 700 per 100 (by mail. year 50 per 700 (by mail. postpaid, 50 for $70 \mathrm{c}$, $100)$ per 1,$000 ; 2$ years old, 75 c. per 100 ;
500 for $\$ 3.25 ; \$ 6.00$ per 1,000 , by freight or express.

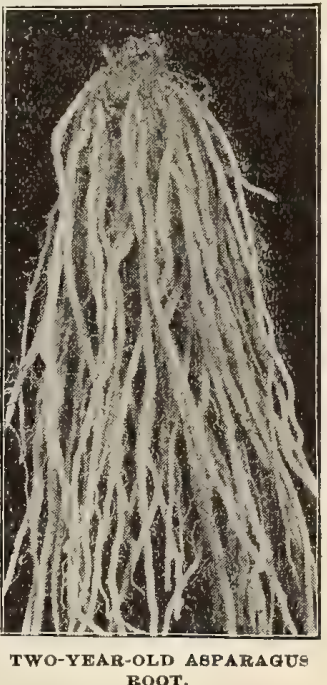

\section{Barr's Philadelphia Mammoth}

This variety originated with Crawford Barr, a promt nent market gardener of Pennsylvanith. Grown side by side with Conover's Colossal, it grows twice as large and more productive. In Philadelphia it is much sought after and sells at top-notch prices. SEED: Pkt, 5c.; Oz, 10c, 1/1 1b, 20c. it 65 c GOOD STRONG ROO'S, i year old $65 \mathrm{c}$, per 100 (by mail, postpaid, 50 for $50 \mathrm{c}$; $90 \mathrm{c}$, per 100 ); $\$ 4.50$ per 1,$000 ; 2$ y ears old, $70 \mathrm{c}$. per $100 ; \$ 5.00$ per 1,000 (500 rootg at 1,000 rate).

\section{Columbian Mammoth White}

This is a most distinct variety, discovered on Long Island a few years since. The stalks are large, produced abundantl and early. They are clear white and remain so as long as fit for use, without enrthing up or any other artificial blanching. There is a large demand from canners for this sort. Prices of Seed: Pkt., 5c.; oz., 10c.; $1 / 4$ lb., 25c.; lb., $75 \mathrm{c}$. GOOD STRONG ROÓTS, 1 year old, 70 c. per 100 (by mail, postpaid, $\$ 1.00$ per 100 ); $\$ 5.50$ per 1,$000 ; 2$ year old roots, $75 \mathrm{c}$. per $100 ; \$ 6.00$ per 1,000 .

\section{Palmetto Asparagus}

This asparagus is now quite extengively grown for New York and Philadelphis markets, where it sells at high prices, owing to its fine size and regularity. Although of Southern origin, it is equally well adapted to the North. Pkt., 5c; oz., 10c.; 1/4 1b., 20c.; 1b., 65c. ROOTS, same price as Barr's Philadelphia Mammoth.

\section{Conover's Colossal Asparagus}

A well-known old standard variety. Prices of Seed: Pkt., 5c.; oz., 10c.; 1/4 lb., 20c.; lb., 50c. SPLENDID S RRONG ROOTs, 1 year old, 50c. per 100 (by mail, post paid, $75 \mathrm{c}$, per 100$) ; \$ 4.00$ per 1,$000 ; 2$ years old, $60 \mathrm{c}$. per $100_{0}$
$\$ 4.50$ per 1,000 . 


\section{BEANS-Dwarf Green Podded Snap Short}

One quart will plant one hundred feet of drill, two bushels will plant an acre in drills

Large, full=sized packets of any variety of Beans, 5 c. each.

Half pecks and half bushels supplied at peck and bushel rates.

Improved Round Pod Red Speckled Valentine. Finest strain Rerugee or Thousand to One. Medium early, hardy, productive New Extra Early Refugee. Two weeks earlier than the old Refugee, Stringless Green Pod. Extra early and of very fine quality

Early Mohawk. Very early and hardy ; long, flat, straight pods Long Yellow Six Weeks. Early, with full, flat green pods

Early China Red Eye. Very early old standard sort

\begin{tabular}{|c|c|c|c|c|}
\hline \multicolumn{2}{|c|}{$\begin{array}{l}\text { By Mail, } \\
\text { Postpaid. }\end{array}$} & \multicolumn{3}{|c|}{ By Express or Freight. } \\
\hline Pint. & Qt. & Qt. & Peck & Bush. \\
\hline (1) 20 & 8035 & $\$ 020$ & $\$ 125$ & $8+75$ \\
\hline 20 & 35 & 20 & 125 & \pm 75 \\
\hline 20 & 35 & 20 & 135 & 500 \\
\hline 20 & 35 & 20 & 135 & 500 \\
\hline 20 & 35 & 20 & 115 & 4.25 \\
\hline 20 & 35 & 20 & 115 & 425 \\
\hline 20 & 35 & 20 & 110 & 400 \\
\hline
\end{tabular}

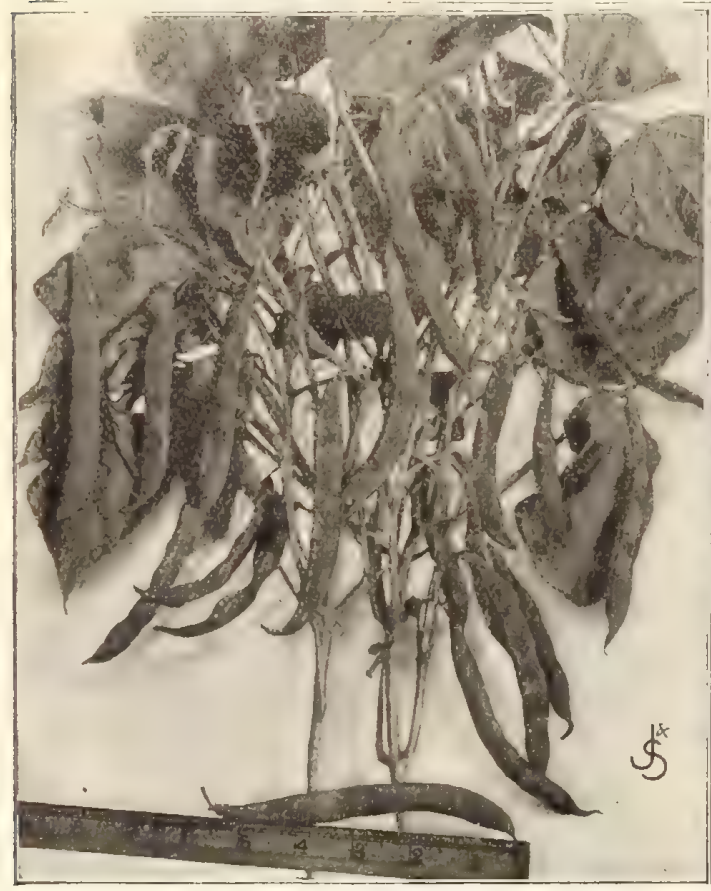

NEW GIANT GREEN POD STRINGLESS VALENTINE BEAN, Earlier, more prolitic, with pods $1 / 3$ larger than Valeutine.

Pkt., 10c. ; pint, 25c. ; qt., 40c., by mail, postpaid. By express or freight, qt., $25 \mathrm{c}$,; peck, $\$ 1.50$; bush., \$5.75.

\section{DWARF WAX PODDED}

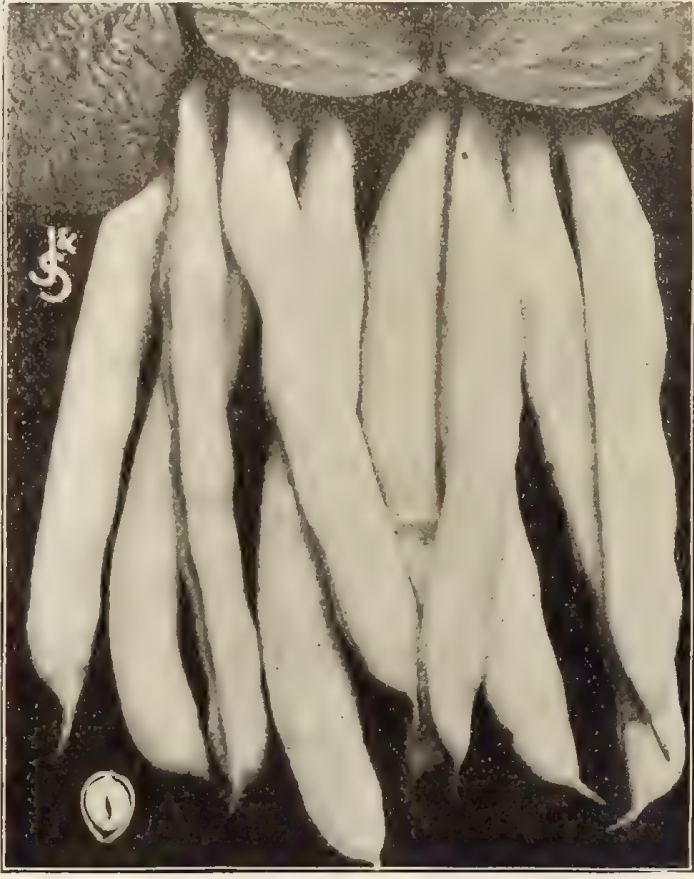

OURRIE'S RUST-PROOF BLAOK WAX BEAN. EXtremely early, large pods. The best Wax Bean for market and ghipping.

Pkt., 10c.; pint, 25c.; qt., 45c., postpaid ; by freight or express, qt., 30c.; peck, $\$ 1.75$; bush., $\$ 6.75$.

\section{SNAP SHORT BEANS}

Half pecks and half bushels will be supplied at peck and bushel rates. Seed of many varieties of Wax Beans is again a very short crop this season, and early orders are advisable.

New Round Pod Kidney Wax. See Novelties, page 2

Golden Wax. The well-known old sort; popular for market Grennell's Improved Rust=Proof Golden Wax. Very superior New Valentine Wax. One of the earliest wax beans; pods round Wardwell's Kidney Wax. Very popular, long, broad, Hat pods . Davis Kidney Wax. A new white-seeded bean. Long, oval pods Keeney's Improved Refugee Wax. (New.) A decided improvement, Dwarf German Black Wax, or Butter. Well-known old sort New Prolific German or Cylinder Wax. Very carly and prolific . Keeney's Pencil Pod Black Wax. New, round, full and stringless, Fuller's Ringleader. (New.) The best Black Wax yet introduced, Golden=Eyed Wax. Early, hardy and prolific; popular market sort, Scarlet Flageolet Wax. Early, very large, flat, stringless pods Vlolet, or Perfection Wax. Large, handsome pods, very showy

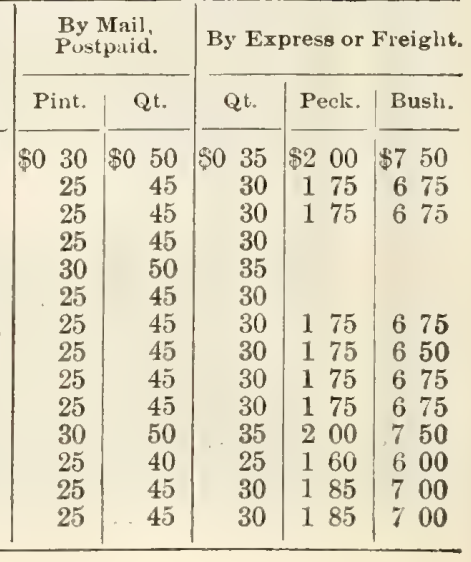




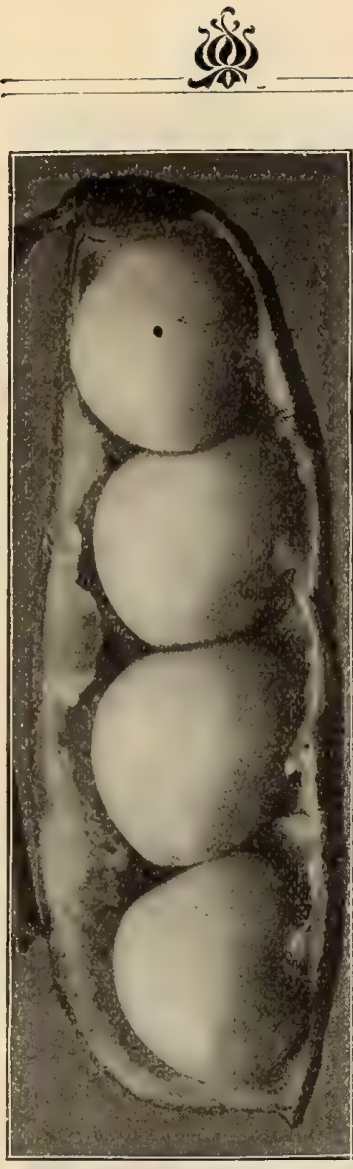

DREER'S OR KUIMERLE BUSH IMA

\section{THE BEST of the DWARF OR BUSH LIMA BEANS}

NEW WONDER BUSH LIMA

Largest in size and best of all.

The New Wonder is the earliest, dwarfest and most prolific of the whole class of Bush Limas. A decided improvement on the original type of Burpee's Bush Lina, being larger in size, more hardy and prolific. Pkt., 10c.; pint, $25 \mathrm{c}$. qt., $45 \mathrm{c}$., postpaid ; by express or freight, qt., $30 \mathrm{c}$. peck, $\$ 1.85$; bush., $\$ 7.00$

Dreer's or Kumerle Bush Lima

Possesses all the good qualities of the Dreer's Improved or Challenger Pole Lima, growing vigorously about two feet high and showing no disposition whatever to run. It produces pods in great abundance. The beans grow close together, four and sometimes five in a pod, and are thick, sweet and succulent. Pkt, 10c.; pint, $25 \mathrm{c}$ q $\mathrm{t}, 45 \mathrm{c}$, postpaid; by express or freight, $q \mathrm{t}$. $30 \mathrm{c}$.; peck, $\$ 1.85$; bush., $\$ 7.00$

Dwarf White or Burpee Bush

The true bush form of the old large Limg Pole Bean and most popular of the class. It grows vigorously to a height of twenty inches. Pint, 25c; at, $40 \mathrm{c}$, postpaid; by express or freisht, qt., 25 c.; peck, $\$ 1.75$; bush., $\$ 6.50$.

WOOD'S PROLIFIC BUSH LIMA

An "Improved Henderson Bush Lima."

Earlier than the Burpee's Bush Limn, but somewliat smaller in size of bean. Making a larger grow th than others; stems are loaded down with beans in great clusters. Pkt., joc.; pt. 25e.; qt., 45c., postpaid; by express or freight, qt., 30c.; peck, $\$ 2.00$; bush., $\$ 7.50$.

Henderson's, or Dwarf Sieva Lima Size of the small Southern or Sieva Lima. Enormously productive. Pint, 25e.: qt., 45c., postpaid ; by express or freight, qt., 30c.; peck, $\$ 2.00$; bush., $\$ 7.50$.

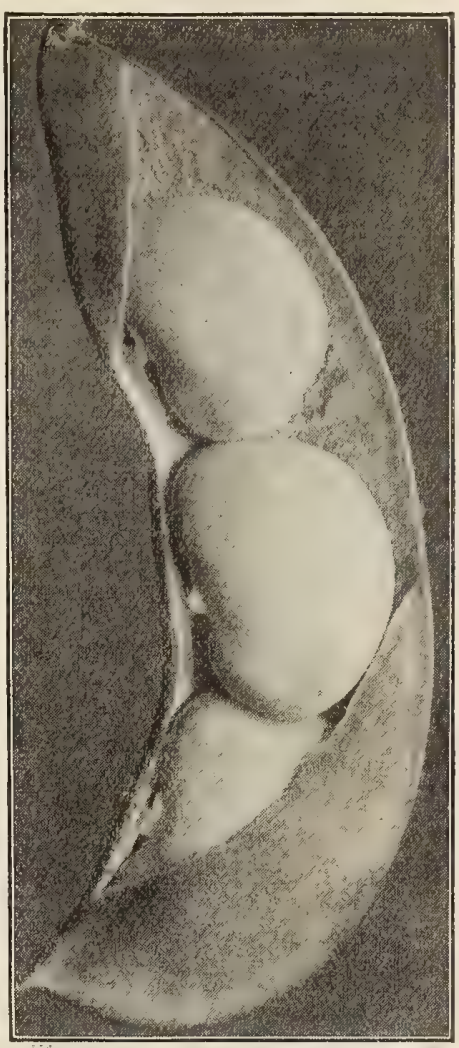

NEW WONDER BUSH TIMA. PODS NATURAL SIZE.

\section{BEANS-WHITE SHELLING VARIETIES}

Large packets, 5 c. each.

Half pecks and half bushels supplied at peck and bushel rates.

Day's Leafless Medium. Vine stands up well, grows abundant foliage, and previous to ripening, the leaves fall off, so that pod is exposed to the sun, so they ripen evenly. Matures in eighty days, Burlingame Mediums. The leading field bean in New York . White Navy or Pea Bean. A productive standard sort

Royal Dwarf or White Kidney. Very productive, fine for baking, White Marrowfat. Well known; extensively grown for winter

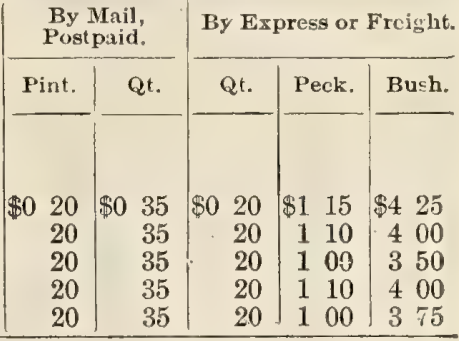

\section{THE CREAM OF THE POLE OR RUNNING BEANS}

Half pecks and half bushels will be supplied at peck and bushel rates. Large packets of any variety of Pole Beans, 5c. each.

New Golden Andalusia Wax. Most productive and profitable of all the pole wax varieties; pods, 5 to 6 inches long; broad, fleshy and stringless, surpassing all others in quality; come early and continue to bear profusely the entire season; beans pure white,

Early Golden Cluster Wax. Early, large, flat fleshy yellow pods,

Lazy Wife's. Best and largest Green Podded Snap Short Pole Bean,

produced in large clusters; pods broad, thick, fleshy and stringless,

White Crease Back or Fat Horse. One of the earliest Round Pod, Improved Kentucky Wonder or Old Homestead. Very long, round, straight pods; early, entirely stringless, very productive Southern Prolific. Continuous bearer, giving snap shorts in $\varepsilon 0$ days, Speckled Cut Short or Corn Hill. Best for planting among corn Dutch Case Knife and Horticultural or Wren's Egg. Each

\begin{tabular}{|c|c|c|c|c|}
\hline \multicolumn{2}{|c|}{$\begin{array}{l}\text { By Mail, } \\
\text { Postpaid: }\end{array}$} & \multicolumn{3}{|c|}{ By Express or Freight. } \\
\hline Pint. & Qt. & Qt. & Peck. & Bush. \\
\hline $\begin{array}{l}\$ 025 \\
25\end{array}$ & $\begin{array}{rr}\$ 0 \quad 45 \\
\quad 45\end{array}$ & $\begin{array}{r}\$ 0 \\
30 \\
30\end{array}$ & $\begin{array}{rl}\$ 2 & 00 \\
1 & 90\end{array}$ & $\$ 77$ \\
\hline 25 & 45 & 30 & 160 & 60 \\
\hline 25 & 40 & 25 & 150 & \\
\hline 25 & 45 & 30 & 175 & \\
\hline 25 & 40 & 25 & 150 & \\
\hline 25 & 40 & 25 & 150 & 5 \\
\hline 25 & 40 & 25 & 150 & 575 \\
\hline
\end{tabular}




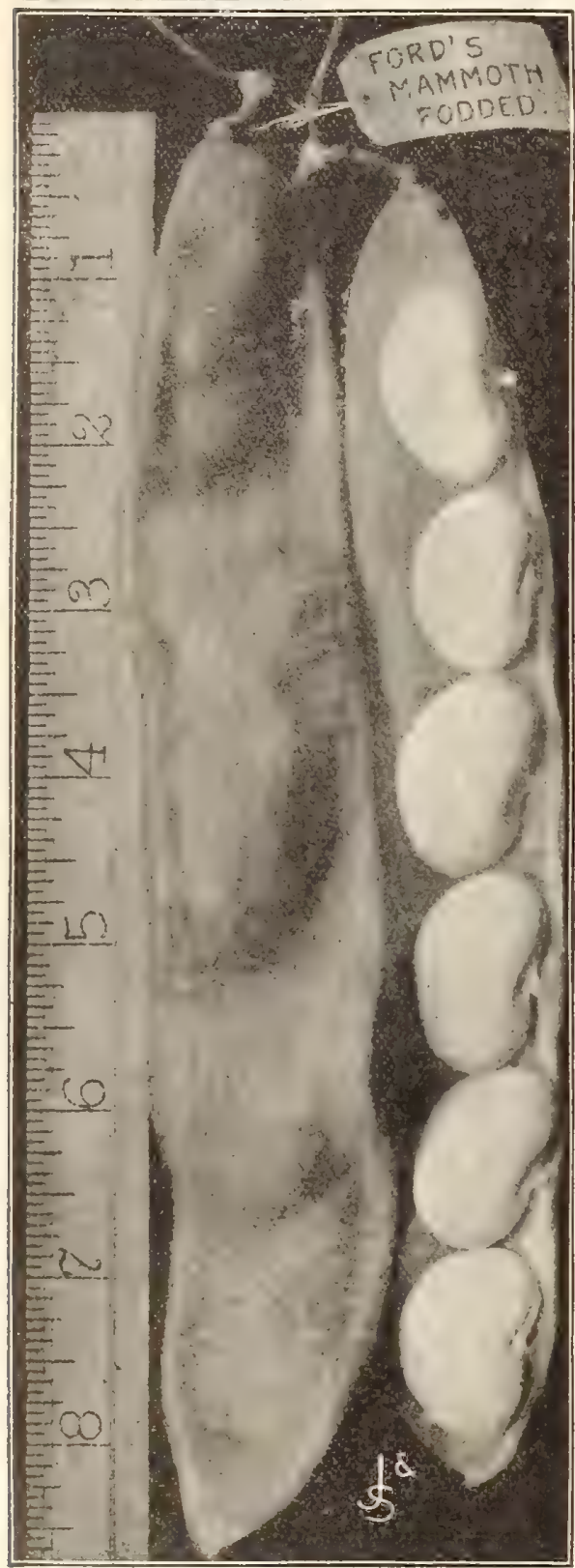

\section{New Jersey Grown Pole Lima Beans} WHY THEY ARE THE BEST

For nearly half a century Southern New Jersey has had the reputation, and deservedly so, of growing the finest Lima Beans in the United States, the product being eagerly 8onght after by Boston, New York, Philadelphfa and other Eastern cities, for both seed and consumption. For some years past, however, most all seedsmen have been growing their supplies in Southern California, where they are grown very cheaply and without poles. We have made hundreds of tests of various' Limas from California seed, and find the product much inferior in both quality and productiveness to those grown in New Jersey. It is also difficult to get them to take the poles, owing to the method by which they are grown, while the beans are smaller and lack the rich, buttery flavor peculiar to the New Jersey Limas.

Twenty quarts of Pole Limas are required to plant an acre in hills four by four feet. We sell Large Packets of each variety, 10c. each, postpaid. Pints, when sent by freight or express, at half the quart rates: half peck and half bushel at peck and bushel rates.

\section{Ford's Mammoth Podded Pole Lima Bean}

This Lima Bean is the result of over twenty years' selection by the late Jas Philadelphia. The pods grow to an average length of eight juches, are Philadelphia. The pods grow to an averge produced in great elusters, with from five to seven beans per pod, of wost excellent quality for using either green or dry The vines grow vigorously, setting the beans early at the bottom of the pole, and continue in bearing right up to frost. Ford's Mammoth Podded is, without exception, the largest podded, finest flavored and most productive of all Lima Beans. Pkt., 10c.; pint, $30 \mathrm{c}$; qt., 55c., postpaid; by freight or express, pint, 20c.; ot. 40c.; 2 qto., 70c.; peck, $\$ 2.00$; bush., $\$ 7.50$.

SEIBERT'S EARLY LIMA. This new variety is one of the very earliest. The vine is vers viorous and productive. Pods are large eartiest. The vine is very vigorous an prod those of other varieties. but thin, and can be more easly oped The green beans are very large, handsone and of the best quality. In eariness, ease of shelling, size, beauty and quality of the gicen beans, this variety is superior, and is now recogned as one of the best for either the garden or niarket. Pkt., 10c.; pint, 20c,; qt., $45 \mathrm{c}$, , postpaid; by freight or express, qt., 30c.; veck, $\$ 1.75$; bush., $\$ 6.50$.

JERSEY EXTRA EARLY LIMA. The pods are large and numerous, invariably having from four to five beans in each. These beans appear in Phila delphia markets nearly two weeks ahead of ordinary Limas, selling at from $\$ 3.00$ to $\$ 4.00$ per bushel of pods, and, previous to the introduction of Seibert's Early, were considered the earliest. Pkt, 10c.; pint, 25c.; qt., 45c. postpaid: by freight or express, qt. $30 c$, peck, 81.75 ; bush. 86.50 .

STOKES' EVERGREEN LIMA. The Stokes' Erergreen not only hold the full size and great productivenes of the Salem Mammoth, but lias the remarkable additional quality of holding, in ell stages of growth, and even when dry and shelled, the deep green color of the unripe state, giving the sppearance the unripe state, giving the sppearance cooked. Pkt, 10c.; pint, $35 \mathrm{c}$; qt., 65e.

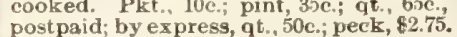

KI N G O F T F G R T T IIMA. More prolific than the ordinary Iima bearing pods five to six inches long in clusters of four and five, with five to six beans in a pod. Pkt., 10c.; pint, $25 \mathrm{c}_{.}$, qt., 45c. postpuid : by express or freight, qt., 30 c.; peck, $\$ 1.75$; bush., $\$ 6.50$.

SALEM IMPROVED LIMA. A selection from the lare Lima Bean, of extraordinary alze and deep green color. Pint, $30 \mathrm{c}_{\text {.; }} \mathrm{qt}_{\text {, }}, 55 \mathrm{c}$, postpaid; by freight or express, $\mathrm{qt}$., $40 \mathrm{c}$. peck, 82.00 ; bush., $\$ 7.75$.

LARGE WHITE LIMA. (Extra Selected Size.) The well-known farorite. Our strain is fine. Pint, 25e.; qt., 45c., postpajd; by express or freight, qt., $30 \mathrm{c}$; peck, $\$ 1.60$; bush., $\$ 6.00$

DREER'S IMPROVED CHALLENGER or POTATO POLF LIMA. When green, is as large as the Large Lima. Thicker, sweeter and more tender and nutritious, remaining green in the pod for a long time after maturing. Pkt., 10c.; pint, 25c-; qt, 45c., postpaid; by express or freight, qt, $30 \mathrm{c}$; peck, $\$ 1.75$; bush, 86.50 .

\section{Shotwell's Improved Thick Pole Lima Bean}

Orjginated by one of the best and most experienced srowers of Northern New Jersey. It is of the thick or Potato Lima class, but will be found a decided improvement on the Dreer's Improved Pole Lima or any other bean of its class in earliness, productiveness and fine quality. All claims made for it have been fully substantiated by hundreds of our customers who tried it in past seasons, and we recret we have not room here to publish the many strong recommendations received from them. Pkt., 10c.; pint, 35c.; qt., 65c., postpaid by freight or express, qt., $50 \mathrm{c}$.; peck, $\$ 2.25$; busl., $\$ 8.50$.

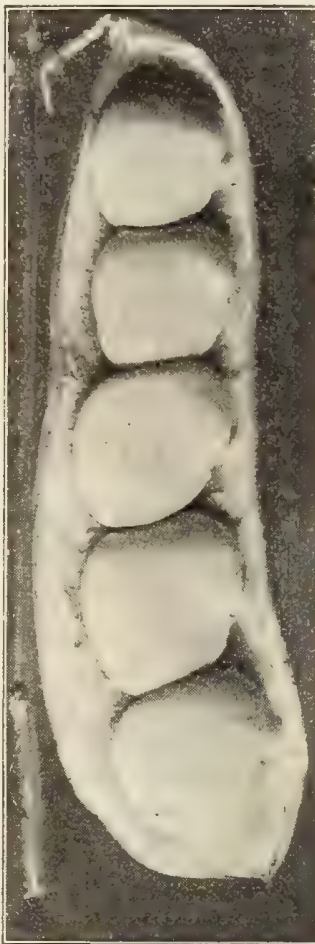

SHOTWELL'B IMPROVED THICK POLE LIMA BEAN. 


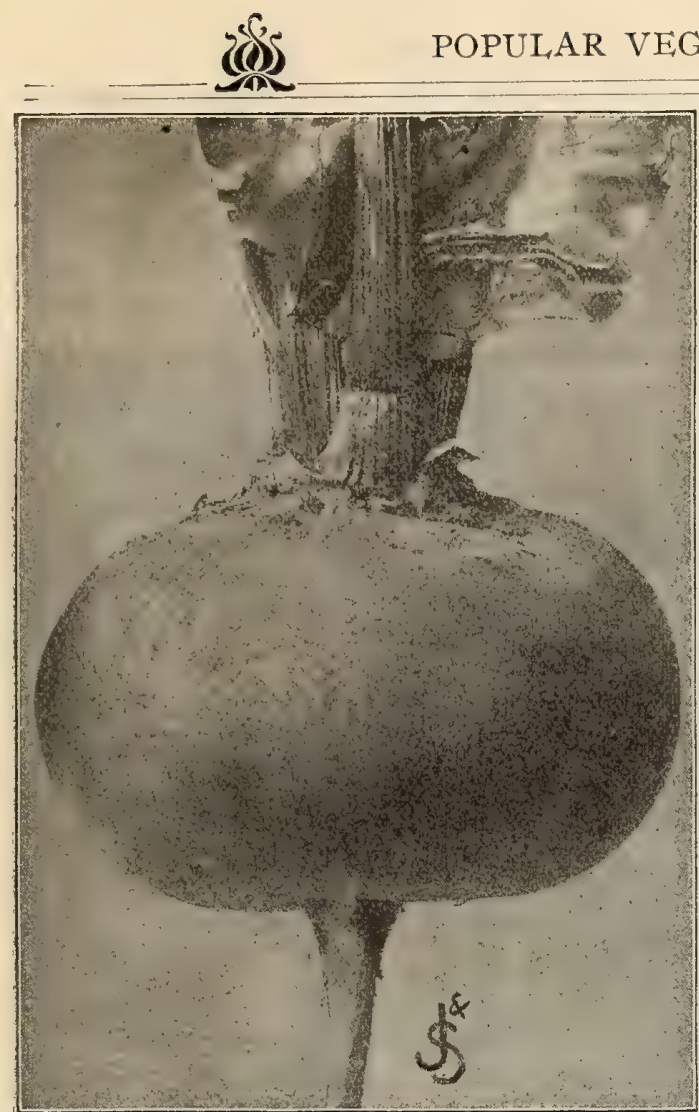

CROSBY'S IMPROVED EGYPTIAN, THE EARLIEST BEHT.

\section{CROSBY'S IMPROVED EGYPTIAN BEET}

Still in the lead as the best Extra Early Blood Turnip Beet for market or home table. 1t retains its superior quality and does not become woody and tasteless, like the old Egyptian, when allowed to stand too long, and may be sown outside as late as July. Crosby's Egyptian Beet, as originated and selected by Mr. Crosby, is a very shy seeder, and the genuine seed from seed stock grown and selected by the originator himself cannot be obtained at a lower price than here offered. Pkt., 5c.; oz., 10c.; + lb., 30c.; lb., $\$ 1.00$, postpaid; by express, 1b., 90c.; 5 lbs. and over, $85 \mathrm{c}$. per lb.

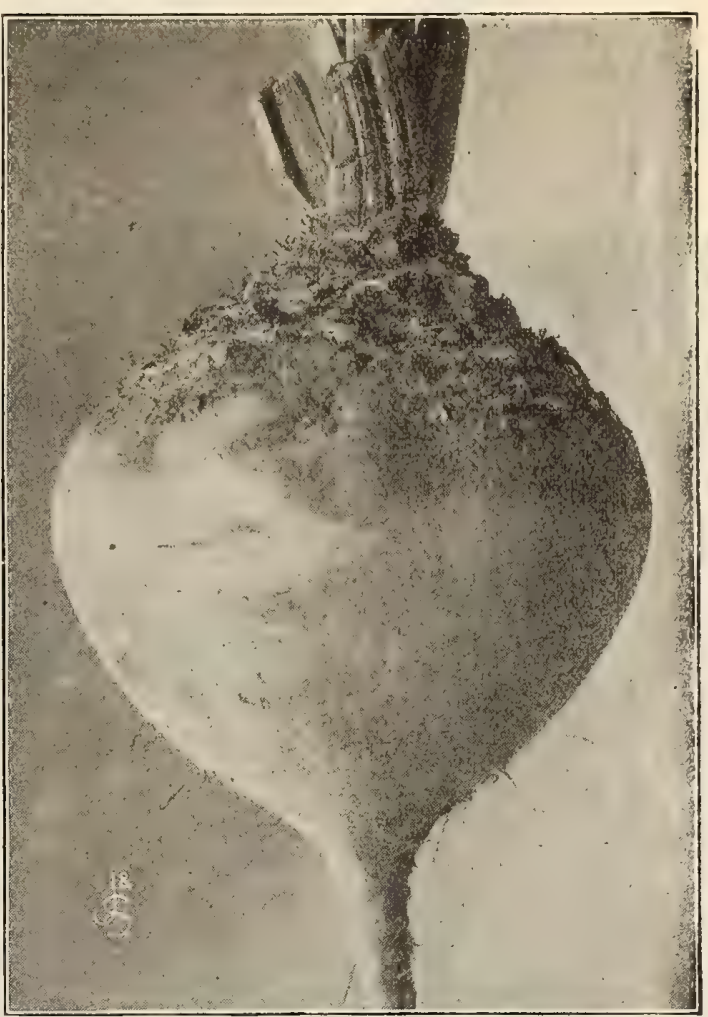

PHOTOGRAPH OF THE NEW RUBY DULCET BEET.

\section{Ruby Dulcet Beet}

We were the first seedsmen to introduce in America this valuable new beet, which is receiving the highest praise from all gardeners who have grown it. They grow to good size, very free from fibrous rootlets, with a slender tap-root, and absolutely free from stringiness. Foliage small and of a rich bronze purple. The skin and flesh are a deep, rich purplish crimson, fine grained, sweet and tender in all stages of growth. Pkt., 5c.; oz., 15c.; $\frac{1}{4} \mathrm{lb} ., 35 \mathrm{c} . ;$ lb., $\$ 1.25$.

\section{GARDEN BEETS-A Select List of the Best}

One ounce of seed will sow sixty feet of drill, five pounds will sow an acre in drills

All varieties in regular large =sized packets, at 5 c. per packet.

Lannier's Superba (Novelty 1904). Fine shape, rich red, very sweet. See page 3,

Extra Early Egyptian Blood Turnip. A standard early sort with small top.

Johnson \& Stokes' Surprise. Extra early, small top, splendid shape and color Improved Eclipse. A fine round beet of first quality; very early, greatly improved, New Meteor. Fine round shape, skin dark blood-red, flesh red, very sweet .

New Columbia. (Carter's Excelsior.) Round, smooth, deep red flesh

Arlington Favorite. Very early and handsome Blood Turnip with dark leaves Lentz Extra Early Blood Turnip. First introduced by us-original stock.

Bastian's Extra Early Blood Turnip. Very early and popular, small top

Early Bassano. Quite early, very sweet, light colored flesh, fine form

Detroit Dark Red Turnip. Of fine dark color and form; splendid for market

Dark Stinson. Very popular with Philadelphia gardeners, good for winter

Edmand's Early Red Turnip. Fine medium early, deep red, very uniform

Bastian's Half-Long Blood. One of the most popular winter keepers .

Ford's Perfected Half-Long. An improvement on the above; better shape; by far the handsomest and best half-long beet for winter use

Long Smooth Blood Red. An excellent, large, very late sort

Swiss Chard or Silver. Cultivated for leaves, which are used as greens

\begin{tabular}{|r|r|r} 
Per oz. & $1 / 4 \mathbf{l b}$. & Per lb. \\
\hline$\$ 020$ & $\$ 0 \quad 60$ & $\$ 200$ \\
10 & 20 & 50 \\
10 & 30 & 90 \\
10 & 25 & 75 \\
10 & 30 & 90 \\
10 & 20 & 65 \\
10 & 20 & 60 \\
10 & 20 & 50 \\
10 & 20 & 50 \\
10 & 20 & 50 \\
10 & 20 & 50 \\
10 & 20 & 50 \\
10 & 20 & 50 \\
10 & 20 & 50 \\
10 & 25 & 80 \\
10 & 20 & $\mathbf{5 0}$ \\
10 & 20 & $\mathbf{5 5}$ \\
\hline
\end{tabular}




\section{MANGEL=WURZEL AND SUGAR CATTLE BEETS}

We strongly recommend the Mangels and Sugar Beets for feeding to cattle, sheep and swine. The roots grow to a very large size, make a much heavier yjeld than Turnips, and are more nutritious and fattening for food during the winter, largely increasing the vield of milk in cows. They can be grown at trifling cost. The seed should be sown during A pril or Nay, in rows $2 \frac{1}{2}$ to 3 feet apart, at the rate of five pounds per acre. When the plants are 2 or 3 inches high, thin or cut out with the hoe to 10 or 12 inches apart. The roots should be harvested before frost and stored in pits or cellars.

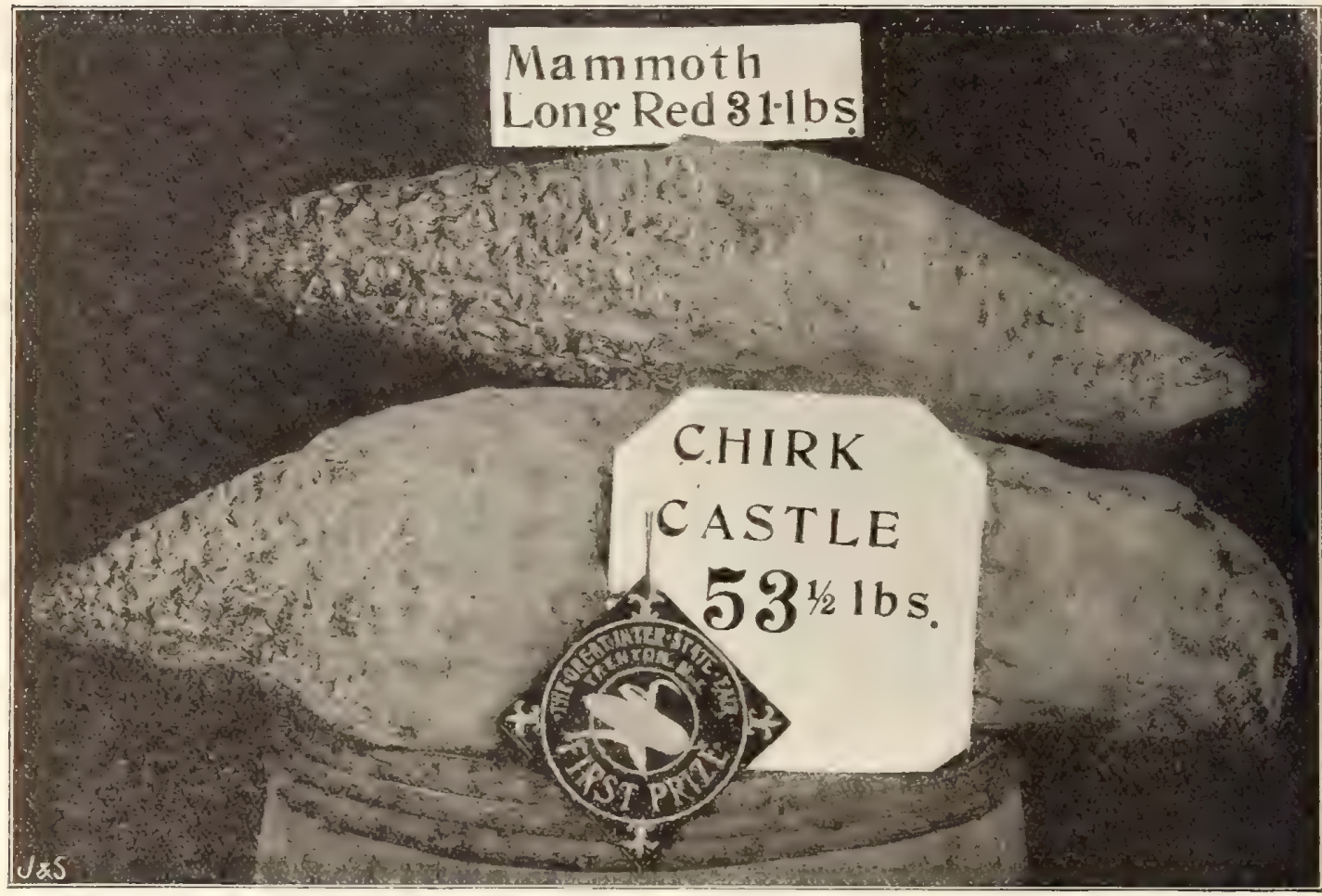

Photograph of Prfze Chirk Caetle Mangel In comparison with the largest Improved Mammoth Long Red, both specimens crow in same field, with same cutivation. We believe this specimen to be the largest Mangel ever grown in America.

\section{THE CHIRK CASTLE MANGEL-WURZEL BEET}

Remarkable for its handsome, thick, uniform shape and very broad shoulders, its diameter being greater and its weight much heavier than Mammoth Long Red, as shown in our photograph above. Flesh is deep red, containing less water and more eugar than any other Mangel, making it more nutritious and milk-producing. Sheep also thrive better when fed on it, picking out pieces of it in preference to other kinds. It was originated in Scotland, where it has been known to produce 60 tons to the acre. Plt., 10c.; oz., 15c.; J lb., 25c.; lb., 75c., postpaid; by freight or express, lb., $65 \mathrm{c} . ; 5 \mathrm{lbs}$. (enough for one acre), $\$ 3.00 ; 10$ lbs. and over at $50 \mathrm{c}$. per $1 \mathrm{~b}$.

All the following varieties of Mangel=Wurzel and Sugar Beets are put up in regular large=sized packets, each at $5 \mathrm{c}$. per packet.

If ordered to be sent by mail, add roc. per lb. for postage. When pur= chased in 5=lb. lots, 5c. per lb. may be deducted.

Mammoth Long Red Mangel. Sometimes called Jumbo, Norbitan, Giant, and Colossal. Extensively grown for stock feeding

Taber's Gate Post Mangel. The most useful, largest and best yellow, often weighing $40 \mathrm{lbs}$. and over, and producing 2,000 to 2,500 bushels to the acre

Golden Giant Intermediate (Yellow Leviathan Mangel). Grows more than half above ground; flesh white, firm, sweet

New Golden Yellow Mammoth Mangel. Form and size resembles Red Mammoth; flesh golden yellow, large and very productive

Champion Yellow or Orange Globe. Heavy cropper; succeeds on light land

Golden Tankard Mangel. Broader than Mammoth Long Red; hardy and early

Giant Half Sugar Rose. A cross of the Mammoth Red Mangel and Improved Sugar Beet, containing more sugar than other Mangels; root large, long and smooth, and of a beautiful light rose tint; fine quality and a heavy cropper

Improved Klein Wanzleben Sugar Beet. Possesses the highest sugar-producing qualities. A very fine and shapely root

Lane's Improved Imperial. An improvement on the French Sugar Beet. Hardier, more productive, yielding thirty-five to forty tons per acre

Red Top White Sugar Beet. The old variety, largely grown for stock feeding

\begin{tabular}{|c|c|c|}
\hline Per oz. & $1 / 4 \mathrm{Jb}$ & Per Ib \\
\hline$\$ 010$ & $\$ 015$ & $\$ 030$ \\
\hline 10 & 20 & 50 \\
\hline 10 & 15 & 30 \\
\hline 10 & 20 & 45 \\
\hline 10 & 15 & 30 \\
\hline 10 & 15 & 30 \\
\hline 10 & 20 & 45 \\
\hline 10 & 15 & 30 \\
\hline 10 & 15 & 30 \\
\hline 10 & 15 & 30 \\
\hline
\end{tabular}




\section{Figh-Bred American Srown Cabbage Seed}

To gardeners generally no vegetable is of greater importance than the cabbage; and to many growers the success or failure of this crop means gain or loss for the year. It does not pay, therefore, to take any risks in buying seed. Much of the seed commonly sold has not had the great care necessary in growing to make it reliable. Our Cabbage Seed is the very best that can be grown, raised only from the centre shoots and from carefully selected solid heads. Our crops are all personally inspected with untiring care and watchfulness. As a standing evidence of its quality, we annually supply hundreds of the best marketgardeners about Philadelphia, New York, Chicagọ and other large cities.

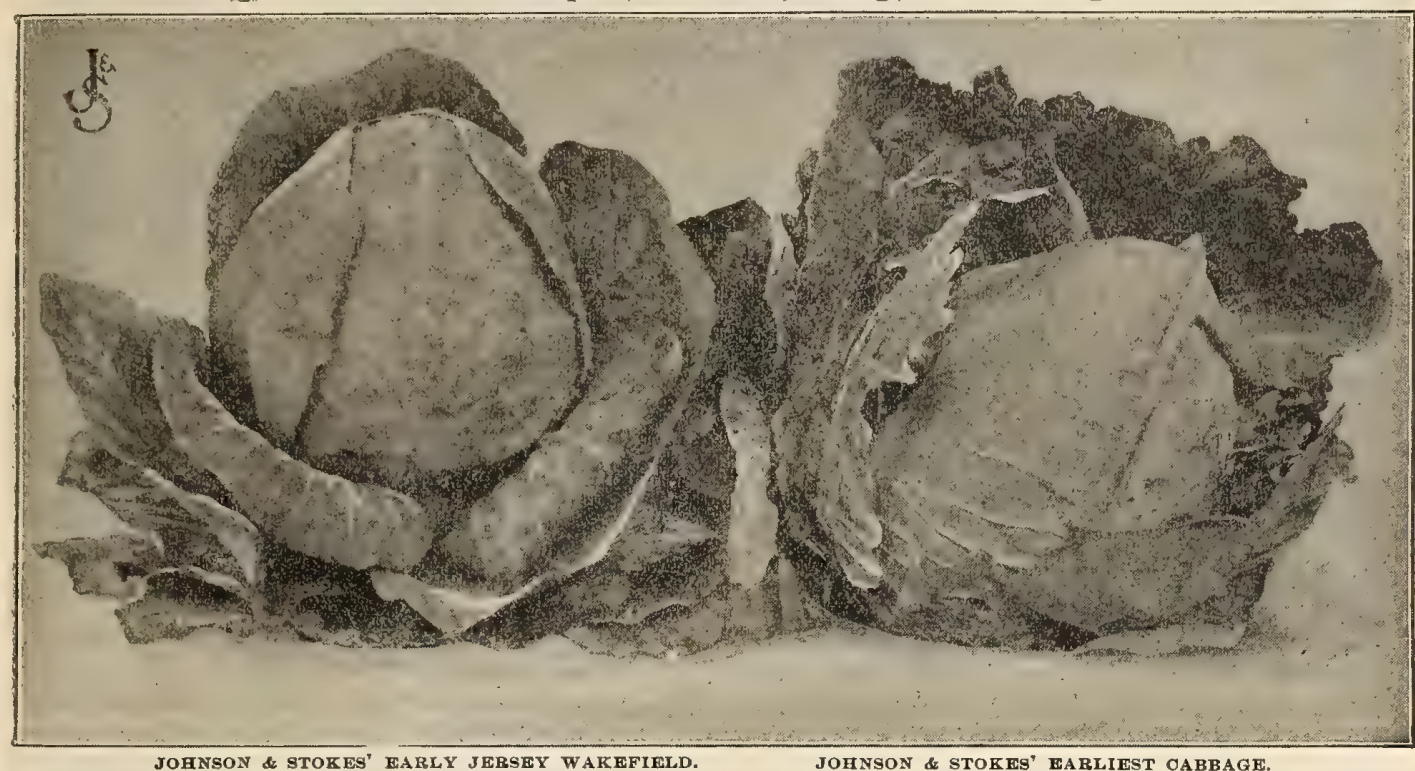

\section{JOHNSON $\epsilon_{f}$ STOKES' EARLIEST of The Earliest and Hardest Heading}

No words of praise can be written that would recommend this most desirable cabbage too highly. It is to-day more largely planted by market and private gardeners than any other first early cabbage.

It is ten days earlier than Early Jersey Wakefield, and is unsurpassed in fine quality, great beauty and vigor of growth. The heads are slightly conical, large, solid and remarkably uniform in growth. Prices, pkt., 15c.; oz., 45c.; $\frac{1}{4}$ lb., $\$ 1.25$; lb., $\$ 4.50 ; 2$ lbs., $\$ 850 ; 5$ lbs. and over, $\$ 4.00$ per lb.

\section{Johnson \& Stokes' Selected Early Jersey Wakefield Cabbage}

While this sort is not so early as Johnson \& Stokes' Earliest, it will be found to be the very best conical headed sort to come in immediately after it. It heads up remarkably hard and solid, with but few outside leaves, which are unusually thick and heavy, enabling it to stand cold weather without injury when carried through the winter either in the open ground in the South or in cold frames in the North. Pkt., 10c.; oz., 25c.; $\frac{1}{4}$ lb., 75c.; lb., \$2.50.

\section{An Ideal List of Early and Summer CABBAGES}

Large packets of following varieties, 10 cents each, except where noted :

Earliest Etampes. An extra early small French sort, with pointed heads ; pkt:, $5 c$., Extra Early Express. Earliest of French cabbages; small pointed heads; pkt., 5c., Wonderful. One of the earliest American sorts ; heads small and loose

Early Spring. A new round, flat-headed cabbage, as early as Jersey Wakefield, Charleston or Large Wakefleld. A bout a week later than Jersey Wakefield

Foremost German. (Novelty 1901.) Very handsome; matures early, with fine large solid white heads; the best foreign cabbage ever introduced in America,

Early Winningstadt. (Grown from Prussian Prize Stock.) Those intending to plant this variety will find our strain far superior in earliness, size and solidity,

Earfy Winningstadt. Best imported seed as generally sold by others ; pkt., 5c., All Head Early. A flat head, coming in with Early Summer; much larger Early Flat Dutch. We offer a remarkably fine strain; a sure solid header

Henderson's Early Summer. A most popular and superior second early sort .

All Seasons (Vandergaw). One of the finest, growing to a large size quickly

Henderson's Succession. An excellent second early; on style of All Seasons

Louisville Early Drumhead. Dark, bluish-green color; popular in the southwest,

Fottler's Improved Flat Brunswick. Large, solid hearls ; fine for early or late,

\begin{tabular}{|c|c|c|}
\hline Рer oz. & $1 / 4 \mathrm{lb}$. & Per lb \\
\hline$\$ 015$ & $\$ 040$ & $\$ 140$ \\
\hline 15 & 45 & \\
\hline 30 & 85 & 300 \\
\hline 20 & 65 & 2 \\
\hline 25 & 75 & \\
\hline 30 & 85 & 300 \\
\hline 20 & 60 & 2 \\
\hline 15 & 40 & 14 \\
\hline 20 & 60 & 2 \\
\hline 20 & 60 & 2 \\
\hline 20 & 65 & \\
\hline 20 & 60 & \\
\hline 20 & 65 & 2 \\
\hline 20 & 50 & 1 \\
\hline 20 & 50 & 1 \\
\hline
\end{tabular}




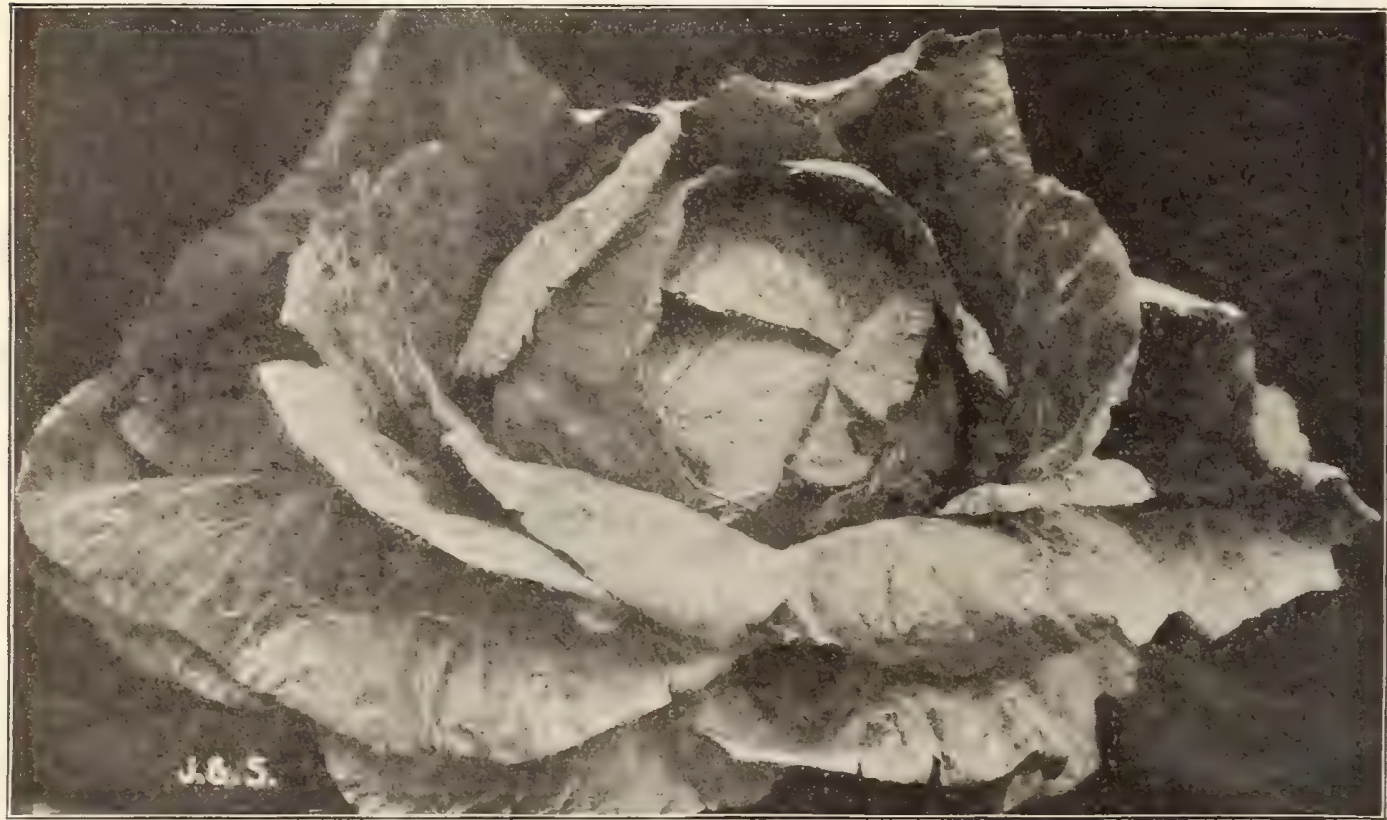

JOHNSON \& STOKE' MARKET GARDENERS' XO, 2, THE MO8T PERFECT CABBAGE IN EXISTENCE,

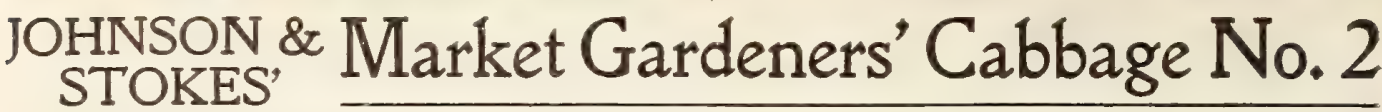

A Flat-Headed Cabbage, Coming in with Wakefield and Producing Double the Crop of any other Extra Early

In this, the most pe fert and uniform cabbage in existence, we have also the earliest and most compact of all large. cubbages. It receives nothing but praise from Maine to California, and is pronounced by prominent gardeners everywhere the very best of all large early cabbages, either for Summer or Winter use. In it we have a cabbage so hardy and vigorous that it can be set earlier than Jersey Wakefield or Early Summer, and will produce fine, solid, marketable heads, more than twice as large as Jersey Wakefield and one-half again as large as Early Summer and comes in as early as Large Wakefield atd fully a meek earlier than Early Summer or any other variety of its size or class. When planted for a Fall or. Winter crop there is no other cabbage which will withstand the Sunmer sun so well and is so sure to form large, deep, solid heads which keep perfectly all Winter. Choicest seed of our own selection and growth: Pkt., 15c.; oz., 45c.; 童 lb., $\$ 1.25 ; 1 \mathrm{~b} ., \$ 4.50 ; 5 \mathrm{lbs}$. and over, $\$ 4.00$ per lb.

\section{Johnson \& Stokes' Quick-Cash Cabbage}

The Earliest and Hardiest Flat-Headed Cabbage. See Novelties, Page 4

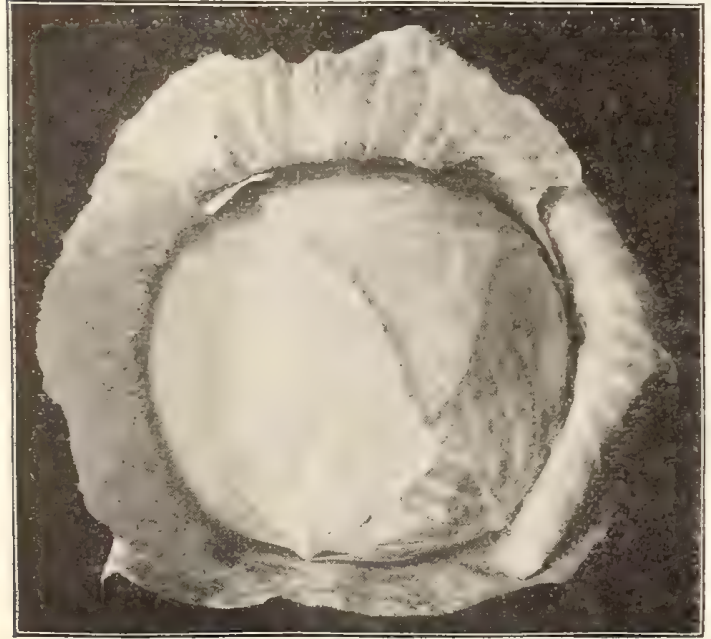

DANGH BALL-HEAD CABBAGE.

\section{DANISH BALL=HEAD CABBAGE}

Genuine Seed Grown by Originator in Denmark

An extremely hardy imported cabbage, which is growing in popularity in America, having proven one of our best Winter sorts. It thrives well on thin soils and in highly exposed situations. The heads are of good marketable size, not quite so large as Flat Dutch, but very hard, round, fine grained, and will weigh one-fourth more than other varieties of equal size. Pkt., 10c.; oz., 20c.; $\frac{1}{4}$ lb., $65 \mathrm{c}$; 1 lb., $\$ 2.25 ; 2 \mathrm{Ibs}$. for $\$ 4.00$.

\section{NEW EARLY \\ DANISH ROUND=HEAD CABBAGE}

A new strain of the popular Danish Ball= Head Cabbage, with heads fully as large and solid, maturing about ten days earlier. The stem is shorter, while the hardness of heads is really marvelous. We offer seed grown for us by the introducer, in Denmark: Pkt., 10c.; oz., 30c.; $\frac{1}{4}$ lb., $85 \mathrm{c}$.; lb., $\$ 3.00$. 


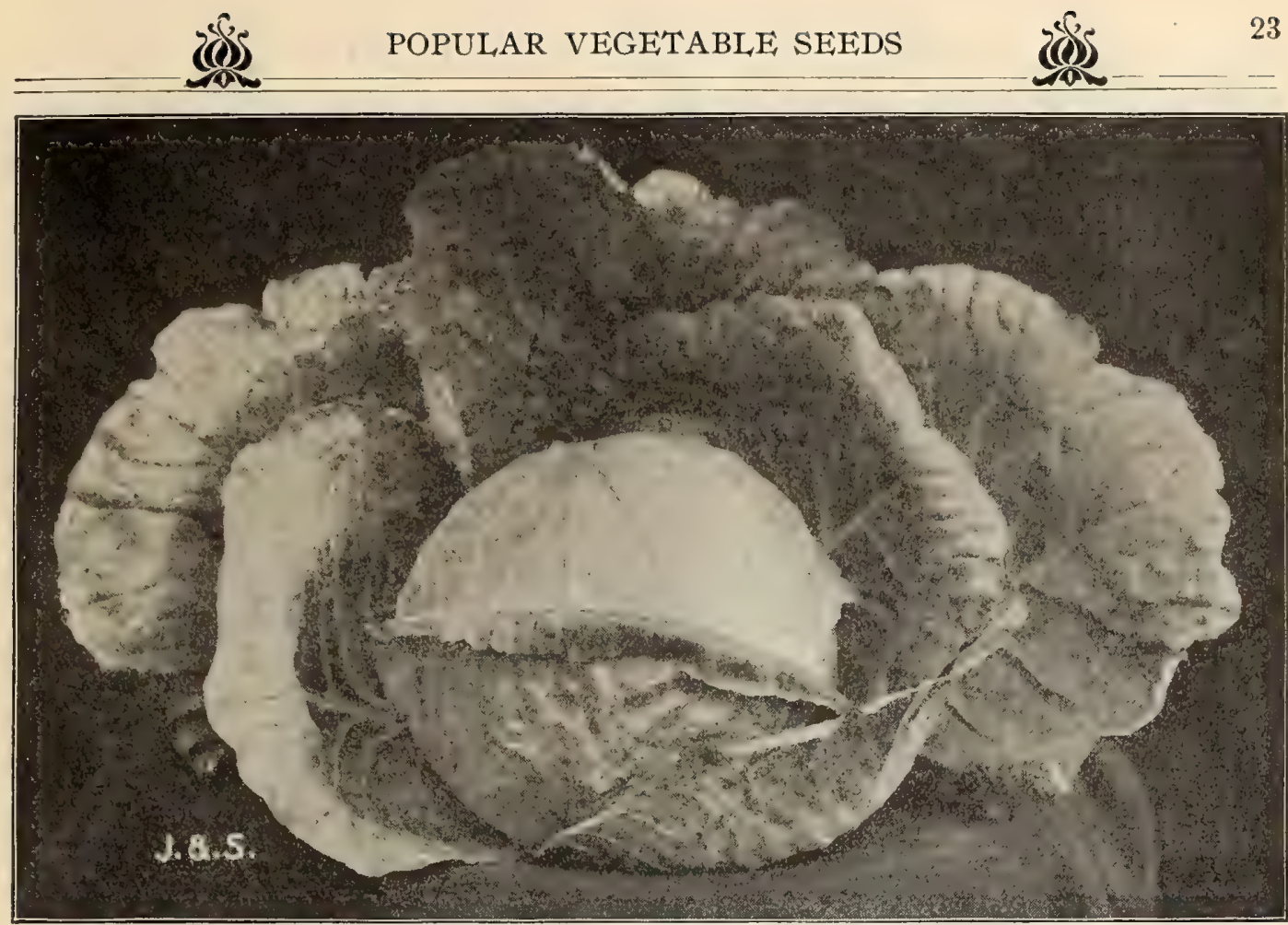

LOUDERBACK'S ALL, THE YEAR ROUND CABBAGE.-Unflagging under the hottest sun or heaviest frost.

\section{Louderback's All the Year Round Cabbage}

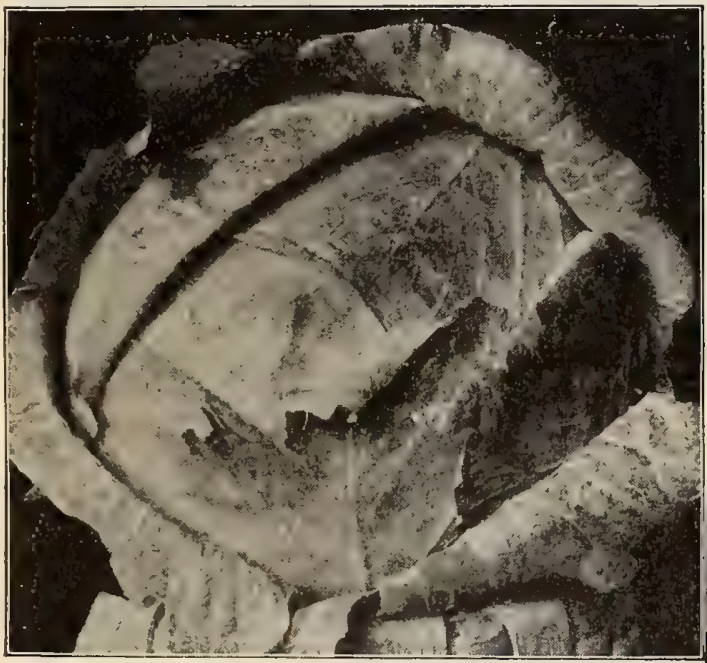

AN AVERAGE FEAD OF HOUSER CARBAGE.

\section{The Houser Cabbage}

This new cabbage originated near Harrisburg with the successful market gardener whose name it bears. Mr. J. M. Lupton, the noted cabbage seed grower of Iong Island, writes of it as follows: "The Houser Cabbage is entirely distinet from anything I have ever grown or anything now on the market. It is fully two weeks later than other sorts and a very hard header. It is a first-class keeper, retaining its color to a marked degree." Pkt., 10c.; oz., 30c.; $\frac{1}{4}$ lb., 85c.; 1b., $\$ 3.00$.
This cabbage, originated by Daniel Louderback, has for many years been the standard early roundheaded cabbage with Philadelphia gardeners, who prefer it to Early Summer and similar sorts, the originator frequently getting as high as $\$ 10.00$ per pound for his seed. It is not only the finest early Drumhead in cultivation, but is equally as good for second and third early, intermediate and late. Heading large, compact and solid at all seasons. Pkt., 10c.; oz., 30c.; $\frac{1}{4}$ Ib., 75c.; lb., $\$ 2.75$.

Johnson \& Stokes' Hard Heading Savoy

The best and most profitable strain to grow, being far superior to the Imported Drumhead Savoy, as generally eold, the seed of which can be supplied at less than half the price. The heads are large, very uniform, solid and of deep green color. Pkt., 10c.; oz., 30c.; $\frac{1}{4}$ lb., 75c.; lb., $\$ 2.75$.

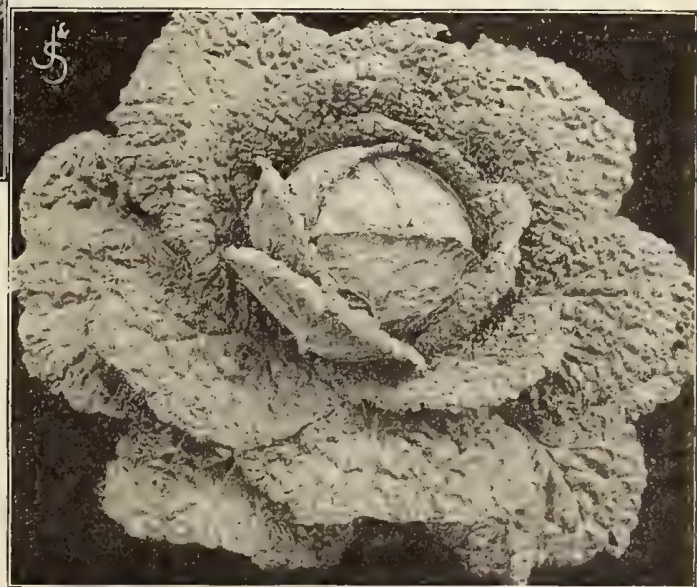

JOHNSON \& STOKES' HARD HEADING BAYOY 'ABBAGE. 


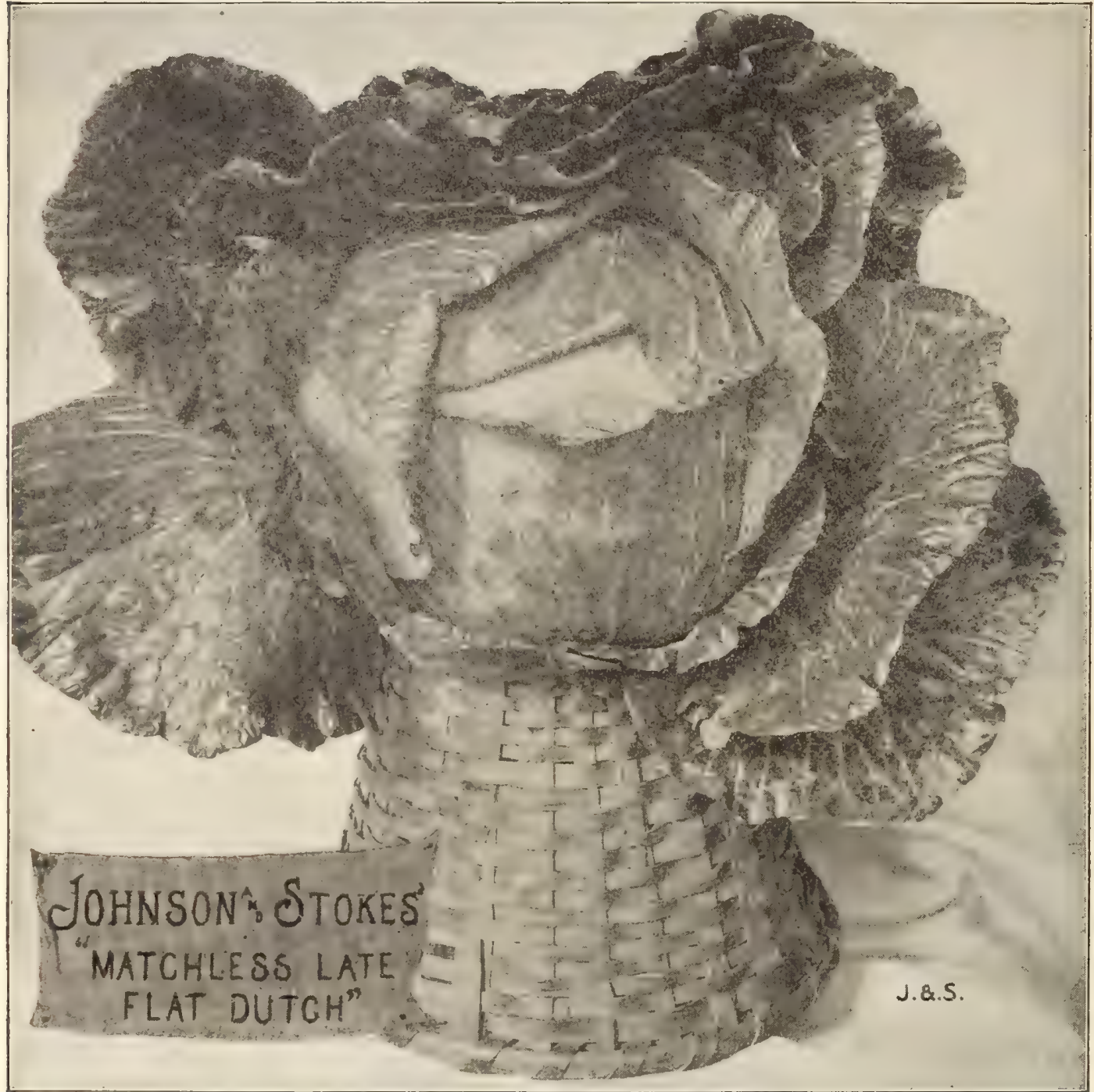

\section{Johnson \& Stokes' Matchless Late Flat Dutch Cabbage}

The largest, handsomest, most uniform and solidest of all late sorts, pronounced by experienced cabbage growers the finest strain of late cabbage in the world. Pkt., 10c.; oz., 25c.; $\frac{1}{4} 1 \mathrm{~b} ., 75 \mathrm{c}$; $1 \mathrm{lb} ., \$ 2.50$.

\section{An Ideal List of Standard Late or Winter CABBAGES} All varieties in regular large-sized packets at roc. per packet.

Surehead. (Original seed.) Strong, vigorous; very uniform ; large and solid Rockhead Winter. Large, perfect shape, sure header and long keeper.

Worm=proof Hardiana (Novelty 1904). See illustration and description, page 5, Autumn King, or World Beater. A new strain; enormous solid heads

The Lupton. Earlier than Flat Dutch; of closer growth ; a large sure header Hollander, or German Export. Heads solid; medium size : white; very distinct, Diamond Winter. Heads extra hard and solid, somewhat flattened; medium . . Carolina Hard Header. Large, round, solid heads; popular in the South . . . . Short Stem Drumhead. Surpasses the old Late Drumbead, ripening earlier. Large Late Drumhead. Old favorite winter sort; valuable for main crop . . . . Premium Flat Dutch. Largely grown for main crop; a favorite for winter market, Long Island Colossal Savoy. New, large, hard heads of finest quality

Perfection Drumhead Savoy. Large, loose heads, nearly round ; fine quality . Improved Red Dutch Erfurt. Tery hard heads ; deep blood color ; for pickling, Mammoth Red Rock. Largest, hardest heading and best red cabbage

\begin{tabular}{|c|c|c|}
\hline Peroz. & $1 / 4 \mathbf{l b}$ & Per 1 \\
\hline $\begin{array}{r}\$ 0 \\
20 \\
30 \\
70 \\
20 \\
20 \\
20 \\
30 \\
25 \\
20 \\
15 \\
15 \\
35 \\
20 \\
20 \\
20\end{array}$ & $\begin{array}{r}\$ 050 \\
\quad 75 \\
2 \quad 25 \\
60 \\
60 \\
60 \\
60 \\
75 \\
\\
75 \\
60 \\
40 \\
40 \\
100 \\
100 \\
50 \\
50 \\
60\end{array}$ & $\begin{array}{rr}\$ 1 & 75 \\
2 & 75 \\
8 & 00 \\
2 & 00 \\
2 & 00 \\
2 & 00 \\
2 & 75 \\
2 & 50 \\
2 & 00 \\
1 & 40 \\
1 & 40 \\
3 & 50 \\
1 & 75 \\
1 & 75 \\
2 & 00\end{array}$ \\
\hline
\end{tabular}




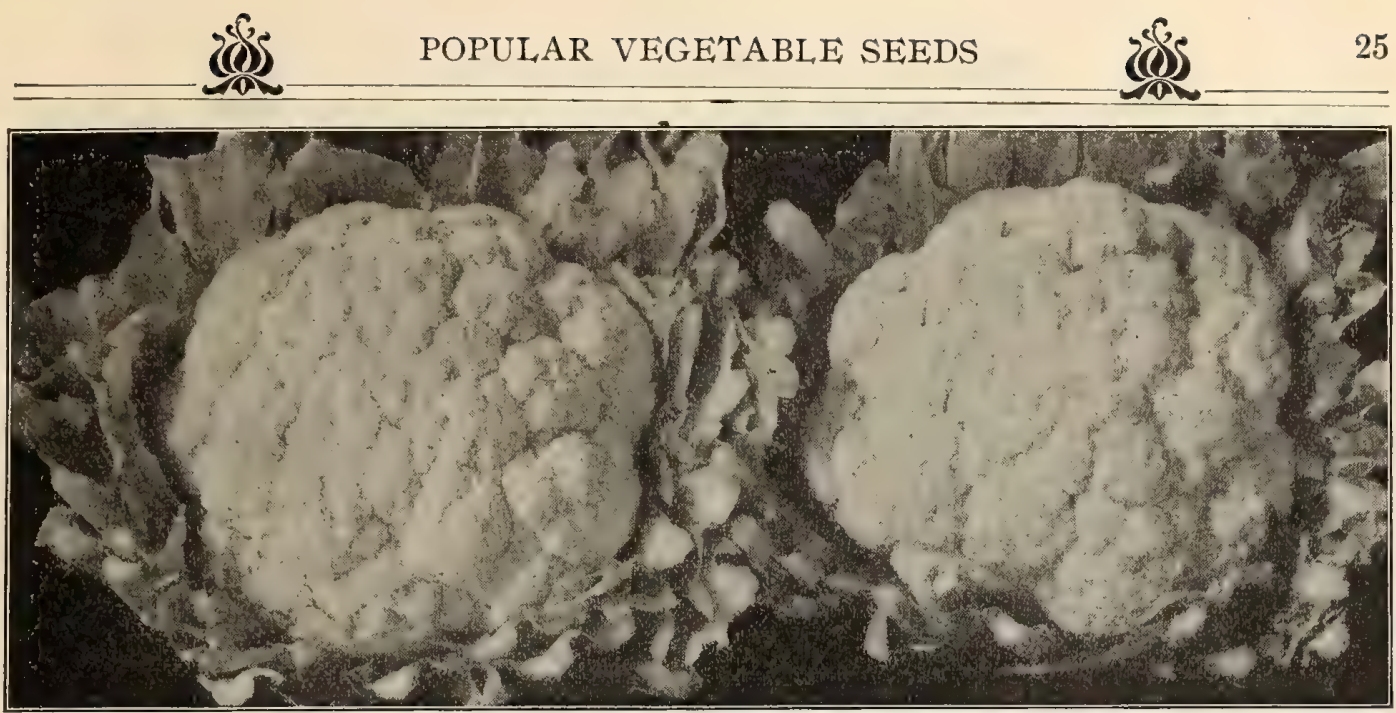

PHOTOGRAPE OF TWO AVERAGE HEADS OF JOHNSON \& STOKIE' EARLY ALABASTER OAULIFLOW RR TRIMMED FOB MARKET.

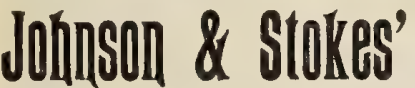

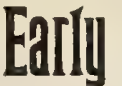 \\ Hlabaster Gaulifíower \\ EARLIEST OF ALL EASIEST GROWN
SUREST HEADER}

This is not only the earliest, but is the finest cauliflower in the world, and it is so pronounced by all growers who have had it. It is of very dwarf, erect habit, with short outer leaves. Can be planted less than two feet apart each way. It succeeds everywhere, is a sure header, every plant forming a large, solid, perfect head, of the finest table quality. Our seed of the Early Alabaster is American grown, thoroughly acclimated, and from it a crop of cauliflower can be grown as easily as a crop of cabbage, and with greater profit. Pkt., $25 \mathrm{c}$.; 5 pkts., $\$ 1.00 ; \frac{1}{2}$ oz., $\$ 2.50 ;$ oz., $\$ 5.00 ; \frac{1}{4} 1$ lb. $\$ 16.00$.

\section{CAULIFLOWER}

One ounce will produce about fifteen hundred plants and sow about forty square feet. Onehalf ounces and one-half pounds furnished at ounce and pound rates.

Gilt Edge Early Snowball. Extra fine stock. For forcing under glass during Winter and early Spring, or for planting later in the open ground, no stock of Snowball can surpass it

Extra Early Dwarf Erfurt (Extra Selected). For forcing or open ground Denmark, or Dry Weather. Almost as early as Snowball, with larger heads ; sucreeds every where; finest imported Danish seed

Extra Early Paris. Heads of medium size; first-class, sure header

Lenormand Short Stem. Has very large heads; white, firm and late

Large Algiers. Market gardeners' popular late sort; enormous size

Veitch's Autumn Giant. Vigorous in growth, very large and late .

\section{BRUSSELS SPROUTS}

A Miniature Cabbage Growing on Stalks, Equal to Cauliflower in Flavor

If more widely known, the Brussels Sprout would be as popular as it is valuable; few people appreciate its full worth as a Winter vegètuble.

It is hardier than cahbage and not the least affected by frost.

I M P R O V D HALE-DWA RF, or PARES MARKET. The most productive The most productive and hardiest variety, bearing fine, hand some, solid sprouts, growing closely on the stalk and of finest quality. Pkt., 5c; oz., $15 \mathrm{c}$.; $1 / 2$ 1b., 45e.; 1b., $\$ 1.60$.

LONG ISLAND gTRAIN. Compact sprouts, largely grown sprouts, largely grown Pkt, 10c.; oz., 25c.; 1/4 Pkt., 10c; oz., 25c;
lb., 70c; lb., $\$ 2.40$.

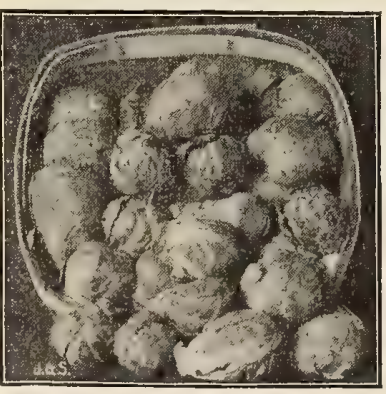

BRUSSELS SPROUTS.

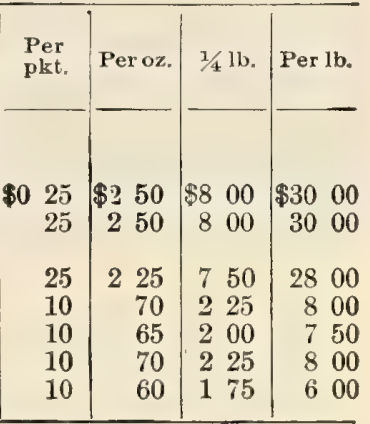

\section{CHICORY}

The roots dug in the Fall, dried, cut in thin slices, roasted and ground, are used largely as a substitute for coffee. 'The leaves make a good Spring salad.

LARGE ROOTED, or COFFEE. The chicory of commerce; the best. Pkt., 5c.; oz., 10c.; $1 / 4$ lb., 20c.; 1b., 60 c.

\section{CHIVES}

Chives are very hardy and perennial members of the onion family. They are grown exclusively for their tous. Planted in clumps in any garden soil, they grow readily, and increase so as to render a division necessary. The tops appear very early in Spring, and can be cut througliout the season. Roots, per bunch, 25c. by mail, postpaid.

\section{COLLARDS (COLEWORT)}

Collards are largely used as "greens" in some parts of the country, especially South. They are a form of the cab. bage, bearing new leaves as the old ones are pulled off.

JOHNSON \& STOKES' EVERGREEN VELVET LAWN SEED MIXTURE

is the Best Lawn Grass Seed for the American Climate. With it you can renovate old and make new lawns, grass plots, tennis courts, golf links, etc., as soft as velvet and as green as emerald, insuring a beautiful, dwarf, green, compact sward, remaining green and fresh throughout the season. See page 66. Quart, 20c.; 2 quarts, 35c. (qt., postpaid, 25c.); peck, $\$ 1.00$; bushel, 20 lbs., $\$ 4.00$. 


\section{The Three Best Carrots for Market or Home Garden}

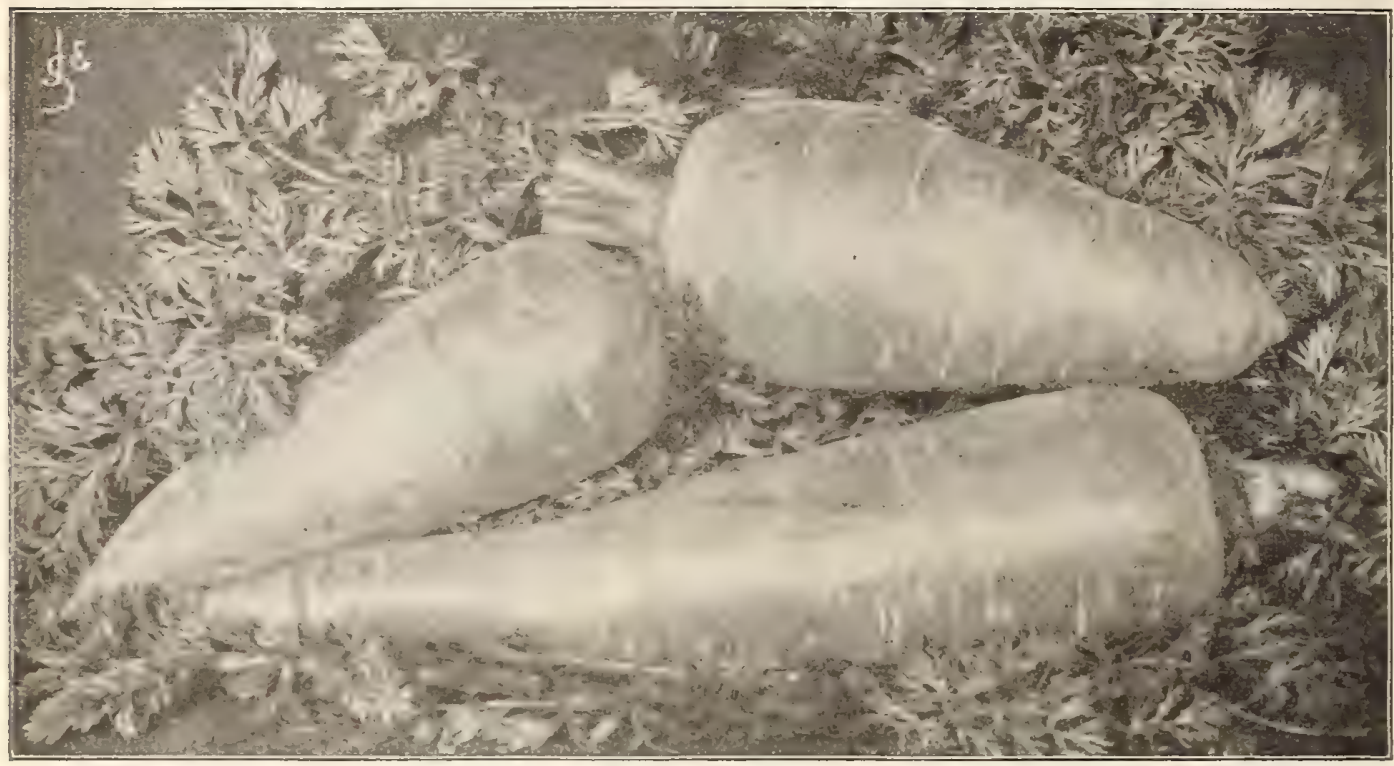

IMPROVED DANVERS.

NICEOLS' LONG ORANGE.

RUBYCON HALF-LONG.

\section{CARROTS-For the Table and Stock Feeding.}

One ounce will sow about one hundred and twenty-fire feet of drill; four pounds will sow an acre.

All varieties in regular large=sized packets at $5 \mathrm{c}$. per packet.

Rubicon Half=Long Orange. The best and most popular half-long carrot. Earlier than Danvers, heavier and thicker at the shoulders, as shown in our photograph above, making it more productive ; the leaves are also shorter and finer. A wonderfully heavy cropper, producing 30 to 40 tons to the acre under good culture (5 lbs, and over, $\$ 1.00$ per $1 \mathrm{~b}$., by freight or express)

Improved Danvers. (Improved American strain.) Top small; color rich orange; shape, handsome and smooth; superior quality; valuable also to grow for feeding stock, being well adapted to all soils ( 5 lbs. for $\$ 3.50$ by express),

Nichols' Long Orange. Much earlier than the old Long Orange, with shorter top; color deep golden orange when young, shading to a deep orange red when fully grown. Perfectly smooth and grows without neck (5 lbs. and over, $\$ 1.00$ per lb., by express or freight)

Early Scarlet Horn. (Shoit Horn.) Old standard and favorite early cort . .

Ox-Heart, or Guerande. Early, short, thick, very smooth and handsome . .

Early Half=Long Scarlet, Pointed. Tery productive and handsome, fine quality,

New French Market. (French seed.) Fine deep orange color, beautiful, smooth, distinct, half-long shape, free from core. Heavy cropper and a great keeper, Chantenay. (Stump-rooted.) Similar to the old French Nantes carrot

Saint Vallery, or Intermediate Red. Rich red color, late, thick and smooth Long Orange. (Improved.) Well-known standard sort (5 lbs., \$3.00, by express)

Large White Belgian. For cattle feeding ; very productive and large . . . .

Large Yellow Belgian. Differing from above in color; a fine late keeper

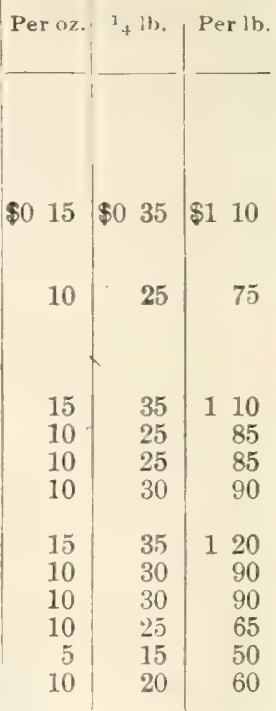

\section{SPECIAL GRASS SEED MIXTURES FOR PASTURES AND MOWING LANDS} SOW TWO AND ONE=HALF BUSHELS TO THE ACRE

Johnson \& Stokes' No. I Mixture for Permanent Pasture.-Contains, blended in proper proportions for the purpose, the following grasses: Orchard Grass, Sheep's Fescue, Meadow Fescue, Hard Fescue, Canadian Blue, sweet Vernal, Meadow Foxtail, Tall Meadow Oat, Red Top, Kentucky Blue, Italian Rye (irass, Perennial Rve Grass, Rbode Island Bent, Timothy, Wood MIeadow, Rough-Stalked Meadow, Alsike Clover, White Clover, Mammoth Clover. Bushel, \$2.50; 10 bushels, \$22.50, sacks included. Johnson \& Stokes No. 2 Mixture for Permanent Mowing.-Contains, properly blended, according to condition of soil and climate: Red Top, Perennial Rye Grass, Orchard Grass, Timothy, Red Clover, Mammoth Clover, White Clover, Fine-Leaved Fescue, Rhode Island Bent, Rough-Stalked Meadow, Meadow Fescue, Meadow Foxtail. Bushel, $\$ 2.50 ; 10$ bushels, $\$ 22.50$, sacks included. 


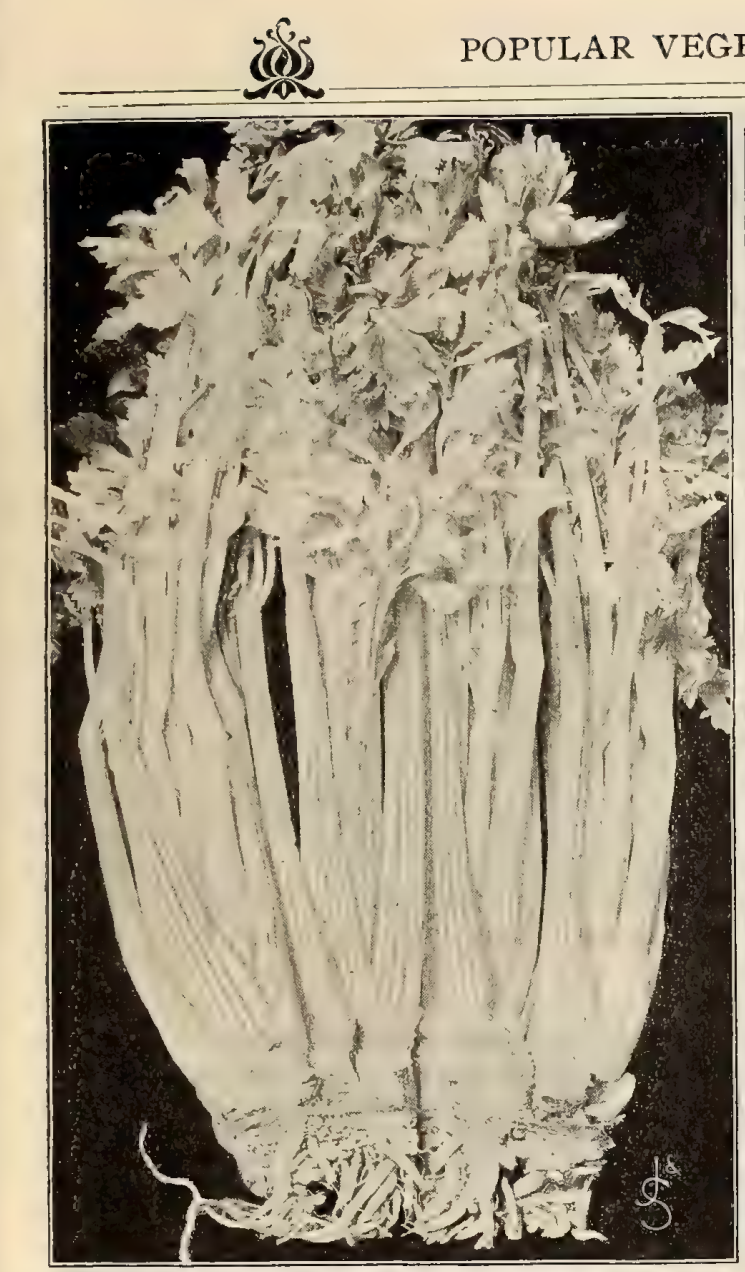

PARIS GOLDEN SELF-BLANOHING CELERY. (From French Seed,

\section{Paris Golden Self-Blanching Celery}

\section{Seed Grown in France by the Originator}

While we have annually had contracts with the originator of this grand celery in France, this is the first season we have been able to secure a good supply from this source. Market gardeners generally prefer the French-grown seed when obtainable. It is very early; entirely self-blanching, with large beautiful golden yellow heart; very crisp, solid and nutty. Pkt., 10e.; oz., 40e.; 1/4 Jb., \$1.15; 1b., \$4.00.

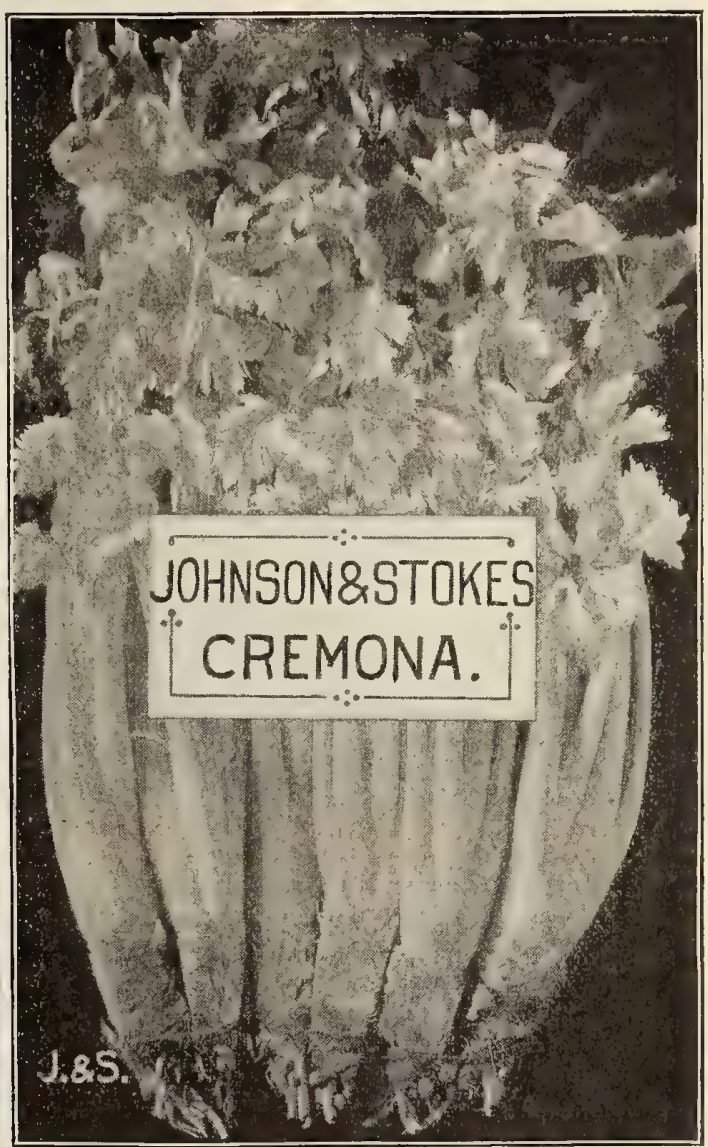

JOHNSON \& STOKES' NEW CREMONA. Trimmed for Market.

Johnson \& Stokes' Cremona Celery

The Best Late Keeping Winter Celery

A sport from our Winter Queen; established by five yearg' careful selection, partaking of all its best qualities, much handsomer in color and form, bleaching more quickly requiring only about five or six days, and with but slight earthing up. Stalks are broad, thick, crisp and of superior flavor. It is the best late celery, being unsurpassed as a long keeper. Pkt., 15c.; oz., 45e.; 1/4 1b., \$1.25; 1b., 84.50 .

\section{The Best of the Standard CELERIES}

One ounce will produce about twenty-five hundred plants and sow about two hundred feet of row.

Large packets, ro cents each, except where noted.

Perfected White Plume. Very early and extensively grown for market. Our extra selected and perfected market garden strain is entirely free from green celery found in most other strains of this important market sort; pkt., 5c. . . Myer's Quick Growing White Plume. See Novelties, page 6

Johnson \& Stokes' Golden Self=Blanching (Am=rican Seed.) Pronounced by many growers the most profitable celery in cultivation, and many gardeners are now planting their entire crops with our superior strain of th is variety,

Rose Ribbed Golden Self=Blanching (Golden Rose). Ribs assume a rosy hue,

Giant Pascal. Popular green sort, very brittle, crisp and nutty in flavor; pkt., 5c.

Winter Queen. The best late or winter keeper. Stouter, thicker, heavier and containing more heart than any other celery. Ribs thick and very solid

Perle le Grand. A new, large, green celery, for early and late use ; pkt., 5c.

Golden Dwarf or Golden Heart. Fine, large, solid, waxy-golden heart; pkt., 5c.

Perfection Heartwell. Large heart; superior quality; excellent for winter; pkt., 5c.,

Schumacher. Immense size ; solid, crisp ; firm golden-yellow heart

Fin de Siecle. A fine selection from Schumacher; fine keeper and shipper

Far Superior Many Heart. New late celery; fine keeper

Evans' Triumph. A new large, solid green variety; very large ribs; pkt., 5c., Giant White Solid. Of tall, large size; very solid, pure white; pkt., $5 \mathrm{c}$.

Soup or Flavoring Celery. (Old Seed.) Used for flavoring soups, stews, etc.

CELERIAC, or Turnip=Rooted Celery. Extra Large Smooth Prague. Pkt., 5c.

Per oz. 1/4 1b. Per lb. Per oz. 1/4 16. Per $11 \mathrm{~b}$ $\$ 020 \$ 060 \quad \$ 200$ \begin{tabular}{l|ll|rr}
45 & 1 & 25 & 4 & 50
\end{tabular}

$35 \quad 100 \quad 350$

$\begin{array}{lllll}30 & 85 & 3 & 00\end{array}$

$15 \quad 40 \quad 150$

$35 \quad 100 \quad 350$

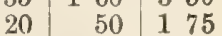

$15 \quad 40 \quad 150$

$20 \quad 50 \quad 175$

$25 \quad 75 \quad 250$

$\begin{array}{lll}25 & 75 & 275\end{array}$

$\begin{array}{lllll}25 & 75 & 2 & 50\end{array}$

\begin{tabular}{l|l|l|l}
15 & 40 & 1 & 50
\end{tabular}

$15 \quad 40 \quad 150$

5 | 10 - 25

\begin{tabular}{l|l|l|l}
20 & 50 & 175
\end{tabular}




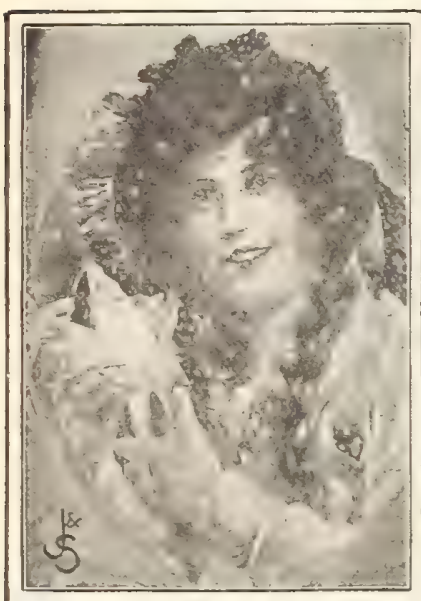

Holmes' Premo Sw'eet Corn

A very valuable new extra early variety, giving boiling ears in 60 days from planting. See Novelties, page 6 . Pkt. , 10c.; pint, 25c.; qt., 40c. postpaid; by express, qt., 30c.; peck, $\$ 2.00$.

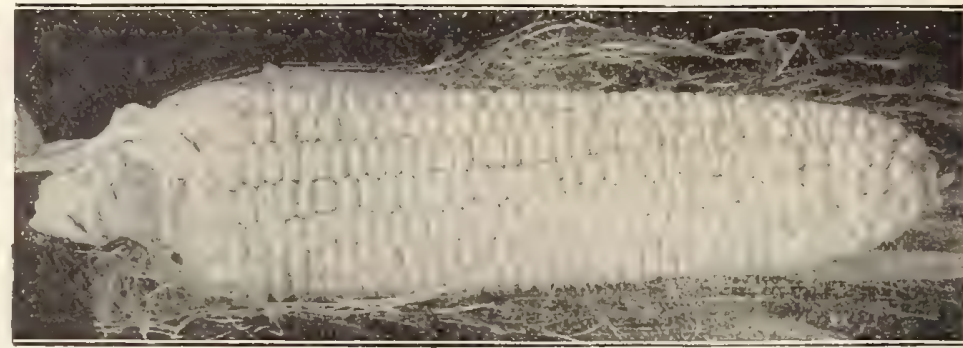

AN EAR OF NEW BUCK MOUNTTAN IY PROPER CONDITION FOR ROILISG.

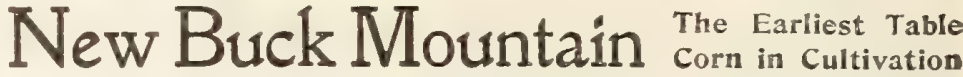

This valuable new table corn was originated at Stamfort, Conn., where it has been monopolized by a few large sweet corn growers, who have nade large profits in growing it for New York, Boston anıl other principal Eastern markets. In general apnearance it resembles the celebrated Burlington $\mathrm{Hybrid}$, first introduced by us severd rears ago, the grain being smooth and of a creamy white color; the ears, however, are not quite so large, but it is ready for the table a week earlier, making it decidedly the earliest table corn in cultivation. It is also ex. tremely hardy, and can be planted with safety two or three weeks before any of the early sugar corns, and if pulled when young is very tender, sweet anil juicy. The stalks grow five feet in neight, and when on good ground give two to four good ears. Pkt., 10c.; pint, 25c.; qt., 45c., by mail, postage paid; by express or freight, qt., 35c.; peck, $\$ 1.50$; bush., $\$ 5.50$.

\section{Selected Strains of SWEET CORN-Eastern Grown Seed}

One quart will plant about two hundred hills, and one peck is required to plant an acre in hills.

SPECIAL NOTICE. In 25 years' experience growing Seeds, we have never known so near a complete crop failure as that of Seed Sweet Corn in 1903 . The great amount of cold, wet weather in the East, where the best seed is grown, shortened the crop very materially, reducing many varieties to almost a failure. Prices by peck and bushel are euhject to market changes and supplies being unsold.

Varieties are arranged in the order of maturity. Large packets, 5c. each; ears, 15c. each.

\section{STANDARD EXTRA EARLY VARIETIES}

Adams' Extra Early. Not sugar corn; small ears for early use Burlington Hybrid. Most profitable for market; resembles sweet corn; nearly as early as Adams', with ears as large as Evergreen ; very prolific

Early Cory. (Red Cob.) A very early variety, with fair-sized ears, First of All. A selection from Cory; ears medium size; tender Burbank's Early Maine. One of the earliest; large, white ears White Cory. Resembles ordinary Cory; but white cobs and grain, New Mammoth White Cory. A selection from above; larger ears, Minnesota. Nearly as early as Cory; of dwarf growth ; ears white, New Early Champion. Ripens ahead of Crosby's; larger ears Kendel's Early Giant. Large, handsome ears; ready in 70 days Metropolitan. (New.) Grows vigorously; free from smut; fine, Crosby's Extra Early. Fair-sized eurs ; of excellent quality

Perry's Hybrid. Very early and of large size; valuable for market,

\section{SECOND EARLY, Or INTERMEDIATE VARIETIES}

Potter's Excelsior, or Squantum. Ears large and well filled out, Shaker's Early. Very large, white grain; early and productive. The Honey. Husksand stalks deep red color; ears cream white: New Early Evergreen. Lars as large as Stowell's; 10 davs earlier, Early Mammoth or Asylum. Much earlier than Late Mammoth, LATE, or GENERAL CROP VARIETIES

Country Gientleman. One of the sweetest of all for home table. . Ziz-Zay Evergreen. Guod-sized ears, deliciously sweet . . Shoe Peg, or Ne Plus Ultra. Small ears, with very irregular rows, Stowell's Evergreen. Original stock as introduced by Mr. Stowell, Black Mexican. Black grains, sweet and delicious, fine for home use, Egyptian, or Washington Market. Fine for market, ears large Late Manmoth. The largest ears of all ; rich, sweet and superior

\begin{tabular}{|c|c|c|c|c|}
\hline \multicolumn{2}{|c|}{ Postpaid. } & \multicolumn{3}{|c|}{ By Express or Freight. } \\
\hline Pint. & Qt. & Qt. & Peck. & Bush. \\
\hline$\$ 020$ & $\$ 030$ & $\$ 020$ & $\$ 085$ & $\$ 300$ \\
\hline 20 & 30 & 20 & 110 & 400 \\
\hline 25 & 40 & 30 & 150 & 575 \\
\hline 25 & 40 & 30 & 150 & 575 \\
\hline 25 & 40 & 30 & 150 & 575 \\
\hline 25 & 40 & 30 & 150 & 575 \\
\hline 25 & 40 & 30 & 150 & 575 \\
\hline 25 & 40 & 30 & 150 & 550 \\
\hline 25 & 40 & 30 & 160 & 625 \\
\hline 25 & 40 & 30 & 160 & 6. 25 \\
\hline 25 & 40 & 30 & 160 & 625 \\
\hline 25 & 40 & 30 & 160 & 625 \\
\hline 25 & 40 & 30 & 150 & 575 \\
\hline 25 & 45 & 35 & 175 & $\longrightarrow$ \\
\hline 25 & 45 & 35 & 175 & $\Phi$ \\
\hline 30 & 50 & 40 & 200 & $\overrightarrow{02}$ \\
\hline 25 & 45 & 35 & 175 & $\Xi 2$ \\
\hline 30 & 50 & 40 & 200 & $\cong 0$ \\
\hline 30 & 50 & 40 & 200 & \pm .0 \\
\hline 30 & 50 & 40 & 200 & 59 \\
\hline 30 & 50 & 40 & 200 & $\infty$ \\
\hline 30 & 50 & 40 & 200 & 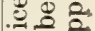 \\
\hline 30 & 50 & 40 & 200 & $\bar{a}=\bar{a}$ \\
\hline 30 & 50 & 40 & 200 & 55 \\
\hline 30 & 50 & 40 & 200 & \\
\hline
\end{tabular}




\section{Pop Corn for the Boys}

OUEEN'S GOLDEN POP CORN. This new sort is one of the best of all for popping, owing to its large size, extreme tenderness and pure white color when popped. Ear 10c.; 4 ears, 25c.; shelled, per pkt., 10c.; pt., 25c.; qt., 45e. postpaid; Ib., 15c.; 2 lbs., 25e; 10 lbs., $\$ 1.00$; 25 lbs., $\$ 2.25$; 50 bs. and over, $8 c$. per lb., by expless or freight.

MAPLEDALE PROLIFIC, WHITE RICE and BILVER LACE POP CORN. Well known and popular productive sorts. Each, per ear, 10c.; large packet, shelled, $10 \mathrm{c}$; pint, 20c.; qt., $40 \mathrm{c}$, post paid; 1b., 15e.; $10 \mathrm{lbs.} \$ \$ \mathrm{~L} .0 \mathrm{u} ; 25$ lbs., 82.00 ; $50 \mathrm{lbs}$. and over, $6 \mathrm{c}$, per $1 \mathrm{~b}$,, by freight or express. Special prices for larger lots.

\section{Corn Salad, or Vetticost}

One ounoe will sov about eighteen square feet, and six pounds will sow one acre.

BROAD LEAVED (LARGE SEEDED). A delicious salad, used during the winter and spring months as a substitute for lettuce, and is also cooked and used like spinach. Sow in spring in drills one foot apart. Io will mature in six weels over like spinach Pkt, 5c.; oz, 10c.; $1 / 1$ lb., 20c:; lb.,60c. postpaid ; $51 \mathrm{bs}$, and over, $45 \mathrm{c}$. per ib., by express.

\section{Cress}

One ounce will sow about fifteen square feet

EXTRA CURLED. (Pepper Grass.) Fine flavor: will cut several times. Pkt., 5c.; oz., 10c.; 1/4 lb., 20c.; 1b., 60c.

TRUE WATER CRESS. A well known aquatic plant, with oval leaves, making a delicious and apuetizing salad. Pkt., 10c.; oz., 35c.; 1/4 lb., $\$ 1.00$; lb., $\$ 3.25$.

UPLAND ORESS. Perennial, grown same as spinach: flavor resembles water cress. Pkt., 10c.; oz., $30 \mathrm{c}$.

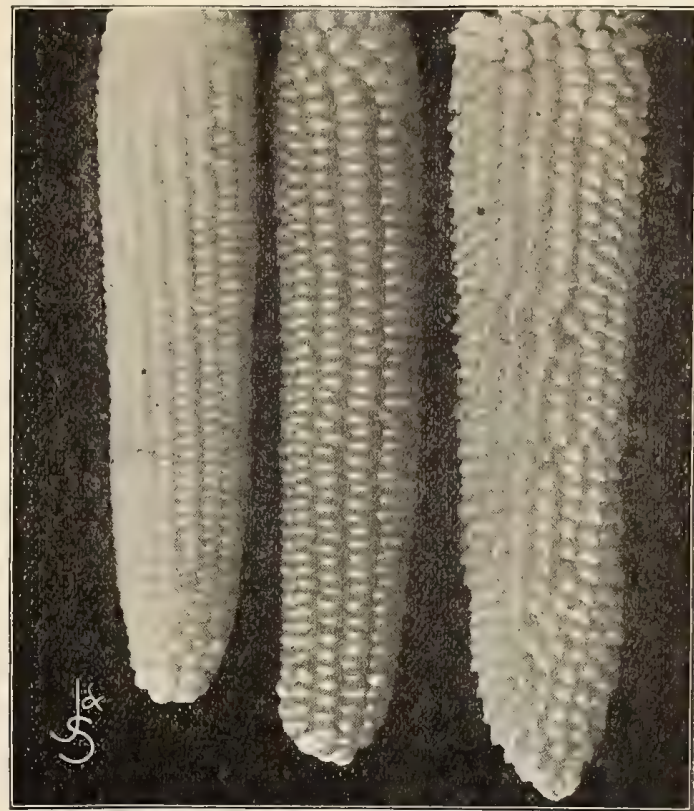

MAPLEDALE PROLIFIO. QUEEN'S GOLDEN. RIOE POP CORN.

\section{CUCUMBERS-Seed Crops Very Short}

One ounce will plant about fifty hills, two pounds will plant one acre Large packets, 5c. each.

Coy's Early Cyclone. The Farliest White Spine by 3 weeks. Wonderfully prolific, Peerless, or Improved White Spine. A fine strain; very early and handsome Evergreen White Spine. Retains its deep green color in all s'ages of growth. Arlington White Spine. The old standard favorite for market and shipping Improved Arlington White Spine. A marked improvement on the above New Eskimoso. Earliest Russian Cucumber; a week ahead of old Russian Early Frame or Short Green. For slicing or pickling; productive and early Westerfield's Chicago Pickle. One of the best pickles; very popular west Nichol's Medium Green. Thick through; full ends; for slicing or pickling Green Prolific, or Boston Pickling. Dark green ; uniform small size.

Improved Long Green. (Jersey Pickle.) Dark green, crisp and productive. Johnson \& Stokes' Perfected Jersey Pickle. New and fine The best pickle New Cumberland. Very prolific, fine for pickling or slicing. See illustration Fordhook Pickling. Excellent new sort, but not equal to J. \& S. Perfected Giant of Pera. Grows 1 to $11 / 2$ feet long; one of the best for table use New White Pearl. Small; smooth fruits; the best white cucumber . West India Gherkin, or Burr. Small ; prickly fruits ; best for small pickles .

\begin{tabular}{|c|c|c|}
\hline Per $o z$ & $1 / 4 \mathrm{lb}$. & Per 11 \\
\hline 025 & $\$ 075$ & \\
\hline 20 & 75 & $\$ 250$ \\
\hline 25 & 75 & 275 \\
\hline 25 & 75 & 25 \\
\hline 25 & 75 & 2 \\
\hline 20 & 50 & 1 \\
\hline 20 & 65 & 2 \\
\hline 25 & 75 & 2 \\
\hline 25 & 75 & 250 \\
\hline 25 & 75 & 2 \\
\hline 20 & 65 & \\
\hline 25 & 75 & \\
\hline 25 & 75 & \\
\hline 20 & 65 & 22 \\
\hline 20 & 50 & \\
\hline 20 & 50 & \\
\hline 20 & 50 & 17 \\
\hline
\end{tabular}

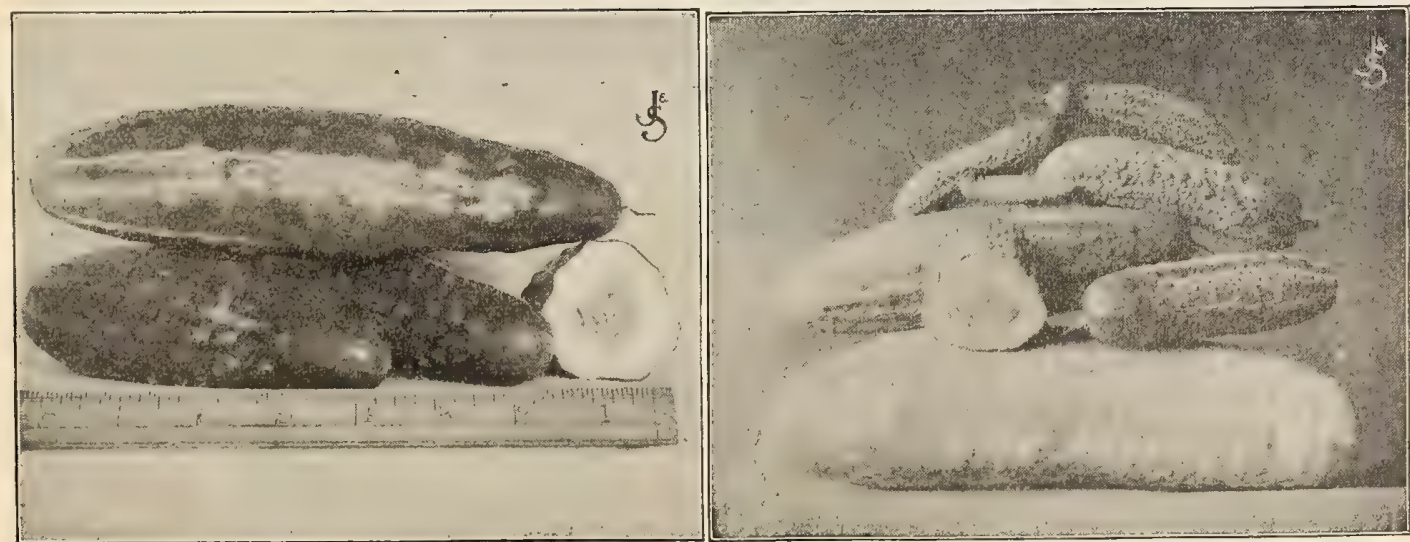




\section{Dandelion}

IMPROVED CARGE OR THICK LEAVTD. A very early and healthful spring salad. Sow early in drills eighteen inches apart. Pkt., 10c.; $0 z$, $50 \mathrm{c}$; $1 / 4$ Ib., $\$ 1.50$.

\section{Egg-Plant}

One ounce will produce about one thousand plants.

NEW EARLY BLACK BEAUTY. See Novelties, page 7 . Pkt., 15c; oz. $85 \mathrm{c}$. $1 / 1 / \mathrm{lb}, \$ 2.50$. SMOATE STEM. In the great markets of New York and the North the finest egg-plants seen are those produced in New Jersey, whose growers have, by long experience, attained remarkable skill in bringing this plant to the greatest improvement on the New York Large Purple in quality, size, and great beauty. The plants are large and vigorous: leaves of a light green shade; fruit earl: very large, oval and of a fue deep purple-never red or yellow: flesh white, tender and superior. Pkt., 10c; oz., 45c; $1 / 4$ lb., $\$ 1.50$; lb.,

NET TORK MPROVED LARGE PURPLE SPINELESS. A standard leading market variety, grown extensively in sections where the New Jersey Improved has tive Pkt, 10c; oz, 45c; $1 / 4,1 \mathrm{c}, 81,25 ; 1 \mathrm{~b}, 84,75$.

\section{Endive}

One ounce will sow fifteen feet of drill and will produce about three thousand plants.

MI MOTH GREN CDRLED. Superior to the old Green Curled. Leaves are very crisp, tufty and full. Midrib is pure white, with large white heart, fleshy and tender. Equilly suitable for spring, sumwer or autumn planting. Pkt. 10c; 0z, 20c. $1 / 4$ b., 60c; lb., $\$ 2.00$.

GIANT FRINGED OR "OYSTER" ENDIVE. A very handsome variety, largely used in Philadelphia and other Eastern cities to decorate the display of oysters during Winte in restaurunts and oyster houses, bence its distinc five nume By tying up the centre, can be easily blanched.

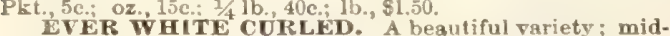
rib yellow. Leaves almost white, large size, crisp and tender. Pkt., 5e; 0z., 15c; $1 / 4$ lb., 40c.; 1b., 81.50 .

BROAD-LEAVED (Escarolle). Large and sweet

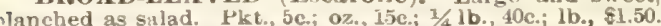

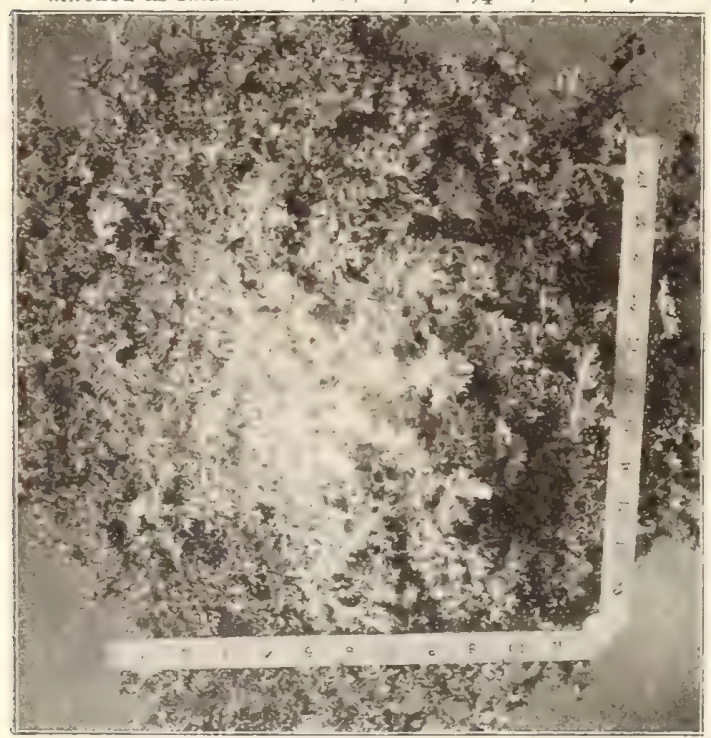

NEW BERLIN GIANT-THE LARGEST AYD BEST EXDIVE.

NEW BERLIN GIANT ENDIVE. With market gardeners whis tested it the past seasons this new German Endive has proven to be by far the largest in cultivation, even excelling our Mammoth Green Curied, which it resem-
bles in form and leaves, but of greater size. No other Enbles in form and leaves, but of greater size. No other En-
live-compares with the Now Berlin Giant in large size and handsome appearance. Pkt., 10c,; oz., 25c.; 1/4 lb., 75c.; 1b., $\$ 2.50$.

\section{Gourds}

The most useful for household and farm purposes.

IUFFA, or DISHCLOTH. This remarkable and handsome climber is a native of the East Indies. In it

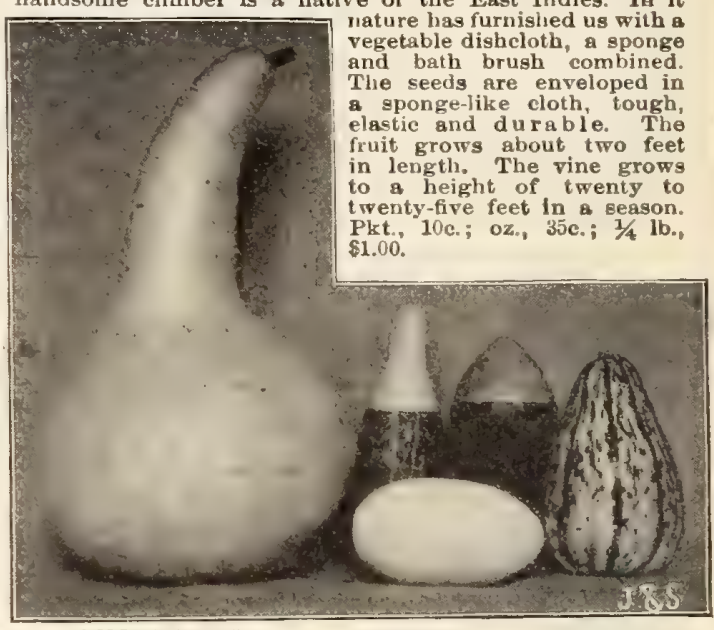

DIPPER, GOURD.

NEST-EGQ.

ORNAMENTAI.

DIPPER. Named for its resemblance to a dipper. The capacity varies from aint to a quart, with handles six to twelve inches long. They are convenient for dipping hot liquids, ete. Pkt., 10c.; $0 z_{.}, 20 \mathrm{c}$; $1 / 4$ 1b., 60c.; 1b., $\$ 2,00$.

JAPA NESE NEST EGG. These exactly resemble the egge of hens, making a capital nest egg; superior to glass eggs, as they do not break and are uninjurad by cold or wet. A rapid-growing climber. Pkt., 10c.; oz., 25c; 1/4 1b., 75c.

SUGAR TKOUGH. Very useful for baskets, dishes, buckets, etc. They have hard, thick shells, lasting for years, and capable of holding from two to ten gallons each plant rows rapidly. Pkt, 10c.; oz, 20c.; 1/4 lb.,60c: 1b., $\$ 2.00$

FINE MIXED ORNAMIENTA L. A collection of the most ornamental, beautifully colored, mottled and striped and including all the above. Pkt., 10c.; 3 pkts., 25c.; oz.,

\section{Garlic}

The sets should be planted in spring. Cultivate same as onions. Sets, per $1 / 4 \mathrm{lb}, 15 \mathrm{c}$; $3 \mathrm{~b}, 40 \mathrm{c} .$, postpaid ; by express, lb., 30c.; 10 tbs. and over, 25c. per lb.

\section{Horse Radish}

Horse radish is grown from young roots or sets which should be planted out in the spring. They will form a largesized radish, fit for use in one season's growth. Roots, per dozen, 20c.; per $100,75 \mathrm{c}$, postpaid (50c. per $100 ; \$ 3.00$ per 1,000 , by express). Write for special prices in large lots.

\section{Kale-Borecole}

JOHNSON \& STOKES' NEW IMPERIAL or LONG STANDING. A beautifully curled and crimpled sort. Of strong, vigorous habit, perfectly hardy, bright green color, and very attractive appearance. Superior to all other sorts, and will stand longer without shooting to seed than any other. Height, two feet. Pkt., 5c; 0z, 10c.; $1 / 4 \mathrm{lb}, 25 \mathrm{c}$; 1 b., FXTRA DWARF GREEN CURLED SCOTCH KALE. This is one of the best kales for spring sowing in the North, and is the principal sort grown in the South for Northern markets. It is hardy, and will remain over winter in any place where the temperature does not go below zero. The habit is very dwarf and spreading, and will rarely ex: ceed eighteen inches in height. The leaves are of a bright green color, beautifully curled, and produced in great abunnce. Pkt., 5c.; oz,., 10c.; 1/4lb., 25e; 1b., 80c.

GREEN CURLED SCOTCH. A favorite with Northern gardeners, growing about two feet in height and herdier than the Extra Dwarf Green Curled Scotch, being improved by frost; leaves green and beautifully curled and wrinkled. Pkt.,5c.; oz., 10c.; 1/4 1b., 25c.; 1b., 75c.

SIBERIAN CURLED." (German Greens.) This variety grows a little larger and coarser than the preceding; the leaves are not so deeply curled and are of a bluish green olor; verv hardy. Pkt., 5c.; oz., 10c.; 1/4 1b., 20c.; lb., 60c.

SEA KALE Grown for its blanched shoots; cooked like Asparagus, Pkt., 10c; oz., 25c; 1/4 1b., 75c.; 1b., $\$ 2.50$.

We Deliver Pree I To any Post-office in the Dnited States, all Tegetable and Flower Seeds, 


\section{Kohl-Rabi}

or Turnip-Rooted Cabbage

This is a favorite vegetable in Europe, where it is extengively grown for feeding cattle, as well as for table use. The bulb is formed above ground, and, if used when young and tender, makes a most delicate dish for the table. One ounce will sow one hundred and fifty feet of drill.

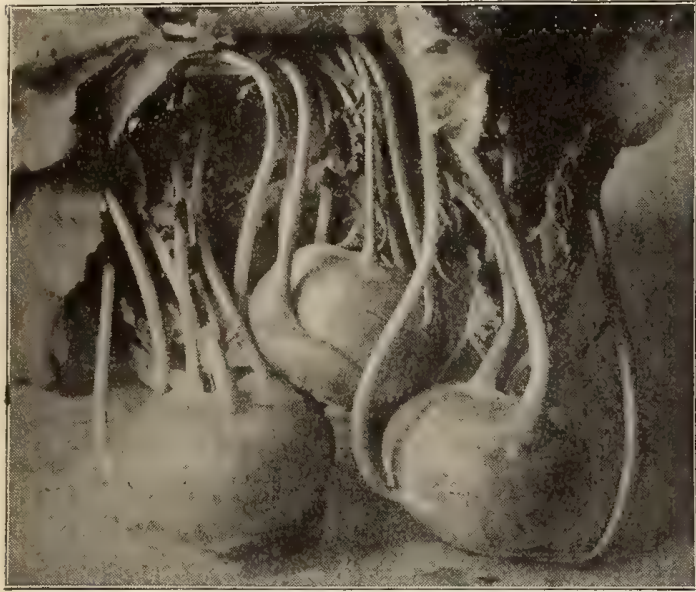

SMOOTH WHITE SHORT-LEAVED-THE BEST KOHL-RABI.

New Smooth White Short=Leaved

After several years' comparative tests, we find this new sort decidedly the best for market and table use, being much superior to Vienna. It is very early and the best for forcing as well as for outside growth. Bulb is greenish white, beautiful smooth shape anu of the very finest texture and quality. Pkt., 10c.; oz., 30c.; 1/4 1b., 75c.; 1b., $\$ 2.75$.

\section{Kohl-Rabi-(Continued)}

NEW SMOOTH PURPLE. Very Short-Lesved. Like the preceding except in color. An extra fine purple. Pkt., 10c.; oz. 30c.; 1/ 1b., 75c.; 1b, $\$ 2.75$.

EARLY WHITE VIENNA." Suall bulb, early, Flesh tender and white. Pkt. $5 \mathrm{c} ; 0 \mathrm{z}, 20 \mathrm{c} ; 1 / 4 \mathrm{lb}, 60 \mathrm{c} ; \mathrm{lb}, \$ 2,00$

EARLY PURPLE VIENNA. A little later colo bluish-purple. Pkt., 5c.; oz., 20c.; 1/4 lb., 60c.; lb., \$2.00.

\section{LEEK}

One ounce will sow one hundred feet of drill, and produce about one thousand plants.

NEW GLANT ITALIAN. This new leek from Italy is fully trice the size of the ordinary London Leek, and much handsomer in appearance. Like the Italian onions, it is very mild and agreeable in flavor: extremely lourdy and a fiavor, extremely hardy and a miown its large size and fine white appearance. It is by far the best leek that can be grown either for the market or home use. Pkt., 10c.; oz., 20c.; 1/4 lb., $60 \mathrm{c}$; $1 \mathrm{~b}$., $\$ 2.00$.

LARGEAMERIC N FLAG. Previous to our introduction of the Giant Italian, this was the favorite variety. Very fine and large. Pkt., 10c. oz., 20c.; $1 / 4$ lb., 40c.; lb., $\$ 1.50$.

CARENTAN, or SCOTCH CHAMPION. A large variety from Scotland, growing rapidly and very hardy. Pkt., 10c.; oz., 20c.; $1 / 1$ 1b., 40e.; 1b., 1.50

LONDON FLAG. Popular old sort. Pkt., 5c.; oz., 10c.; $1 / 4$ lb. 30 c.; 1b., $\$ 1.00$

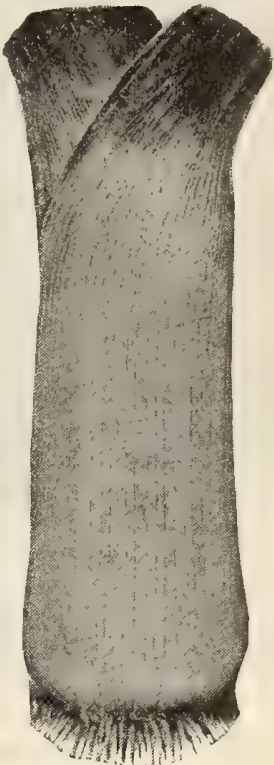

GIANT ITALIAN LEEK.

\section{The Best Seeds that Grow and a List of Varieties it Pays to Grow}

\section{What Others Say: We recelve each season hundreds of voluntary}

\section{OUR SEEDS GENERALLY}

BIGGEST BARGAIN OF HIS LIFE

Wy. H. MeEK, P. M., Mimosa, Ark., March 1, 1903, writes: "I have just received the seeds from you and congider my purchase the biggest bargain in $m y$ life. I never got so many extras, and I have bought from many seeds-

\section{TNHEREN PCRITY AND OUALITY}

C. H. Prelps, East Smithfield, Pa., May 7, 1903, writes "I could get any of the seeds ordered in my own town, but I have become so fully satisfied of the superior growing power, inherent purity and quality of your seeds, which I have planted so many years, that I would rather wait \& reasonable

\section{COME QUICKER AND GROW BETTER}

I. Q. Selby, Rover, Md., May 7, 1903, writes: "I have used a great many seeds from a great many different seeds men and Johnson \& Stokes' seeds have giver me more satisfaction than any I have ever used. They come up quicker, grow better and are always pure and true to name."

\section{NOVECTIIS ON DNTUT WORTE}

JоHN Cook, Decatur, Mich., Aug. 24, 1903, writes: "I have bought your seeds for twenty years, including many novelties, ard $I$ have always been more than satisfied. Everything got from you has proven of unusual worth." BETTER THAN REPRESENTED

Jонn W. Soots, Florist, Lisbon, Ohio, July 23, 1903, writes: "I have used your seeds for the past eighteen years and have always found them to be as good or better than represented.

BEST GARDEN IN THE NEIGHBORHOOD

M. I KING, East Brady, Pa Aug, 7, 1903, writes: "Your seeds al ways prove true to name. I have the best garden this year in the neighborhood. Some complain about their poor yielding crops, but I tell them if they had bought their seed of Johnson \& Stokes as I did, their gardens and fields would be all right."

$$
\text { CARRIED OFF 12 PRIZES }
$$

W. W. Williamson, Colorado Springs, Colo., Sept. 12 , 1903, writes: "Last year I purchased my seed of you and was able to carry off 12 prizes (including the silver cup for best sweet peas) at the annual exhibition of the El Paso County Horticultural Society."

\section{SOME OF OUR SPECIALTIES}

\section{J. \& \$. MARKET GARDENERS' CABBAGE No.?}

JоHN Kart, North Columbus, O., Sept. 1, 1903, writes: "Your J. \& S. Market Gardeners' Cabbage No, 2 is the best cabbage that grows. I sold heads on the 4 th of July that weighed 13 pounds. It far surpassed all others."

\section{GOLDEN ANDALUSIA WAX POLE BEANS}

Louis S. Peaoney, Pedricktown, N. J., Aug. 30, 1903, writes: "Your Golden Andalusia Pole Beans go ahead of anything $I$ ever tried or ever saw. A marvel in productive. ness."

FORD'S ITAMIMOTH PODDED LIMA BEANS

A. S. DREW Ry, Galveston, Texas, January 30, 1903, writes: ' Your Ford's Mammoth Podded Limas are the best beans I ever saw. I commenced picking them last July and they have borne up to this time.

\section{J. \& S. MATOHLFSS FLAT DUTCH CABBAGE}

John W. Mricer, Allentown, Pa., September 29th, writes: "Your seeds are simply perfect. I bave about ten thousand of your Matchless Late Flat Dutch Cabbage, and it is the finest late cabbage I have ever grown or seen.

\section{JOHNSON \& STOKES' CREMONA CELERY}

C. Nelson, Comstock, Mich., Oet. 14th, writes: "Your New Celery 'Cremona' is perfect-every stalk uniform and alike. Most beautiful and salable when prepared for market."

\section{NEW COPPERHEAD LETTUCE}

R. B. WIIturs, Fast Mauch Chunk Pa, July 6, 1903 writes: "I found your New Copperhead Lettuce to be one of the quickest growing and most tender lettuces I ever had. I forced it in may greenhouse and it is fine. All my trade ask for it."

\section{PARISLAN LONG STANDING SPINACH}

E. Hollister, St, Louis, Mo., May 9, 1903, writes: "Your Parisian L. S. Spinach has made a most rapid grow th sowed at the same time with a Long Standing Spinach from a noted firm in New York; yours is superior and a long way ahead in glowth, some of which is now fit for the table. 


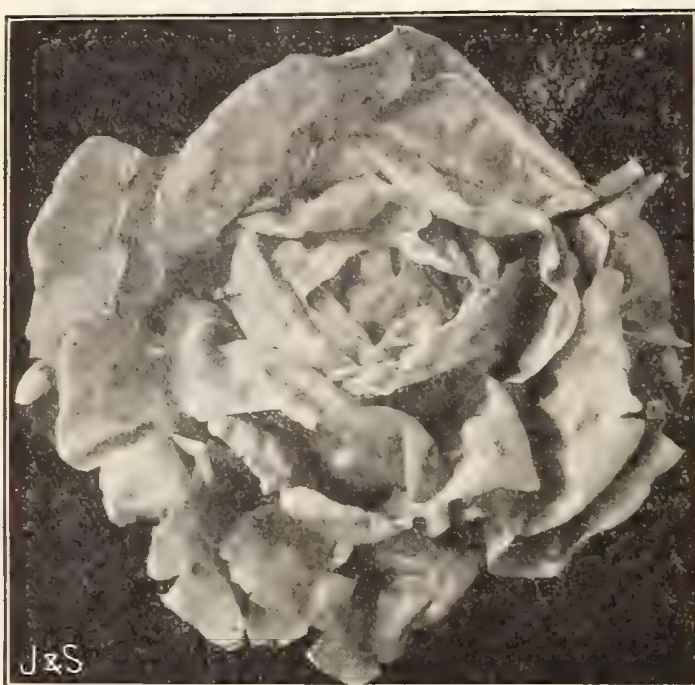

\section{New Golden Gate Lettuce}

Since our introduction of this grand new summer cabbage lettuce, which we brought from California five yeurs ago, we have received hundreds of letters endorsing its wondermi qualities and pronouncing its large, magnificent cream-yellow colored heads the finest ever grown. It is not only one of the surest headers, but one that Till lemain in condition fol use longer than most others. Plet. 100 ; 02 . $25 \mathrm{c} ; \mathrm{1} / \mathrm{ib}, 75 \mathrm{c} ; \mathrm{lb}, \$ 2.50$.

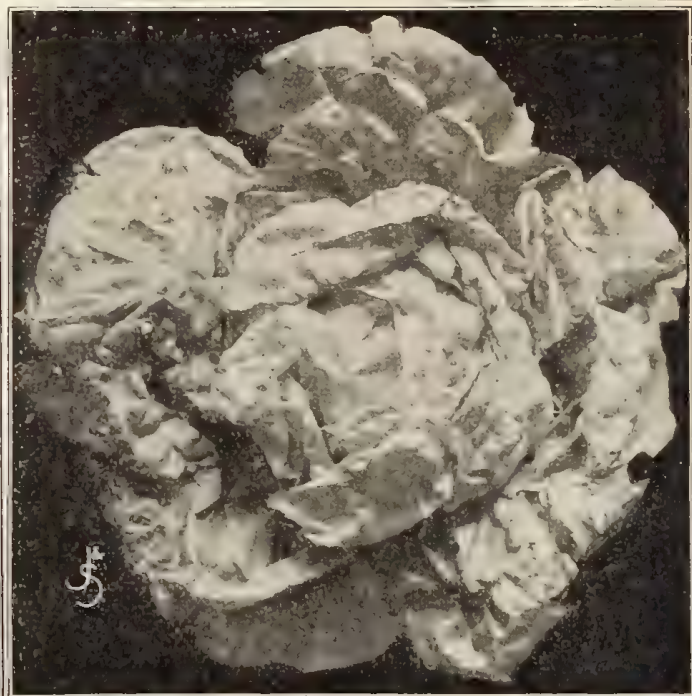

\section{Mammoth Salamander Lettuce}

In the New Mammoth Salamander we have a variety which possesses all the desirable qualities of the old Salamander, but grows to double the size. It is the result of many years' careful selection and breeding by a Philadelphia market gardener, whose main crop is lettuce, Owing to its handsome a pue rance and fine quility it is lo-day the most rapid seller in New York and Philadelphia markets. Plt., 10c; oz., 25c.; 1/4 b., 75c; 1b., $\$ 2.50$

\section{LETTUCE_-The Cream of the Cabbage or Heading Varieties.}

One ounce will sow about one laundred square feet, and produce three thousand plan:s.

All varieties in regular large=sized packets at $5 \mathrm{c}$. each per packet.

White-Seeded Tennis Ball, or Boston Market. A well-known forcing sort Arlington Tennis Ball. Improved strain; saved from plants started under glass, Johnson \& Stokes' Hot House. Double the size of Tennis Ball; never rots Myers" "All Right." Produces beautiful large solid heads of finest quality ; equally valuable for forcing or open ground planting; few equal, none better, Reichner's Early White Butter. Large, solid; fine for forcing or oven ground, Big Boston. A fine strain for forcing or open gronnd; very large, solid heads, Johnson \& Stokes' Summerlead. A grand new Summer lettuce, very large, handsome yellow heads of perfect quality; remarkable to withstand heat, and the slowest to shoot to seed. See illustration

Mongolian. A new variety from Asia, valuable for Spring and Fall planting outdoors; very crisp and delicate in flavor

The Copperhead. Large, solid and distinct color, light brown outside, shading to light pink inside; crisp and handsome

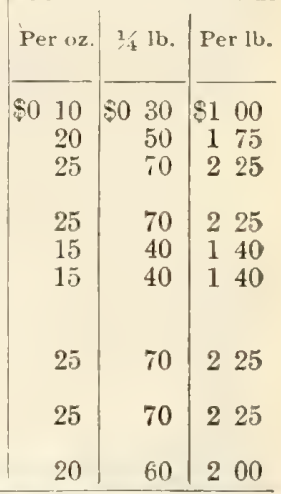
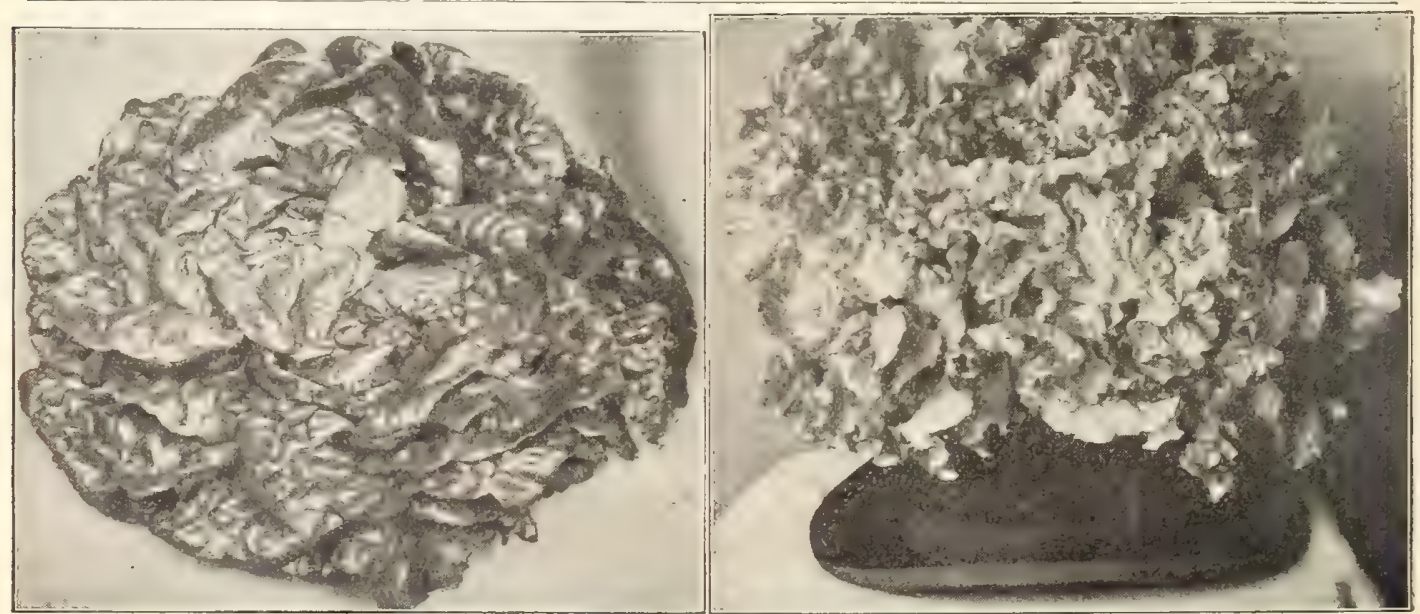

JOHNSON \& STOKES' SUMMERLEAD-BEST TO STAND HEAT.

NEW MORSE-BRST CURLED LETTUOE FOR EARLY AND SUMMER. 


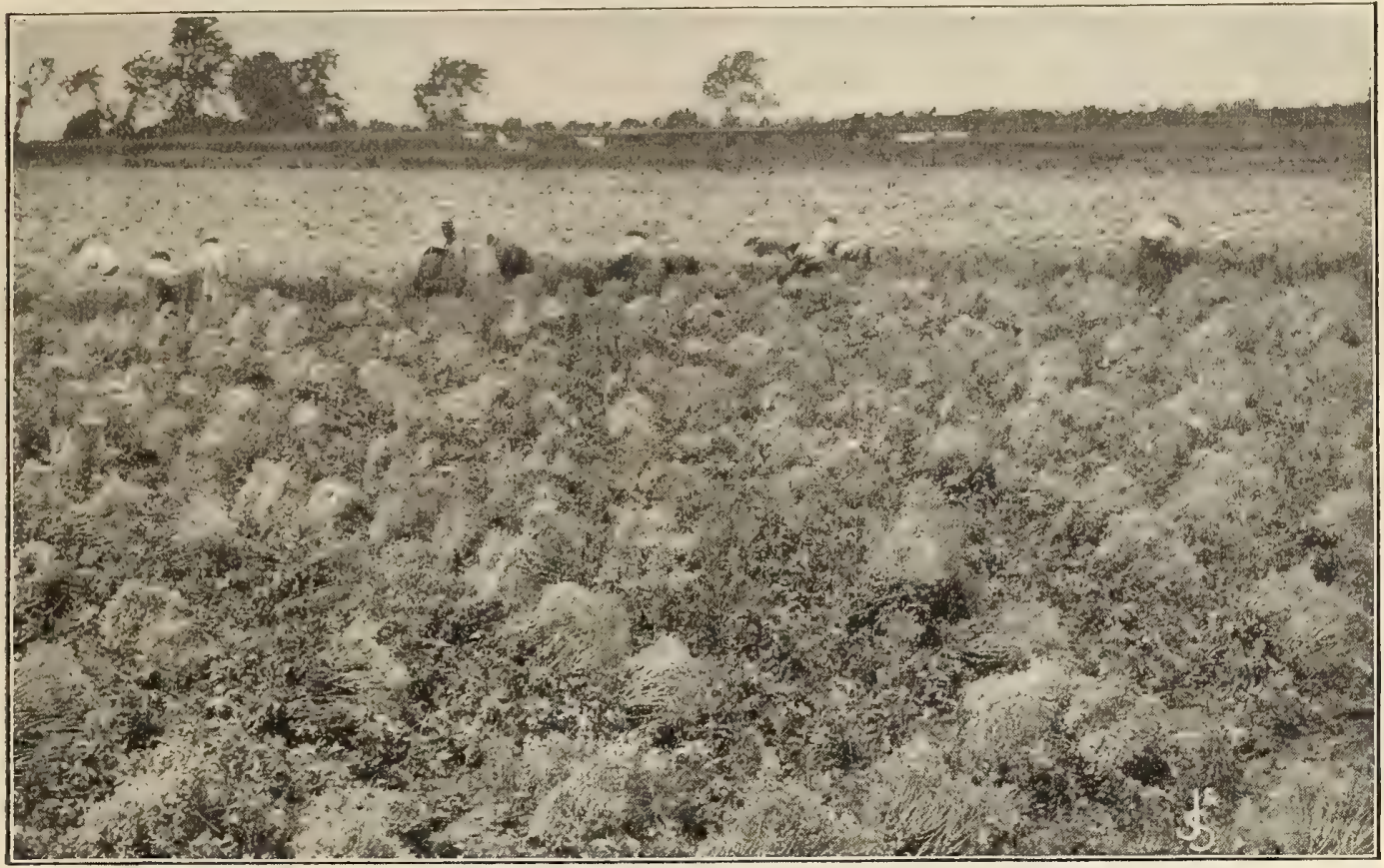

IARVESTING THE SEED FROM A FIELD OF OUR MAMMOTH SALAMANDER LETTUOF.

Although only first introduced by us four years ago, New Mammoth Salamander has grown in popularity to such an extent that to-day it is more largely grown than any otber Summer Lettuce for Philadelphia and New York markets. See illustration of single head on preceding page.

\section{LETTUCE-Cabbage or Heading Varieties (Continued)}

Large packets, 5 c. each.

Giant Glacier. (New.) Large light green heads ; leaves crimpled and swollen, like Savoy Cabbage; withstands heat and drought

Sensation. The best and most popular all-year-round Lettuce; forms a solid head befure half grown; light yellowish green color, of the finest quality

silver Ball. Head white, solid, firm; splendid for Spring and Summer use

Philadelphia Dutch Speckled Butter. Fine, large heads of excellent quality .

Hornberger's Dutch Butter. Improvement on Dutch Butter; private stock

New Iceberg. Very solid; large, handsome cabbage lettuce; superior quality

White Russian Summer. Very large, handsome heads; fine for open ground

Champion Spring and Summer. Large, solid, golden yellow heads of the most showy type, very popular for market and shipping

Treasure. Extra large, solid, creamy yellow heads; slow to shoot; fine for South,

California Cream Butter, or Royal Summer Cabbage. Fine, solid heads.

Salamander. Fine compact heads, which resist Summer heat admirably

Deacon. A large, solid cabbage lettuce for Summer; heads light green outside .

Nansen, or North Pole. (New.) Style of Deacon; ten days earlier, very hardy,

New York (Wonderful). Large, dark green heads; used only as a Summer sort .

Philadelphia Early White Cabbage. Handsome heads of superior quality

Improved Hanson. Very large, solid and of fine quality; withstands the hot sun,

\section{LETTUCE-Curled or Loose Leaved Varieties.}

New Morse. The best curled growing lettuce, large leaves, light green outside, blanching to light yellow inside; splendid for both early and Summer use; crisp and tender. See illustration, preceding page

Black=Seeded Simpson. Our improved strain; large, loose heads; light color .

Grand Rapids. A famous shipping, loose-headed forcing sort; popular West

Baltimore Oak Leaved. Very distinct; for Summer ; resists great heat

Early Prize-Head (Brown Cabbage). Large, loose heads, tinged with brown .

Early Curled Silesian. A leading early curled sort; fine for cutting

New Trianon Cos, or Celery Lettuce. The finest of all the Cos sorts; leaves when bleached are stiff like celery stalks, and can be eaten in the same manner,

Lettuce-American Varieties Mixed. Fifteen kinds mixed in one package, giving a succession of fine lettuce the whole season

\begin{tabular}{|c|c|c|}
\hline Per oz. & $1 / 4 \mathrm{lb}$. & Per lb. \\
\hline $\begin{array}{lll}\$ 0 & 15\end{array}$ & $\$ 040$ & $\$ 140$ \\
\hline 25 & 70 & 225 \\
\hline 15 & 40 & 140 \\
\hline 15 & 35 & 120 \\
\hline 20 & 60 & 200 \\
\hline 15 & 35 & 120 \\
\hline 15 & 40 & 140 \\
\hline 15 & 40 & 140 \\
\hline 25 & 70 & 225 \\
\hline 15 & 35 & 120 \\
\hline 15 & 35 & 120 \\
\hline 15 & 35 & 120 \\
\hline 15 & 35 & 120 \\
\hline 15 & 35. & 120 \\
\hline 10 & 30 & 100 \\
\hline 15 & 35 & 120 \\
\hline 15 & 45 & 150 \\
\hline 15 & 40 & 140 \\
\hline 15 & 40 & 140 \\
\hline 25 & 70 & 225 \\
\hline 10 & 30 & 100 \\
\hline 10 & 30 & 100 \\
\hline 15 & 40 & 150 \\
\hline 10 & 30 & 100 \\
\hline
\end{tabular}




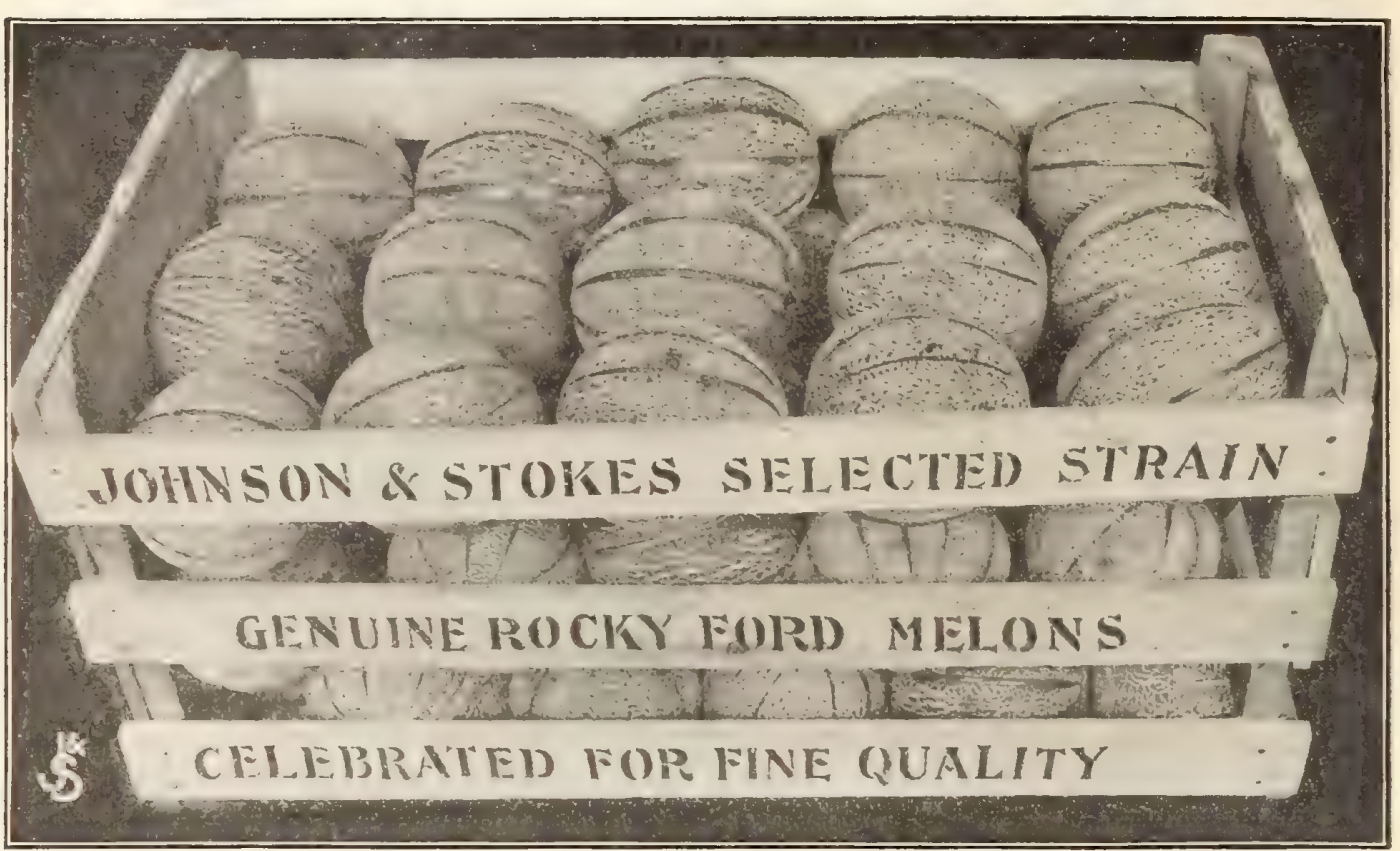

Our selected strain of this celebrated Rocky Ford Melon has hecome so popular that thousands of crates like the above appeared in Eastern markets the past season, bringing the highest prices. Much seed now being offered is saved from culls. We warn our customers to beware of such. We offer selected seed of our own growing. Per pkt., 5c.; oz., 10c.; 1 lb., 30c.; lb., $\$ 1.00$, postpaid; by express or freight, lb., 90c.; 5 lbs. and over, $80 \mathrm{c}$. per $1 \mathrm{~b}$.

\section{MUSKMELONS OR CANTALOUPES — A SELECT LIST}

One ounce will plant about seventy hills, three pounds will plant one acre.

All varieties in regular large-sized packets at $5 \mathrm{c}$. each per packet.

Netted Beauty. Very early ; productive; densely netted; free from ribs Ivy Gem. Earliest of red-fleshed sorts; large, fine and showy; superior quality Netted Gem. (Golden Jenny.) Very early; small, round and of fine flavor Early Jenny Lind. Small; light green flesh; fine for market. 5 lbs., by express, $\$ 5.25$ McCleary's Improved Jenny Lind. Earliest strain; very productive; uniformly good size and well netted. Roughing up better and keeping longer

Norfolk Button. (New.) Very early; thick green flesh; fine for market Extra Early Prize. Small; rounder than Jenny Lind; requires good soil Jersey Belle. Larger than Jenny Lind; green flesh; nets up well on light soils, Newport. Shape of Jenny Lind; larger and thicker, but not quite so early Shipper's Detight. (New.) Early, good size well netted, thick green flesh New Sweet Home. Large, oblong; thick green flesh; of finest flavor (crop short), New Melrose. Ten days later than Jenny Lind; oval; sweet green flesh

Large Hackensack, or Turk's Cap. Large, round, Hattened; green flesh New Early Hackensack. Ten days earlier than Hackensack, which it resembles, Superb. Very large, late and showy; heavily netted; sweet green flesh Emerald Gem. Small, early, productive; sweet salmon flesh; smooth skin Lone Star. Large, oblong; finely netted; free from ribs; rich salmon flesh Perfected Delmonico. Large, oval; orange pink flesh; of very superior quality, Green=Fleshed Osage . Very hardy, prolific; globe-shaped; lusciously sweet

Red-Fleshed Osage or Miller Cream. Medium size; globe-shaped; very sweet Beck's Strawberry. Delicious new red-fleshed sort, 6 to 8 lbs., each

Long Island Beauty. The best of the Hackensack type; very early; fine quality, Cannon Ball. Round; medium size; heavily netted; green flesh; fine shipper, The Banquet. Globe-shaped; densely netted; dark, very rich salmon flesh . Bay View. Very prolific and of good size; oblong; green flesh; late

Improved Montreal Nutmeg. Large, round, netted; flesh thick and light green, Acme, or Baltimore. Early, oblong, pointed; light green flesh; a fine shipper, Banana. Iate; grows 18 to 20 inches long; lighly perfumed; fine quality Mango Melon, or “Vegetable Peach." For preserving or pickling

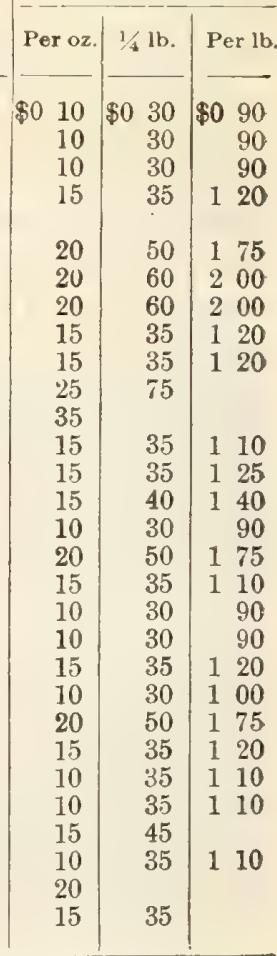




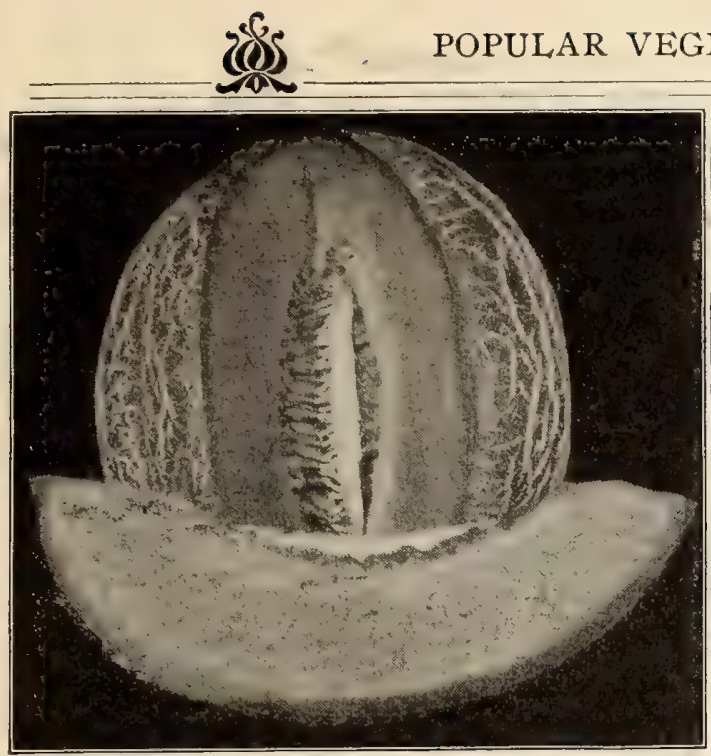

\section{Paul Rose, or Petoskey Muskmelon}

A cross of Osage and Netted Gem, and best of the salmon or red-Heshed sorts. Flesh unusually thick, firm and delicious; well netted and fine for market. Pkt., 5c.; oz., 10c.; $\frac{1}{4}$ lb., 35c.; lb., \$1.20.

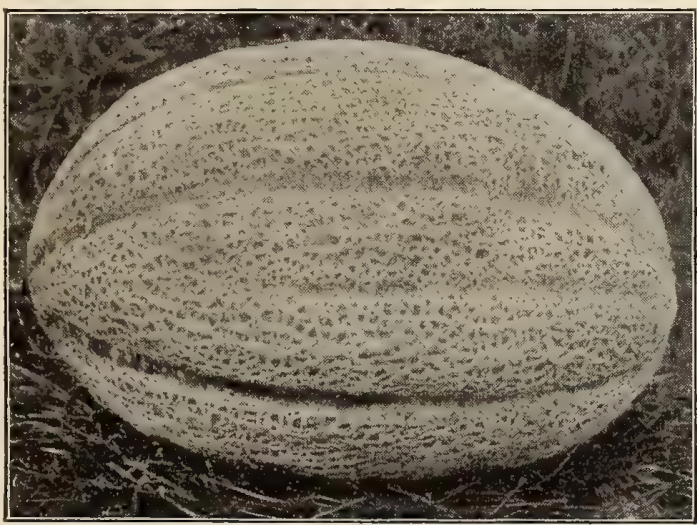

THE ANNE ARUNDEL MUSKMELON.

\section{Anne Arundel Muskmelon}

An improvement on the well-known Acme or Baltimore, growing to larger size, with thicker flesh. Notwithstanding its large size, it is ready for picking immediately after the extra early sorts, is a heavy yielder and bears shipment well, ite shape enabling it to resist pressure much better than the rounder melons. The Anne Arundel is fast becoming the most popular green-fleshed sort for both market and family use. Pkt., 5c.; oz., 15c.; $\frac{1}{4}$ lb., 40c.; lb., \$1.40.

SHORT SEED CROPS Owing to attacks of inconts and bad climatic conditions in many seed-growing sections seed crops of both muskmelons and watermelons have been shorter than for many years. There is not half enough seed in the country for normal requirements. Before going to print with this catalogue, we have declined wholesale orders for thousands of pounds of the leading sorts, preferring to supply our retail customers with their wants, and hope our action will be appreciated.

Varieties not listed are a total failure.

\section{MELONS_Watermelon}

One ounce will plant about fifty hills and four pounds will plant one acre.

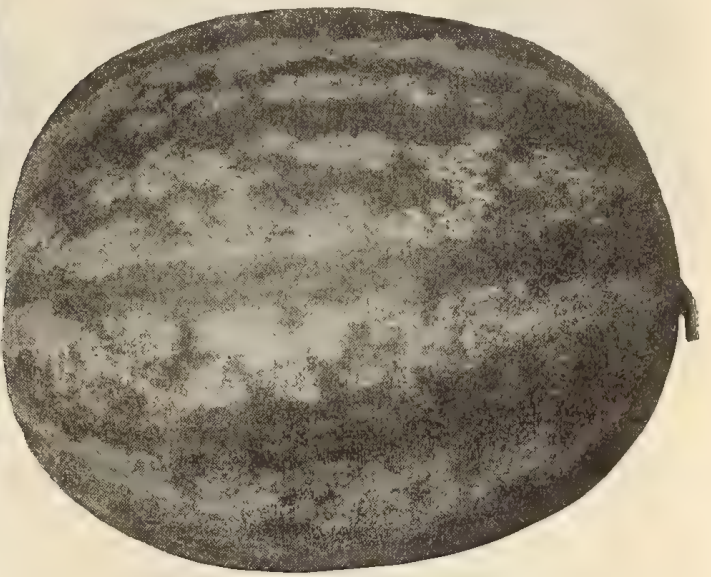

SPECKMEN OF PAUL'S BONNY BEST-RTPENED IN 62 DAYS.

\section{Paul's Bonny Best Watermelon}

The earliest watermelon in cultivation. It originated with the late Aaron Paul, the famous New Jersey melon grower and hybridizer. In our trials in past seasons we had good-sized melons, plenty large for market, weighing 15 to $20 \mathrm{lbs}$. each, on July 10th, from seed planted May 9th, while most other varieties could not be eaten until about August 1st. Flesh red, deliciously sweet, with but few seed. Pkt., 10c.; oz., 20c.; $\frac{1}{4}$ lb., 60c.; lb., $\$ 2.00$.

\section{New Triumph Watermelon}

This new melon has created quite a furore among shippers on account $\mathrm{c} f$ the very high prices realized by those who have grown them. Triumph is a cross between the Duke Jones and Kolb Gem, having the handsome dark green color of the former and the fine shipping qualities of the latter, but infinitely superior in flavor and grows much larger than either, having been known to attain a weight of over 100 lbs. Pkt., 5c.; oz., 10c.; $\frac{1}{4}$ lb., 25c.; Ib., $75 \mathrm{c}$., postpaid ; by express or freight, $1 \mathrm{~b} ., 65 \mathrm{c}$.; $5 \mathrm{lbs}$. and over, 60 cts. per $1 \mathrm{~b}$.

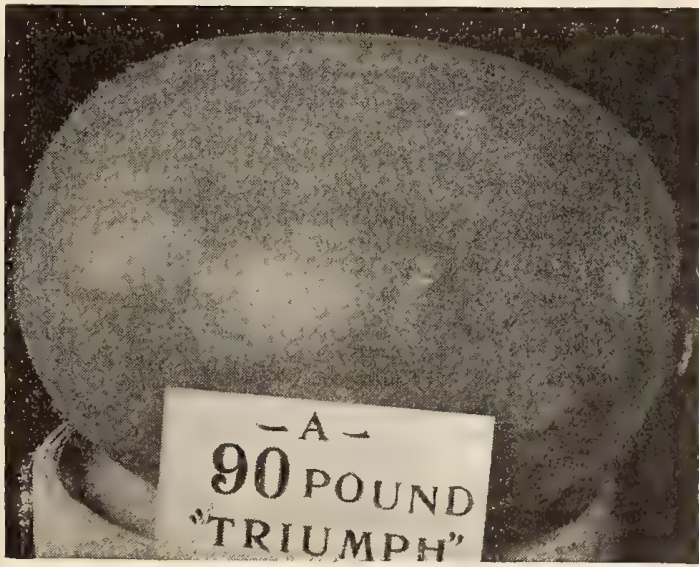




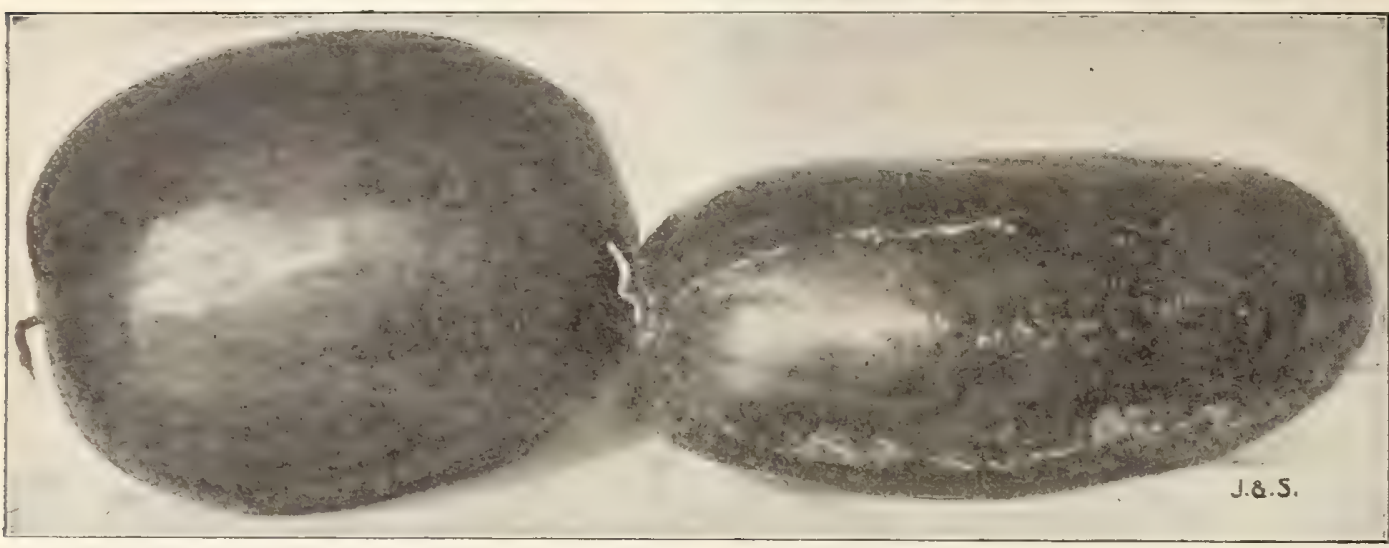

BLACK BOTLDER WATERMELON.

TRUE JOBNSON'S DIXIE WATERMELON.

\section{BLACK BOULDER-The Great Shipping Watermelon}

For this grand new and distinct watermelon we are also indebted to the late Aaron Paul. It is enormously productire, reaching a manmoth size, with rich, dark green skin. It cuts equal to any market melon we have ever eaten, and its shipping qualities are phenomenal, no other melon equaling it in tulgh skin and rind. While it has rapidly become one of the leading melons for market, it is one of the best "all round " melons in existence, and for the family garden it is also without a peer. Pkt., 5c. ; oz. 10 c.; 1 1b. 30c.; 1b., $\$ 1.00$.

EXTRA SELECTED STOCK SEED. Sared entirely from picked melons. The largest and finest in our patch. Pkt., 10c.; Oz, 20c.; $\frac{1}{4} \mathrm{lb},, 60 \mathrm{c}$; ; lb., $\$ 2.00$.

\section{GENUINE JOHNSON'S DIXIE WATERMELON}

The true Johnson's Dixie is a cross between the Kolb Gem and Old=Fashioned Mountain Sweet, and surpasses the Kolb Gem in shipping qualities, and fully equals the Mountain Sweet, Kleckley and Florida Favorite in superior eating yuality, and is ten days earlier than any of them. Its great productiveness is shown from the fact that it frequently matures six to eight large melons to the vine. Owing to the great polularity of this variety, another and much inferior melon is frequently substituted and sold forit. If you want quality and genuine seed, send to the introducers. Pkt., 5c.; oz, 10c.; 1 lb., 25c.; lb., 75c., postpaid ; by express, lb., 65c.; 5 lbs. and over, 60c. per lb.

EXTRA SELECTED STOCK SEED. From picked melons. Pkt., 10c.; oz., 20c.; $\frac{1}{4}$ lb., 45c.; 1b., \$1.50.

\section{Standard WATERMELONS with Real Merit}

One ounce will plant about fifty hills and four pounds will plant one acre.

Large Packets of any variety, 5c. each. If ordered sent by express or freight, deduct 10c. per lb. In 5-1b. lots and over, 15c. per $1 \mathrm{~b}$. may be deducted.

Fordhook Early. Very early; good size ; medium green, red flesh of fine quality, Early Jumbo. Round; of large size; dark green skin ; extra good quality Dark Icing. Early, round, solid, with thin dark green skin ; of superior quality Light Icing, or Ice Rind. Round in form like the above; flesh of fine quality Gray Monarch, or Long White Icing. Very large, long; crimson flesh

Black Diamond. Large, round; skin dark green; tough; red flesh, fair quality, Black-Eyed Susan. (New.) Oblong; striped; rind tough; delicious red flesh, Sweet Heart. Mottled light green; large, oral, heary; red flesh; fine shipper, Alabama Sweets. A grand new shipping melon; equal to Icing, Kleckley and Florida Favorite in luscious quality ; long, dark green, continuous bearer Mclver's Wonderful Sugar. Resenibles Old Rattlesnake, superior in quality Pride of Georgia. Round, large, crisp ; bright red flesh; fine shipper Santiago Mammoth. Superior to Mammoth Ironclad, which it resembles Ice Cream, or Peerless. Tery early ; red flesh of fine quality ; white seed Cuban Queen. Early, solid and heary; skin striped dark and light green

Kolb Gem. Very large; flesh red; a good shipping sort; popular in the South Blue Gem, or Iceberg. A blue Kolb Gem, better quality; desirable for shipping, Florida Favorite. A superior strain; large, oblong, striped ; luscious red tlesh, Scaly Bark. Very large; dark green ; light crimson flesh of good fla wor Gypsy, or Georgia Rattlesnake. Oblong, dark and striped; bright red flesh Colorado Preserving Citron. (Green seed.) Also called Apple Pie; for preserves, Green Citron. (Red seed.) Round and handsome; for preserving only . . . .

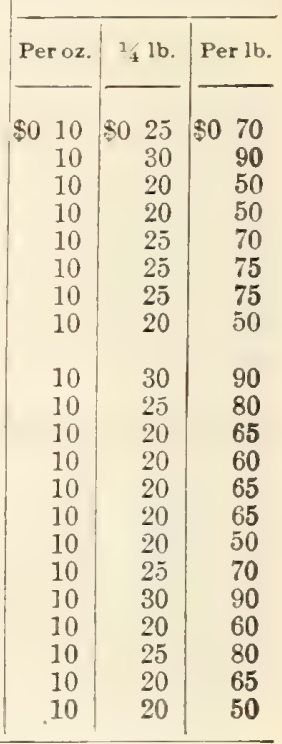




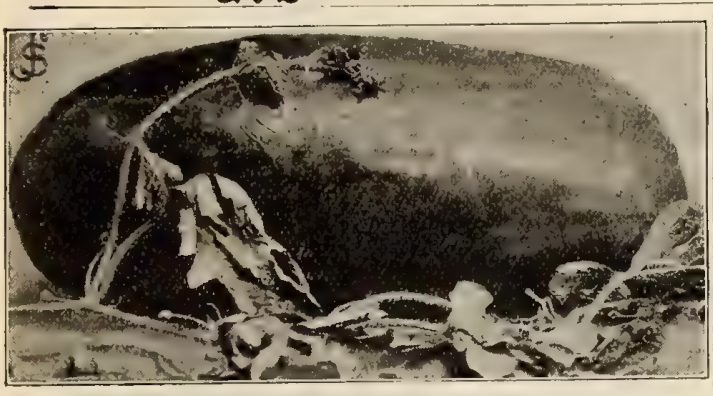

KLEOKLEY SWEETS WATERMELON, GROWN BX MR. KLEOKLEY

\section{Kleckley Sweets Watermelon}

This is one of the best and sweetest-flavored large watermelons in cultivation. Skin dark green, thin rind, flesh scarlet, very solid, firm and most luscious quality. For the home market or family garden it is hard to beat. Pkt., 5c.; oz., 10c.; $1 \mathrm{lb}$., 30c.; lb., $\$ 1.00$.

\section{Halbert Honey Watermelon}

A superb new variety from Texas and a peer of the famous Kleckley Sweets. See illustration under Novelties, page 8. Pkt., 10c.; oz.; 20c.; \& lb., 50c.; lb., $\$ 1.50$.

\section{A New Watermelon for 1905}

We have been fortunate in securing a limited amount of seed of a magnificent new watermelon, which we propose to introduce in 1905 . Desiring to have it fully tested this season, we shall be glad to include a good-sized trial packet in all orders of $\$ 1.00$ and over where watermelon seeds are ordered.

\section{MUSHROOMS}

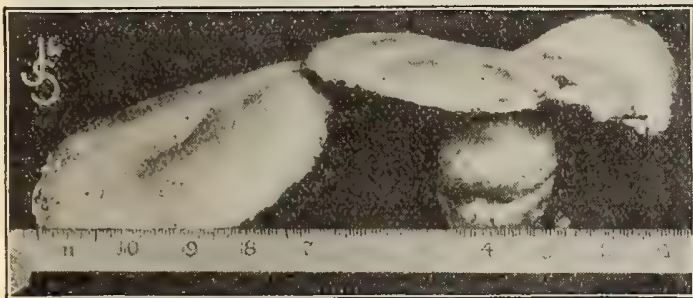

MUSHROOMS MEASURING OVER SIX INOHES ACROSS, GROWN FROM RIOHARD'S OELEBRATED ENGLISH MILLTRACK MUSHROOM SPAWN.

RICHARD'S ENGLISH MILLTRACK MUSHROUM SPAWN. (Freshly imported.) This celebrated hrand is preferred by all the large mushroom growers of Grand is preferred by al the large mushroom growers of Great Britain, and has given better success in this country than any other brand, on accour

Mushrooms can be successfully and profitably grown during the Winter and Spring months on greenhouse benche among other plants, in frames, under greenhouse benches as well as in the open fields or in cellars or outhouges. They cout the delicious and healthful food.

Richard's English Milltrack brand (made by the most experienced maker in England) can be thoroughly relied on to produce a good crop of the best mushrooms. One brick will plant eight square feet of bed. Per briek, $11 / 4 \mathrm{lbs}$, 15e. (brick, postpaid, 30c.); $10 \mathrm{lbs}$., \$1.15; 25 lbs., \$2.50; $100 \mathrm{lbs}$ and over, $8 \mathrm{c}$, per lb., by express or freight. Leaflet-Essay with directions for cultivation accompanies each order for spawn.

\section{MARTYNIA}

MARTYNIA PROBOSCIDEA. The best nnd most productive varieiy for pickling. Pkt., 10e.; oz., 30c,; $1 / 4 \mathrm{lb}$. 85c:; $1 \mathrm{~b} ., 83.00$.

\section{MUSTARD}

One ounce will sow about seventy-five feet of drill.

SOUTHERN GIANT CURLED. Highly esteemed in the South, where the seed is sown in the Fall, and used in the Spring as a salad. Our stock is the true curled leaf, and produces plants two feet high, and of greater breadih forming 作

NEW CHINESE, Lenves twice the size of the ordinary White Mustard, crimpled like a Savoy cabbage; stems more succulent; flavor pleasantly sweet and pungent. In six weeks from the time of sowing, the leaves are enten boiled like spinach, and the plants will continue to yield until frost sets in. Pkt., 5c.; oz., 10c.; 1/4 lb., 25c.; lb., 70c.

WHITE LONDON. The old sort, used for salads anc

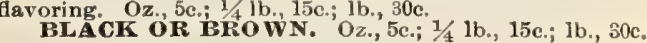

\section{NASTURTIUM}

TALC YELLO $W$. The best for pickling, seed pods or

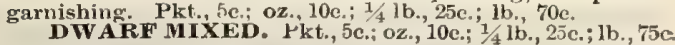

\section{OKRA-Gombo}

One ounce will plant one hundred hills.

\section{Perkins' Mammoth Long Podded}

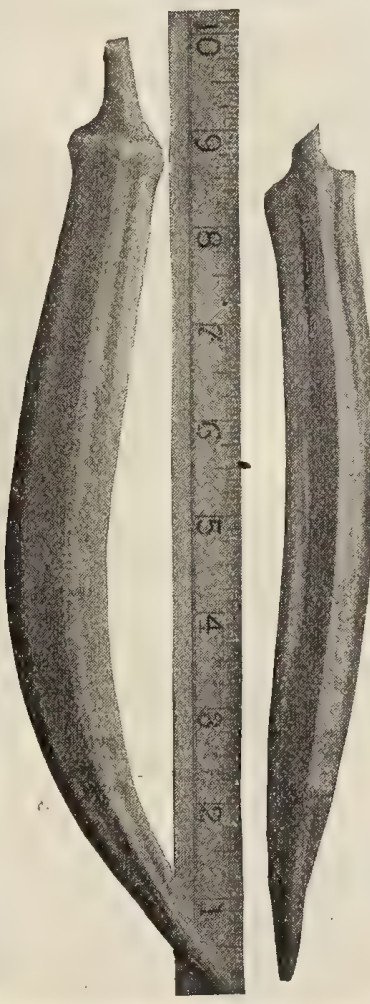

PERKINS' MAMMOTH LONG GREEN PODDED OKRA.
This distinct new okro is by far the best. It originated by $\mathrm{M}$, B Perring, a well-known Jersey trucker, after main Jersey trucker, after manc cears of careful study ancs selection. Its productiveness is simply wonderful. The pods shoot out from the stalk within three inches of the ground, and the rvhole plint is covered with them to the extreuse height of the plant The pods are an intense green olor, of unusual length, eight to nine inches, very slim, and do not get hard. as is the case with other okras. It is also much sought after by canners, being the best of all green sorts for canning forWinter use Our seed is grown by . the originator. Pkt, 5c. 2., roc., postpaid, by freiglit or express: 1b., 65e.; 5 lbs. and over, $60 \mathrm{c}$. per $1 \mathrm{~b}$.

L A U Y F I G E R. A fine new variety from the South. Very productive of very long, slender pods of fine round form, white and smooth. If used in its early state of growth, it will be found exceptionally tender and exceptionally tender and choice Pkt., 5c.; Oz., 10c.; $1 / 4$ lb.20c.; ib., 60c

DWARE GREEN PROLIFIC, or DENSITY, A distinct variety . growing about 14 inches in heipht Very productive of fiue, smooth pods. Plet 50.0 , shoth pods. Plkt., 5c.; 0z., 10c.; 1/4 lb., W H I TE VELVET。 This distinct and beautiful new okra was originated in Georgia. The pods are very large, perfectly 8 mooth, never prickly, round, not ridged or square, as in other okras. Pkt.,5c.; oz., 10c.; $1 / 4$ lb., 20c.; lb., 60c.

YOU ARE INVITED TO CALL OR WRITE for Special Prices on SEED POTATOES, ONION SETS, COW PEAS, GRAINS and GRASS SEEDS, the prices of which vary with the market. 


We

There is no vegetable in which the quality of the seed exerts a greater infunence upon the crop than in onions. Our stock is all grown from choice bulbs, selected by hand, and is unsurparsed in this country. During our whole business career as seelsmen, it has always been our aim to make quality a first consideration, price afterwards, and in no one crop have we met with greater reward fur our efforts than in onions, the demand for our seed having increased so rapidly that we have been obliged to largely increase our facilities for growing every year for several years past.

PHILADELPHIA-GROWN SEED, or that raised in the southeastern part of Pennsylvania, is unquestionably earlier than New England seed, and still earlier compared with ivestern seed. This is an important feature, as the early market onions always bring the lighest prices. The growth conclusiveiy proves our claim, the Philadelphia seed making bulbs of better quality ior keeping or imme diate use, either as sets or full-sized onions, long before seed from any other locality. Larce, full-sized onions can be grown from oul seed the firt season in any section of the United States, North or South

One ounce will sow one hundred feet of drill. To grow large onions from seed, five pounds to the acre; to grow small sets, fifty to sixty pouriss to the acre are required. For full information, for culture storage and marketing onions and onion sers, sew our New Leaflet-Essays on tr.is subject, which will be sent free with all orders for onion seed, when raguested.

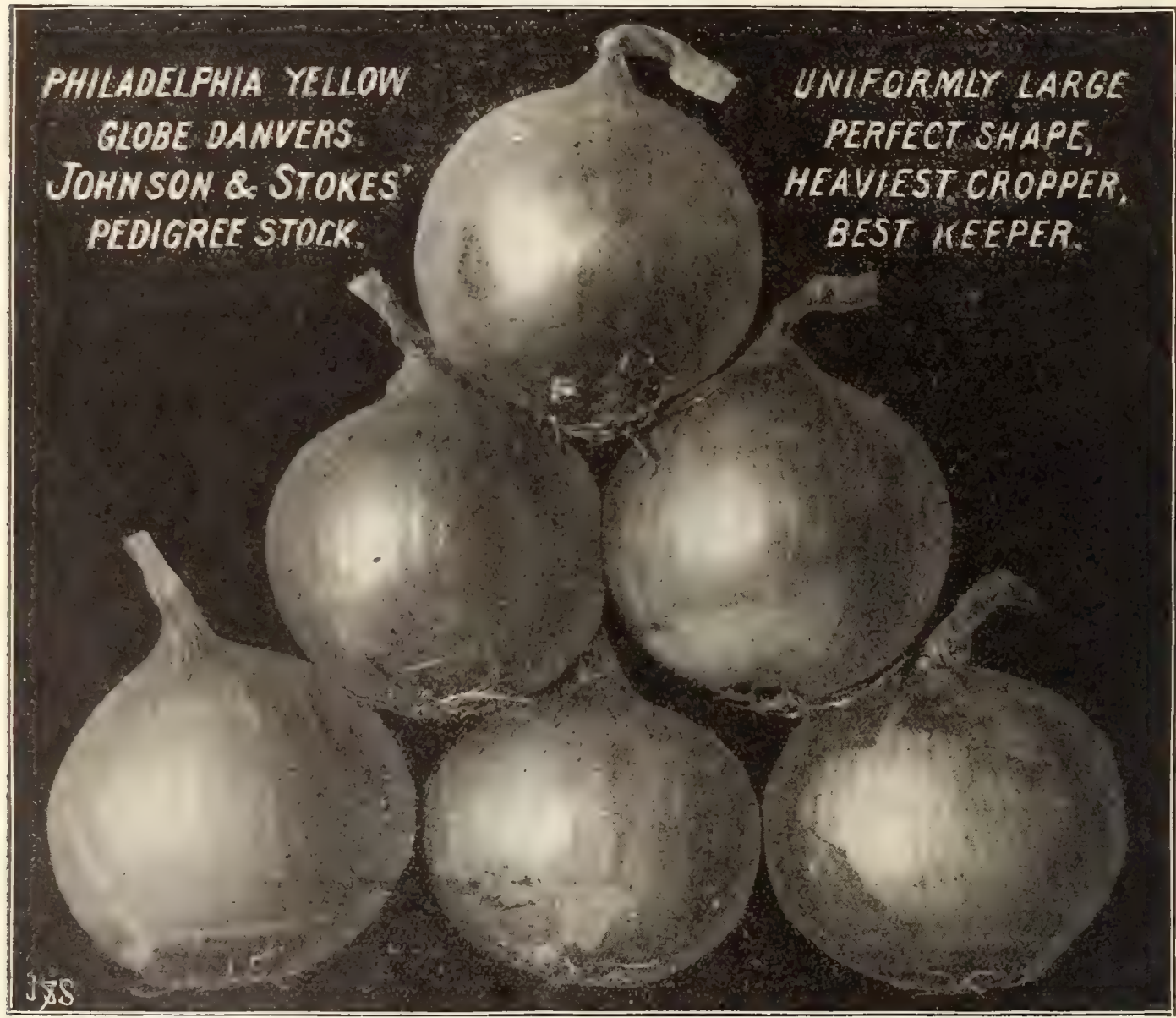

\section{Philadelphia Yellow Globe Danvers Onion}

Do Not Confound with the Ordinary Yellow Globe Danvers of other Growers

This improved variety is pronounced by onion growers, who now grow it in preference to all other onions, the very best strain in cultivation. It is the earliest yellow globe variety, large in size, uniformly perfect in shape and the largest cropper, producing from seed 1,000 bushels to the acre with good cultivation. It is also the most reliable for bottoming, and one of the best keepers of all American Onions. Prices, new crop, Pedigree Tested Seed, grown from selected hand-picked bulbs: Pkt., 5c.; oz., 15c.; 1 lb., 35c.; lb., $\$ 1.25$, by mail, postpaid; by express or freight, lb., $\$ 1.15 ; 5-1 b$, loti for $\$ 550$; 10 lbs., $\$ 1.00$ per lb.; 25 lbs. and over, 95c. per ib. 


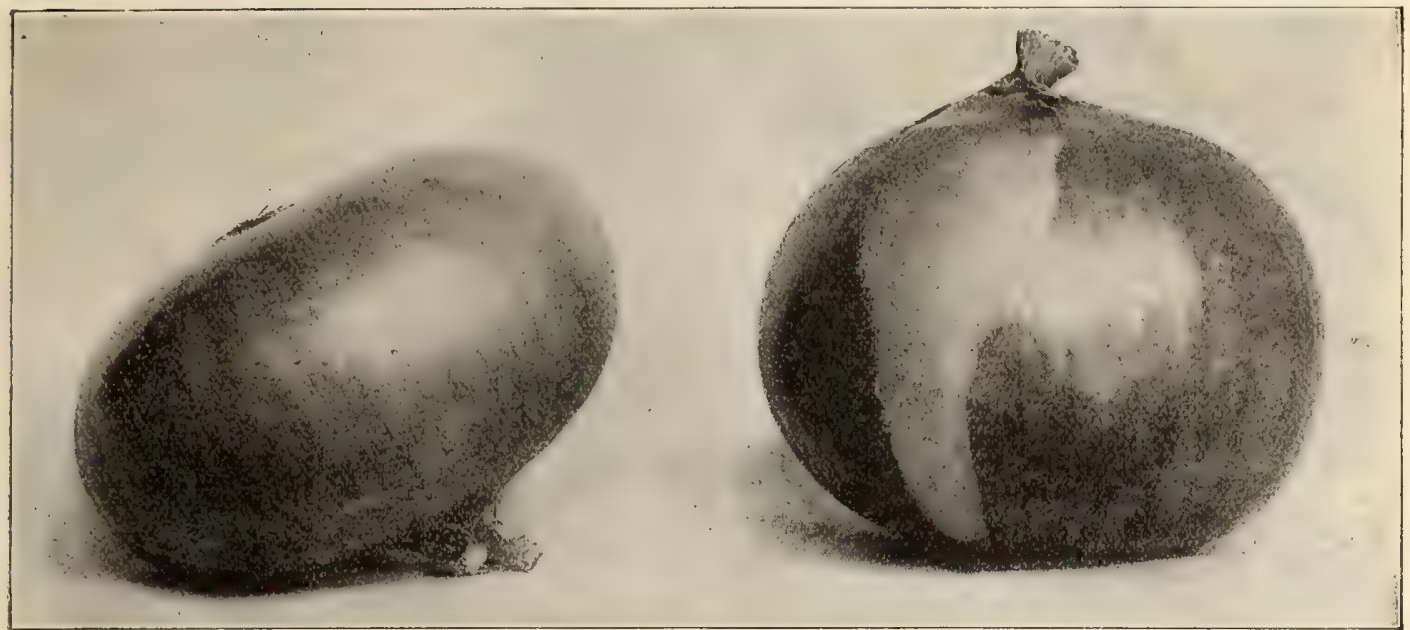

PAILADELPEIA YELLOW DUTCH, OR STRASBURG ONION.

TREE ROUND YEILOW DANVERS ONTON.

\section{Phila. Yellow Dutch or Strasburg Onion \\ 'The great set onion-our pedigree Philadelphia-yrown seed.} The most popular variety for sets, grown so extensively by market gardeners around Philadelphia. The sets of this variety grow round, plump and bright. Full-sized onions are somewhat flattened, as shown in photograph, flesh white, mild flavor and an excellent keeper. Skin bright yellow. Pkt., 5c.; oz., 10c.; 1 lb., 30c.; lb., $\$ 1.00$, postpaid ; by express or freight, 1b., 90c.; 5 lb. lots, 80c. per lb.; 25 lbs. and over, 75 c. per lb.

\section{True Round Yellow Danvers Onion}

Our superior stock of this celebrated variety is of fine round shape, as shown in photograph above. It grows to good size, with thin yellow skin, white flesh, fine grained and excellent quality. It ripens early, keeps well and is very productive. This variety is catalogued by many seedsmen as Yellow Globe Danvers, which is a misnomer. Pkt., 5c.; oz., 10c.; $\frac{1}{4}$ lb., 30c.; lb., $\$ 1.00$, postpaid. By express or freight, lb., $90 \mathrm{c}$; $5 \mathrm{lbs}$. for $\$ 4.25$; 10 lbs., 80c. per lb.; 25 lbs. and over, 75c. per lb.

\section{Model Export Hardy Onion}

This new onion, seed of which we offered for sale for the first time last season, originated in Northern New York, where the seed had heretofore been controlled by a few market growers. In fine color they are different from all other onions, and might be described as a pinkish dark yellow or distinct mandarin color. They have become noted for their long-keeping qualities, commanding high prices and much sought after by onion dealers in New York and Boston for shipment to foreign countries. Their rapidity of growth makes them invaluable, as they are ready for bunching for market two weeks before any other onion, growing good-sized onions from the black seed almost as early as other onions grown from sets, and can therefore be produced much cheaper. Per pkt., 10c.; oz., 30c.; $\frac{1}{4}$ Ib., 90c.; lb., $\$ 3.25$; 5 lbs. for $\$ 15.00$.

\section{What Growers Say of 2 Grand Onions}

WARren Webster, Port Monmouth, N. J., Aug. 29, 1903, writes: "I had on Auqust 2lith onions of your Model Export Hardy, measuring 4 inches in dianeter, said by onion growers in this section to be ahead of all onions they ever saw grown from seed. They grew splendidly while other kinds wele a fuiles a home market for them all at good prices."

R. G. White, W. Orange, S. Dak., Oct. 24th, writes: "It is beyond my power to properly describe the merits of the New Hardy Export Onion. It is very large for one so early, distinct and beautiful in color, extremely hardy, and the onions look to me as though they would keep for a year."

John O. RAsser, Mill Hall, Pa. Aug. 13, 1903, writes: "Your Philadel. phia Yellow Globe Danvers Onion seed has produced for me the finest crop of onions in all this section; no other will be planted here next year."

HENRY Hoskins, Binghamton, N. Y., writes: "In twenty years' experience your Philadelphia Yellow Globe Danvers has proven the best and handsomest onion I have ever grown ; a wonderful seller and keeper."

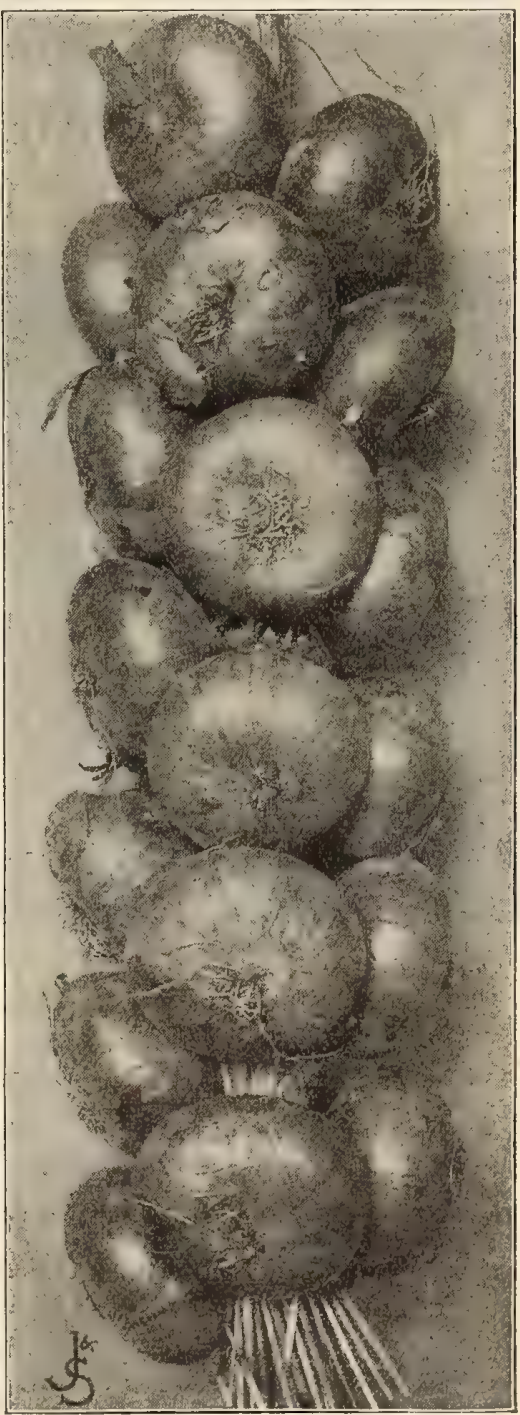

MODEL EXPORT HARDY ONION, as bunched for early home market. 


\section{Extra Early Red} Globe Danvers

\section{Onion}

This beatiful new onion, first introduced by us, has rapidly grown in favor. Its extreme earliness has been a great surprise to all market gardeners who have grown it. It is of perfect globe shape, resembling the Southport Large Red Globe in its rich purplish-crimson color, but is ready for market several weeks ahead of that variety, and is unquestionably the earliest American red variety ever introduced, and one of the best keepers. Per pkt., 10c.; oz., 20c.; \& 1b., $50 c$; lb., $\$ 1.70$, postpaid ; by express, lb., $\$ 1.60 ; 5 \mathrm{lbs}$, and over, $\$ 1.50$ per lb.

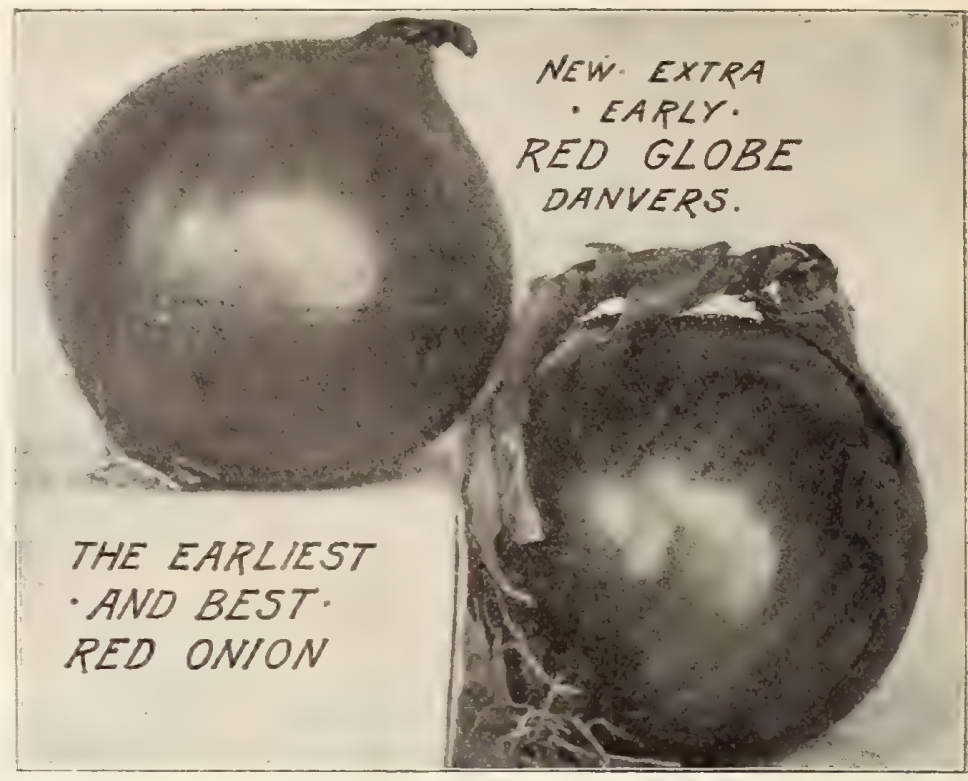

New Extra Early Australian Yellow Globe Onion

A fine deep globe strain of the celebrated Australian Brown Onion. Bulbs very solid and heary, with remarkable keeping qualities. Pkt., 5c.; 0z., 15c.; $\frac{1}{4}$ lb., 40c.; 1b., \$1.40.

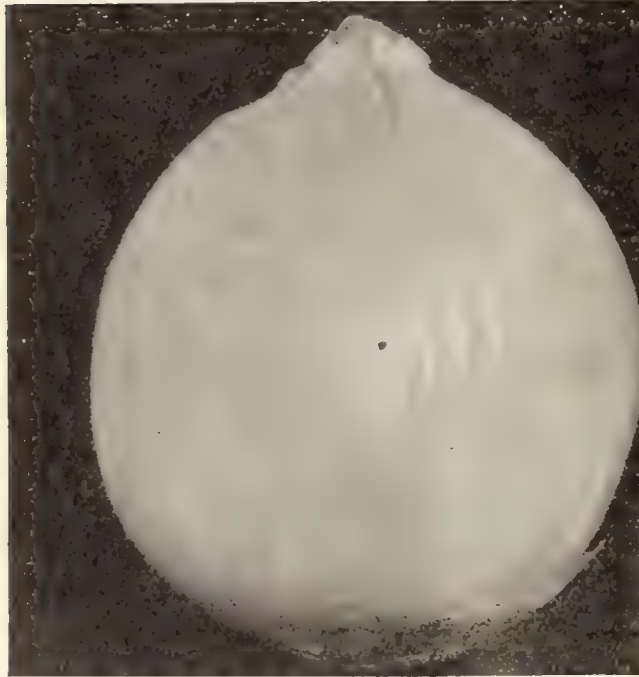

MINNESOTA WHITE GLOBE ONION

\section{Minnesota Globe Onions}

These are new true globe onions of the finest and most select type, so called to distinguish them from all other stocks of red and white globe onions, differing in earliness, productiveness, perfection of shape and longkeeping qualities. From reports of customers and our trials with them, we believe them to be the onion of the future. We offer choice new seed grown in Minnesota by the originator

Minnesota Globe Wethersfield Red Onion. Per pkt., 5c.; oz., 20c.; $\frac{1}{4}$ lb., 60c.; lb. $\$ 2.00$.

Minnesota White Globe Onion. Per pkt. 10c.; oz., 30c.; + lb., 80c.; lb., $\$ 2.75$.

\section{Philada. Extra Early Red Flat}

Ten days earlier than Wethersfield; of medium size and deep red color; well adapted to cold mucky soils, where other varieties fail to produce full sized onions. Pkt., $5 \mathrm{c} . ; \mathrm{oz}, 10 \mathrm{c}$. $\frac{1}{4}$ lb., 30c.; lb., \$1.10, postpaid ; by express, lb., $\$ 1.00 ; 5$ lbs., $\$ 4.75$; 25 lbs. and over, 90c. per lb.

\section{Extra Large Red Wethersfield}

A magnificent strain, far surpassing the ordinary Red Wethersfield in size, produc. tiveness and keeping qualities. immense crops of this onion are grown each season from our seed by some of the largest growers in the United States. Pkt., 5c.; 0z., 10c.; $\frac{1}{4} 1 \mathrm{~b} ., 35 \mathrm{c}$. lb., $\$ 1.20$, by mail, postpaid; by express, lb., $81.10 ; 10 \mathrm{lbs}$. and over, $\$ 1.00$ per lb.

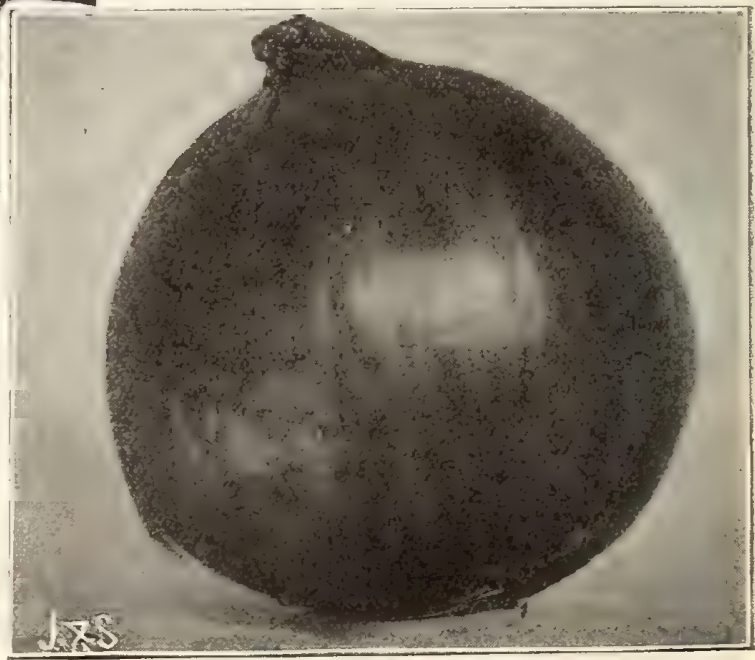

MINNESOTA GLOBE RED WETHERSFIELD ONION. 


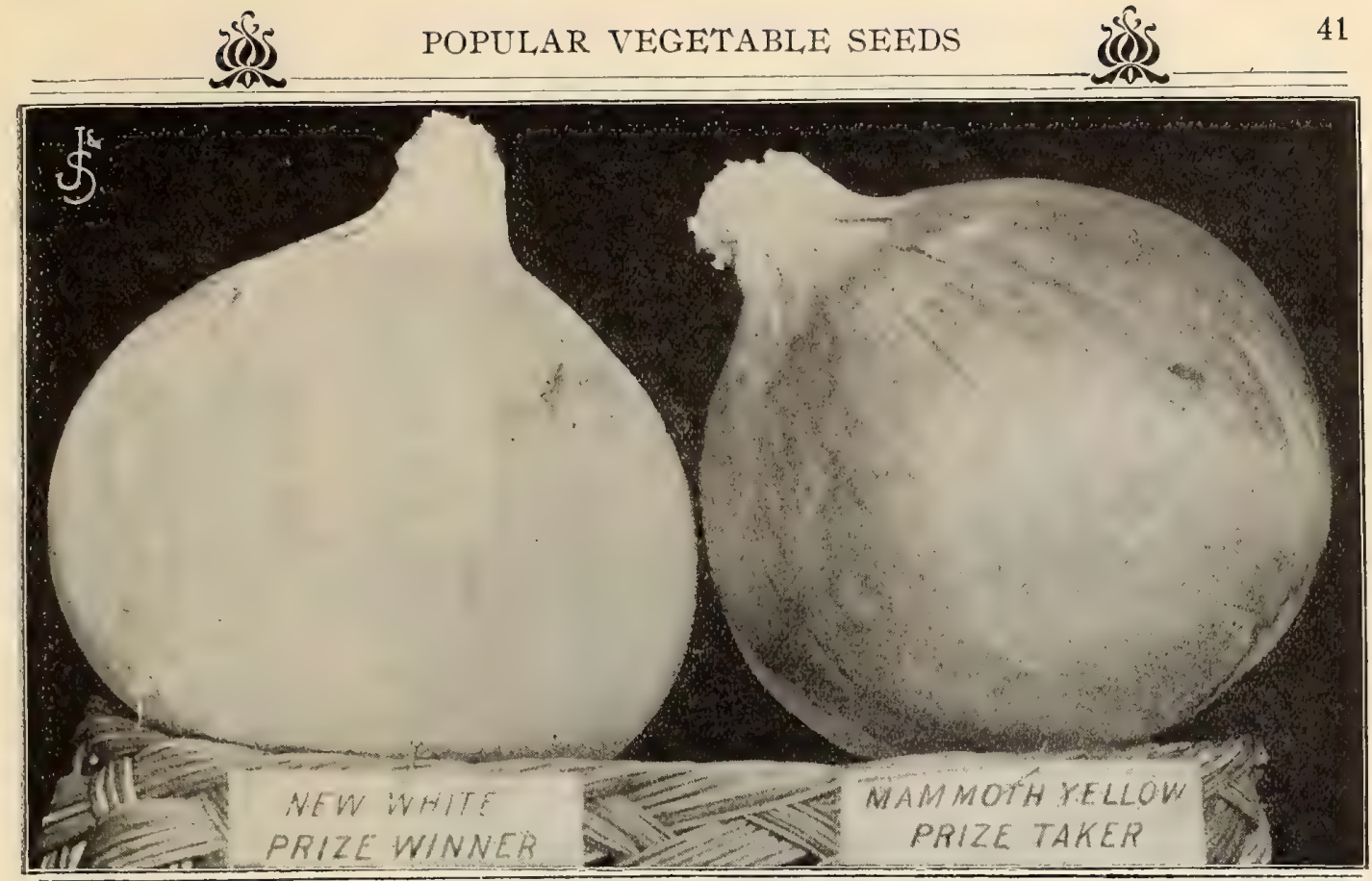

\section{A Select List of other Standard American ONIONS}

Large packets, 5c. each, except where noted. If ordered sent by express or freight, deduct $10 \mathrm{c}$. per $1 \mathrm{~b}$. In 5-lb. lots and over, $15 \mathrm{c}$. per $1 \mathrm{~b}$. may be deducted.

Mammoth Yellow Prize Taker. Very large and fine skin; rich yellow flesh; white, sweet, mild and tender; enormously productive

Philadelphia Long $=$ Keeping Yellow Egg. See Novelties, page $9 . . . . . .$.

Australian Brown. New long keeper; early, flat; fine quality ; distinct color

Southport Large Yellow Globe. Popular in New England; very deep globe

Michigan Yellow Globe. True Globe ; rich orange ; suitable for muck lands

Golden Ball. Very deep globe; skin rich golden yellow ; fine keeper ; superior

Rhode Island Yellow Cracker. Earliest yellow onion; flat shape ; great keeper, Southport Large Red Globe. Matures late ; a splendid keeper; of fine quality, American Extra Early Pearl. Earliest of all white onions ; very large ; pkt., 10c., New White Prize Winner. Counterpart of Mammoth Prize-Taker.' Pkt., 10c., Southport Large White Globe. Very large, solid and handsome; deep globe . .
Philadelphia White Silver Skin, or Portugal. Best white onion for sets. . Ivory Ball. Perfectly round, pure white skin and flesh; best of keepers ; pkt., 10c., Hard Round Silver Skin. The best for pickling; uniform, small, round bulbs,

White Bunch. Very early ; one of the best for bunching in a green state THE BEST FOREIGN ONIONS

Giant Rocca. Very large globe Italian; reddish brown skin

Red Bermuda Very early

White Bermuda. Freshly imported from Island of Teneriffe; genuine seed . : . 30

White Q ueen. Very early ; grows rapidly ; mild ; remarkable keeper ... . . . 20

White Adriatic Barletta. Neatest and smallest; valuable for pickling

Mammoth Silver King. Handsome flat onion ; reaching enormous size

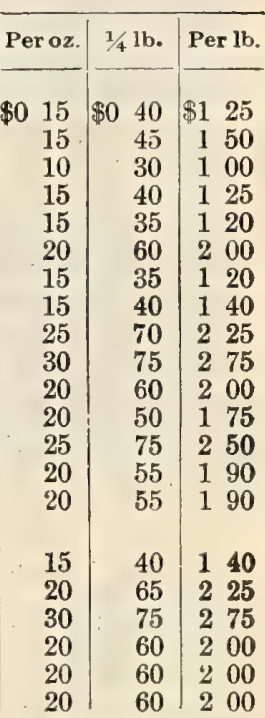

\section{CHOICE PHILADELPHIA GROWN ONION SETS}

"Philadelphia-grown onion sets" are everywhere recognized as the best. Experienced gardeners insist upon having them, and enormous quantities are supplied annually to growers in all sections. We grow each season large quantities from our Philadelphia seed, which, being earlier, makes beautiful, small, round sets of better quality than those grown in any other section.

\section{MODEL EXPORT HARDY ONION SETS}

We have grown a limited supply of handsome sets from this valuable new onion. Those planting them should get the very earliest onions. Qt. 30c. (qt., postpaid), 40c.; peck, \$1.75.

AUSTRALIAN BROWN ONION SETS. This new onion makes a beautiful round set, which keeps until late in the spring. Per qt., 30c. (qt., postpaid, 40c:); peck, \$1.75.
Prices on the following vary with the market from $\$ 3.00$ to $\$ 4.00$ per bushel. We are always glad to quote special prices for bushels or barrels.

PHILADELPHIA YELLOW DUTCH, or STRASBURG and PHILADELPHIA YELLOW DANVERS ONIUN SETS ; each : per qt., I5c.; qt., by mail, postpaid, $25 \mathrm{c}$.

EARLY YELLOW CRACKER and PHILA DELPHIA EXTRA EARLY RED ONION SETS; each : per qt., 25c.; qt., postpaid, 35c.

PHILADELPHIA WHITE, or SILVER SKIN, per qt., 25c.; qt., postpaid, $35 \mathrm{c}$.

YELLOW OR RED POTATO and WHITE MULTIPLIER ONION SETS; each: per qt., 25c.; qt., postpaid, $35 \mathrm{c}$. 


\section{THE BEST NORTHERN GROWN SEED PEAS}

One quart will plant one hundred feet of drill. One and one-half to two bushels will plant one acre.

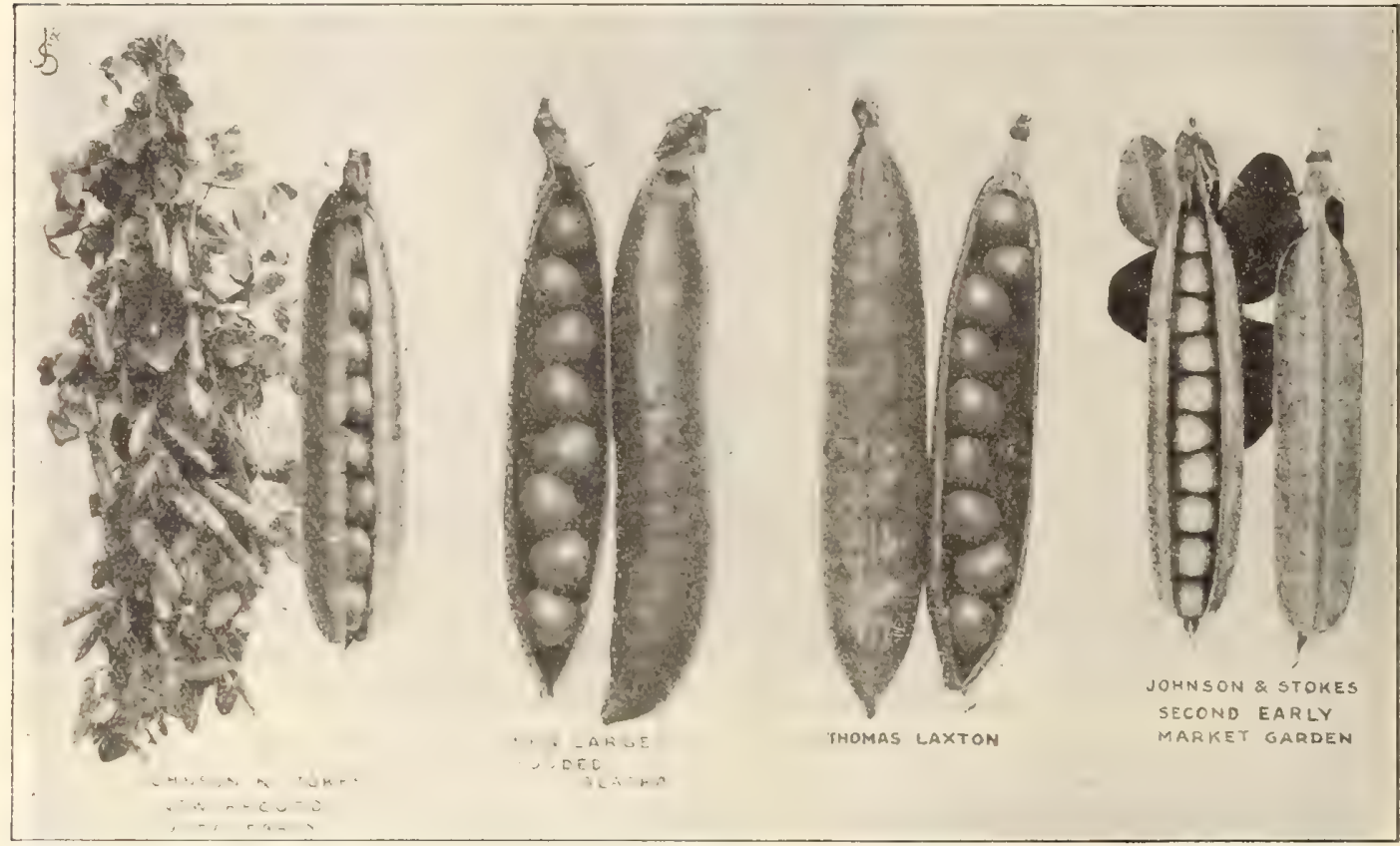

Four of the Best Early Peas to Plant for Succession

In photographing the above pods they were reduced to one-half natural size.

PEAS-Northern Grown Extra Early Varieties.

Each of the following, soc. per large packet, postpaid.

We furnish $\frac{1}{2}$ pecks at peck rates, $\frac{1}{2}$ bushels at bushel rates.

Those marked with a $\left(^{*}\right)$ are wrinkled varieties.

Johnson \& Stokes' New Record Extra Early. The very earliest, most vigorous, uniform and productive; ex tra early

Johnson \& Stokes' Extra Early. The popular fine standard,

Cleveland's Alaska. The earliest and most popular blue pea,

New Large Podded Alaska. As early as Alaska, with pods and peas almost double the size, more vigorous and proNuctive; a great acquisition

First and Best. Tervearly; popular for market and shipping,

Philadelphia Extra Early, Dan O'Rourke, Hancock. Each,

*Thomas Laxton. The finest early wrinkled pea, superior in earliness and hardiness to Gradus; pods fully as large, enormously productive

* Gradus or Prosperity. Magnificent new, large podded sort,

*Gregory's Surprise. (Eclipse.) Earliest wrinkled variety,

* Nott's Excelsior. An improvement on American Wonder,

*Nott's Perfection. New ; cross of Excelsior and Premium Gem: hardier than either; larger pods, more productive,

*American Wonder. Well known and very popular.

*McLean's Little Gem. Very prolific; a garden favorite.

* Extra Early Premium Gem. Long, well filled, prolific pods, PEAS-SECOND EARLY AND MEDIUM

*Johnson \& Stokes' Second Early Market Garden. Best and surest cropper; produces more pods than any other,

*The Admiral. Fine quality ; one of the best for canning.

* McLean Advancer. Fine standard sort; of excellent quality,

*Abundance. Long, round, well-filled pods; very prolific .

*Horsford's Market Garden. Style of Advancer; very prolific,

*Heroine. Large, full pods; productive ; quality perfect

Improved Fillbasket. Excellent; one of the best for market,

"Sutton's Satisfaction. Showy pods; borne double; delicious,

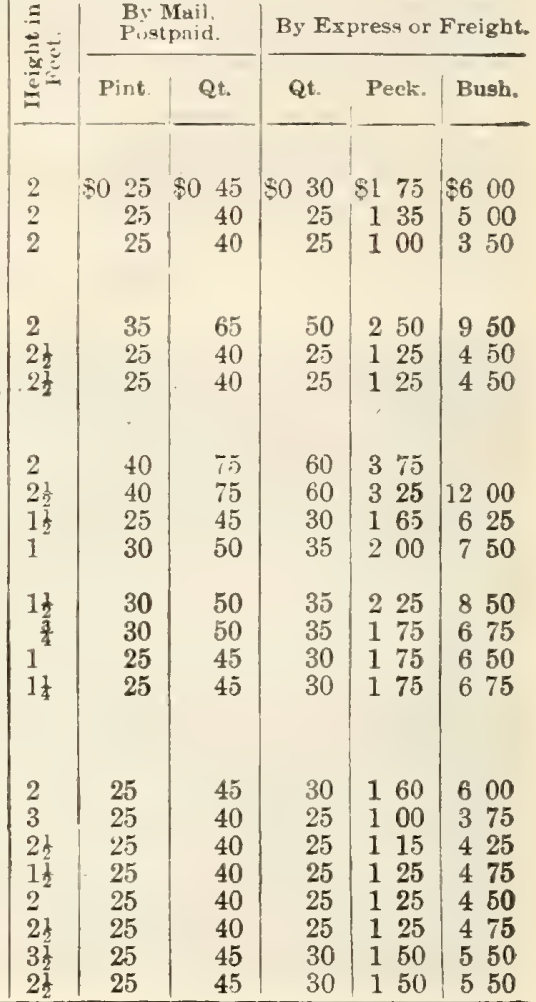




\section{A Grand New English Pea THE MARKET MASTER}

The Best Pea for Medium and Late Use

First imported and introduced by us three years since. Vine is very hardy, growing vigorously to a height of about two feet, unusually prolific. Handsome pods growing uniformly to larger size than any pea we have ever seen, and filled with 8 to 10 very large, delicious peas.

We have received many letters from market gardeners who have planted it the past three seasons, and are sorry we have not room to publish them. One writes: "I am sure Market Master is the best pea the world has ever seen;" another says: "The Market Master created a furore in our market ;" still another writes: "Market Master is a marvel in productiveness, melting in the mouth for sweetness."

Prices: pkt., 10c.; pint, 30c.; qt., 55c., postpaid. By express or freight, qt. 40c.; peck, \$2.25; bush., \$8.50.

\section{NEW DWARF CHAMPION PEA}

This new pea possesses all the merits of the Champion of England, with less vine ( 26 inches), larger pods and more of them and coming a little earlier. Pkt., 10c.; pint, 25c.; qt., 45c., postpaid; by freight or express, qt., 30c.; peck, $\$ 1.60$; bush., $\$ 6.00$.

\section{CARTER'S DAISY, or DWARF TELEPHONE PEA}

A cross of Stratagem on Telephone, giving all the excellent qualities of the Telephone without its tall vines. Vines grow only about 16 inches high, very stocky, vigorous and productive. Pods long, well filled with 8 to 9 large, delicious, pale green peas. Pkt., 10c.; pint, 30c.; qt., $50 \mathrm{e}$., postpaid ; by freight or exprese, qt., 35c.; peck, $\$ 1.75$; bush., $\$ 6.50$.

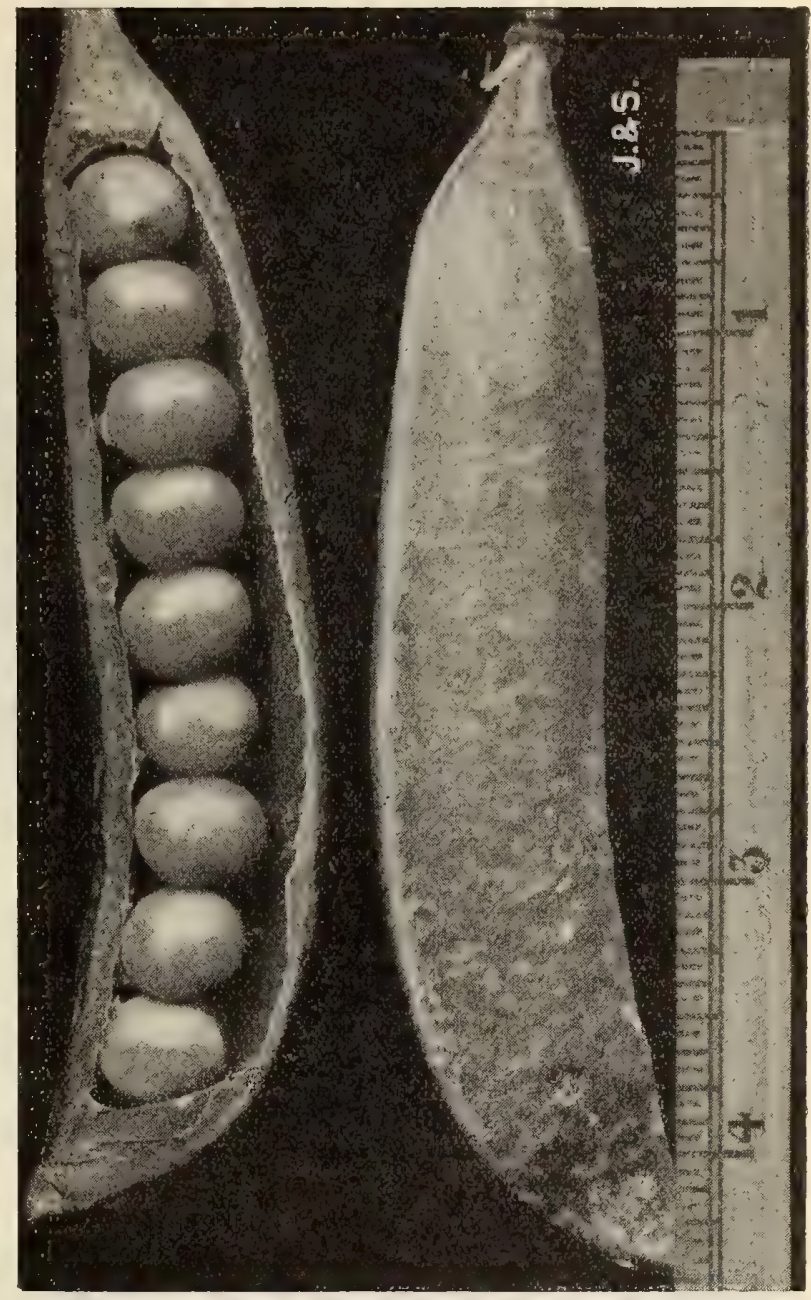

PODS, NATURAL SIZE. NEW MEDIUM AND LATE ENGLISH PEA, MARKET MASTER. LAEGEST PODDED AND MOST PRODUC'IVE PEA KNOWN.

\section{PEAS_Late or Main Crop Varieties}

Each variety in large packets at $10 \mathrm{c}$. each, postpaid

We sell $\frac{1}{2}$ pecks at peck rates, $\frac{1}{2}$ bushels at bushel rates.

Those marked with a $\left(^{*}\right)$ are wrinkled varieties.

*Duke of Albany. (American Champion.) Immense pods .

*Improved Stratagem. More uniform than old Stratagem; larger pods; filled out better in ends of porl ; first quality, Long Island Mammoth or Telegraph. Large pods and peas, *Telephone. Enormous pods and peas of first quality; prolific, Pride of the Market. Our greatly improved uniform strain * Champion of England. Well-known standard variety . *Bliss' Everbearing. Peculiar branching vine ; peas large * Yorkshire Hero. A spreading variety; very productive Blue Imperial. A productive market garden Summer favorite, French Canner. Does not blacken under processing New Giant Podded Marrow. Hardiest large podded pea . Improved Sugar Marrow. Long pods; true marrow flavor . Royal Dwarf White Marrowfat. A favorite for market Black-Eyed Marrowfat. Very hardy and prolific; poor quality, Canada Field. Grown with oats for fodder, also for pigeons * Dwarf Sugar. Extra fine; pods used same as Snap Beans Tall Melting Sugar. One of the best; large, broad pods New Mammoth Podded Prolific Sugar. Largest and best of the edible podded sorts; broad, fleshy, teniler pods

\begin{tabular}{|c|c|c|c|c|c|}
\hline \multirow{2}{*}{ 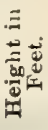 } & \multicolumn{2}{|c|}{$\begin{array}{l}\text { By Mail, } \\
\text { Pustpaid. }\end{array}$} & \multicolumn{3}{|c|}{ By Express or Freight. } \\
\hline & Pint. & Qt. & Qt. & Peck. & Bush. \\
\hline 4 & $\$ 025$ & $\$ 045$ & $\$ 030$ & $\$ 160$ & $\$ 600$ \\
\hline 2 & 25 & 45 & 30 & 160 & 600 \\
\hline $3 t$ & 25 & 40 & 25 & 135 & 500 \\
\hline 42 & 25 & 40 & 25 & 160 & 600 \\
\hline $1 \frac{1}{2}$ & 25 & 40 & 25 & 135 & 500 \\
\hline 5 & 25 & 40 & 25 & 110 & 400 \\
\hline 2 & 25 & 40 & 25 & 135 & 500 \\
\hline 3 & 25 & 40 & 25 & 125 & 450 \\
\hline $2 \frac{1}{2}$ & 25 & 40 & 25 & 100 & 350 \\
\hline 4 & 20 & 35 & 20 & 85 & 300 \\
\hline 2 & 30 & 50 & 35 & 200 & 700 \\
\hline $3 \frac{1}{2}$ & 25 & 40 & 25 & 125 & 475 \\
\hline $2 \frac{1}{2}$ & 20 & 35 & 20 & 85 & 300 \\
\hline 3 & 15 & 30 & 15 & 75 & 275 \\
\hline 5 & 15 & 25 & 10 & 50 & 175 \\
\hline $1 \frac{1}{2}$ & 25 & 45 & 30 & 175 & 675 \\
\hline 5 & 30 & 50 & 35 & 225 & \\
\hline 3 & 50 & 90 & 75 & & \\
\hline
\end{tabular}




\section{Parsley}

One ounce will sow one hundred ind forty feet of drill.

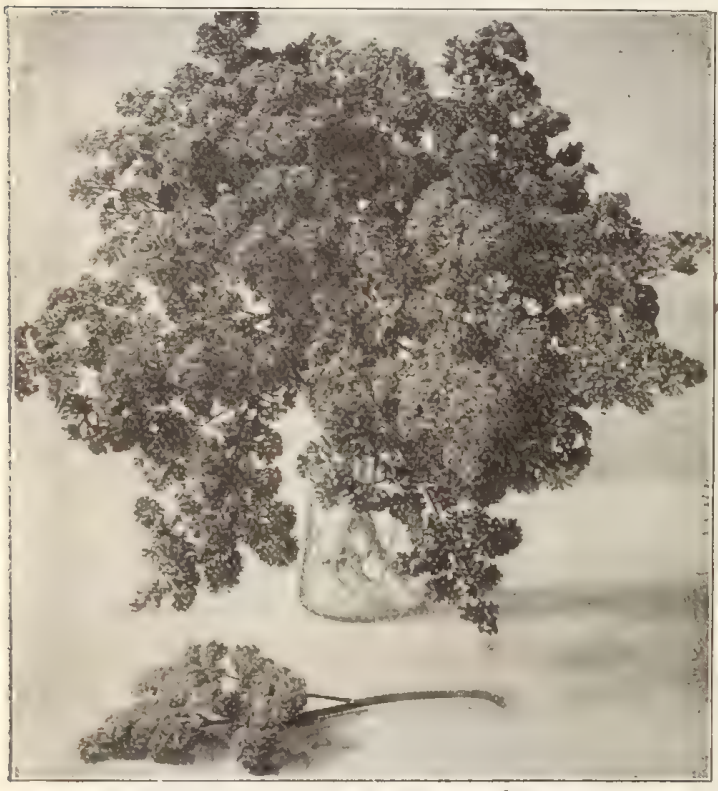

A BNGLE PLANT OF MARKET GARDENER' BEST PARSLEY

\section{MARKET GARDENERS' BEST PARSLEY}

Plant very robust, and is greatly improved by severe cut ting. The leaves are large and beautifully curled and of a very dark green. It stands heat, drought and cold better, and will yield double that of any other sort. The whole appearance of the plant is very handsome, and it ceriainly is "the parsley for either the market or fumily garden." Pkt., 5c.; oz., 15c.; 1/4 1b., 35c.; lb., \$1.20, postpaid : if by express or freight, lb. $\$ 1.10$ or 5 lbs for $\$ 5.00$.

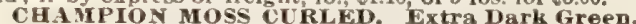
Leaves crimped and curled, giving a most beautiful decorative appearance. Pkt., 5c; oz., 10c,; 1/4 1b., 25c.; Ib., 75e.

EMERALD, OT D'WARE'EXTRA CURLED. Leave tender, beautifully crimped; handsome, bright green color

very ornamental. Pkt., 5c.; oz.. 10c.; 1/4 1b., $25 \mathrm{c}$; 1b., 70c.

EXTRA DOUBLE CURLED. An old curled variety

for garnishing. Pkt., 5c.; oz., 10c.; 1/4 lb., 20c.; lb., 65c.

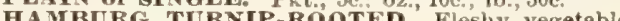

roots, for soups, etc. Plit., 5c.; Oz., 10c.; 1/4 1b., 25c.; 1b., 75c.

\section{Parsnip}

One ounce will sow about two hundred feet of drill; 5 lbs. will sow one acre.

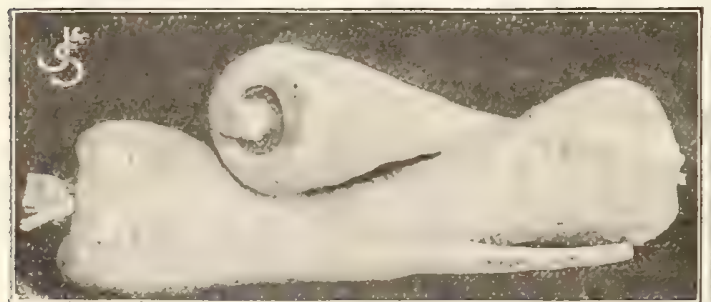

NEW IDEAL HOLLOW CEOWN PARSTIP.

New Ideal Hollow Crown

A greatly improved and wonderfully fine strain of true Hollow Crown Parsnip. The roots do not grow as long as the old Hollow Crown variety, are of larger diameter and more easily gathered, It is a very beavy cropper. The roots are very smooth, flesh fine prained and of excellent quality. The best variety for the market or home garden. Pkt., 5c. oz., 10c." 1/4 1b., 25c.; 1b., 75c., postpaid; by express, 1b., $65 \mathrm{c}$.

LARGE SUGAR, or LONG SMOOTH HOLLOW CROWN. Well-known old standard sort. Plt. 5c. 10e; $1 / 4$ 1b., 20c; ;b., $50 \mathrm{c}$

\section{Peppers}

One ounce will sow one hundred yards of row

TWO NEW PEPPERS. Ruby Giant and Chinese Giant. See illustrations and descriptions under Novelties, page 10

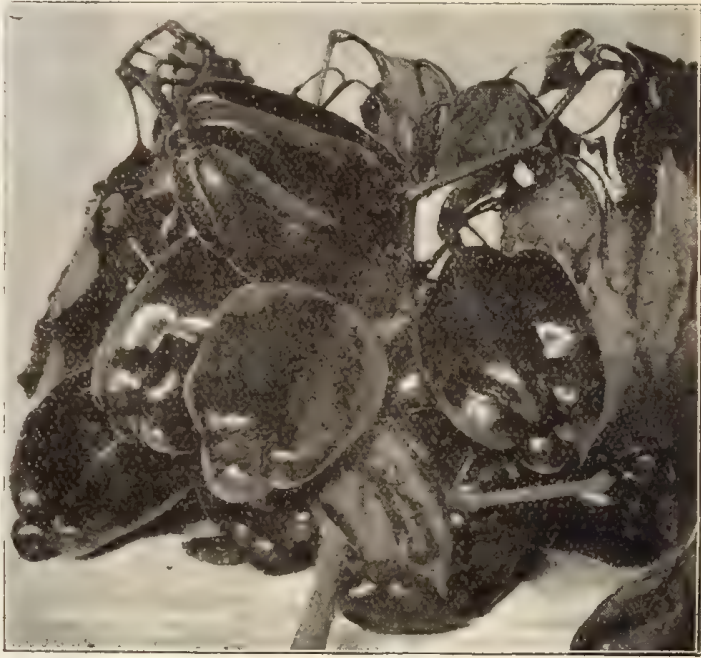

A SINGLE PLANT OF RCBX KING PEPPER.

RUBY KING. Grows to double the size of Bull Nose. The fruits are five to six inches long by about three and onehalf inches through. They are bright red, renarkably mild and pleasant in flavor, having no fiery taste. Single plants ripen from eight to ten fruits. The most popular red pepper. Pkt., 10c.; oz., 25c.; 1/4 Ib., 70c.; 1b., \$2 25

MAMMOTH GOLDEN OUEEN. Originated on our own grounds, where we first found a single plant growing in a lurge field of Ruby King some years ago. They grow irom fifteen to twenty perfect fruits on a plant, from eight to ten inches long and four to five inches through. Color. bright golden yellow, and so mild they can be eaten like tomatoes. Pkt., 10c.; oz., 30c.; $1 / 4$ 1b., 80c.; 1b., $\$ 3.00$

The following Peppers, 10 cents per pkt.

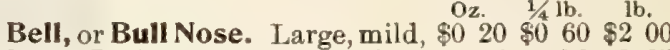
Long Red Cayenne. True, hot, $25 \quad 70 \quad 225$ True Red Chili. Very hot, $25 \quad 75250$ Tabasco. Small, very hot, 40 Cherry Red. Small, for pickles, $25 \quad 75$

\section{Peanut, or Ground Pea}

Full directions for planting, growing and harventing Peanuts printed on each packet.

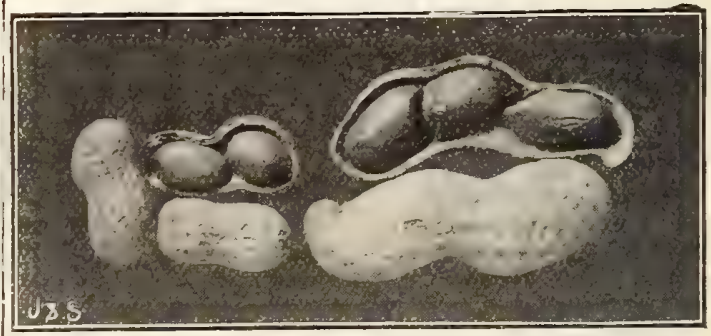

SPANISH PEANUT

GEORGIA IMPROVED PFANUT.

SPANISH PEANUT. Valuable for the Northern States on account of its great earliness. It is smaller than the ordinary peanut, and can be planted closer in the row. Large plet $10 \mathrm{c}$. $25 \mathrm{c}$. at $45 \mathrm{c}$ postpaid peck, 81.75

GEORG A PR OVED GROUंND PEA, or PEA.

NUT. This variety is much superior to the ordinary peanut, yielding fewer imperfect pods and combining earliness, productiveness and size; yields, on ordinary land, over one Ii undred bushels to the acre. Large pkt., 15c.; pint, 30c.; qt., 50c., postpaid; qt., 35c.; peck, $\$ 2.00$, by express or freight. 


\section{SELECTED SEED POTATOES AROWNAT HOULTON,}

These are universally acknowledged to be the very best. Grown in the cold Northeast, where nature and the elements alike decline existence to all but the very hardiest varieties. We make a specialty of and handle this seed solely. Pure and true to name. We pack all our potatoes in the full-size barrel, which is packed solid full and double headed. Special prices by letter on lots of 5 barrels and over.

PI A S N T T T As prices are subject to market fluctuation, we would request that PLEASE NOTICE our customers send in their orders as soon as possible. All orders weather permits, in time for spring planting. Customers residing South can have them shipped at any time during the winter with little or no risk, but those residing North or West had better wait until the extreme freezing weather is over, in March or April.

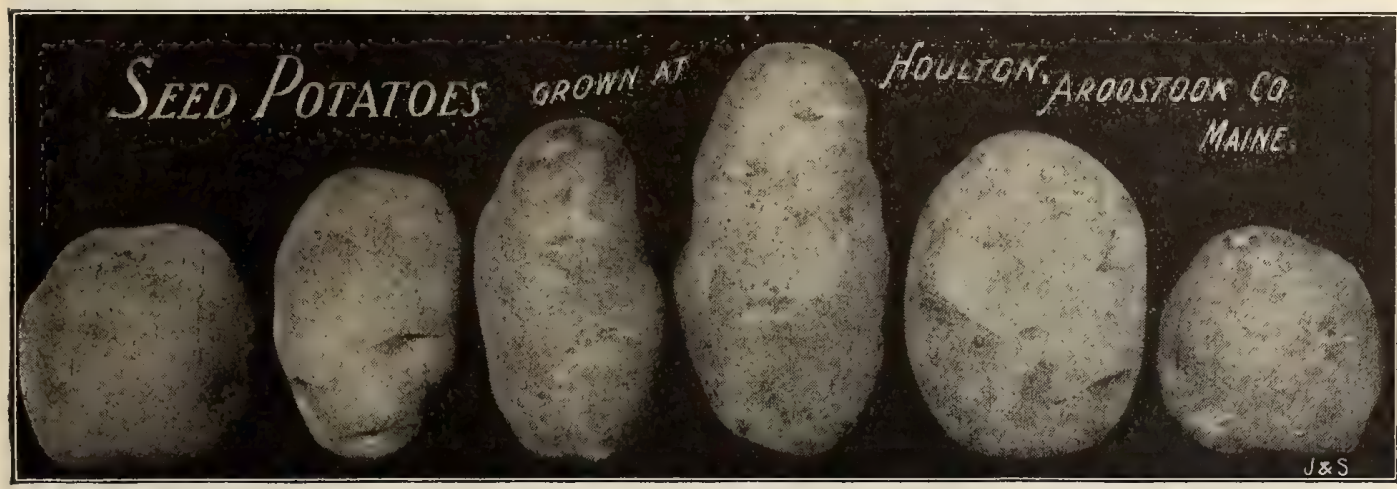

PRIDE OF SOUTH

BOVEE.

PENN MANOR.

THOROEGHBRED.

TABLE KING.

BLISS' TRIUMPE.

POTATOES_Seed grown at Houlton, Aroostook County, Maine. We will furnish in barrel sacks at 15 cents per barrel less than prices here quoted. Prices quoted are subject to market fluctuations.

True Houlton, Maine, Early Rose. Pure and genuine, very fine and early Early Beauty of Hebron. Popular early sort, of excellent quality ; productive, Early Thoroughbred. Earlier than Rose; more productive ; light pink .

Bovee. Earlier than Early Ohio ; very prolific; fine marketable size ; mealy Crown Jewel. Very early; fine and productive; pink, (These three varieties are) Bliss' Triumph, or Stray Beauty. Early, round, red, $\{$ the most popular of all Pride of South, or White Bliss. Early, round, white, $\{$ with Southern truckers. Junior Pride. Extra early ; sport of the above, surpassing it in yield and vigor. Irish Cobbler. New ; round, chunky, 80-day sort; popular for home market Penn Manor. Very early and productive; light pinkish skin ; fine quality Early Ohio. Popular first early ; does well on upland soil ; round and smooth Rural New Yorker, No. 2. Fine for main crop; large, white, smooth, prolific Table King. Productive and fine for main crop ; extra fine in quality; white State of Maine. Heavy cropping, late oval variety; white skin and flesh

Carman, No.1. Fine medium or intermediate; very large shallow eyes; white White Star. Sure cropping late sort; large, smooth, white skin and flesh Green Mountain. Shape oval ; white skin ; big cropper and splendid cooker

\section{VERMONT GOLD COIN POTATO}

A main crop potato of very superior quality, which has been grown quite extensively for a few years past in the great potato sections of western Vermont and eastern New York. It is a very vigorous grower and enormously prolific. Peck, $75 \mathrm{c}$. ; bush., $\$ 2.50$; barrel, $\$ 5.50$.

\section{New Potato-CRINE'S LIGHTNING}

A new and productive extra early sort, of a distinct russet color, quite unlike that of any other potato. Its form is well shown in our photograph alongside. Peck, 70c.; bush., \$2.25 ; barrel, $\$ 4.75$.

\section{POTATOES BY MATL}

All varieties of potatoes can be sent by mail, postage prepaid, at $30 \mathrm{c}$. per pound ; 4 pounds for $\$ 1.00$, correctly labelled and packed to reach the purchaser in good condition.

WHITE POTATO SEED. MIXED. From the best hybridizers. Per pkt., 25c.

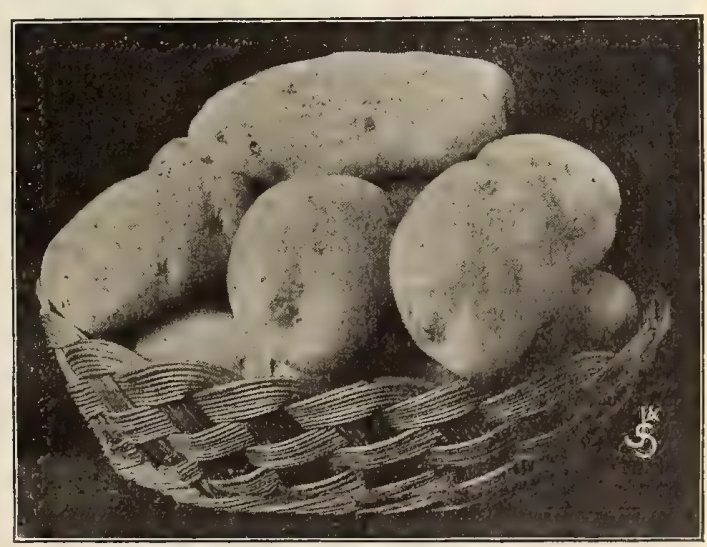

CRINE'S LIGHTNING POTATO. 


\section{SEED SWEET POTATOES}

Wo make a specialty of Seed Sweet Potatoes, growing our stock exclusively in New Jersey, about nine miles from our Philadelphia warehouse, where we have unequalled facilities for handling and storing. New Jersey grown sweet potatoes are everywhere acknowledged to be the best in quility, beine much dryer and sweeter than those grown in the South and West, while their keeping and shipping qualities are away oheed. and barrels, with greatest care; but as they are very suscepand barrels, with grespontible to chmatic changes, wo cannot sible for their condion distinctly understood that customers miles, and wish it distimetis u deliver in good condition to the express or railroad company here. We do not ship until about planting time unless specially ordered to do so. Our barrels contain three bushels-good measure. Full and concise directions for bedding and sprouting the seed setting out and ing a storing forwinter, will be found in our new LeafletFsays on Sweet Potato Culture, which we will send free with all orders when requested to do so.

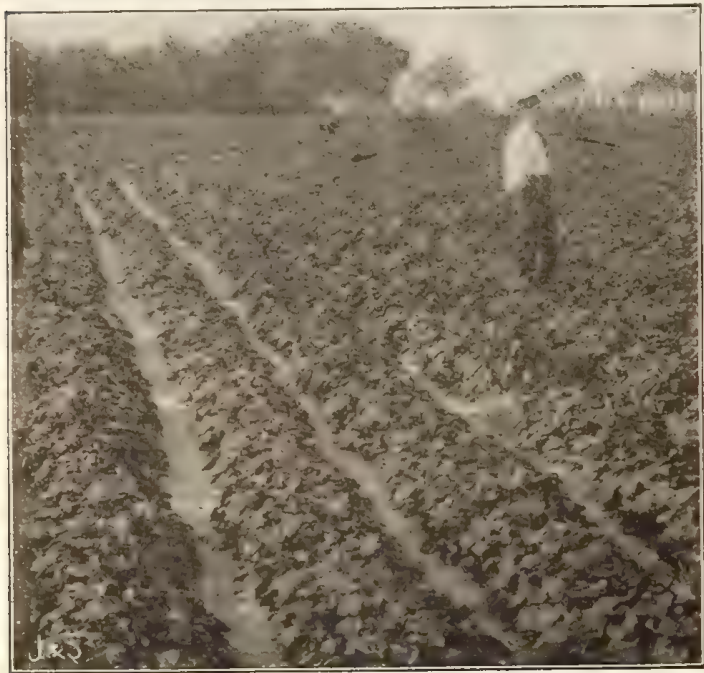

Photograph of Section of Field Grown by the Originator for us, of the NEW VINELAND BUSH BWEET POTATO.

\section{Vineland Bush Sweet Potato}

The New Vineland Bush Sweet Potato is bound to revolutionize $\mathrm{B}$ weet potato culture. It originated on the farm of John May rot, the extensive gweet potato grower of Vineland Sireet Potato. It is a perfect bush, with no inclination for spinning, resembling a bean bush very elosely. ation for spinning, resembling a bean bush very closely. The tubers grow directly under the stalk. They are most abundant excellent keepers. Customers who have tried them say: and excellent keepers. Customers who have tried them say: "They are simply perfection and a great

OF TVTEREST TO DAIRTMEN. Mr. Maytrott writes: "From 2,000 plants I had in one patch $I$ harvested 86 baskets of prime potatoes, 35 seconds and 27 culls, making a total of 1485 bushel baskets. I then had the tops, which average 3 pounds each, which made 6,000 pounds of green forage, which was eaten with great relish by my cows. The milk was rich and had a sweet, pleasant flavor. All other stock except horses thrive on it. By planting in rows, 30 inches wide and 15 inches apart, one acre will contain about 14,000 plants. With proper care you will have a fine crop of potatoes and about Twenty-one Tons of Green Forage,

Prices: ver lb., 40c; 3 lbs., \$1.00, by mail, postage paid; peck S1 50; bushel' 8500 by express. Plants of the New Vineland Bush Sweet Potato, ready after May 1st: 50 for 60 .; 100 for $\$ 1.00$, by mail, postage paid; 75c. per $100 ; \$ 5.00$ per 1,000 , by express. 500 plants at 1,000 rates.

EXTRA EARLY CAROLINA, JERSET "UP RIVERS" AND EARLY NANSEMOND. The justly. celebrated Philadelphia grveet potatoes, universally grown for market. Each, per peck, $80 \mathrm{c}$; bush., $\$ 2.50$; bbl., 84.50 .

We will make special prices by letter for larger quantities-write us before sou-buy.

Plants of the above, ready May 1st, $60 \mathrm{c}$. per 100 , by mail, postpaid; by express, $40 \mathrm{c}$. per $100 ; \$ 2.50$ per 1,000 .

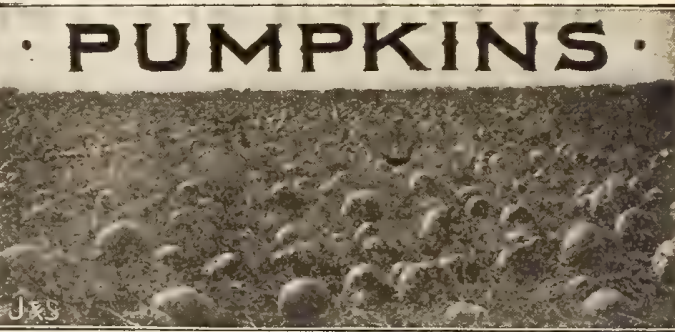

Our field of King of the Mammoths growing for seed, show ing their wonderful productiveness. See next page.

\section{NEW CALHOUN PUMPKIN}

This new pumpkin is pronounced by all who have grown th the best for pies. Shape nearly round somewhat flattened on the ends; skin ereamy brown; flesh iuside of a deep salmon yellow, very thick, fine grained and of most excellent quality. Pkt., 5c; oz.. 10c.; 1/4 lb., 25c.; 1b., 75c.

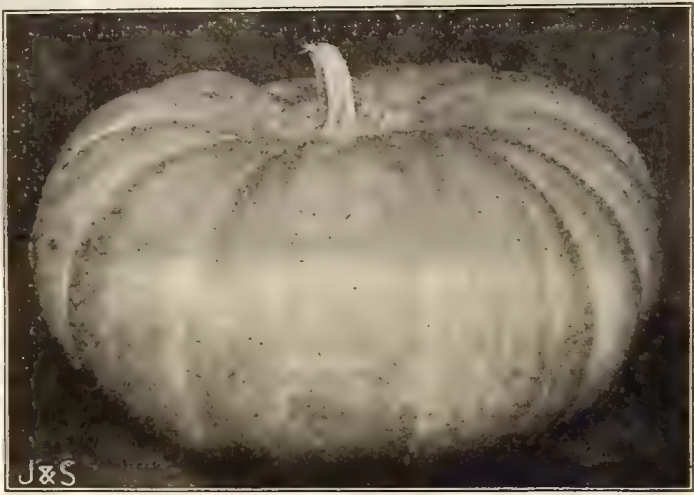

LARGE CHEESE, OR KENTUCKY FLELD PUMPKIN,

LARGE SW EET CHEESE, or KENTUCKY FIELD. A most popular variety. Skin mottled light green and yellow, changing to rich cream color as it matures. Flesh yellow, thick, tender, very nutritious; excellent quality and enormously productive. Pkt.,5c,; oz., 10c.; $1 / 6 \mathrm{lb}, 25 \mathrm{c}$; $1 \mathrm{~b} ., 75 \mathrm{c}$

\section{BIG TOM FIELD PUMPKIN}

This new pumpkin is the result of many years' selection from the old Golden Marrow or Michigan Mammoth Pumpkin. So carefully has the selection been made that the Big Toms will run uniformly to more than twice the size and weight. Skin and flesh are of a deep, rich orange color, of excellent flapor for pies, etc., cooking soft and tender. For table use and stock feeding no more profitable or better vari ety can be grown. Plst., 5c, ; oz., 10c.; $1 / 4$ lb., 25c; $1 \mathrm{~b} ., 70 \mathrm{c}$.

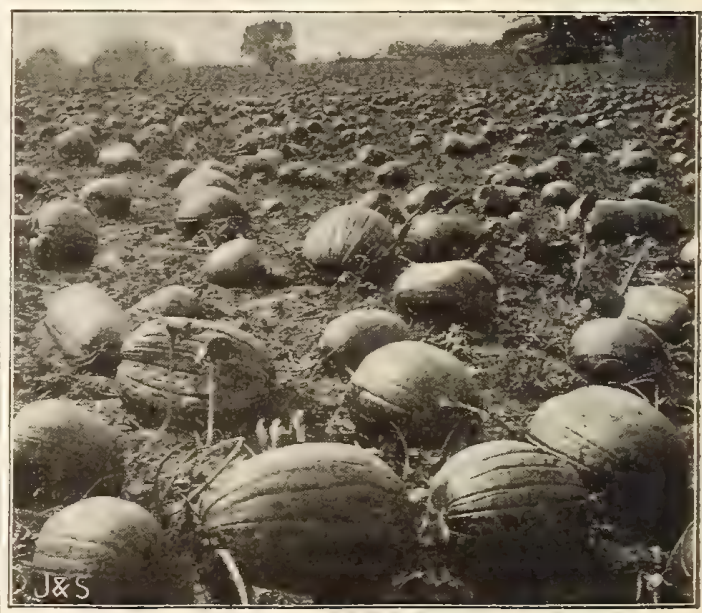

Field of BIG TOM PCMPKINS. Over 20 tons to the acre 


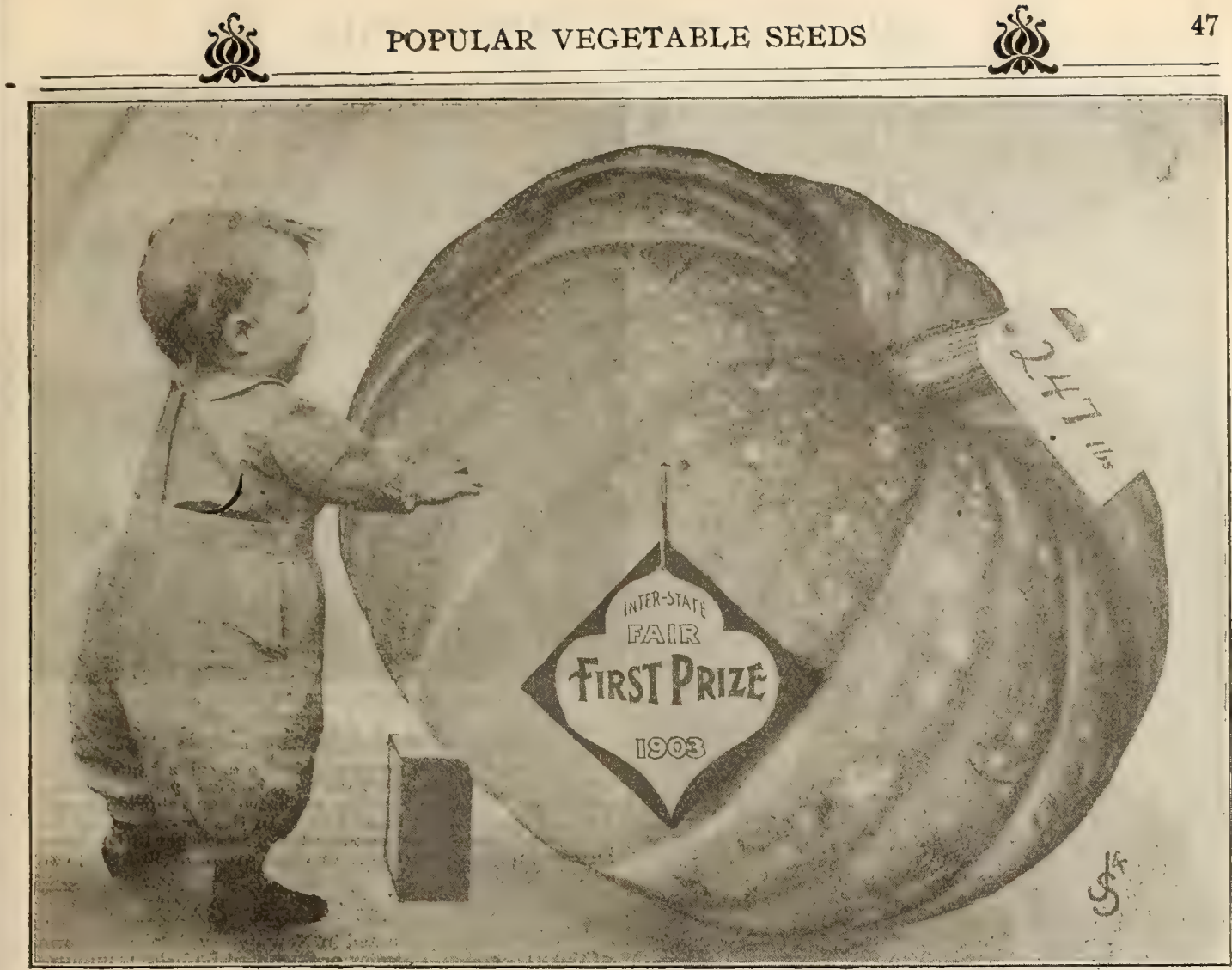

A prize-winning King of the Mammoths, grown in 1903 from Johnson \& Stokes' selected seed, which attracted the greatest attention and wonder at the great Interstate Fair, Trenton N. J., and afterward when placed on exhibition at greatest attention and

\section{KING OF THE MAMMOTHS-The Great Prize Pumpkin}

This now famous pumpkin first came to our attention some years ago, while visiting France, where we secured seed and distributed it among our customers. The results have been astonishing. No other pumpkin ever introduced has reached such enormous weights, and been awarded as many prizes. Hundreds of our customers have raised specimens weighing over one hundred and fifty pounds each, the heaviest ever grown, and sent in to us, being the above specimen, which tipped the scale at two hundred and forty-seven pounds. It frequently attains a diameter of over four feet. The flesh and skin are golden yellow, and notwithstanding its enormous size, it makes a good table pumpkin.

PRICES FOR 1904. Seed saved from specimens selected from our patch weighing one hundred pounds and over. Pkt., r5c.; 4 pkts., 50c. Seeds saved from the general crop, all good, large, uniform specimens. Pkt., 10c.; oz., 25c.; $\frac{1}{4}$ lb., $75 \mathrm{c}$.

\section{PUMPKINS-A Select List of Standard Sorts.}

One pound will plant two hundred to two hundred and fifty hills; four to six pounds plant one acre. Large packets, 5c. each.

Cashaw, or Crook Neck. The old Standard and Popular Crook Neck Cashaw

Improved Green Striped Cashaw. Improvement on White Cashaw, green and white striped ; flesh rich yellow, solid, fine grained, very thick, sweet ... .

New Mammoth Golden Cashaw. The best yet. Skin and flesh rich orange. .

Nantucket Sugar, or Negro. A New England variety with dark green skin .

Small Sugar. Early, prolific and very sweet. orange color. fine treeper

Tennessee Sweet Potato. Bell-shaped, white flesh, very thick and sweet . . .

New Winter Luxury. Golden yellow, finely netted, shape round, flesh very rich, unequalled as a winter keeper and cooking variety

Quaker Pie. Shape nearly oval. Cream-colored skin and flesh; fine quality . .

Golden Marrow. Round oblong, deep orange, fine flavor, good keeper

Common Yellow, or Connecticut Field. Yery productive; grown largely for feeding stock (by express or freight, $10 \mathrm{lbs}$. for $\$ 2.50$; bush., $25 \mathrm{lbs}$., for $\$ 5.00$ ),

MAMMOTH FRENCH PUMPKINS. Packets, 5c. each.

Mammoth Bright Red Etampes. Glossy red, flat, reaching a very large size . . Mammoth Tours, or Citrouille. Very large used in France for feeding cattle. Gray Boulogne. Large, grayish-green; round flattened on ends

\begin{tabular}{|c|c|c|}
\hline Per oz. & $1 / 4 \mathrm{Jb}$. & Per lb. \\
\hline 10 & $\$ 020$ & $\$ 060$ \\
\hline 10 & 30 & 100 \\
\hline 10 & 30 & 100 \\
\hline 10 & 30 & 100 \\
\hline 10 & 25 & 75 \\
\hline 15 & 35 & 120 \\
\hline 10 & 25 & 75 \\
\hline 15 & 35 & \\
\hline 10 & 30 & 100 \\
\hline 5 & 10 & 30 \\
\hline 20 & 50 & 175 \\
\hline 10 & 25 & 75 \\
\hline 20 & 50 & 175 \\
\hline
\end{tabular}




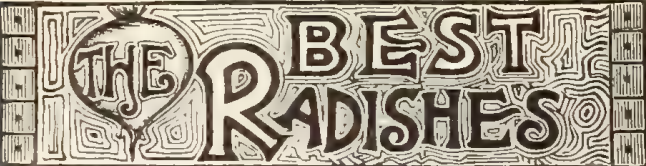

One ounce of radish seed will sow one hundred feet of drill; nine pounds will sow one acre in drills.

\section{Scarlet, or Cardinal Globe Radish}

For forcing in greenhouse hot-beds or cold-frames, and for sowing on open borders early in the Spring, there are no other red varieties better than this and Johnson \& Stokes" New Olive Scarlet Radish, described below. On account of its very attractive color and shape, it sells better than most other sorts. It is one of the earliest; in favor it is mild, crisp, juicy and tender. It forms a small top and will stand a great amount of heat without becoming pithy. Pkt., 5c; oz. 10c.; $1 / 1$ b., 25e.; 1b., 70c.

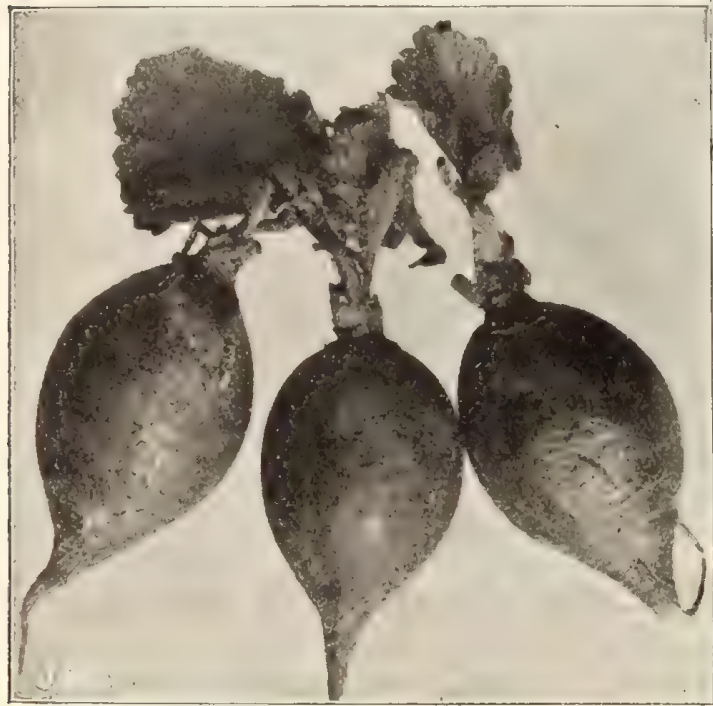

JOHNGON \& STOKES OLIVE SCARLET FORCING RADISH.

Johnson \& Stokes' Olive Scarlet Radish

A decided improvement on the ordinary deep scarlet olive-shed radish selected and perfected by a Philade? phia market grower. The tops are so small that the radishes may almost stand touching each other in the rows. Its fine shape, as shown in photograph above, is not its only superior quality, but it is the handsomest in color of all deep red sorts, selling better in market than other olive-shaped sorts. It is also the best early red radish for the home garden, being

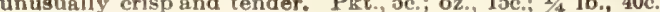
1b., $\$ 1.25$

\section{New Crimson Giant Forcing Radish}

See illustration and description under Novelties, page 10.

\section{THE COMET-A New French Radish}

Since we first introduced, a few years since, this superior new, early, long white radish, we have received hundreds of letters unqualifiedly endorsing it as by far the earliest, handsomest and best in quality of any of its class. In our own trials it has never failed to give good edible radishes in twenty days from soring, and has remained in fine condition for use longer than any other extra early variety. We offer choice seed grown for us by the originator in Prance. Plit. 5c.; oz., 10c.; 1/4 lb., 30c.; 1b., $\$ 1.00$.

\section{New Triumph Radish}

A Valuable and Distinct Novelty in Forcing Radishes The roots are about the same size and shape as Rosy Gem but are creany-white, beautifully marked. with spots and dashes of carmine. The tops are small and it imatures about as early as any variety in cultivation. Desirable on accoun of its distinct beauty, earliniess and good quality. Pkt., 5c. oz., 10c.; 1/4 lb., 30c.; lb., $\$ 1.00$.

\section{Jis}

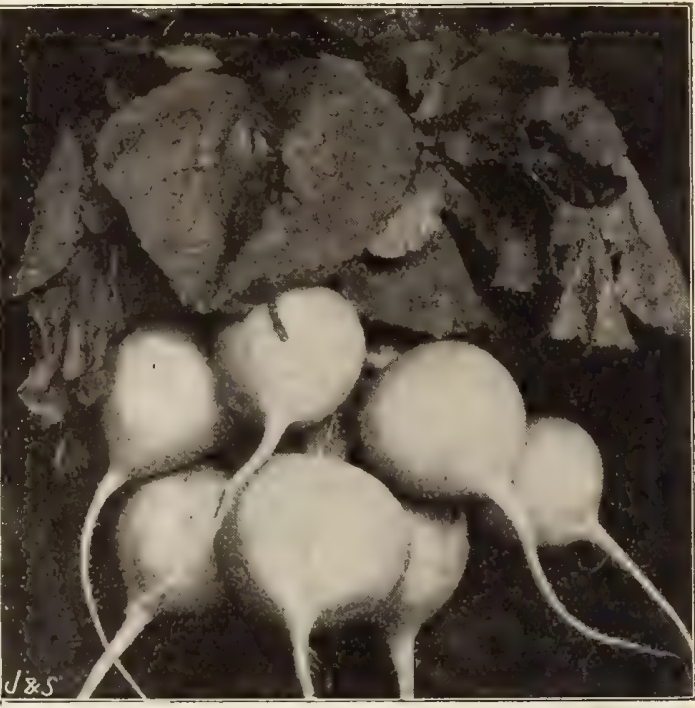

Felton's Model White Box Radish

Felton's Model possesses all the excellent qualities of the old Philadelphia White Box, but is superior in being much handsomer and earlier, with fewer and shorter leaves; hence it can be sown more thickly in the row, ensbling the grower to raise at leagt one-third more radishes in the same apace under glass, in boxes or open ground. Pkt.,5c; oz., $10 \mathrm{c}$; $1 / 4 \mathrm{lb}$., 30c.; lb., 90c.

\section{New White Chartier Radish}

This variety, originated in Nev Jersey, is a white form of the well-known Chartier or Shepherd Radish. It matures in about six weeks from sowing, and remains fit for use three weeks afterward. Tops short, flesh mild, erisp and fine for slicing. Our seed is grown for us by the originator. Pkt., 5c.; oz., 10c.: 1/4 lb., 25c.; lb., 75̄e.

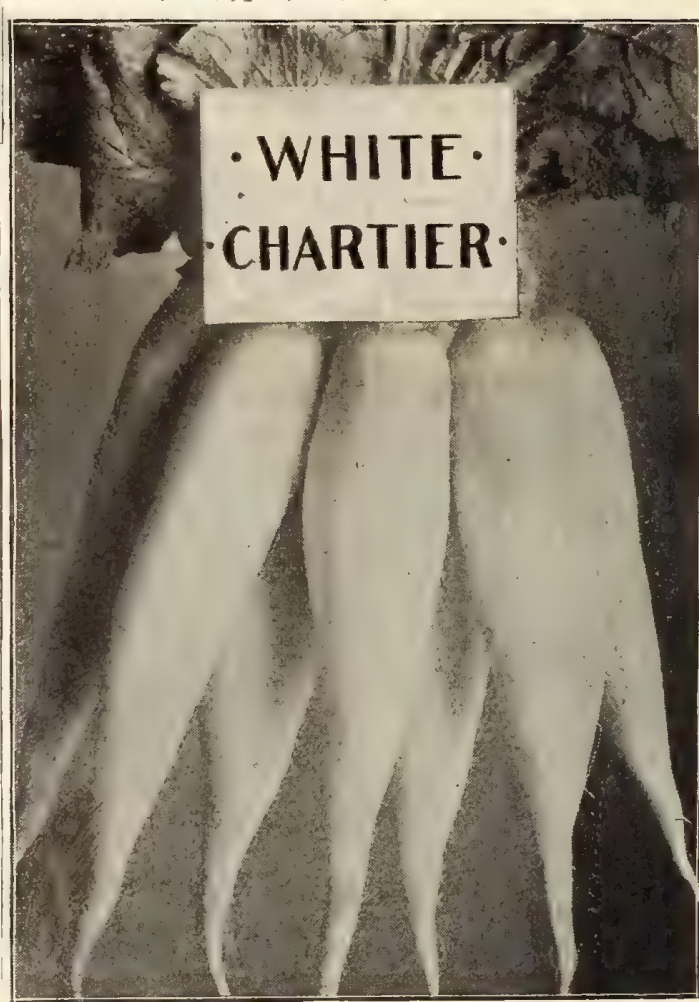




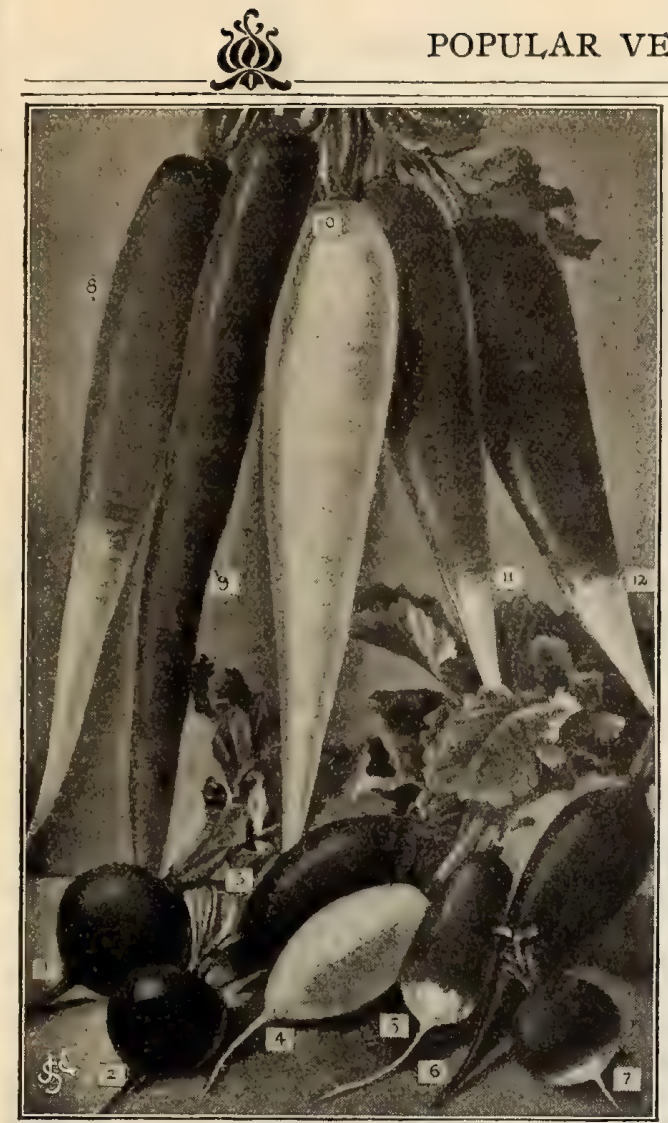

No. 1. Earliest Round Dark Red Radish.

2. Fireball Forcing Radish.

3. Startle, or 20-Day Forcing.

"4. New White Rocket Radish.

“5. French Breakfast Radish.

4 6. Searlet Olive-Shaped Radish.

7. Rosy Gem, or Rapid Foreing.

4. Long Brightest Scarlet, White Tip.

“ 9. Early Long Searlet, or Salmon.

"10. Lady Finger, or White Vienna.

“ 11. Philadelphia Gardeners' Long Scarlet.

“. 11. Chartier, or Shepherd Radish.

\section{Popular Early and Summer RADISHES}

Large packets of any variety, 5c. each.

Extra Early Scarlet Turnip. Very early, small, round (5 lbs., by express, \$2.25).

Earllest Round Dark Red. (Scarlet Button.) Very fine and early ; cut No. 1

Fireball. (Non Plus Ultra.) One of the finest round, red forcing varieties; No. 2 ,

Startle, or Twenty-Day Forcing. (Red Rocket.) Earliest half-long red; No. 3,

Scarlet Turnip White Tip. Popular (5 lbs. and over, by express, 45c. per lb.)

Rosy Gem or Rapid Forcing. Resembles above in color; a week earlier ; No. 7 ,

White Rocket. (New.) Earliest half-long white ; cut, illustration No. 4 .

Double Quick White Forcing. (New.) Very early ; handsome long white .

Early White Turnip. Both skin and flesh pure white (5 lbs., \$2.25, by express),

French Breakfast. Olive-shaped; red, tipped with white; very handsome; No. 5,

Scarlet Olive $=$ Shaped. Quite early and handsome ; of fine quality ; cut No. 6.

Early White Olive-Shaped. White flesh and skin; crisp and mild flavor

Olive-Shaped Golden Yellow. (Surprise.) Earliest yellow; fine for early or Summer,

Newcom. Earliest, best and largest half-long white (5 lbs., $\$ 3.00$, by express).

Half =Long Deep Scarlet. or Paris Beauty. A great favorite; bright, crisp flesh,

Early Long Scarlet, or Salmon. Old sort; cut No. 9 (5 lbs., $\$ 2.25$, by express)

Philadelphia Gardeners' Long Scarlet. A great improvement on Long Scarlet ; earlier, shorter top; better shape and color, fine keeper; No. 11 ( 5 lbs., \$3.00),

Cincinnati Market. New long scarlet type, straight, smooth, very small top

Long Brightest Scarlet, White Tipped. (Long Cardinal.) New French sort; No. 8

Wood's Early Frame. Similar to the Long Scarlet; better for forcing (5 lbs, $\$ 2.25$ ),

Chartier, or Shepherd. Large, long Summer radish ; scarlet; white tip ; No. 12,

Lady Finger, or Long White Vienna. One of the best; cut No. 10 (5 lbs., \$2.25),

Large White Summer Turnip, or Globe. Very popular (5 Ibs., $\$ 2.50$, by express),

Improved Large Yellow Summer Turnip. Improved shape, fine (5 lbs., \$2.25),

\begin{tabular}{|c|c|c|}
\hline Per oz & $1 / 41 \mathrm{lb}$. & Per Ib \\
\hline$\$ 010$ & $\$ 020$ & $\$ 0 \quad 50$ \\
\hline 10 & 20 & 65 \\
\hline 10 & 25 & 75 \\
\hline 10 & 30 & 90 \\
\hline 10 & 20 & 50 \\
\hline 10 & 25 & 80 \\
\hline 10 & 30 & 90 \\
\hline 10 & 30 & 90 \\
\hline 10 & 20 & 50 \\
\hline 10 & 20 & ${ }^{\circ} 50$ \\
\hline 10 & 20 & 65 \\
\hline 10 & 20 & 65 \\
\hline 10 & 25 & 70 \\
\hline 10 & 25 & 70 \\
\hline 10 & 25 & 70 \\
\hline 10 & 20 & \\
\hline 10 & 25 & 70 \\
\hline 10 & 25 & 70 \\
\hline 10 & 25 & 75 \\
\hline 10 & 20 & 50 \\
\hline 10 & 20 & 60 \\
\hline 10 & 20 & \\
\hline 10 & 20 & 6 \\
\hline 10 & 20 & 5 \\
\hline
\end{tabular}




\section{ALL SEASONS RADISHES}

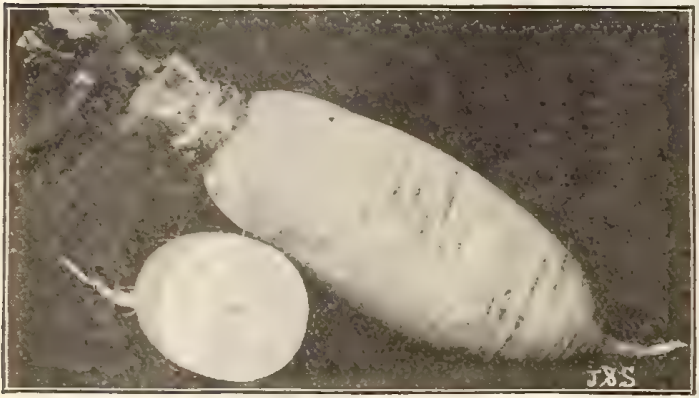

NET CELESTIAL-AN ALL SEASONS WHITE RADISH.

New Celestial, or White Chinese

Seed of this very valuable new Radish should not be sown until summer, June or July, and is ready for use when three inches long, and continues until ten inches long, by four inches in diameter. It also makes one of the hest Winter radislies from seed sown in August. Flesh firm, solid, crisp, pure white. Plt., 5c.; oz., 10c; $1 / 4 \mathrm{~b}$., 20c.; $1 \mathrm{~b} ., 70 \mathrm{c}$.

\section{New Round Scarlet China Radish}

This new variety of the China Radisin is an all seasons red redish: may be sow"u at intervilo from Spring until A utumn. Matures in from six to sevell weeks, and is much hardier than wost other varieties. Valuable as a Wiuter radish, as well as for Summer. Its handsome round shape, rich scar! et color, and pure white flesh commend it to all who grow it. Plat., 5c.; oz, 10c.; $1 / 4$ lb., $30 \mathrm{c}$; $1 \mathrm{~b}, 90 \mathrm{c}$.

\section{WINTER RADISHES}

Improved Half-Long Black Spanish

Tytermediate in shape between the Round and Long Blect Guanish, and is wuch superior to either. Flesh mild, very crisp and sweet never pithy, and is decidedly the best of black radishes. If stored in damp sand in the cellar they ill keep all Winter. Pkt.

CHIVA ROSE WIVTER. One of the best Winter varieties, bright rose-colored; flesh white, firm and of superior quality. Pkt., 5c,; Oz., 10c.; $1 / 4$ lb., 20c.; lb., $65 \mathrm{c}$

OSAKA. A new variety from Japan. growing to mam. moth size, of beautiful half-long shape, with pure white skin and flesh. Pkt.,5c; oz, 10c; $1 / 4 \mathrm{lb}$, 25c.; $1 \mathrm{c}_{\text {. }} 85 \mathrm{c}$.

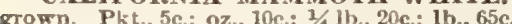

ROUND BLACK \$PA VISH. Very popular with Germars, known as Rettig. Pkt., 5c.; 0z., 10c.; 1/4lb., 20c.; 1b., 65e LONG BLACK SPANISH. One of the hardiest, keep Ing until Spring. Plet., 5c; oz., 10c.; 1/4 1b., 25c; $1 \mathrm{~b} ., 75 \mathrm{c}_{\text {. }}$

\section{SALSIFY, or OYSTER PLANT}

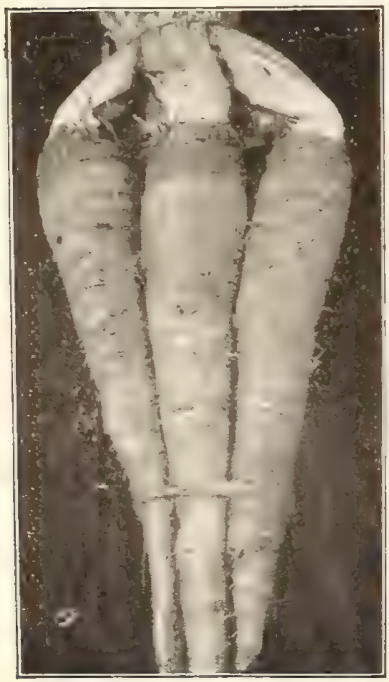

One ounce will $80 \pi$ about sixty feet of drill. Salsify is a most nuvegetable, and is one of the crops that should be nore generally cultivated on the farm for Winter use and sale, as it can be grown just as cheaply as carrots, parsIips, etc.
WISCONSIN GOLDEN. (New.) Fully as large as Sand wich Island with very rich light gol den tinge, 'bunching up handsomely, and in quality rich, teider and de. licious, All lovers of salsify should try this new sort. Pkt., 5c.; oz., 15e; $1 / 4$ MNOTH \$ANO. WICH ISLAND. Grows fully double the size of the old Long White. The root is pure white, much heavier and thicker throughout, and notwithstanding their enormous size, are much superiorinquality. Pkt. 1b. $\$ 1.20$

\section{Rhubarb (Pie Plant)}

One ounce will produce about one thousand planta.

LARGE VICTORIA. An excellent cooking variety.

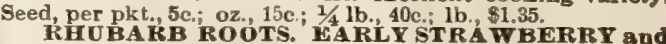
VICTORLA. Each, per large root, 15c; doz., $81.00 ; 100$, $\$ 4.50$, by express; by mail, postpaid, $25 \mathrm{c}$. each; $\$ 2.00$ per doz.

\section{Spinach}

One ounce will sow one hundred feet of drill. Twelve pounds will sow one acre.

\section{Improved Early Giant Thick-Leaved}

This new English Spinach, seed of which we offered for aale two yeans ago for the first time in America, has gained wonderful populsrity with the market gardeners of London since its origin there a few years ago. In our trials it has proven the earliest and quickest growing of all, extremely hardy, productive, large and handsome. We offer seed grown by the originator in England. Pkt, 5c; oz, 10c.; $1 / 4$ grown by the or
lb. $15 \mathrm{c}$. : $1 \mathrm{~b} ., 40 \mathrm{c}$.

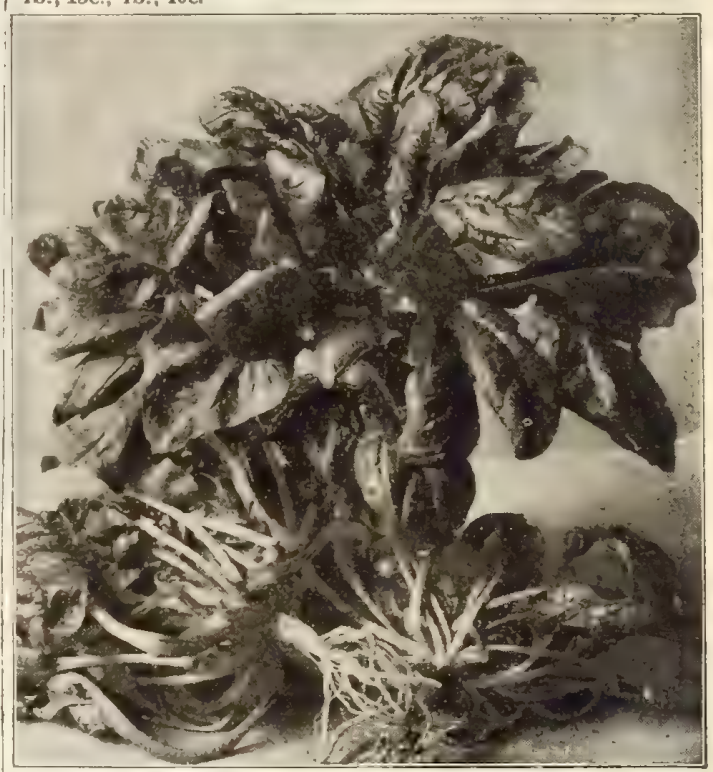

PLANTS OF PARISIAN LONG STANDING-SHOWING FROM TH ROOT ITS WONDERFUL STRONG, HEAVY GROWTH.

New Spinach-Parisian Long Standing

This New French Spinach surpasses our famous Enkhulzen Long Standing in its broad and heavy dark green leaves, which have the true Savoy appearance. It will stand fully two weeks longer than any other variety without running to seed, making it by far the most raluable for spring planting For wintering over it has proven hardier than the famous A mericen Savoy or Bloomsdale, coming out from under the snow with its dark green leaves in prime condition. Pkt, 5c, oz, 10c, $1 / 1 \mathrm{lb}, 20 \mathrm{c}$, 1b, 60c, postpaid; express or freight, 1b., $50 c_{.} ; 10 \mathrm{lbs}$, and over, $45 \mathrm{c}$. per $1 \mathrm{~b}$.

NEW VICTURIA. Leaves very dark green, almost black, very thick and spread out flat upon the ground. It is a long-standing variety, but not very hardy. Pkt., 5 c.; oz., $10 \mathrm{c}$; $1 / 4 \mathrm{lb}, 15 \mathrm{c}$.; 1b., $40 \mathrm{c}$., postpaid ; by express or freight, lb., $30 \mathrm{c}$.; 10 1bs. and over, $25 \mathrm{c}$. per $1 \mathrm{~b}$.

ENKHUIZEN LONG-STANDING. Leaves round large, thick, dark green. Our stock is grown in Holland especially for us. Superior to ordinary Long-Standing generally offered. Pkt., 5c.; oz., 10c.; 1/4lb., 15c.; lb., 40c., postpaid.

AMERICAN ROUND-SEEDED SAVOY, or BLOOMSDACE. Onr celebrated Philadelphia stock. Popular for fall sowing. The leaves are large, thick, finely curled, heavy, produced in great numbers, and stand hand. ling better than most other sorts. Pkt, 5e.; oz., 10c.; 1/4 1b., $15 \mathrm{c}$; $1 \mathrm{~b} ., 40 \mathrm{c}$, postpaid; by express or freight, per $1 \mathrm{~b} ., 30 \mathrm{c}$.; $0 \mathrm{lbs}$, and over, $25 \mathrm{c}$. per $\mathrm{lb}$.

THICK-LEA VED ROCND, or VIROFLAY. Large, thick, dark green leaves, very hardy, and most popular in New York markets, where it is the lending variety for Spring

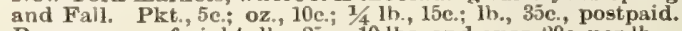
By express or freight, 1b., 25r.. $10 \mathrm{lbs}$, and over, $20 \mathrm{c}$, per $1 \mathrm{~b}$.

NEW ZEALAND SPINACH. (Tetragonia Expansa.) Supplies the place of ordinary spiuach during hot weather: succeeds everywhere. Sow in May where the plants are to stand. Plt., 5c.; oz., 10c.; 1/41b., 30c.; Ib., \$1.to. 


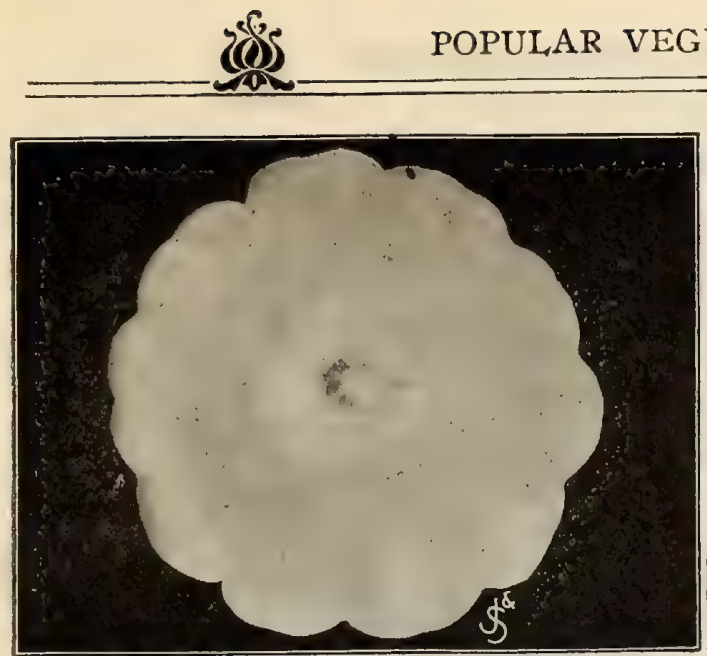

NEW KXTRA EARLY JERSEY WHTTE BUSE.

An improved strain of the old White Bush.

The best and most prolific early Summer Squash.

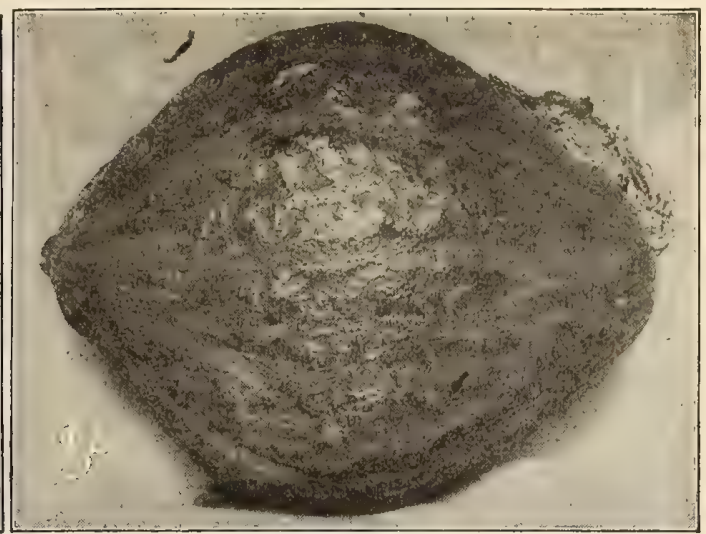

BOSTON MARROW.

The most popular and most productive Squash for Autumn and Winter use. A fine keeper.

\section{SQUASHES-A List of Varieties Worth Growing}

One ounce will plant twenty to forty hills. Four to six pounds will plant one acre.

Large packets of any of the following varieties, 5 c. each.

\section{THE BEST SUMMER SQUASHES}

White Bush Scallop. The well-known white Patty Pan (5 lbs., \$3.00, by express), Mammoth White Bush (Silver Custard). Grows to twice the size of above

New Extra Early Jersey White Bush. An improved extra early strain of the old White Bush. Selected and improved by a New Jersey grower. Very productive and show less ridge or scallop, containing a larger amount of flesh, Early Golden, or Yellow Bush. Differs from White Bush only in orange color, Golden Custard. (New.) Very large Golden Yellow Bush; fine for market. . Golden Summer Crookneck. Small yellow crookneck; early and prolific . . . Long Green Summer Crookneck. Best frying squash; superior to egg plant, New Giant or Mammoth Summer Crookneck. Large and fine for market . . White Pineapple. Peculiar shape, white skin, great keeper, very prolific . . .

\section{FALL AND WINTER SOUASHES}

Boston Marrow. Bright orange ; skin and flesh of very superior quality ; a splendid Winter keeper and most popular for autumn use. See cut

Early Prolific Orange Marrow. Earlier than Boston Marrow ; very productive, Hubbard. The old favorite popular winter squash ; dark green skin ; rich flesh, Red, or Golden Hubbard. A perfect type of its parent, with red skin

Chicago Warted Hubbard. Improvement on Hubbard ; skin heavily warted .

White Chestnut. Sweet, yellow flesh; dry as a boiled chestnut ; prolific . . Fordhook. Early, sweet and dry ; also a good summer variety ; form oblong . Mammoth Chili. The Jumbo of all squashes, often weighing 200 pounds; pkt., $10 \mathrm{c}$,

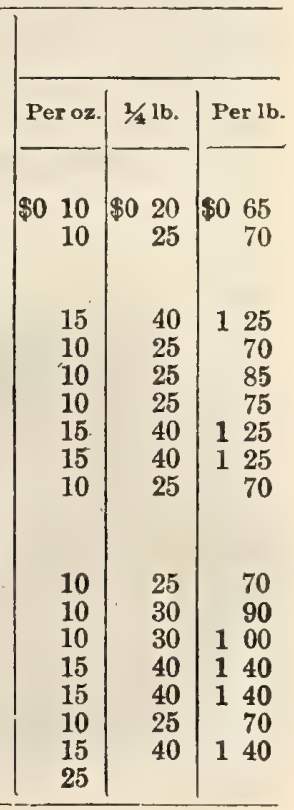

\section{VEGETABLE PLANTS-Grown at Floracroft}

\section{Always Reliable-We get them at the store fresh daily, in season}

CABBA GE PLANTS. Early. All leading varteties. For A pril and May delivery. 35e. per $100 ; 82.50$ per 1000 . LATE CABBAGE PLANTS. Standard varieties. Ready July Ist. 25e, per 100; $\$ 2.00$ per 1000.

CAULIFLOWER PLANTS, Early Alabaster and Snow Ball. Ready in April. 25c. per doz.; $\$ 1.50$ per 100.

CELERY PLAN'TS. Ready July 1st. Perle Le Grand, Winter Queen, Golden Self-Blanching, White Plume, Pascal, etc. 40c. per $100 ; \$ 3.00$ per 1000 .

LETTUCE PLANTS. Ready in April. 40c. per 100.
EGG PLANTS: Ready in May and June. Black Beauty, New Jersey Improved Large Purple, smooth stem. Grown in pots, 60e. per dozen; $\$ 4.00$ per 100 . Out of hotbeds, $30 \mathrm{c}$. per dozen; $\$ 2.00$ per 100

PEPPER PLA N'TS. Ready in May and June. Large Bell, Ruby King. 20c. per dozen; $\$ 1.25$ per 100.

SIVEET PÖTATO PLANTS. See price list at bottom of page 46.

TOMATO PLANTS. (Transplanted.) Ready in May and June. We make a specialty of Tomato plants, and can supply oll the leading varieties. 20c. per dozen; 81.00 per $100 ; \$ 7.00$ per 1000 . Not transplanted, $\$ 5.00$ per 1000 .

\section{JOHNSON \& STOKFS, 217 and 219 Market Street Philadelphia, Pa.}




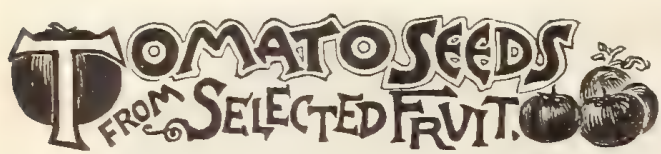

For years we have made a careful study of growing the very best tomato seed. All tomatoes showing the slightest variation from the standard type are rigidly discarded, thus securing the purest possible seed.

One ounce will produce about thirteen hundred plants.

\section{CHALK'S EARLY JEWEL TOMATO}

Introduced last season as a competitor of Sparks' Earliana by another seedsman. After a thorough trial at Floricroft and among our customers, we find it three reeks later and fir less productive than Earliana. We recommend it, however, as a good secord early. Pkt., 10c.; oz., 45c.; $1 / 4$ lb., $\$ 1.25$; $1 \mathrm{~b} ., \$ 4.50$.

\section{THE EARLY BIRD TOMATO}

With the exception of Sparks' Earliana, this is the earliest tomato. Notwithstanding its smanll to medium size. many have written us they have found it a most profitable variety to grow. Very smooth, with pink skin. Pkt., 10c. Oz., 30c.; 1/4 1b., 85c.; 1b., \$3.00

\section{ATLANTIC PRIZE TOMAT응}

First introduced by 18 in 1889. Thousands of acres are now annually planted from Maine to Texas. The rines grow strong, stiff and very rapidly, setting the crown fruit when very young. Egch vine produces from sixty to eighty large, perfect tometoes. Plt, 10c, oz, 20c, 1/4 lb, 60c.; 1b., \$2.00

\section{SANTA ROSA TOMATO}

A new mammoth main crop variety, now first offered. See illustration and description under Novelties, page 11. Pkt., 15c.; oz., 70c.; $1 / 4$ 1b., $\$ 2.00 ; 1 b ., 87.00$.

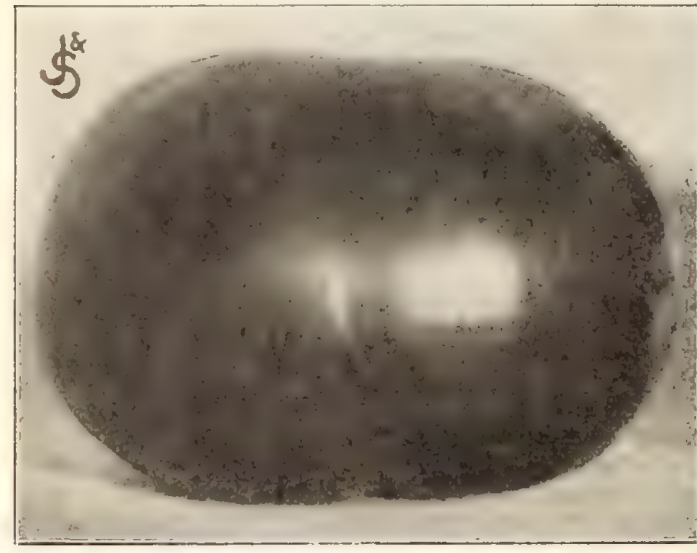

THE QUICKSURE TOMATO

With the adrent of the Santa Rosa Tomato this year, we claim to have introduced the three most valuable tomatoes in cultivation. With the Sparks Carliana for first early, Quicksure for second early and Santa Rosa (described on page 11) for main crop, no grower need be without a succession of magnificent tomatoes throughout the entire season. The Quicksure, which we first introduced in 1900 , Tas originated by Mr. Howard Russ, a well-known trucker of Burlington County, N. J. Color bright red; very solid, heavy and wonderfully prollfic of very large, fine fruit. Pkt., 10c.; 0z., 25c.; $1 / 4$ lb., 75e; 1b., $\$ 2.50$.

\section{QUARTER CENTURY TOMATO}

Originated by Dr. Van Fleet, horticultural editor of the Rural New Yorker. It might be called an Improved Dwarf Aristocrat, its erect bushy rines and fine red fruits closely resembling that variety. It is very early and has proven a valuable acquisition. Plt, $10 \mathrm{c} ; \mathrm{oz}, 35 \mathrm{c} ; 1 / 4 \mathrm{lb}, \$ 1.00 ; \mathrm{lb}$. $\$ 3.50$.

\section{THE MATCHLESS TOMATO}

A great favorite for both market and family use. Produces uniformly large, bright red fruit th roughout the season. Flesh very solid and heavy, free from core, and will keep in good condition for a week to 10 days after being taken from the vine. Pkt., 10c.; oz., 25c.; 1/41b., 75c.; 1b., $\$ 2.50$.

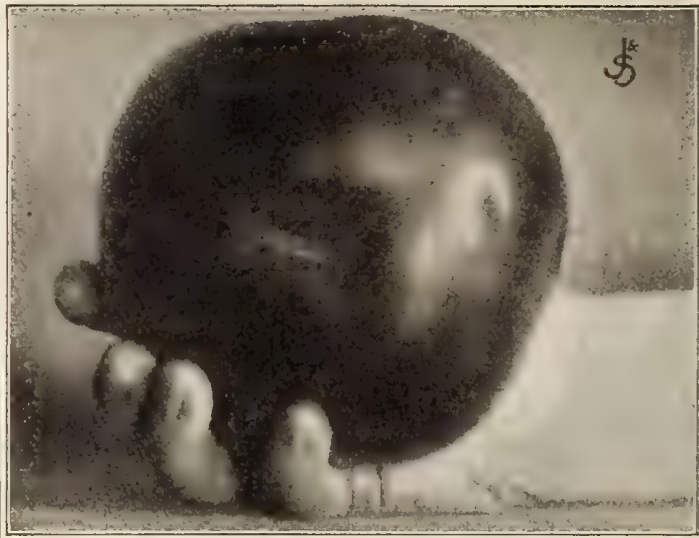

STONE TOMATO, MOST POPULAR WITH TRUCKERS AND CANNERS.

\section{NEW STONE TOMATO}

This is deservedly the most popular main crop tomato for market and canning, owing to its large size and great solidity. When grown from properly seleeted seed the fruits are very uniform, smooth and of handsome bright scarlet color. Flesh meaty and fine in flavor. Our strain is unsurpassed. Pkt., 5c.; oz., 20c.; 1/4 1b., 50c.; lb., \$1.75, postpaid; by express or freight, lb., $\$ 1.65 ; 5$ lbs. and over, $\$ 1.60$ per $1 \mathrm{~b}$.

\section{THE SUCCESS TOMATO}

$A$ new scarlet-fruited tomato somewhat resembling our Great B. B, or Brinton's Best. It is of very large size, handgome, smooth and of very fine quality. Fruit sets in clusters and ripens second early. Pkt, 10c.; oz., 30c.; 1/4 1b., 75c.; lb., $\$ 2.75$.

\section{LIVINGSTON'S MAGNUS TOMATO}

An improvement on the old A cme and Beauty, which it resembles in color, being thicker, heavier and more solid than either. Fruit in clusters, ripening evenly and maturing quickly. Pkt., 10c.; oz., 25e.; $1 / 4$ lb., 75c.; 1b., \$2.50.

\section{TRUCKERS' FAVORITE TOMATO}

A very large purple tomato, of superior quality; very solid and free from cracks or rot. Very popular in Northern New Jersey. Pkt., 10c.; 0z., 30c.; 1/4 Ib., 75c;; 1b., \$2.75.

\section{THE ENORMOUS TOMATO}

Fruits uniformly large, four to five inches across and very deep through. Borne two and three in a cluster : smooth, solid and brilliant scarlet. Pkt., 10c.; oz., 25e.; 1/4 1b., 75c.; Ib., $\$ 2.75$.

\section{THE GREAT B.B.(BRINTON'S BEST)}

This is one of the very best for second early and main crop The vines grow vigorously and produce abundantly until killed by frost. Fruit of deep red color, uniformiy even large size and perfectly smooth. It will keep in good marketable condition for two weeks after picking. Pkt., 10c.; oz., 30c.; 1/4 lb., 85c.; lb., $\$ 3.00$

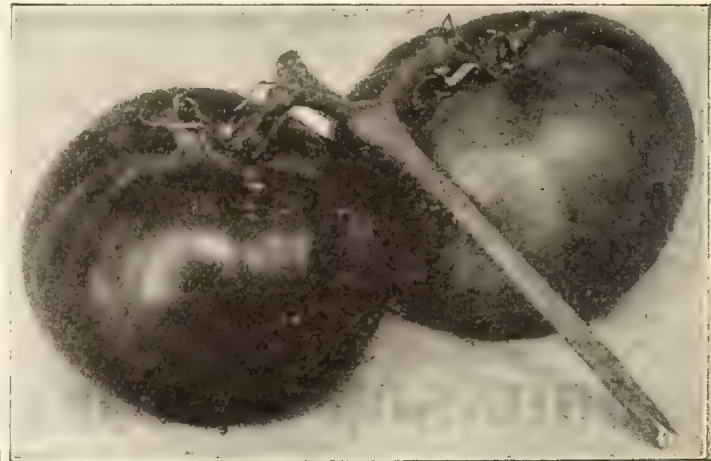

THE GREAT B. B. (BRINTON'S BEST) TOMATO. 


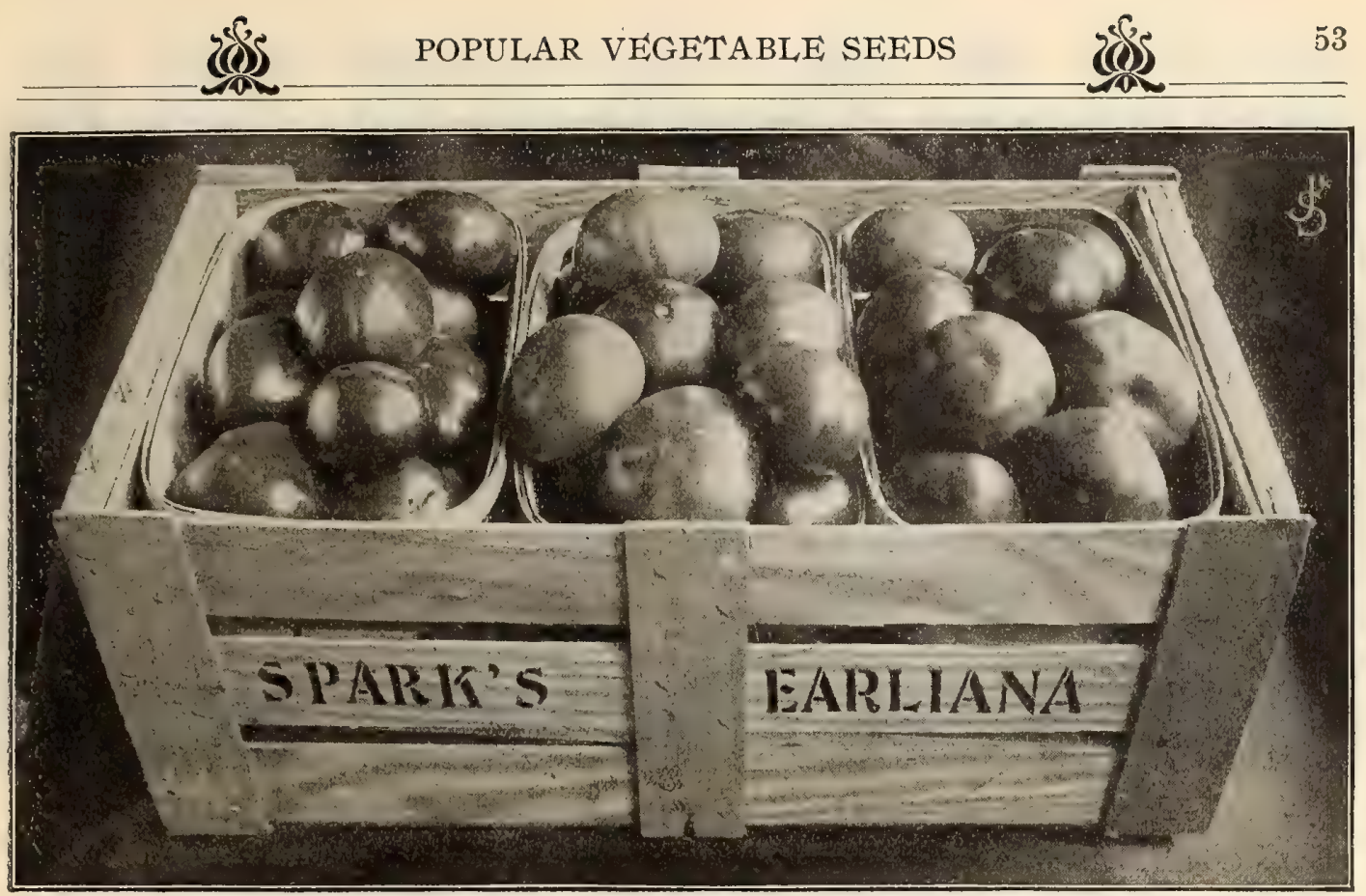

For the past three seasons crates of fine large Tomatoes, like the above photograph, have appeared in Philadelphia and New York markets two to three weeks ahead of all others. For description and testimonials of this now famous Tomato see pages 12 and 13. Prices of genuine seed, Sparks' Earliana Tomato, grown by ourselves, direct from stock seed selected by the originator: Pkt., 15c.; $\frac{1}{2} \mathrm{oz} ., 40 \mathrm{c} . ;$ oz., 80 c.; $\frac{1}{4}$ lb., $\$ 2.50$; lb., $\$ 9.00$.

\section{Select List of Standard TOMATOES_ SEED $\underset{\text { GROWING }}{\text { OF OWN }}$}

In regular size, large packets, each 5 c. per packet, except where noted.

Extra Early Advance. One of the earliest; small, smooth, bright red and solid Early Paragon. Bright red; productive ; standard for market and canning Early Michigan, or Red Apple. Very early; medium size; red, smooth . Livingston's Perfection. Early ; large size ; very productive ; fine blood red Livingston's Favorite. Large, smooth, productive ; a good shipper and canner Livingston's Beauty. Large, smooth, purplish pink ; thick flesh; regular form New Stone. Very large; perfectly smooth; bright scarlet; solid; best for canning, and most popular of all as a main crop tomato for market ; extra fine strain French Marvel. Extra early; of good size; round, bright scarlet; pkt., 10c. Early Acme. Bright pink; smooth, round, uniform size; productive and popular, New Imperial. First early, large, smooth, solid; pinkish purple when ripe; pkt., 10c., Buckeye State. Very large, solid, meaty; deep purple; heavy cropper; pkt., 10c. Livingston's Royal Red. Skin and flesh intense bright red; fine for main crop Lorrilard. Best for greenhouse forcing; bright glossy red; very smooth and solid Liberty Bell. Extra early ; large size ; red ; fine quality; splendid for market. Dwarf Aristocrat. Erect, strong vine; large red fruits of finest quality; pkt., 10c. Brandy wine. Finest late; large, solid, smooth, bright red; prolific ; pkt., 10c. Ponderosa. The largest variety in cultivation; a monster; pkt., 10c.

Crimson Cushion. An improvement on Ponderosa; more solid; pkt., $10 \mathrm{c}$. Ignotum. One of the earliest of large, deep red, smooth varieties; productive Dwarf Champion. Early ; fruit resembles Acme; foliage upright ; pkt., 10c. Early Market Champion. Very early ; large; purple; productive ; pkt., 10c. The Moneymaker. First early; purple; of handsome form; fine quality; pkt., 10c., Autocrat. An improved Acme ; larger, much more productive; pkt., $10 \mathrm{c}$. New Fortune. Second early ; large red fruit of superior quality ; pkt., 10c. Cumberland Red. Very large; tough skin ; popular with canners ; pkt., $10 \mathrm{c}$. . Trophy. Very solid; large; late sort; improved smooth strain; pkt., 10c. . Golden Queen. The best large, smooth, yellow tomato ; finest quality; pkt., 10c. Yellow Plum. Plum shape; bright yellow ; used for pickles ; pkt., 10c. Clusterosa Yellow Egg. A great improvement on all other small yellow tomatoes. The best for preserving or pickling ; wonderfully productive; pkt., $10 \mathrm{c}$.

Peach. Resembling peaches in shape and color ; for preserves and pickles

Red Cherry. An inch in diameter; borne in clusters ; for pickles ; pkt., 10c.

Strawberry, or Winter Cherry. (Husk Tomato.) Small, yellow fruit; pkt., 10c.,

\begin{tabular}{|c|c|c|}
\hline Per $o z$ & $1 / 4 \mathrm{lb}$. & Per lb. \\
\hline$\$ 015$ & $\$ 045$ & $\$ 150$ \\
\hline 20 & 50 & 160 \\
\hline 15 & 45 & 150 \\
\hline 20 & 50 & 160 \\
\hline 20 & 50 & 160 \\
\hline 20 & 60 & 200 \\
\hline 20 & 50 & 165 \\
\hline 25 & 75 & \\
\hline 20 & 50 & 175 \\
\hline 25 & 70 & 225 \\
\hline 25 & 70 & 225 \\
\hline 20 & 50 & 175 \\
\hline 20 & 60 & 200 \\
\hline 15 & 45 & 150 \\
\hline 25 & 75 & 275 \\
\hline 25 & 75 & 275 \\
\hline 40 & 100 & 375 \\
\hline 40 & 100 & 375 \\
\hline 20 & 50 & 175 \\
\hline 25 & 75 & 275 \\
\hline 25 & 75 & 250 \\
\hline 30 & 85 & 300 \\
\hline 25 & 75 & 250 \\
\hline 40 & 100 & \\
\hline 30 & 75 & 275 \\
\hline 25 & 70 & 225 \\
\hline 25 & 75 & 250 \\
\hline 25 & 75 & 250 \\
\hline 50 & 150 & \\
\hline 15 & 45 & \\
\hline 25 & 75 & \\
\hline 25 & 75 & \\
\hline
\end{tabular}




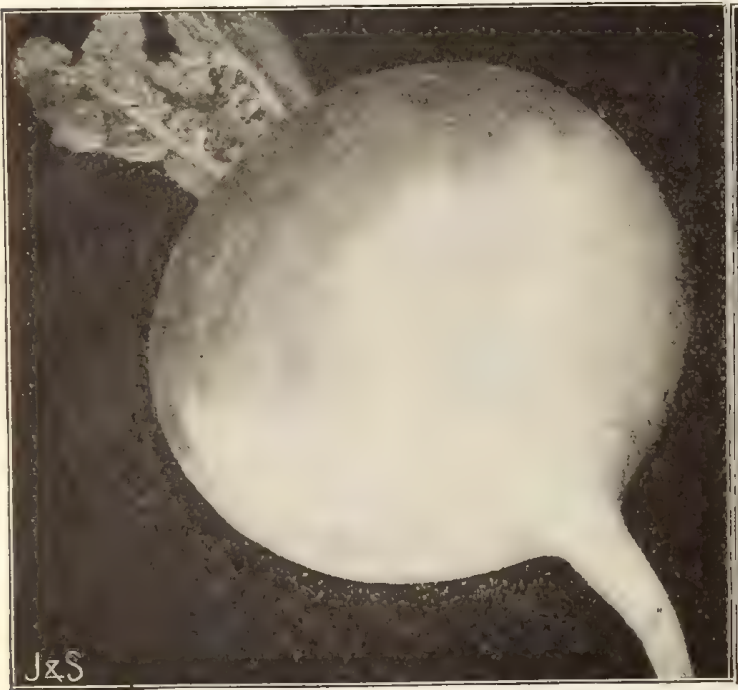

NEW MAMMOTH PURPLE-TOP GLOBE TURYIP.

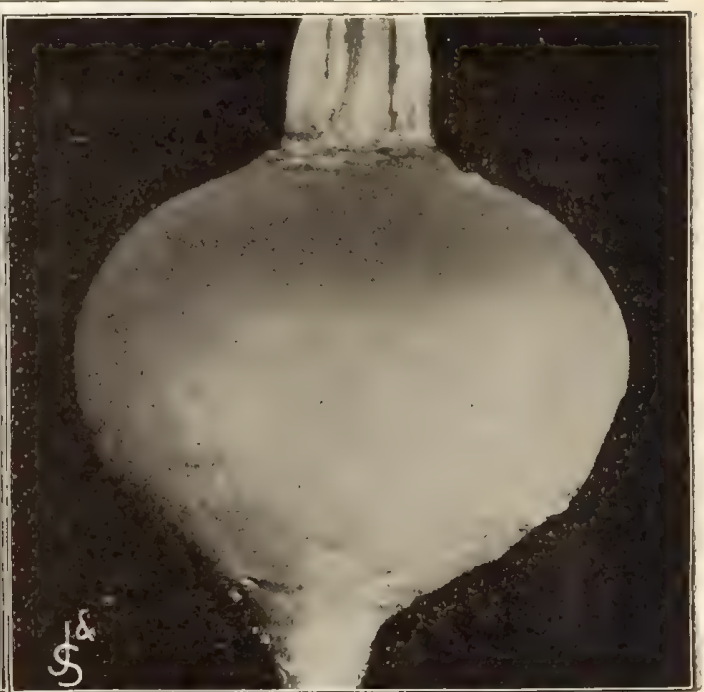

MYER'S PURPLE-TOP BEAUTY RUTA-BAGA.

\section{TURNIPS AND RUTA=BAGAS, OR SWEDES}

One ounce will sow one hundred and fifty feet of drill; one to one and one-half pounds will sow an acre.

\section{Large packets of any variety, 5c.}

Early Snowball. Very handsome; extra early, pure white, tender and sweet Purple-Top Flat. (Strap-leaved.) Well-known standard popular early sort . Early White Flat Dutch. Very popular for spring sowing; fine for market . Ear!y Red-Top White Globe. Early, productive and popular for market . Mammoth Purple-Top Globe. An improvement on Red-Top White Globe, Purple-Top Milan. (True.) The earliest flat turnip; a very shy seeder . Extra Early White Milan. Same as the Purple-Top Milan, except white skin . Early White Egg. Very handsome; pure white; excellent for early or late. Improved Sweet German. Flesh white, hard and firm; sow early Pomeranean Large White Globe. Useful for both table and stock; very large, Long Cow Horn, or White French. Very heavy cropper; best for stockmen Golden Ball, or Orange Jelly. Small ; very early ; fine quality and flavor Yellow, or Amber Globe. Vigorous grower ; fine keeper ; popular for market, Yellow Aberdeen, Globe-Shaped. Very large; fine for table or cattle Budlong, or Breadstone. Very early half-long white; fine table sort

Rhode Island White Rock. (New.) Early, productive and very handsome . Monarch, or Elephant Ruta-Baga. (New.) Large, oval-shaped; yellow flesh Long Island Ruta=Baga, Purple Top. Very large; fine yellow flesh Myer's Purple=Top Beauty Ruta-Baga. An improved narket garden sort. Improved Purple=Top Yellow Ruta-Baga. Our finely bred strain; very popular, Large White Ruta=Baga. Tery large and productive; white skin and flesh . Seven Top. Very hardy; grown for leaves, which are used as greens or salads

\begin{tabular}{|c|c|c|}
\hline Peroz. & $1 / 4 \mathrm{lb}$. & Perlb \\
\hline$\$ 005$ & $\$ 015$ & $\$ 040$ \\
\hline & $\begin{array}{l}\$ 0 \\
15\end{array}$ & 40 \\
\hline 10 & 20 & 50 \\
\hline 10 & 20 & 50 \\
\hline 10 & 20 & 65 \\
\hline 10 & 25 & 75 \\
\hline 10 & 30 & 100 \\
\hline 18 & 20 & 60 \\
\hline 10 & 20 & 60 \\
\hline 5 & 15 & 40 \\
\hline 5 & 15 & 40 \\
\hline 10 & 20 & 50 \\
\hline 1 & 20 & 50 \\
\hline 1 & 20 & 50 \\
\hline 10 & 25 & 75 \\
\hline 10 & 25 & 75 \\
\hline 10 & 20 & 50 \\
\hline 10 & 20 & 50 \\
\hline 1 & 25 & 75 \\
\hline 1 & 20 & -50 \\
\hline 18 & 20 & 50 \\
\hline 10 & 20 & 50 \\
\hline
\end{tabular}

SEEDS OF POT, SWEET AND MEDICINAL HERBS, ETC.

All Herbs in Large Packets at 5 cents each, except where noted

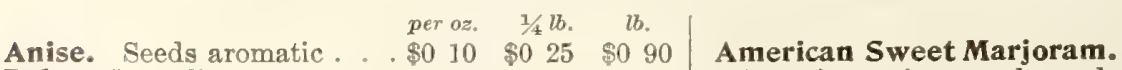

Balm. For culinary purposes, $20 \quad 65 \quad 2 \quad 25 \quad$ Superior to imported; seed

Borag. For culinary purposes,

Borage. Used for flavoring, $15 \quad 40 \quad 125$

Sweet Basil (Broad-Leaved),

Caraway Seed. For flavoring,

Catnip (Cat Mint). Pkt., 10c.,

Chervil. Used like parsley,

Coriander. Seeds aromatic,

Dill. For flavoring vinegar .

Fennel (Sweet)

Fennel (Florence Cielexy :

Rooted). Flavor like celery, Horehound. Pkt., $10 \mathrm{c}$.

Hyssop. Medicinal. Pkt., 10c., Lavender. For oil and water, Marigold, Pot. For soups.
Superior to imported; seed
of own growing. Pkt., 10c.,

Rosemary. For seasoning and aromatic oil. Pkt, 10c., Sorrel. (Large-Leaved.) Cultivated for acidity ... .

Summer Savory. Culinary, Winter Savory. Flavoring, Tansy. For bitters. Pkt., 10c., Thyme. Broad-leaved. 10c., Wormwood. For Poultry ? Imported Sweet Marjoram, per $0 z, \quad 1 / 4 l b . \quad l b$.

$\$ 0 \quad 30 \quad \$ 0 \quad 85 \quad \$ 3 \quad 00$ $15 \quad 40 \quad 125$ Saffron. Medicine and dyeing, $\quad \begin{array}{lll}10 & 30 & 90\end{array}$ Sage. Most used of all herbs, $\quad 20 \quad 45 \quad 150$
30100

30100

$50 \quad 175$

$100 \quad 350$

$75 \quad 250$

$40 \quad 140$ 


\section{OUR FHWOUS VEGETABLE AND FLOWER SEED COLLCCTIOHS}

GOLD AT RETAIL FOR LESS THAN WHOLESALE PRICES

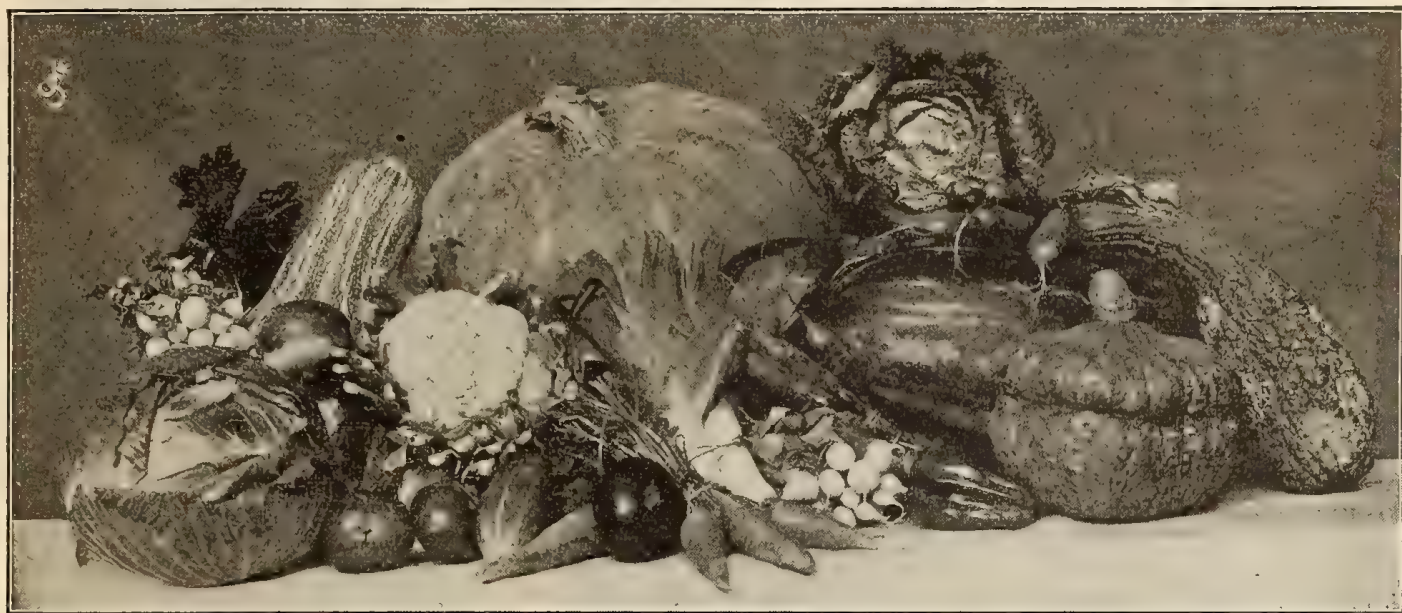

For the purpose of inducing thousands of new customers to give our seeds a fair trial, we offer at a nominal price the following splendid collections, knowing that we can safely count on making permanent friende of those who buy them. We cannot sell any other seed so cheaply, nor can we make any changes in these remarkable bargain collections.

\section{A GREAT SPECIALTY OFFER FOR ONLY 50 CENTS}

For 50 cents we will send by mail, all postage paid, 10 full-sized packets of the following choice Specialties, which. would cost at regular prices almost double what we ask here for them:

1. New Wonder Bush Lima Bean. The earliest, dwarfest, most prolifie and best of all the Bush Limas.

2. New Ruby Dulcet Beet. The earliest and best first quality beet for the home table; fine globe shape.

3. Johnson \& Stokes' Warliest Cabbage. Wonderfully early; hard heads; fine quality.

4. New French Market Carrot. Superior in earliness, fine shape and color; flesh tender and sweet throughout.

5. Johnson \& Stokes' Golden Self-Blanching Celery. Very handsome and early ; one of the easiest to grow.

6. New Mongolian Lettuce. New variety from Asia. Unequalled for Spring and Fall planting outdoors; superb fiavor.

7. Rocky Ford Muskmelon. Johnson \& Stokes' selected strain. Celebrated for its remarkably fine quality.

8. New Extra Early Australian Yellow Globe Onion. Very early and handsome.

9. Johnson \& Stokes' Olive Scarlet Radish. The earlies* and handsomest red radish.

10. New Quicksure Tomato. Extra early, large, smooth, solid and perfect.

We send all the above neatly packed, postpaid, by mail, for only 50 CENTS IN STAMPS or cash; FIVIF COLLECTIONS, each separate, to one or different addresses if desired, For \$2.00. A decided bargain.

\section{A COMPLETE VEGETABLE GARDEN FOR \$1.00}

OUR SPECIAL INTRODUCTION BOX OF SEEDS embraces 25 full-sized packets of the choicest Vegetable Seeds, includine all the above-named 10 choice Specialties and the 15 varieties described below, making a magnificent collection for only 81.00 and sent by mail all postage paid.

New Giant Stringless Valentine Bean. Earlier, more prolific than old Valentine; extra quality.

12. Johnson \& Stokes' New Surprise Beet. Splendid in shape, color and quality; a fine keeper.

13. Johnson \& Stokes' Matchless Late Fiat Dutch Cabbage. The finest strain in the world.

14. New Perle Le Grand Celery. Valuable for both early and late uae; superior in keeping qualities.

15. New Eskimoso Cucumber. The earliest in cultivation.

16. New Giant Italian Leek. The largest of all and mildest in flavor.

17. Lettuce-Ten of the best American Varieties, mixed. Give fine lettuce for the table the entire season.

18. Philadelphia Long-Keeping Yellow Egg Onion. One of the handsomest and best Winter onions.

19. Market Gardeners' Best Parsley. The hardiest and best of all known sorts; very dark-green color.

20. Ideal Hollow Crown Parsnip. Beautiful, smooth, very productive and very sweet

21. Ruby King Pepper. One of the largest and finest red peppers; flesh thick, mild and sweet flavored.

22. New Celestial, or White Chinese Radish. Equally valuable as a Summer or Winter radish.

23. Mammoth Sandwicl Island Salsify (Oyster Plant). The only sort worth cultivating; very large and tender.

24. New Mammoth White Bush Squash (Silver Custard). An improved strain; early, large and fine quality.

25. New Early Snowball Turnip. The best for Spring sowing; earliest and sweetest of all; pure white.

\section{HN EXCEPTIONAL FLOMLER SEED OFFER I5 PACKETS CHOICEST FREE-BLOOMING ANNUALS FOR 25 CENTS}

ASTER. Prize Mixed. Embracing Giant, Comet, Semple's Branching and many popular sorts suitable for cutting. CARNATIUN. Marguerite. A beautiful strain; will bloom abundantly till cheeked by frost.

CHR YSA NTHEMOM. Summer Flowering. Single and double varieties in all colors; véry effective and fine for cutting. DIANTHU, or PINKS. Single and double Japanese varieties, with brilliant flowers 2 to 4 inches in dianeter.

JAPANESE CLIMBING HOP. An ornamental and rapid climber, with luxuriant foljage, resisting heat and insects. NASTURTIOM. Dwarf, or Tom Thumb. The rich colors and freedom of bloom make them the most popular of aunuals, PANSY. Large flowering mixed. A strain of rare excellence.

PETUNia HYBRIDA. Finest Mixed. Veined and striped varieties; very effective for bedding; bloom all Summer.

PHLOX DRUMMONDI. Rich, brilliant colors; splendid for bedding; a popular and free bloomer

POPPIES. Profuse bloomers and brilliant colors. This struin is unsurpassed for quality and variety.

PORTUL A CA. Brilliant dwarf annuals, blooming profusely all Summer.

SWEET ALYSSUM. Little Gem. Of compact habit; splendid for borders, rockwork, edgings, pot culture and cutting.

SWEET PEAS, J. \& S. Giant Flowering Mixed. Comprising only the best large flowering sorts.

VERBENA. Mammoth Mixed. Unsurpassed for size, billianey of bloom and luxuriant growth.

ZINNIAS. Giant Flowexing. (Youth and Old Age.) A general favorite and one of the ghowiest of annuali. 
56
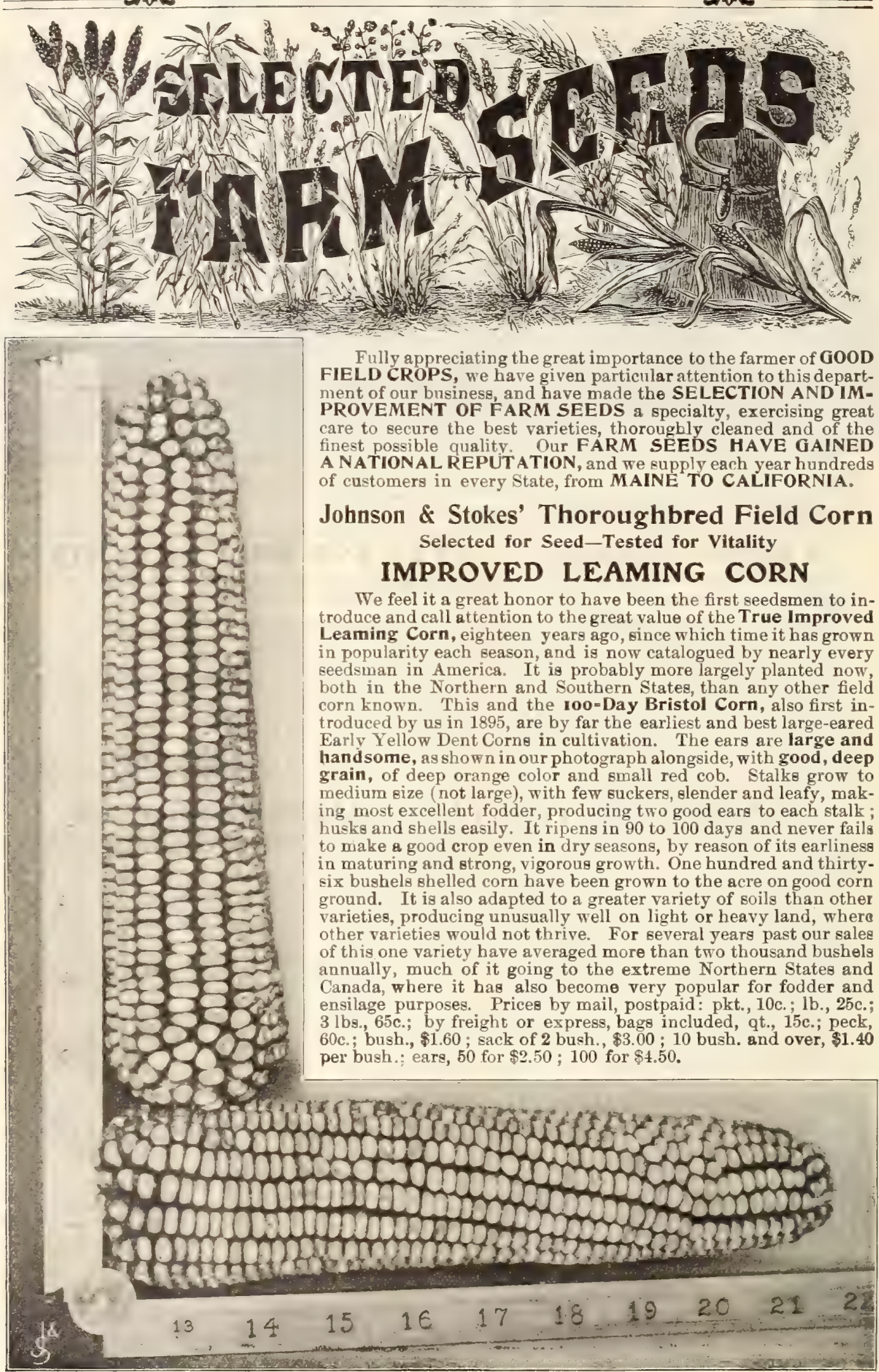

Fully appreciating the great importance to the farmer of GOOD ment of our business, and have made the SELECTION AND IMPROVEMENT OF FARM SEEDS a specialty, exercising great A NATIONAL REPUTATION, and we supply each year hundreds ,

\section{ohnson \& Stokes' Thoroughbred Field Corn} Selected for Seed-Tested for Vitality Leaming Corn, eighteen years ago, since which time it has grown in popularity each season, and is now catalogued by nearly every corn known. This and the 100-Day Bristol Corn, also first inYelo in 1895, are by far the earliest and best large-eared hand some, as show $n$ in our photograph alongside, with good, deep grain, of deep orange color and small red cob. Stalks grow to ground. It is also adapted to a greater variety of soils than other of this one variety have averaged more than two thousand bushels annualiy, much of it going to the extreme Northern states and per bush : ears, 50 for $\$ 2.50 ; 100$ for $\$ 4.50$ 


\title{
Austin's Colossal Yellow Dent
}

\begin{abstract}
AN ENTIRELY NEW AND REMARKABLE FIELD CORN. A perfect wonder in large size of ears, uniformly over a foot in length
\end{abstract}

\section{The Highest Average Yielder}

This new corn excited the admiration and wonder of thousands of farmers who visited the Agricultural Building at the Pan-American Exposition at Buffalo, in 1901. Of the hundreds of varieties there exhibited, from almost every State in the Union, it carried off the honors, and we feel justly proud in being the first seedsmen to procure the seed from its experienced originator, Mr. H W. Austin, and offered it for sale to our customers two years ago. The yield on the farm of the originator the past season was at the rate of 120 bushels to the acre, and in the most unfavorable seasons it has never given less than 100 bushels to the acre of its magnificent ears, borne 2 to a stalk, ripening in 110 to 120 days from planting; grain deep, ric ' yellow, very heavy, and will sell for the highest prices on any market in the land; stalks medium, not too large, and produce enormously on both light and heavy land. Prices for 1904: 1b., 40c. 3 lbs., $\$ 1.00$, by mail, postpaid; by freight or express, sacks included, peck, 80 c.; bush. $\$ 2.50$; bag of 2 bush. for $\$ 4.50$. On ear, 25 ears for $\$ 2.00 ; 50$ ears for $\$ 3.00 ; 100$ ears for $\$ 5.00$.

\section{WHAT CUSTOMERS SAY OF IT}

iVe have received hundreds of just such letters as those published below from those who planted it.

86 BUSHELS FROM $1 / 3$ PECK

Fletcher M. Mok knney, Perrysville, Pa. Nor. 2, 1903, writes: "I canuot help writing you about the Austin's Colossal Yellow Dent Corn We have just finished husting and hare 86 born. els from the half peck sown."

\section{SURELY A WORLD BEATER}

GECRGE MuMMert, Goshen. Ind Sept 16 1908, writes: "Austin's Colossal Yellow Dent Corn from your seed is surely a world bealer. The ears are from 13 to 16 inches long and filled to the tips."

\section{BUSHELS ON 4 ACRES}

I. M. Tola NEY, Little Falls, W. Va., Sept. 30 writes: "Your new A ustin's Dent Corn is the largest and best corn I ever saw measure over 15 inches in length. I have four acres that will surely make 500 bughels."

\section{AN EAR 19 INCHES LONG}

John O. Foohliger, Cincinnati, O., oct. 12, writes: "All who have seen my erop of Austin's Colossal Corn are astonished and loud in its praise. I shall send you a photo of an ear that is 19 inches long. It is a most wonderful that EARS OVEK 10\% INCHES IN CIRCUMFERENCE

Homer HaM, Chambersburg, Iil., Oct. 14 writes: "The Austin's Colossal Yellow Dent Corn has made me over 85 bushels to the and would go more than 100 bushels if storm liad not hit it so bad. It is by for the lar storm liad ever satw, some of the ears being over $10 \% / 2$ inches around."

YIELDS MORE THAN DOUBLE

A. J. MoChesnex, Andrew, IR., Oct, 18 writes: "I am more than pleased with your Austin's Colossal Yellow Dent Corn. It is a won derful grower, yielding more than double any other corn grown here.

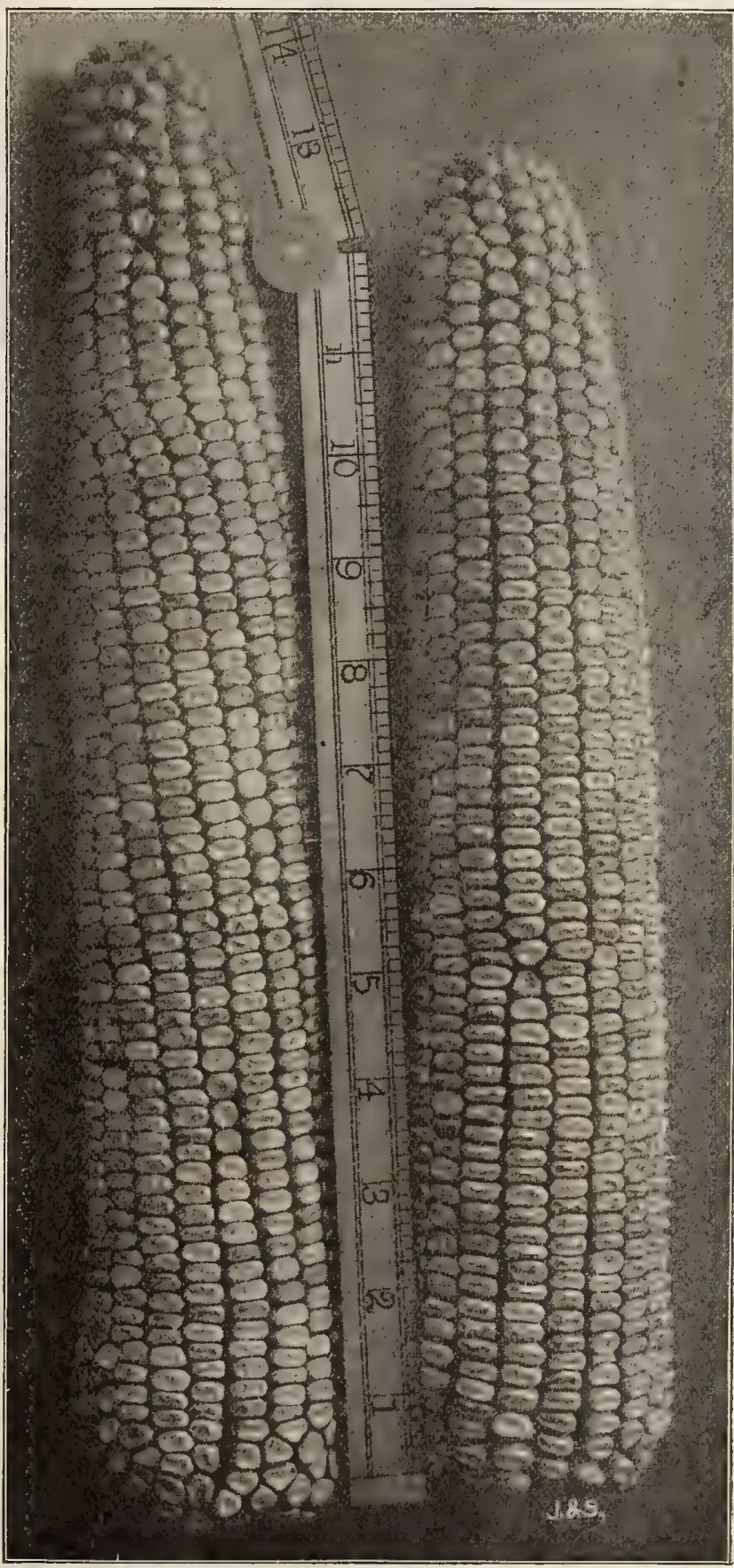

PHOTOGRAPH OF AVERAGE EARS AUSTIN'S COLOSGAL YELLOW TENT, ABSOLUTELY THE LARGEST AND MOST PRODUCTIVE FIELD COBN IN OULTIVATION. OUR SKED SELECTED AND GROWN BY THE OBIGINATOR. 


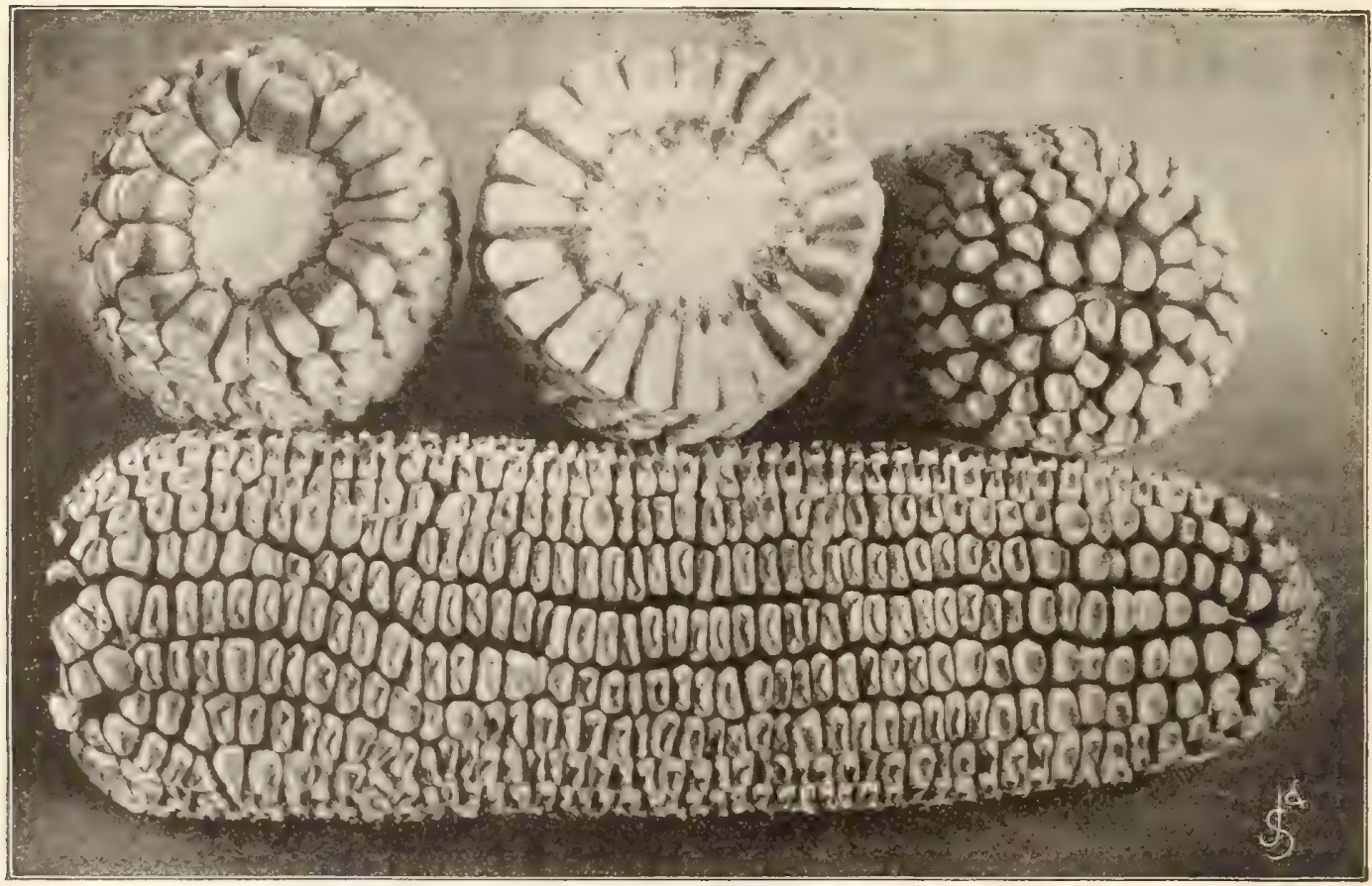

Photograpi of JOHNBON \& sTOKRS' GIANT BEAUTY CORN. Showing also section and ends of ear.

\section{JOHNSON \& STOKES' NEW GIANT BEAUTY CORN}

In the new Giant Beauty we have a very valuable and long-sought-for variety, viz: A very large ear and grain, yet a very early Yellow Dent Corn. Giant Beauty is a cross between Cloud's Early Dent and Golden Beauty, possessing the earliness and deep grain of the former, with the handsome, deep yellow color and breadth of grain of the latter. It is absolutely the largest grained of all yellow corn. Its small red cob and great depth of grain are well shown in our photograph above, mado from average ears. Its rich, deep golden color and fine quality of grain make it very superior for grinding into meal, and indicate its strong, nutritive qualities. It is a very vigorous grower, taking strong hold in the ground and averaging eight feet in height, producing two large ears, well filled to the extreme ends of the cob. The most perfect type of Yellow Field Corn ever introduced. Pkt., 10c.; ear, 25c.; lb., 30c.; 3 lbs., 75c., postpaid, b7 mail; by express or freight, sacks included, peck, 75c.; bush., $\$ 2.25$; sack of 2 bush., $\$ 4.25 ; 10$ bush. and over, $\$ 2.00$ per bush.; 50 ears, $\$ 3.00 ; 100$ ears for $\$ 5.00$.

\section{THE 100-DAY BRISTOL FIELD CORN}

When we first saw this corn growing in the field, with its enormous stalks and fodder, twice the height of an ordinary sized man, and its magnificent ears, averaging nearly a foot in length, as shown in photograph below, we were inclined to doubt its earliness. But after growing it ourselves and on the farms of hundreds of our customers, the past four seasons, we have found it cut and shocked ready for husking in ninety-five to one hundred days from the time the seed was planted. The grain is a light yellow; the cob is small considering the size of the ear. It will produce as much fodder and more corn than the famous Chester County Mammoth and other late varieties, which require three to four weeks longer to ripen. In fact, it is a perfect field corn in all respects. Prices: Pkt., 10c.; ear, 25c.; 1b., 30c.; 3 lbs., 75c., postpaid, by mail. By express or freight, shelled, peck, $75 \mathrm{c}$; ; bush., \$2.25; eack of 2 bush., $\$ 4.25 ; 10$ bush. and over, $\$ 2.00$ per bush.; 50 ears, $\$ 3.00 ; 100$ ears, $\$ 5.00$, aacks included.

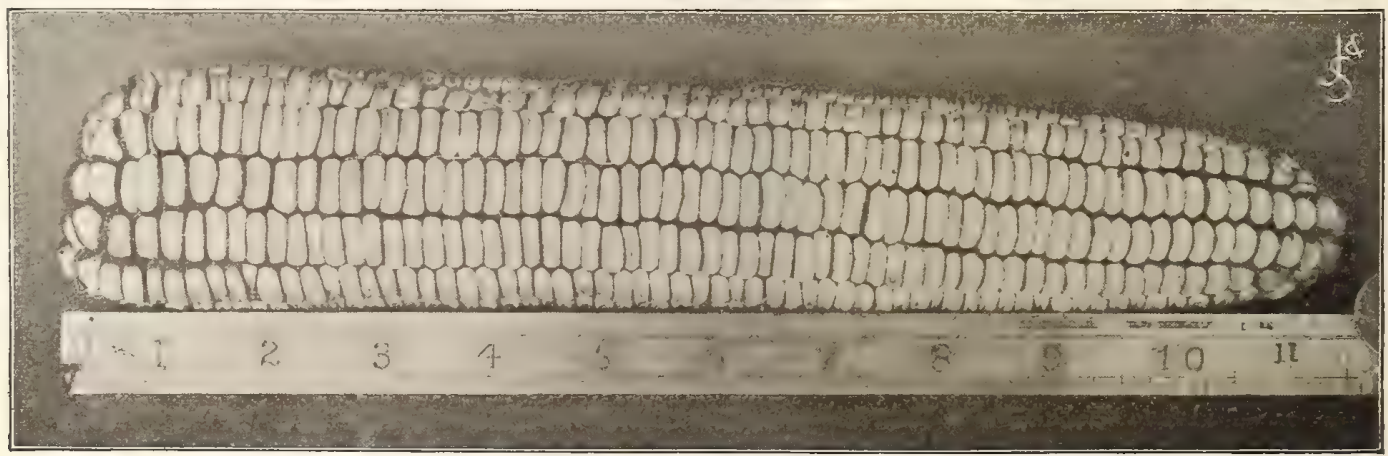




\section{Seed Corn-Standard Varieties}

Prices of the following eight varieties, each, per pkt., 10c.; Ib. 25c,; 3 lbs. for $65 \mathrm{c}$., postpaid, by mail. By express or freight, quart, $15 \mathrm{c}$.; peck, $60 \mathrm{c}$.; bushel, w1.60; sack of two bushels, $\$ 3.00$; ten bushels or more at $\$ 1.45$ per bushel. Eacks included.

IMPROVED SNOW-WHITE DENT. The earliest, most prolific and best white corn in cultivation. The stalk grows so remarkably quick that it is seldom caught by grows so rers large and ripen in 105 to 115 days.

PERFECTED GOLDEN BEAUTY. A large, broadgrained yellow corn, maturing in 110 days from planting.

LEGAL TENDER YELLOW DENT. Originated in Iowa. Very productive, ear large, with deep yellow grain on a small cob, stalk 9 to 10 feet, and matures in 110 to 115 days. DELAWARE COUNTY DENT. Very productive; ears large, grain bright yellow and of great depth, maturing in 110 to 120 days from time of planting.

FARMERS' FAVORITE GOLDEN DENT. Early, with large ears, productive and adapted to thin soil.

CHESTER COUNTY MAMMOTH. Grain large, deep and bright yellow: stalk large averaging i2 feet

EARLY YELLOW CANADA FLINT, Well adapted to the North and for late replanting.

HICKORY KING. The largest-grained and smallestcobbed pure White Dent Corn in cultivation.

\section{Ensilage and Fodder Corn}

RED-COB ENSILAGE. This new and superior ensilage corn we can recommend as the heaviest cropping variety, producing 50 to 75 tons per acre. It is a pure White vent Corn, growing on a red cob. The fodder is pure the der, juicy, grows 13 to 14 feet in height. Peck, 50c.; bush., \$1.35; 10 bush. and over, \$1.25 per bush., sacks included.

BLUNT'S PROLIFIC ENSILAGE. Also called Mammoth Ensilage. Has produced 70 tons of fodder to the scre, and is one of the most popular. Peck, 60c.; bush., $\$ 1.60$; sack of 2 bush., $\$ 3.00$; 10 bush. and over, $\$ 1.45$ per bush.' SOUTHERN HORSE TOOTH. Adapted for ensilage. Peck, 50c.; bush., \$1.25; 10 bush, and over, \$1.15 per bush.

SUGAR CORN FOR GREEN FODDER. Profitable for milch cows. Bush., $\$ 3.50$; 5 bush. and over, $\$ 3.25$ per bush.

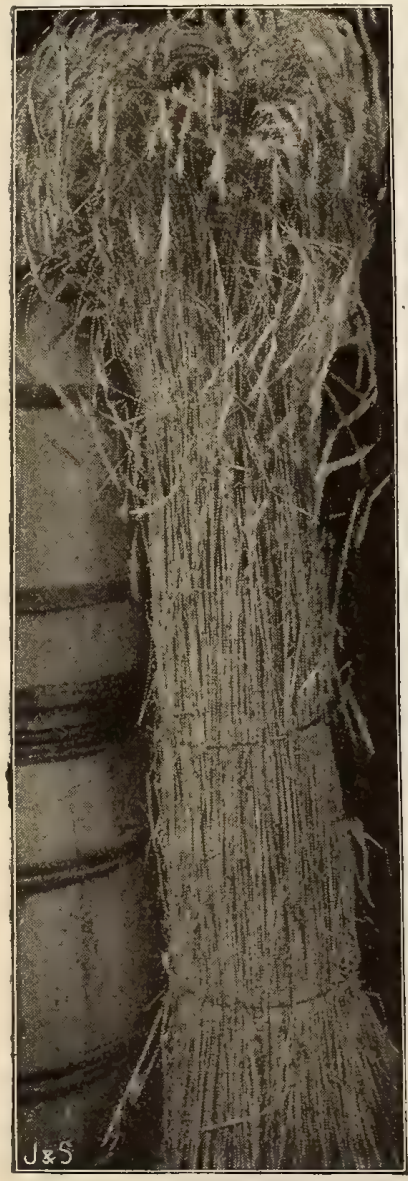

8PRING RYE, SHOWING HEIGHT AND PRODUCTVRNESS OF STRAW.

\section{SPRING RVE}

Distinct from the winter rye, grain of finer quality and more productive; can be successfully grown in any latitude, and is now being largely sown in the Middle States in place of oats, being a much more profitable crop, on account of the production of nearly four times the straw, and also as a "catch", crop where yinter grain has failed. The straw is equally as yaluable as that of the fall or winter rye, gtandfall or winter rye, standing stiff, 7 to 8 feet high.
Produces 30 to 40 bushels Produces 30 to 40 bushels of grain per acre. As it does not stool like wintwo bushels to the acre should be sown. Pkt. 10c.; 1b., 35c.; 31 bs., $\$ 1.00$, post pa id: peck, $50 \mathrm{c}$. postp a $\$ 1$ peck, 50c. $\$ 2.75 ; 5$ bush. and over. $\$ 2.75 ; 5$ bush, and over,
$\$ 1.35$ per bush., bags included.

B U CK WH EA T FOR SEED

NEW JAPANESE. The kernels are nearly twice the size of any other, of a rich dark brown color, and manufacture a superior flour. It has rapidly displaced all others, and is now more largely planted than any other, being about two weeks earlier. Pkt., 10c. Ib., $25 \mathrm{c}$;; 3 lbs., 60c., postpaid; qt., 15c.; peck, 40c. bush., \$1 20; 5 bush. and over, \$1.15 per bus h. sacks included.

SILVER H UL T. Qt. 15c.; peck, 40c. bush., $\$ 1.25$.

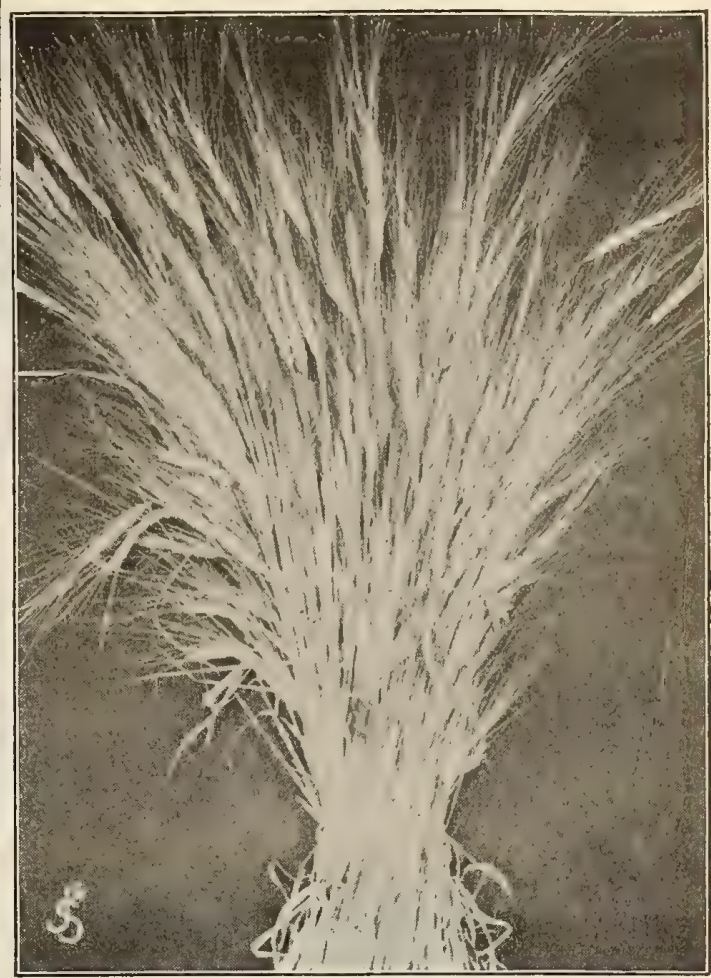

HEADS OF SPELTZ, OR EMMER.

\section{Speltz, or Emmer (Triticum Sperta)}

This grain has been grown for centuries in Russia, near the Caspian Sea. It was recently brought to this country by an emigrant, and 'has already attracted very wide attention on account of its successful cultivation in the Northwestern States. The grain is intermediate between wheat and barley, and is readily eaten by all kinds of stock. It is adapted for milling, as well as for feeding, making a grade of flour similar to rye. The straw resembles wheat straw. It grows large crops -40 to 80 bushels per acre- on poor lands, stony ground and open prairies, and will give double the crop of oats or barley It resists drought successfully, and is adapted to droughty sections and Northern latitudes. Drill at rate 3 bushels per acre. Pkt., 5c.; $1 \mathrm{~b} ., 30 \mathrm{c}-3 \mathrm{lbs}, 75 \mathrm{c}$. postpaid; by freight or express, qt., 15c.; peck, 50c.; bush., \$1.50.

\section{Spring Wheat}

SASKATCHEWAN FIFE. This whert is pronounced by the great milling kings of the Northwest the best. Fifty bushels to the acre is not an uncommon vield. Pkt. 10c. 1b., 35c.; 3 lbs.. 81.00 , postpaid; by express or freight, peck, $65 \mathrm{c}$ bush., $\$ 2.00 ; 5$ bush, and ver, $\$ 1.75$ per bush., bags included.

\section{Seed Barley}

NTW MANSHURY. Earliest and most productive Qt., 15c.; peck, 50c.; bush., $\$ 140$.

SPRING BARLEY. Most popular in the North. Qt. 15c.; peck, 50c.; bush., 48 lbs., $\$ 1.35$.

\section{Tobacco Seed}

CONNECTICUT SEED LEAF. Saved from selected plants, Pkt, 10c.; oz, 20c.; 1/4 lb, 60c.: lb, $\$ 2.00$

HAVANA. Genuine imported seed, direct from Cuba. Pkt. 10c.; oz, 35c.; $1 / 1 \mathrm{lb}$., $\$ 1.00 ; 1 \mathrm{~b}$., $\$ 3.75$

SUMATRA.; STERLING, GENERAL GRANT, PEN YSYLVANIA AND TANCASTER BROAD LEAF, each, pkt., 10c.; oz., 25c.; $1 / 1$ lb., 75c.; 1b., $\$ 2.50$.

\section{Fruit Tree Seeds}

Peach Pits. Pure Tennessee, natural, lb., 20c., post paid; bush., \$2.75. Apple Seed, lb., 40c.; bush., \$8.50. A pricot Pits, Oz, 10c.; lb. 50c. Plum Pits, Oz, 10c.; lb., 50c. Pear Seeds, French, oz., 20c.; lb., \$2.00. Quince Seed, oz. 20c.- lb, \$1.75. Mulberry Seed, Oz, 30c.; fb., \$3.00. osage Órange. For hedges. Lb., 45e; bush., $\$ 8.00$. 


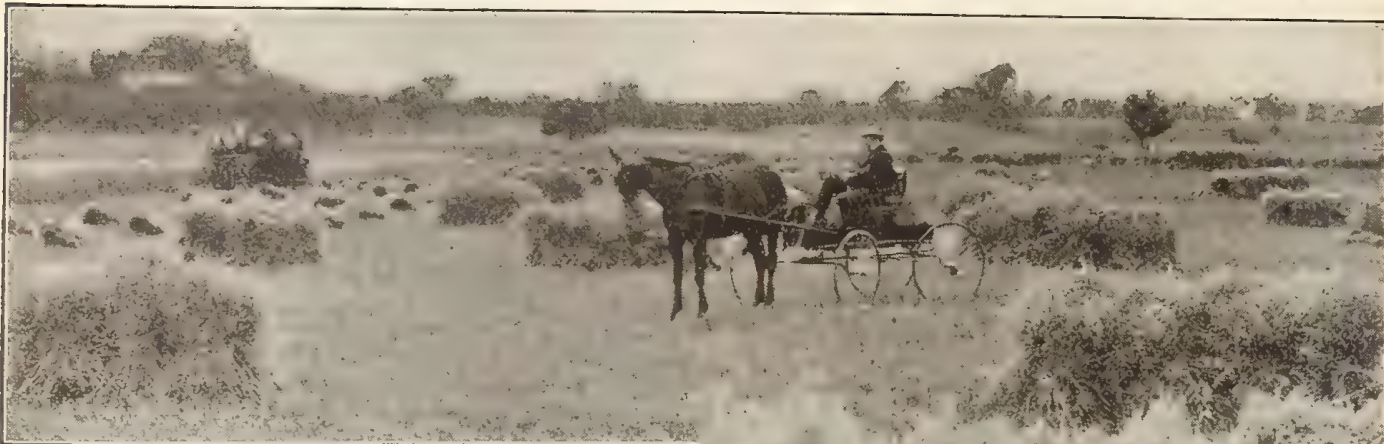

Golden Fleece 0ats

First Introduced by Us in 1901

Three years ago we secured from the originator in Genesee County, New York, his entire crop of seed of this valuable new oats and offered it for sale for the first time. Hundreds of customers have written us about its merits, and we regret we have not room to publish more of the hundreds of letters received from them. It is, without doubt, the heaviest cropping and handsomest oats ever introduced. One of the largest and most experienced oat growers in Chester County, Pa., says:

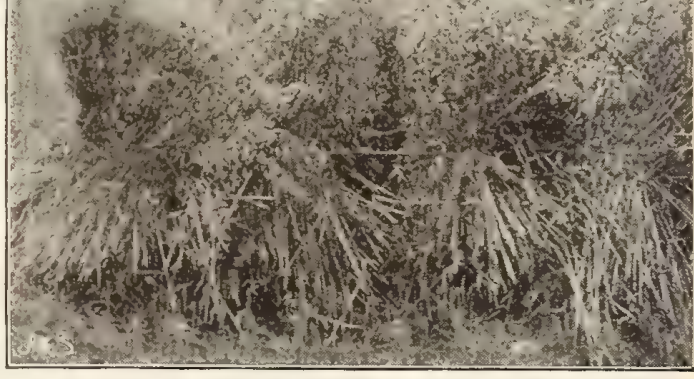

SECTION OF OUR FIELD OF GOLDEN FLEECE OATS.

"Its wonderful productiveness is far beyond what the most enthusiastic farmers in this section ever expected to realize." The field photograph herewith represents our crop while being harvested, and after threshing and cleaning for seed the yield was 108 bushels per acre of large, plump, handsome, meaty, white grain, weighing $44 \mathrm{lbs}$. to the bushel. The yield of other varieties on neighboring farms was from 35 to 50 bushels per acre, or less than one-half that of the GOLDEN FLEECE. This can be partly attributed to the fact that in many cases the spikes or breast will contain three full kernels where other oats give but two. The straw is very strong and does not lodge even when others with less weight of grain in the head go down. The blade is nearly double the size of that of ordinary oats, which is the best evidence of its inherent vigor. This new oats is remarkable for its heavy stooling property, and for this reason 6 pecks ( $1 \frac{1}{2}$ bushels) is sufficient to seed an acre. Prices: Lb., 35c.; 3 lbs. for $\$ 1.00$, by mail, postage paid. By freight or express: Per peck, 65c.; per legal bush. (of 32 lbs.), $\$ 1.75$; sack of 3 legal bush. (96 lbs.) for $\$ 5.00 ; 10$ bush. and over, $\$ 1.50$ per bush., sacks included.

\section{What Others Write of Golden Fleece Oats}

Never Saw Anything Like Them

C. E. BRADLEY, Patten, Mo., November 6, 1903, writes: "I never saw anything like the Golden Fleece. I counted 17 different shoots with full heads of grain from one seed sown, and 4 bushels sown harvested over 200 bushels."

\section{Bushels More per Acre}

D. L. MoCown, Mount Air, Ya., October 24, writes: "Your new Golden Fleece Oats have yielded 20 bushels more per acre than the common White Oats sowed beside them.

\section{Bushels from 20 Quarts}

ARTHER C. VAN HORN, Groton, N. Y. August 17 writes: "I planted last spring 20 quarts of the Golden Fleece, which yielded me 47 bughels of plump, heavy grain of very finest quality."

\section{Standard Varieties of Northern=Grown Seed Oats}

Prices of each of the following: 30c. 1b., or 3 lbs., 65c., postpaid; by freight or express, peck, 40c.; per legal bush. (32 lbs.), \$1:20; 10 bush. and over, $\$ 1.10$ per bush., bags included.

White Maine, very early, handsome, wonderfully fine and productive.

Mortgage Lifter; Danish Island, originally from Denmark; very early and hardy.

Lincoln, early and rust-proof, with strong stiff straw.

Welcome, Clydesdale, White Russian, Virginia Winter Turf, and other well-known and popular varieties of seed oats, choicest seed carefully recleaned, at above prices.

Where larger lots of Seed Grain than those quoted on this and other pages are wanted, please write us for special prices. No trouble for us to answer your letters and inquiries at any time. 


\section{THE FARMER IS THE REAL CAPITALIST-A BRIOHT OUTLOOK}

The farmer is the real capitalist and aristocrat. He has brought out of the earth this year enough to buy a large majority of the big corporations of the country. The corn crop would buy, at present quotations (December 15, 1903), all the stocks and bonds of the United States Steel Corporation, and have 200 millions left over with which to buy the independent companies. The hay crop is worth 560 million dollars, or more than the present market value of a controlling interest in all the stock of the Pennsylyania New York Central, Eris, Baltimore \& Ohio Atchison and Union Pacific Railroad Companies the stock of the Pennsylvania, New York Central, Eri3, Baltimore c Ohio, Atchison and Union Pacific Railroad Companies that the aggregate value of our crops in 1903 is close to 5,000 million dollars, which would buy at par the total capital stocks of that the aggregate value of our crops in 1903 is close to 5,000 million dollars, which would buy at par the total capital stocks of
80 per cent. of all the railroads of the country. Now, with such a tremendous accretion of real national wealth, and the prosperity which it indicates to the great agricultural and the transportation industries, how can one be a "bear" upon the country or anticipate commercial disaster?

While some of the so-called great financiers of the large cities have been facing bad times for the past year, the farmers with their fields in the East, their prairies in the great West and their cotton plantations in the South, are filled with invigorating cheerfulness and can see only clear skies ahead. Thank God that we live in the greatest and most resourceful country of the globe!

\section{VELVET BEAN (The Great Nitrogen Gatherer)}

A Worthy Rival of the Cow Pea

This new and important forage plant from India is creating a great sensation throughout the Middle and Southern Btates, where it is supplanting the cow pea for cattle food and as a soil renovator. Since our introduction of it four years and as a soil renovator. Since our introduction of it four years with great success and is worthy of a trial everywhere. It witrogen-gathering properties are said to surpass those of the cow pea. It is the rankest grower of any of the legumes two or three seeds planted four feet apart in rows five fee apart will literally cover the ground two to three feet thick with a mass of foliage and vines 20 to 25 feet long, no matte how poor the soil. It leaves a mulch on the ground that is very beneficial to the soil

Dr. Stubbs, Director of the Southern State Experiment Sta tion, says: "I believe that it can be cut advantageously elmost any time from June to October and cured in less time than cow pea hay, because the stems are smaller. It makes an excellent hay and stock eat it well. A heavy nitrogen gatherer, and the tubercles on its roots are the largest of an plant I have observed; corn-like clusters of tubercles have been collected, that make a mass, from one single growth, almost as large as a common hen's ego. The vines of this plant are now about 30 feet in length, from seeds planted in May " "The cultivation is the same as for cow peas. pkt, 10c.; lb., 25c.; 3 lbs, for $60 \mathrm{c}$ by mail, postpaid : by treight, qt., 20c.; peck, $90 \mathrm{c}$.; bush. of $60 \mathrm{lbs}$, $\$ 3.50$.

\section{SOJA BEAN-Late Variety}

The demand for the SOJA or JAPANESE SOY BEANS has grown remarkably of late years. Their great value is as a forage crop and for fertilizing the soil and for pasturing or feeding the green fodder much in the same way as the cow pea. This late variety is very valuable south of the Potomac and ohio Rivers. the acre, or it may be planted in drills three feet apart and the acre, or it may be planted in drills three feet apart and
one foot between plants. Pkt., 10c.; 1b., 25c.; 3 lbs., 60c., postpaid ; by freight or express, qt., 20c.; peck, 60c.; bush., $\$ 2.00 ; 5$ bush, and over, $\$ 1.75$ per bush.

\section{SOJA BEAN-New Early Variety}

The ordinary or late soja bean described above, while valuable south of the Potomac and Ohio Rivers, is too late to be of value in the far Northern States. This variety ripens in all the Northern States, where it has been grown over four feet in height, heavily podded with seed and yielded over ten tons per acre. It is a valuable fodder variety either for feeding green or for the silo. Being a rich nitrogenous feed, it is unsurpassed as a flesh-former, and, like the clovers, is soil-improver deriving its nitrogen from the air are interested in this class of plants Farly Sojo or Soy Michoja express or freight, qt., 25c.; peck, $\$ 1.00$; bushel of 60 lbs., $\$ 3.75$.

\section{CANADA FIELD PEAS AND OATS FOR FODDER}

For Dairy Cows and Hogs, Equal to Corn, and Six Weeks Earlier.

These make a fodder and hay which in every case doubles the production of milk. The Canada Field Pea, which we sell at $\$ 1.75$ per bushel, is the best for this purpose. They should be sown in March or early April, two bushels of peas and two bushels of oats to the acre. The peas should be sown first and plowed under about four inches deep; the oats then sown and harrowed in. They will be readi for cutting about the latter end of June, when the ready for milk and the pods formed on the peas. Farmers who have never gown this crop will be surprised at its large yield. It is a nutritious food and relished by all kinds of farm animals This crop also makes an excellent soil-improver when turned under like cow peas as described above. Since we firat called attention to the great value of Canada Field Peas for this purpose, some years ago, the demand has become so great purpose, some years ago, the demand has become so great Canada and can al ways quote Low PRICES BY LETTER when wanted in lots of 10 bushels and apwards.

\section{PEAS For Fodder and Plowing Under}

"Peas could be made to bring more nitrogen to the soils of this country every year than is now purchased annually by the farmers at a cost of millions of dollars." -U. S. Department of A griculture.

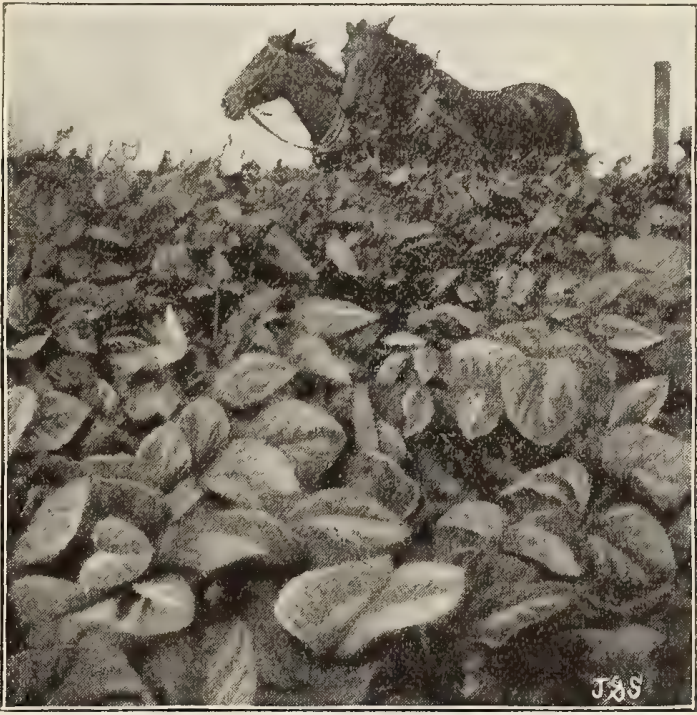

FIELD OF SOUTHERN BLACK OR RAM'S HORN COW PEAS IN ThE NORTH. SOWN JUNE 16th, PLOWED UNDER AUGUST 3ist.

\section{COW PEAS (The Great Soil Improver)}

Make Poor Land Rich. Make Good Land More Productive. Enriching the Soil Even When the crop is Cut off.

Green crops plowed under are one of the best and cheapest ways of improving the soil. For this purpose the cow pea is most popular, especially for medium or light soil. They should be sown in May or June, at the rate of $11 / 2$ bushels to the acre, and plowed under as soon as they have attained their full growth. While this crop is very largely grown wherever known, with the results attained from it the wonder is, that it is not grown ten times as much as at present. There is no surer or cheaper means of improving poor soil than by sowing cow peas. In its capacily as a nitrogen gatherer its growth largely enables the farmer to dispense with the use of nitrogen or ammoniated fertilizers. Nitrogen or ammonia in commercial fertilizers is valued at fifteen cents per pound. The cow pea, to a greater extent than any other leguminous crop, with possibly the exception of the New Velvet Bean, described alongside, has the power to extract this costly nitrogen or ammonia from the atmosphere.

\section{COW PEAS FOR HAY}

If planted early, say by middle of May, in the central corn belt section, a crop can be cut and cured frr hay the same as clover, then the stubble in a short time will put out a new growth to be turned under in the fall as a fertilizer.

The best varieties for all purposes are the following: PRICEs variable with the market.

SOUTHERY BLACK EVE COW PFA PER BUSH. EXTRA FARLY BLA CK EYE COW PEA : : BLACK, or RAM'S HORN WHIP-POOR-WILL and CLAY, EACH : : PRICES BY LETTER ON LARGER Lo'Ts. 


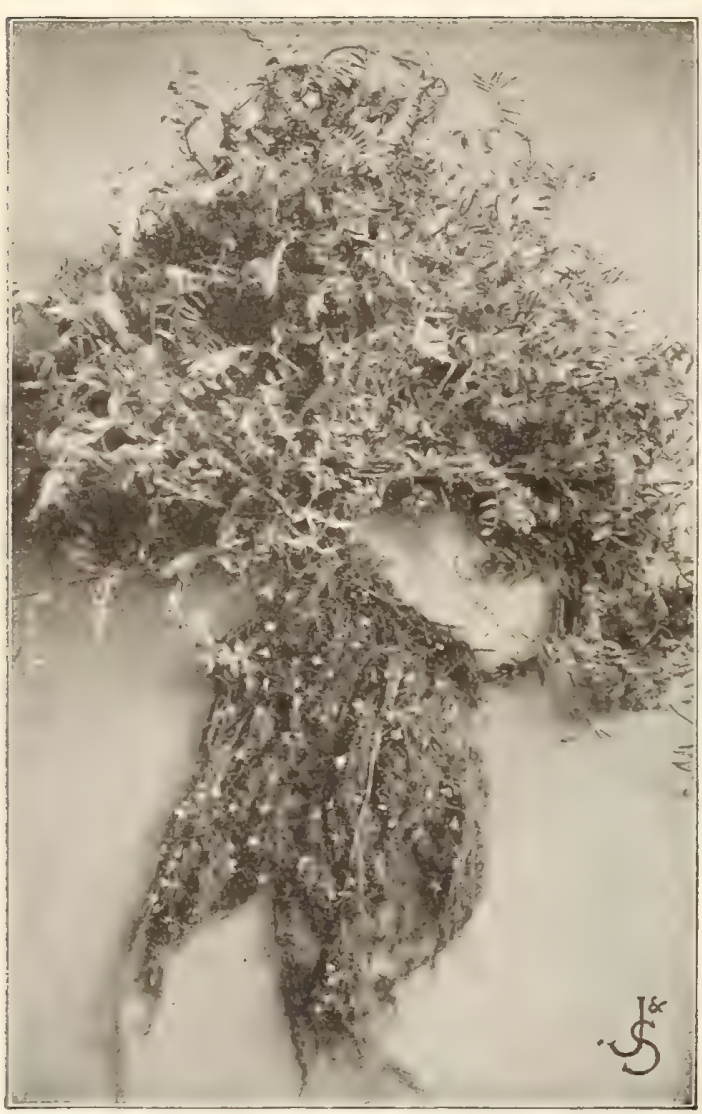

PLANT OF 8AND OR WINTER VETOH-NOTE THE GREAT NUMBER OF SMALL TUBEHCLES ON ROOTS.

SAND, or WINTER VETCH (Vicia Villosa)

Vicia Villosa succeds and produces good crops on poor sandy soils as well as on good land; grows to a height of four to five feet. It is perfectly hardy throughout the United States, remaining green sll winter, and should be sown in the spring, mixed with osts, spring rye or barley; or during August and September with winter rye, which serves as a support for the plants. It is the earliest crop for cutting being hardier and nearly a month earlier than Scarlet Clover, and a full crop can be taken off the land in time for planting spring crops, Every dairyman and stock-breeder in the United States should have a field of it, and if you try it once you will never be a season without it. It is exceedingly nutritious, eaten with relish, and may be fed with gafety to all kinds of stock. Sow 50 to $60 \mathrm{lbs}$. per acre with Batety to all kinds or stock. Sow 50 to ore-half bushel of rye, Oals or barley. Lb., 35c.; 3 Ibs., $\$ 1.00$, postpaid; lb., 25c.; 10 lbs., $\$ 2,00$; bush. of 601

\section{SPRING VETCHES, or TARES}

A species of very small pes, grown extensively in England and Canada for stock feeding. The seed is also largely used for pigeon feed. Culture same as for field peas. Lb., 25 c., postpaid; qt., 20c,; peck, $\$ 1.00$; bush., 83.50 , by freight.

KAFFIR CORN-The Great Forage Plant

Will make a fine crop of forage if cut in early bloom, and the shoots that then follow will mature a full crop of seed and forage. Both grain and fodder are excellent, the whole stalk tender to the full maturity of seed. There is no failure about it, as it possesses the quality that all the tribe possess, of waiting for rain without any loss of capacity to yield. The grain is extremely valuable for feeding to poultry and will make a flour that is like whest. Cultivated the same as our common Indian corn, requiring four to five pounds of seed per acre. By mail, pkt., 10c.; lb., 25c.; 3 lbs. $60 \mathrm{c}$; by freight or express, qt., 15c.; peck, $60 \mathrm{c}$; bush., 60 Ibs., 81.75 .

\section{RED AND WHITE MILLO MAIZE}

These are popular varieties of sorghum, somewhat gimilar to the above, valuable for both forage and grain. Four pounds will plant an acre. Cultivation is same as for Kaffir Corn. Pkt., 10c.; ]b., 25c.; 3 lbs., 60c., postpaid; by freight, qt., 15c.; peck, 65.c; bush., $\$ 2.00$.

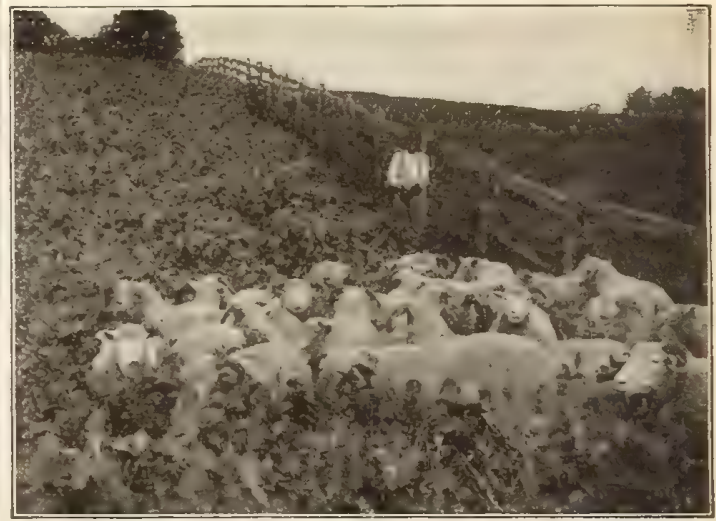

DWARF ESSEX RAPE-EIGHT WEEKS FROM SOWING.

TRUE DWARF ESSEX RAPE

Dwarf Essex Rape, of the True Biennial Variety, is now largely grown in this country on account of its rapid growth, being ready to reed in eight to ten weeks rom 80 w Ing, and producing twenty-five to thirty tons of green forace to the acre. It grows to a height of three feet and covers the surface so densely as to smother out all weeds. It can be the eall pron, being perfectly hardy, with ing broadcast at the rate or fve to ten pounds to the acre Whic unequaled as a pasture for sleep, as a food for all cattle, calves or pigs, it is without a rival, its fattening properties being twice as great as clover, making a much relished and most succulent food from May to December. Lb., 25c.; 3 lbs., 60c., by mail, postpaid; by express or freight, 1b., 15c.; $10 \mathrm{lbs}, 51.00 ; 25$ lbs., $\$ 2.00$; bush of $50 \mathrm{lbs}$. for $83.50 ; 100 \mathrm{lbs}$. and over, at $6 \mathrm{c}$, per lb. Special prices by letter for larger lois.

\section{EARLY AMBER SUGAR CANE}

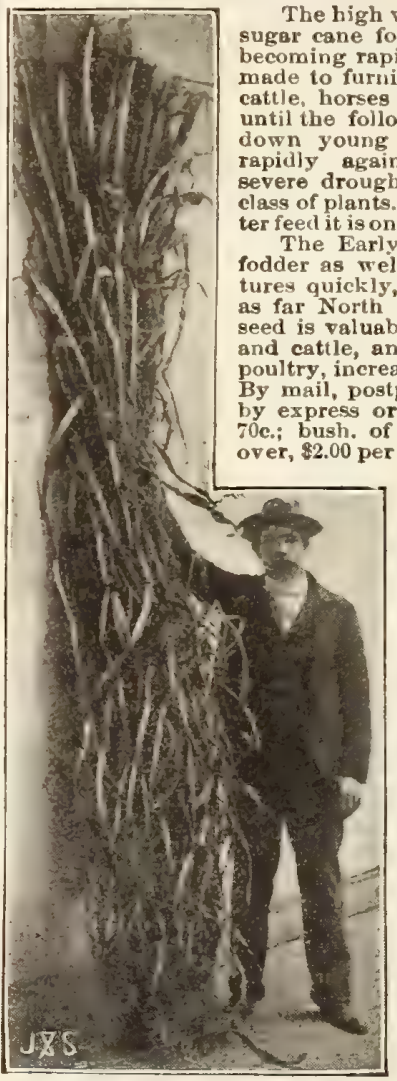

\section{TEOSINT E}

(Reana Luxurians)

This gigantic Grammea will furnish a continuous daily supply of most nutritious green food for hores and all kinds of cattle all
through the summer. It also makes splendid dry fodder, yielding enormously, and being more nutritious and better rel. ished by all stock than corn fodder. In appearance it somewhat resembles Ind i $n$ corn, but the leaves are much larger and broader, and the stalks contain sweeter sap. It stools out enormously after being cut. Sow in May or June, at the rate of three pounds per acre, in drills four feet apart. Pkt 50 10c; $1 / 41$ b., 25c.; 1b., 80c. postpaid; by express or and over at $65 \mathrm{c}$. per $1 \mathrm{~b}$. 


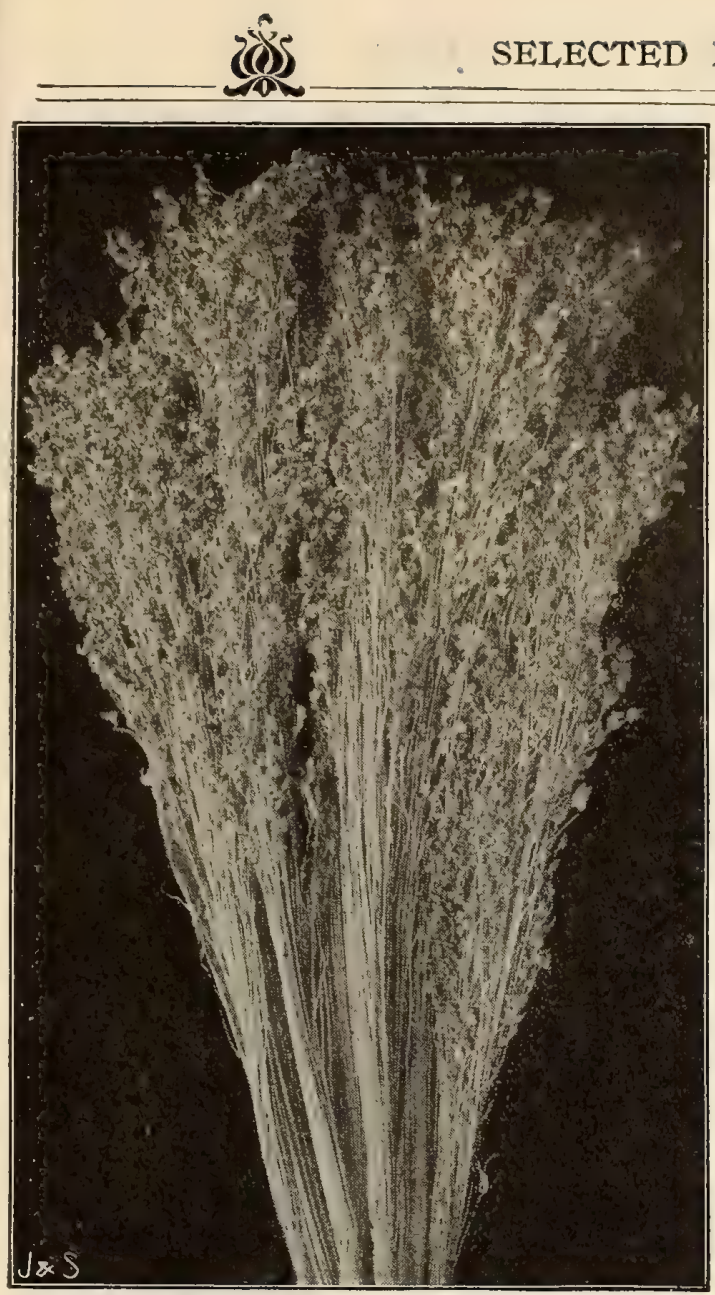

BRUSB OF WEBER'S MMPBOVED RVERGREEN BROUM OORN.

\section{Weber's Improved Evergreen} THE BEST BROOM CORN IN CULTIVATION

The high prices which have prevailed the past three years for broom corn brush indicate that the demand las overtaken the supply, and farmers, where possible, should add it to their crops. The most important question is the securing the best variety and good seed. Weber's Improved Evergreen is the best and purest in cultivation, originated and selected by Mr. Geo. Weber, one of the largest growers and Montgomery County. $\mathrm{Pa}$., who has for many years had of Montgomery County, Pa, who has for many years had the reputation of having the best in the State, having made strength and straightness of brush. It is of a very bright green color without the elightest reddish tinge. It makes by far the best brooms of any corn grown and commands the very highest prices. Oustomers who have grown this corn report yields of over 1,000 lbs, of brugh to the acre. Height, 7 to 8 feet. Lb, 35 c; 3 lbs, 75 , postpaid peck, $90 \mathrm{c}$; bush., $\$ 8.00$; sack of 2 bush. for $\$ 5.50$.

\section{Evergreen Broom Corn}

The old standard variety largely grown in many sections of the West, but is not equal to or as salable as the brush of the Weber's Improved. Qt., 20c.; peck, 75c.; bush., \$2.50.

\section{Wild Rice (Zizania Aquatica)}

A native plant, furnishing food for wild fowl, ducks, geese, etc., also valuable as a forage plant for swamps and inundated lands, as it grows rapidly, and all stock are fond of it when green or cured for fodder. It attracts all wild birds from September on, and also purifies the water and affords a refuge for the small fry from the large fish. To sow:- "Put the seed in coarse linen or cotton bags, and sink in water for 24 hours. Sow in water which is from 6 inches to 5 feet deep, in soft mud bottom, and in places where there are but few weeds. It is useless sowing this seed except on a mud hottom, or on low marshy places which are covered with water the year round. In running water sow as much out of the current as possible." Lb., 35c.; 3 lbs., \$1.00, postpaid; by express, Jb., 25c.; 10 lbs, and over, $20 \mathrm{c}$. per lb.

\section{Jerusalem Artichoke Roots}

This variety is not produced from seed. They are sometimes used as a table vegetable when pickled but their greatest value is for feeding stock. They are the best hog food known. They are remarkable for their fattening rop erties, great productiveness (over one thousand bushels having been grown on one acre) and ease with which they can be grown. They need not be dug; the hogs should be turned in on them, and will help themselves by rooting. One acre will keep from twenty to thirty hogs in fine condition from October until April, except when the ground is frozen too hard for them to root. Thev are also said to be a preventive of cholera and other hog diseases, and they are also highly recoramended for milch cows, increasing the yield of milk and at the same time improving their condition. Three bushels will seed an acre. They should be cut the same as potatoes, one eye to a cut being sufficient, planted in April or May, in rows three feet apart and two feet in the rows, and covered about two inches deep. They can be shipped at any time during the season, as they are not injured by freezing. Lb., 35c.; 3 lbs; $\$ 1.00$, postpaid. B freight or express, peck, $\$ 1.00$; bush., $\$ 3.00$; bbl. of 3 bush (enough for one acre), $\$ 7.50$.

\section{Chufas, or Earth Almond}

(Cyperus Esculentus.)

A speeies of "grass nut" used to fatten hogs. They ghould not be confounded with the cocoa, or nut grass, for though it belongs to the same class, the Chufa is eradicated with great ease, and is never a pest. The nuts grow under ground, very near the surface, easily reached by pigs or poultry. Plant in A pril, ten to twelve inches apart in threefoot rows. Cover lightly. If the seed is very dry, soak well before planting to secure a good stand. They mature early in September, and lie in the ground till wanted. One peek of seed to the acre. Pkt., 10c.; pint, 25c.; qt., 40c., postpaid. By express, qt., 25e.; peck, $\$ 1.25$; bush. $\$ 4.50$.

\section{Long White Cow Horn Turnip \\ THE MOST POPULAR AND BEST FOR STOCKMEN}

Has rapidly grown in fav or for agricultural purposes. It is a fine keeper, heavy cropper ; color pure white, except \& little shade of green at the top, and is currot-like in form growing nearly half out of the ground, and generally slightly crooked. It is delicate and well flavored, of rapil growth and very nutritious. Pkt., 5e.; oz., 10c.; $1 / 41 \mathrm{lb} ., 20 \mathrm{c}$ Ib., 50c., postpaid; 5 lbs. and over, by express, 35c. per $1 \mathrm{~b}$.

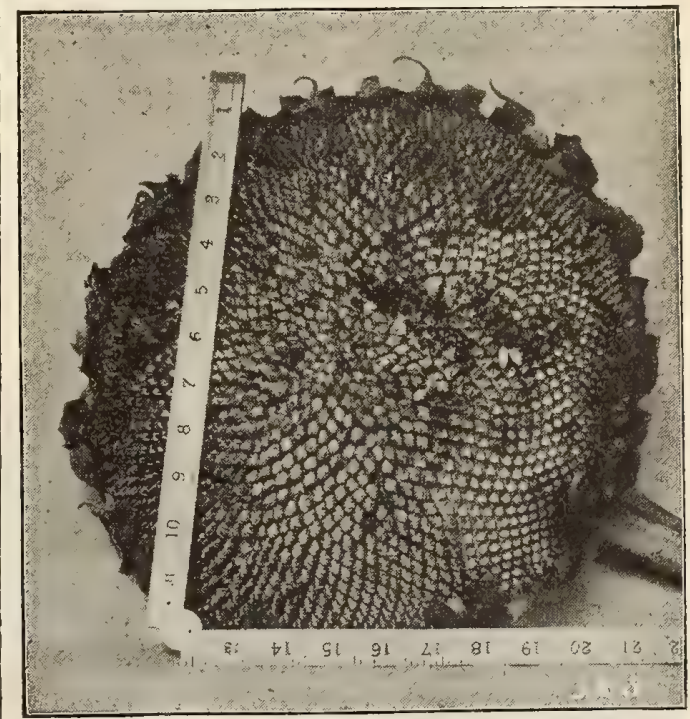

A SEED HEAD OF HAMMOTH RUSSIAN SUNFLOWHR.

\section{Mammoth Russian Sunflower} THE GIANT OF ALL SUNFLOWERS

The best variety for the farmer. Growing to double thsize of the common, and the yield of seed is twice as greas. One hundred and twenty-five bushels to the acre have been gropn at a legs expense than corn. It is highly recommended for poultry: the best egor-producing food known the leaves make the leaves make splendid foder, much relished by all kinds quality of oil. The strong, thick stakks are used for fuel
Oz., 5c.; qt., 15c. (qt., postpaid, 25c.); peck, $60 \mathrm{c} . ;$ bush., $\$ 2.00$ Oz., 5 c.; qt., 15e. (qt., postpaid, $25 \mathrm{c}$.); peck, $60 \mathrm{c}$; bush., $\$ 2.00$;
sack, 2 bush., $83.75 ; 5$ bush. and over, $\$ 1.75$ per bush. 


\section{American Ginseng}

It is claimed by good authorities tion of Ginseng in America is a coming industry of immense proporhowever, not as en thusiastic over the great fortunes to be made from it as some. The extersive advertising given it by others has brought us so many inquiries for that we give it a place in our cataour customers to go into it only in small experimenta land needed for its very little thet eren a restricted city lot will hold a bed. Any one can little time is required Ginseng

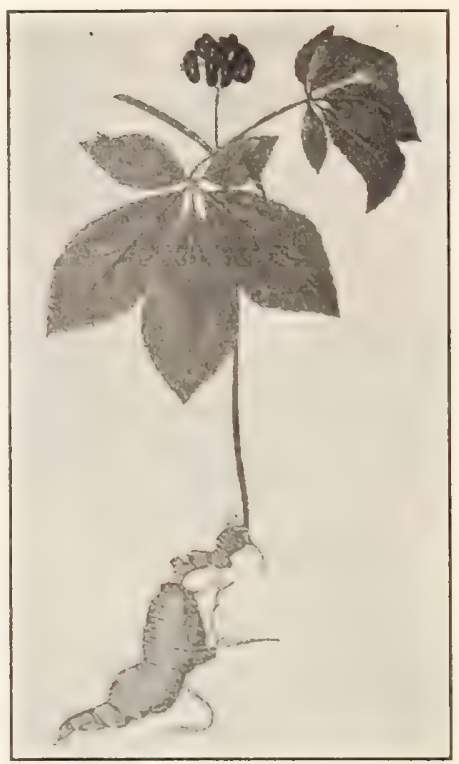

GINSENG PLANT AND ROOT. root brings from $\$ 6.00$ to $\$ 8.00$ per pound in American markets for exporting to China, where they are considered marvelous "cure-all." Seeds and young plants also bring splendid profits to growers here.

Ginseng may be set at any season of the year, as the plant is extremely hardy, so far as cold is concerned, and was originally found a native of many parts of Northern New York and Canada. Our New. Leaflet Essay giving history. possibilities, directions for culture, etc., will be sent with all orders for seeds and plants when requested. American Ginseng seeds and plants are yet extremely scarce and prices quoted aresubject to our present supply being unsold. Prices: Ykt. of 50 seeds, $81.00 ; 3$ pkts. for $\$ 2.50$; plants 1 year old, $15 \mathrm{c}$. each, $\$ 1.50$ per dozen ; 2-year plants, $20 \mathrm{c}$. each, $\$ 2.00$ per dozen, by mail, postage paid.

\section{Japanese Barnyárd Millet}

This wonderful and valuable new forage plant was introduced into this country by Prof. Brooks, of the Massachusetts Agricultural Experiment Station. It has proven an enormous yielder in all sections of the United States-hay and fodder of most excellent quality growing on any soil, yielding 12 to 20 tons per acre and growing 6 to 8 feet in height. Cattle and horses eat it greedily. Sow in May and June broadcast, 10 to 12 pounds per acre (it stools remarkably), or in drills, 8 lbs. per acre. Prices: By mail, postpaid, per lb., 30c.; 31 bs., 75c.; by express or freight, 1b., 20c.; 10 lb\$., $\$ 1.00$ bush. of 30 lbs. 82.00 ; bag of 2 bush. for $\$ 3.50$.

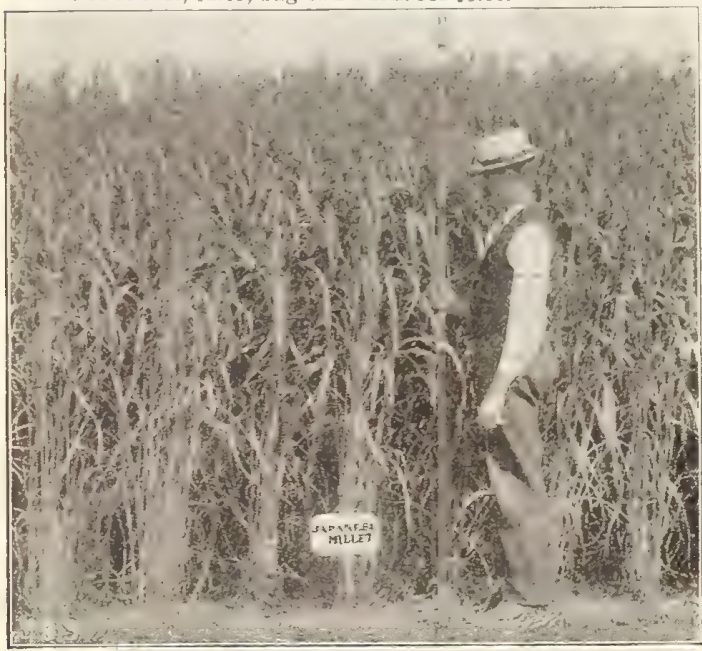

JAPANESE MILLET IN MASSACHTSETTS-FIELD FROI
OUR BEED WAS SAVED BY THE INTRODUCER.
Siberian

or

Russian Millet

A new and wonderfully productive forage plant from Russia, which has given excellent results in the United States and is rapidly becoming the most popular of all the millets. It is ex. tremely hardy with. stends droubt wonder. fully, and is about two weeks earlier than German Millet, growing four to five feet in height, much ranker, producing more leaves than either the Hungarian or German Millet. Its stooling man Hilet. Its stooling properties are remark atalks having bee gtalks having been grown from one seed. The leaves start close to the ground and continue nearly to the top of the stem, are wide and tender, making it preferable to all other mil?ets for hay. Yield of hay is onethird to one-half more per acre than Hungarian and German: besides. the hay is softer when cured, greener in color and preferred by all stock, being very nutritious and fattening. Sow in May or June, 15 to $25 \mathrm{lbs}$. to the acre. Lb., 25c,; $31 \mathrm{lbs}, 60 \mathrm{c}$, postpaid, by mail; by freight or express, $101 \mathrm{bs}, 75 \mathrm{c}$. bush, of 50 lbs. 82.00 2 bush, and over, $\$ 1.75$ per bush.

\section{Pearl Millet, or Pencillaria}

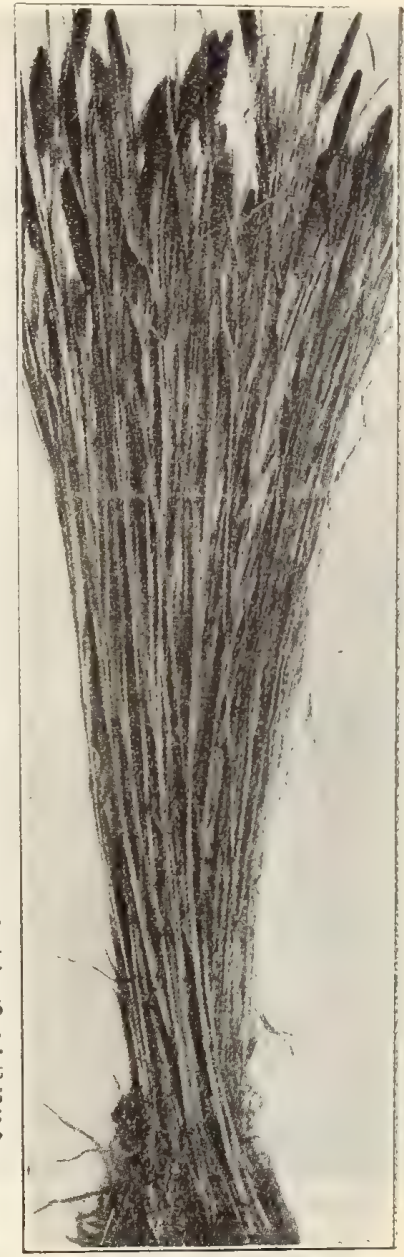

SYBERIAN MILLET.
For several years we have been expermenting with all the known forage plants and have found nothing superior to Pearl Millet either in enormous growth or quality. It has produced the most abundantly and can be cut several times during the season. The United States A gricultural Department has also made numerous experiments and with about the same results as those at Floracroft. If you grow green forage, try East Indian or Pearl Millet, and you will find there is notbing better. Drill in 2 feet rows, $10 \mathrm{lbs}$. to the acre. By mail, postpaid, per pkt, 10c.; 1b., 30c.; 3 lbs., 75c.; by frelght or express, 1b., 20c.; $10 \mathrm{lbs}$. (enough for 1 acre), $\$ 1.00$; bush, of $50 \mathrm{lbs}, 84.50$.

\section{German or Golden Millet (Southern Grown)}

Southern grown German or Golden Millet Seed is far superior, both in quality and yield, to Western or Northern rrown seed. When properly grown and handled, makes an enormous yield of nutritious feed, succeeding in almost any soll. Sow in May or June, one bushel to the acre. Price varies with the market. Qt., 10c.; bush., about 50 lbs., $\$ 1.75$.

\section{Hungarian Millet}

The most popular annual millet, yielding two or three tons of hay per acre. Sow $1 \frac{1}{2}$ bushels to the acre in May or June. Price varies. Qt., 10c.; bush., 48 lbs., about $\$ 1.50$.

\section{Australian Salt Bush}

Valuable for arid and slkali soils. It remains green all winter, and will yield 20 to 30 tons to the acre. One pound of reed will plant an acre. Sow broadcast, in soil well pulverized, after all danger of frost is past. Mix the seed with ten times its weight of loam, sand, ashes or plaster; cover lightly, not exceeding $1 / /$ of an inch. Or it may be sown in a hot bed, cold frame or boxes; 


\section{High $=$ Grade Extra Cleaned Clover and Grass Seeds}

Our grass and clover needs are extra cleaned and of the highest quality. We take great care to have them absolutely free from all noxious weed seeds.

\section{POSTAGE ON CLOVER AND GRASS SEEDS}

Remit, in addition to price, 10c. per lb. and 15c. per qt., except on light varieties, which do not weigh over 1 lbs. per bush., on which remit 5c. per qt., to prepay postage, when ordered to be sent by mail

\section{CRIMSON, or SCARLET CLOVER \\ ifolium incurnatum}

A most valuable crop is this an improver of the soil, or for an early summer forage or hay crop, it is firstclass. As a green manuring crop for grain, truit. or trucking crops, it gives the very best results, while for improving poor equals. It succeeds on every kind of soil, st an d i $n$ Southern suns and Northern winter It has succeeded i almost every State. Sow ten to fifteen pounds to the acre in June or July. Lb., 15c.; 10 lbs. 1100 . 10 los. ibs., about $\$ 3.75$.

$A \mathbf{L} I \mathbf{K}$ E SWEDISH, O HYBRID ĆLO VER. The hardiest of all; well adapted for permanent pas tures or for hay crop. Never heaves or throws in the winter; thrives equally well on we or dry soil, through extreme drought or excessive rains. Grows on clover sick 1 a $\mathrm{d}$. yields a heavy bulk of herbage wher no other clover succeeds. Blossom heads much liked by bees. Sow six pounds per acre in spring or fall. Lb. $25 \mathrm{c}$; 10 lbs. $\$ 2.00$ $25 \mathrm{lbs}_{.}, 84,00$; bush.

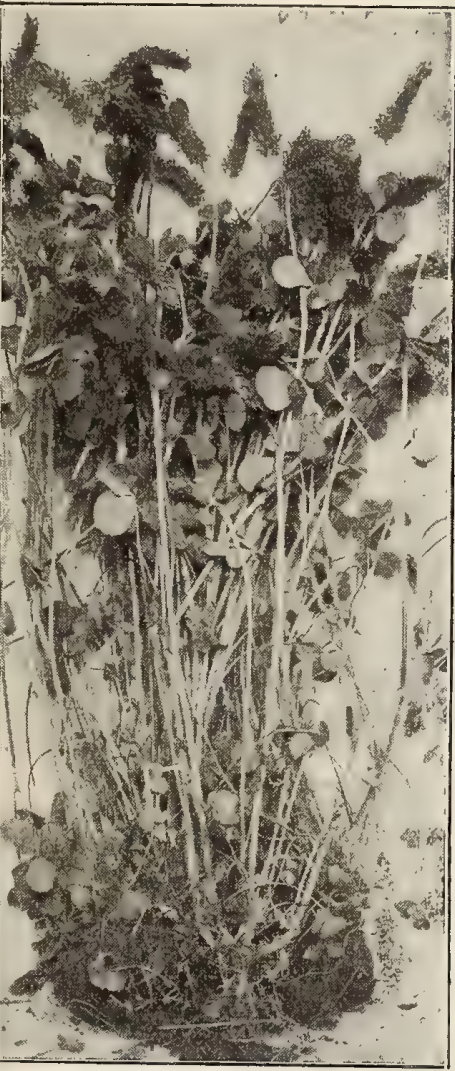
$60 \mathrm{lbs}$, about $\$ 8.50$

RIMSON OR SCARLET CLOVER, TH

LUCERNE, or ALFALFA CLOVER. A perennial forage plant, and when once properly seeded in suitable soil will produce fine crops for several years. It has a remarkably strong growth, roots penetrating the ground to a great depth-ten to twenty feet. Sow twelve pounds to the acre. b., 25c.; 10 lbs., $\$ 2.00$; bush., 60 lbs., about $\$ 9.00$.

TURKESTAN ALFALFA-(True). This variety imported from Turkestan has for the past few years withstood the drought of summer and cold dry winters both North and South better than ordinary alfalfa, giving two crops in the most northerly latitude where the other would winter-kill. most northerly latitude where the other woul

WHITE DUTCH CLOVER. The best to sow with
WH. The lawn grass and valuable in permanent pastures. $\mathrm{Oz} ., 5 \mathrm{c} . ; \mathrm{lb}$.

35c.; 10 lbs. and over, 30c. per lb.; bush., $60 \mathrm{lbs}$., $\$ 15.00$.

CLOVER COMMON RED. Lowest market prices.

MAMMOTH PEA VINE, OR SAPLING CLOVER. Market variable. Write us for lowest market prices.

SAINFOIN, or ESPARSETTE. (Holy Hay.) A landenriching, luxuriant, hest-resisting perennial clover. Lb. 15c. (lb. postpaid, 25c. $101 \mathrm{bs}, \$ 1,00$; bush. of $251 \mathrm{bs} ., \$ 2.25$. BOKHARA CLOVER (Honey Plant). Excellent for bee food, growing well on poor soil. Lb.; 30c.; 10 lbs., $\$ 2.50$.
Write for prices on Grass and Clover Seeds, stating kinds and quantities wanted. Prices vary with the market, and we can frequently supply lower than Catalogne rates.

HUNGARIAN BROME-GRASS (Bromus Thermis). This great drought-defying, frost-resisting grass is now at tracting much attention in the United States. It yields enor mous crops of splendid hay, and affords rich, abundant pasturage Bromus Inermis has afior rich, abundant over one hundred and thirty years. It is grown extensively over one hundred and thirty years. It is grown extensively Smooth Brome-grass. Smooth Brome-grass. It endures extremes of temperature loam, but its roots will penetrate the stiffest clays. It is equally good for cutting green, pasturing or cutting into hay. It can be sown alone and also does well sown with clover and timothy. Use 20 pounds to the acre if alone; if with clover, 15 pounds. It may be sown in the fall with winter wheat, or in the spring.

Seed, per lb., 30c., postpaid; by express or freight, $q t_{\text {, }}$ 15c. bushel of 131 bs. $\$ 2.00 ; 2$ bushels for $\$ 3.75$

CANADIAN BLUE GRASS (Poa Compressa), The hardiest grass in cultivation; should not be confounded with the Kentucky Blue Grass. Canadian Blue Grass shoots its leaves very early. All grazing animals eat it greedily: cows fed on it produce a very rich milk. It is especially relished by sheep. Its bluish green stems retain their color after the seed is ripe. An excellent grass for dry, sandy, thin soils and banks, and for covering the surface of rocky soils. Qt, $15 c_{\text {. }}$ bush. 14 lbs. $\$ 1.50 ; 5$ bush, and over, $\$ 1.40$ per bush. KENTUCKY BLUE GRASS (Poa Pratensis). Valuable for pasture when mixed with other varieties. Qt., 15e.; bush., 14 1bs, $\$ 1.60 ; 5$ bush, and over, $\$ 1.50$ per bush.

ORCHARD GRASS. One of the most desirable pasture grasses. Qt., 15c.; bush,, 12 lbs., about $\$ 2.25$,

TIMOTHX. Qt., 20c.; bush., 45 lbs., about $\$ 2.50$

HERD, or RED TOP GRASS. A valuable native permanent grass, as a mixture in meadows or pastures. Choice seed in chaff. Qt, 15c.; bush, $10 \mathrm{lbs}$. 75c.; in sacks of $50 \mathrm{lbs}$ about $\$ 3.00$; extra fancy solid seed, 1b., 20c,; 10 lbs., $\$ 1.50 ; 100$ lbs and 0 ;er $12 c$.

JOHNSON GRASS (SORGHUM HALAPENSE). Valuable for the South. Qt., 20c.; bush,, 25 lbs., $\$ 2.50$.

NATURAL GREEN GRASS. Qt,, 20c.; bush,, $\$ 3.00$.

MEADO W FESCUE, Or ENGLLSH BLUE. Qt., 20c.

TALL MEADOW OAT GRASS. A valuable grass for permanent pasture, on account of its early, luxuriant growth. Takes splendid hay. Qt., 20c.; bush., 13 lbs., $\$ 2.25$

ENGLISH RYE GRASS. A nutritious, permanent grass for meadows and pastures. Qt., 20c.; bush., 24 lbs., $\$ 1.75$.

ITALI A N RYE GRASS. Qt,, 20c.; bush., $20 \mathrm{lbs}, \$ 2.00$.

CRESTED DOGTAIL. A very valuable grass for lawns, golf links, etc., which require close cutting and to stand wear. Lb., 50c., postpaid; bush., $20 \mathrm{lbs}$., $\$ 6.50$.

WOOD MEADOW GRASS. Adapted for pleasure grounds under trees; fine for pastures under close feeding. Sow 28 pounds to acre. Lb., 50c., postpaid; bush., 14 lbs., $\$ 5.50$.

SWEET VERNAL GRASS (True perennial). Lb., 60c.; weet Vernal (annual), lb, 25c.; bush, $10 \mathrm{lbs}, \$ 2,00$

MEADOW FOXTAL, ROUGH'STALKED MEADOW, RHODE ISLAND BENT, HARD FESCUE, SHEEP'S FESCUE, WATER. MEADOW, WATER FESCUE, CREEPING BEN'T. Each, per lb, , 40c., postpaid;

$10 \mathrm{lbs}$, and over, 30c. per lb, by express. FESCUE. Each, per 1b., 45c., postpaid; 10 lbs, and over, $35 c$. per $1 \mathrm{~b}$., by express.

\section{Good Pastures are the Founda- tion of Successful Farming}

\section{SPECIAL MIXTURES FOR PERMANENT} PASTURES AND MOWING LANDS

\section{SOW TWO AND ONE-HALF BUSHELS TO THE ACRE}

JOHNSON \& STOKES' NO. 1 MIXTURE FOR PERMANENT PASTURE. Contains, blended in proper proportions for the purpose, the following grasses: Orchard Grass, Sheep's Fescue, Meadow Fescue, Hard Fescue, Canadian Blue, sweet Vernal, Meadow Foxtail, Tall Meadow Oat, Red Top, Kentucky Blue, Italian Rye Grass, Perennial Rye Grass, Rhode Island Bent, Timothy, Wood Meadow, RoughStalked Meadow, Alsike. Clover, White Clover, Mammoth
Clover. Bushel, $\$ 2.50 ; 10$ bushels, $\$ 2.25$ per bushel, sacks inClover.

JOHNSON \& STOKES' No. 2 MIXTURE FOR PERMANENT IMOWING. Contains, properly blended, according to condition of soil and climate: Red Top, Perennial Rye Grass, Orchard Grass, Timothy, Red Clover, Mammoth Clover. White Clover, Fined-Leaved Fescue, Rhode Island Bent, Rough-Stalked Meadow, Meadow Fescue, Meadow Foxtail. Bushel, $\$ 2.50 ; 10$ bushels and over, $\$ 2.25$ per bughel, sacks included. 


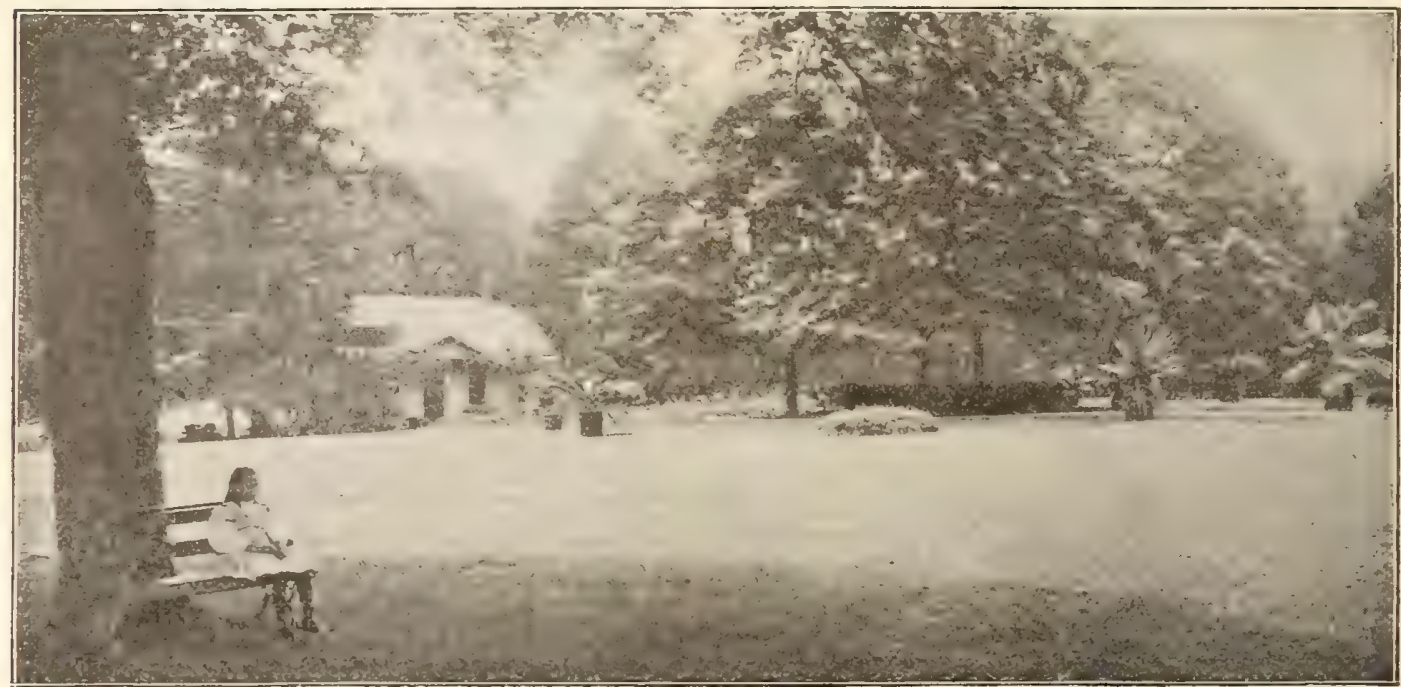

SOFn with JOHYGON \& GTOKEG' EVERGBEET VELTET LAwN SFED MIXTURE, which, owing to jts beautiful and enduring effeet, is now anuuglly used by many of the finest parks in the country, especially in New York, Philadelphia and Boston.

The judicious selection of Grass Seed, for the creation of a beautiful lawn or grass plot, or a durable pasture or hay crop, requires a knowledge obtained only by an intimate study of the habits of varieties as respeots quality of herbage and vigor of cunstitution. It is not suthcient to select the one Grass indigenous to the soil or climate, for it may not possess the many qualities desirable for the purpose desired, for hardiness and permanence, which combination of qnalities and character is best found in a mixture of sorts.

A quart of Lawn Grass Seed will sow about 300 square feet. Three to four bushels are required to Bow an acre. Instructions how to prepare and sow a lawn accompany each package or bag of seed.

\section{JOHNSON \& STOKES' EVERSREEN VELVET LAWN SEED MIXTURE}

is the Best Lawn Grass Seed for the American Climate. With it you can renovate old and make new lawns, grass plots, tennis courts, golf links, etc., as soft as velvet and as green as emerald, which flourish during different months of the year, and insure a beautiful, dwarf, green, compact sward, remaining green and fresh throughout the season. It has become widely known, and is exclusively used on the finest public and private grounds around Philadelphia, New York, Boston, Chicago, and other cities. Quart, $20 \mathrm{c}$.; 2 quarts, 35c. (qt., postpaid, 25c.); peck, $\$ 1.00$; bushel, 20 lbs., $\$ 4.00$.

\section{FAIRMOUNT PARK LAWN GRASS SEED MIXTURE}

This is composed of fine grasses, but less expensive than those used in our Evergreen Velvet Mixture, and will give excellent results. Quart, 15c. (qt., postpaid, 20c.); peck, 75c.; bushel, 14 lbs., \$2.50.

\section{SPECIAL GRASS SEED MIXTURES FOR GOLF LINKS}

Fair Green Mixture. (For outlying grounds.) Specially prepared of the most enduring and serviceable grasses, without clovers. Per bushel, $\$ 2.50 ; 10$ bushels and over, $\$ 2.25$ per bushel.

Putting Green Mixture. A carefully prepared combination of grasses for sowing on putting greens, which will produce a dense, close sward. Per bushel, $\$ 4.00 ; 10$ bushels and over, $\$ 3.75$ per bushel.

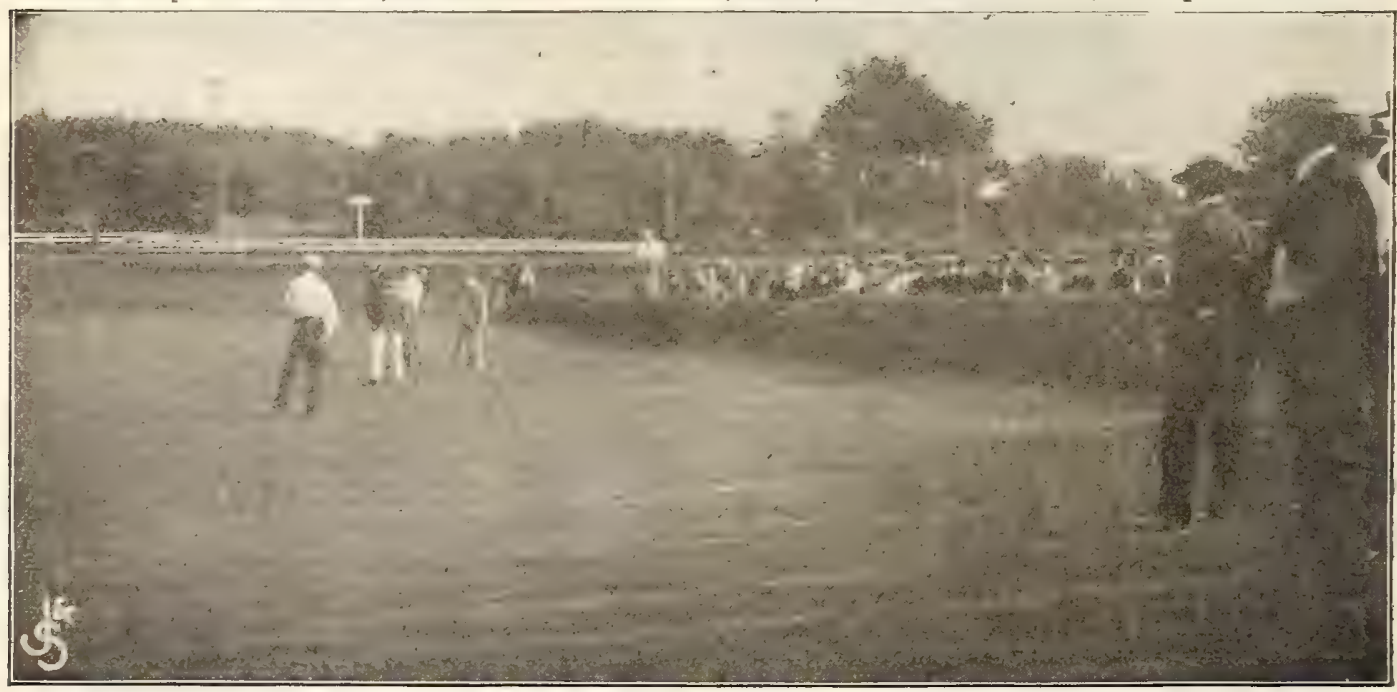

A famous golf ground near Philedelphia, sown with JoHsson \& ETOKeg' GoLF LINK Mixtures. 


\section{FLOWER SEED NOVELTIES}

It is our practice each season to test on our "Floracroit" Trial Grounds all Floral Novelties, and in this way we become, by personal positive knowledge, acquainted with all the best that is offered both in this country and abroad. Of many of the finer sorts, we grow our full stock of seed on our own ground, thus being enabled to know that the type is kept pure and true.

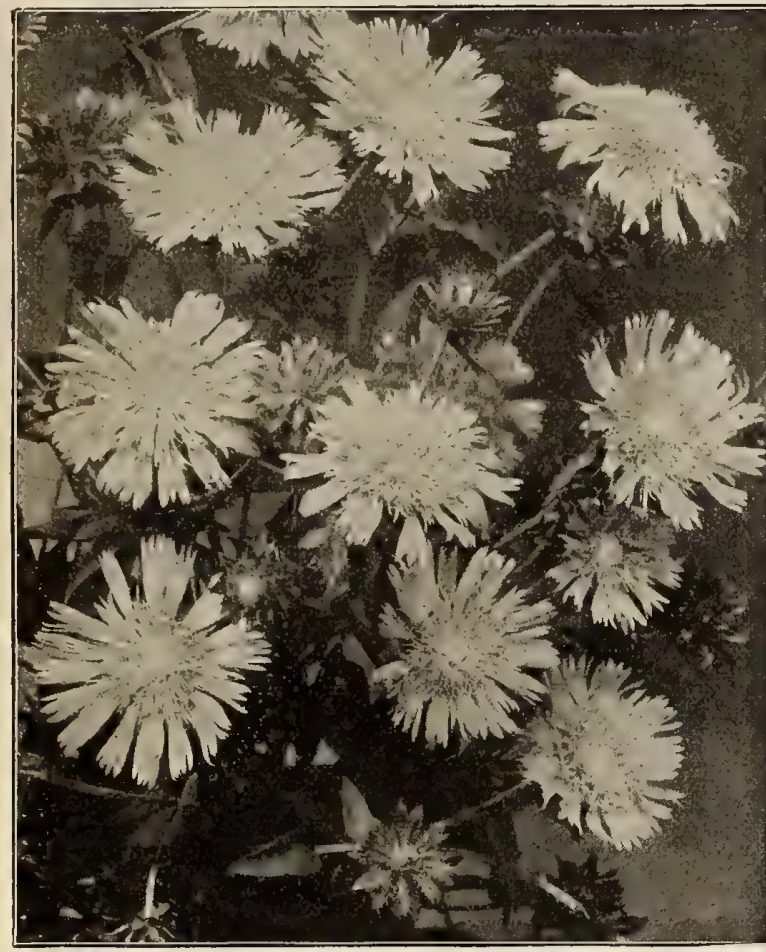

STOKESIA CYANEA.

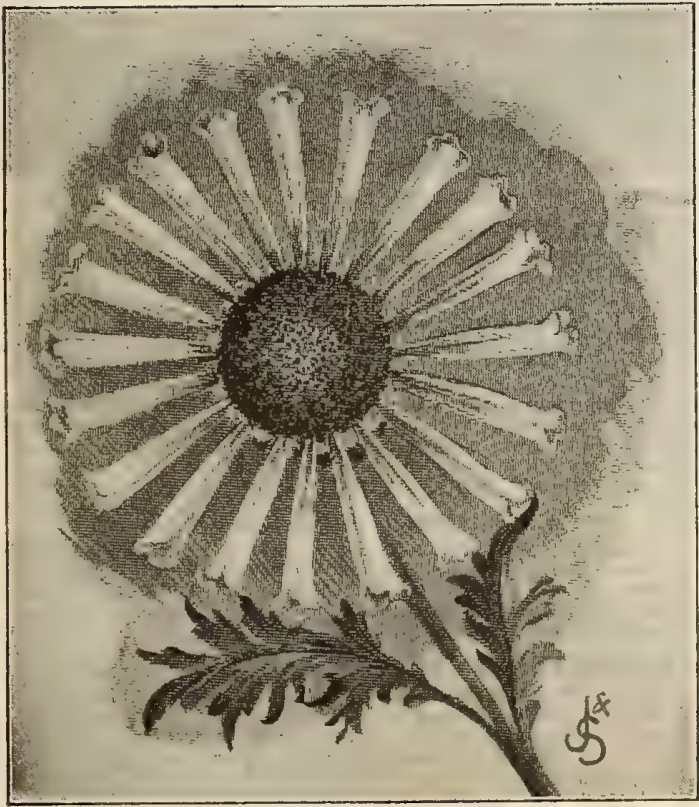

CHRYSANTHEMOM, GOLDEN WHEEL,

\section{STOKESIA CYANEA}

(The Cornflower or Stokes' Aster)

No. 2655. This is one of our most charming and beautiful native hardy plants. The plant grows from 18 to 24 inches high, bearing freely, from early July until frost, its handsome lavender-blue Centaurea-like blossoms each measuring from 4 to 5 inches across. It is one of the easiest culture, succeeding in any open sunny position, and is not only desirable as a single plant in the mixed hardy border, but can be used with fine effect in masses or beds of any size. Like many other native plants which are neglected at home, this is grown in considerable quantities in Europe to supply the demand for blue cut flowers in the Autumn.

We have no hesitation in saying that Stokesia is one of the most valuable and desirable hardy plants offered. Seed : per pkt., 15c.; 2 pkts., 25c. Plants: each, 15c.; per doz., \$1.50.

\section{New Annual Chrysanthemum}

\section{"GOLDEN WHEEL"}

No. 705. This striking novelty is a very free blooming annual. The flowers assume a peculiar form, the quillshaped golden yellow petals standing out all around the purple disk in the centre, like the spokes of a wheel. Very desirable for cutting, lasting a long time. Pkt., 15c.; 2 pkt8., 25c.

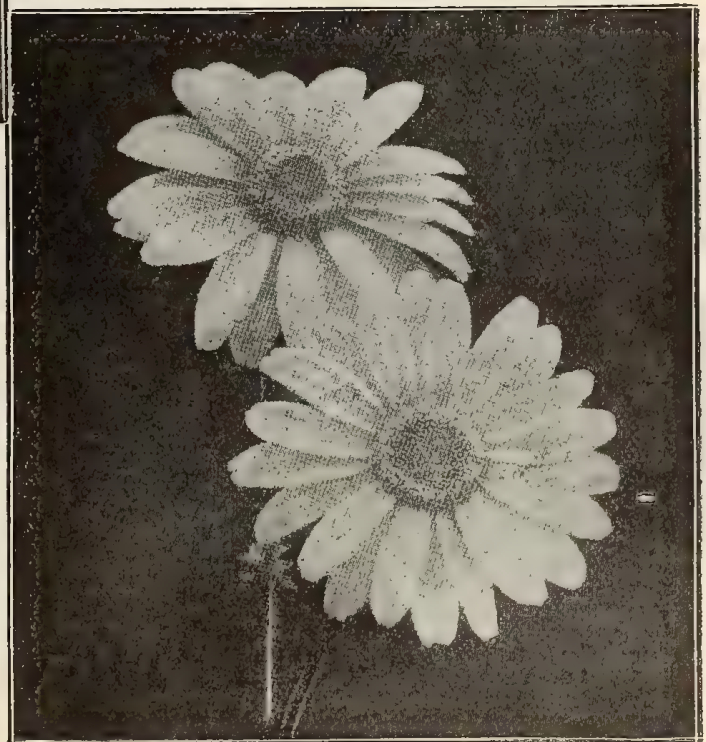

ANNUAL CHRYSANTHEMUM, "EVENING STAR."

\section{New Annual Chrysanthemum}

\section{"EVENING STAR"}

No. 706. These pure golden yellow flowers are often 3 to 4 inches across, and after cutting, last a long time in water. They are very beautiful, and make a valuable addition to our list of choice annuals for cut flowers. Price, per pkt., 15c.:2 pkts., 25c. 


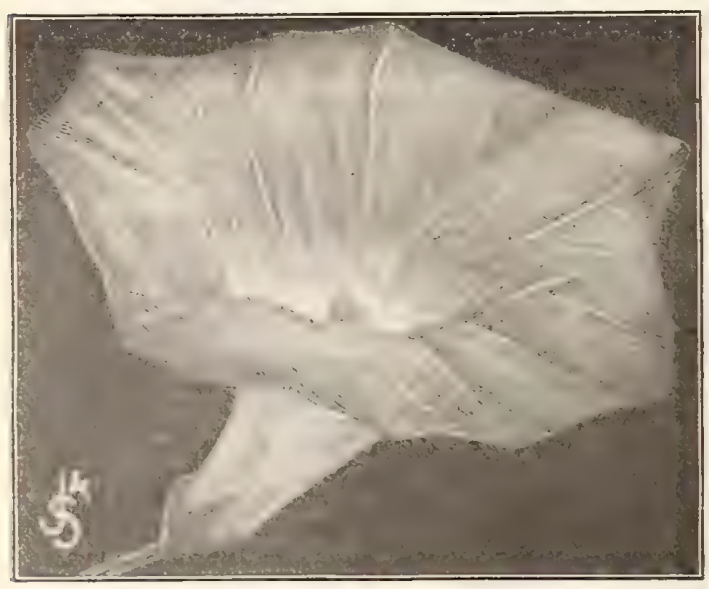

NEW IPOMCA-HEAVENLY BLUE.

\section{New Ipomœa " Heavenly Blue"}

No. 1665. This beautiful Ipomaen is of Merican origin and it is difficult to exaggerate its beauty. Its numerous flowers are three inches or more across, of a very brilliant azure blue, passing insensibly |to a rosy violet, with a light colored throat. Price, per pkt., 10c.

\section{New Dwarf Star Phlox “Radiata”}

No. 2368. The petals unite in the form of a small five or six-pointed star, quite unique in its appearance and of a peculiar charm. The plants are distinct in growth, being even dwarfer and more floriferous than any of the dwarf varieties they form sturdy miniature bushes literally covered with blo The flowers are petal, a very pleasing tint which shows off their novel shape to particular advantage. Price, per pkt., 15c.

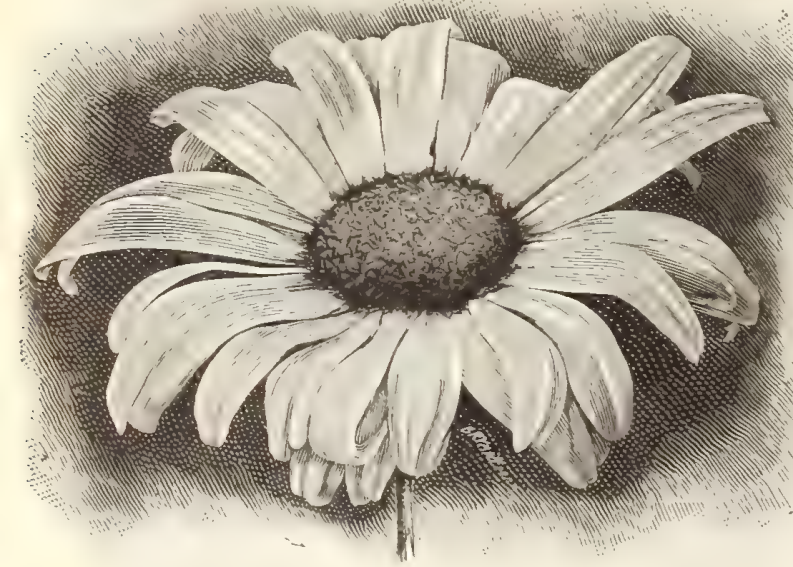

\section{Giant Shasta Daisy}

No. 1025. The Shasta Daisy is one of the most marvelous productions in the flower line that has ever been brought to the notice of floriculturists. It is the first of a new type, which has been obtained by first combining the free-flower ing American species with the large but coarse European species and the Japanese species, Nipponjeum, after which rigid selection through a series of years has produced the present wonderfully beautiful and useful strain. Its first qualification is hardiness; it can be grown out of doors by anybody, where it is not cold enough to kill oak trees. It is perennial, blooming better and more abundantly each season. It can be multiplied rapidly by simple division, and it is not particular as to soil, and it blooms for several in is not particular as to soil, and it blooms for several averaging about 4 to 5 inches in diameter. Packet, $15 \mathrm{c}$.

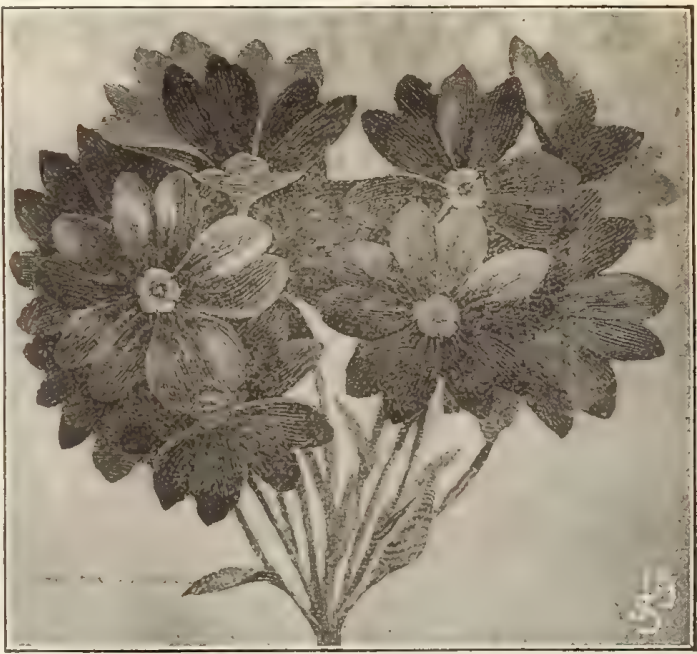

PRIMULA OBCONICA "VESUVIUS,"

\section{Primula Obconica "Vesuvius"}

No. 2422. The beautiful Primula Obconica have been en riched with a new variety, "Vesuvius," which is a fine true bright carmine color. The Obconica Primulas are all very desirable, being very foriferous and having a much longer blooming season than the $\mathbf{P}$. Sinensis section. For other varieties see page 82 . Price, per pkt., 20c.

\section{NE W P I N K S}

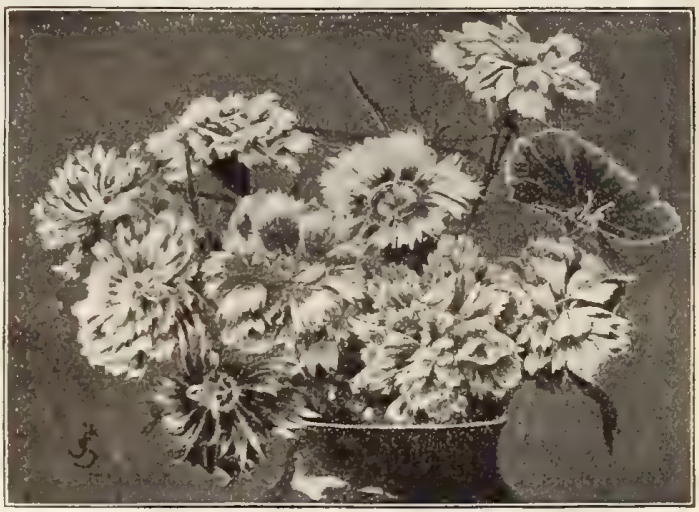

DIANTHUS "ROYAL PINK."

"ROYAL PINK." (Dianthus Heddewigi Nobilis.)

No. 1095. This is a great improvement on the old-fashioned Indian Pink, which has been a favorite for many y ears. They are of easiest culture and constant and graceful bloomerg. The flowers are very large and the petals are frilled and fringed, giving the large flower a graceful and light appearance. The colors are, first of all, of a deep yet very bright blood red then shade to carnine and pink and even white The foliage is grayish blue, sometimes darker. The plant grows vigorously and tall, and gives lots of first-class cu fowers with long stalks, and keeping a full week in water.
The more the blooms are cut, the more the plaut will proThe more the bioom
duce. Per pkt., $10 \mathrm{c}$.

" STAR PINK." (Dianthus Stellaris.)

No. 1096. This novelty represents a new class of the Chinese Pink. Each single flower has the form of a 5 or 6 rayed star, hence the name, "Star Plnk." "They bloom continuously from June to October with a matchless display of color and variety of markings. Pkt. $10 \mathrm{c}$

\section{DOUBLE DIANTHUS “SALMON OUEEN."}

No. 1097. This beautiful double annual pink has finely fringed flowers of a fiery salmon red, turning to a charming salmon pink as they get older. Plants are 10 to 12 inches high, and bloom profusely throughout the whole season. Pkt., 10e.

"PINK COLLECTION"-One pkt. each of above 3 choice Piuks for $25 \mathrm{c}$. 


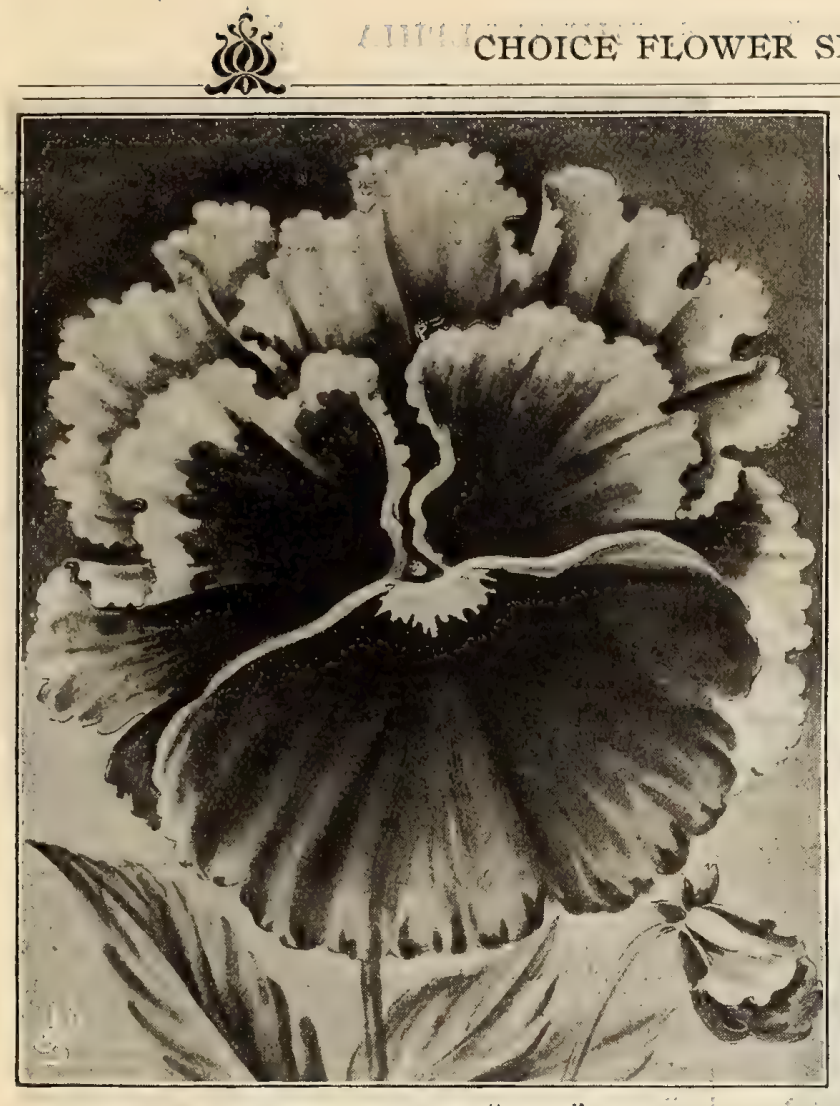

Five Grand New Pansies

New Giant Pansy "Hero"

No. 2313. No more beautiful pansy has ever been introduced than "Hero." It is a very. large, well-shaped flower of great substance; has beautiful regularly crimpled and curled edges, as shown in the illustration. Its color is an exquisite deep blue, shading to white on the upper petals. Price, per pkt., 20c.

\section{Mme. Perret}

No. 2312. A new French strain of pansies particularly rich in shades of red, but of the largest size and borne erect on long stems. Price, per pkt., 20c.

Pansy Giant "Pretiosa"

No. 2309. This flower is similar to the new "Masterpiece" Pansy introduced two years ago, and has the same frilled edges, but it is of the true giant five-spotted sort. Each petal marked with a large blotch of deep violet on a ground color of brilliant crimson rose, and each petal margined with a pure white edge. Price, per pkt., 20c.

\section{Pansy Giant "Indigo King"}

No.2310. The brightest blue pansy ever offered. The old variety, "Emperor William," looks a dull color when compared with this grand new sort. Price, per pkt., 20c.

\section{Pansy Prince Henry}

No. 2311. A new giant variety of vigorous habit, the flowers often attaining $3 \frac{\pi}{2}$ inches across, of a brilliant dark indigo with velvet lustre, each petal having a large black-brown veined blotch, like the Bugnot race, with slightly undulated edges. Price, per pkt., $20 \mathrm{c}$.

\section{Giant Novelty Pansy Collection}

One pkt. each, above five choice new varieties, $75 \mathrm{c}$.

\section{New French Collerette Dahlias}

No. 1003. An entirely new type of Single Dahlia, which has produced a great sensation during the past two years wherever exhibited, and which have been awarded highest honors. The peculiarity of the type consists of their having a row of short petals around the disc, which form a frill or collar, and which are of an entirely different color from the rest of the flower (the arrangement is well shown in the illustration). Can be grown readily from seed. Price, per pkt., 20c.

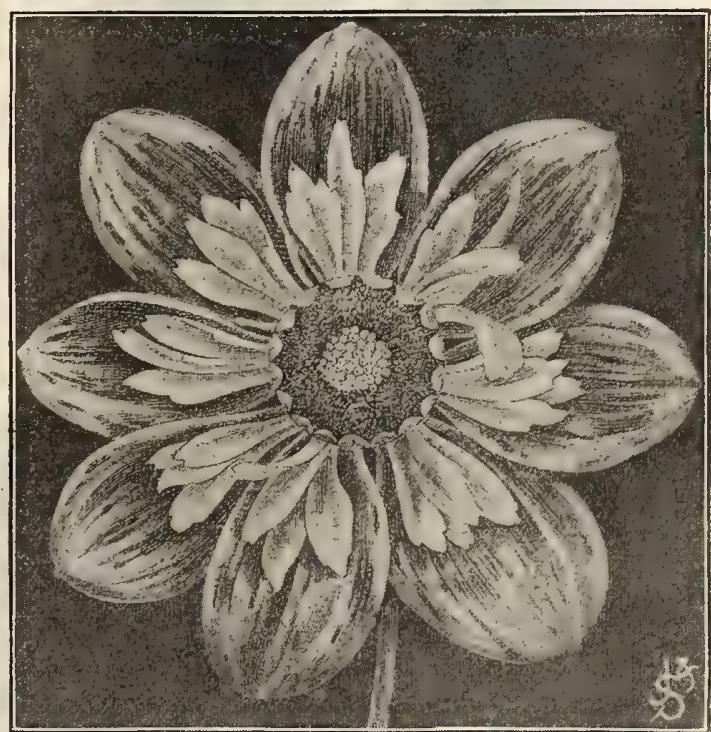

FRENCH COLLERETTE DAHLIA.

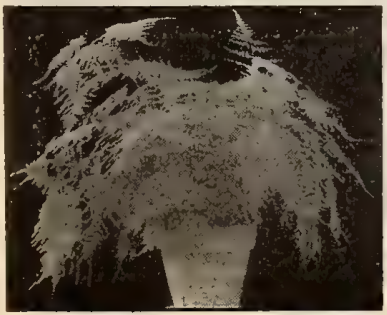

\section{Asparagus Plumosus Robustus}

No. 302. A very remarkable variety of the now universally grown ornamental Asparagus. The fronds, which sometimes attain a length of 9 or 10 feet, are very finely feathered and of the darkest green color. Being of vigorous, robust and uncommonly rapid growth, this new variety yields more sprays for cutting than any other and has the further advantage of being very early and easily propagated. Price, per pkt., 15c.; per 100 seeds, \$1.25. 


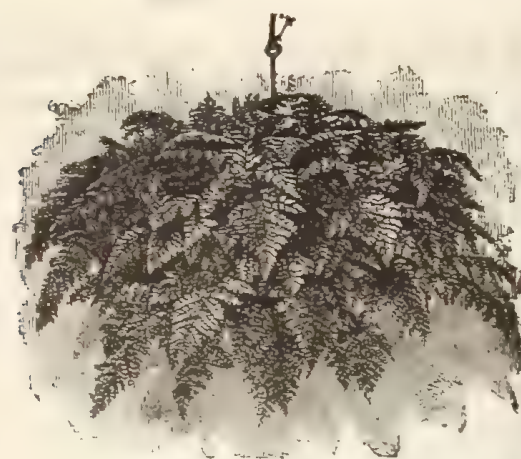

JAPANESE FERN BALLS

These are dormant balls of fern roots. Directions for Starting.

Submerge the ball in water for fifteen minutes, then hang up where the temperature is about $70^{\circ}$. On the second day soak the ball for five minutes, after which water may be applied daily in sufficient quantity to prevent the roots from 40c. each (by mail, postpaid, 50c.); per doz., 84.00 . 8mall size, 5 to 7 inches in diameter, $25 \mathrm{c}$. each (by mail, postpaid, $30 \mathrm{c}$ ); per doz.. \$2.25.

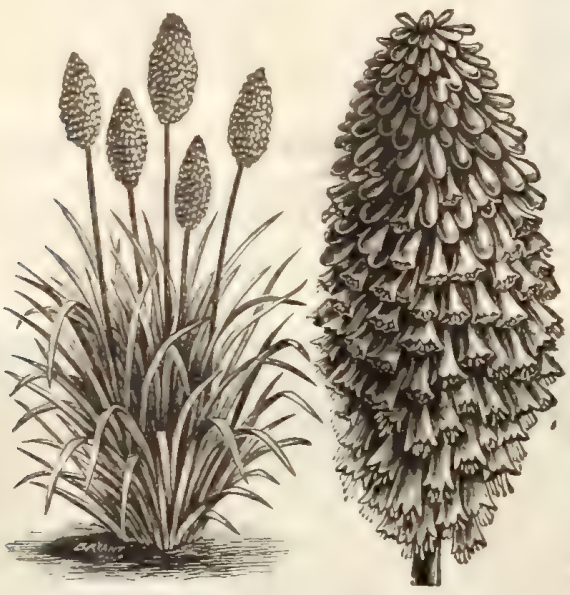

TRITOMA PFTTZERU

TRITOMA PFITZERII

This new variety is a marvelous improvement over the olc well-known "Red Hot Poker" plant. It is a very free blooming sort, flowering continuously throughout the season. The flowers are long stalkg gracefully poised above the rich green foliage 4 bed of this in bloom is a grand sight; a border of it around Cannas is admirable; thess and is in (all other flowers are seared with early frosts. The roots should be dug up before hard frost and kept in sand in the cellar during the winter. (See cut.) Price, 20c. each; \$2.00 per dozen.

\section{NEW GLADIOLUS HYBRIDUS "PRINCEPS"}

Hybrid between the rare African Glad iolus Cruentus and a selected Childsii seedling. Grows 4 feet high, with broad, healthy foliage. Spike erect and often 18 inches long, bearing 16 to 22 immense broad-petaled circular flowers, opening flat and perfect, 5 tet with cream-white feathering on scarlet with cream-white feathering on lower petals. Endures the sun and wind well, and opens perfectly to the last bud in water. Has received Award of Merit, Royal Horticultural Society, London, England, 1901. Price per bulb, 25c. each; 82.50 per dozen.

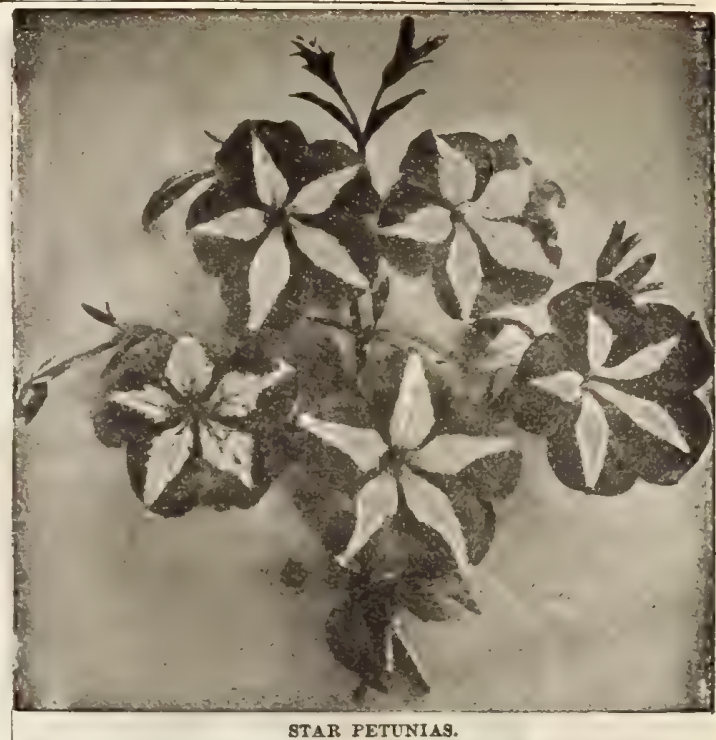

NEW STAR PETUNIAS

No. 2344. In form, intensity of color and markings, this new strain of Petunias is something wonderful. From the centre of each flower start the points of a five-rayed star. which broadens half-way up, narrowing to a point at the margin of the flower.

Their ground color is a dark crimson maroon, with a rich velvety texture, justly pronounced equal to that of the pansy. Showing through the ground color are violet veinings.

This star is a very light bluish pink, some almost white, which deepens in color as it reaches the margin and finall blends with the maroon ground color. Over 80 per cent. of the plants from seed will produce the star markings. Other with veined and feathery markings on dark or light ground are not less surprisingly beautiful.

The plants are free growers, branching freely and attaining an average height of 18 inches by 24 inches in diameter.

They are remarkably prolific bloomers, single plants often having one hundred or more fully expanded flowers at a time. Per pkt., 15c.; 2 pkts., 25c.

\section{THE WILD-FLOWER GARDEN}

No. 2960. Our Wild Flower Mixture consists of many varieties of beautiful, easy.growing flowers, producing a constant and varied bloom the whole season, for sowing in shrubbery, under trees and in beds on which no care will be bestoved, or even for sowing in exposed situations, where wildness is preferred to order and precision. The mixture comprises mignonette, candytuft, larkspurs, marigolds, poppies, foxgloves, and many other garden favorites, which will flower successively and yield an abundance of bloom. Large pkt., 5c.; 0z., 10c.; 1/4 lb., 30c.; 1b., $\$ 1.00$.

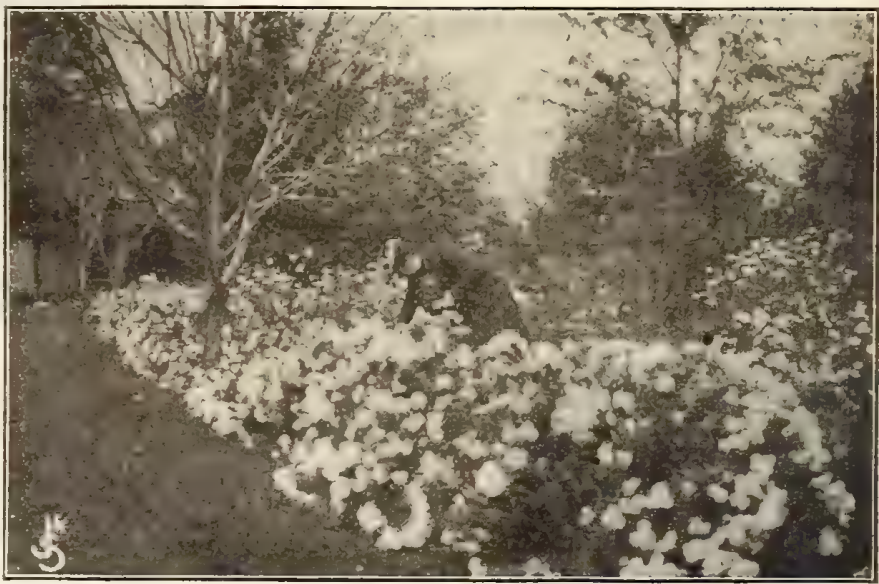

OUR WID FLOWER GARDEN AT FLORACROFT. FLOWRRS TO CUT FROM APRT TO NOY EMBER. 


\section{General List of Flower Seeds}

\section{PLEASE ORDER BY NUMBER}

\section{ABRONIA}

40. Umbellata. Charming annual trailer for vases, rockwork, etc. Pkt. $5 c$.

45. Abutilon, Large bell-shaped flowers; various colors, richly veined. Mixed colors; tender perennial. Pkt. $10 \mathrm{c}$

50. Acroclinum. Mixed double flowering. An "ever lasting " for winter bouquets. Pkt., $5 \mathrm{c}$.

\section{ADLUMIA}

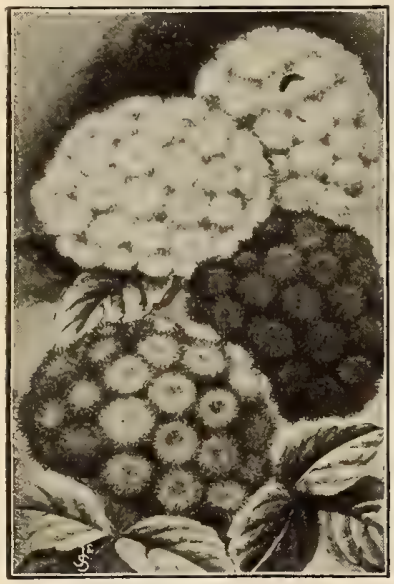

AGERATUM.

\section{Ci r r h o s a (Mountain Fringe o Allegheny Vine) A charming climber. Pkt., 10c.}

\section{AGERATUM}

Annuals bearing a profusion of feathery flowers. Excellent for bedding in summer or pot culture in winter. Flowering profusely and continually ; 2 feet high. 100. Mexica $n$ um. Lilac blue. Pkt., $5 \mathrm{c}$.

101. Las seanxi. Beautiful rose color. Pkt., 5c.

102. Choice Mixed Per oz., 25c.; pkt., $5 \mathrm{c}$.

104. White Gem

Very rwarf, free flowering. $\mathrm{Pkt}_{\text {, }} \mathrm{5} \mathrm{c}$.

105. Little Dorrit. Azure blue. Pkt., 5c.

106. Swanley Blue. Large flowers; fine

Pkt, , 5c. Blue Perfection. Very dark blue, dwarf, finest of all. Pkt., $5 c$.

109. Princess Victoria Louise. Novelty. Centre white, edged with blue. Very beautiful sort, dwarf. Pkt., 10c

\section{ALYSSUM}

A garden favorite, flowering profusely throughout the season from spring-sown seed. Excellent for ribbon lines and edging. Very fragrant annual, 6 to 9 inches high.

140. Sweet Alyssum. Oz., 20c.; pkt., 5c

141. Tom Thumb. Dwarf. Oz., 25c.; pkt., $5 \mathrm{c}$.

142. Little Gem. Distinct, very dwarf. Oz, 40c.; pkt.

143. Saxatile Compactum. Perennial; yellow. Pkt.

144. Carpet of Snow. Pure white, only 2 to 3 inches high, a profuse bloomer, showing as many as 300 heads of snow-white flowers at one time on one plant; annual. Pkt. bc.

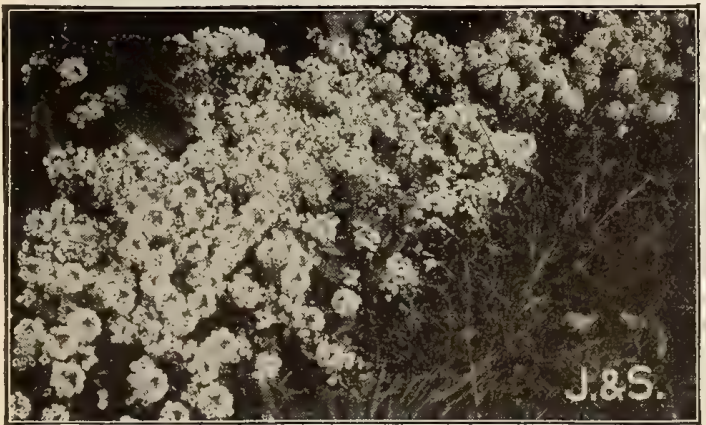

BORDER OF ALYSSUM "CARPET OF SNOW"

\section{AMARANTHUS}

Ornamental foliage and flowering annuals. Very rapid growth and easy culture. For semi-tropical gardening they are very effective.

160. Caudatus (Love-lies-bleeding). Pkt., $5 c$

161. Tricolor (Joseph's Coat), 'Pkt., 5c,
AMPELOPSIS VEITCHII (Boston Ivy)

The Ampelopsis Veitchil is a hardy perennial climber from Japan, with beautiful, glistening, olive-green leaves, which turn a beautiful scarlet in the autumn. It is the best and most popular climber for covering stone or brick walle

180. Seed, 10c. per pkt;; 25c. per oz, Plants, 20c. each; $\$ 2.00$ per dozen.

\section{ANTIRRHINUM}

(Snapdragon)

Half - hardy perennials for the summer flower bed or border. Are very show y and flower the first season from seed. Two to three feet high.

220. Nanum. Dwarf, mixed. Pkt., 5c

221. Majus. Tall mixed. Pkt., 5c.

223. Queen of the North. Iarge, pure white; fine for beds or borders, Pkt., 10c.

\section{AQUILEGIA, OR COLUMBINE}

Ha r d y perennials, luxuriating in the moister gituations in the garden, where they form permanent clum ps, grow-

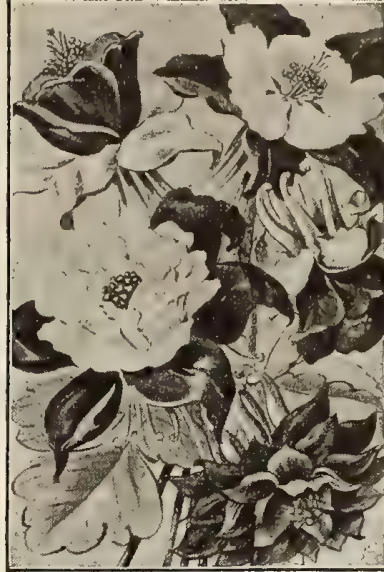

AOUILEGIA, OR COLUMBINE. ing from 114 to 3 feet

high. The large, unique, long-spurred flowers, gracefully hung on long stems, are not only brilliantly effective on the plant, but equally as desirable when cut for vase and house decoration

240. Single Varieties. Mixed, Pkt, $5 \mathrm{c}$.

241. Double Varieties, Mixed. Pkt., 5c

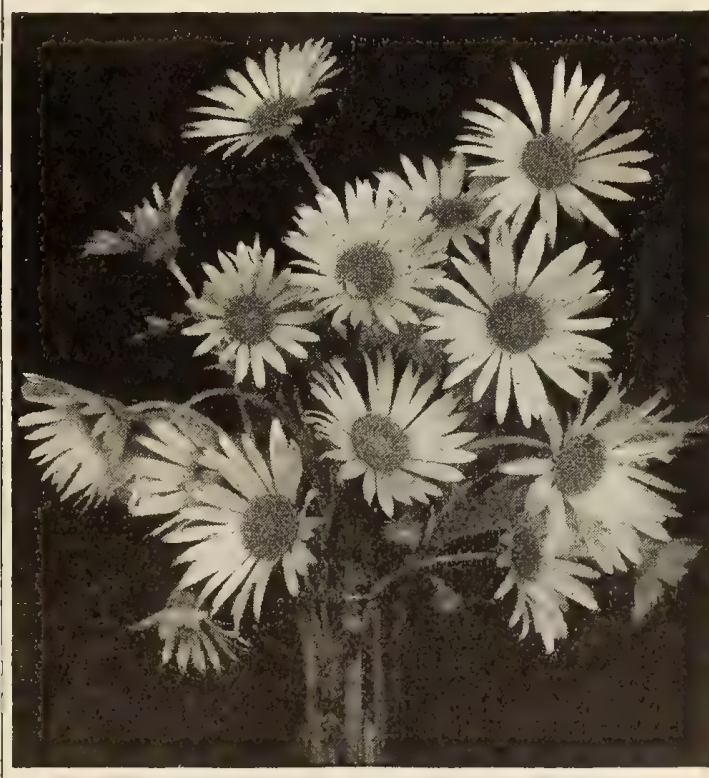

AROTOTIS GRANDIS. 10C.

\section{ARCTOTIS GRANDIS}

No. 250. A handsome new annual, growing luxuriantly in our climate and forming profusely branched bushes of about 2 to $21 / 2$ feet in height and breadth. Its flowers are large and showy, from $2 \frac{1}{2}$ to 3 inches across ; pure white on the upper surface, embellished by a narrow yellow zone at their base; reverse of petals pale lilac. Prt., 10c. 


\section{SUPERB ASTERS}

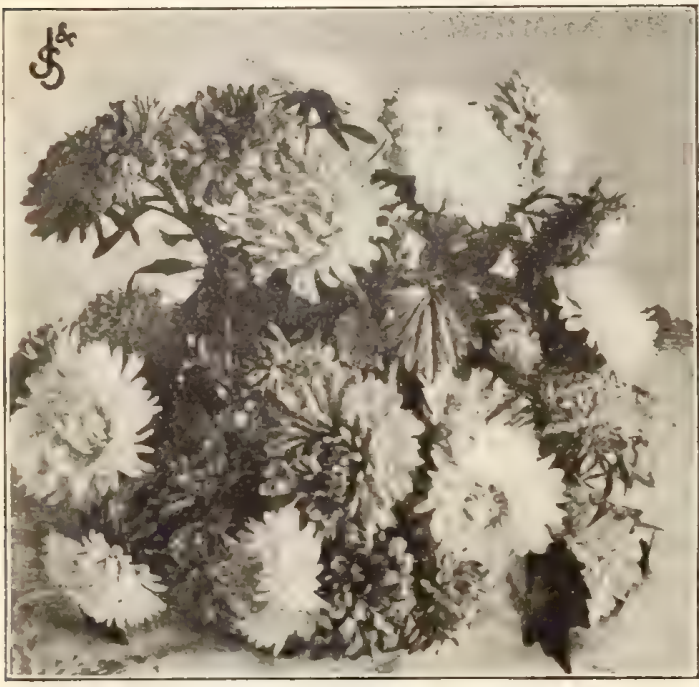

\section{PAEONY FLOWEPED PERFECTION ASTERS}

A very favorite type. Thrifty upright plants; large, fine flowers, with long incurved petals. 'The Florists' Aster, and one of the finest.

321, Snow white; 322, Glowing crimson; 318 , Brilliant rose; 323, Azure blue; 324 , Purple; 320, Carmine, edged white; 325 , mixed sorts. Price, all the above, 10c. per pkt.

\section{DWARF CHRYSANTHEMUM FLOWERED ASTERS}

Plants only ten to twelve inches high, producing flowers of the largest size and choicest colors.

PER PKT.

327. A. Chrysanthemum Flowered, mixed
328. A. Chrysanthemum Flowered, pure white .8010
10

\section{VICTORIA ASTERS}

A magnificent race of Asters. The colors include many delicate and some gorgeous ghades: flowers very double and four inches across, and from twenty to thirty in a single plant; fifteen to eighteen inches high.

355, Pure white; 356, Deep pink; 357, Light blue; 358 , Deep scarlet; 359 , Peach blossom; 360 , Choice mixed sorts. Price, ail the above, $10 \mathrm{c}$. per pkt.

\section{COMET OR PLUME ASTERS}

A very beantiful and distinct class, with long corled and twisted petals formed into a loose yet dense half globe, resembling the Japanese Chrysanthemum.

345 , Yure white; 346 . New carmine; 348 , Deep pink; 349 Delicate pink, edged white; 347 , Choice mixed sorts. Price, all the above, 10c. per pkt.

\section{GERMAN QUILLED ASTER}

Flowers composed of tube or quill-shaped petals. Ver beautiful, with a great variety of colors.

331. German Quilled. (Betteridae's Prize) Mixed. \$0 05 332. o 64 Pure white...

\section{DEEP SCARLET TRIUMPH ASTER}

333. This is undoubtedly the most beautiful and perfect of all dwarf Asters. Fach plant forms an elegant bouquet of itself, seven or eight inches high. The flowers measure from two and one-half to three inches across. of faultless form, The color is rich, brilliant scarlet; each plant bears at least thirty or forty flowers of exquisite beauty. Pkt, 10c.

NEW JEWEL OR BALL ASTER The fowers are perfectly round or ball-shaped. Nine inches in circumference, the petals being short an

351. Apple Blossom. Shell pink . Crimson. Very showy and handsome.

353. Deep Rose. An excellent color Asters, 2

354. New Jewel. Mixed colors.

\section{NEW EXTRA EARLY GIANT PLUME ASTER}

The Queen of the Market Asters have heretofore been our earliest Asters, but this new Giant Piume Aster is quite as early and grows to an immense size, many blooms measuring five inches in diameter. The long, recurved petals give the flowers an exceedingly graceful effect, heightened in many cases by the irregular character of the petals in the centre of the flower. The type is well established, the flowers all coming perfectly double.

364. Pure white

PER PKT

365. Pure rose 20

\section{NEW OSTRICH FEATHER ASTER}

366. The new Ostrich Feather Asters are a new type, with long, wavy, twisted feathery petals, like the wavy beautiful feathers of the ostrich. They are a very valuable addition to the decorative class of Asters. Flowers frequently measure four inches across, in long, thin, wiry stems. Price mixed colors, $15 \mathrm{c}$. per pkt.

\section{CROWN ASTER}

339. The centre of each flower is white, surrounded by a broad margin of color, such as crimson, rose, violet, etc. flowers large and freely produced; height, 18 inches to 2 feet. Pkt., 10c.; 3 pkts., 25c

\section{NEW YELLOW ASTER}

361. A Yellow Aster is at last at our disposal. It is a double flower in the form of a perfect ball; the quills are close together, and of the brightest sulphur-yellow. The flowers Are borne upon long, erect stems, excellent for cutting. Per pkt. $19 \mathrm{c}$; 3 pkts. for $25 \mathrm{c}$.

\section{QUEEN OF THE MARKET ASTER}

The earliest Aster known, two to three weeks ahead of most of the other sorts of dwarf branching habit very doubl flowers, valuable for cutting. A favorite Florist' Aster for early market. Mixed.

302, White; 303, Pink; 304, Crimson; 305, Light blue; 306 , Purple; 307, Mixed. Price, all the sbove, $10 \mathrm{c}$. per pkt.

\section{NEW BRANCHING ASTERS}

The new Branching A ster is quite different in serera respects from any Aster known. The branching habit is accompanied with great vigor of growth and profusion of bloom. The flowers are of extraordinary size and exceedingly graceful, and are borne erect on very long stems.

310. White Branching Aster

311. Crimson Branching Aster

313. Shell Pink Branching Aster

Mixed Branching Aster ... 10

\section{NEW DWARF QUEEN ASTER}

The dwarf, bushy plants grow only 10 to 12 inches high, and while branching very freely, the branches are upright (not loose in habit), making a dense compact bush. The flowers are of extraordinary size, perfectly double, and resemble the finest Victoria Asters in form.

335. Satin White Queen. Spotless white ... PER PKT.

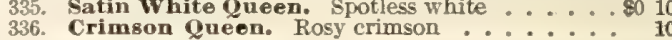

\section{POPULAR MIXTURE OF ASTERS}

362. This is a mixture of all the best varieties of Asters suitable for cut flowers, consisting principally of white, pink and the brightest of red, with a small proportion of blue and purple and some intermediate shades. This mixture, being made by ourselves, we know contains only the most salable colors for cut-flower use, and offer it as a good substitute for the higher-priced separate colors. Large pkt., 15c.; oz., $\$ 1.25$. 363. White Asters in Mixture. This mixture is mad up by ourselves of all the white-flowering Asters suitable for cut flowers, and includes Giant Comet Snow and White Branching. Large plt., 15c.; oz., \$1.50.

\section{NEW ASTER "WHITE LADIE"}

330. This exquisite new Aster, of which we control the entire supply of seed, was offered by us in 1890, but the crop of seed the next season was an entire failure, and we are very glad to be able to again place it before our customers, knowing that all who try it will be charmed with its exquisite blooms. It is quite dwarf, thus making it suitable for decorative uses of all kinds, also for bedding. The needle character of the aster is of modern date, and is one of new type, which is attracting much attention, the long, graceful, tubular petals giving it a very distinct and attractive feature. Its pure white form makes it exceedingly useful as a cut flower and for use in designing: it remains fresh a long time after cutting, and this, with its long stems and beautiful form and divarf habit, makes it one of the most valuable asters ever offered; it will prore a very useful and popular novelty. Price, per pkt, 10c. 


\section{BALLOON VINE}

340. A rapid-growing handsome summer climber, small white flowers, followed by inflated seed vessels shaped like -mall balloons, 10 to 15 feet; annual. Pkt., $5 \mathrm{c}$.

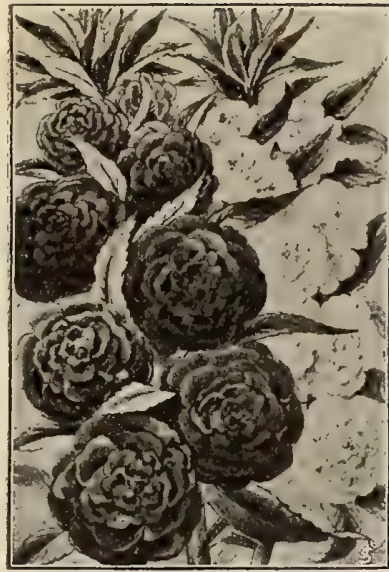

BAL9AM

\section{BALSAM}

(Lady Slipper)

The old garden fo vorite marvelously improved.

380. White Per fection. The finest pure white. Pkt., 10c.

384. Double Mixed Sorts. Pkt., 5c.

386. Royalcamellia Flowered, Prize Mixed. A fine strain of very double flowers of exquisite shades. Pkt. $10 \mathrm{c}$

388. Improved Camellia Pure White (A1 ba Perfecta). A really pure white, very double Balsam has long been a desideratum both for the private plante and the practical florist Our stock of this grand gequisition is absolute perfection in snow-white color, size of bloom doubleness and symmetry of plant. Price, per pkt., 10c. Balsam Apple. See Momordica, page 79.

Balsam Pear.

\section{BEGONIA (Tuberous-Rooted)}

Magnificent flowering plants. The single varieties are a revelation in color and sice, measuring 6 to 9 inches in circumference, and the double are as fine as the choicest roses in coloring and form.

420. Single Large Flowering, Mixed. Pkt., 15c.

421. Double " " " " $25 \mathrm{c}$.

\section{BEGONIA (Fibrous-Rooted)}

422. Rex Hybrids. Large, ornamental-leaved plants, very rich and decorative. Pkt., 25c.

423. Vernon. Flowers waxy, blood-scarlet, borne in immense quantities; fine foliage, green at first, turning red. Pkt., $10 e$.

\section{CANARY BIRD FLOWER}

490. (Tropreolum Canariense.) Of the Nasturtium family, the fowers resembling a canary bird with expanded wings. A heautiful climber. Pkt., 5c.

\section{CALCEOLARIA}

Gorgeous plants for greenhouse and window decoration the large pocket-shaped flowers are borne in the greatest profusion through spring and summer; colors: yellow,

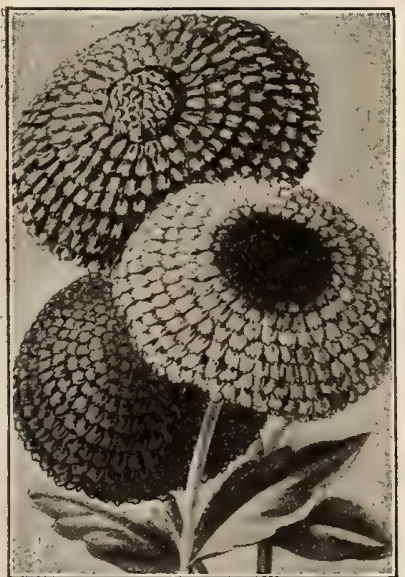

CALENDULA. (See next column.) spotted and blotched in the most unique fashion; $11 / 2$ feet.

520 , C. Hybrida Grandiflora, $\mathbf{T}$ a 11 Mixed, 20 in. Pkt., $25 \mathrm{c}$

521. C. Hybrida Grandiflora Pumila Compacta, Mixed. A new strain, dwarf and compact, producing large and brilliant gelf colored and spotted flowers; 1 foot. Pkt. $25 c$.

522. C. Rugosa. Small flowering varie ties for bedding, of the finest colors; 2 feet. Pkt., 25c.

523. J a m e s' $\mathrm{s}$ Giant. This strain of Calceolaria $w$ ill be found without a peer. It containg the most brilliant colorings of the tigered, mottled spotted and variegated varieties that we know of. Compact in growth and vigorous in constitution. Pkt.,

\section{CALENDULA}

Profuse blooming, dwarf, bushy annuals; of easy culture and flowering till frost.

644. " Orange King." The grandest of all the double Pot Marigolds. The color is a rich, dark orange decidedly more striking than that of Prince of Orange. Plkt, $5 \mathrm{c} . ; \mathrm{Oz}$,

545. "Lemon Queen." Just as fine as the Orange King, but a clear lemon-yellow. Pkt.,5c.; Oz., 20c.

540. Meteor. Double yellow, striped orange. Pkt., 5c.

511. Prince of Orange. Pkt., 5c.; oz., 20c.

542. Ranunculoides, F1. P1. (Cape, or Garden Mari. golds.) Deep orange color; 1 foot. Pkt., 5c.

543. Calendula.

oz., $15 c$

\section{CAMPANULA}

(Canterbury Bells)

601. Single Mixed. Pkt., 5c.
602 . Double Mixed. Pkt., 5c

604. CUP and SAUCER Varieties. Are : very striking and beautiful variety of Canterbury Bells. The flowers are large and resemble a cup and saucer. Colors are mixed blue blue, rose, lilac and white. rose, lilac and white kt., $5 c$.

606. Pyramidalis Mixed. A grand sort, known as the "Pyramidal Bell Flower." Color, blue or white; plants grow about 4 feet high, of elegant pyramidal form, earing pyousiand of exquisite bell-shaped of exquisite bell-sh
fowers. Pkt., $5 \mathrm{c}$.

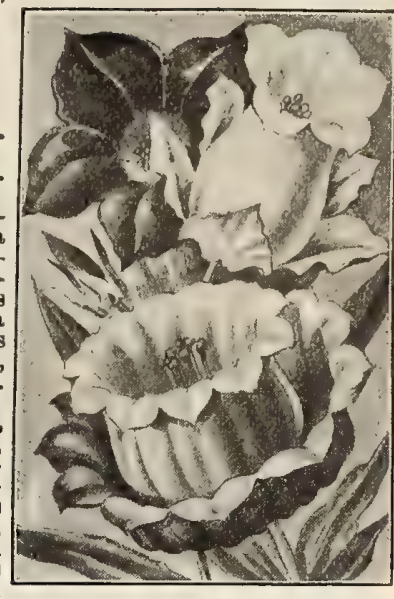

CAMPANULA.

\section{CANDYTUFT (Iberis)}

Half-hardy annual of low growth and very free flowerIng. The plants bloom early from seed and continue a long time in bloom. Useful for bedding and for cutting.

620. White Fragrant. Pure white, pinnated foliage; 1 ft. Pkt., 5c.; Oz., 20c.

621. Crimson. Very beautifud; $1 \mathrm{ft}$. Pkt., 5c.; oz., 20c.

622. WHITE ROCKET. Large trusses of pure white flowers; $1 \mathrm{ft}$. Pkt., 5c.; oz., 20c.

623. White Tom Thumb. A new dwarf variety, growing about 6 inches high, branching into a handsome bush about 16 inches in diameter. Pkt., 5c.; oz, 20c.

624. Fine Mixed. Pkt., 5c.; oz., 15c.

625. N E W E M PRESS. One of the fin. est varieties of recent introduction. The plant is of a very branching habit, and assumes, when fully grown and covered with its large trusses of pure white flowers, a very handsome candelabrum-like aspect. Pkt., 10c.; $02 ., 30 \mathrm{c}$.

\section{CANNAS}

645. Crozy's Dwarf Large Flow ering Fremch. In this new class of Cannas the folage is luxuriant and th plants dwarf in habit Their great merit, however lies in the large size and brilliant hues of the flowers, ranging through all shades of yellow and orange to the richest crimson, scarlet and vermilion; some are also beautifully $\mathrm{s}$ ot ted.

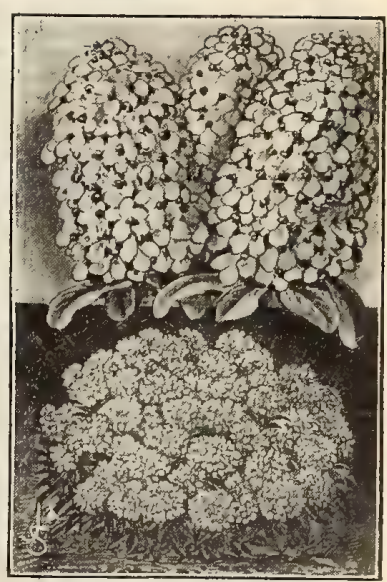

EMPRESS OANDYTUFT ixed. Pkt $50 \cdot 0 z^{2}$

640. C. Marechal Vallant. Foliage rich maroon; arge, bright orange flowers ; 5 ft. Pkt., $5 \mathrm{c}$

641. Tricolor. Foliage green, red and creamy yellow; bright scarlet flowers ; 3 ft. Pkt., 5c.

612. Finest Mixed. Embracing twenty of the best sorts. Prt., 5c.; oz., 10c.

643. C. Gigantea. $8 \mathrm{ft}$. Pkt., 5c. 


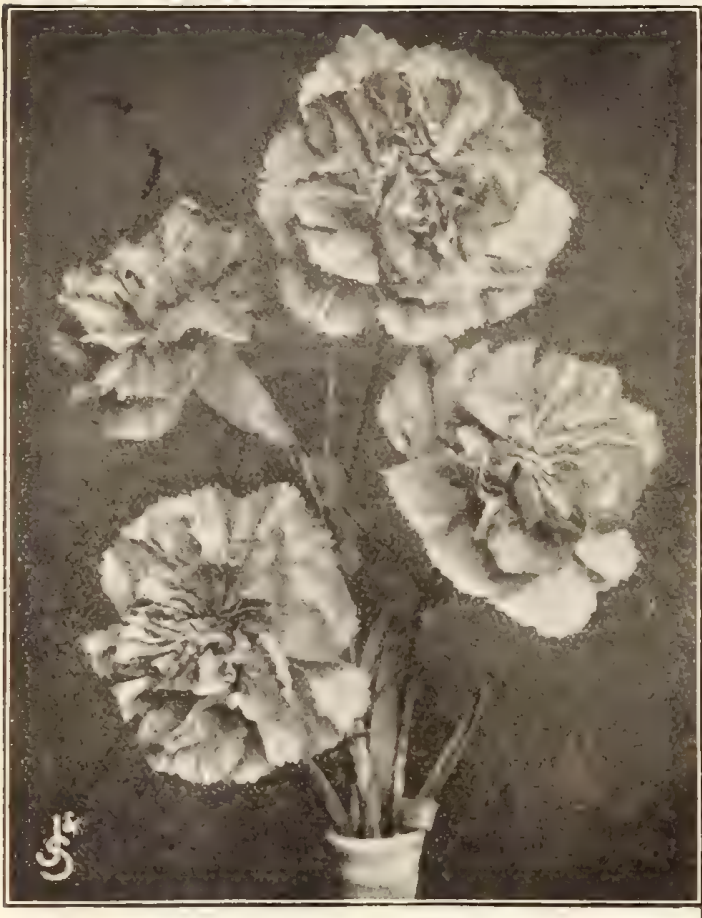

PINK PLUME CELOSIA

(Celosia Spicata)

671. The flowers of this charming Celosia open of a fresh bright rose tint and the lower involucres change gradually to a silvery white, thus presenting to the eye a most charming combination of color. The elegant long-stemmed flowers preserve their beauty even in un favorable weather, and furnish quite an excelmaking up bor quets, etc. In addition to this they are very suitable for drying, and as the plant blooms for a very long period, it is equally valuable both for the open border pots. Per pkt., 15c. TRICH FEATHER. This new Feathered Celosia produces very large plumes, which are exquisitely curved act resemblance to an ostrich feather. Plt., 10c.

\section{CENTAUREA}

(Dusty Miller)

Extengively used for margins, beds and vases. Half-hardy perennial.

\section{CARNATIONS}

663. Marguexite Carnations. Without exception, these are the most abundant bloomers of all the Carnation Pinks. The flowers are of brilliant colors, ranging through many beautiful shades of red, pink, white, variegated, etc they are of perfect form and large size. Those sown in spring they are of perfect form and large size. Those sown in spring lavish profusion until checked by frost. Plt., 10c.; 3 pkts. $25 \mathrm{c}$

656. Carnation Marguerite, Crimson .... 8010

657. 658 White $\quad$ Rose

659. "Striped "

the above in size of flower, dwarfer and more stocky plants. Per pkt., 15c.

661. Finest German Double Mixed. Saved from extra choice named double flowers. Pkt., 15c

662. Fine Double Mixed. Comprising the hardiest and best rarieties for garden culture; $11 / 2 \mathrm{ft}$. Pkt., 10c.

664. FINEST DOUBLE STRIPED. Pkt, 10c. The Guillaud Pinks bloom profusely in the summer and autumn from spring-sown seed. The flowers are very large, of perfect shape, very fragrant, 'They contain flowers of clear yellow and others with rellow stripes, Plat, $20 \mathrm{c}$

667. NEW DOUBLE PERPETUAL (Chabaud). As early as the Marguerite Carnation, this new sort will be found invaluable for florists. The stalks cre wery stiff and the flowers large and very double. The cals $x$ rarely ever bursts, and the percentage of double flowers is very great. Pkt., 15c.

\section{Celosia (Coxcomb)}

Very popular annuals of the easiest culture, producing large, ornamental. combilike heads; useful both for summer bedding and pot plants as well

\section{CRISTATA, OR CRESTED VARIETIES}

675. DWARF CRIMSON. Large combs, Pkt., 5c

676. VARIEGATA. Crimson and gold. Pkt, 5c.

677. JAPONTCA. Rufled scarlet combs. Pkt, $5 \mathrm{c}$

678. GLASGOW PRIZE. Immense crimson. Pkt., 5c.

680. QUEEN of the DWA RES. Only 8 inches high combs often 10 inches across; dark scarlet. Pkt., 10c.

681. EMPRESS. Mammoth bright combs; bronze foliage. Pkt., 10

679. CRISTATA. Mixed. Pkt., 5 c. dissima. Attrac. tive, silvery, eut leaves; 1 ft. Pkt, 10c. 686. Gymnocarpa. Graceful finely cut, silvery gray leaves; $11 / 2 \mathrm{ft}$ Pkt., 10c.

\section{CENTAUREA}

Blue Bottle or Corn

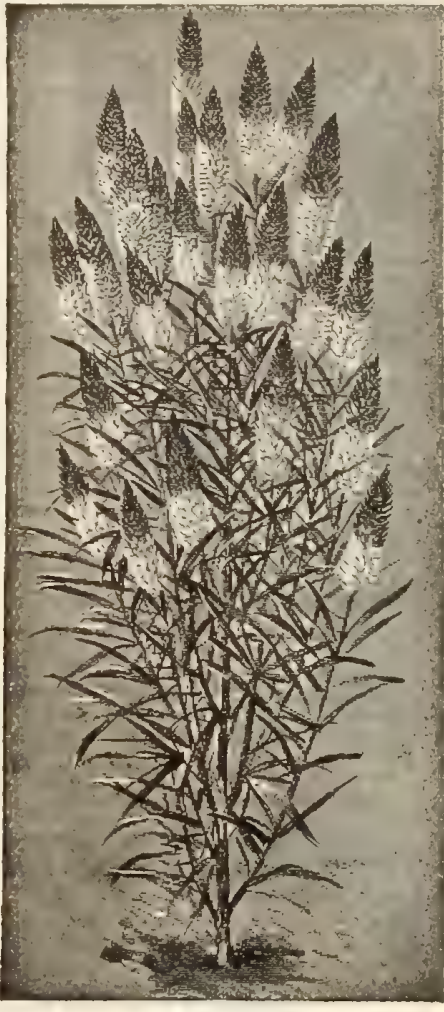

PINK PLUME CF LOSIA. Flowe

688. BLUE. Per pkt., 5c.

689. WHITE (Alba Pura), Pkt., 5c.

690. DWARF VIC TORIA. Very dwarf beautiful for borders Per pkt., 5e.

\section{CHRYSANTHE- MUMS}

Single Annual Varieties.

Summer blooming annuals, growing 12 to 18 inches high, very floriferous and effective for beds or cut blooms.

704. S e 1 e cted Mixed Varieties. Com prising a full assortment of single and double varieties with the richest variety of colors, rich crimson, golden yellow, striped and mottled. Pkt., bc.

708. C、MАХIMUM. A grand addition to our collection of $\mathrm{choice}$ hardy perennials. It beautiful snow - white flowers are produced in great abundance th whole season and cut flowers they are unexcelled in lasting qualities. Dkt., $5 \mathrm{c}$.

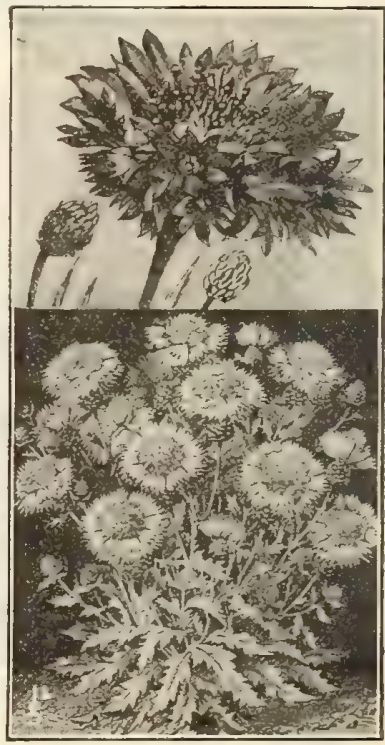

CENTAUREA, OR BLUE BOTTLE. 


\section{CINERARIA}

Magnificent and indispensable flowering plants for spring decoration for the conservatory or window garden. The flowers measure 2 to 3 inches across, are of white, blue, viole and crimson shades, covering the plant with a sheet of bloom.

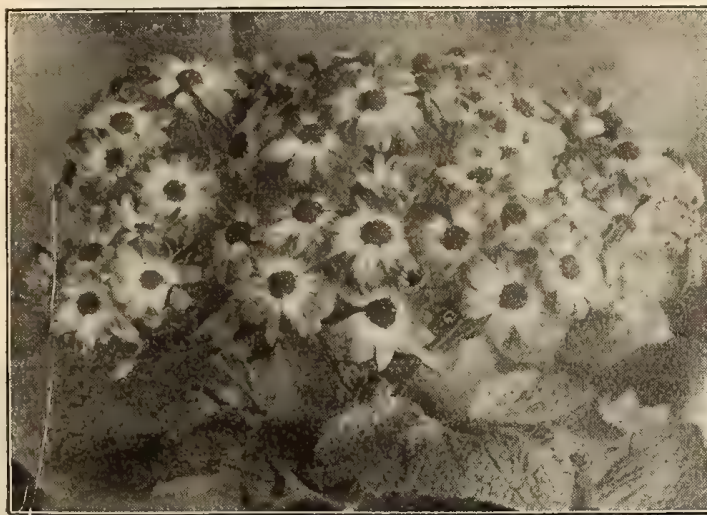

CINERARIA ENGLISH PRIZE.

742. This prize strain has received the highest awards at the largest shows in England, and is unrivaled both in vari ety of color and marking and size and quality of bloom. Blooms measure $2 \frac{1}{2}$ to $23 / 4$ inches in diameter. Pkt., 35c.

740. Maritima Candidissima (Dusty Miller). Pkt., 5c.

741. Acanthifolia (Dusty Miller). Pkt., 5c.

\section{CLARKIA}

Charming annuals for flower beds, with colors, white, rose red, purple, etc., borne in profusion during the summer.

761. Elegans (Purple King), Pkt., 5c.

760. Single Mixed. Pkt., 5c,

762. Double Mixed. Pkt., 5c.

\section{CLEMATIS}

Hardy Perennial Climbers $10 \mathrm{c}$

780. Jackman's Large Flowering Hybrids. Pkt,

781. Coccinea Scarlet. Tubular flowers. Pkt., 10c.

783. Flammula. White, sweet scented. Pkt., 5c.

784. Paniculats. One of the finest; fine white flowers atrong grower ; very hardy. Pkt., 10c.

\section{CLEOME PUNGENS}

(Giant Spider Plant)

800. A showy rose-colored annual, whose stamens resemle spiders' legs. Very

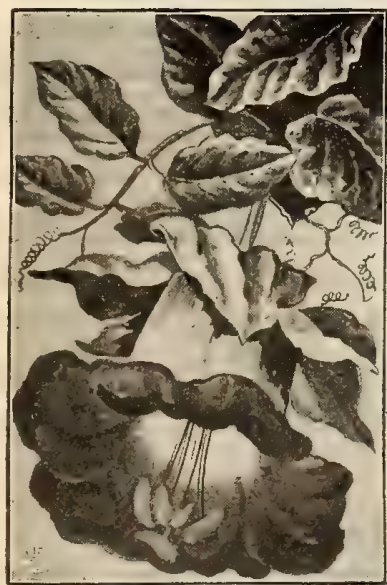

COBEA BCANDENS. effective planted amon shrubbery. H eig ht feet. Pkt., 5c.

\section{COBEA}

840. Scandens. A beautiful rapid-growing climber, with handsome foliage and large bellhaped flowers, green at first changing to benut ful deep violet blue Half hardy perennial ; 20 to 30 ft. Pkt., 10c.; pkts., $25 \mathrm{c}$.

\section{CROTALARIA}

RETUSA

(West India Rattle Box)

938. This is a lowgrowing, profusely branching plant, every branch and branchlet ending in racemes 6 to 10 incheslong, of beautifu large, sweet-pea-like flowers. These flowers are of thick substance, fragrant, and in color centre, which looks like brown velvet, and are followed by clusters of short, smooth pods, in which, when shaken, the seeds sound like child's rattle, hence its common name Pkt., 5c.

\section{COREOPSIS}

Very showy, freeflowering plants, natives of this country; fine for borders and beds ; easily cultivated. Hardy annuals.

560 , C. Drummondi. Yellow, with a circle of rich crimson brown $1 \mathrm{ft}$. Pkt., $5 \mathrm{c}$.

561. C. Atroganruiner. Dark erimson 2 ft. Pkt., $5 \mathrm{c}$.

562. C. Mixed. Pkt. 5c.; Oz., 20c.

563 . C o r e o p is Lanceolata. The flowers of this charming new hardy perennialareborne on long stems and are of a lovely bright goldenyellow color. Pkt., 10c.

564. Ca 11 i o p is Golden Wave. Pkt., 5c.; Oz., 20c.

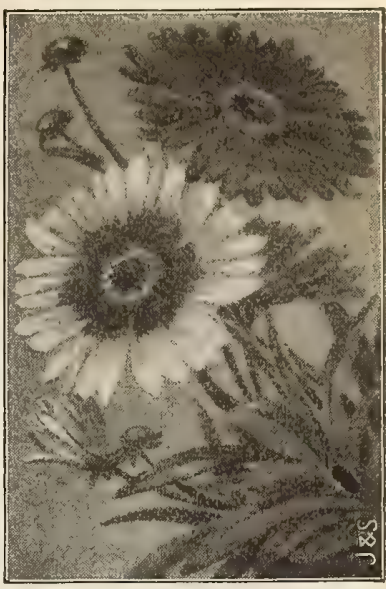

DOREOPSIS.

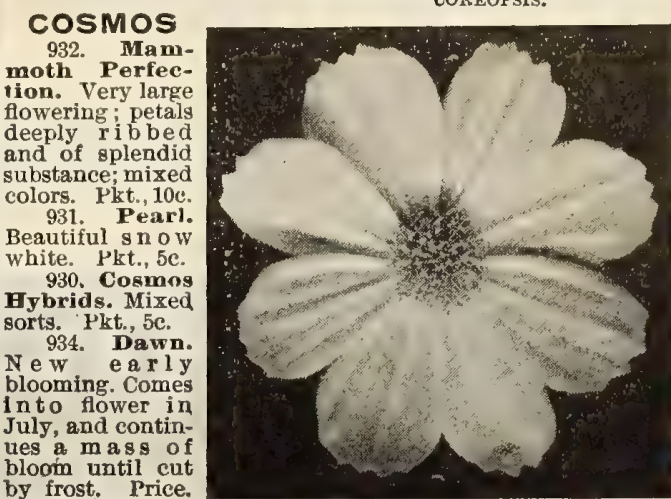
by frost, Price. per pkt., $10 \mathrm{c}$.

NEW EARLY BLOOMTNG COSMOS, "DAWN."

\section{CYCLAMEN PERSICUM GIGANTEUM}

Grown by a specialist, who has received the highest awards at the largest English shows, and is unquestionably the finest strain of Giant Cyclamen obtainable.

962. Crimson Queen. Rich deep maroon red963. Dizon Hartland Pure white, claret base 964. Duke of Connaught. A superb cherry color :. 25

965. White Swan. The finest white Cyclomen in cultiWhite Swan. The finest white Cyclamen in culti-
vation . 966. Rosy Morn. Bright rose with claret base . 961. Cyclamen Persicum Giganteum, mixed .

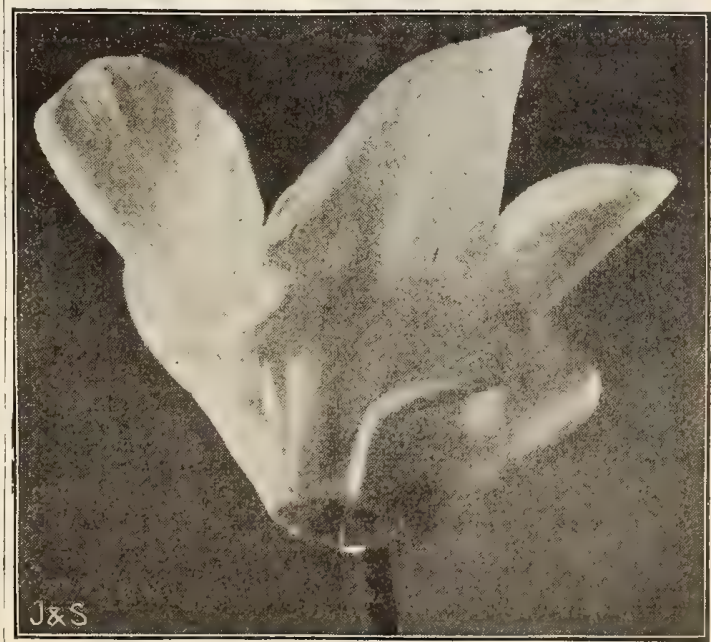

CYCLAMEY PERSIOUM GIGANTEUM (WHITE SWAN) 


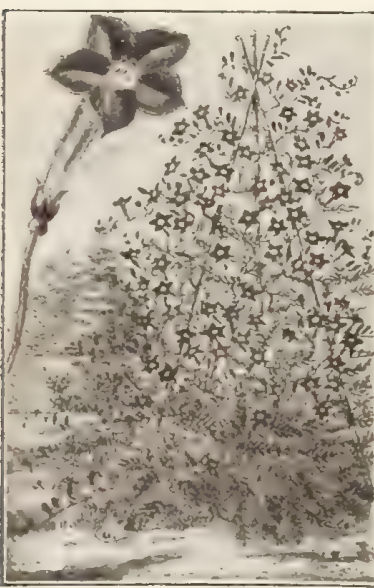

CYPRESS VINE.

\section{CYPRESS VINE}

A summer climbin annual with fine feather foliage and pretty star shaped flowers.

980. Crimson.Plkt., $5 \mathrm{c}$

981. White. Pkt., 5c. OZ., 25c.

982. Mixed sorts. Pkt., 5c; oz., 25c

Scerlet, Iv Leaved. Pkt., $5 \mathrm{c} ; 0 z$

\section{DAHLIA}

Although perennials, these flower freely th same season from seed, if sown early.

Choice Doubl Varieties. Mixed. Hkt.

1001. Cholce Single Tarieties. Mixed. Pl.

5c. 1002 - Cactus Dahlia. Mixed. These double dahlias have their petals quilled and

curved looselr and gracefully. Plat, 10c.

\section{DAISY (Bellis Perennis)}

Well-known farorites: admirably adapted for edgings, borders and low beds, and also well suited for growing in pots. Although perennials, they will flower the same season if the seed is sown early in the house, though it is preferable to sow it in the fall, and winter the plants over in cold frames: 1/2 foot. (See cut.)

1022. Longfollow. Double pink. Pkt., 10c.

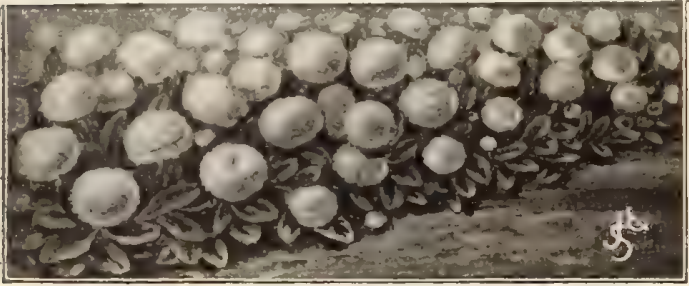

DOCBLE GIANT DAISY

1023. Snowball. Double white. Pkt, 10c.

1024. New Giant Double Mixed. Beautiful imbri cated flowerg; $11 / 2$ to 2 inches in diameter. Pkt., 10c.

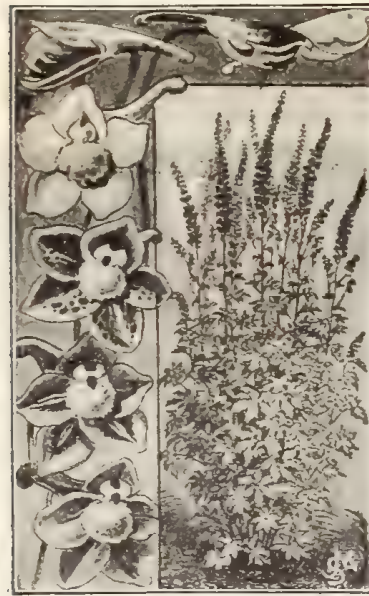

\section{DATURA}

Strong growing orna mental annuals, with very large, showy tlowers; 2 to feet high.

1043. Cornucopia (Horn of Plenty). A grand variety; immense trumpetshaped fiowers with three cones or funnels, one within the other; French white on inside, marbled with roval purple on the outside. Pkt., 10c.

No. 1044. New Golden oneen. A magnificent punt for open ground, with plant for open ground, with most brilliant golden-yelsize, many of them 10 inches long. Pkt, 10c.

\section{DELPHINIUM}

(or Perennial Larkspur)

Handsome and hardy perennials, with splendid flowers, very showy and inor borders.

1060. D. Formosum. Brilliant blue with a white cen tre. Pkt.,

1067. D. Chinensis. A distinct and neat variety, growing about 18 inches high, with fine feathery foliage and producing freely spikes of large blossoms varying in color through all the delicate shades of blue. Pkt. 5c.

1064. D. Finest Mixed Hybrids. Pkt, 5c.

\section{DIANTHUS OR PINKS}

The family of "Pinks" is unrivaled for brilliancy and rich variety of color; blooming profusely until late in the autumn, rendering them one of the most satisfactory of all our annuals for garden decoration. Height about 1 foot.

\section{DOUBLE ANNUAL VARIETIES}

1080. D. Chinensis, F1. P1. (China Pink.) Large, double, tragrant flowers; mixed. Pkt, 5c.;0z, 25c.

1081. Heddewigii Diadematis, Fl. P1. (Double DiaGem Japan Pink.) Densely double flowers, 3 inches in dismeter; beautiful tints of crimson, lilac, purple; outer edges fringed with white; 6 inch. Pkt, $5 \mathrm{c} ;$; oz, $75 \mathrm{c}$

1084. D.Imperialis. Double imperial pink. Pkt., 5c. $\mathrm{OZ}, 40 \mathrm{C}$

1085. D. Laciniatus, F1. P1. (Double Fringed Japan Pink.) Large, double, showy flowers, with fringed edges various colors and beautifully striped. Pkt., $5 \mathrm{c}_{\text {. }} ; \mathrm{Oz}_{*}, 50 \mathrm{c}$.

1092. Mourning Cloak. Rich blackish velvety crim son, margined with pure white. Pkt., 5 c.

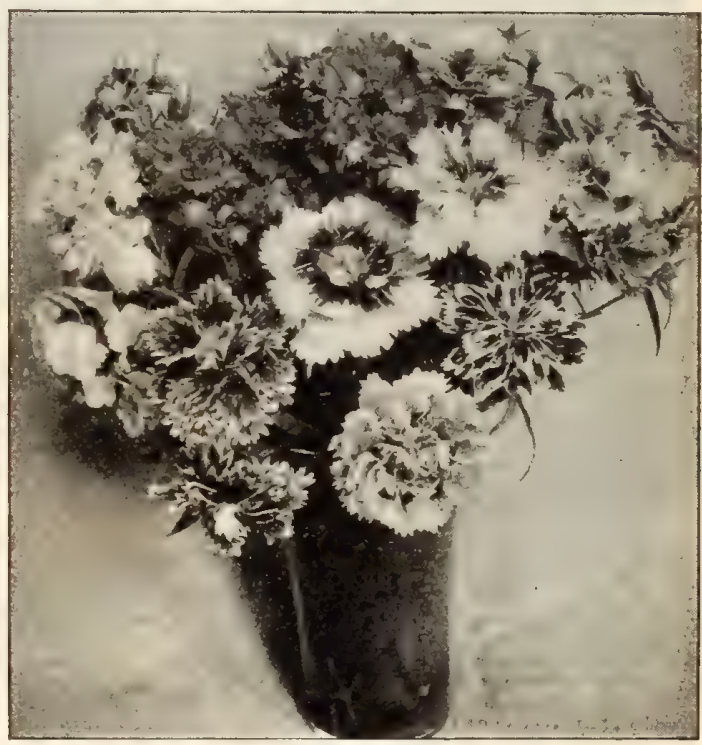

DIANTHUS "NEW HYBRIDS," PLt., 10c.

\section{SINGLE ANNUAL VARIETIES}

1094 Dianthus Laciniatus Vangs “New Hzbrids" This is ond the ated or fringed petals. The flowers very in shade from whit to deep rose and even to purplish red, are all tinged more or less with bright salmony red or salmeny scarlet. The plants grow only about 10 inches high, and are remarkable for their free flowering character. Mrice, 10c. per pkt.

1086. Crimson Belle. Magnificent large, single fringed flowers of lustrous velvety crimsog Plot.

1087. Eastern Queen. Immense single flowers, beautifully fringed, marbled and suffused with carmine, rose, mauve and lilac. Pkt, $5 c$.

1088. Snowflake. Snow - white; exquisitely fringed Pkt, 5c, Laciniatus, Mixed Colors. Single fringed. Pkt., 5c.; $\mathrm{oz}_{.}, 40 \mathrm{c}$

1090. Hediewigii, Mixed Colors. Bingle Japan Pinks. A magnificent strain, the flowers averaging 2 to inches across, of many exquisite colors. Pkt., 5c.; oz., 40c. 1093. Salmon Queen. A new variety, of a most brilliant salmon color. Ykt., $10 \mathrm{c}$.

\section{HARDY PERENNIAL VARIETIES}

1082. Dianthus Plumarius (Pheasant Eye). A beautiful, single, hardy pink, with fringed-edged white flowers, with a dark centre. Pkt., 5c,; oz., 20c.

1083. Plumarius, F1. P1. ' Double and semi-double varieties in beautiful colors. Pkt, $10 \mathrm{c}$

1091. Fine Garden, or Clove-scented Pinks (Hor tensis Varieties). Beautiful double mixed colors. Pkt., 10c. 


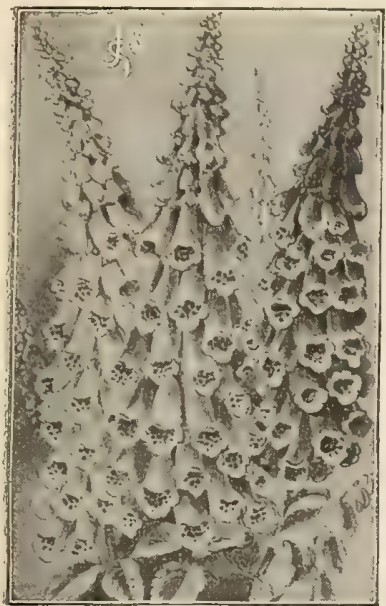

FOXGLOVE

\section{DIGITALIS OR} FOXGLOVE

Beautiful, hardy perennials of easy culture. Long spikes of showy flowers, many beautifully spotted; height, 3 to 5 feet.

1120. Mixed Colors. Pkt., se.

1121. G 1 o $\mathbf{I}$ n i a Flora. Gloxinia-shaped flowers, a lovely type. Pkt., 5c.

\section{DOLICHOS- PURPLE SOUDAN}

No. 1125 A very curious and highly decorative climber. The twining stems are of an intense purple color and the beautiful sweet pea-like flowers are produced during the entire summer. They are white and rose in color contrasting strikingly with the dark foliage. Following the flowers there come heautiful glossy, dark-red seed pods. These are very freely produced, and are a great ornament to the plant. Useful for covering porches, trellises, etc. Pkt., $5 \mathrm{c}$.

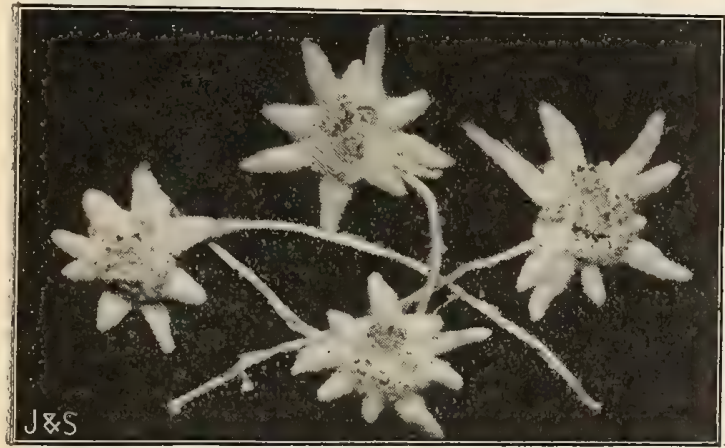

EDELWEISS,

\section{THE GENUINE EDELWEISS}

or Sunflower of Switzerland

No. 1190. There is a world of poetry connected with this charming flower, to obtain which many travelers have sacrificed their lives. It blooms right through the snow, and when cut lasts for years. The flowers are rare and beautiful, as white as snow and as soft as velvet, growing someing rosette. Naturally as hardy as a rock, they grow in any ang rosette. Naturally as hardy as a rock, they grow in any Taised rockwork, and even as a border plant, in chalky open raised rockwork, and even as a border plant, in chalky open soil. Lasting for years in beauty, it will

\section{ESCHSCHOLTZIA \\ or California Poppies}

A beautiful annual of easy culture. Bloom soon after spring-sown seed and continue until late in the autumn. Height, I foot.

1180. Californica. Yellow and Orange. Pkt., 5c.

1181. Rose Cardinal. Rich rosy purple. Pkt., 5c.

1182. Single Mixed. All colors. Pkt., 5 .

1184. Double Mixed. All colors. Pkt, 5c.

\section{EVENING PRIMROSE}

$$
\text { (GEnothera) }
$$

2260. Delicate pale yellow flowers. Pkt., 5c.

\section{EVERLASTING FLOWERS}

These are very popular and desirable for winter decorations, bouquets, wreaths, etc. They should be cut when they come into full bloom, tied into bunches and dried in the shade, with their heads downward.

1240. Acroclinium Reseum, F1. P1. Bright rose, alouble. Pkt., 5c

1241. Ammobium Alatum Grandiflorum. A leading everlasting; flowers very large and pure white color. skt., 5c.

\section{EVERLASTING FLOWERS (Continued)}

1242. Gomphrena, Mixed (Bachelor's Buttons). Pure white crimson, orange and variegated colors: Pkt. $5 \mathrm{c}$. 1243. Helipterum Humboldianum (Sanfordi). Large clusters of bright golien yellow flowers. Pkt., $5 \mathrm{c}$.

1244. Helichrysum, Finest Mixคd. Large, beautiful, very double, white, yellow, scarlet. Pkt. $5 \mathrm{c}$.

1245. Rhodanthe, Finest Mixed. Very rich colors of rose, crimson, purple, carmine and white. Pkt., $5 \mathrm{c}$.

1246. Xeranthemum. Leaves silvery, brilliant colors of purple, rose and white flowers; 2 it. Pkt., $5 \mathrm{c}$.

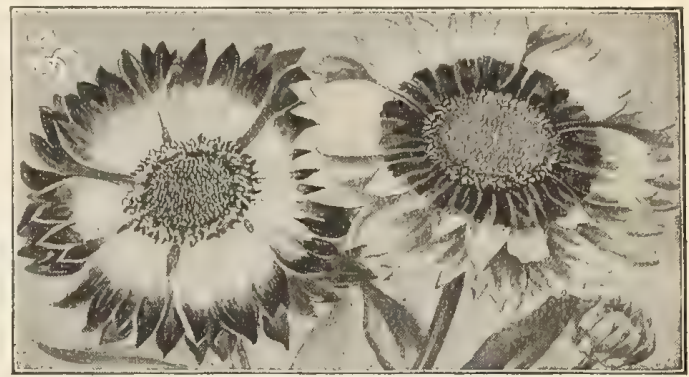

GAIIIARDIAS.

\section{GAILLARDIA}

Beautiful annuals for the flower garden. Very effective grown in masses. Large flowers produced from early sum mer till frost. 1 to 2 feet high.

1300. G. Picta Lorenziana. Sulphur, golden, bright yel low, orange, claret and amaranth. Hkt., 5e.

1301. G. Picta Grandiflura. Large flowers of rich crimson and yellow. Pkt., 5c.

1302. Pieta Nana (Painted Lady). Showy crimson, bordered with yellow. Pkt, $5 \mathrm{c}$.

\section{GERANIUM}

Although perennials, they will produce nice bushy plants and flower from seed the same sea-

1320. G. Zonale, Mixed. Pkt., $10 \mathrm{c}$

1321 . A p p 1 e Scented. Very fragrant. Pkt., 10c.

\section{GLOXINIA}

Charming greenhouse plants. Flowers of most exquisite and gorgeous colors, beautifully spotted, mottled and lended. Sow in March. 1380. Grandiflora. Choice mixed sorts. Pkt. $25 \mathrm{c}$.

\section{GODETIA}

Exceedingly hand some and showy annuals, of dwarf, comapact growth, a bout 1 foot high, bearing freely large flowers 3 to 4 inches across, of exquis-

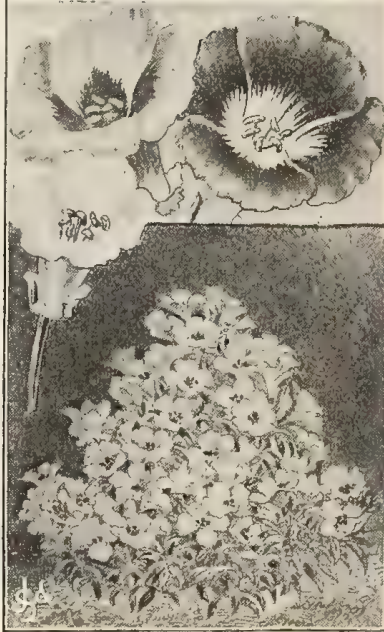

GODETIA te colors and shade

that glisten in the sunlight like satin. (See cut.)

1400. Lady Satin Rose. Crimson, tinged, pale lilac Pkt, 5c. Bljou. Dwarf, white flowers, with carmine spot on each petal. Pkt., 5c.

1403. Lady Albemarle. Large crimson rose. Pkt., 5c.

1402. Choice Mixed Varietıes. Pkt., 5c.; oz, 20c.

\section{GOURDS}

Mixed Ornamental. A choice assortment, PIst, 10c. 3 pkts., $25 \mathrm{c}$.

For other varieties of Gourds, see vegetable list, page 30.

\section{GRASSES (ORNAMENTAL)}

1443. Coix Lachryma (Job's Tears). $2 \mathrm{ft}$. Pkt., 5c

1444. Erianthus Ravennz. Very ornamental; $10 \mathrm{ft}$ Pkt., 5e.

1445. Gynerium Argenteum (Pampas Grass). $10 \mathrm{ft}$. 
PURPLE FOUNTAIN GRASS

(Pennisetum Rueppelianum)

1451. Decidedly the most ornamental decorative grass ever introduced and will be found as useful for room, hall or table decoration as many a palm. Fine purple plumes a foot long. Pkt., 10c.

\section{GREVILLEA ROBUSTA}

1460. (Silte Oal) Beautiful and graceful fern-leaved foliage plant. Pkt., 10c.

\section{GYPSOPHILA}

Dainty free flowering plants of easy culture. Fine for miring in bouquets, giving them an airy-fairy look that i charming : $1 \frac{1}{2}$ feet high.

1480. Elegans. Star-shaped, white and pink flowers. Pkt, $5 \mathrm{c}$

1481. Paniculata. Produces numerous panicles of small, white, handsome flowers: fine for bouquets. Pkt., $5 \mathrm{c}$.

\section{HELIANTHUS (See Sunflower)} HELIOTROPE

Deliciously fragrant flowering plants, 1 to 2 feet high. Favorites for pot culture in winter and bedding in summer. 1520. Finest Mixed. Plit..

1521. King of the Blacks. Rich purple. Pkt, 10c.

1522. Lemoine's Ciant Hybrids. Immense clusters

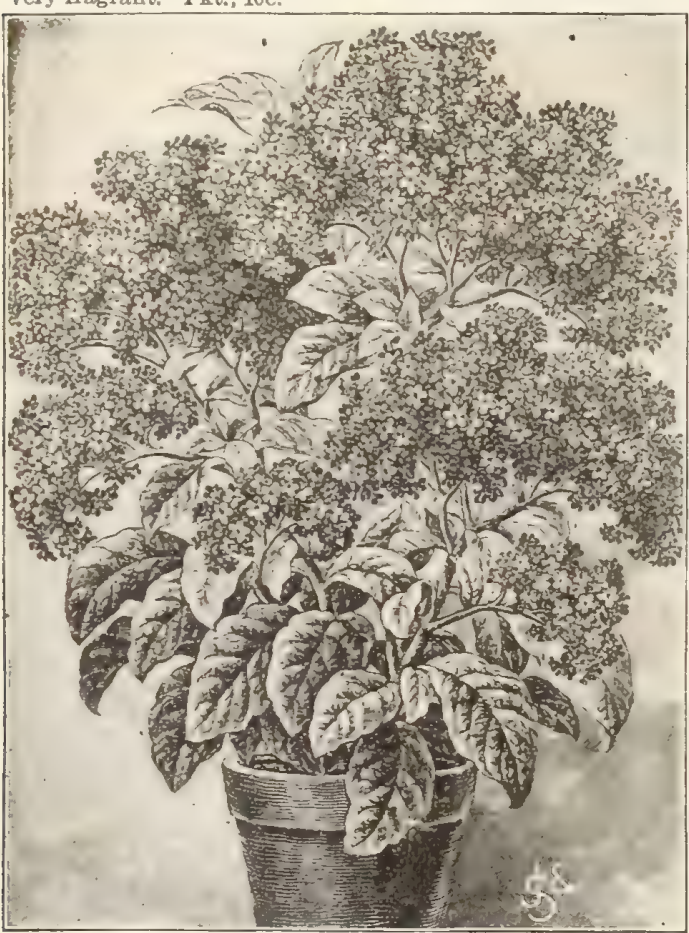

HELIOTROPE-LEMOINE'S GIANT HYBRIDS.

\section{HOLLYHOCK}

Grand summer and sutumn flowering plants. Old inhabitants of our garden, but marvelously improved of late years both in doubleness and enlarged size.

Chaters. Prize Double, Red. Pkt, 10c.

1562 .

1560.

Pink, Pkt., 10c.

Yeliow, Plkt, 10c.

Pal, $10 \mathrm{c}$

1558.

Crimson. Pkt, 10c.
Mixed. Pkt, 10c.

1563.

New Mammoth Flowering "Allegheny Hollyhocks"

1564. The flowers of this new variety are so differen from the old conventional ones that but for the similar habit of the plant it would not be taken for a Holly hock.

They are from 4 to 6 inches in diameter, ranging from emi-double to double, and finely fringed and curled

The colors are shelı pink, rose and ruby red, a shade or two deeper at the centre, and exquisitely tinted towards the edge. Price, per pkt., $10 \mathrm{c}$; 3 pkts., $25 \mathrm{c}$.
HUMULUS JAPONICUS OR JAPANESE HOP

1620. Very ornamen. tal and fast growing an. nual climber from Japan. Pkt., $5 c$

1621. H $\mathbf{~ m ~} \mathbf{x} \mathbf{1}$ o Japonicus Varlegatus. A beautiful variety with variegated folithe ravages of insects. Pkt, $10 \mathrm{c}$

\section{KENILWORTH IVY}

1780. A very neat climber, clings to walls and is a valuable plant o $r$ hanging - baskete, vases, etc. Pkt., $10 \mathrm{c}$

\section{LANTANA}

1720. Rapid-growing, constant-blooming, tender perennial plants for
pot culture in the winter pot culture in the winter or garden decoration in the summer; clusters of mixed colors; 1 to 3 feet. Plkt., 10c.

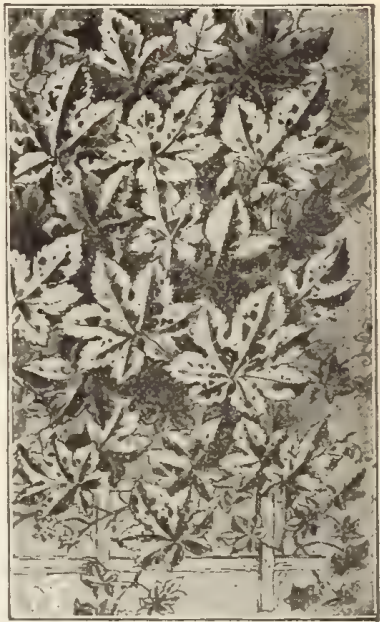

HUMULUS OR JAP HOP.

\section{LARKSPUR}

Quick-growing, free-flowering annuals

1065. Dwarf German Rocket. Hyacinth-flowered Larkspur; mixed. Plet., 50

1063. E im p e r or furkspur. Has beautiful, long spikes of briland red striped; double and red striped;
flowers. Pkt., 5c

\section{LATHYRUS}

Everlasting or Hardy Sweet Peas. Hardy climbers, growing 6 to 8 feet high when trained on a trellis. The flowers are borne in large clusters, but have no fragrance, a beautiful plant. 1740. Lat if olius flowering plant: useful for covering trellises, old for covering trelises, old stumps, scarlet.

1711. Latifo 1 in Albus. Large clusters of pure white; grand, hardy, low climber. Pkt., 10c.

1742. Splendens. A fine novelty from California bearing dense clusters of brilliant deep rose flowers. Pkt., 10c.

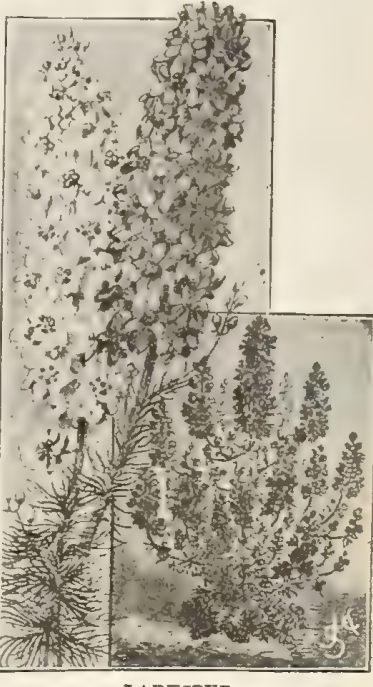

IARKSPUR.
No. 1743. Pink Beauty. We have here an entirely new variety, the color of which is a delicately shared pink on the gtandard, the lacing on the edge being paler than the centre; the wings are rleeper pink, of a very rich shade, riving it a very striking appearance. Price, pkt. 50. per OZ., 20c. 1744. Everlastin $\mathbf{P}$ e a Crimbon. Pkt., 5c.

\section{LOBELIA (Compacta} Varieties )

Compact plants, 4 to 6 inches high, forming little mounds of bloom. 1840. Crystal Palace. Rich blue. Pkt., 10c. 1840. Mixed Com pacta Varieties. Pkt.

Erinus, or Trailing Variaties.

Useful for vases or hanging baskets or rockeries

1844, Mixed, Trail ing Varieties. Pkt., 50 .

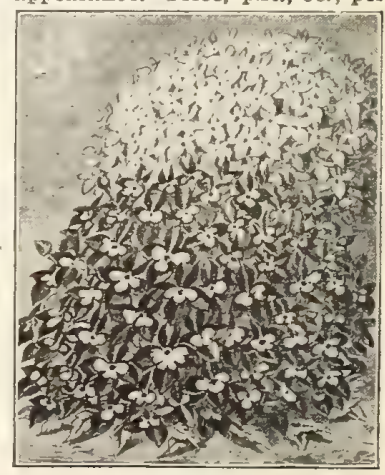

LOBELTA. 


\section{LYCHNIS}

1900. Chalcedonica. The old garden farorite; very nardy, brilliant scarlet flower; deserves a place in every garden. Pkt., 5c.

MARIGOLD

Well-known annuals, very free flowering and easy culture. The African varieties have large, yellow or orangecolored flowers, and are adapted to large beds. The French are dwarfer in growth, with beautiful striped flowers, and are better suited to pot culture.

\section{AFRICAN VARIETIES}

1941. EL DORADO. Flowers 3 to 4 inches in diamecer, perfectly and extremely double. Every shade. Pkt, 5c. 1943. LA RGE A FRICAN. Very large; orange, brown and yellow. Oz., 15c.; pkt., 5c.

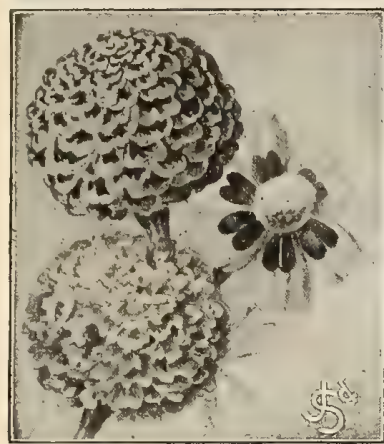

FRENCH VARIETIES

1940 G O I D S T R I P D. Double dwarf brownish red. striped golden yellow. Pkt., 5c.

1942. D W A R F FRENCH MIXED. Oz., $15 \mathrm{c}$; ; pkt., $5 \mathrm{c}$

1944. LI T T L B R O W N I E (Leoion d'Honneur). Charming, compact little bushes. Flowers single, golden yellow, with large spot yellow, with large spot of crimson velvet. Pkt. This charming variety is a fine match to the old "Legion of Honor" in growth, height and free flowering. In color it is MARIGOLD a dark velvety brown, each petal gracefully surrounded with a distinct gold ring. The compact, bushy plant blooms with a richness and constancy that is surprising. Pkt, 10c.; 3 pkts., 25c.

\section{MARVEL OF PERU (Mirabilis)}

\section{(Four-o'clocks)}

The Marvel of Peru, or Four-o'clocks, is a pretty, freeflowering annual of easy culture, that grows and flowers in olmost any location.

1960. Mixed Choice Colors. Pkt, 5c; oz, 150

1961. White Tom Thumb. Only growing 10 inches high. Snow-white flowers. Pkt, $5 c$.

\section{MESEMBRYANTHEMUM}

2000. M. Crystallinum (Ice Plant). Flowers white with ice-like foliage. Pkt., $5 \mathrm{c}$.

\section{MIGNONETTE (Reseda)}

This deliciously fragrant annual is a favorite with all. It does best in a cool situation.

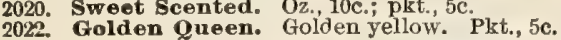

2024. Machet. Very compact; fine for pot culture; red. oz., 60c.; pkt., 10c.

2025. Gabrielle. I a $r g e$ spikes of red flowers, very fragrant; fine for pot culture. Plt., 10c.

2026. Miles' Fybrid Spiral. Pure white. Pkt., 5c.

2027. Giant White Spiral. Oz., 25c.; pkt., 5c.

2028. Red Victoria. Dwarf branching habit, very sweet red flowers. Pkt., 10c.

2029. Allen's Defiance. Immense spikes, 12 to 15 inches long; very fragrant. Pkt., 10c.

\section{MIMULUS}

mirable for pot plants; Admirable for pot plants;
colors and markings of the flowers are very rich and beautiful. Annuals of low spreading growth.

2060. Mos chatus (Musk Plant). Beautiful yellow flowers. $1 \mathrm{kt}$, $5 \mathrm{c}$.

\section{MOMORDICA}

2090 (Balsam Apple.)

Plkt., 5c.; oz., 20c.

MOMORDICA

CHARANTIA

2091, (Balsam

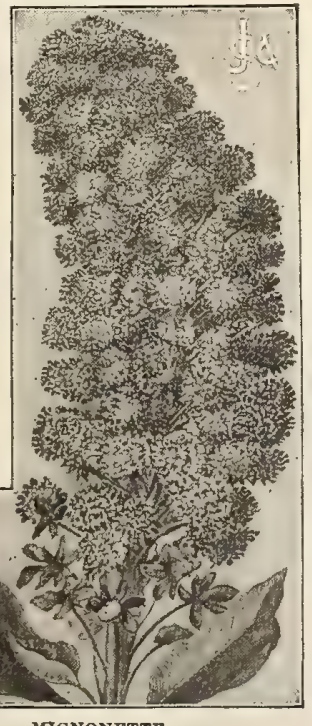

MLGNONETTK.
MON FLWER (Ipomaa Grandiflora Noctifora)

1664. The White-seeded Moonflower. No one who has a trellis or arbor to cover should neglect to plant The Moonflower-the most rapid-growing of all annual climbing vines. The vines are literally covered with thousands of immense, pure white, fragrant flowers, opening in the evening and remaining open until noon the following day, and if cloudy, all day, many of them measuring over seven inches across. Planted in rich ground, in a sunny gituation, and given plenty of water, the vines attrin a height of seventyfive feet. Pkt., 10c.

Plants of above, 10c. each (by mail, 15c.).

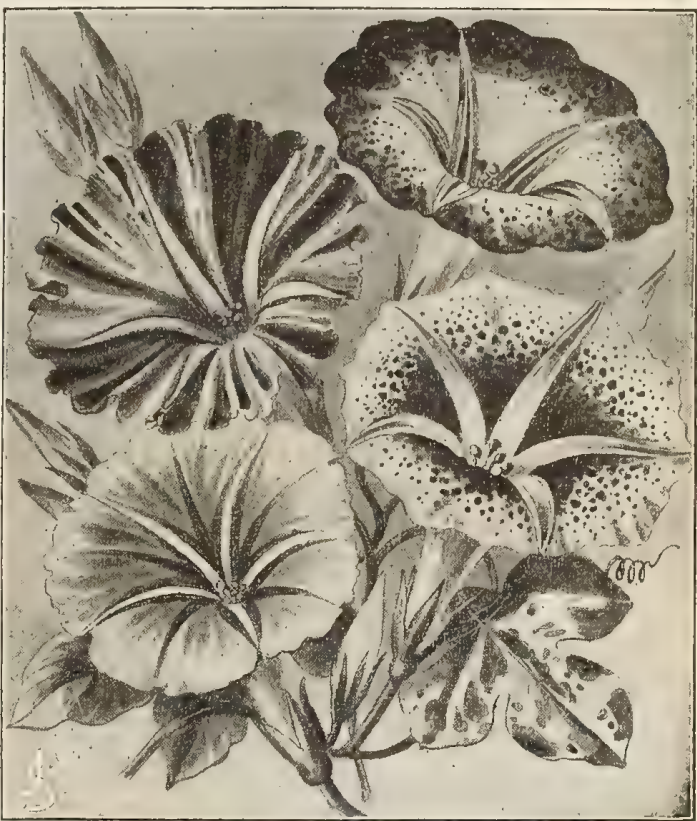

IMPERIAL JAPANESE MORNING GLORY.

\section{IMPERIAL JAPANESE MORNING}

925. The surpassing charm of these Imperial Japanese Morning Glories lies in the entrancing beauty and gigantic size of the flowers; they measure from four to six inches across. The colors of the flowers, shadings and markings are limitiess. Pkt., 10c.; 3 pkts., 25c.

920. Tricolor Roseus. Rose color, with white centre and bands of golden yellow. Pkt., 5c.

921. Major, Mixed. Common Morning Glory. Oz,, 15c.; pkt., 5c.

922. Mauritanicus. Trailing plant for baskets; blue. Pkt., 10c.

924. Minor, Mixed. Pkt., 5c.

\section{MYOSOTIS (Forget-Me-Nots)}

The popular "Forget-Mo-Nots," Bushy plants, 6 to 10 inches high, bearing clusters of lovely small flowers. They are perennials and hardy enough to remain in the open ground excepting in very cold latitudes, where they should be well protected; but they are generally sown in the fall and wintered over in cold frames, when they will flower early in the spring; if sown early in the house, they will flower the first season.

2100. Palustris: The true Forget-Me-Not; beautiful blue. Pkt., 5c.

2102. Dissitiflora. Large, blue flowers, compact and very early. Pkt., 10c.

\section{ALPESTRIS VARIETIES}

2103. Victoria. of bushy habit; large, bright azure blue flowers; very fine. Pkt., 10c.

2101. Pure white

PIR

$\$ 00$

2107. Alpestris, mixed $\ldots \ldots$

2105. " rose . .

“OBELISK" VARTETIES.

These are an upright, pillar form, 10 to 12 inches high and very floriferous.

2108. Obelisk, blue .................... 10

$\begin{array}{lll}2109 & \text { " } \\ 2110 . & \text { pink } & \text { white }\end{array}$ 


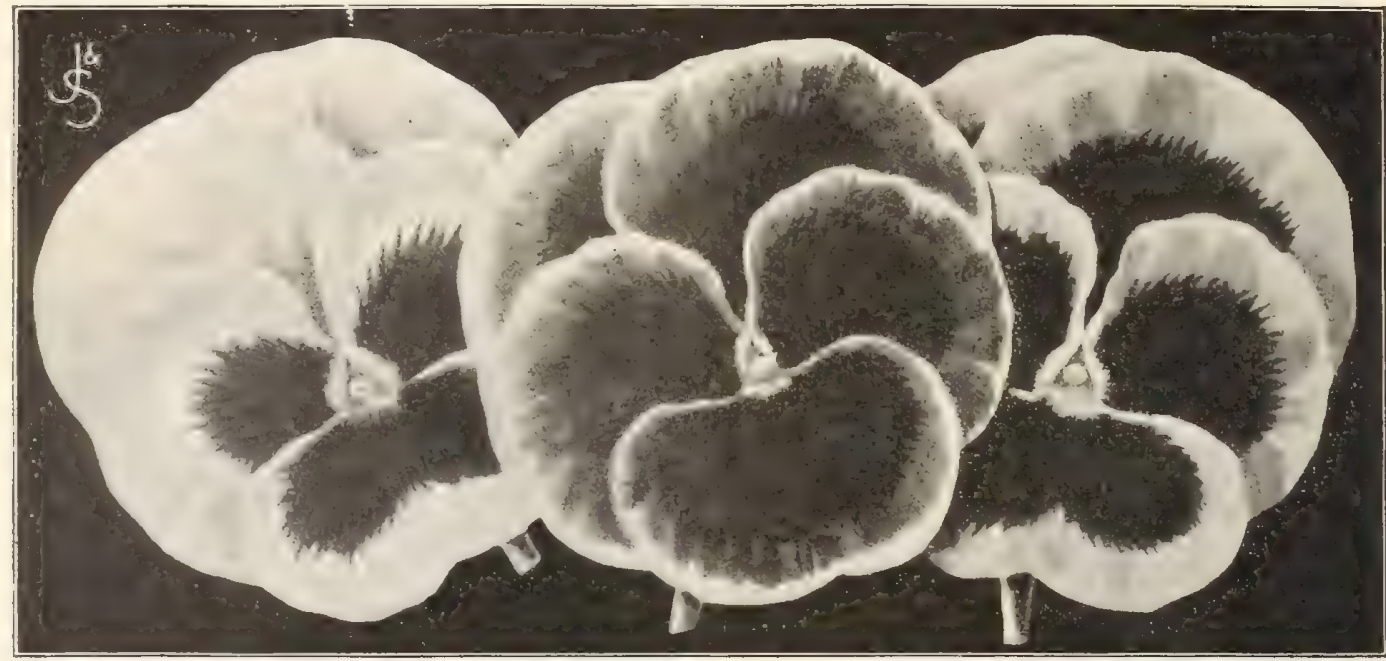

\section{PANSIES}

JOHNSON \& STOKES' KINGLY COLLECTION

2299. This superb collection cannot be surpassed for size, shape, markings or richness of color of the flowers. No pains \&re spared to make this strain absolute perfection in torm, firmuess of texture, size and freedom of bloom, and elegance and variety of markings and colorings. Price, 25c. per pkt.; $\$ 1.00$ per $1 / 8$ oz.

2281. Bugnot's Large Stained. Mixed colors. A cele. 2291. Cassier's Five Bloiched. Round flowers of great tatched grand grand new Panss pets that the border or edge of each petal frilled and curled. The flowers are large, borne very freely well above the plant. Price, per pkt,, $15 \mathrm{c}$.; 2 pkts., $25 \mathrm{c}$

2279. Ongrish Show Mixture. Ykt., 10c.

2308. Azure Blue, very fine

2296. Black. . Ykt., \$0 05 2306. Mahogany

1274. Bronze . " 5 . 5297 . White.

22.2. Emperor Frederick (New), dark red

$227 \%$. Fire Dragon, fiery orange and bronze

"245. Giant White, $1 \mathrm{kt}$. $\$ 010$ 2291. Giant Black

2249 . Giant Yellow " 10 22:0. Giant Azure Blue,

2203. Giant Black-Blue, $10 \quad 2292$. Giant Striped the

2309. Madame Perret (grown by Lucien Peret, the excellence, very early, vigorous and rich com. bination o

2282. Improved Giant Trimardeau, mixed

2278. Lord Beaconsfield, deep purple violet

2264. Meteor (New), bright brown

2264. Meteor (New), bright brown

2283. Prince Bismarck, beautiful golden bronze

2284. Quadricolor, or Pheasant's Eye (Rainbow)

2266. Red Victoria (New), very fine

2285. Snow Queen, sautiny white

2287. Striped and Mottled, large flowered

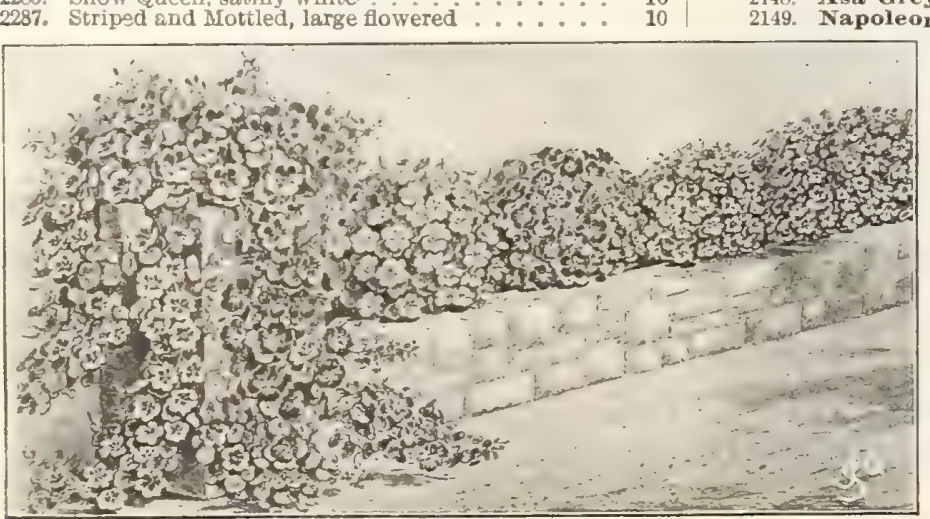

CLIMBING AND DWARF NASTURTIUMS,
NASTURTIUMS

Tom Thumb, Dwarf or Bedding Varieties

2146. Aurora. Balmon-rose, mottled . . . . $\$ 015$. 15005

2131. Bronze Color. A coppery bronze .... 15

2132. Chameleon. Crimson bronze and yellow, $15 \quad 5$

213t. Crystal Palace Gem. Sulphur, spotted

2143. Empress of India. "Brilliant crimson",

2135. Golden King. Grand flowers, 3 inches across; deep golden yellow, maroon blotches, $15 \quad 5$

2141. King Theodore. Dark scarlet maroon,

2145. Lady Bird. Orange-yellow, red spots

2130. Prince Henry. Cream color, spotted scarlet and tipped with wine-red

2142. Pearl. White

2140. Scarlet

TALL OR CLIMBING VARIETIES

2137. Hemisphoricum. Yellow, with rosy scariet

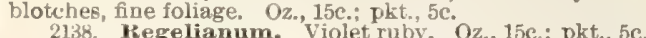

2138. Vogelianum. Violet ruby. Oz, 15c; ; pkt., $5 \mathrm{c}$

2153. Nigro Purpureum. Maroon. Oz., 15c.; pkt., 50. 21i4. Orange. Oz, 15c.; pkt, 5c.

2156. Scarlet. Oz, 15c.; pkt., 5c.

\section{NEW HYBRIDS OF MADAME GUNTER}

215\%. A new section, distinguished by dark-colored foliage and flowers of immense size and richmess and variety of coloring. Per oz., 15c.; pkt, $5 \mathrm{c}$.

\section{LOBB'S TRAILING NASTURTIUM} 2148. Asa Grey. Cream, blotched crimson. Pkt., 5c.
2149. Napoleon II. Yellow striped, scarlet. Pkt, 5c. 2150, Roi des Noirs. Almost black. Pkt., 50 .

2151. Spitfire. Fiery red. Pkt., 5c. 2152. Lobb's Nasturtiums, Mixed. Pitt., 5c.; oz, $15 \mathrm{c}$

2158 primcess Victoria Lonise. Creamy-white, with conspicuous orange scarlet blotches and spur. One of the finest. Ykt, $5 \mathrm{c}$.

2159. Giant of Battles. Sulphur with red blotches; very free-flowering Pkt., 5c.; Oz., 20c

\section{HOW TO GROW PANSIES}

The seed can be sown from August to March. The best plants and largest flowers can be obtained from seed sown in August, September or October in a cold frame with a southern aspect. Plenty of air and light is essential During mild weather sashes should be removed. The plants from spring sowing should be planted in shady border Pansies require fresh soil enriched with decomposed manure. 


\section{Petunia}

For outdoor decoration or house culture few plants equal the Petunis in effectiveness. They commence flowering early and continue a sheet of bloom throughout the whole season until killed by frost; easily cultivated, only requiring a rich soil and a sanny position.

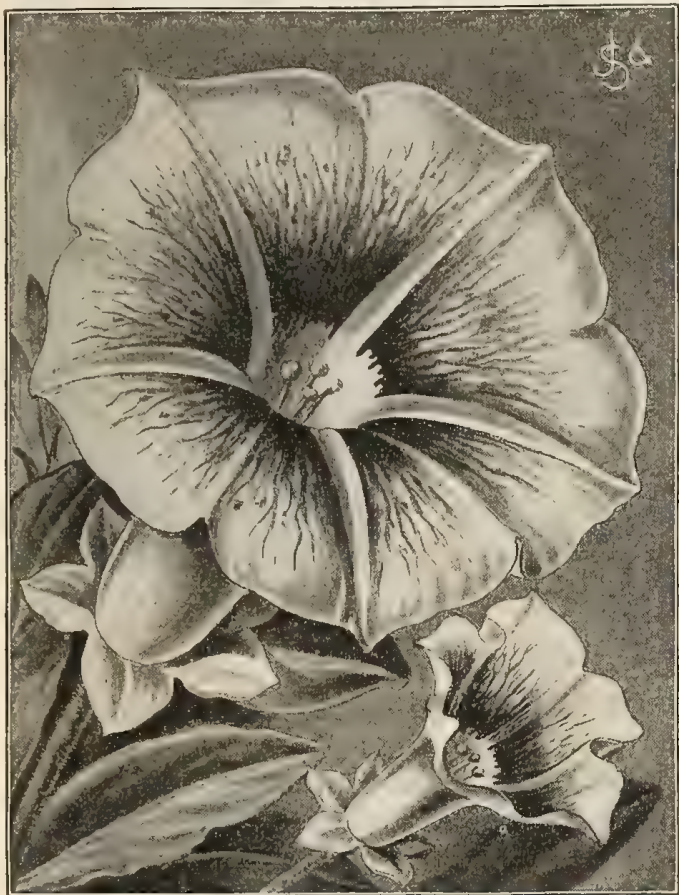

PETUNIA "GIANTS OF CALIFORNIA." PKT., 20C.

\section{SINGLE PETUNIAS (FOR BEDDING)}

2340. Dwarf Inimitable. Dwarf plants, 6 to 8 inches high, flowers cherry red, with a white centre; splendid for eagings, massing, etc. Pkt., 10c.

2341. Striped and Blotched. Extra strain. Pkt., 5c.

2342. Alba. White; suitable for cemetery. Pkt., 5c.

2343. Choice Single Mixed. $1 / 4$ oz., 20c.; pkt., $5 \mathrm{c}$.

2354. "Snowball." A new very dwarf Petunia. Its well-siraped, beautiful satiny white flowers cover the whole plant with one mass of bloom. Admirably adapted for bedding or pot culture. Price, per pkt., 10c.

\section{SINGLE LARGE FLOWERING PETUNIAS}

2345. Grandiflora Venosa. Large flowering, finest shade of color, beautifully veined. Pkt., 10c.

2346. Grandiflora Fimbriata. A fine strain, with handsomely frilled and fringed flowers. Pkt., 20c.

2347. Tellow Throated. The flowers are very large and of perfect form, with a broad, deep yellow throat. Plst., 20c.

2348. "Giants of California." A Californla strain of incomparable beauty, size and luxuriance. The flowers are exquisitely ruffled or fringed on the edges, and are enormous. (See cut.) Pkt., 20c.

\section{NEW GIANT FRINGED BLUE PETUNIA}

Petunia hybrida grandiflora fimbriata cerulea.

2349. An enormously large, deeply cut and finely fringed Petumia of an exquisitely delicate steel-blue color, beautifully veined. Free flowering and very desirable in every way. Price, per pkt., $15 \mathrm{c}$

\section{DOUBLE FLOWERING PETUNIA}

2351. Double Mixed. Best large flowering double, in finest mixture Pkt., $25 \mathrm{c}$

2352. Extra Large Flowering, Double Fringed. This extra choice strain produces about 30 per cent. of splenfid double fringed flowers. Plat., 35c.

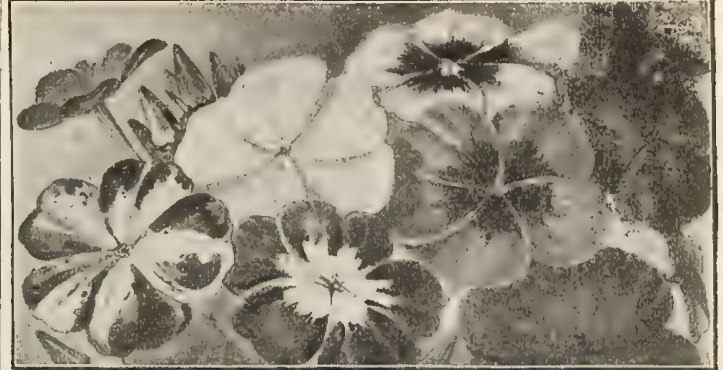

PHLOX DRUMMONDI.

\section{Phlox Drammondi}

For beds and massing nothing can surpass these beantful anvuals. They produce immense trusses of large, brilliant flowers of numberless hues throughout the summer. Hardy anuual: $11 / \mathrm{g}$ feet.

2360. Phlox Drummondi, Mixed Colors. Pkt., 5c.; $\mathrm{Oz}, 50 \mathrm{c}$

2371. Large Flowering, Mixed. Pkt., 10c.; oz., 75c,

2376. New Dwanf Large Flowering, Mixed." Splendid for pot culture and ribbon bedding. Pkt., 10c.

2367. Star of Quedlinburg. The flowers of this striking novelty have a most distinct and star-like appearance. Pkt, 10c.; 3 pkts., 25c.

2366. Hardy Peronmial Phlox. Fine mixed varieties. Pkt., 10c.

\section{POPPIES-SINGLE ANNUAL VARIETIES}

2379. Dan e b rog. Very showy variety large, single flowers of brilliant scarlet, with a silvery white spot on each petal, thus forming a white cross. Pkt., 5c. 2380. Umbrosum. Richest vermilion, with a deep shining black spot on each petal, thus forming a black cross. Pkt, $5 \mathrm{c}$. 2383. Shixley. These charming Poppies range in color extending from pure white through the most delicate shades of pale pink, rose and carmine to deepest crimson. Pkt. 5e.

2388. Tulip Poppy (Papaver glaucum). The plants grow about 14 inches high and produce from 50 to 60 large flowers of dazzling searlet. Pkt., 10c.

2389. Fire Dragon. Flowers of brilliant deep scarlet, with black spots margined white; 2 to $21 \%$

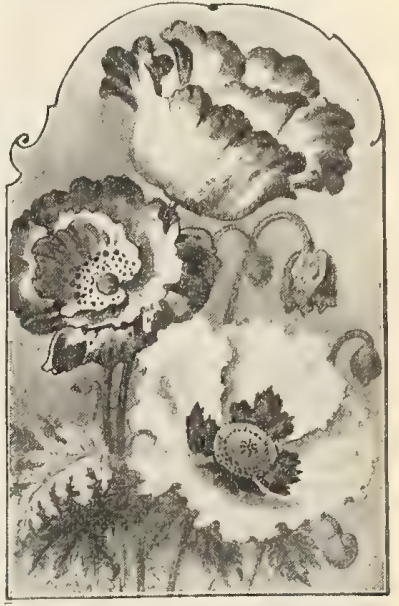
feet. Pkt, $5 \mathrm{c}$.

2385. The Bride. A beautiful variety, with very large, pure white, perfectly formed flowers. If cut when barely expanded and put in water, they will last a long time. Ptrt. 10c.

2391. Single Mixed. Annual sorts. Pkt., 5c.

\section{DOUBLE ANNUAL POPPIES}

2384. SNOWDRIFT. Pure snowy white, extremely double flowers, of perfect form and large size. Pkt., $5 c$

2387. P. NEW WHITE SWAN. Immense size, very double, with beautifully laciniated petals and of the purest possible white. Pkt., 5c.

2381. Mikado. Brilliant scarletand white, with elegantly curved petals, like a Japanese Chrysanthemum. Pkt., 5c.

2382. Carnation-Flowered. Splendid, double fringed flowers, mixed colors. Pkt, $5 c_{-} ; 0 z, 20 \mathrm{c}$

2390. Proony-Flowered. Large, showy, double globular flowers, mixed colors. Pkt., $5 \mathrm{c}$

\section{HARDY PERENNIAL POPPIES}

2386. Orientale. Gorgeous summer-flowering plants, producing in abundance deep crimson flowers five or six inches across. Pkt., $10 \mathrm{c}$

2392. Orientale Hybrids. Beautiful new hybrids of the Oriental Poppy, producing flowers 6 inches and over in diameter, and of many novel colors, such as salmon and cherry. Pkt, 15c. 


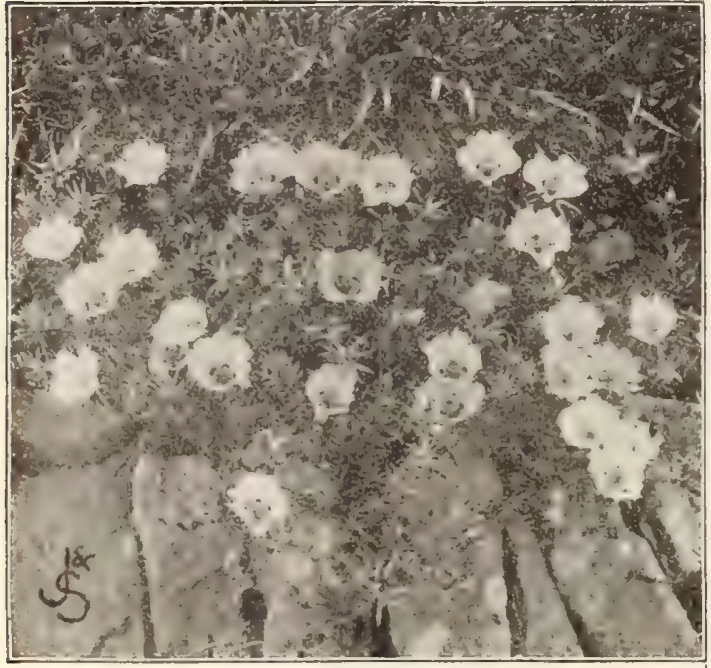

BED SINGLE PORTCLACA.

\section{PORTULACA}

Brilliant dwarf annuals, blooming profusely from early summer to autumn. For low beds and masses of color they are very desirable.

2400. Finest Single, Mixed. A large variety, of the most brilliant colors. Pkt., 5c, ; oz, $30 \mathrm{c}$.

2401. Double Rose-Flowered, Mixed, The most brilliant shades and choice flowers. Pkt., 10c.

\section{PRIMULA}

This beautiful flowering plant is indispensable for winter decoration in the home or conservatory. Our seed is very choice, being saved from the best English strains. Sow in March, April or MIay.

\section{Single Primula}

2420. Sinensis Fimbriata, Fringed varleties. Very choice, mixed. Pht., 20c.

This mixture contains, besides all the above-named varieties, a number of other colors, selected from the best strains of American, French, English and German growers, and we know it will give entire satisfaction. Pkt, $30 \mathrm{c}$.

\section{PRIMULA FORBESI (or Baby Primrose)}

This is the freest flowering Primula we know of. The seed comes up very readily, and the little plants throw up

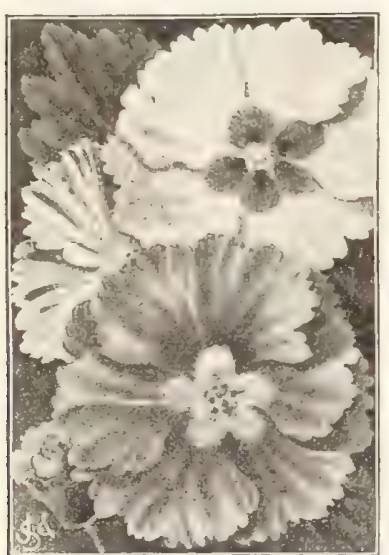

J. \&. PRIZE PRIMULA. only a few weeks old. These, however, should be pinched off, and the plants kept growing until October. When the flowers may, be allowed to develop, and from then on until late in spring they produce their sprays of beautiful rosy lilac flowers in seemingly never-ending profusion. Pkt. 20c.

\section{DOUBLE PRIMULA}

2421. Double. Mixed Pkt., 35c. Our Double Primulas of double flowers. 2424 . O b conica Grandifiora. A profuse blooming primrose, bearing on long stems hcads containing ten is fifteen flowers. The flowers are purc white, shading have the true primrose fragrance. Pkt., 10c.; 3 pkts., $25 \mathrm{c}$. 2436. Floribunda. Bimilar to "Obconica," but the flowers are a beautiful primrose yellow. Pkt., 20c.

2425. Japonica (Japanese Primrose). Pkt., 10c.
2426. Vulgaris. Yellow English Primrose, Pkt., 5c.
PYRETHRUM (Feverfew)

2440. P. Parthenifolium Aureum (Golden Feather) A highly ornamental golden yellow foliage plant, unexcelled for bedding. Hardy perennial; $1 \frac{1}{2} \mathrm{ft}$. Pkt., 5c.; oz., 50c.

2441. P. Roseum (Persian Insect Powder Plant). Hand some aster-like flowers, with pink rays and deep yellow centres; foliage fern-like ; most beautifully cut. Pkt., 10c.

\section{RICINUS}

(Castor Oil Plant)

Large, luxuriant. rapid-growing foliageannuals, with large, handsome metallic l.e aves Used for sub-tropical ef fects on the lawn, or for the taller centres of foliage beds; 6 to 10 feet.

2460 . Gib s o ni. Handsome deep red foli. age. Pkt., 5c.

2463. Mixed. Many choice sorts. Pkt, $5 \mathrm{c}$. Oz., $15 \mathrm{c}$.

2464. R I CIN US DUCHESS OF EDIN BURGH. The stem and leaves are of $\mathrm{a}$ bright metallic bronze; the large branches of the fruit are of a vivid red. Pkt., 5c.

2465. Ricinus Zanzibariensis. The leaves of this new variety attain a gigantic gize tain a gigantic gize,

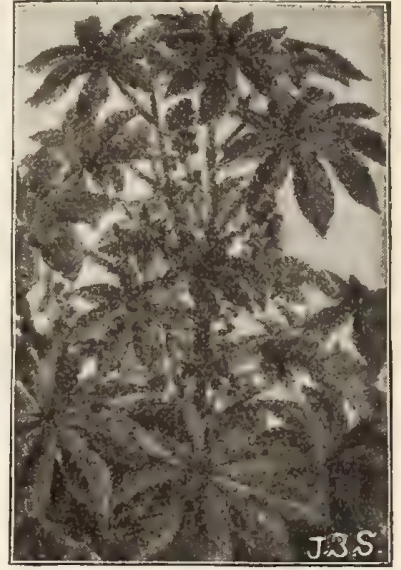

RICINUS, CASTOR OIL PLANT. across, and include light and dark green and coppery bronze colors. Hkt., 5c.; per oz., $15 \mathrm{c}$

\section{SALVIA, OR SCARLET SAGE}

Gorgeous effects can be produced by massing on the lawn or in the garden, or planted in rows along a sunny drive. A perennial, but from seed.

from seed. $25 \% 0$. S p 1 e n a n s. Scarlet sage. Pkt., $10 \mathrm{c}$ 2521. Patens. Blue sage. Pkt., 10c.

NEW SALVIA SPLENDENS, "SILVER SPOT",

2522. The leaves are rich, soft, dark green. with light sulphur or cream-colored spots of various sizes liberally sprinled sizer them The intense bright sem. The fintense bright fowers are very large, and the plants of neat, compact habit. Seed, per pkt., 10c.

2523. Clara Bedman, or Bonfire. Very compact, with long, erect spikes of brilliant scarlet flowers. The finest Saly ia ever intro duced, and by far the best for bedding and massing on the lawn. massing

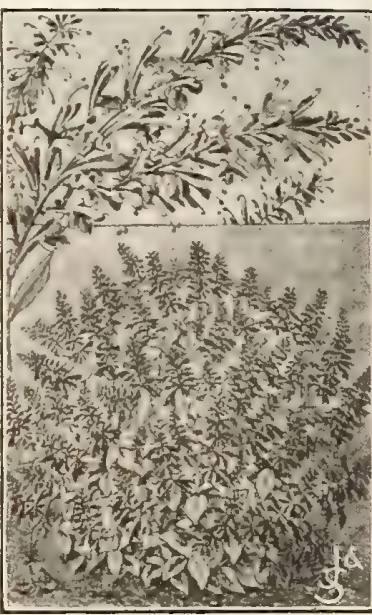

SCARLET SAGE。
SALPIGLOSSIS (Velvet Flower)

The flowers are singularly marked and delicately penciled -in shape resembling a Petunia.

2500. S. Fine, Mixed. Sky-blue and scarlet flowers, very beautifully penciled. Pkt., $5 \mathrm{c}$.

2501. SALPIGLOSSIS GRANDIFLORA. The large flowering Salpiglossis is one of the most beautiful of flowerng annuals. In rich coloring they vie with orchids. Pkt., $5 \mathrm{c}$

\section{TROPEOLUM CANARIENSE}

490. CANARY BIRD VINE. A rapid growing, summer-climbing annal corer trellig work in the most graceful manner, producing cover trellis work in the most graceful manner, producing
hundreds of its pretty fringed bright yellow flowers, which resemble a canary bird with expanded wings. Pkt., $5 \mathrm{c}$. 


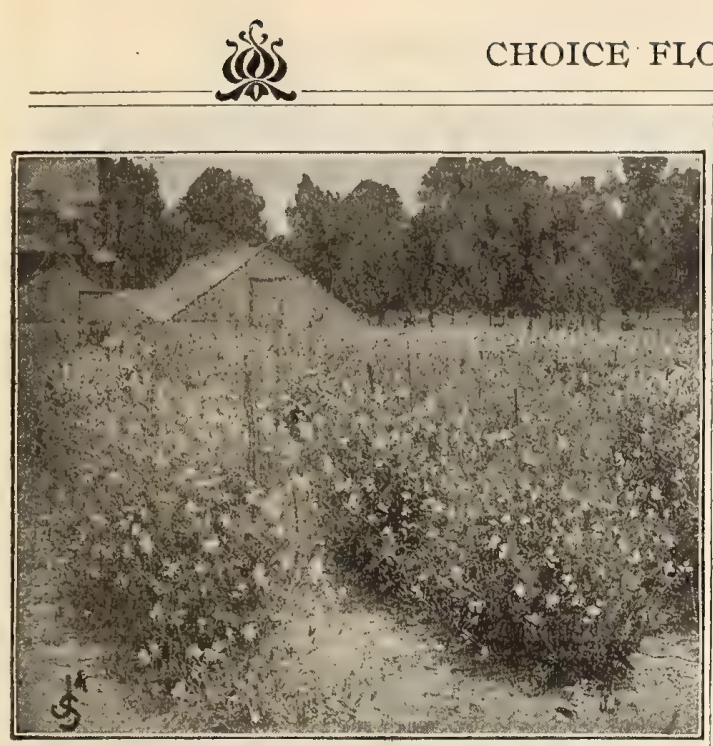

\section{SWEE'T PEAS}

Sweet Peas are among the most beautiful of all our hardy annuals. Select a sunny, open place, several feet from any building, or close fence, and as far as possible from large trees. Sow as early in the spring as possible. Do not wait for fair weather. Plant in double rows 6 inches apart and 4 inches deep, dropping the seed 3 inches apart. Furnish support early. In dry weather water freely and keep the flowers picked closely. If you allow them to produce seed pods the plants will soon stop flowering. Price per packet, 5c.; 0z., 10c.; 1/4 1b., 20c.; 1/2 1b., 30c.; 1b.,
60.

\section{WHITE}

2769. Bride. Pure white-hooded form.

2722. Emily Henderson. Large, pure white.

2711. Mont Blanc (new). The earliest-flowering white.

\section{YELLOW}

2773. Mrs. Eckford. A delicate primrose-yellow self.

2736. Primrose. Pale primrose yéllow.

2695. Queen Victoria. Light primrose, self-colored.

2767. Stella Morse. Rich primrose, flushed pink.

\section{ORANGE-PINK}

2810. Gorgeous. Rich glowing scarlet-orange

2775. Lady Mary Currie. Standard crimson-orange : wings crimson with tint of orange.

2706. Lady Penzance. Orange-pink, wings pure white.

2714. Orange Prince. Orange-salmon, wings pink.

2771. Oriental. Bright orange-pink, heavily veined.

\section{PINK}

2681. Blushing Beauty. Delicate pink-hooded form.

2685. Countess of Aberdeen. Pink, turning lighter.

2685. Countess of Aberdeen. Pink, turning 2743. Countess of Lathom. Delicate pink self.

violet; wings creamy white, tinted with rose.

2717. Hon. F. Bouverie. Standard and wings both deep pink at base, shading to light pink.

2750. Katherine Traey. Soft but brilliant pink.

2797. Little Dorrit. Beautíful clear pink.

2774. Lovely. Beautiful soft shell-pink.

2777. Modesty. Most delicate shade of pink.

2798. Mrs. Gladstone. Lovely soft pink.

2798. Mrs. Gladstone. Lovely soft pi

2732. Prima Donna. The softest clear pink self

2752. Royal Robe. A bright but soft pink self.

2768. Sensation. White, suffused with bluish-pink

2737. Venus. Boft salmon-buff, shaded with rosy pink.

\section{PINK AND WHITE}

2712. Blanche Ferry. Pink and white,

2698 "Farliest of Ali" Pink and white very early.

2755. Extra Early Blanche Ferry. Pink and white.

\section{ROSE OR DEEP PINK}

2730. Har Majesty. A most beautiful rose.

2720. Lady Skelmersdale. Standard light carmine, chading to white; wings almost pure white.

2790. Majestic (new). Rich deep rose-pink self

2778. Ovid. Rose pink margined with deeper rose.

2766. Royal Rose. Standard rose; wings light pink.

\section{ROSE-CRIMSON}

2791. Lord Kenyon (new). Rose-magenta, flushed crimion.

2715. Mrs. Dugdale. Crimson-rose; self-colored. One of the largest-tlowered.

2675. Oddity. Peculiar pale carmine and bright rose.

2733. Prince of Wales. Rose-crimson; self-colored Flowers extra large.

\section{SCARLET AND CRIMSON}

2728. Firefly. Brilliant scarlet.

2747. Mars. Crimson scarlet.

2772. Prince Edward of York. Standard crimson scarlet; wings crimson, Extra large.

2688. Salopian. The best of the crimson-scarlets

\section{MAROON}

2705. Black Knight. Deep maroon; self-colored.

2713. Boreatton. Very dark maroon; self-colored

2727. Duke of Clarence. Rich deep claret self.

2670. Duke of Sutherland. Claret and indigo-blue

2735. Monarch. Deep bronzy maroon with blue.

2721. Othello. A very deep glossy maroon self.

2689. Shahzada. Rich dark maroon, shaded purple

2753. Stanley. Rich dark maroon.

\section{BLUE AND PURPLE}

2792. Captain of the Blues. Standard purple-blue wings bright blue.

2774. Celestial. Delicate ezure blue.

2716. Countess Cadogan. Standard light bluis purple; wings clear blue.

2796. Duke of Westminster. Standard clear purple wings purple, with tint of violet.

2703. Navy Blue. Standard indigo and violet; wing indigo, shading to navy blue and bright blue.

\section{PURPLE-MAUVE}

2680. Captivation. Light purple-magenta.

2725. Dorothy Tennant. Rich rosy mauve self.

2734. Emily Eckford. Rosy mauve, changing to an almost true blue.

2794. Fascination (new). Delicate magenta-maure.

\section{LAVENDER}

2738. Countess of Radnor. Pale mauve or lavender

2731. Golden Gate. Shaded lavender.

2719. Lady Grisel Hamilton. Standard mauve; wings lavender. Flowers extra large.

2687. Lady Nina Balfour. Delicate light lavender.

\section{BLUE OR LAVENDER-EDGED}

2723. Lottie Eckford. White, shaded and edged with soft lavender.

2776. Maid of Honor. White, edged and shaded with light blue.

\section{VARIEGATED}

2677. America. Crimson-scarlet, striped on white.

2748. Aurora. Orange-rose, striped on white.

2746. Coquette. Primrose-yellow, shaded pale lavender.

2686. Countess of Powis. Orange-suffused purple.

2672. Daybjeak. Crimson-scarlet, on white ground.

2770. Dolly Varden. Purple-magenta, shaded white.

2674. Gray Friar. Beautiful light watered purple on white ground, having a grayish effect.

2756. Juanita. White, striped with pale lavender.

2756. Juanita. White, striped with pale lavender.

2673. Lottie Hutchins. Cream, flaked with pink.

2671. Mrs. Joseph Chamberlain. White, striped and flaked heavily with pale rose.

2795. Pink Friar. Carmine rose on white ground.

2678. Ramona. Creamy white, splashed with pale pink

2754. Waverly. Standard rosy claret, wings light blue.

Price, any of the above choice named sorts, pkt., Бc.; oz., 10c.; 1/4 1b., 20c.; 1/21b., 30c.; 1b., 50c.

\section{J. \& S. STANDARD MIXTURE}

This is the highest grade mixture that can be made, and our sweet-pea-loving customers can rely upon it producing excellent results. Plkt., 5c.; oz., 8c.; $1 / 4$ lb., 15c.; per $1 \mathrm{~b} ., 10 \mathrm{c}$.

\section{DWARF CUPID SWEET PEAS}

The Cupid Sweet Peas should become popular for bed. ding and borders. They are of true dwarf habit and literally cover themselves with flowers.

2799. Alice Eckford Cupid. Flesh pink and white.

2800. Beauty Cupid. Soft rose and carmine.

2801. Blanche Ferry Cupid. Pink and white.

2802. Boreation Cupid. Rich wine brown.

2803. Countess of Radnor Cupid. Delicate lavender.

2804. Firefly Cupid. Dazzling scarlet.

2804. Firefiy Cupid. Dazzling scarlet.

2805. Primrose Cupid. Rich ere

2806. White Cupid.

Price of all Cupids, plet., 5c,; oz., 10c.; 1/4 1b., 960.; lb., 7бс., postpaid. 


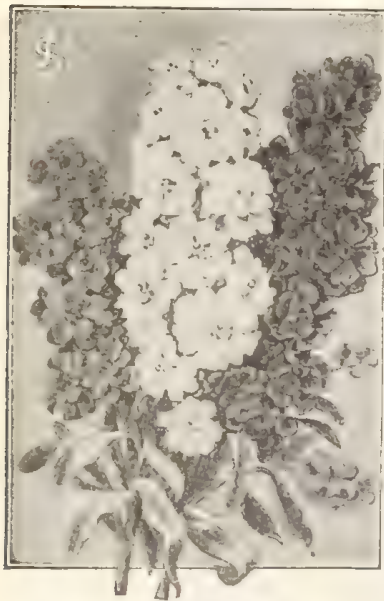

DWARF LARGE FLOTERING STOCKS. flowar Leaved, Mixed. Pkt., 10c. 2667. Snowflake. A tine variety. double pure white flowers. Plat, 100. with 2669. Princess Alice (Cut and Come Again). A perPlit., $10 \mathrm{c}$

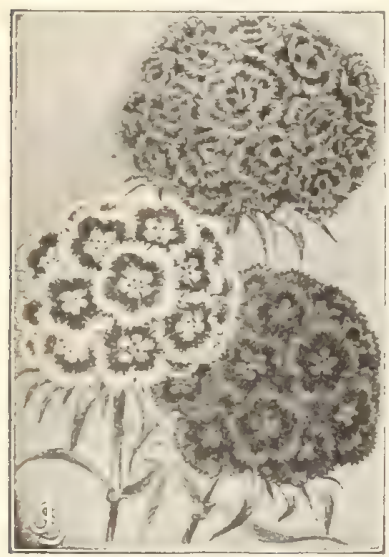

STEET WILLLAN.
SENSITIVE

PLANT (Mimosa)

2040. A curious plant, leaves close if trat 5 or a

\section{SMILAX}

2120. $\mathrm{g}$ racefu climber. Largely used quets. Pkt., 10c.; 1/4 oz. 5c.; per $0 z$, $40 \mathrm{c}$.

\section{DWARF LARGE LOWEAING \\ The DVar}

Ten Weeks Stocks are easily grown and are of great beauty and fra grance.

2660. Flood Red. 8010 2661. Crimson

2662. White

2668. Pink

2665 . Mixed

\section{SWEETWILLIAM}

garden. Perfectly hardy and with a rich profusion of bloom. No plant can surpase this old favo2741. Perfectio I
8ingle Mixed. Hkt., 5c. oz., $25 \mathrm{c}$. Double Mixed. Pkt. $10 \mathrm{c}$ Flowered, C hoice ingle varieties. $P \mathrm{kt}$, $6 \mathrm{c}$

\section{SUNFLOWER}

Helianthus) - SRGLE

VARIETIES

1511. Miniature Sunflower (Cucumeri folius). Dwarf branch withabit, flowers orange Oz., 25c.; pkt., 5c.

\section{DOUBLE VARH}

1510. Californicus Plentssimus. Extra large, double Plet. 50 1512 . Glubosus Fistul. sis

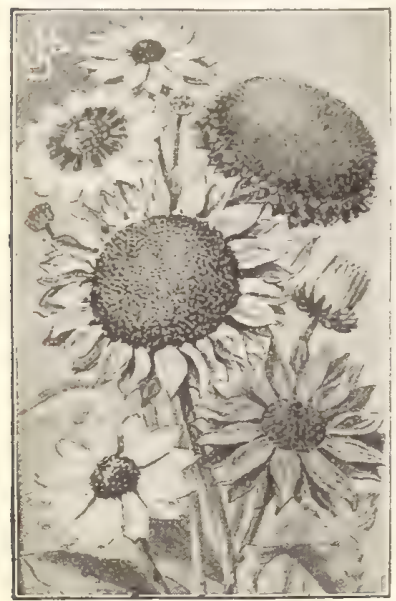

SUNFLONER.

\section{TROPAOLUM}

(Canary Bird Flower)

A rapid growing annual climber. Flowers resemble a bird with Pkt. 5c. rite. Height, $1 \mathrm{ft}$

2742 A uricula

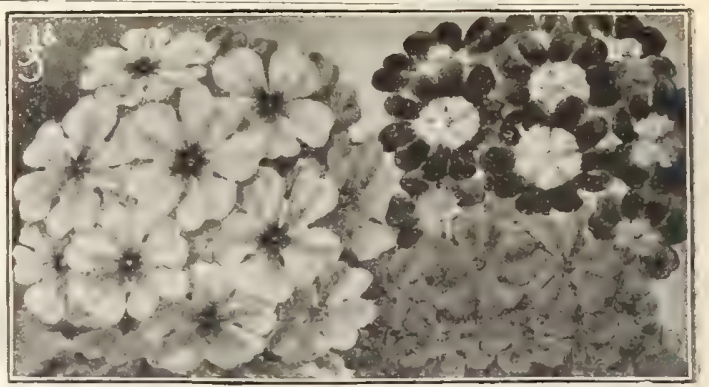

MAMMOTH VERBENAS

\section{VERBENA}

For garden beds or massing the Verbena is unrivaled ; flowers of the most brilliant colors, blooming continually from opring until late in the autumn. Although perennials, these form luxuriant plants and bloom profusely the firs season from seed.

New Marawoth. Our strain of Mammoth Verbenas is nexcelled; flowers of the largest size and brilliant colors.

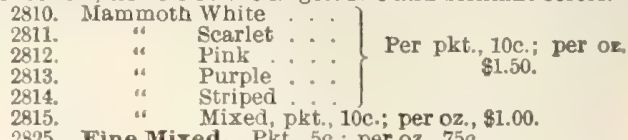

2815. Mixed, pkt, 10c; per oz, $\$ 1.00$

2826. Lemon Verbena (Aloysia Citriodora). Pkt., $10 \mathrm{c}$

\section{NEW MOSS VERBENA}

No. 2827. This new strain of Verbena is notover 6 inches high, but branches out and literally covers the $\mu$ round. It is smothered with flowers of the true Verbena type all summer long. It is valuable anywhere, but especially so for bedding and edging. Price, per pkt, 10c.

\section{VIOLET (Viola Odorata)}

A great favorite, much in demand on account of its abundant and fragrant bloom. Hardy perennial; $x / 3 \mathrm{ft}$.

2N60. V. Single White. Sweet scented. Pkt., 10c.

WALLFLOWER (Cherianthus Cheri)

A handsome, popular plant, with massive spikes of fra grant flowers. Hardy perenuial; $2 \mathrm{ft}$.

2900. Wallflower, Double Mixed. Yellow, brow 2901. Single Mixed. Showy colors. Pkt., 5c.; oz., $25 \mathrm{c}$

ZINNIA-(Youlh and old Age)

The double Zinnis is one of the most brilliant and showy

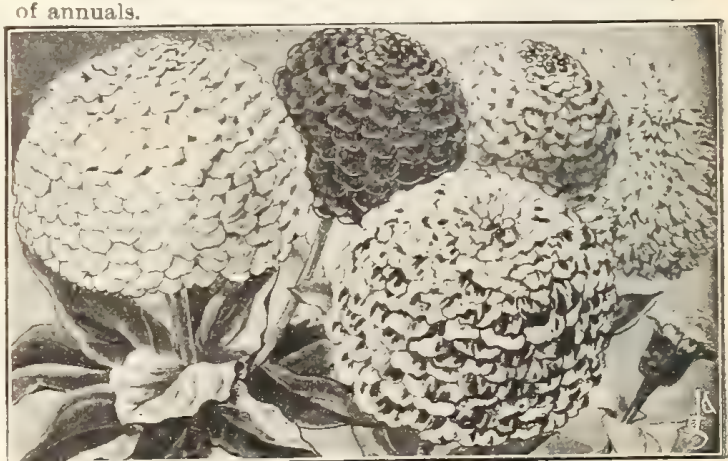

MAMOTH ZINNLAS.

Mammoth (Robusta Plenissima). Very large flowers of striking colors. Bushy babi Plat, 10c; oz. $40 \mathrm{c}$

Large Flowering Double Dwarf,

2930. Scarlet. Pkt., $5 \mathrm{c}$

2931. Orange. Pkt., $5 \mathrm{c}$.

2932. White. Pkt, $5 \mathrm{c}$

2933. Canary. Pkt, 5c. lar flower the petals being distinctly striped. They run through ail shades known to the Zinnia, such as orange, on, pink yellow rose, violet and white. 29:38. Corled and Crested. Large flowers with twisted petals, great range of color. Pkt., 10c

2939. Dwarf Varieties. Mixed. Oz., 35c.; pkt., $5 \mathrm{c}$.

2910. Tall Varieties. Mixed. Oz., 20c.; pkt., 5c. 


\section{Summer Flowering Bulbs}

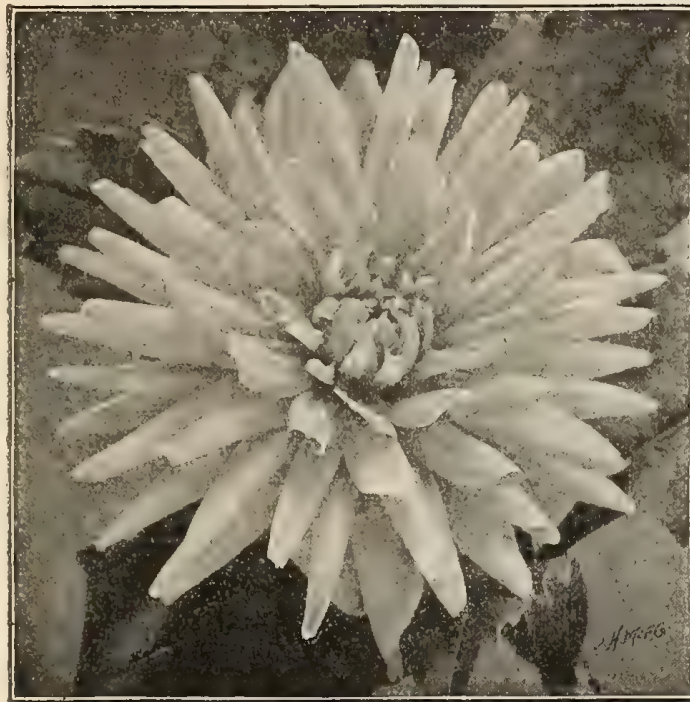

CACTUS DAHLIA, JOHN H. ROACH.

DAHLIAS

Collection of 12 best Dahlias from all classes, comprising the most valuable and comprehensive collection of 12 Dahlias ever offered.

A. D. Livoni. (Show.) Pure, soft pink with quilled petals and full to the centre; an early and profuse bloomer.

Americun Flag. (Fancr.) Rich cardinal red with white stripe running through the centre of each petal.

Alewine. (Pompon.) White flushed rosy lavender rery fine, on long stems.

c. W. Bruton. (Decorative.) The best yellow; of immense size; perfect form and of the finest canary yellow; tall, vigorous grower and an extremely profuse bloomer.

Grand Duke Alexis. (Decorative.) A magnificent flower, of largest size and distinctly unique form, with besutifulty quilled petals. Color is pure white, tinged delicate lavender-pink.

John H. Roach. (Cactus.) A fine, light yellow; of perfect form, with long, incurved, pointed petals; a beautifu] perfect form, with long, incurved, poin

Matchless. (Cactus.) Large, rich, glistening crimson, shading to dark velvety maroon; an extremely early and profuse bloomer-a grand variety.

Penelope. (Fancy.) Pure white, flaked soft, rosy lavender; of perfect form; beautiful and chased.

Purity. (Show.) A beautiful pure white, of large size; fine form and finish. One of the best.

Queen of Yellows. (Show:) A beautiful clear yellow large size; fine form; an early and extremely profuse bloomer. Snowclad. (Pompon.) The best white pompon to date An early and extremely profuse blonmer.

Price, 15c. each; $\$ 1.50$ for set of 12 sorts.

\section{CANNAS}

LARGE FLOWERING FRENCH SORTS

PENNSYLVANIA. The most magnificent orchid-flow ering Canna to date. Immense flowers of a pure, deep red; a tremendous bloomer, 6 to 7 feet high.

Burbank. A new orchid-flowering sort. Rich canary yellow, fully 7 inches across. 4 feet.

Black Prince. Very dark velvety maroon. Extra large flowers. Very fine. 3 to 4 feet.

Allemania. Orchid-flowering sorts. Very large. 6 feet. Galmnn scarlet with broad yellow border.

Philadelphia. The finest crimson Canna to date. 3 feet. Luray. New clear bright rose pink. Very fine. 4 feet. Niagrax. Rich, deep crimson, with wide golden yellow boriler. 3 feet.

Egandale. Bronzed-leaved variety; cherry-red flowers. 4 feet

Queen Charlotte. Dwarf compact sort. Red with yellow margin. 21/2 feet.

Chas Henderson. Deep, rich crimson. 3 feet.

Paul Marquant. Deep salmon, 4 feet.

Milo. Berat. Bright pink. 4 feet.

Robusta. Dark-leaved tall sort for tropical effect. 6 to 7 feet.

Price of each above sorts, 10c. each; $\$ 1.00$ per dozen 38.00 per 100 .

\section{GLADIOLUS}

One of our most satisfoctory summer-flowering bulbs. Make successive plantings, so as to continue the blooming season. As cut flowers, nothing could be finer.

Floracroft Mixture, No. 1. This is a magnificent strain of flowers, with all undesirable sorts weeded out, and the bulbs all uniformly sound and large. Per dozen, post paid, 50c.; by express, per 100, $\$ 3.00$.

Floracroft Mixture, No. z. Same as above, but smaher bulbs, all bloomers. Per dozen, postpaid, 30c.; per 100, by express, $\$ 2.00$

Separate Colors. Shades of red, of orange and yellow, of white and light, and of striped and variegated for beds and massing. Per dozen, postpaid, $50 \mathrm{c}$; by express, per 100 $\$ 3.00$.

\section{CALADIUMS (Elephant's Ears)}

A very effective plant and suitable for either a single plant on the lawn, masses in beds, or for margins of water, its leaves often attaining the length of 3 feet by 20 inches wide. First size, 10e. each: $\$ 1.00$ per dozen. Second size 15c, each; \$1.50 per dozen. Extra large bulbs, 25c. each; $\$ 2.50$ per dozen, postpaid.

\section{GLOXINIAS}

Bloom in six weeks, and are unexcelled in magnificent coloring and blooming qualities, large bulbs. Each, 10c.; pe dozen, $\$ 1.00$. Second size, $7 \mathrm{c}$. each ; 75c. per dozen.

\section{SUMMER-FLOWERING OXALIS}

For bordering or margining nothing can surpass the Summer-flowering oxalis. The bulbs, when planted about 3 inches apart, produce an unbroken row of elegant foliage and pretty flowers, and as they bloom in a very short time after planting, furnish a neat and attractive border the whole season. Price, per dozen, 10c.; per 100, 50c.

\section{IRIS (Flower-de-Luce)}

Japanese. Perfectly hardy, beautiful flowers, all colors, Exquisitely mottled and veined Bloom in July, and need a moist, sunny situation. Each, 10c.; \$1,00 per dozen

German. These rival the orchid in variety of coloring shape and shading. Perfectly hardy and adapted to al situations. Bloom in June. Each, $10 \mathrm{c}, ; 1.00$ per dozen.

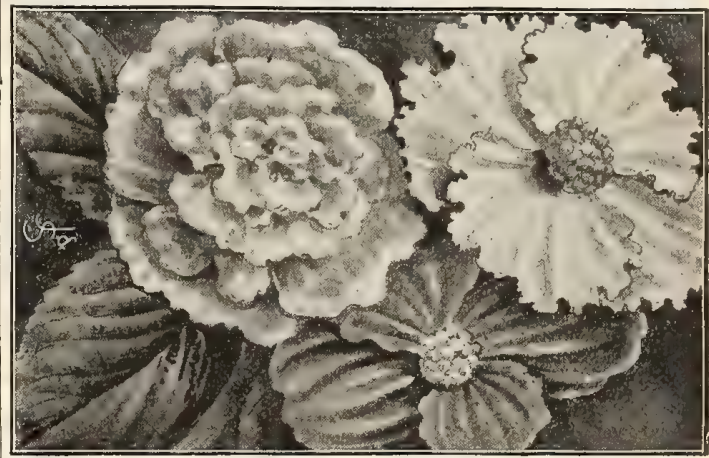

TUBEROUS-ROOTED BEGONIAS.

\section{TUBEROUS BEGONIAS}

The tuberous-rooted Begonias are among the handsomest of our summer-flowering bulbs. They bloom continuously throughout the summer, till frost cuts them. Planted eithe in the rockery or flower border, they rival the rose with their rich and varied colors, ranging from the most delicate shades of white, yellow and salmon to the most striking shades of white, yell

crimson and scarlet. $\quad$ Each. Doz. 100.

Single, Scarlet, Orange, Crimson,
Pink, White, Yellow . . \$ $06 \quad \$ 060 \quad \$ 400$ Single. A 11 colors mixed : : $05 \quad 50 \quad 50 \quad 350$ Double. All colors mixed : : $08 \quad 75 \quad 600$

\section{HARDY HERBACEOUS PAEONIES}

Magnificent and perfectly hardy plants, almost rivaling the rose in brilliancy of color and perfection of bloom. The fragrance of the large flowers resembles that of a highly scented rose.

Separate Colors. Pink, white or red, 15c. each; 4 for 50c.; $\$ 1.40$ per dozen, postpaid

Mixed Colors, embracing many beautiful and variows sorts, 12c. each ; 4 for 45 c.; $\$ 1.25$ per dozen, postpaid.

\section{TUBEROSES}

Deliciously fragrant and beautiful; popular with every. body. We grow them in immense quantities.

Excelsior Pearl. Large No, 1 bulbs. 3 for 10c.; 35c. per dozen; $\$ 2.00$ per 100 . 


\section{DOSES $\approx$}

NOTICE. We send all 1-year roses postpaid; 2-year plants by express at purchaser's expense.

Set of Novelty Roses

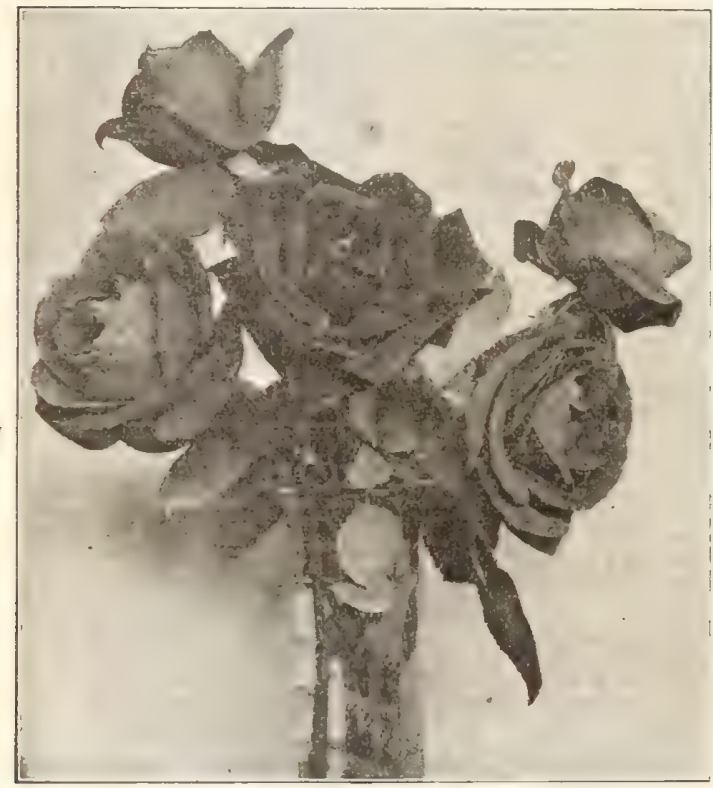

NOVELTY ROSE. MAD, EUGENE C, MARLET.

SIR THOMAS LIPTON. Undoubtedly the Finest Pure White Hybrid Rugosa Rose yet produced. A handsome bush covered with very fragrant, perfectly double, now-white flowers, and bright glossy green leaves.

Price, strong plants, 50c.; 2-year, 75c.; 3-year, 81.50.

BEAUTY OF ROSEMAWR. An elegant new ever blooming rose; fine large flowers with overlapping petals and a raised centre; a lovely shade of carmine veined with fine crimson and white markings. Price, 25c. each; 2уear, Б0с.

MAD. EUGENE C. MARLET. A fine rose: flowers large, full and very double; bright rich carmine red and deliciously sweet. Price, $30 \mathrm{c}$. each; 2-year, $50 \mathrm{c}$.

BESSIE HROWN. A lovely new rose, extra large, full and double and delightfully perfumed; healthy, vigor ous grower. Constant, profuse bloomer; color, lovely peachy pink, delicately shaded with rose and fawn, Price, 25c.; 2 year, $40 \mathrm{c}$

MAD. JEAN DUPUY. A lovely high-class, ever-bloomIng rose just introduced from Europe. Color, fine creamy rose with golden yellow centre, outer petals edged with red large, fully double and remarkably fragrant. Almost thornless. Price, $30 \mathrm{c}$, each ; 2-year, $50 \mathrm{c}$.

\section{NOVELTY ROSE COLLECTION}

One each of the above five lovely sorts for ouly 81.25, postpaid; 2-year, 82.00; by express at purchaser's expense.

\section{HARDY MEMORLAL ROSES}

ALBA RUBIFOLfA. The finest hardy Memorial Rose known. The flowers are pure double white and the foliage and young growth bright red. It retains its foliage all win. ter.

"ROSA WICHURATANA." Creeps on the ground like ivy. Has dark-green leaves and numberless satiny white flowers, with golden-yellow discs. Specialiy adupted for use in cemel eries

DOUBLE PINK MEMORIAL ROSE. Same as the Double White, except in color, which is clear, bright pink.

EVERGREEN GEM. Pretty buff-yellow fiowers, 2 or 3 inches in diameter, perfectly double, with a rich sweet Briar fragtance.

PRICE, HARDY MEMORIAL ROSES

160. ench; 2-year, by express, 35c, each.

Bet of 4 , boc., by mail, postpaid.

Set of 4, z-y ear, by express, at purchaser's expense,

\section{Hardy Perpetual Roses}

NEW CENTURY. A gTand, new, ever-blooming perfectly hardy rose; flowers very large, perfectly full and double, and borne in clusters. Color is a bright rich carmine rose, with deep red centre, and the petals are bordered with fine creamy white. Is very sweet, with the delightfit fragrance of the Sweet Briar.

PAUL NEYRON. One of the grandest and most mag. nificent hybrid perpetual roses in existence. The flowers are immense size and superb form, very double and of great depth and substance; $\mathrm{a}$ good hardy grower; free blaomer.

MADAME MASSON. Bplendid, constant-blooming hy. brid perpetual rose. Bright rich crimson, large, very fah, fragrant flowers. Sturdy grower. A real floral treasure

PRINCE CAMILLE DE ROHAN. Very dark, vel. vety crimson, almost black; darkest of all.

MAD. PLANTIER. One of the hardiest and a profase bloomer. Snow white.

MAGNA CHARTA. Extra large, full flowers of nn usual depth and substance; bright rosy pink; very grand, profuse bloomer.

GEN.JACQUEMIN OT. Bright, shining crimason, ficb and velvety.

COUNTESS OF RoSEBERT. Fine carmine red, large and full, finely cupped form; makes a handsome bush.

OAKMONT. Fine peach pink flowers, large and sweet good bloomer, hardy and productive, always gives satisfac. tion.

COQUETTE DES BLANCHES. Large, very double pure white flowers; constant bloomer, one of the best.

HARDY PERPETUAL ROSES

PRICE: Any of the above, 15c, each, postpaid; 8 year, $35 \mathrm{c}$. by express at purchaser's expense.

Set of 10 -Beanties-81 15 , postpaid.

Set of 10-2-year-old, by express, 83.00 .

\section{Ever-Blooming Climbing Roses}

CLOTILDE SOUPERT (Climbing) New. This is undoubtedly one of the most beatiful and satisfactory of al the hardy Ever-blooming Climbing Roses yet introduced. It is similar to the well-known Clotilde Soupert, bat the flowers are larger and deeper in color, and the bush is strong, vigorous climber, which begins to bloom very quickly strong, vigorous climber, which begins to bloom very quickly and continues loaded with lovely buds and fowers all summer and fall until stopped by freezing weather. It is entirely hardy here. It is also free from the attacks of insects, rust, and blight. The flowers are borne in clusters and are of large, round, flat form, perfectly full and double and delight fully fragrant. Color beautiful creamy white, finely tinged both red and white roses are borne on the same sometis

MADAM WAGRAM. This magnificent rose comes to us from France; is claimed by the originator to be one of the us from France; is claimed by the originator to be one of the most extraordinary roses ever sent out, It has shown up finely here, and is undoubtedly a rose of remarkable beauby.
The flowers are of the very largest size, and well filled with The flowers are of the very largest size, and well filled with
broad shell-like petals; color, lovely clear satiny rose, ele gantly tinted with soft ruddy crimson and fine silvery pink The bush is a strong, vigorous grower.

REINE MARIE HENRIETTA, or RED-FLOWER ING GLOIRE DE DIJON. A strong, vigorous grower flowers large, full. and of fine form. Color, a pure cherry red, sweet-scented. This is planted more largely than any clumb ing Rose, because it gives such universal satisfaction.

"CLIMBING AUGUSTA VICTORIA" (Mrs, Rober Peary). A grand, pure white, hardy, ever-blooming climber. Strong, vigorous grower

THE EMPRESS OF CHINA is a hardy, perpetual blooming climbing rose ; it resembles a tea rose. The color is soft dark red, passing to light pink or apple blossom.

MARECHAC NEIL (Noisette). A most beautiful large golden yellow rose; very full and double and exceeding fragrant. It is naturally a climbing rose, and should not be pruned too short.

EVER-BLOOMING CLIMBLNG COLLECTION

Price, 15c. each, postpaid ; 2-year, 35c. by express, at purchaser's expense.

Set of 6 for $65 \mathrm{c}$., postpaid, or 2-year size, by express. for $\$ 1.60$. 


\section{"Nera" EvermBloom- ing Roses}

FELEN GOULD. A hardy, ever-blooming hybrid tea The flowers are perfectly doubl and deliciously fragrant; color is rich vinous crimson legantly shaded and exceedingly beautiful. Price, 20c. each; 2-year size, $40 \mathrm{c}$.

FRANCES E. WILLARD. This pure white ever blooming rose is a magnificent variety. Strong, vigorous grower, the flowers so full and double that they resemble a camellia. Price, 15c. each; 2-year size, 35c.

RMPRESS ALEXANDRA OF RUSSIA. An eXquiste new rose of novel beauty. The flowers are large and double, with full centre and broad thick petals. The buds are dark violet red, and the open flowers rich purplish lake, deepening at the centre to fiery crimson. Price, 15c. each; -year, 35c

AÚGUSTA VICTORIA, NEW HARDY TEA ROSE. This grand new rose is unsurpassed in beauty. Extra large anely formed flowers borne singly on strong upright stems: rery deep, full and sweet; color pure white, shading to emon; a free and constant bloomer. Price, 15c. each; 2-year, (5c.

MRS. B. R. CANT. A fine new garden rose, very free and strong grower and great bloomer; flowers open bright reddish rose and shade to salmon rose, flowering double and lasting. Price, 20c. each; 2-year, 40c

IVORY. A beautiful new white rose with very attraccive buds and flowers, entirely distinct; a free bloomer and great prize winner at the flower shows. Price, 20c. each 2-year, $40 \mathrm{c}$

KILCA RNEY. A splendid new rose, beautiful long pointed buds and extra large double flowers; bright rich coral pink, very fragrant and beautiful. Price, 15c. each; 2-year,

GRUSS AU TEPLITz. Color when first opening is dark, rich crimson, quickly changing to bright scarlet. Flowers large, full and very handsome. Price, 15c. each; 2-year size, $35 c$

MAD. JULES GROLEZ. Color lovely china rose, passing to a rich satiny pink; handsome buds and large flowers. 15e, each: 2-year, $35 \mathrm{c}$

HENRY M. STANLEY. Deep chamois rose-colored flowers, delicately tinged with fine apricot-yellow petals, bordered with bright carmine red. 15c. each ; 2-year, 35c.

\section{NEW EVER-BLOOMING COLLECTION}

Set of 10 sorts, by mail, postpaid, \$1.15.

" 10 " "express, at purchaser's expense, 2-year-old, $\$ 3.00$.

\section{General Set Ever-Blooming Roses}

COOUETTE DE LYON. Lovely canary yellow, immense bloomer, elegant for bedding; bright yellow roses, blooms quickly and profusely the whole season.

ISA BELLA SPRUNT. Flowers of bright canary yellow; buds are remarkably fine, a truly splendid rose.

MAMAN COCHET. Well known as a queen among roses. Flowers enormous, very full, rich coral-pink shaded with rose and deliciously sweet.

PEARL RIVERS. Flowers large and full, with peachyred buds; prevailing color ivory white, petals delicately shaded and bordered with pale rose.

MADAM OLGA. Crean white, clouded with pale car

CLOTILDE SOUPERT. Fine for bedding; color, rich creamy white, with pink centre.

MAD. F. KRUGER. Soft rose pink, shaded crimson and amber. Very large and handsome.

QUEEN'S SCARLET. A rich velvety scarlet, very bright and handsome.

CHARLES LA GRADY. A first-class rose of sterling value: makes beautiful buds and large handsome flowers Color fine chamois-red, passing to violet-crimson; a great bearer.

LÚCULLUS, THE BLACK ROSE. Splendid, large rich crimson, extra full and fragrant, very double and a con stant and profuse bloomer. Excellent for bedding and garden culture.

CEARLES ROVOLLI. Always admired for its splendid buds, which are extra large and elegantly formed, colo creamy white, tinted with lemon, the centre sometimes rosy blush.

LA FRANCE. Buds and flowers of lovely form and cood size; exceedingly sweet; color fine peach blossom clouded with rosy flesh.

BRIDESMAW. Fine large, full flowers, delightfully tea-soented, clear rose-pink with crimson shading. A good healthy grower, makes elegant buds; one of the best for cut flowers.

Price, 10c. each, or any 6 for 50c., or the set of 13 for $\$ 1.00$, postpaid ; 2-year-old, 30c. each ; any 6 for $\$ 1.50$, or 13 for 83.00, by express, at purchaser's expense.
RAMBLER ROSES

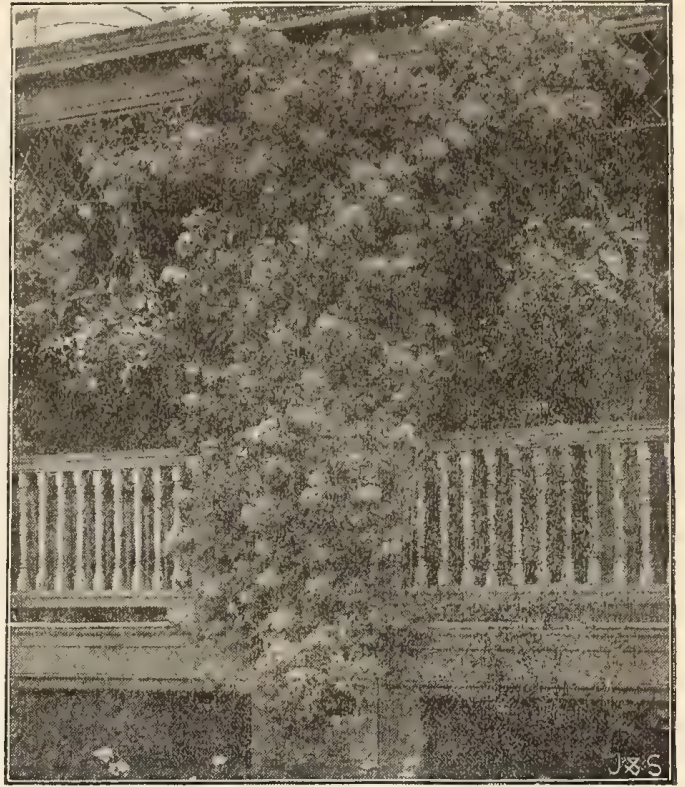

NEW CRIMSON "RAMBLER, "PHILADELPHIA."

\section{The New American Crimson Rambler "PHILADELPHIA"}

The Philadelphia Crimson Rambler is the product of Crimson Rambler and the splendid hybrid perpetual rose, Victor Hugo, one of the best and most brilliant of the hybrid perpetual class, and it is recommended strongly both for outdoor planting and for forcing.

The "Philadelphia" Crimson Rambler differs from the old variety in three imprrtant particulars: (1) The color is brighter, deeper and more intense; (2) the flowers are perfectly double to the centre, very durable and of excellent gubstance; (3) the blooms are almost entirely free from the fubstance; (3) the blooms are almost entirely free from the faded or washed-out appearance so frequently seen in the
flowers of the old kind. It is a good, healthy grower, a free and abundant bloomer, producing grand clusters of intensely brilliant, perfectly double flowers. 20c. each: 2-year, by express, 40c.; 3-year, $\$ 1.00$

DOROTHY PERKINS. This is a splendid new hardy climber, grows 10 to 15 feet in a season, blooms in immense clusters like the Crimson Rambler, but the blooms are more double and of a beautiful shell-pink passing to deep rose; makes large-pointed buds and is a very pleasing and satisfactory rose for general planting. Price, 20c. each; 2-year, 40c.

ELECTRA. A hardy yellow climbing rose, has long been greatly desired by rose lovers everywhere. This one comes highly recommended by the English growers, who claim that it is a strong, rapid grower and very free bloomer bearing large double yellow roses in great profusion, and undoubtedly the finest hardy yellow climbing rose yet produced. Price, 25c. each; 2-year, $50 \mathrm{c}$.

Set of 3 Climbing Roses, as above, 50c., post-

paid; 2-year size, 81.00 , by express at purchaser's expense.

CRIMSON RAMBLER. As we become more ac quainted with the sterling qualities of this crimson beaut we find we have not praised it to the full measure of it deserts. No garden or yard should be without it. 15c. each 2-year, 35c; ; strong 3-year, 80c.

ROYAL CLUSTER, OR WHITE RAMBLER. This fine new rose is an entirely hardy cluster rose; a strong. growing climber, a most profuse bloomer and the clusters are remarkably large. The color is a rosy white, changing to white. The stamens are prominent and are a bright yeliow, a striking feature $15 \mathrm{c}$.

NEW YELLOW RAMBLER (Aglaia). An absolutely hardy yellow climbing rose. The blossoms are of moderate size and last three to four weeks without fading, and are fre quently borme in clusters of from 120 to 150 flowers. $15 \mathrm{c}$ each ; 2-year, 35c.; strong 3-year, $80 \mathrm{c}$

NEW PINK RAMBLER. Color a clear light red, with numerous golden anthers. A very profuse bloomer and vigorous grower. 15c. each; 2-year, 35c.; strong 3-year, 80c.

Set of 4 as above, postpaid, $50 \mathrm{c}$

" "4 " " " $"$ "year, $\$ 1.10$ By express, at pur 3-year, 2.40$\}$ chaser's expense. 
NEW TWENTIETH CENTURY STRAWBERRIES

\section{PALMER'S VERY EARLY STRAWBERRY}

This berry was

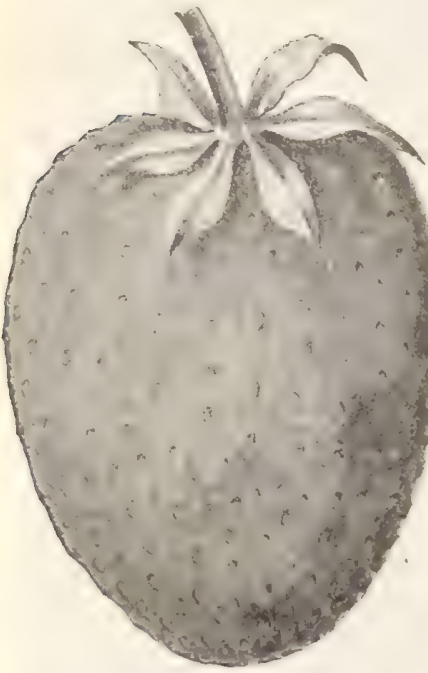

PALMER'S TERY FARLY.

originated by Mr. I. S. Palmer, of Northproves to be the larg proves to be the largest and most beautiberries, perfect bl o o m e r, plants strong a nd robust. fo un fruit stalks to each plant, all of them well filled with large berries. Berries are large, rich, dark, are large, rich, dark,
glossy red, perfectly glossy red, perfectly conical, with flesh berry is a fountain of juice. The cut shown is exact size. The largest, best-shaped and most beautiful extra early berry ever known in proever known in prorank with Crescent, Parker, Earl, Glen Mary, Haverland and other great yiolders. It ripens fully ten days ahead of Mitchproduces tw a and el Early, Johnson Early and Excelsior.

Price by mail, postpaid, 50c. per dozen; by express, $\$ 1.25$ per 100; $\$ 8.00$ per 1,000. BLACKBERRIES ELDORADO. New; very hardy; no core. Very sweet,
with the flavor of the wild berry. Prolific and of good size. Postpaid, 10c. each; 65c. per dozen. By express, 50c. per dozen; $\$ 2.50$ per 100 .

ERIE. Hardy; productive: large and of good quality. Postpaid, 10c. each; 65c. per dozen. By express, 50c. per dozen; \$TTATINY. Very large, medium to late. Not hardy north of New York City. Postpaid, 10c. each; 65c, per dozen. By express, 50c. per dozen; $\$ 2.50$ per 100

LUCRETIA. The old standard dewberry. Postpaid 6.7. per dozen. By express, 50c. per dozen; $\$ 2.50$ per 100; 815.00 per 1,000 .

\section{CURRANTS}

NEW "CHAUTAUOUA" CCLMBING CURRANT. Something new and very tine. Can be trained over trellis or fence. Rapid grower and very prolific. Large dark red fruit, conce. Rapid grower and very prolific. Large dark red fruit, preserving or table use. Price, postpaid, \$1.00 each. By express, \$10.00 per dozen.

PRES. WICDER. In size of bunch and berry, color and quality of fruit, the Wilder is much superior to Fay's Prolific. Price, postpaid, \$1.15 per dozen. By express, \$1.0 per dozen; $\$ 6.00$ per 100 .

CHER RY. Large red. 2-year, postpaid, $\$ 1.15$ per dozen. By express, $\$ 1.00$ per dozen; $\$ 3.00$ per $100 ; \$ 25.00$ per 1,000

FAY's PRoLIFIC. 2-year, postpaid, 81.15 per dozen. By expres8, $\$ 1.00$ per dozen; $\$ 3.00$ per $100 ; \$ 25.00$ per 1,000 .

\section{OOOSEBERRIES}

INDUSTRY. An English sort. Fruit dark red, large and of good quality. Season early.

DOWNING. Large, light green; suitable for family use or for market.

Prices, postpaid, 15c, each; $\$ 1.15$ per dozen. By express, $\$ 1.00$ per dozen; $\$ 4.00$ per $100 ; \$ 0.00$ per 1,000 ,

\section{RASPBERRIES}

\section{Red Varieties}

MILLER. Large bright red berry, holding size until end of season; does not fade; small core, very firm. Price, postpaid, 45\%, per dozen. By express, 30c. per dozen; $\$ 1.00$ per 100; \$8.00 per 1,000.

CUTHBERT. The old standard and hard to beat; very Miller.

\section{A Yellow Raspberny}

GOLN QUEEN. Seedling of the Cuthbert. Very lent quality. A fine garden berry Postpaid 65c per dozen. lent quality, A fine garden berry. Postpaid, $65 \mathrm{c}$. per doze
By express, $50 \mathrm{c}$. per dozen; $\$ 1.50$ per $100 ; \$ 10.00$ per 1,000 .

$$
\text { Black Cap Varieties }
$$

CUMBERLAND. The business Black Cap. Fruit very large, wonderfully productive aud absolutely hardy. Early. Price, postpaid, 15c. each; 75c. per dozen. By express, 60c. per dozen; $\$ 3.00$ per $100 ; \$ 25.00$ per 1,000 .

GREGG. The standard Black Cap. Profitable market sort. Postpaid, 10c. each; 45c. per dozen. By express, 30c. per dozen; $\$ 1.00$ per 100; $\$ 8.00$ per 1,000 .

\section{OOM PAUL.}

The new strawberry, OOM PAUL, is a wondcr. Stupen dous in size and delicious in flavor, nice shape, elegant color. sh ip ping the best. The plant is a very rank grower. Another 8 trong point in favor is that the last picking never runs $8 \mathrm{mall}$. Very prolific; in shape inclined to Jessie. The berries are giants. Single plants yield a full quart. A -six berries filled a quart box, for which $\$ 10.00$ was paid at our Field Neeting, June $15,190 \mathrm{l}$. On e hu $u$ red an

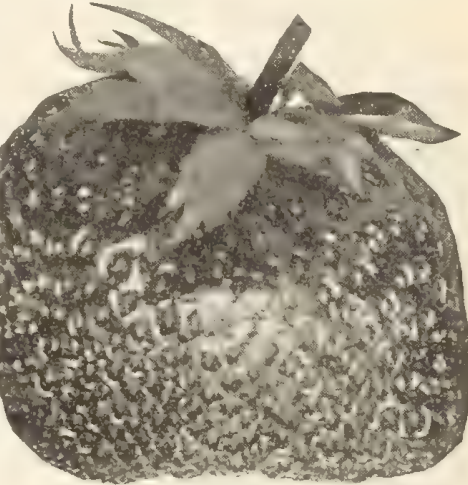

OOM PAUL, BIGGEST OF ALL. forty quarts were picked from two hundred and eighty OOM PAUL plants at one single picking. Price, postpaid, 50c. per dozen; by express, $\$ 1.25$ per 100; $\$ 8.00$ per 1,000 .

\section{NEW CHELLIE STRAWBERRY}

This berry originated in Camden County, N. J. The plant has a perfect blossom, is a strong grower, free runner, clear of rust, very productive, and a sure bearer, the fruit ripening midseason to late. The large, symmetrically shaped berry, with a fresh green calyx, is a bright, glossy red; color ing all over, and having no green point, it presents a strikingly attractive appearance throughout the season. It is of firm texture and superior flavor, resembling that of the wild strawberry. Price by mail, postpaid, 40c. per dozen. By express, $\$ 1.00$ per $100 ; \$ 7.00$ per 1,000 .

\section{THE MAXIMUS}

we find to be one of the largest and most beautifu of all strawberries. Perfect bloomer; plant strong and robust. Produces two and four fruit stalks to a plant, all of them well filled with large to very large berries. Berrie conical, deep glossy scarlet; flesh pink, sometimes white a the centre, very tender, of mild flavor.

GLEN MARY. Very vigorous, perfect blooming plant of Brandywine and Isabel type Enormously productive o large to very large, bright, deep red berries. Yellow seeds on surface; flesh very firm. Light red clear to the centre: sweet, rich and high-flavored; $\mathbf{a}$ decidedly good berry in point of plant, yield, great size, fine form, bright color, firmness and good quality.

BISMARCK. Perfect flowering. A new and vigorous seealing of Bubach. Plant very vigorous, fruit stalks very seealing of Bubach. Plant very vigorous, fruit stalks very the berries are large to very large. Light scarlet color and glossy.

MARSHALL. (Mfidseason.) The berries are very beau. tiful and average extraordinarily large - often fourteen will fill a quart measure. As a berry for home use it is peerless. It is the first of the extra larce varieties to ripen, and al. though of great size, the fruit is rarely ever misshapen. The color is a rich glossy crimson that every one admires.

BRANDYWINE. (Midseason to very late.) Brandywine is already world-famous; in fact, we doubt if any strawberry ever before has received such enthusiastic praise over so wide an extent of territory. The berries are of large size, glossy scarlet, very firm, solid and shapely, of delightful aroma. rich, juicy and luscious, and wonderfully productive

"THE GANDY." (Late.) One of the best late strawberries ever introduced. Strictly fancy. The fruits are uni formly large, perfect in form and firm; color, bright crimson and as glossy as if varnished. Quality superb; delightful aroma, suggestive of both strawberries and peaches.

BUBACH, No. 5 (P). (Midseason.) A prominent straw berry grower says: "If all varieties were culled out but ten, he would place Bubach, No. 5, at the head of the list on account of its large, bright berries, immense yield and fine flavor."

\section{PRICES ON THE ABOVE SEVEN VARIETIES}

By mall, postpaid, $40 \mathrm{c}$, per dozen; $\$ 1.50$ yer 100 . By express, 25c. per dozen; $\$ 1.00$ per $100 ; \$ 6.00$ per 1,000 


\section{FRUIT AND}

APPLES, by express only

Plant 30 feet apart, 48 trees per acre

Starr. Large, pale green fruit. Fruits young. Early from July to September. Good for eating and cooking

Mammoth Black Twig. A fine winter apple. A seed. ling of the Winesap, which it resembles, but is superior in many ways.

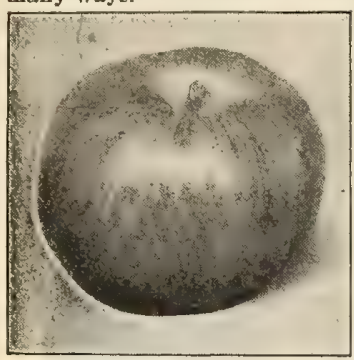

Bismarck. Fruit beau tiful golden yellow, large, bears young and profusely. Early; good keeper. Good for cooking.

Gravenstein. Large, yellow, striped beautiful, tender, sub-acid.

Yellow Transparent. Skin clear white, changing to pure yellow when fully ripe. Tender, juicy, early.

Red Astrachan. Large BEN̄ DAVIS APPLE. summer red.

Orange Pippin. Yellow autumn sort. Maidon Blush. Beautiful blush cheek.

Baldwin. Crisp, juicy, winter red.

Ben Davis. Striped winter.

Willinm's Early Red. Good for cooking or eating.

Rome Beauty. Pale yellow, shaded red winter.

PRICE of any of the above apples, except where noted : 85c. each; 83.50 per dozen; $\$ 25.00$ per 100.

\section{CHERRY TREES}

Black Tartarian. Large, black, sweet and early.

ox-heart. Large, light, with red cheek; solid, meaty, ecellent.

Napoleon Bigarreau. Very large, pale yellow, with bright red cheek. Firm, juicy, good flavor.

Early Richmond. Red pie cherry.

Montmorency. Large, bright red, late. Larger than Early Richmond.
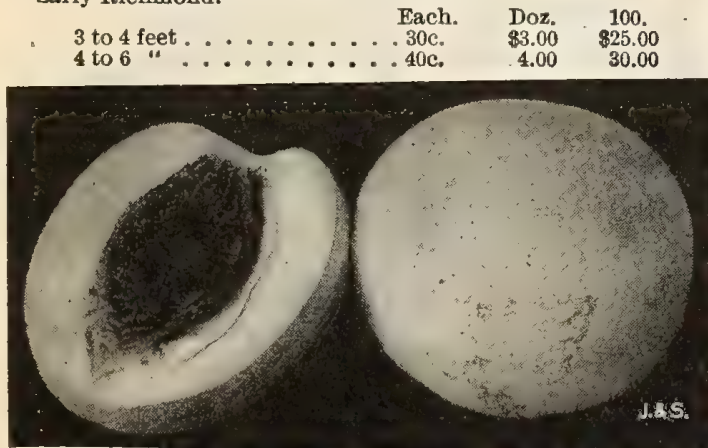

TRIUMPH PिACH.

PEACHES, by express only

Plant 16 feet apart each way; 170 trees per acre.

sneed. A new early peach; a grand sort. Large, beauliful red on sunny side; flesh white; very sweet and juicy bears shipping well.

Triumph. The earliest yellow freestone yet introduced. Large size and small pit.

Crosby. Free dwarf. Fruit yellow, streaked crimson with very small pit, Free.

Wonderful. Large, rich, yellow; a good keeper; very late freestone.

Mountain Rose. Freestone; pink flesh.

old Mixon. Creamy white; popular.

Stump the World. White, red cheek.

Crawford's Late. Best late, yellow; free.

Late Heath Cling. Best white cling.

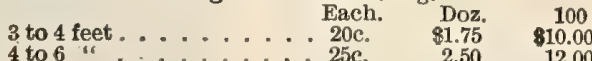

ORNAMENTAL SHADE TREES AND EVER * GREENS

Send for our special catalogue of Ornamental Shade Trees and Evergreens and Hardy Shrubbery, Hedge Plants, etc.

\section{NUT TREES}

PEARS, by express only

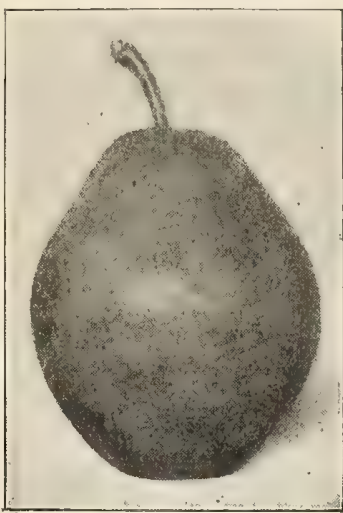

KEITFER PEAR. Price of above pears: 2 -year, 4 to 6 feet Extra 3-jear ....30c. \$3.00 \$20.00

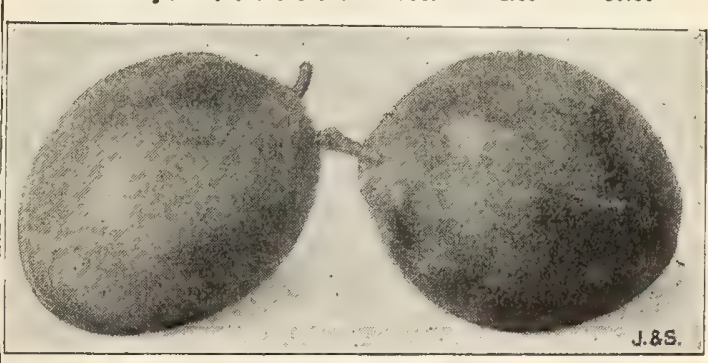

ABUNDAKCE PLUM.

\section{PLUM TREES}

Satsuma. Japanese variety, medium to large in size color very dark dull red all over, with greenish dots.

ogon. Golden yellow, good quality, freestone.

Abundance. Rich yellow with blush red cheek. Flesh deep yellow, very prolific.

Burbank. Orange-yellow, overlaid with red. Later than Abundance

Willard. Earliest plum on the list. Medium size, round, dark red, splashed yellow

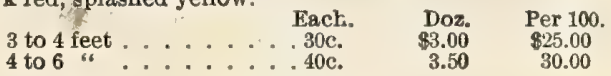

\section{GRAPES}

McPike. Wonderful new white grape. Very superior in quality. Perfectly hardy. Earlier than Concord. Bunches large; berries mammoth. Fruit will keep 100 days on the vine in good condition.

Moore's Early. Very early, large black grape; skin hin, flesh sweet.

Concord. The standard black grape. Berries large, skin thin. Tender, juicy, sweet

Niagara. The favorite white grape. Very prolific. Handsome bunches, good shipper.

Catawba. Dark red, medium-size berry, skin thick, flesh pulpy and of best quality.

Delaware. Small red berry, compact bunches, skin thin, but firm; juicy and very sweet

PRICES of any of above Grapes:

1-year-old, 15c. each; $\$ 1.50$ per dozen; $\$ 5.00$ per 100.

\section{NUT TREES}

The culture of nuts has becone very profitable, and large orchards are being put out to good purpose.

\section{CHESTNUTS}

Alpha. Very early, large size. $75 \mathrm{c}$. each; $\$ 8.00$ per Paragon. Later, large and fine. dozen; $\$ 25.00$ per 100 . Walnuts, Pecans, Shellbarks, Filberts, Almonds, Butternuts, $40 \mathrm{c}$. each ; $\$ \hat{0} .00$ per dozen. 


\section{INSEGTIGIDES. Spray Your Fruit Trees}

The annual loss to farmers in this country from fungus diseases and insects has been closely estimated at $\$ 5,000,000$. So important have these things become that the United States Department of Agriculture, at Washington, has two of its most important divisions investigating them. One is called Vegetable Pathology, under Professor Galloway; this pertains to Plant Diseases, such as blight, rots, mildew, etc. 'The other is called Entomology, under Prufessor Riley, which pertains to Insects $\rightarrow$ both divisions carrying on investigation as to the cause and effects, and making experiments and recommendations for the benefit of farmers, gardeners, horticulturists and florists.

We have a full line of both insecticides and implements for applying them. (Send for our "Spraying Outfit" Circular.)

\section{INSECTICIDES}

APHIS PUNK. A preparation of nicotine in most convenient form for killing insect life on plants and fovers whinout injuring sensitive blooms or foliage. $60 \mathrm{c}$. per box of 12 rolls

BOHDEAUX MUXTHE. For black rot, mildew or blight. In liquid form. Ready for use by adding vater. One gallon of mixture makes 50 gallons. Price, 1 quart can, $15 \mathrm{c}$; 1 gallon can, $\$ 1.25$

COPPER SULPHATE for early spraying and making Bordeaux Mixture. Lb., 15c.; 25 libs., $\$ 3.00 ; 100$ lbs. \$10.00

FIR TREE OIL. For mealy bug, red spider, scale, thrip, green fly, etc. $1 / 2$ pt, $40 \mathrm{c} ;$ pt., 75c.; qt., $\$ 1,25 ; \mathrm{gal}, \$ 1.00$ HELLEBURE. For rose glugs. $1 \mathrm{lb}, 25 \mathrm{c} . ; \mathbf{~ l b s . ~} \$ 1.00$

LNSECT NOWDER. (Persian.) For ants, roaches, fleas, etc. $1 / 41 \mathrm{~b}, 15 \mathrm{c}$; $1 \mathrm{~b}, 50 \mathrm{c}$.

Concentrated for pea louse, San Jowe scale and all sucking insects, 1 quart cans, $35 \mathrm{c}$. 1 gallon cans, $85 \mathrm{c}$. tle; 75 c. per quart.

LEMON OIL. Fur mealy bug, scale, thrip, etc. $1 / 2$ pint, 25c.; pint, $40 \mathrm{c}$ - quart, $7.5 \mathrm{c}$

LONDON PURPLE. Lb, 20c.; $51 \mathrm{hs}, 90 \mathrm{c}$

PARLS GREEN (Pure). Lb., 20c.; 5 los., $90 \mathrm{c}$

PILLAR C ITTER. For preventing insects crawling up trees. Invilumble for the Elu Beetie. Per yard, 150

ROSE LEAF EXTRACT OF TOBAOCO. Pt., 25e.; qt.

$51 \mathrm{c}$ : 1 gal. $\$ 1.25$.
SLOG SHoT. For potato bugs, cabbage and currant worms. 5 ibs., $25 \mathrm{c}$.; per 100 lbs., $\$ 3,50$.

TOFACCO DEST. Pure ground tobacco (not ground stems). Per lb.,5c.; per 100 lbs., $\$ 2.50$

TOBACCO STEMS. Per bale of about $250 \mathrm{lbs}, 81.50$; per ton, $\$ 10.00$

WHALE OIL SOAP. For washing treeg and for insects on tender plants. $1 \mathrm{lb}$. box, 15c; $51 \mathrm{bs}, 10 \mathrm{c}$. per ib.

"WEEDICIUE." For killing weeds in walks, drives, ete. One gallon pail makes 20 gallons tregting liquid, 75c; 2 gallon puil, $\$ 1.25$.

\section{HAZLETINE'S NIGHT MOTH CATCHER}

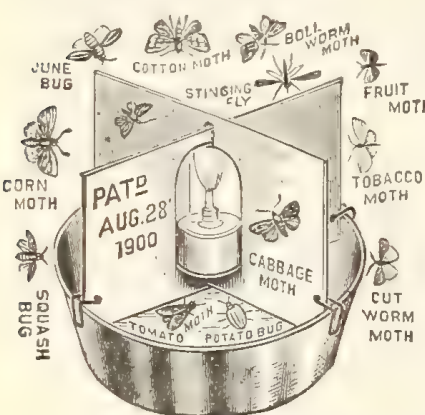

Is a night torc with reflector, that attracts the moths that fly at night. They strike the tin refiector and drop down into the pan of kerosene oil.

hills the mother of the APPLE and PEAR W O R M T HE CODLING MOTH, also the stinging insect that stings the truit, the TENT CATERPILLAR and the BORER BEETIF. Price, without pan, 85c.

\section{LIGHTNING INSECT SPRAYER}

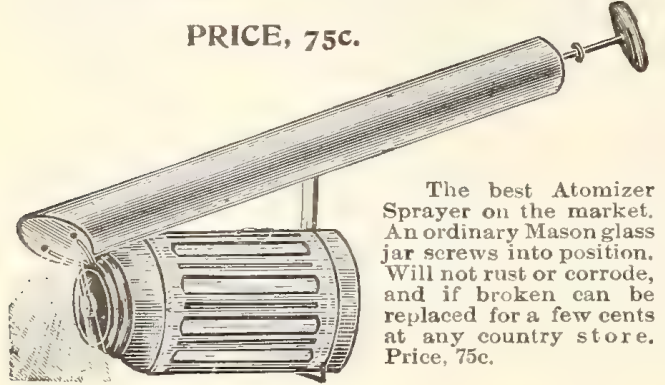

\section{EMPIRE KING SPRAY PUMP}

This is a large, powerful pump for the largest orchard work. Has a seamless birass cylinder, $2 \frac{1}{2}$ inches inside diameter, yinches long, with solid briss plunger and rod, brass valves without leather or rubber. His two Eureka nozzles on two tenfoot sections of heavy hose, so two rows of trees or vines can be sprayed at one time. Has mechanical agitator and all brass working parts. Price, $\$ 1200$

\section{LEGGETT'S PARIS}

GREEN GUN

For applying dry powders, suek as Paris green, on plants, the powder being evenly distributed over a wide space. The reservoir holds 4 pounds of Paris green (ox over a quart of other powder), and by a rapidly re-

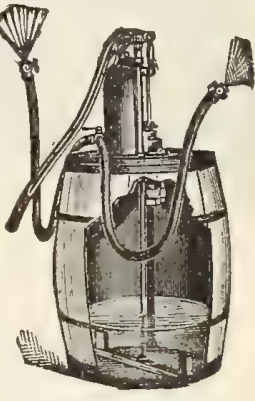

EMPIRE KING PUMP WITH AGITATUR. green without the necessity of mixing it with plaster. It can be gauged to throw any amount per acre desired. Will do two rows of potatoes at once. Price, $\$ 7.50$ each.

\section{THE BLIZZARD AIR PRESSURE SPRAYER}

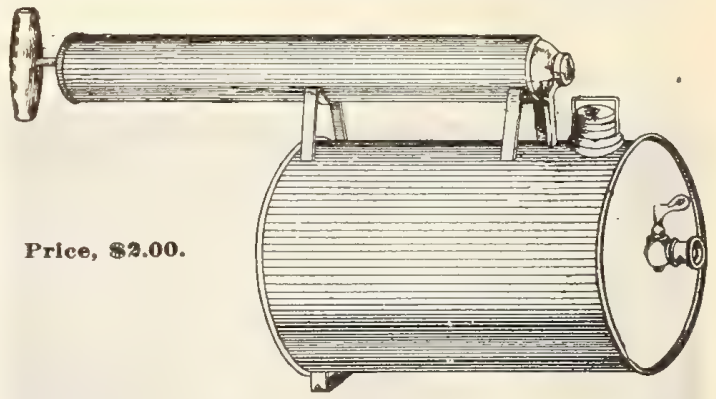

This is the best and most complete and up-to-date line of sprayers on the market. They are very quick and easy working sprayers. You put in the liquid, pump a few strokes with the air pump, and then open the cock and the air pressure does the rest. They will spray your fruit trees, tobacco, grape or potatoes, whitewash your poultry houses, etc. They will throw a broad mist-like spray or a coarse Bordeaux spray, or a straight strean.

\section{PRICE LIST}

1 gal, (see cut), galvanized tank, $\$ 2.00$ copper tank

galvanized tank

copper tank

double cylinder, galvanized

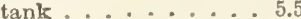

4 " double cylind., copper tank, 7.50

\section{ASBESTOS TORCH}

A ball of Asbestos in wire guard, and made to attach to a pole. Soak the Asbestos in kerosene and let flam burn off nests of eaterpillars. Writl
burn for half an hour. Price, $30 \mathrm{c}$. burn for half an

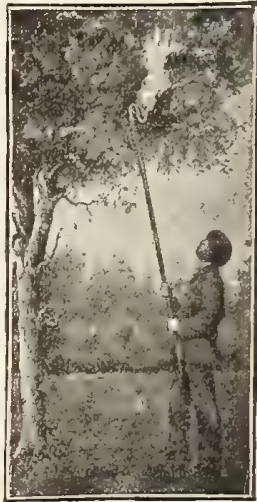

Asbestos TOROH. 


\section{HIGH GRADE FERTILIZ \\ For the Farm, Lawn, Garden and Greenhouse}

\section{WRITE FOR SPECIAL PRICES IN QUANTITY}

ASHES (Canada Unleached Hardwood). Indispensable as a lawn dressing, or to apply to orchards. They should be applied late in fall or early in spring, so that the rains and snows may leach the ashes and carry the elements down to the roots of grass or trees. These contain all of the fertilizing elements except nitrogen. They drive away insects, and are indispensable for all crops requiring potash. Apply about 1000 lbs. to the acre. Per 100 lbs., $\$ 1.50$; bbl. of 250 lbs., $\$ 2.50$; ton of 2000 lbs., $\$ 18.00$.

GROUND BONE. In fertilization nothing takes precedence in importance over animal bones, because they furnish the soil with the essential requisite of nitrogen as well as phosphoric acid. The most substantial fertilizer for lawns and plants. It keeps on feeding the soil for fully ten months. 3-lb. box, 15c.; 5-lb.bag, 25c.; 10 lbs., 40c.; 25 lbs., 75c.; 100 lbs., \$2.00; sack of $200 \mathrm{lbs}$., $\$ 3.50$; ton, $\$ 30.00$.

BONE FLOUR. Ground perfectly fine; an excellent fertilizer for pot plants or beds where an immediate effect is wanted. 5 lbs., $25 \mathrm{c}$.; 100 lbs., $\$ 3.00$; bbl. of 200 lbs., $\$ 5.00$; ton, $\$ 45.00$.

No. 1.-BONE PHOSPHATE. This is the leading ammoniated phosphate. A perfectly pure and bigh-grade article, and the best for general purposes. In making new lawns or golf links this brand is one of the best for immediate effect. 5 lbs., 25 c.; 100 lbs., $\$ 2.00 ; 200$ lb. bag, $\$ 2.50$; ton, $\$ 23.00$.

J. S. PLANT FOOD. Made especially for plants grown in conservatory, house or garden. Clean, free from offensive odor. Full directions with each package. Package, 15c. ; by mail, $25 \mathrm{c}$.

CLAY'S FERTILIZER. Imported manure especially recommended for flowers or vegetables, to bring the highest perfection. Should be used in potting soil, and spread on staging of greenhouses planted with flowering plants. Per bag of 25 lbs., $\$ 2.00 ; 50$ lbs., $\$ 3.50 ; 100$ lbs., $\$ 6.50$.

COTTON SEED MEAL. $\$ 2.00$ per $100-1 b$, sack $\$ 25.00$ per ton. Special price will be quoted on larger lots.

GILT-EDGED POTATO MANURE. Made expressly for white and sweet potatoes and tobacco. Has great power to retain moisture. Keeps tubers clean and smooth. Per 200-1b. bag, $\$ 3.25$; per ton, $\$ 29.00$.

KAINIT (German Potash Salt). One of the most useful ingredients for making "Commercial" fertilizers or using alone. Apply at the rate of $1000 \mathrm{lbs}$. per acre. If used on lawns it should be spread during winter. 100 lbs., $\$ 1.50$; 200 lbs., $\$ 2.50$; per ton, $\$ 14.00$.

LAND PLASTER. Excellent for composting, fertilizing or mixing with guano. A tine lawn fertilizer. 100-lb. bag, $\$ 1.00$; karrel, 200 lbs., $\$ 1.50$; per ton, $\$ 10.00$.

LAWN DRESSING (Odorless). A scientific food for lawns. Guaranteer, $10 \mathrm{lbs} ., 40 \mathrm{c}$; 25 -lb. bag, $\$ 1.00 ; 50$-lb. bag, $\$ 1.75 ; 100-1$ b. bag, $\$ 3.00$.

MANURE. We can supply at short notice strictly first-class, clean, short or long stable manure. In carload lots only. Special prices by letter -delivered at your station.

MURIATE OF POTASH. A high-grade fertilizer, and one of the best orchard fertilizers known. Used largely in peach cultivation, and as a general fertilizer. $25 \mathrm{lbs} ., \$ 1.00 ; 50 \mathrm{lbs}$, $\$ 1.75 ; 100$ lbs., $\$ 3.00$.

NITRATE OF SODA. A fertilizer for all crops. It is very quick in action, and hastens maturity of crops fully two weeks. Being extremely soluble, it should not be applied until the plants are above ground, when 100 to $300 \mathrm{lbs}$. per acre should be sown mixed with woodashes or land-plaster. Nitrate of soda does not exhaust the land. 5 lbs., 25c.; 25 lbs., $\$ 1.25 ; 50$ lbs., $\$ 2.00$; $100 \mathrm{lbs} ., \$ 3.50 ; 300 \mathrm{lbs} .$, $\$ 9.00$.

POUDRETTE. Native Guano. Contains all the elements necessary for plant life; used extensively among market gardeners. Per 100 lbs., $\$ 1.50$; per ton, $\$ 20.00$

SALT (Agricultural). For top-dressing asparagus beds. Apply very early in spring, at the rate of 800 to $1000 \mathrm{lbs}$. per acre. $200 \mathrm{lbs}$, $\$ 1.50$; per ton, $\$ 10.00$.

SHEEP MANURE (Pulverized). This is a pure natural manure and the most nutritious food for plants. One of the best manures to mix with soil for potting plants-one part manure to six parts soil. For vegetable garden, placed directly in hills or drills, it promotes a rapid, steady growth until maturity. As a lawn topdressing it is unequaled. 5-lb. package, 25c.; 10 lbs., 40c.; 50 lbs., $\$ 1.50 ; 100$ lbs., $\$ 2.50$.

TOBACCO STEMS. This has become an indispensable lawn covering for winter. It not only acts as a protector, but imparts Iarge quantities of ammonia, and drives away insects and moles, which harbor in a lawn during winter. Bbl., $\$ 1.00$; bale of about 250 lbs., $\$ 1.50$. 


\section{TWINES}

(Prices subject to market changes.)

Pot Herb White Cotton Twine. Per lb., 25c, 5-lb. bag, 81.20.

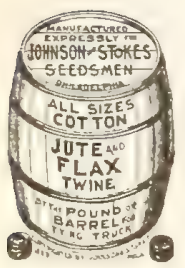

Celery Cotton Twine, 5 and 6 PIy. Per lb., 25c.; 5-1b. bag, \$1.10.

Coarse Cotton Twine. For beets, carrots, etc. 20c. per lb.; 5-lb. bag, 90c.

Jute Twine, 2,3 and 4 ply, of very finest quality. 15c. per lb.; 5-lb. bag, $60 \mathrm{c} . \$ 11,00$ : per $100 \mathrm{lbs}$

Onion or Flax Twine, For celery and onions, 2 and 3 ply. $25 \mathrm{c}$. perlb.; 5-1b. onions. 2 and 3 ily. 25 c. per

Tarred Rope or Fodder Yarn for tying corn fodder, and for nursery purposes. Pure Manila fibre. 10c. per Ib.; $\$ 3.00$ per 100 iths.

Celery Wire for wiring celery. 80c. per stone (12 lbs.).

\section{SILKALINE}

Indispensable for stringing asparagus, smilax and other climbing greenhouse plants, silkaline is the very thing so long needed.

Green Silkaline is fast color and will not fade; is very atrong and will not break down. Coarse or fine, put up on 2-oz. spools, 8 in a box, $16 \mathrm{oz}$ of silkaline guaranteed. Price, 81.25 per 1 b.: perspool, 20c. Silkaline is also used for bouquet and general florist work. In three weights, F, FF and FF F. For stringing asparagus use the FFF.

\section{RAPHIA}

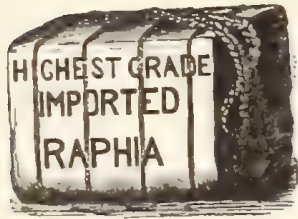

Large asparagus growers find this substance to give better satisfaction for tying asparagus into bunches than anything else they can get. It is light, strong, neat, durable and cheaper than any other tying material made. Useful for tying plants, vines, etc. Per 1 b. $15 \mathrm{c}$. 10 lbs. $\$ 1.25 ; 100$ lbs., $\$ 11.00$; per bale

of about 220 lbs., $10 \mathrm{c}$. per lb.

\section{SUNDRIES}

Peat (Jersey) ..................... per bbl., \$1.25 Mo88, Sphagnum

1 bale, 3.25

Paper for Banking Celery (Outdoors). "Per roll, 85e.; rolls, $\$ 4.00 ; 10$ rolls, $\$ 7.50$; per ton, $\$ 35.00$

Grafting Wax, $1 / 1 \mathrm{~b}, 10 \mathrm{c}, 1 / \mathrm{lb}, 15 \mathrm{c}$; $1 \mathrm{~b}, 25 \mathrm{c}$

Wax Paper. For lowers. Per 1b., 15e; per ream, \$2.00,

\section{PLANT, POT AND TREE LABELS}

Labels quoted below are first quality, painted on one or both sides as preferred, and put up in packages of 1000

PRICE LIST

Per 1000

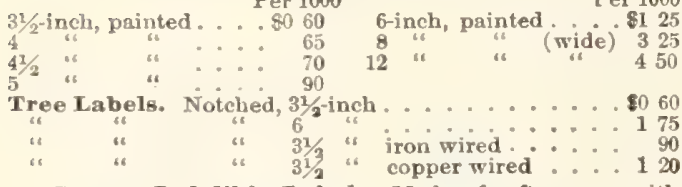

Copper Indelible Label. Made of soft copper with copper wire. Name is indented by a stylus, which is fur-

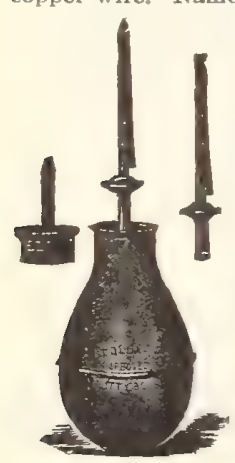
nished free rith each 100 labels. Price, per dozen, 15c; per $100, \$ 1.00$.

Scollay's Putty Distributor

The best appliance for distributing putty. It has been used by a large number of the leading florists, who have proven its merit. $75 \mathrm{c}$. each; 89.00 per dozen; by mail, $85 \mathrm{c}$, each.

\section{Scollay's Hand Sprinkler}

Each .........8075 Each ............... . . . 850

By mail, 85c. each.

\section{THERMOMETERS}

Tin Case. 8, 9 and 10-inch, 15c, each \$1.25 per dozen.

Distance. 20c, each; 82.00 per dozen.

\section{PLANT BED CLOTH}

A SUBSTITUTE FOR GLASS SASH ON HOT BEDS AND COLD FRAMES AND THE LIGHT GRADE FOR SHADING GREENHOUSES

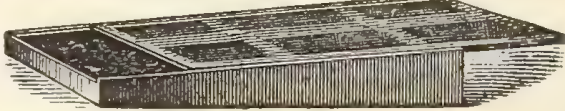

This will be found an excellent substitute for glass (at one-tenth the cost) in protecting all kiuds of seeds and plants on which glass sasbes are used in early swring. It is safer in fact than glass, as it protects at night, while the temperature is not raised too high during the day-as is the case with glass sashes unless great care is given in ventilutingand being light and portable, it can be sent into section where it would be difficult to get sash. LIGHT GRADE, mostly used in the South for tobrcco beds and in the Nori for shading creenhouses peryard, $4 \frac{1}{\mathrm{c}} \mathrm{e}$. by the piece of 68 yards, 31/ per yard MEDIUM GR A DE the best for eral purposes per yard yard Ho Pen Gate north of Pennsylvania, per yard, $1012 \mathrm{c}$., by the piece of 40 yards, 10c. per yard. One yard wide. Samples mailed on application.

\section{HOT BED MATS}

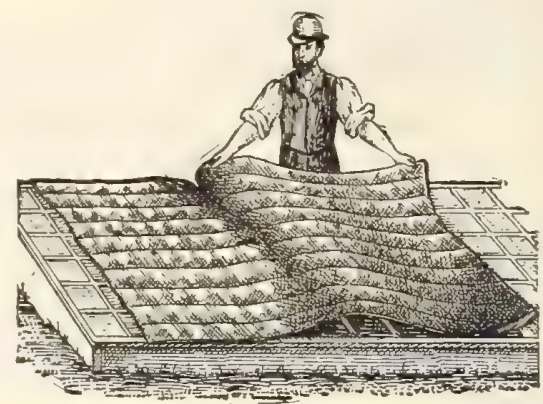

\section{PALMER WOOL-FTLLED BURLAP MAT}

Frost-Proof. Made expressly for winter covering of hot beds, cold frames, plants and seeds of all kinds. Indestructible, Cheap and Warm. Will not harbor mice or vermin. Easily handled. Dry out quiekly after rain. Cost less than old-fashioned straw mats and entirely take their place. Size, $40 \times 76$ inches. $76 \times 76$. $: \$ 080 \quad \$ 900$ per dozen.

\section{RATTAN HOT BED MATS}

Indestructible; frost-proof; made of strips of rattan securely bound with tarred rope.

Size, 6 × 6 feet. Price, $\$ 1.75$ each; $\$ 18.00$ per dozen.

\section{GLAZING POINTS}

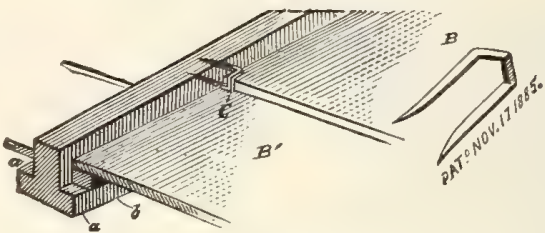

These are made of steel wire and galvanized, having double points and lap over the glass in such a manner as to positively keep it from sliding. They may be used on either side of the sash bar, thus preventing the annoyance of rights and lefts.

Per box of 1000 (by mail, $77 \mathrm{c}_{\text {. }}$. . . . $\$ 060$
Lots of 5000 and over, per box $\ldots 5$
Pincers for driving

\section{GLASS CUTTERS}

Extra quality steel wheel cutters. Price, 15c. each; 81.50 per dozen 
DISINFECTANTS

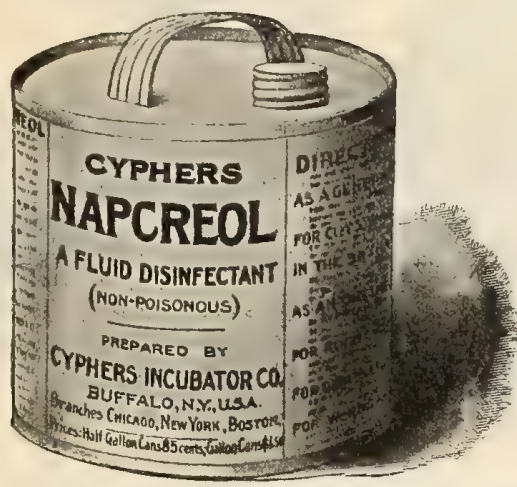

NAPCREOL

A Fluid Disinfectant and Deodorant (NON-POISONOUS)

Napcreal is unexcelled for disinfecting poultry houses and runs, stables, dog kennels, toilets, or any place where a good germ or odor destroyer is needed. One gallon will make 100 gallons of disinfectant.

For Poultry Discases. It is a reliable home remedy for all germ diseases affecting poultry. Its use prevents disease. It will cure roup, diphtheria, cholera, chicken-pox, sore eyes, canker, scaly legs, favus, and diarrhœa. It will destroy disease germs, mange, parasites, fleas, mites, lice, ticks, and worms.

Napcreol is a thoroughly reliable preparation, and is made with as much care as if it were to be used for human beings. It is ready for immediate use by simply mixing with fresh water, and is a safe and sure substitute for poisonous disinfectants.

For Horses and Cattle. Cures cuts, galls, mange, scratches, thrush, cracks, and fissures. Destroys ticks, mites, and other parasites. It is an ideal stable disinfectant; removes odors, prevents flies from breeding, and purifies and sweetens.

For Dogs and Cats or Other Pet Animals. A disinfectant and deodorant. Cures wounds, scratches, and mange. Kills fleas and ticks.

Napcreol is put up in half-gallon and gallon cans, with full directions for use on each package.

Price, half-gallon can, $85 \mathrm{c}$.; gallon can, $\$ \mathrm{I}$.50.

\section{"SANITAS" DISINFECTING SAWDUST}

A clean and effective preparation for use in dwellings, markets, kennels, stables, cattle sheds, poultry houses, and runs. It absorbs offensive moisture, and is very rapid in its action, not only as a deodorizer, but also as an air purifier.

DIRECTIONS FOR USE: This is a very strong preparation, and may be diluted with from one to fifty parts of ordinary sawdust, according to requirements.

Sold in tin cans holding $81 \mathrm{bs}$., $\$ \mathrm{r} .00$; in barrels of about $60 \mathrm{lbs}$., at Ioc. $1 \mathrm{~b}$. ; in barrels of Ioo 1bs., at $9 \mathrm{c} . \mathrm{lb}$.

\section{"SANITAS" DISINFECTING POWDER}

"Sanitas" Disinfecting Powder is fragrant, and stronger as an antiseptic than carbolic acid or any other powder in the market, besides which it possesses also powerful oxidizing properties, thus exhibiting a twofold character not rivaled by any other product.

I-1b. perforated tin box, 25c. ; 70-1b. box, $\$ 4.00$; I5o-1b. barrel, $\$ 7.50$.

\section{OIL OF TAR \\ OR STANDARD DISINFECTANT}

For Fleas on Dogs, for Chicken Cholera, for Roup, Canker, Lice, and Gapes

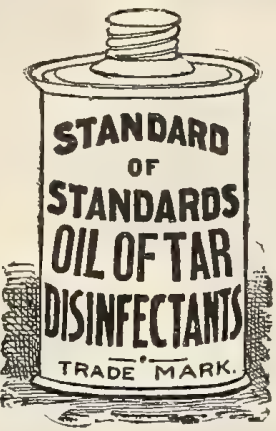

It partakes of the nature of carbolic acid without having its dangerous poisonous and corrosive properties; it is prepared from coal tar, and retains the carbolic acid of the tar in a harmless form ; it mixes with water in any proportion, forming an emulsion, which is handy and pleasant to use.

Simply mix with water (I part to Ioo of water), and use the mixt ure for washing dogs, or for disinfecting your poultry house, or stable, or cow barn. Also a perfect article for sweetening your water closet, drains, etc., and for ridding your buildings of ants, roaches, bugs, etc.

Price, qts., 30c.; $1 / 2$ gal., 55c.; I gal., $\$ 1.00 ; 5$-gal. cans, $\$ 4.00$; lo-gal. cans, $\$ 7.50$.

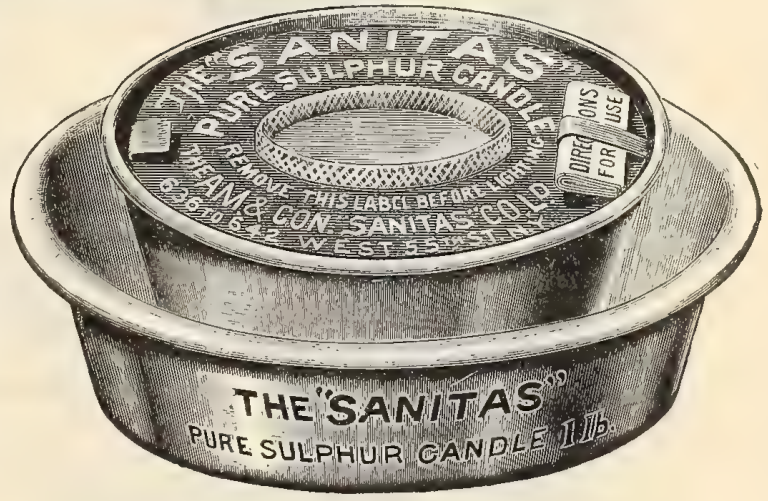

\section{"Sanitas" Pure Sulphur Fumigating Candles WITH WATER JACKET}

For the disinfection of infected rooms, hospital wards, railroad cars, bedding, clothing, and drapery, after cases of diphtheria, cholera, scarlet fever, typhoid fever, smallpox, and other infectious diseases, and for the destruction of disease germs and insect life and vermin in empty rocms, kitchens, stables, kennels, poultry houses, cellars, etc.

The employment of water in connection with burning sulphur is an element of safety from fire, while the vapor produced by its evaporation greatly increases the germicidal power of the sulphur fumes; therefore these candles disinfect more per fectly than any other in the market; they also light more certainly and easily; they may be extinguished at pleasure by covering the tin can with a plate or board.

With water jacket, $25 \mathrm{c}$. each. 

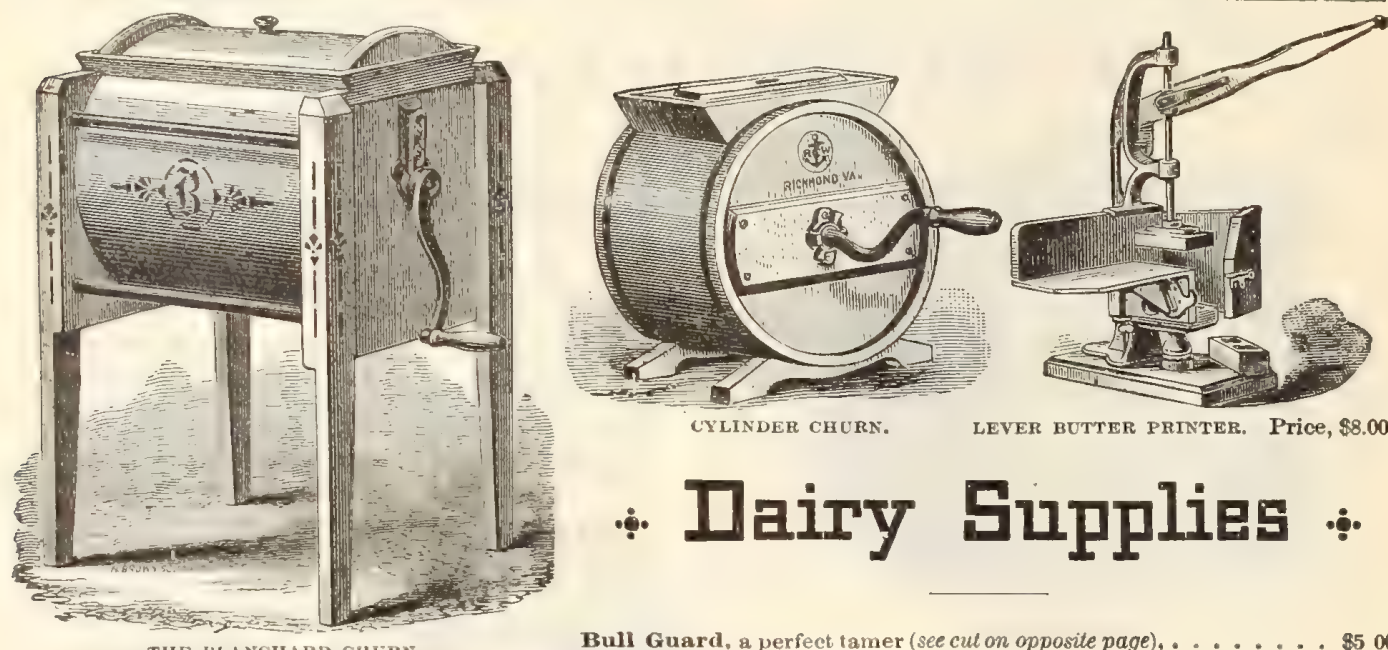

CYLINDER CHURE.

LeVer butter printer. Price, $\$ 8.00$

\section{. Dairy Supplies :}

Bull Guard, a perfect tamer (see cut on opposite page), . . . . . . \$5 00 Leaders, fasten in nose, small, ............. 10

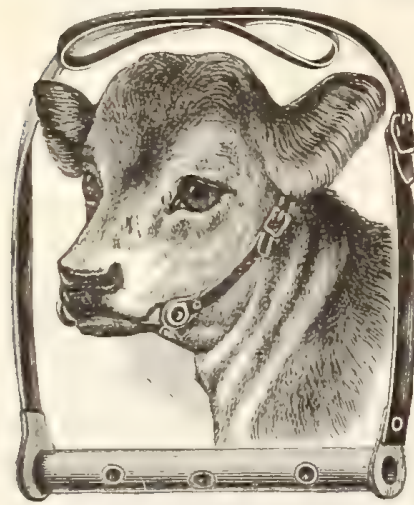

"Rings, copper, 2-inch (see cut), . 20

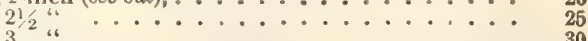

Butter Color, $6-0$ bottles, Moulds, Reid's, . . . . 140 Seeley's, 1/2-1b, 50c.; 1-lb. (see cut), ....... 75

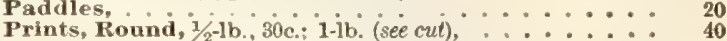
Printex, Lever, either $1 / 2$ or $1 \mathrm{lb}$. $($ see cut $), \ldots . . . .800$ Lafayette," either 1/2-1b, or 1-1b., ..... 1000 Complete with table... 1500 $\$ 1$ extra for initials or monogram. and Cheese Tryers, polished steel, 5-inch, . ....... 110

"4 4 " 6 "..... 135 "Workers, Reid's, No, 4, capacity $10 \mathrm{lbs} . . \cdots 400$ "6 " Calf Feeders, Small's, " 1 , " 50 " ........ 700 Extra Nipples, 25c. each, ............ per dozen, 250 Calf Weaners (also Anti Cow Suckers).

HARTEY'S CALF WEAXER. 40c.
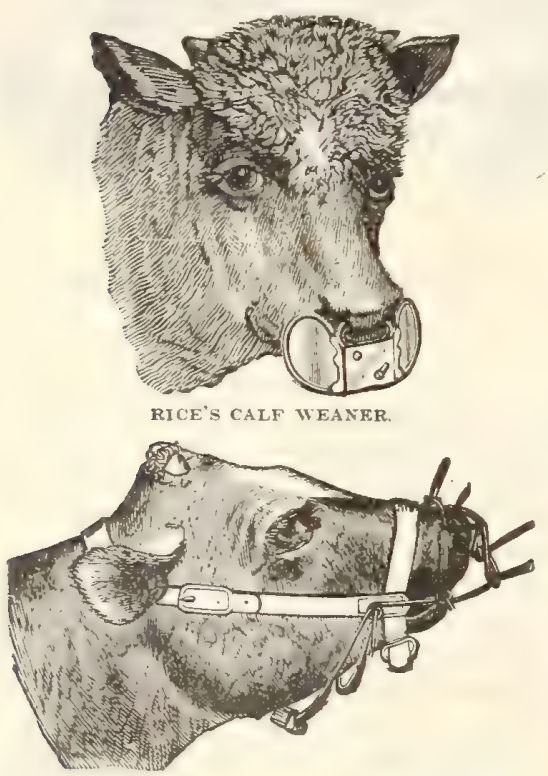

HOOSIER CALF WEANER, SHOWING POSITION

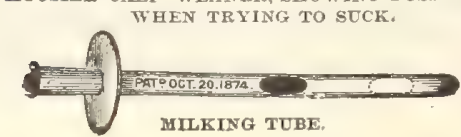

\section{CHURNS.}

Churns, Blanchard, No. 3, 2 gallons (see cut), . . . . . . 400
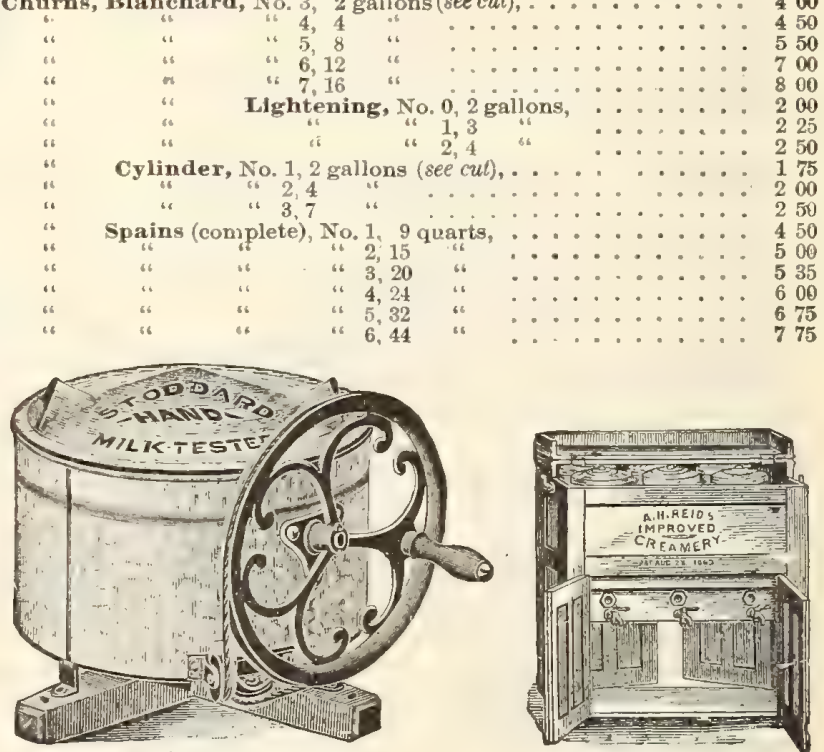

BABCOCK'S HAND MILK TESTER. 4 bottle, complete, $\$ 8.00$.

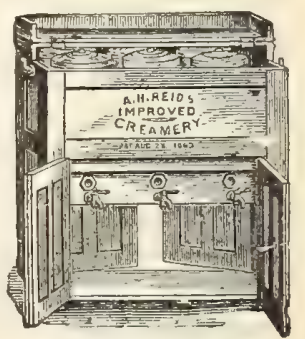

RELD'S PEERLESS CREAMERY. 


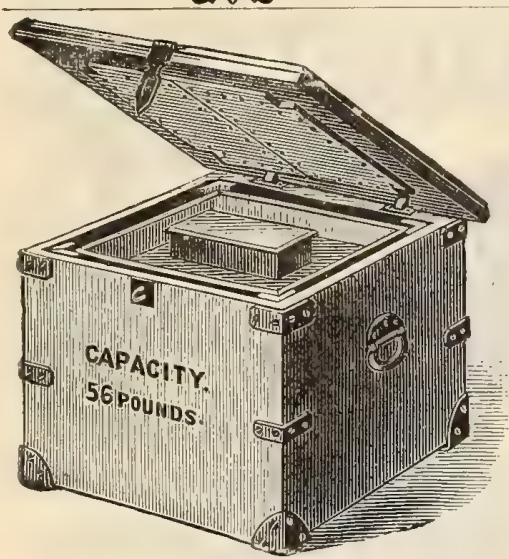

BUTTER SHIPPING BOX.

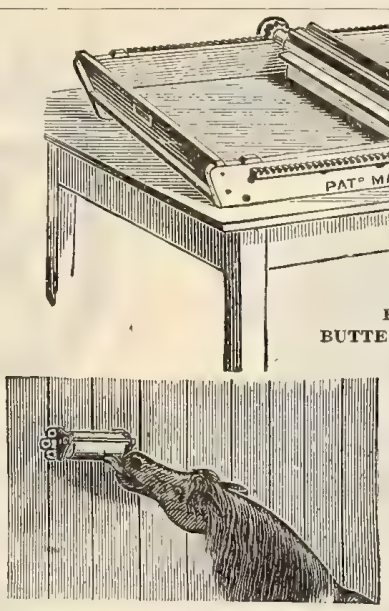

IAIRY SUPPIIES-Continued

Creameries.-Reid's "Peerless."

No. 2,2 cans, 4 to 6 cows $($ See $c u l), \ldots . . . . \$ 2 L 60$ " 3,3 " 7 to 9

" 4,4 " 10 to 12

" 5,6 " " 13 to 18 "

- 4160

Labels, for sheep, hogs and cattle. Stamped with your name and numbered. (See Cut).

For sheep and Нокs, per dozen, 50c; per 100, 250 Punch for above, each

For Cattle, per dozen, $75 \mathrm{c}^{\circ}$ per $100^{\circ} \cdots \cdots, 150$

Punch for above, each,

Lactometers, each, 35c.; by mail, ....... 50

Milk Cans.-Railroad.

20 quart, extra heavy, ........... 300

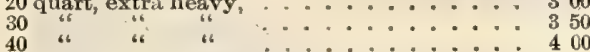

Milking Pail and Stool, "Perfect," . . . . 225

Milking Tubes, silver-plated, three sizes, each, . 30

Ox Balls, for the tips of horns, brass, each, $6 c_{\text {. }}, 8 \mathrm{c}$., 10c. and

30

Parchment Butter Paper. Per 1,000 Sheets. 8 x 8 inches, for $1 / 2$ lb. square prints, . . . \$ $\$ 060$ $9 \times 9$ " 9 " 13 " round ". . . 75 $8 \times 11$ "6 " 1 " square " 1 " sq $10 \times 10$ " " 1 " 1 " round and cot. cheese, 85 $12 \times 1$ " " " " " 130 $12 \times 18$ " " $2 \mathrm{lb}$. square prints, .... 175

Root Cutters, Banner (See cut), . . . . 850

Salt Roll, to fasten to stalls, complete (See cut), . . 50 Extra Salt Rolls, .............. 15

Shipping Butter Boxes.

Capacity, 20 pounds, ............... 275

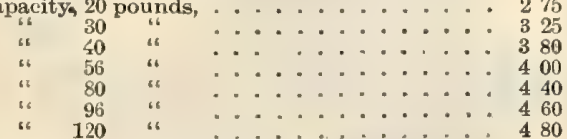

Teat Openers. Humane way of opening obstruc ted teats, .

Thermometers.

Floating Glass Dairy, 15e. each; per dozen, . . 160 Maximum and Minimum, 250 Hot Bed or Mushroom Bed, with brass end, : 150 Wooden Back, red fluid, . . .......... 3

Tin Case, 7 inch, 15c.; per dozen, ..... 150 "6 4 6 10 "6 $18 \mathrm{c}$;

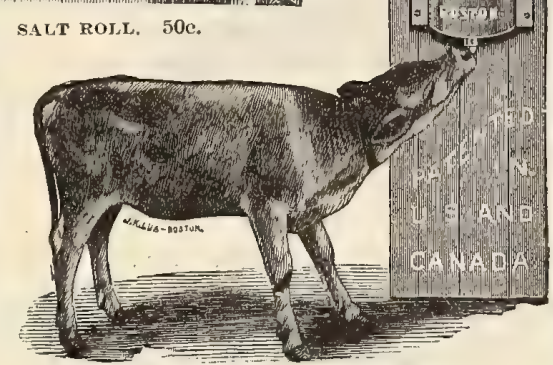

GMALL'S CALF FEEDER, $\$ 2,00$,

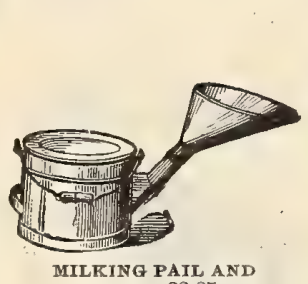
STOOL. $\$ 2.25$.

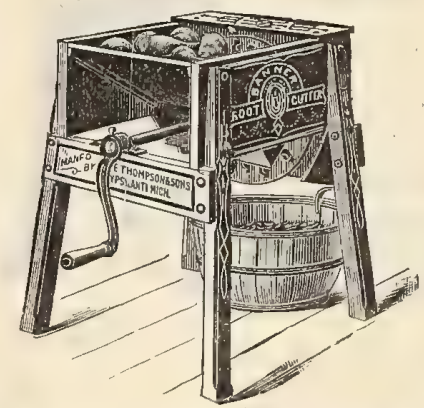

BANNER ROOT CUTTER. Price, $\$ 80$

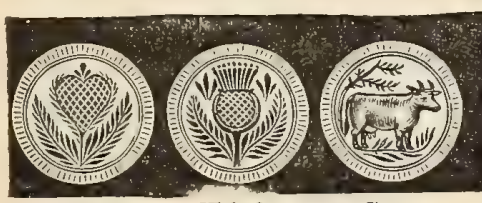

Heart.

Thistle.

Cow.

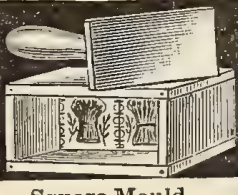

Square Mould.

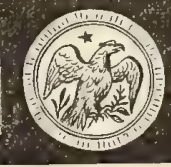

Eagle.

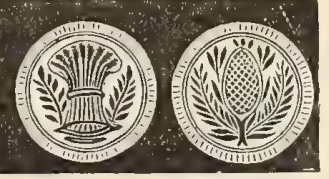

Sheaf.

Pineapple.

Butter Prints-Round Prints, 1/2-1b., 30c.; 1-lb., 40c. Square Moulds, 1/a-1b., 50c.; 1-1b., 75c.

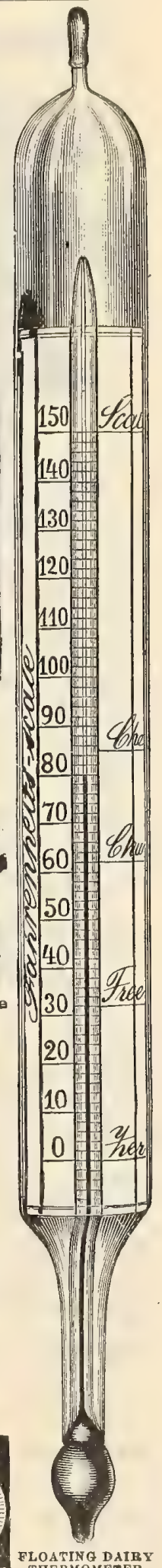

THERMOMETER.

15c. each; 


\section{Garden and Farm Tools}

ALPHABETICALLY ARRANGED

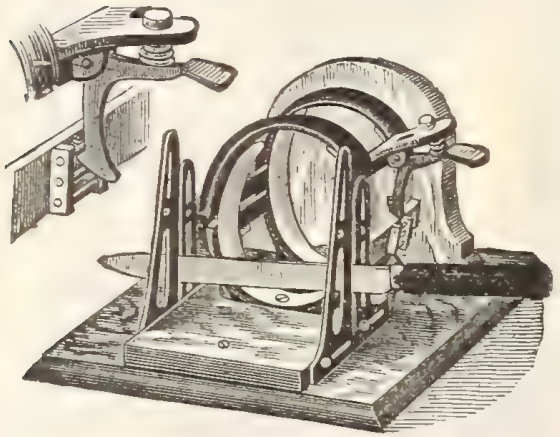

AOME ASPARAGUS BUNCHER, \$1.75.

\section{ACME ASPARAGUS BUNCHER}

Is the best and most satisfactory buncher in every respect of any in the market. It can be gauged to make either short or long bunches, according to the length of the "grass," The fastening arrangement is a very efficient and simple device: fastens automatically. It has a double instead of a single hinge, which makes it very strong and firm. The top of the buncher opens clear back, which renders the filling of the buncher a very easy and rapid operation. . Price, 81.50. Knife guide, extra, 40c

ASPARAGUS KNIVES. Chisel shape, 30c. each; $\$ 3.00$ per dozen

ASBESTOS TORCH. For destroying insects on trees, etc., $30 \mathrm{c}$; by mail, $40 \mathrm{c}$.

AXE. Heavy, \$1.25; medium, $\$ 1.00$; light, $90 \mathrm{c}$

BASKETS.

$$
\begin{aligned}
& \begin{array}{l}
\text { bush. strve } \\
\text { splint }
\end{array} \\
& \begin{array}{r}
\$ 1.00 \\
2.50
\end{array}
\end{aligned}
$$$$
\text { Per Doz. }
$$

REE SUPPLIES. See pages 121 to 123.

BERRY CRATES AND BASKETS.

3.2 quart chests, complete . . .50c each, $\$ 5.50$ per dozen Boxes $\rightarrow$ pint, oval . . . 65c per $100, \$ 5.00$ per 1,000 quart, square $\therefore . .55 \mathrm{c}$ " $100, \$ 4,50$ "t 1,000

\section{BONE CUTTERS} and MILLS

We offer tluree styles of green bone cutters. We do not recommend the sizes smaller than the Mann's No. 7, the Humphrey No. 1, or Stearn's No. 2. All of these are good. Green cut bone is a valuable feed for poultry in the Winter season. It stimulates egg production in a remarkable degree, and is better than any tonic or stimulant or drug. It stops egg-eating and effectually stops feather-pulling. When your fowls are featherpulling it shows they need green

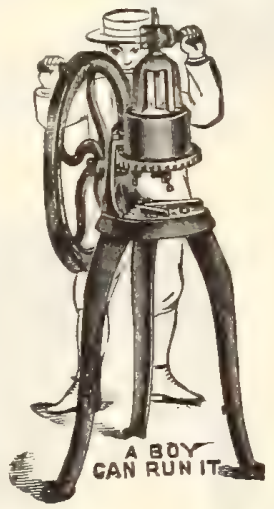
cut bone.

MANN'S open cylinder type.

$$
\begin{aligned}
& \text { No. } 5 \text { C. } \\
& \text { No. } 5 \text { B. } \\
& \text { No. } 5 \text { B. } \\
& \text { No. } 7 \text { - . } \\
& \text { No. } 9 \text {. }
\end{aligned}
$$

HUMPHREY.

No. $1 \ldots . .81200$

No. $2 \frac{1}{2} \ldots$

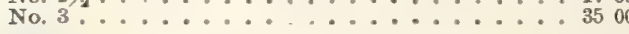

STEARN'S.

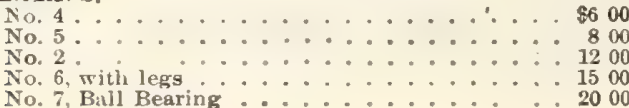

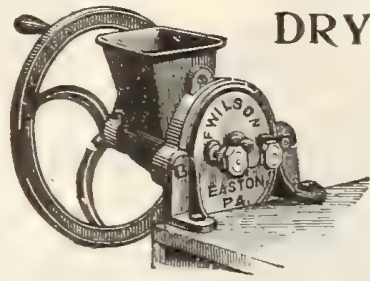

BOILERS. See Feed Cookers, page 97

BRUOMS. Rattan for stable, ${ }_{6}^{4}-\mathrm{row}, 50 \mathrm{c}$.

BRUSH OR BRIAR HOOK. Long Handle, $\$ 1.25$,

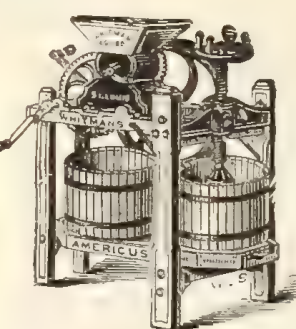

With knife on back, $\$ 1.50$.

\section{CIDER MILLS}

The Buckeve Cider Mills are well known, and for finish and excellence of design and results they stand in the van. Junior PRICIS , \$1200 Medium : . : : 1600 Senior....... 2000

\section{Corn Planters}

Automatic Hand Corn Plant. ers will drop the kernels regularly and surely : cheap and BUCKEYE CIDER MUL. durable. Price, each, $\$ 1.50$.

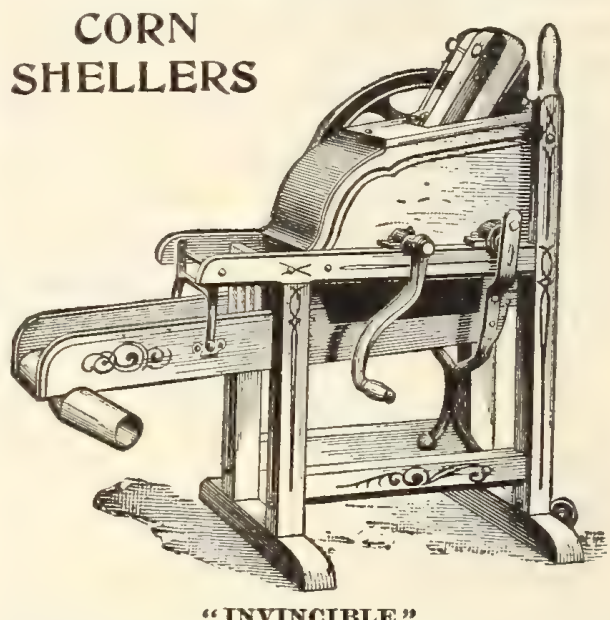

A thoroughly good sheller in every respect. Right hand, with shaker-separator that sieves out all dust and dirt and leaves the shelled product all ready to bag up as it comes from the machine. Price, $\$ 8.00$.

\section{"LIGHTNING" TWO HOLE}

A strong, heavy two-hole sheller, with feed table, and with a capacity for great work. An excellent gheller in every respect. Price, \$14.00.

\section{" FAVORITE JR."}

This is the best low-priced sheller on the market: strong and well made. Right hand, and will take the largest gourd seed corn, and separates the cobs from the corn. Price, \$6.00.

CHAMPION BALL BEARING BOX CORN SFELLER

It can be set to shell any corn that grows. Set it for pop corn and it will shell pop corn ; set it for field corn and it will shell field corn; set it for the largest corn that grows and it will shell the largest corn that grows.

The power gained by using ball bearings makes it run very easy, and saves the expense of a heavy balance wheel. Price, 82.00 . 


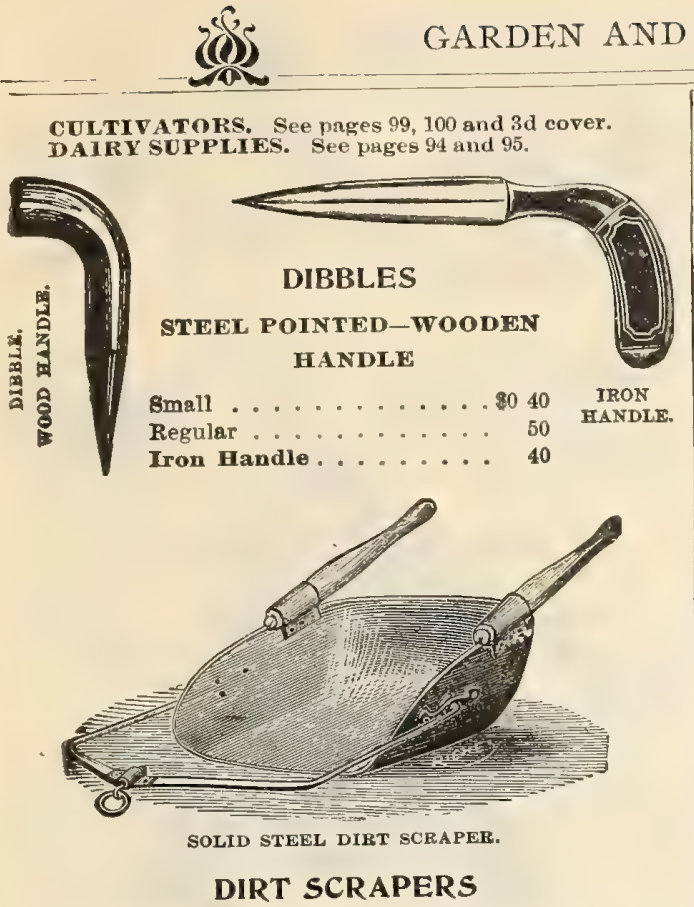

Fitted with steel runners and balanced at swivels so as to turn and dump easily.

.........\$7 00

\section{DOCK EXTRACTORS}

D-Handle, strong . . . . . . . . . . . . \$2 00

DRILLS. See pages 100 and $3 d$ cover.

\section{Feed Gookers}

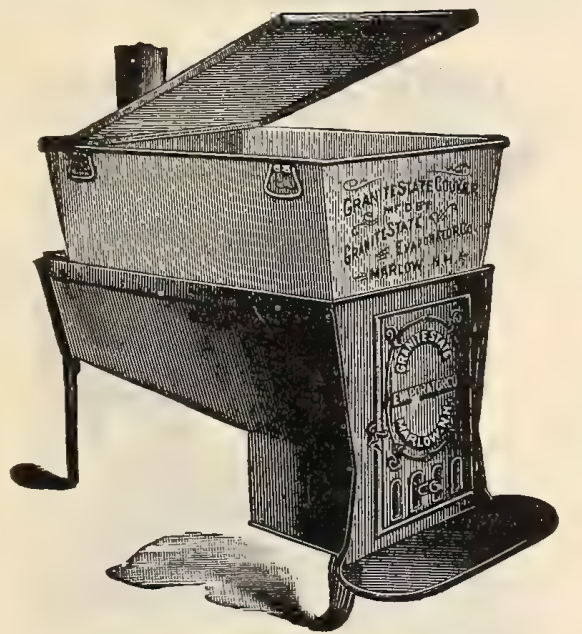

\section{Reliable Stock Food Cooker}

For heating or cooking all kinds of food for Hogs, Cattle, Poultry or Dugs. Alro for heating water when butchering hogs. Requires very little fuel, the sides and linings being of sheet steel plates, and the boiler of galvanized steel that will weither rust nor corrode, nor require painting.

\section{PRICES}

For wood

Size only

20 gallons. . . . . . $\$ 500 \ldots \ldots$

35 "

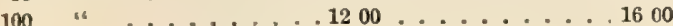

\section{FEED COOKERS-Continued}

\section{“EMPIRE STATE” FEED COOKERS}

Same as Granite State, except that they are made lighter and cheaper to sell for less money. 'The boilers are straight instead of flaring sides.

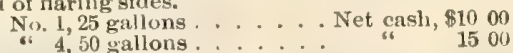

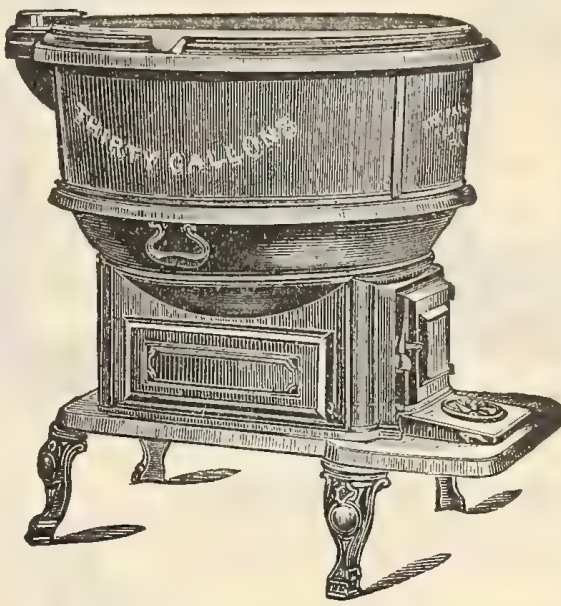

\section{POULTRYMEN'S BOILER}

Often in preparing cooked food for poultry, articles aro used that, while just the thing for poultry, the housewife does not like the odor through the house. A boiler of this sort can be used outside or in the outbuilding. We have them for wood or coal.

PRICE LIST

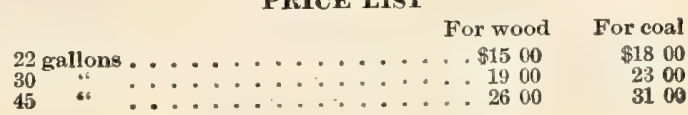

\section{FLOWER POTS} "STANDARD" PATTERN
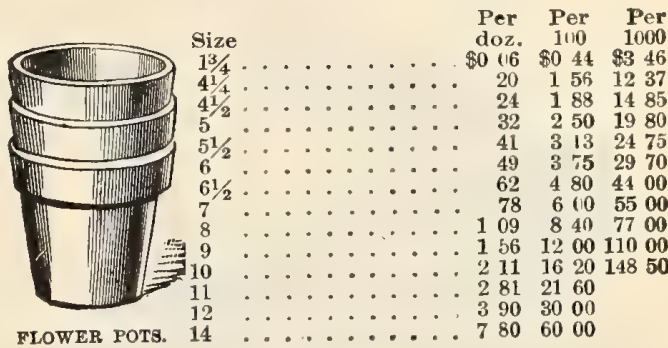

\section{FLORAL, TOOLS}

Set of 4 for children ............ \$ 25 "4, larger................ 100

\section{FORKS}

Hand Weeding, all steel . . . . . . . . . $\$ 035$ Hand we.t malleable ........ 10 and 15 Digging or spading, 4 prong $\ldots . . . . . . .99$ Manure, long handle, 4 tine $\ldots \ldots \ldots \ldots \ldots{ }^{75}$

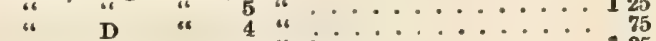
" " 5 " heavy $: \ldots \ldots \ldots 125$ Hay and straw, long handle, 3 tine $\ldots \ldots \ldots \ldots \ldots 60$ 


\section{FUMIGATORS}

\section{PERFECTION FUMIGATOR}

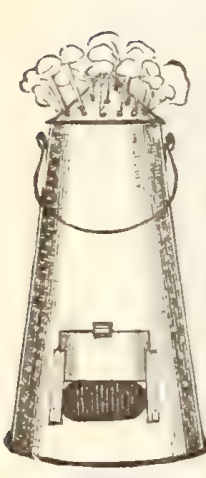

Will fumigate and raporize at the same time. The tank should be filled with water; when the stems are lighted the water boils and emits a dense mass of moistened smoke or steam

Made in two separate bodies, detachable does not become heated when in operation, harmless to the most tender plants.

No. 1 bolds 1 peck of stems, 82.75

No. 2 bolds $1 / 2$ bushel of stems, $\mathbf{\$} 3.25$

No. 3 holds $9 / 4$ bushel of stems, 8375 .

EUREKA.

No. 4 holds 1 bushel of stems, $\$ 5.00$.

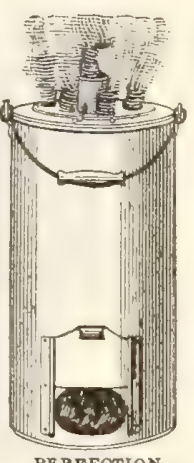

\section{EUREKA FUMIGATOR}

Made of extra heary galvanized iron. No. $1, \$ 1.00$; No. 2 , \$1.50; No. $3, \$ 2.00$; No. 4, $\$ 3.00$.

\section{Garden Reels and Lines}

For marking out the Garden Rows.

Iron Painted, for 100 feet Linen

Line . . . 8040 Iron Painted, for $300^{\circ}$ feet Linen Line

Galvanized, Single

Large Double

60
1

$\begin{array}{ll}1 & 25 \\ 2 & 00\end{array}$

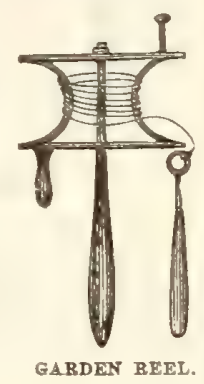

GAFDEN LINES. Best Italian fax, $30 \mathrm{ft}, 20 \mathrm{c} ; 60 \mathrm{ft}$. \&5c; 9 uft., 50c.; $150 \mathrm{ft}$, heuvy, $85 \mathrm{c}$.

GARDEY SETS. See floral tools, page 96.

GARDEN ROLLERS. See page 103.

\section{GLAZING POINTS}

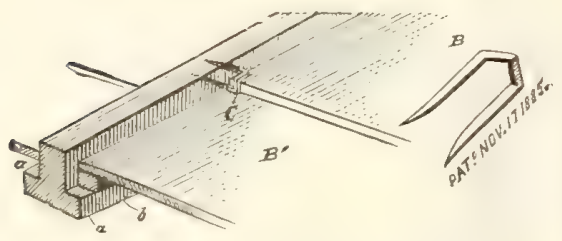

\section{PERFECT GLAZIER POINTS}

These are made of steel wire and galvanized, having double points and lap over the glass in such a manner as to positive ty keep it from sliding. They may be used on either side of the sash bar, thus preventing the annoyance of rights and lefts.

Per box of $1000,60 \mathrm{c}$; by mail

Lots of 5000 and over, per box

$\$ 077$

Pincer's for driving 55

GLASS CUTTERS. Steel wheel, 15 c. $\$ 1.00$

GLOVES. Heavy goatskin for pruning thorny plants, GLOVES, Rubber, for handling bees. Ladies' size, $\$ 1.35 ;$ men's size, $\$ 1.45$.

GRAIN CRADLES. Though the mover and reaper have so largely taken the place of the old-fashioned cradles, yet they are often wanled for cutting small lots where the large horse machine cannot be used to advantage. Price, 5finger, with long steel seythe, complete, $\$ 3.00$.

\section{GRASS EDGLNG \\ English steel, 8-in., \$1.00; 9-in.. \$1.25; Ameri- \\ can, with li andle. \\ GRAS* HOOKS}

English-riveted back.

No. 0

"i 1

" 3

American .

GRAFTING CHISELS, Ste e l, each, $\$ 1.75$.

GRAFTING WAX. 1/4 $1 \mathrm{~b}, 0,10 \mathrm{c}$; $1 / 2$ 1b., 15c; $11 \mathrm{~b}, 25 \mathrm{c}$.
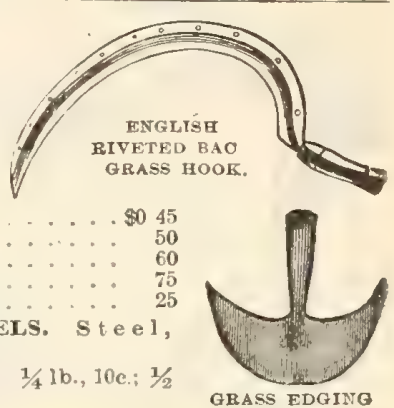

\section{GRINDSTONES}

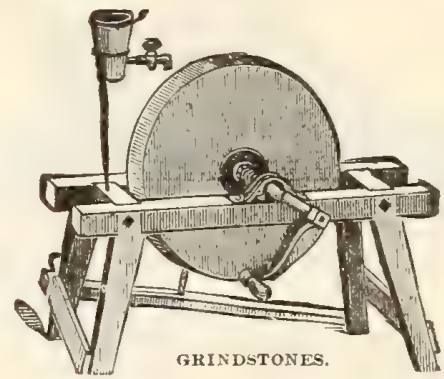

We carry a stock of the finest quality grindstones and can quote you on any style not here given.

\section{PRICE LIST}

Farmer's 18-inch$$
20
$$

$\ldots \ldots . . . . . .3325$

450 Carpenter's 20-inch imported stone, with treadle, New "Quick Edge" pattern, with seat, two treadles and can, 18-inch stone............. 500

\section{GRINDING MILLS}

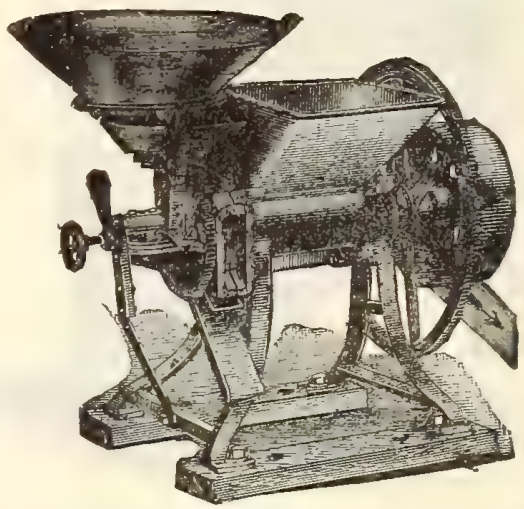

QUAKER CITY GRINDING MILL.

An excellent mill for grinding corn on the cob, also all shelled grain, bones (after they luare been boiled twentyfour hours-not green bones), oyster shells, crackers, dried bread, spices, coffee, etc.

No. 5, for hand or power, including extra set of cones, $\$ 2000$ 10, power only, weight, 300 lbs., 2 to 8 horse-

power, including extra set of discs...... 4500

\section{GRIST MILL}

For grinding corn and cob, fine corn meal and Graham - flour for table use. Either hand or power. Capacity, 5 to 8 hushels per hour. Weight, $150 \mathrm{lbs}$. Pulley, 8 inches. Price, $\$ 2.00$ 


\section{HARROWS AND HORSE CULTIVATORS "PLANET JR." HORSE HOES AND CULTIVATORS}

Complete "Planet Jr." Catalogue Sent on Request.

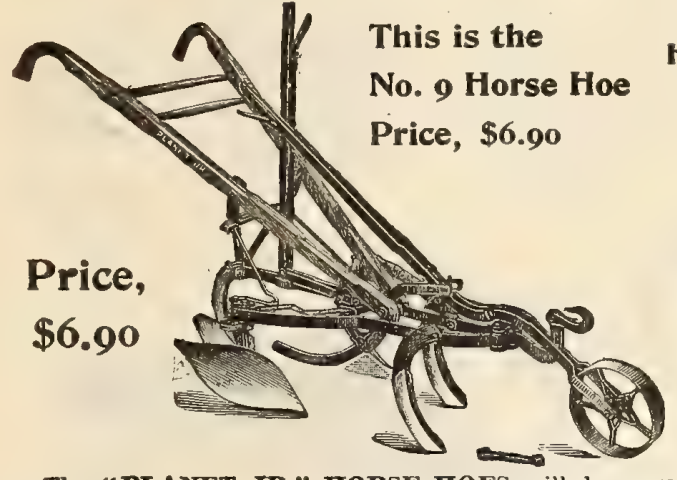

The "PLANET JR." HORSE HOES will do more knds of work, and better work, than any other make of Lerse Hoe. New Depth Regulator and Expander. Hollow nd sidewise. Reversible Side Hoes.

\section{"Buffalo Pitts" Disc Harrows}

The "Buffalo Pitts" line of Harrows, both "Disc, Spring and Spike Tooth" have no superior in the world. They are trictly up-to-date, with Ball Bearings, adjustable spring pressure on the inner end of each gang of Discs. No dust one get into the bearings.

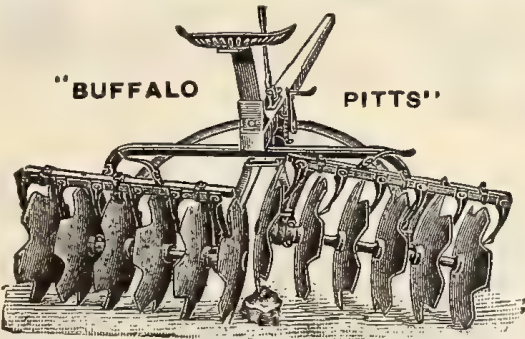

An 8teel, Spring Flexible Dise Spading Harrow Price, 825.00

1 Horse Size, 6 Discs, \$20.00

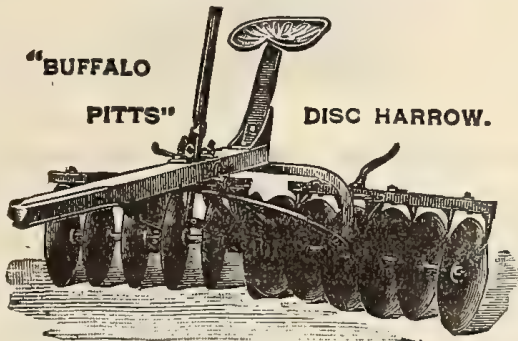

Al Steel, Spring Flexible Solid Disc Harrow

1 Horse Size, 6 Discs, $\$ 20.00$

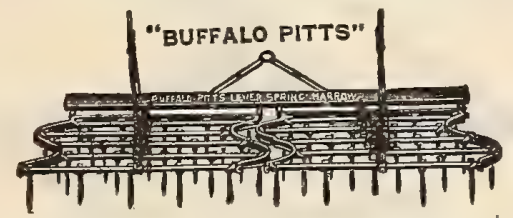

Lever Spring Spike Tooth Harrow

The Best Spike Tooth Harrow Made

Teeth can be set at any angle. Price, 815.00
"PLANET JR."

Harrow and Cultivator

Price, plain, . \$5.30

with Wheel, 6.40
complete, 8.00

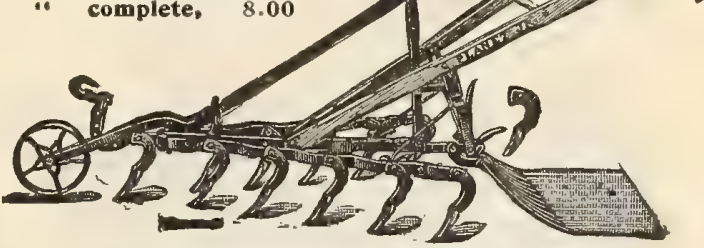

"PLANHT JR." Twelve-Tooth Haxrow

"PLANET JR." PRICE=LIST

Plain Cultivator, No. 4, without wheel ........\$3 V5

" "

" " " 9 , without wheel ....... 485

Horse Hoe, No. 4, without wheel ........ 55

" " 4, with wheel.......... 585

" " "

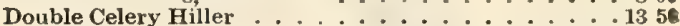

\section{PRICE=LIST OF “ PLANET JR." EXTRAS}

$11 / 4 \times 8$ inch Steels . $\$ 08 \quad 6$ inch Hoe and Bolt, .\$0 40 $134 \times 8$ " " $09 \quad 10$ " 09 " 400 $21 \times 8 \times$ " ": 10 Harrow Teeth...: 15 $3 \times 8$ " " " 11 " Deep Tillage Steel"." 15 $3 \times 8$ " " $412 \quad$ Beet Hoes, each .... 40

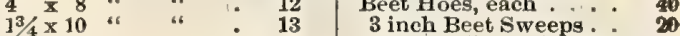
$214 \times 10$ "

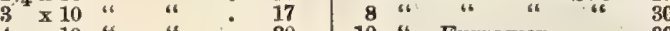
$4 \times 10$ " $40 \begin{array}{llll} & 20 & 10 & \text { " Furrower . . } 80\end{array}$ 6 inch Side Steels, each, $50 \quad{ }_{64}^{15}$ " 60 " "with wings 20 7 " Shovel Steel 25 . 25 . 8 " Shovel steel : 25 Hilling Attachment : . 850 Bolts . . . . $3011 \%$ Roller Attachment .850 8 inch Sweep and Bolt, $30^{-2}$ Reversed Rake : : 80 10 a 35 Pulverizer...... 200

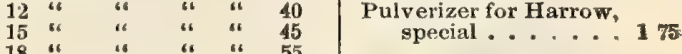

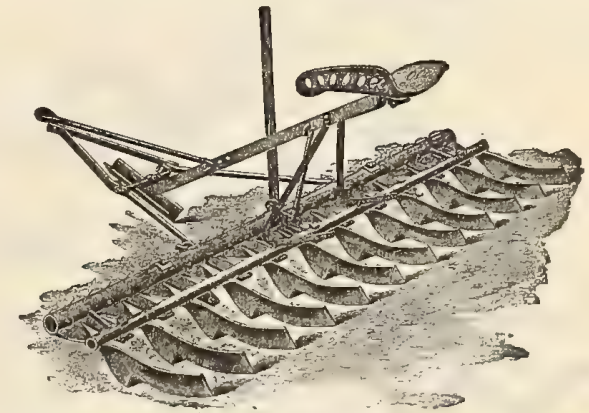

"Acme" Pulverizing Harrow, Clod Crusher and Leveller

is adapted to all soils and all work for which a harrow ig needed. It is the cheapest and best riding harrow on earth.

\section{PRICE L.IST}

No. 23. 2-Horse, $6 \mathrm{ft}$. $6 \mathrm{in}$, Cut, Riding . . . . $\$ 1700$

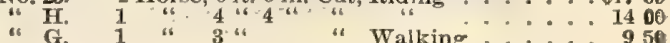
Prices do not include whiffletrees or neckyoke. 


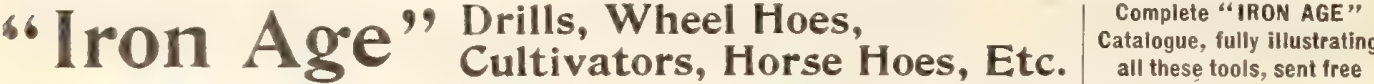

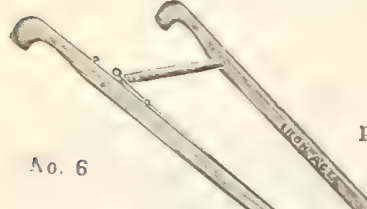

No. 6 "IRON AGE" COMBINED DOUBLE WHEEL HOE, HILL AND DRILL SEEDER

Price, complete, $\$ 11,00$. One of the best implements made Teutools in one. Sows in rows or drops in hills at $4,6,8,12$ or 24 inches apart. Quickly changed inco a Double or Single Wheel Hoe, as No. 1 opposite. Does each and every operation in the most satisfac-
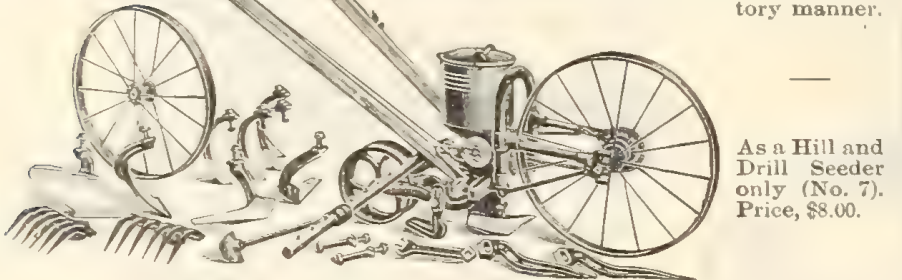

No. 1 "IRON AGE" DOUBLE OR SINGLE WHEEL HOE

Price, complete, $\$ 6.50$

Is equipped with side hoes and plows, slender steel cultivator teeth and a pair of rakes: simplest, strong est and most practical tool of its kind. As a No. 3 (side hoes only), $\$ 3.75$.

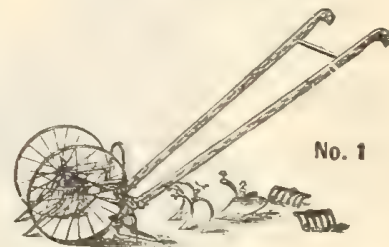

THE GEM OF THE GARDEN WHEEL HOE

Popular for its intrinsic worth.

Single Wheel Hoe. . . . . . . Price, $\$ 400$$$
\text { " } 500
$$
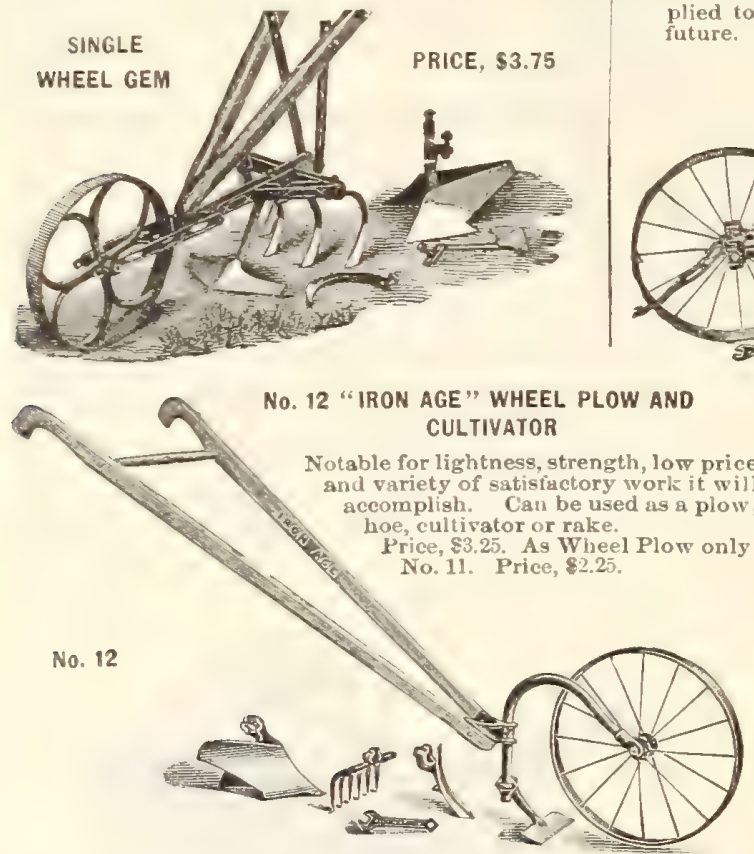

No. 20 "IRON AGE" SINGLE WHEEL HOE Price, complete, $\$ 5.50$.

A most perfect Single Wheel Hoe. Plows, rakes, cultivates and hoes A. seed drill attachment may be applied to this tool any time in the future.

NEW MODEL DAILL It is strongly made, sows any kind of seed with regularity, and is one of the steady reliables.
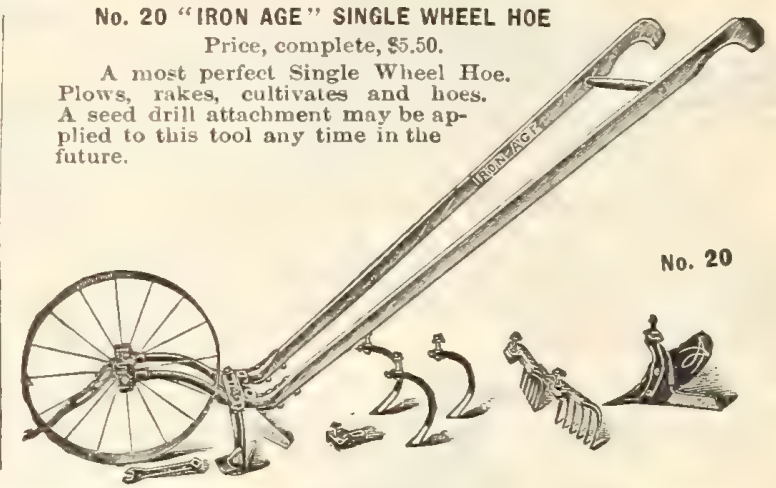
We hare sold the New Model Drill for years; it always gives satisfaction.

PRICE, $\$ 7.50$

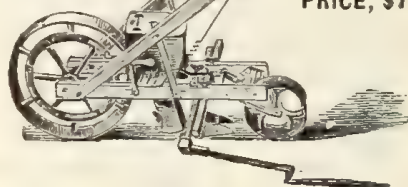

No. 6 "IRON AGE" HORSE HOE AND CULTIVATOR Remarkable for great gdjustability.

With lever is expanded from 11 in, to 30 in. The wheel regulates the depth. The furrow-closing attachment pulverizes and

No.1 "IRON AGE" DIAMOND TOOTH HARROW AND CULTIVATOR.

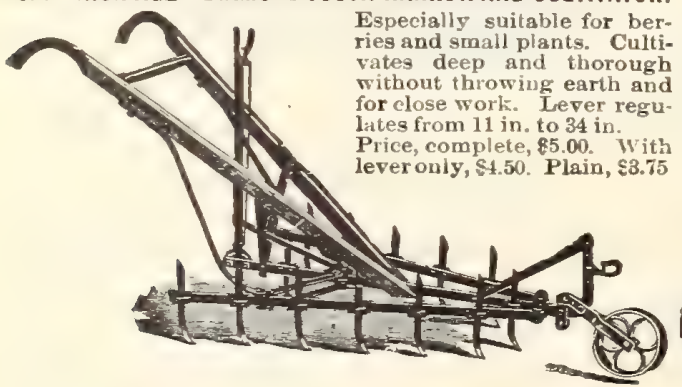
levels the groun and

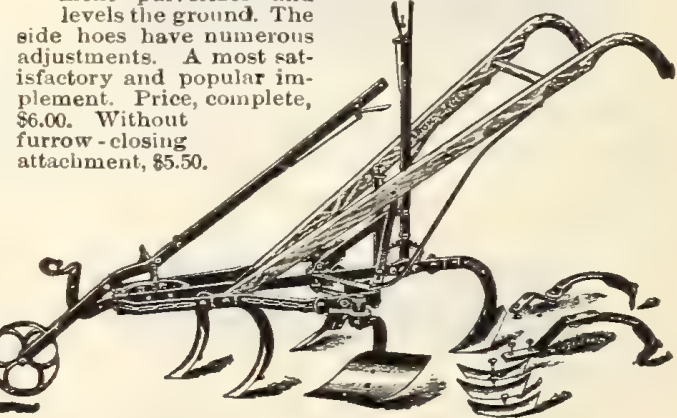




\section{Hanging Baskets}

Rustic .... \$1.00 to $\$ 2.00$ Wire...... 10c. to $40 \mathrm{c}$

\section{Hammers}

Claw ....... 750 Stone.... . . 75c

\section{Harrows}

See pages 99 and 100.

\section{Hatchets}

Various Styles ................ . 75e

\section{Hay Cutters}

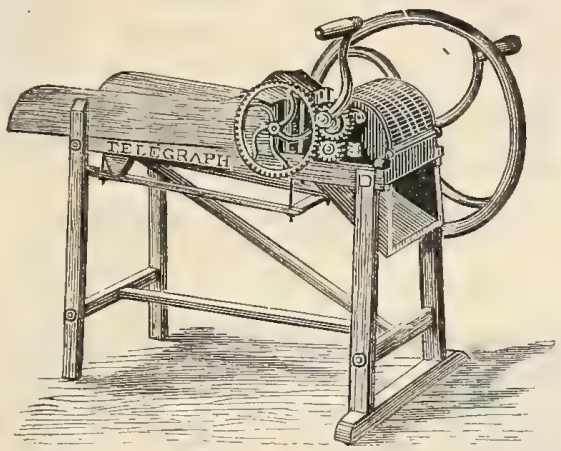

Telegraph Hay Cutters

These cutters have been in this market for years, and we have yet to see the machine of their size and style that wir as good all around as the Telegraph. They are well made, knives of good steel, and with care will last for years. Price, No. $5, \$ 12.00$; No. $4, \$ 15.00$

\section{Lever Hay Cutters}

When only one or two head of stock are to be provided for the Lever cutter will he sufficient. They are furnished with gauges regulating the length of cut, Price, $\$ 3.00$.

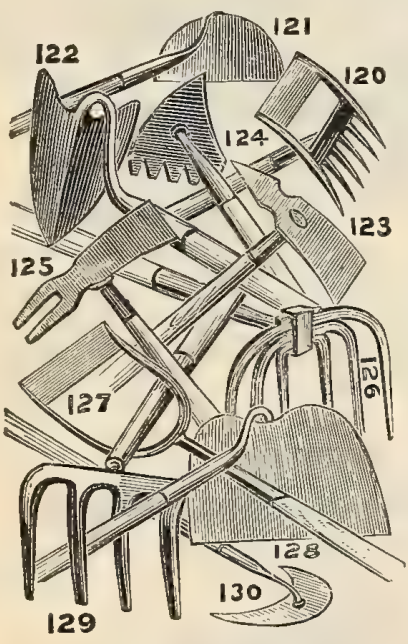

HOES IN ASSORTMENT

\section{Hoes}

Hoe, Square Gar den, 6,7 and 8 -in., $40 \mathrm{c}$.

Hoe, Half-Moon, 3 in., 30c.; 4-in., 35c.; 5 in., 40c.; 6-in., 45c.

Hoe, Warren, three sizes, $40 \mathrm{c} ., 45 \mathrm{c}$., $50 \mathrm{c}$.

Hoe, Dutch Scuffle (Handles, 10c. extra) 4 -in., 40c.; 5-in., 50c. 6-in., 60c, 7-in., 65̃c 8-in., 70c.; 9-in., 85e

Hoe and Rake, 4tooth, 40c; 6-tooth, $5 \mathrm{cc}$

Hoe, Celery, Kal amazoo, $\$ 1.25$. $\$ 1.50$.

Hoe Onion, 1 Prong, 30c. ; 2-Prong.

Hoe, Sweet Potato or Mattock, \$1.25.

Hoe, Transplanting, $70 \mathrm{c}$.

\section{Horse Boots}

For lawns, per set of $4 \ldots \ldots 800$

\section{Horse Hoes}

TRANSPLANTING HOE

ee pages 99,100 and $3 d$ cover.

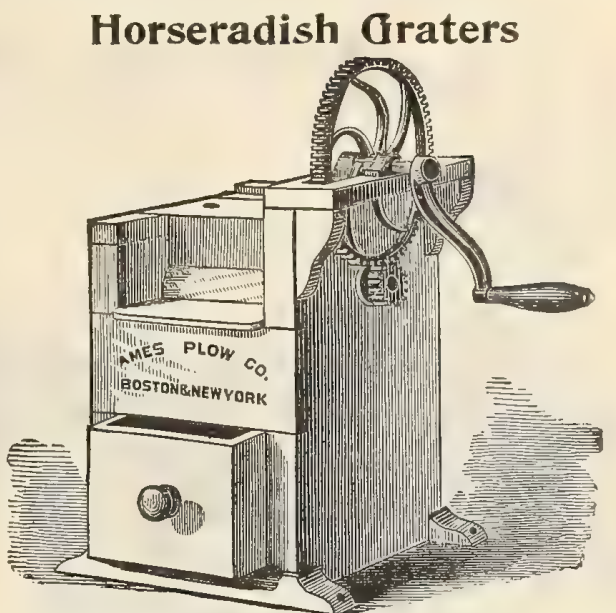

These machines are always in demand by market gar deners for preparing Horseradish Roots for market. The are made in three styles: the Tin Clad Cylinder being \& cylinder with projecting tin teeth; the Steel fin being a solid wooden roller with projecting steel pin teeth to cut the roots. This is the best style.

The No. 3 is the same as above, except it is fitted with legs and a treadle.

PRICE LIST

No. 1-Tin Clad Cylinder. . . . . . . . \$ \$600 No. 2-Steel Pin "................ 00 No.3-" " with legs and treadle ....... 1200

\section{Hose}

Hose, Rubber, Good Quality, 3/4-inch, per foot

8008

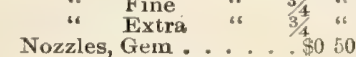

$$
\begin{aligned}
& \text { Nozzles, Gem .... … } \$ 050 \\
& \text { " " }
\end{aligned}
$$

\section{Hot Bed Mats} See page 92

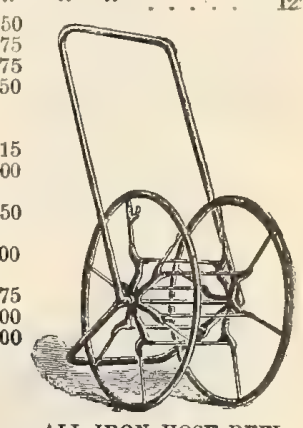

\section{Hot Bed Sash}

Unglazed . . . . . . . . each, \$1.25; per dozen, $\$ 1200$ Glazed and painted ............... each, 275

\section{Jardinieres}

For pot plants, in great assortment. 3-inch, glazed ........... \$0 10 $\$ 100$ 5 " painted ................. $25 \quad 250$

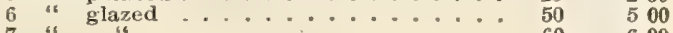
8 " 8 " With Tabourettes

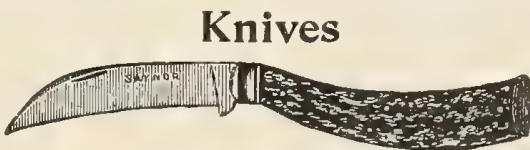

PRUNING KNIFE-STAG HANDLE

Budding, special, don't shut Each doze ivory handle, imported ..... \$ 20 $\cdots 100$ 1 " imported ...... 125 2 blades, one for budding..... 100 C. \& C. potato, curved blade ...: : 30 Corn, American ........... 50 Porn, Aberican . . . . . . . . 50 


\section{LAWN MOWERS}

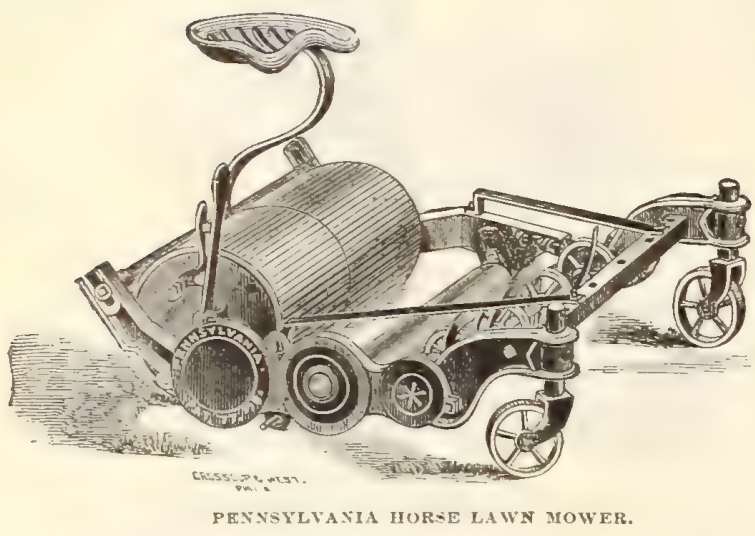

\section{Pennsylvania Horse Mlower}

The Horse Lawn Mower is intended for cutting grass in large lawns and parks. The knives are crucible steel, hardened and tempered in oil, and guaranteed to do the most satisfactory work. We recommend these with draft irons only, thus preventing a horse from walking on the uncut grass, although seat and shafts can be furnished if desired, at following prices:

30 inch cut with handles and draft irons . . . . .\$6000 38 " " " " " ". ". ". 7800 Extra for seat and slanft.

25 incls cut Pouy Mower

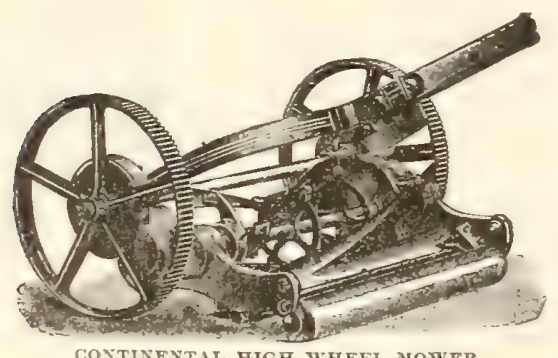

\section{Continental Hand Lawn Mowers}

These are very high-grade mowers with a reputation second to none. They have a double train of gears. The high wheel sizes are recommended for large lawns or where grass is tough or high. They will cut grass 6 to 8 inehes ligh.

\section{PRICE-LIST}

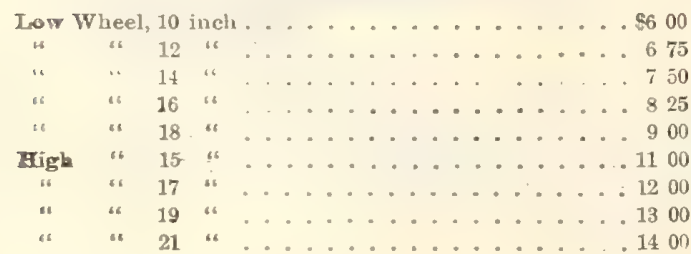

\section{NEW "VICTORY"}

\section{Ball-Bearing}

This new machine is the acme of up-to-date perfection in Grass Cutting Machines, the bearings of the Revolving Cutter are the latest improved ball bearings, just as used in the highest-grade bicycles; the Drive Wheels are ten inches high, thus giving great power, and a man with one of the large sizes of this machine can do the work as easily as with a twelve inch wheel of the old style.

Price-List "VICTORY" Mowers 14-inch "Victory" . . . . . . . . . . . . . \$9 00 $20 " \ldots \ldots \ldots \ldots \ldots \ldots$

\section{The Great B. B. Mower}

With Ball Bearings, and a High-Grade Machine in every respect.

\author{
Price-List B. B. Mowers
}

16 inch
20

$\$ 800$

\section{NEW “FLORACROFT" MOWER}

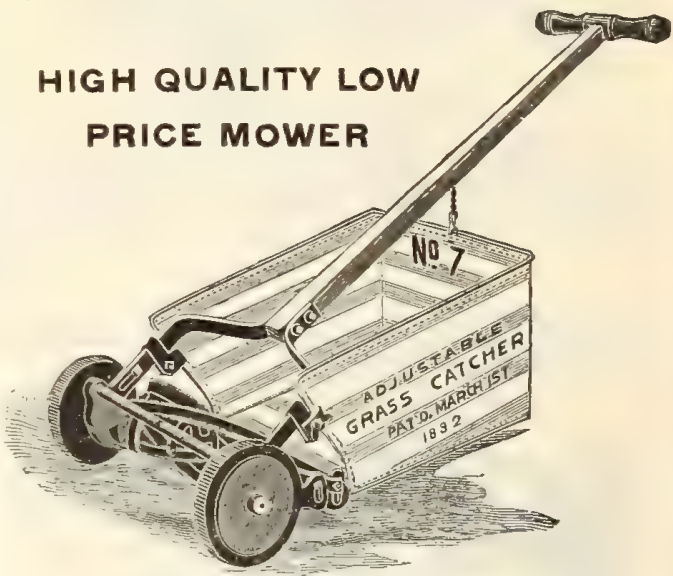

NEW FLORACROFT MOWER, SHOWING ALSO OUR ADJUSTABLE GRASS OATCHEB.

In this "Floracroft" Mower we give better value for the money than any low-price Morver we are acquainted with. It is thoroughly well made, of good material in every respect, and owners of small lots will find it entirely satisfactory.

Price "Floracroft" Mowers

LOOK
THESE
PRICES $\quad\left\{\begin{array}{l}10 \text { inch } \\ 12 \\ 14\end{array}\right.$

\section{fldiustable Grass Catchers} Will fit any Mower

Small, up to 14 inch ............ \$1 50

\section{Horse Lawn Boots}

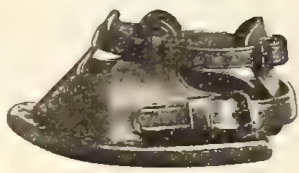

These hoots are made with a rounded and curved toe, finest lawn. Steel rivets are used throughout and the bot toms are thoroumbly waterproof and hardened by a special process.

Price, per set of $4 \ldots \$ 8.00$ 
Tadders. Cedar, per foot, 200 .

Fruit, 16-foot, at 12c. per foot.

MASTICA - For Glazing Greenhouses (new or old) ELASTIC, ADHESIVE, EASY TO APPLY

Used now extensively, and highly recommended by all the up-todate Gardeners and Florists.

Immense Quantities were used Last Season.

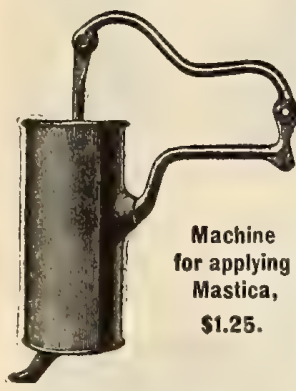

After much study, the inventor of "Mastica" decided that the composition must be of different materials from that used heretofore for this purpose, must be elastic and tenacious, and these qualities must be retained these qualities must be retained to admit the expansion and contraction without cracking. This result has been reuched in "Mastica," which, when applied, in a few hours forms hermetically sealing the oubstance and preventing the evapstance and preventing the evapmains in a soft, pliable and elas tic condition for years.

One gallon will cover about 300 running feet.

Per gal., 81.25; halt gal., 65c.; quarter gal., 35c Machines for applying Mastica, 31.25 each.

MATTOCKS, handled, $\$ 1.25$.

MILK PAIL. Stool, pail and strainer combined, \$2.25. PICKS, steel, with handle, \$1.25.

1.50. " with mattock and handle.

POTATO EYE CUTTERS, 25c.

lever, each, $\$ 3.00$.

PLANT STANDS.

Wooden, 3 shelf ....... \$1 25

Folding Wire, 2 shelf : : : 225

$$
\text { "4 } 4 \text { 4 } 4 . \cdots 375
$$

POWDER GUNS. See page 90.

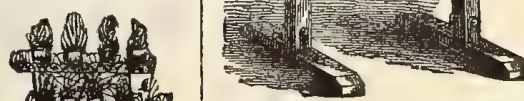

WINE AND BERRY PRESS.

Rakes. Steel, short teeth, for walks, 14 teeth, $40 \mathrm{c}$.

Rakes. Steel, 16 teeth, 50c.; 18 teeth, 60 c.

Rakes. Steel, garden, 6 teeth, 25c.; 8 teeth, 30c.

Rakes. Steel, garden, 10 teeth, 35c.; 12 teeth, $40 \mathrm{c}$.

Rakes. Steel, garden, 14 teeth, 45c; 16 teeth, $50 \mathrm{c}$.

Rakes. Steel bow, 9 teeth, 30c.; 11 teet $\mathrm{h}, 40 \mathrm{c}$.

Rakes. Steel bow, 13 teeth, $50 \mathrm{c}$; 15 teeth, $60 \mathrm{c}$.

Rakes. Hustler lawn, galvanized wire, $50 \mathrm{c}$

Rakes. Wooden, 40c. "6 "" a uto teetl, 70c.; 38 teetl, $\$ 1$.

Rakes. Lawn and Sear. ifying, $50 \mathrm{c}$.

Rakes. Hay and straw, 8 and 10 teeth, $30 c$.

RAT TRAPS. See Traps

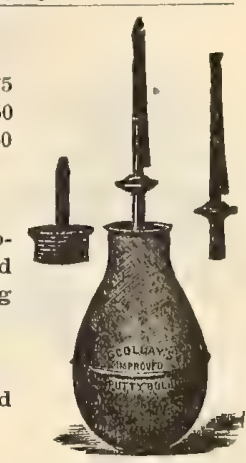

PUTTY BULB.

Wine and Berry

\section{Presses}

Well made, with strong. coarse thread screws and substantial buckets.

PRICES:

No. 1 . . $\$ 309$

is $2 \ldots \ldots . . . . .375$

6. $3 \ldots .600$

\section{RAKES.}

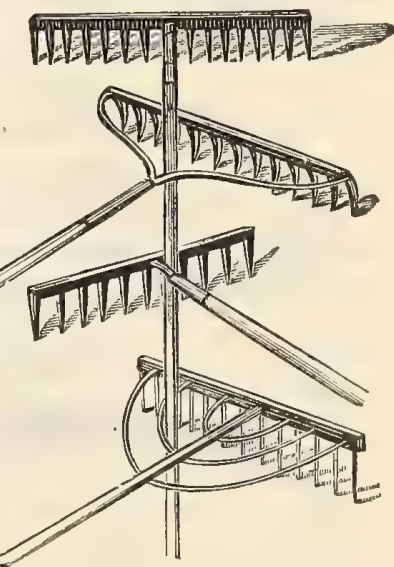

MARKET GARDENER' $\$$ "BOSS" PLOW.

THE MARKET GARDENER'S "BOSS" PLGW.

This plow is fitted with three moldboards, one very omall for loosening up root crops, and two larger ones. Also a very large double moldboard for ridging and furrowing. Price, with three moldhoards and one extra share . . \$5 00 Double moldboard extra

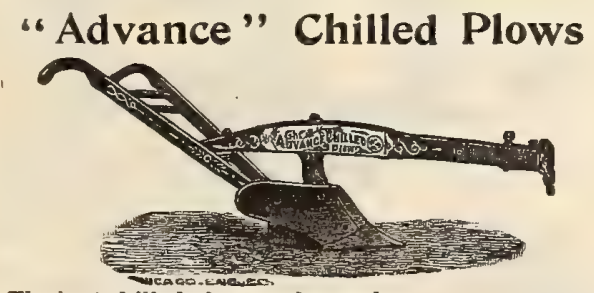

The best chilled plow on the market.

28. Small 1 horse, without wheel or jointer ....\$4 50 29. 31 " 1 " " " 4 " 80 Regular 1 " 81. Small 2 "with " and " 32. Regular 2 " "6 "6 " 83. Large 2 " " " " " " " " 84. Regular 3 " " " " "

Also left-hand sizes.

REELS. See Garden Reels, page 98.

\section{ROOT CUTTERS-Banner}

These are fine machines self feeders, shake off the dirt and leave the cut food fine enough to avoid all danger of choking.

No.20, Hand Machine. Capacity, 31) to 50 bush. $\$ 85$ ก

15. Hand and Power. Has Band Wheel for light power. Capacity, 1 to $11 / 2$ bushels per ninute. $\$ 4.50$

No. 16, Small Power Cutter, with fly-whee and pulley, also has crant fou hand use crank for hand use. Capacity by power, 2 to bus. per minute, \%o. 7. S cutting fine for Poultry; very useful. $\$ 5.00$.

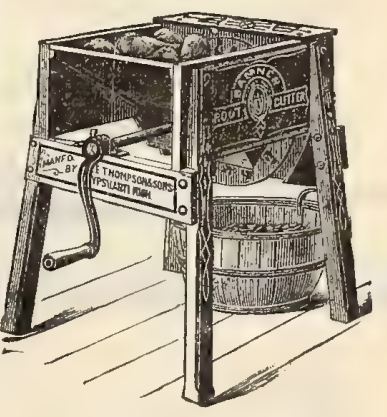

No. 20 BANNER ROOT CUTTER. 


\section{ROLLERS}

\section{FOR WALKS AND LAWNS}

The "BOSS" Roller is a high"grade roller. Rigid, durable and neat.

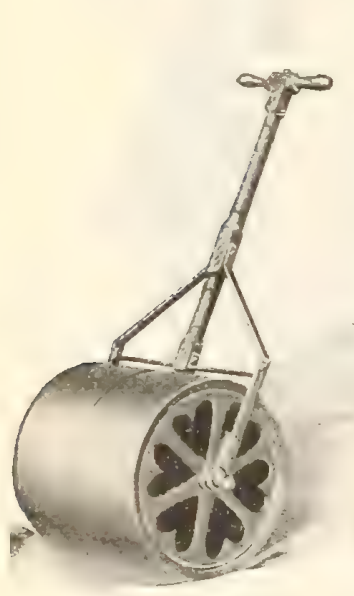

BOSS HAID BOLLER.

\section{Saws}

Pruning, 16 inch, 75̃c; 18 inch, 90c; 20 inch, \$1.10; $2+$ inch, \$1.2

Ligltning Double Edge, 65c

\section{Sash}

See Hot-bed Sash, page 101.

\section{Scissors}

Flower and Fruit Gatherers, hold after cutting,

Flower and Fruit Gatherers, hold after cutting, Inported, 5100

Grape Thinuing, sharp point, Euglish, $\$ 1.00$.

\section{Scythes}

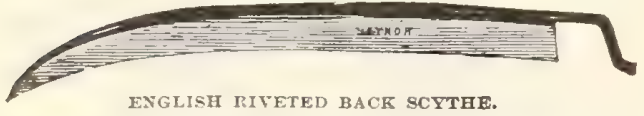

English Lawn, Riveted Back, 30, 32 and 34-inch . . . .\$1 10 " " " " 36 and 38 -inch.... 125 American Lawn, Steel ............ 100 Brush, Slıort and Heavy.......... 90 Sneathe or Handle for Scythe........... 75

\section{Scythe Stones}

Darby, 10c. Telacre or Welsh, 15c,

\section{Seed Tryers}

For drawing samples of seed without opening the bag

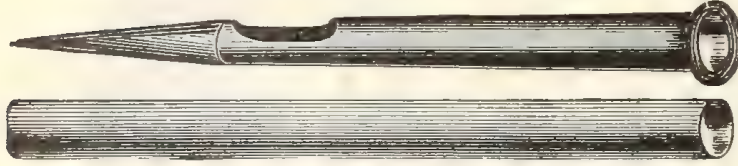

No. 1. Small German Silver, for Clover, Timothy, ote. each, $\$ 1.00$.

No. 2, Large German Silver, for Wheat, Oats and other Graius, each, \$1.25

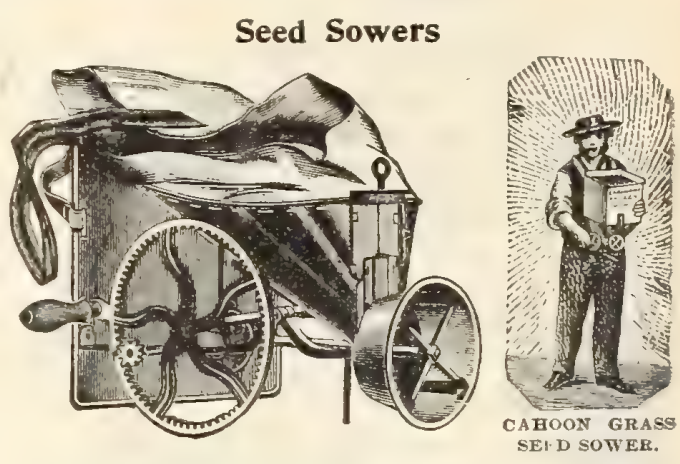

CAHOON BROADCAST SEED SOWER

A well-known sower, carried by a strap around the shoulder, and amount sown is easily regulated by the step of the operator. Price, $\$ 3.25$.

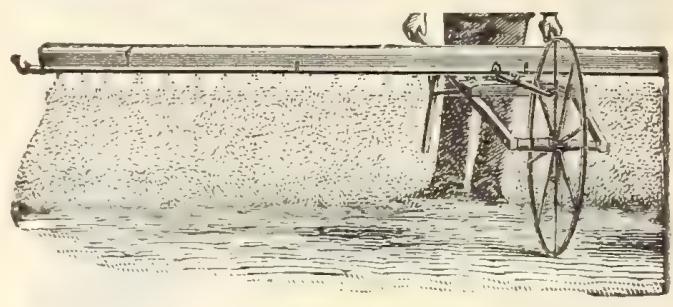

THOMPSON'S WEEELBARROW GRASS SEEDER。

\section{The Thompson Wheelbarrow Grass Seeder}

With this machine seed can be sown on any kind or condition of soil, in auy kind ol weather, auy ausuul per acre required, evenly and accurately. It can lie u-ed by any one who can wheel a barrow. There are no cogs, gears, or iutricate connections in its entire construction. Mud cannot clog its parts. It is impossible for it to sow any wav but acenrately. as the entire working parts are yoverned by the wheel Lightness and strength are combined in its construction, and the large wheel ( $33 \mathrm{in}$. in diameter' mukes it very eisy to run. The actual weight of complete machine is between 35 and 40 pounds.

It is adapted to all classes of work. Clover, Timothy, Alfalfa, Red Top, Hungarian, Millet, Flax. Crimson Clnver, Orchard Grass, Fancy Blue Grass, and Chaffy Seeds are alike sown by it.

Price, No, 1, 14-foot Hopper, for sowing Clover, Timothy, Millet, etc. . . $\$ 7.00$ Price, No. 2, 14-foot Hopper, for sowing Light Grasses, such as Red Top, Orchard, Blue Grass, ete. . . . . \$8.00

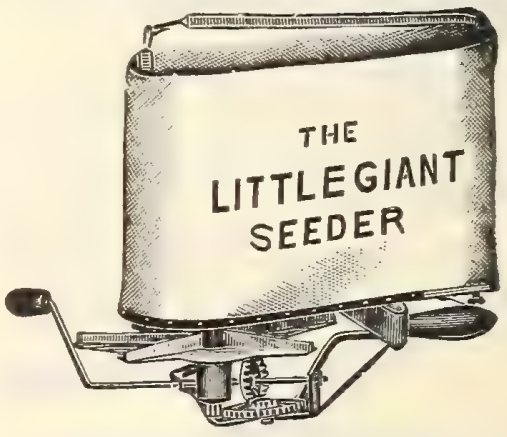

The Little Giant Broadcast Seeder

This machine has a 4-inch clear throat, and cannot be choked even with strawy oats. They sow the ground three times in going over once, leaving no possible chance for kkipping, even in windy weather. They will, by walking at the rate of three miles per hour, sow 90 acres of wheat or 65 acres of Clover Seed in a day of ten hours. They will sow not only. Timothy and Clover Seed, but you can sow Oats, Barley, Buckwheat, etc.; in fact, anything that can be broadcasted. Price, $\$ 1,50$. 

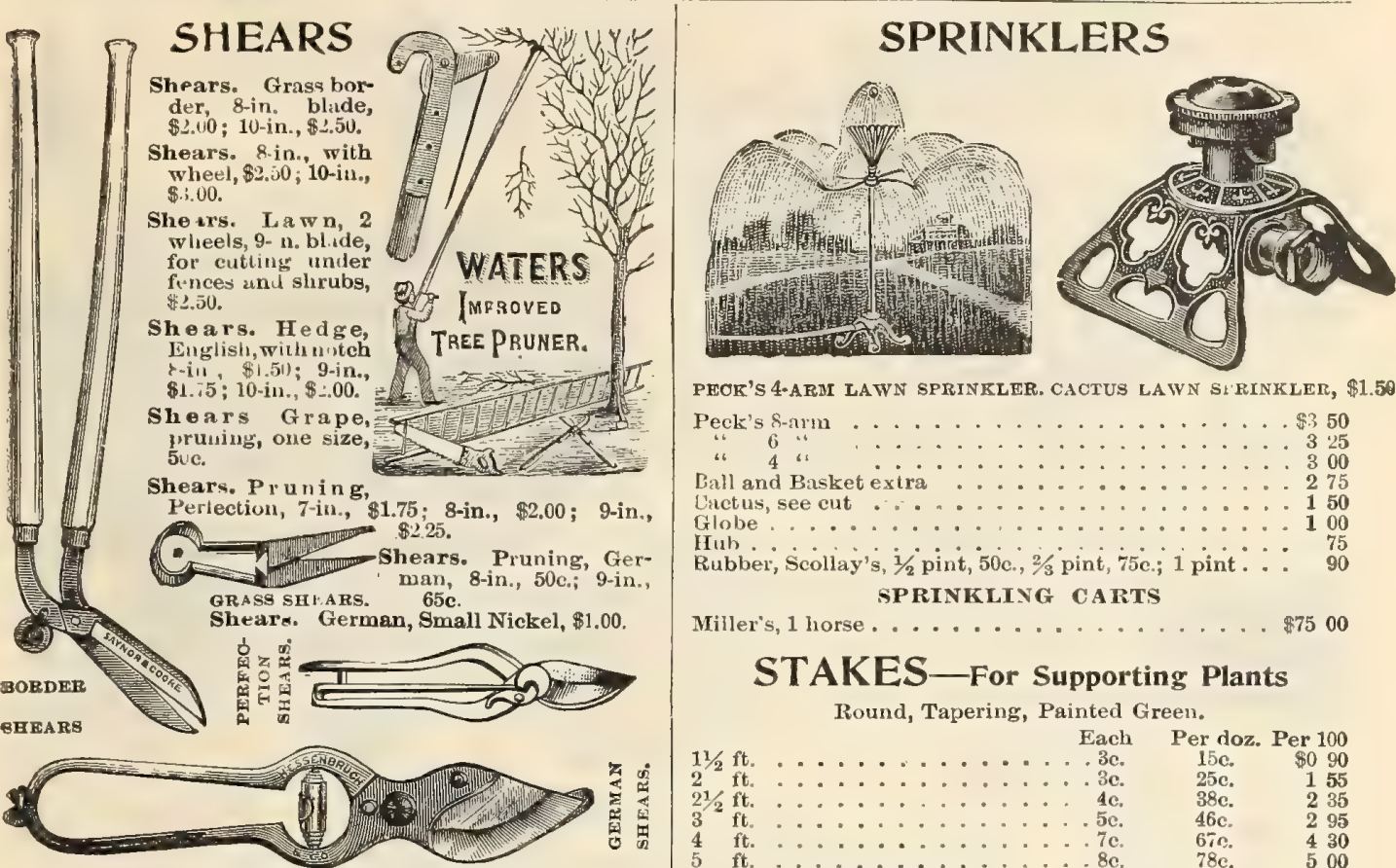

PEOK'S 4-ARM IATN SPRINKLER, CACTUS LAIVN S'RINKLER, \$1.50

Peck's $\$$-arm ................ $\$ 350$

" $\quad 4$ "

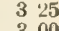

Ball and Basket extra

Cactus, see cut $\ldots . . . . . . .150$

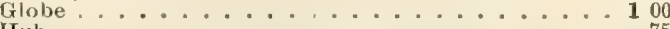

Rubber, Scollay's, $1 / 2$ pint, $50 \mathrm{c}$, $2 / 3$ pint, $75 \mathrm{c}$; 1 pint: $: 90$ SPRINKLIYG CARTS

Miller's, 1 horse . . . . . . . . . . . \$7500

\section{STAKES-For Supporting Plants}

Round, Tapering, Painted Green.

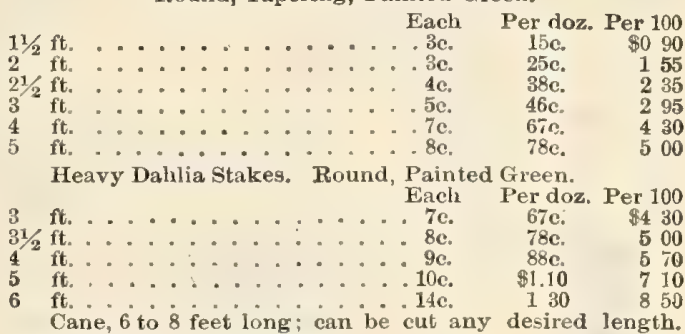

Cane, 6 to 8 feet long; can be cut any desired length. Per $100, \$ 1.00$; per $1000, \$ 8.00$

\section{SYRINGES-Brass}
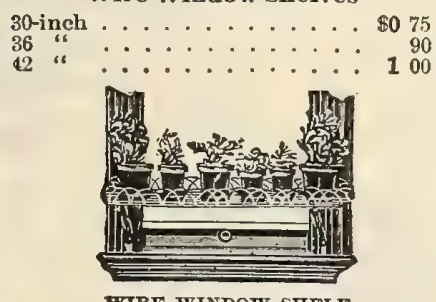

WIRE WINDOW SHELE.

5 c. to $\$ 1.00$.

\section{SHOVELS}

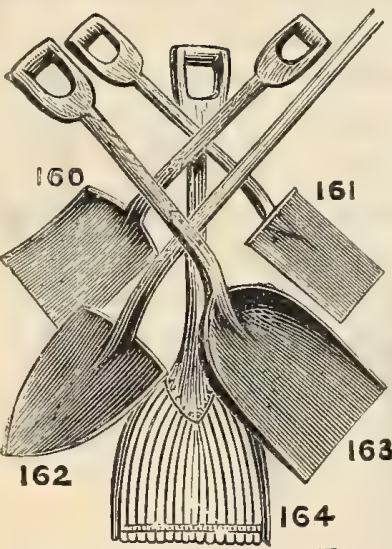

18-inch, any mesh . ....... \$0 60 20 " " Eong handle, with footrest
Long handle, $r$ ound point, $85 \mathrm{c}$ $D$ handle, round point, D handle, square point, $85 \mathrm{c}$.

Long handle, square point, 85c.

handle, barn scoop.

Fire potato, $\$ 1.50$

mes, square point, D handle, 81.50

\section{SPADES}

Long handle, $85 \mathrm{c}$.

.

Ames' Polished, D handle, $\$ 1.50$.

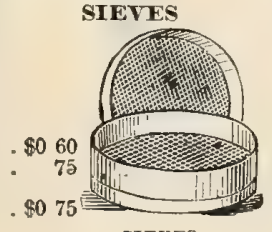

SIEVES.
No. A. Barrel, 12 inches long. 1 spray and 1 stream $\$ 2.00$ No. 2. Barrel, $13 \frac{1}{2}$ inches long. 1 coarse and 1 fine 4.00 No. 10. Barrel, 18 inches long. 1 coarse and 1 fine spray, and 1 stream rose, with patent valves and elbow joint. . 550 No. G. Barrel, 16 inches long, 1 spray and 1 stream 4.25 No. H. Barrel, 18 inches long. (Sheet brass.) 1 spray rose $\ldots \ldots \ldots \ldots \ldots$ Horticultural, zine *............... 100

Tomato Support, wire, per dozen : $: \ldots .17$ Torch, asbestos, for worms on trees....... 40 No.

\section{TRELLIS}

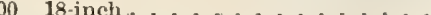

0 24 " ..................... 75

$01 / 224$ " $71 / 2$ inches wide $\ldots$

$131)$ " 10 ................. 175

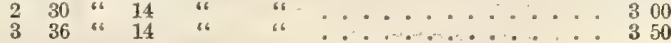

Fan Each

$31 / 2$ feet high ................... \$075

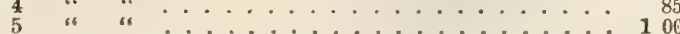

6 " " 6150

Veranda

$\$ 025$

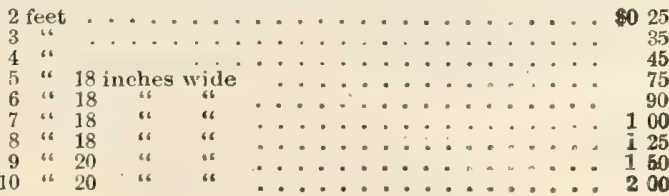




\section{THERMOMETERS}

Tin, Japanned, 8 -inch, 15c.; 10-inch ...... $\$ 020$ Household wood lose Distance, tin. Hot Bed or Mushroom (c.................... Incubator, silver seale .............. 50

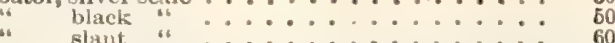

s slant

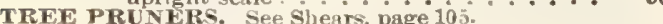
TREE SCRAPERS, triangle, $50 \mathrm{c}$

\section{TREE TUBS}

Made of white cedar, bound with extra heavy iron hoops. Drop handles of speciul pattern, serving as hooks. Substantial iron feet of original design. Removable pertorated botcoms, painted green outside and brown inside.
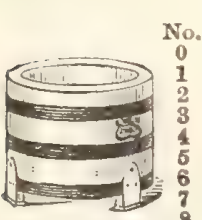

TREE TUBS. Outside Length

diam,
27 in.
25 ":
231 "
$211 / 2 \mathrm{in.}$
18
$161 / 2$ "
15

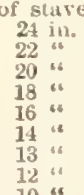

$\$ 500$

"UNION" TUBS

Made of cypress wood, painted green, iron feet.

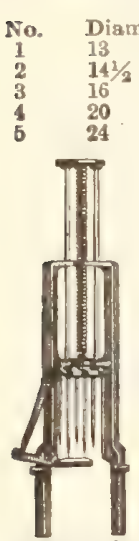
Length

of Stave.

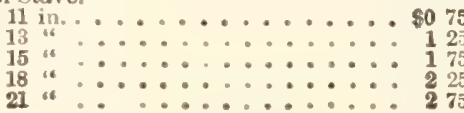

\section{TRAPS}

\section{MOLE}

The Olmstead. This, after trying all the makes, is, we beliere, the very best trap made. It is made short 80 it can be used in cold frames. Price, 81.50 .

\section{"Out o' Sight" Moie Traps}

Very low and can be used in hot beds and can be set without disturbing the runway.

OLMSTEAD'S Price, \$1.00.

\section{"Out o' Sight" Rat and Mouse Traps} The Best Trap for Greenhouse Use

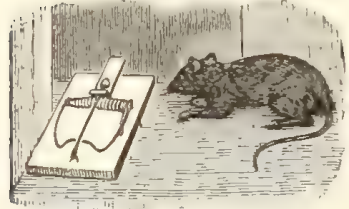

Before Using.

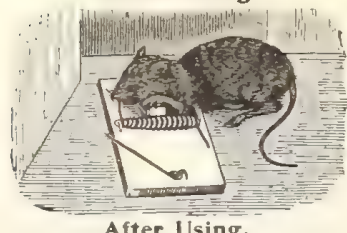

Prices.

10c. each; 8 for $25 \mathrm{c}$; $85 \mathrm{c}$. per dozen.

Mouse size Rat size.

The secret of mouse and rat catching is simplicity of trap (nothing to scere) and the chief practica Sight" is its innocent appearance-nothing about it placid surface which tells a mouse or rat of its apnroachng danger.

Catches them Coming or Going

with or without boit. Sim ply place the trap when set (see cut) with pedal end against the wall where they come ont from behind boxes. back of shelves or in their runways.

\section{IT NEVEK FATLS}

3 for $50 \mathrm{c}: \$ 1.50$ Yoix can sell them at a good profit Write us for prices by the gross.
TROWELS

Stamped Steel, 10c., 15c and 20c Solid Steel, Disston's, 6-inch, $35 \mathrm{c}$ 7-inch, $40 \mathrm{c}$; 8 -inch, $50 \mathrm{c}$.

Transplanting, $35 \mathrm{c}$ TRANSPLANTIN

Cleaves Angle, $15 \mathrm{c}$ and $20 \mathrm{c}$

\section{WATERING POTS}

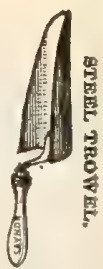

\section{GALVANIZED WATER POTS}

(Wotherspoon's Make.)

These are the best and most dnrable water pots made. Each has two roses of brass-one tine and one coarse, with long spouts

HEA $\nabla$.

4 Quart. . \$1 60

6 " 6175

10 4 : : 225

12 " ... 260

FRENCE PATTERN

6 Quart ..... 200

${ }_{10}^{8}$ ".

$12 \ldots \ldots 285$

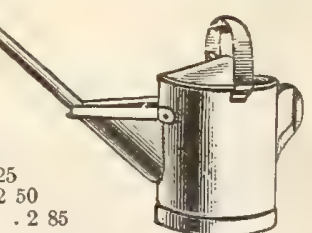

Light Galvanized, short spout; 2 roses, 1 fine and 1 coarse

4 quart. . 40c, 6 quart. . 50c. 8 quart. . $65 \mathrm{c}$ 10 " $85 \mathrm{c} 12$ " $12.00 \quad 16$ quart. $\$ \$ 1.50$

Tin, Painted Green.

1 quart...20 20 quart 2 . 25e, 4 quart .. $35 \mathrm{c}$

\section{WATER BARREL AND TRUCK}

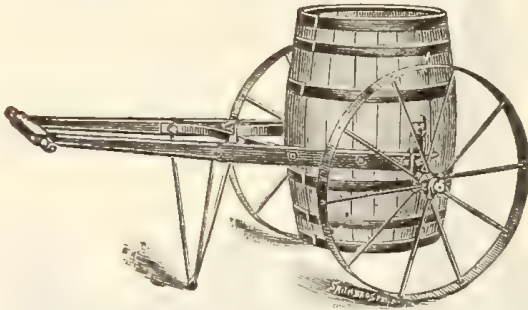

Barrel can be detached from truck without difficulty, or tilted to emply contents. Other barrels can be used and extra jrons furnished if desired. The weight is balanced extra irons fur
over the axle.

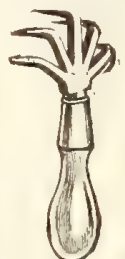

11/2 inch wheels

$\$ 800$ 850

Large box to fit on truck, extra Leaf rack attachment to the water truck . 425 Sprinkling attachment 0.350 Extra barrels with trunnions $\cdots . . .250$

\section{WEEDERS}

Excelsior .... \$0 10

Three-prong fork..... 15 Combination ............. 25

Excersion. Hazletine's
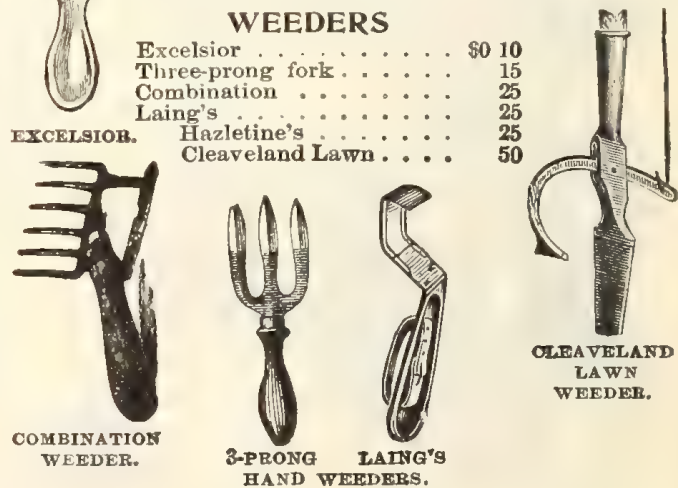

WHEELBARROWS

EASTERN-WIDE TREAD. No. 3, $\$ 3.50$; No. 4, \$4.00; No. $5,84.50$ 


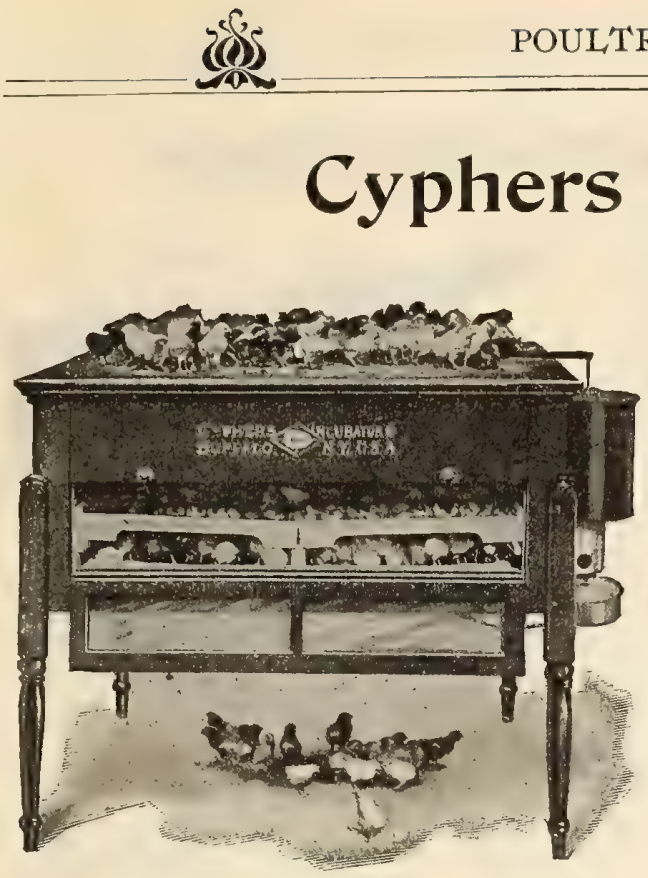

\section{Incubators}

CYPHERS NON=MOISTURE INCUBATORS are now used on more large and successful poultry plants, by more poultry fanciers of national and international reputation, on more Government $\mathrm{E}_{\mathrm{X}}$ periment Stations, and by more public industrial institutions than all other makes of incubators combined.

THE CYPHERS INCUBATOR contains valuable features possessed by no other make, cannot get out of order, or wear out, are absolutely safe from fire, and are self-regulating to a fraction of a degree.

You will not have to sit up nights watching the Cyphers.

\section{The Cyphers Warrant}

The Cyphers Patent-Diaphragm, Non-Moisture, Self-Ventilating, and Self-Regulating Incubators, manufactured and sold under registered trade mark, are warranted as follows:-

FIRST.-To require no supplied moisture, thus solving and disposing of the troublesome " moisture question."

SECOND. -To be self-ventilating, the air in the egg chamber remaining sweet and pure.

THIRD.-To be so constructed that the temperature in the egg chamber is more uniform and equable than in any other incubator.

FOURTH.-To be self-regulating, being equipped with the most sensitive, accurate, and durable regulator thus far invented.

FrFTH.-To be precisely as represented in construction, materials, and workmanship, and, with reasonable care, to last ten years without repairs.

SixTH.-To operate with less oil, and at less expense, than any other make of incubator, and to be as free from offensive odors as an ordinary house lamp.

SEVENTH.-To be easy to set up, hence the most satisfactory incubator for the novice, and to be strictly automatic in operation, except the trimming of the wick, filling the lamp, and turning the eggs.

EIGHTH.-To be, in all essentials, the simplest and easiest to operate and control, requiring less labor and less attention than any other style or make of incubator in the world.

\section{PRICE LIST CYPHERS INCUBATORS}

No. o. Capacity, 60 eggs .......... \$I 4.00

No. I. Capacity, I 20 eggs . . . . . . . . . 20.00

No. 2. Capacity, 220 eggs . . . . . . . . 29.00

No. 3. Capacity, 360 to 400 eggs . .............. 37.00 


\section{Cyphers Three=Apartment Brooder}

\section{STYLE A}

Next to its incubator, the Cyphers Company prides itself on the three-apartment outdoor brooder it manufactures. We unhesitatingly pronounce this to be the best brooding device on the market for either indoor or outdoor use. Briefly, the special merits of this brooder are :-

FIRS' - It is the largest single-flock, popularpriced brooder on the market.

SECOND.-It is rain-proof and storm-proof, havin a heavy, tin-covered roof.

THURD. - It is fire-proof, and is heated by a Cyphers Safety Brooder Stove instead of a lamp.

FOURTH. - The stove is safe and trustworthy.

FIFTH. - The fumes of the stove cannot get into the chick chamber.

Srxтн.-The brooder stove is easy to get at.

SEVENTH. - The round chick guard prevents crowding and keeps the chicks from coming in con-

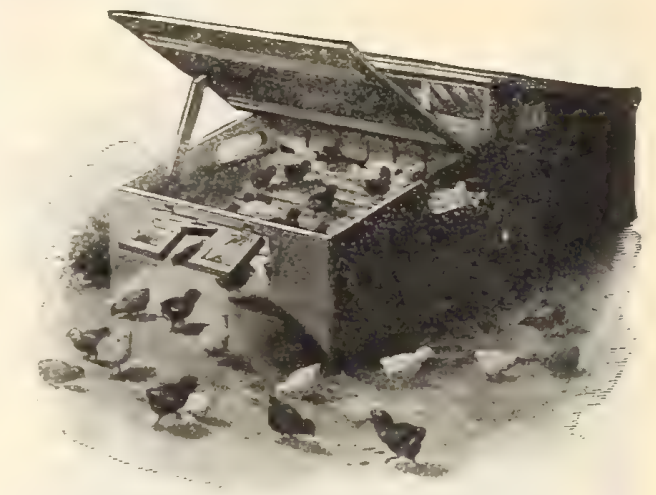

THREE-APARTMENT CYPHERS UNEQUALED OUTDOOR BROODER, STYLE A (FRONT VIEW).

Price

$\$ 12.00$ tact with the heat dome.

EIGHTH.-When the temperature under the hover is go degrees, the temperature just outside the hover is 85 degrees, while in the front apartment it will average several degrees lower. The chicks may therefore suit themselves, going to and from the heat at will.

NIXTH. - There are no stairs to climb, and so no danger of litille chicks getting lost and chilled while learning the way.

Price, Style A, outdoor

$\$ 12.00$

$\mathrm{B}$, indoor

I0.00

\section{Cyphers Sectional Brooder}

The Cyphers Sectional Brooders are made in three sizes, viz.: two sections, three sections, and four sections. They are well built in every particular, and have six overhead hot-water pipes, three outgo and three return. Most broolers of this style have only four, which are insufficient. The Cyphers also hare an upper expansion tank, which renders them perfectly safe to operate, and are equipped with two large-sized lamps with extra-widti burners, thus insuring ample heating power. The space provided for the brooding of the chicks is enclosed with heavy woolen curtains, is large in size, and properly ventilated.

For a practical and inexpensice indoor brooding apparatus, the Cyphers Sectional Brooders cannot be excelled. For example, the four-section bronder, which will brood 400 newly-hatched clicks-roo to each section-costs only $\$ 28$, whereas enough separate indoor brooders to hold the same number of chicks would cost $\$ 40$. There is also a material saving in labor, for with a sectional brooder only two lamps are used, while with four separate indoor brooders four brooder stoves are necessary.

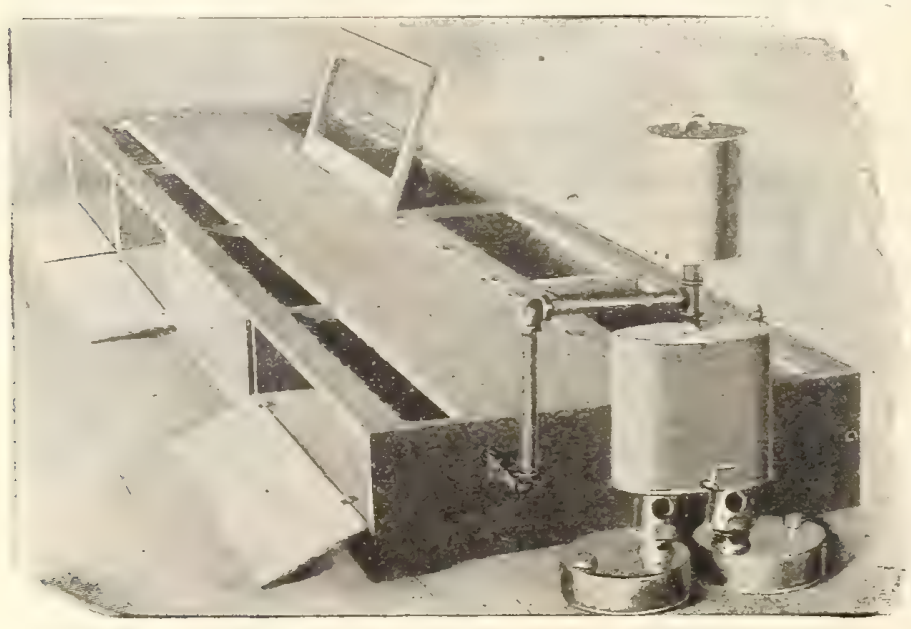

THE CYPHERS IMPROTED SECTIONAL BROODER (FOUR SECTIONS).

\section{PRICE LIST OF CYPHERS SECTIONAL BROODERS}

2 sections, all complete . \$18.00 3 sections, all complete - 23.00 4 sections, all complete . 28.00

\section{Metallic Parts for Cyphers Brooders}

These can be purchased separ. ately where the customer wishes to do his own woodwork. One brooder, however, will need to be ordered for pattern, as we do not furnish plans.

Price for complete outfit, consisting of brooder stove, galvanized iron parts, vents, and ther. mometer for Style B, Indoor, or Style A, Outdoor, \$5.50 each. 


\section{..SHIPPING REQUISITIES.}

\section{Shipping Coops}

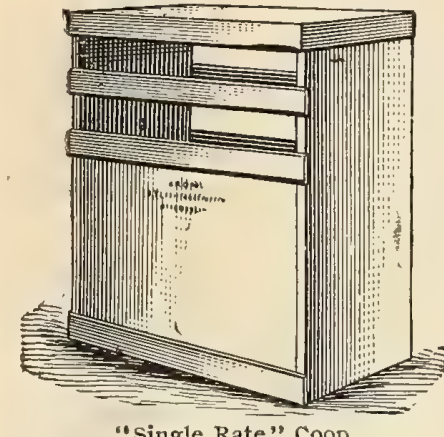

PRICE LIST

Single bird, I5 X I2 X 20 in., each, 25 c.; doz., $\$ 2.25$ Pair, I8 $12 \times 20$ in., " $30 \mathrm{c}$; " " 2.75 Trio, $24 \times 15 \times 20 \mathrm{in.,}$ " 35 c.; " 3.25 Trio (export), $30 \times 18 \times 20$ in., " $50 \mathrm{c}$,; " 5.00

\section{The Keystone Shipping Crate} FOR LIVE POULTRY

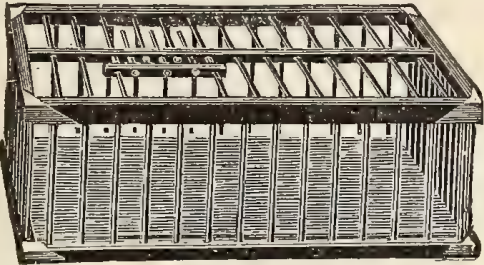

The Keystone Poultry Shipping Crate has been placed on the market to meet the long feit want of a strong but light crate. It is made of strong but light wood; securely braced at every joint with patent strap iron, while each corner is secured with a turned strap iron from top to bottom, and so fastened as to never allow risk of breaking apart in transit. Weight, about ${ }_{5} 1 \mathrm{bs}$. Size, I foot high, 2 feet wide, 3 feet long. Price, \$1.25 each.

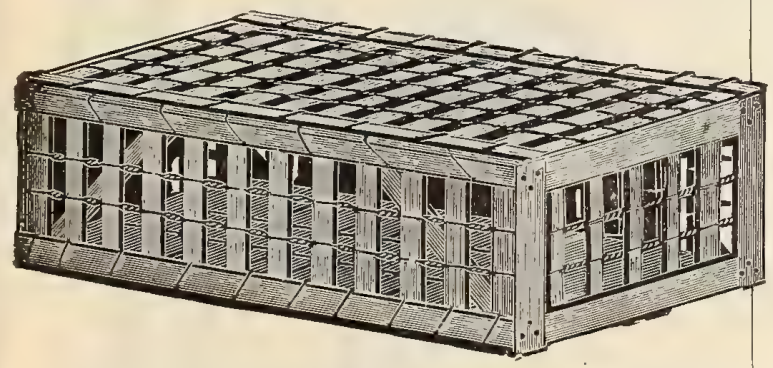

Sites' Ventilated Coop ${ }_{\text {Live Poultry }}^{\text {For Shipp }}$

The Best, Cheapest, Strongest, Lightest and Most Durable Coop in Use

Our latest improved coops have substantial frame ends and thoroughly braced. The door on top of coop is securely held in place by a steel spring which forms a hinge for the door. Chicken coops, standard size, 3 feet long, 2 feet wide and I foot high. Price, .90 each; \$1o per dozen; \$75 per Ioo.

\section{Imperial Egg Package}

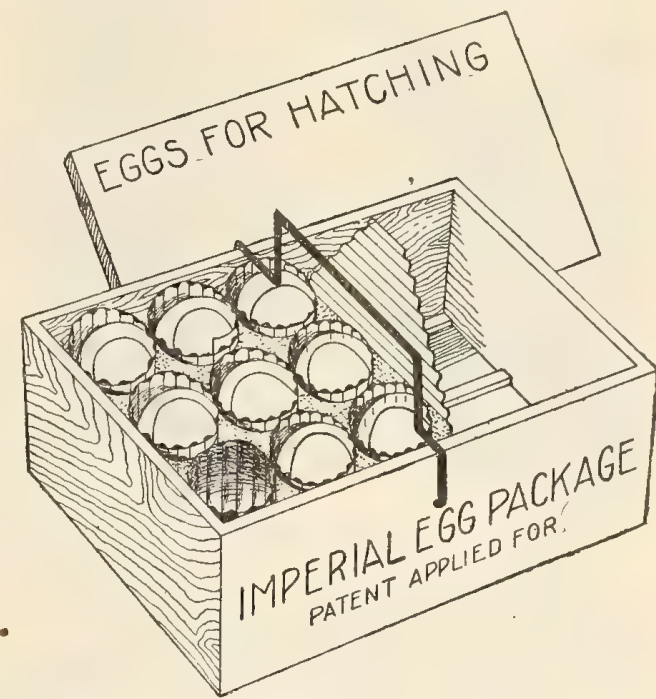

We offer this new package for shipping eggs for hatching, with the confidence that it will be found more satisfactory than any box previously offered. Constructed so that each egg is encased in a corrugated paper cylinder, and rests on a cushion of the same material. These cylinders are adjustable to any size egg, and absolutely prevent breakage.

Each package is equipped with strong wire handles, which lock into the box. Contents of box cannot be tampered with without showing traces, if directions for packing are observed.

\section{PRICES}

I5-egg size, $\$ 1.50$ doz; 30 -egg size, $\$ 2,00$ doz.; 45-egg size, $\$ 2.50 \mathrm{doz}$.

\section{Perfection Egg Cases}

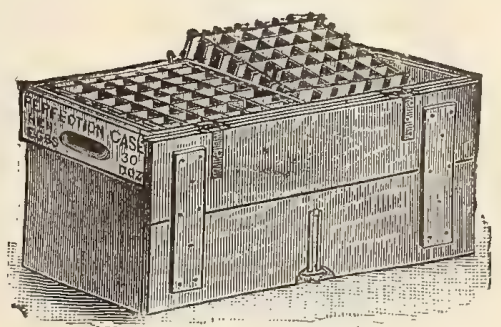

Perfection Eigg Case

These are the best Patent Clasp Egg Crates on the market. Strong hinges, well made, and will stand shipping and returning without damage.

\section{PRICE LIST} Perfection case for hen eggs (30 doz.), $\$ 0.90$ \$ $\$ 10.00$

Hen-egg fillers. Per set, $25 \mathrm{c}$ I3.00

" " Per crate of Io sets, \$2.25

Duck-egg " Per set, 25c.

" "Per crate of 12 sets, \$2.75. 


\section{MANN'S GREEN BONE CUTTERS}

\section{New 1902 Models}

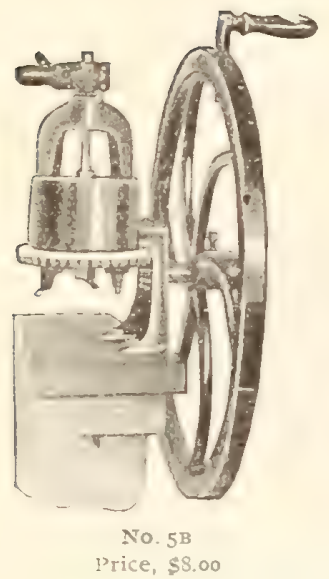

A large part of the value of green bones for poultry is due to the perfectly fresh animal food which they contain. This differs from any food ordinarily obtained for poultry in winter time, and upon this must depend the extraordinary results which are obtained by those who are feeding it.

Fresh bones, meat and gristle, when fed to your poultry, will double the number of eggs. Fresh boues from the market, when fed to the flock, will make the eggs hatch more vigorous chicks.

Fresh bones will increase the vigor of the whole flock.

Fresh bones will make the eggs more fertile.

It stops egg eating. It effectually stops feather picking.

Fresh bones will cause the little chicks to grow much faster and larger.

\section{MANN'S GREEN RONE CUTTERS}

\section{The most wonderful Bone} Cutters ever made

They surpass all others in easy and rapid cutting. They feed automatically and leave both hands free to operate. The feed regulates the power required, so that it caunot run hard. "The feed screw is large, and has a coarse thread that will not weat out or crush down or break. The gears are guarded, so that they cannot clog. The cylinder has been enlarged, and takes in a good-sized bone. They have specially improved currugated and adjustable steel knives. They are strongly built, and will not break or wear out.

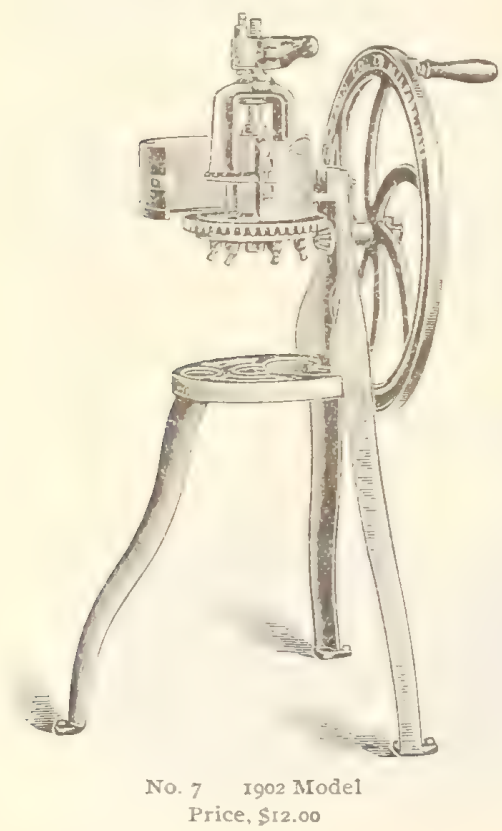

The new No. 5 is an improvement $\mathrm{cn}$ the old style No. I. It has larger cylinder, and four knives instead of three.

The new No. 7 and No. 9 have the new open cylinder design, self-regulatiug feed, and are thoroughly up - to-date machines.
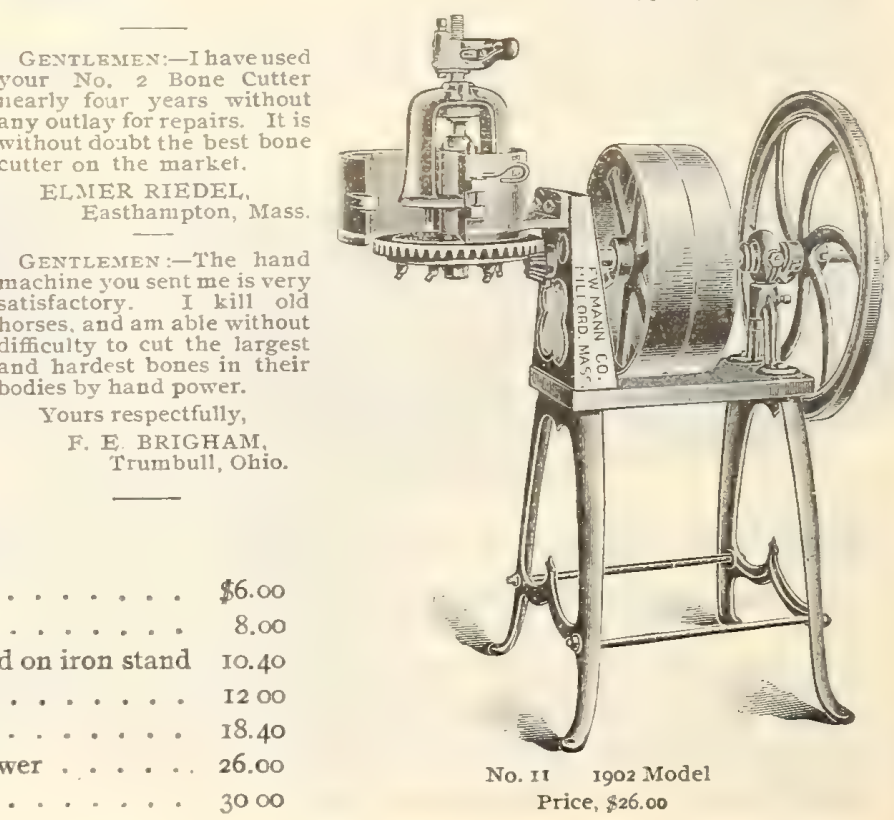

No. 5 C, with crank handle........\$6.00

No, 5 B, with balance wheel . ..... 8.00

No. $5 \mathrm{~B}, \mathrm{M}_{\text {, }}$, with balance wheel, mounted on iron stand $\mathrm{IO} .4 \mathrm{O}$

No. 7 , (see illustration) . . . . . . . . I2 00

Yo. 9, (see illustration) . . . . . . . 18.40

No. II, (see illustration), hand and power . . . 26.00

No. 12, power machine ......... 30 00

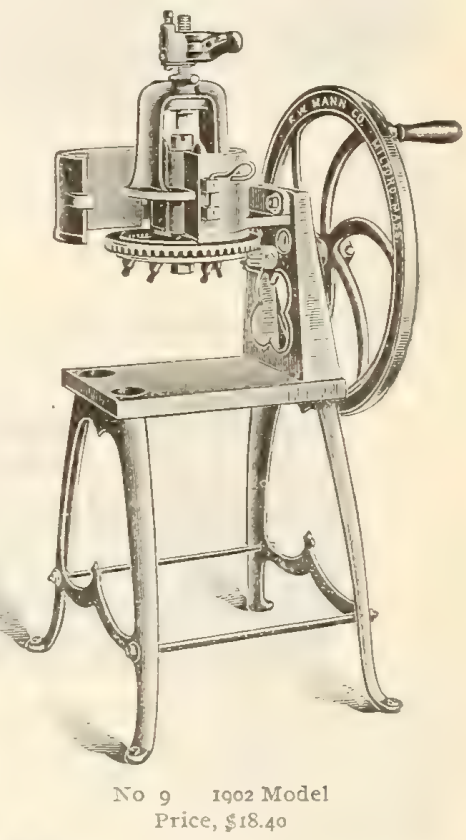

Jours respectfully, F. E. BRIGHAM,
Trumbull, Ohio.

\section{Price List}




\section{Poultry and Pigeon Leg Bands}

Various devices have been brought out to mark fowls. The band around the leg has been found most satisfactory

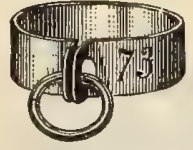

Novelty Band
LEG

BANDS

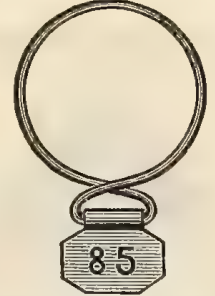

Climax Band
Bands are numbered from I up, as wanted. In ordering state what breed they are for, as we have them bantam size, American class, Asiatic and turkeys.

NOVELTY.-Made of white metal, will not rust, are easily applied, and caunot come off by accident. Price, per dozen, 25c.; per 50,65c.; per $100, \$ 1.00$.

CLIMAX. - Made of spring brass, and so made that the tag acts as a clasp, holding them securely in place. Price, per dozen, 25c: per 50, 65c.; per 100, $\$ 1.00$

\section{"Pliant" Leg Bands, Copper and Aluminum}

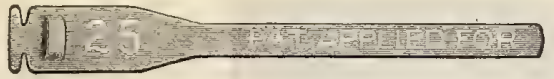

This is one of the best, cheapest and most sensible leg bands ever invented; they are easy to put on and take off. Once on it is almost impossible for them to come off.

These bands are made in both copper and aluminum, in two sizes ( 3 and 4 inch), to fit any fowl.

PRICES IN COPPER (either size)

12 for 15 cents. 25 for 30 cents. 50 for 50 cents PRICES IN ALUMINUM (either size)

12 for 20 cents. 25 for 35 cents. 50 for 65 cents.

These bauds are sent post paid, at above prices. For larger lots write for prices.

\section{The Smith Double Clinch Leg Band}

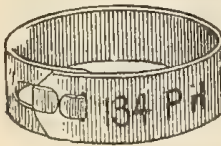

A very secure band. Made of the same metal as the sealed bauds and fasten with two clinches passing through the band and turning toward each other.

PRICE-25c. perdoz.; per 50, 6oc, ; per 100, $\$ 1.00$.

\section{The Smith Sealed Leg Band}

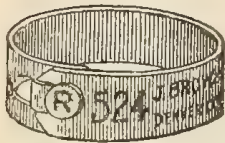

makes positive identification of the banded bird possible. When sealed on, and the band number and description duly entered on score card or award card, any child tliat can read can pick out the bird from card and band. When a bird wins a prize, or

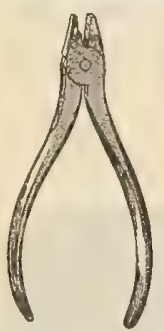
is scored and offered for sale under score or award card, the only way buyers can be sure they get what the card calls for is to insist on having them wear Smith's Sealed Band. PRICE-BANDS

ro for $25 \mathrm{C} .25$ for $50 \mathrm{c}$. 60 for \$1.00. 100 for $\$ 1.50$.

SEALER, plain, 50c. Sealer, lettered

75c. Nickeled, 25c. extra.

I itials on bands, not exceeding 3 20c. for 50 or less, 30c. per 100.

Pigeon Bands

If bands are put on when the bird is only five to eight days old, the seamless aluminum bands can be used. We stanp with two letters and the year, and numbered from up if desired. For old birds the open bands of German silver have to be used. These can also be marked with initial and number, as desired, without extra charge,

PRICE-For homers and similar sized breeds, Seamless Aluminum, 35c. per doz,: $\$ 2.50$ per roo. For dragoods runts, and large breeds, Seamless Aluminum, $45 \mathrm{c}$, per doz. $\$ 3.00$ per 100. Open German Silver-for all sizes, 20c, per doz.; \$1.25 per 100

\section{Message Holders}

A small aluminum box with lid, to fasten to leg of carrier pigeon. Price, each, $25 \mathrm{c}$.

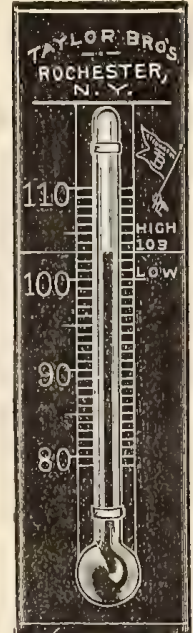

Thermometers

Incubator...

Thermometers

Our Incubator ther- 10 mometers are all contracted for two years in advance so as to allow the tubes to ripen, thus insuring their reliability. Absolutely guaranteed accurate. Either white metal with black letters or black face with white letters. Price, 5oc. each; by mail, 6oc. each. Per dozen, $\$ 5$.

Black face, white figure Incubator Thermometers. Price, $50 c$

\section{White metal, \\ black figure \\ Incubator}

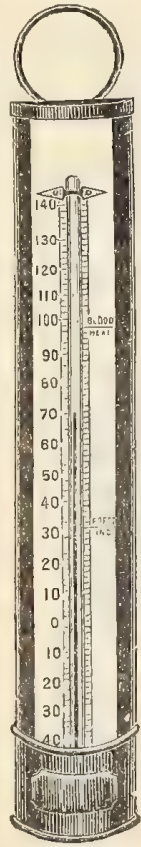

\section{Japanned Tin Case}

Thermometer Thermometers

These are a high grade tested ther mometer, and can be relied upon for reasonable accuracy.

PRICE-8 inch, I5c. each; \$1.50 per dozen. I0 "t 20c. " \$2,00

\section{“DISTANCE" Thermometers}

have white enameled tin case with very large figures that can be seen at a distance.

Price, 20c. each; $\$ 2.25$ per dozen.

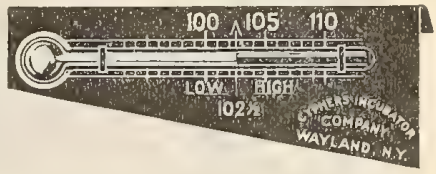

Cyphers

Incubator Thermometer

'These are made to suspend in the egg chamber, and are the same as furnished with the incubator. Accurate and carefully made.

Price, each, $60 \mathrm{c}$; $\$ 1.10$ for $2 ; \$ 3.00$ for 6 $\$ 5.00$ per dozen.

\section{Tin Case \\ Ther \\ mometer}

\section{Upright or}

Pineland Pattern

These are made short to stand upright iu the egg chamber. We consider them very good. Price. 5oc, each.

"New Short Slant"

Black face, white letter) Incubator 'Thermometers are the very newest style and have advantages over any others. From their position the mercury is very sensitive, and the bulb can be made to touch two eggs, if desired. Price, 6oc. each.

\section{Brooder Thermometers}

Made to stand upright in brood er or can be suspended

Price, 35c. each; 3 for $\$ 1.00$.

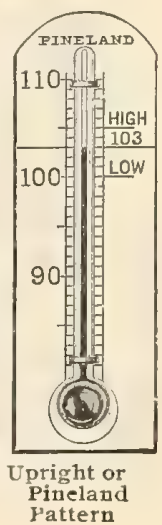




\section{DRINKING}

"THE "SANITARY" FOUNTAIN

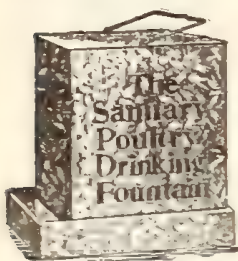

A square galvanized fountain, in two parts. A slight pull on the projecting part of the bottom removes it entirely, and, by using a small whisk broom, both parts are easily and thoroughly cleaned. It is filled instantly. You don't have to wait for the water to gurgle in through a small hole. It can be hung up out of the dirt on an ordinary nail or hook.

Price 1 -gallon size, 5oc.; $\$ 5.50$ per dozen. 2-gallon size, 85c.; \$9.00 per dozen.

\section{ic Philadelphia" Fountains}

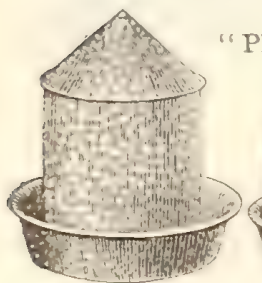

This $c u t$ illustrates our "Philadelphia" Fountains. They

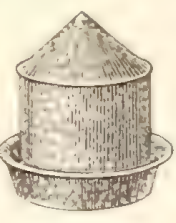
are made in two parts, the pan and the cone. They are thus e as ily cleaned and filled. All thoroughly galvanized.

(No. I (2 quarts), 35c. each; $\$ 3.50$ per dozen. Prico $\{$ No. 2 (4 quarts), 50c, each; 5.00 per dozen. ( No. 3 (8 quarts), $75 \mathrm{C}$. each; 7.00 per dozen.

THE "CLIMAX" FOUNTAIN

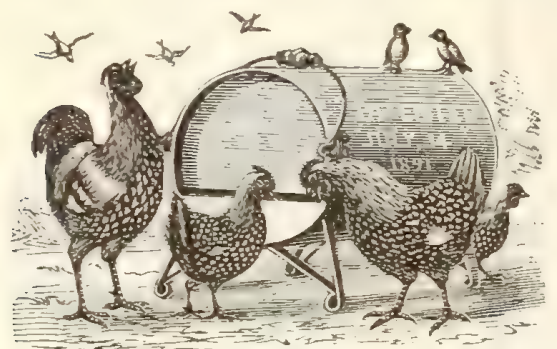

"The "Climax" is made of best galvanized iron. Keeps the water cool and fresh, and will not break in freezing weather. Has handle, and can be carried like a bucket. Price, I gallon, 85c.; 2 gallons \$1.ro; 3 gallons, \$1.30.

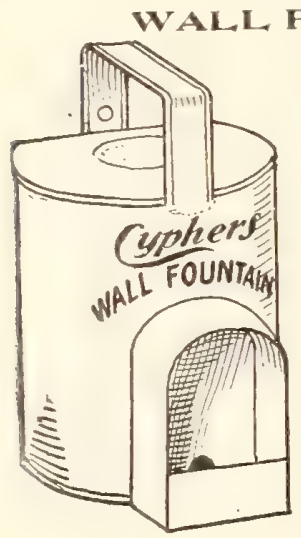

OUNTAINS

Something new and extra serviceable in the way of a poultry fountain. One side is flattened, so that it may be hung on the wall of the building or a post at any height. A hood projects over the water trough and protects the water from becoming soiled.

The founts are equally serviceable for young chicks or adult fowls, also for pigeons. Made from best galvanized iron, and are firstclass in every respect.

Price $\left\{\begin{array}{l}\text { I-gal. size, } 50 \mathrm{c} \text {, each. } \\ \text { 2-gal. size, 75c, each. }\end{array}\right.$

\section{FOUNTAINS}

\section{Hallock Food and Water Holders}

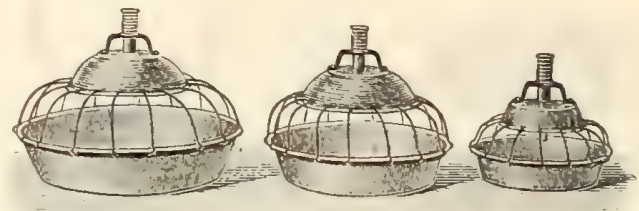

Undoubtedly the best cevice of the kind on the market, adapted for either food or water. Made in two sections, which may be easily separated, so as to clean readily. The wire prevents the birds from soiling or wasting the mash. Made from heavy galvanized iron, in three sizes.

Prices, small (I gallon), 75c. each; medium (2 gallons), \$I.00 each; large (3 gallons), $\$$ I.25 each.

\section{PIGEON DRINKING FOUNTAIN}

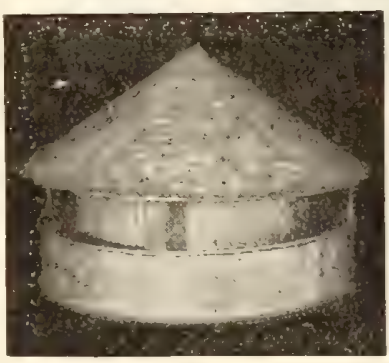

Pigeon fanciers and breeders raising pigeons in large numbers require a large, strong fountain with ample capacity. We have had this made to our own order. The pan is 15 inches in diam. eter and 3 inches deep.

$$
\text { Price, each, } \$ 2.50 \text {. }
$$

\section{PIGEON BATH}

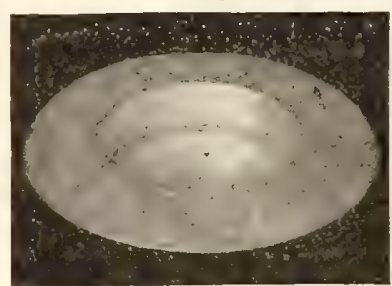

Made of heavy galvanized iron like a large inverted hat. The bath is 16 inches in diameter and 5 inches deep, with a rim 6 inches wide, strongly reinforced to keep from sagging. Price, $\$ 2.50$.

\section{Stoneware Drinking Fountains}

The advantage of stoneware fountains is that they keep the water cooler in summer. But they

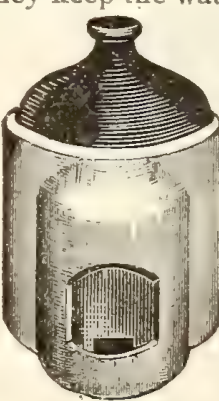

BALTIMORE FOUNTAIN.

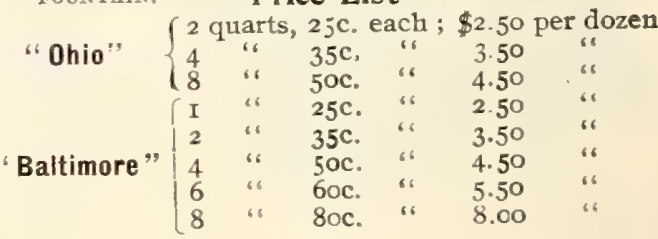
in winter, as they sometimes burst from freezing.

We have several styles of stone fountains, two of which we illustrate.

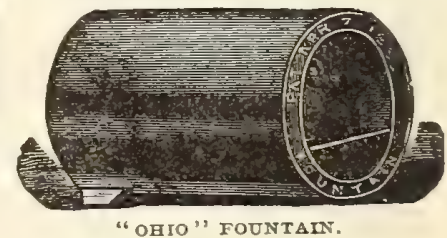

Price List 


\section{Union Lock}

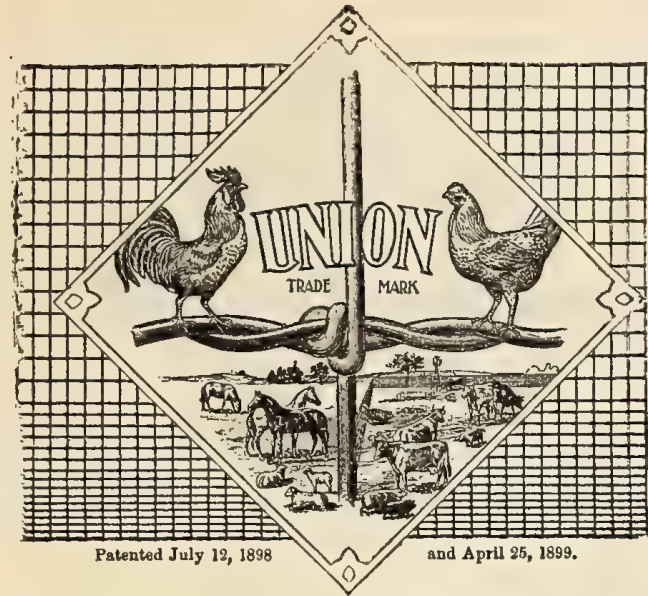

This new fencing for poultry yards will supersede the old 2 -inch mesh wire fence as soon as its merits become known. In the wider sizes it is no more expensive than the regular 2 -inch mesh netting, and the fine mesh at the bottom will appeal to every practical raiser as a great advantage.

The horizontal lines of this fence are all composed of 2 No. 20 galvanized steel wires twisted together.

Beginning at the bottom, the first 7 cablesare $I / 4$ inches apart, the next three cables are $I 1 / 2$ inches apart, then six cables 2 inches apart, and all above that 4 inches apart. This gives a mesh of $I_{1}^{1 / 4} \times 3$ inches at the bottom, where it is needed for small chicks, and above two feet, where fowls can only reach when on the wing, the mesh is $3 \times 4$ inches.

The pickets are No. I9 galvanized steel wires, and are three inches apart.

\section{Price List}

BALES OF IO RODS (I65 FEET)

24 inches wide . \$2.80 60 inches wide . . \$4.80 36 " " . . 3.4572 " 72 " . . 5.40 $4^{8}$ " " . . 4.15 84 " " . 6.15

Lots of 5 bales, 5 per cent discount.

Lots of Io bales, Io per cent discount.

In comparing prices with ordinary poultry netting, remember these bales are 5 feet longer.

\section{Extra Heavy Union Lock Poultry Fence}

Made of No. I7 galvanized steel wire throughout, is twice as heavy as our lighter poultry fence, and is intended for orchards, gardens, etc.

The No. 17 two-wire cable has about the same strength as a No. I 4 wire, and the numerous cables gives this fence a strength equal to our field and hog fence, making it an ideal fence for both poultry and stock.

The spacing between the cables is the same as in the lighter fence described above, but the pickets are four inches apart. In service this fence is superior to the No. 14 two-inch netting.

\section{List Price}

BALES OF IO RODS (I65 FEET)

24 inches high, 16 cables, $\$ 4.50 \mid 60$ inches high, 25 cables, $\$ 7.25$

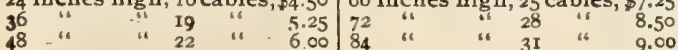

\section{Poultry Fencing}

\section{Union Lock Poultry Yard Gates}

The frame of these gates is made of one piece of steel pipe having an outside diameter of $3 / 4$ inch, and is covered with our Extra Heavy or No. 17 Poultry Fence. The hinges and latch are malleable iron. This gate requires a space 4 inches wiàer between posts than the gate to be used, to allow for hinges and latch.

\begin{tabular}{|c|c|c|c|c|c|c|c|c|}
\hline \multirow{2}{*}{\multicolumn{2}{|c|}{36 inches high }} & & & & & & $\begin{array}{c}\text { Width } \\
36 \text { inches }\end{array}$ & $\begin{array}{l}\text { Width } \\
48 \text { inches }\end{array}$ \\
\hline & & . . . & . & . . & . & & $\$ 2.50$ & $\$ 3.00$ \\
\hline $48 \quad$ " & " & . & . & . . & & & . $\quad 2.75$ & 3.25 \\
\hline “ & " & . & & . . & & & .3 .00 & 3.50 \\
\hline " & “ & • & . & . & & & . 3.25 & 3.75 \\
\hline “ & "“ & . . . & & . . & & & . 3.50 & 4.00 \\
\hline
\end{tabular}

IN ORDERING GIVE WIDTH AND HEIGHT

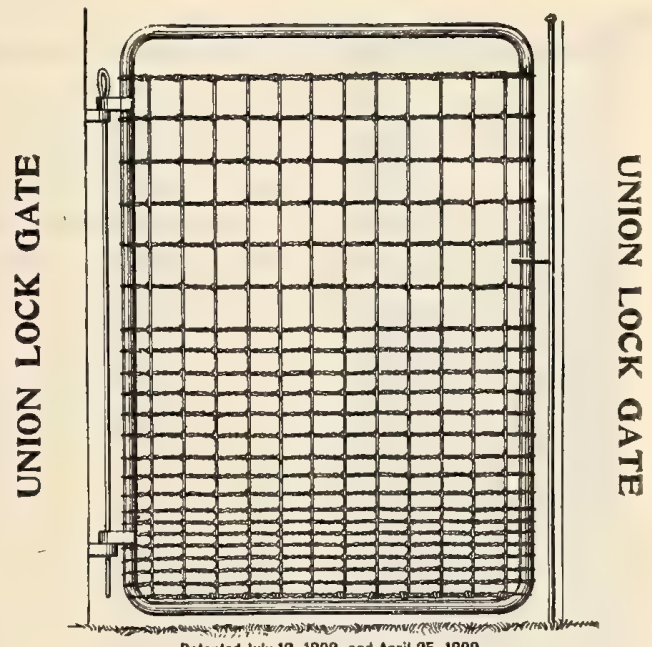

\section{Diamond Mesh Poultry Fencing}

This is the wire fencing that is almost universally used. It is cheaper than "Union Lock," but is not so desirable. As the price is variable, write us for special quotations when wanted in quantity. Bales are $\mathbf{I}$ o lineal feet.

Prices, 2-inch Mesh, No. 19 Wire \begin{tabular}{cr|ccr}
$\begin{array}{c}\text { Weight } \\
\text { Per Bale }\end{array}$ & Price & Width & $\begin{array}{c}\text { Weight } \\
\text { Per Bale }\end{array}$ & Price \\
2 I & $\$ 1.55$ & 60 & 50 & $\$ 3.75$ \\
3 I & 2.50 & 72 & 59 & 4.50 \\
40 & 3.00 & 84 & 69 & 5.25
\end{tabular}

Prices, I-inch Mesh, No. 20 Wire width $\begin{gathered}\text { Weight } \\ \text { Per Bale }\end{gathered}$ Price $\mid$ width $\begin{array}{ll}\text { Weight } \\ \text { Per Bale }\end{array}$

\begin{tabular}{lll|ccc}
12 & 19 & $\$ 1.70$ & 24 & $3^{8}$ & $\$ 3.40$
\end{tabular}

\begin{tabular}{lll|lll}
18 & 29 & 2.55 & 36 & 57 & 5.10
\end{tabular}




\section{"Vigor" Ground Beef Scrap}

Or Prepared Meat for Poultry

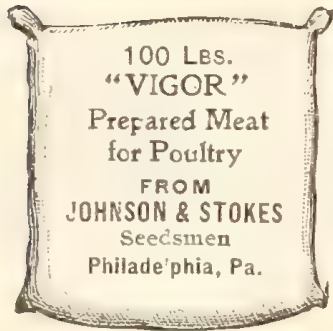

This is prepared with great care, and is shipped by us to all parts of the United States, principally to parties who are engaged in raising poultry and eggs for market. It is the finest thing we know of to cause hens to lay during the winter. Feed three times a week, at the rate of about a handful to every three birds, in the morning meal of hot food. High prices always prevail at this season of the year, which make it extremely profitable' to feed. Io lbs., 40c.; 501 bs., $\$ 1.50$; roo 1 bs., $\$ 2.75$; per toll, $\$ 48.00$.

\section{High Protein Beef Scrap}

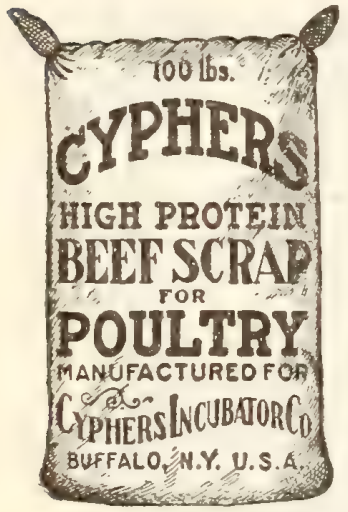

A superior grade of meat prepared for the Cyphers Company, and sold very largely to the largest consumers in this country.

It shows 50 to 65 per cent Protein, which places it at a very high grade.

Price

$5011 \mathrm{s.} . .+.81 .60$

\section{Spratt's Patent Prairie Meat Crissel}

This is a very fine grade of prepared meat, put up by the celebrated "Spratt's Patent" Company. Some of our customers will have it, though at an advanced price, as the brand "Spratt's Patent" is always a guarantee of superior quality.

Price

$50-1 \mathrm{~b} . \mathrm{bag}$

\section{Meat and Bone}

This is a good, clean, sweet article, and not a refuse from a fertilizer works, as many of such products are. It is meat scrap, bone, and dritd blood, cooked under steam pressure, and then dried and ground. It makes an excellent poultry food.

\section{Price}

Io $1 \mathrm{bs}$.

5o lbs.

I. 50

Ioo $1 \mathrm{bs}$.

\section{J. \& S. "Vigor" Egg Food}

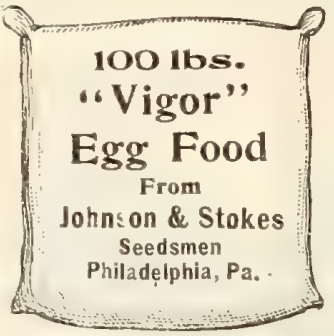

This is a great egg and vigor-producing food. It is our own brand, and we know whereof we sceak when we give it our highest praise and guarantee. It is to be fed as a mash, dry and crumbly. Feed morning and night, and if the fowls are kept in an enclosure, scatter our "Vigor" Scratch

Food in the litter at noon, to induce exercise in scratching for it. This food will keep them in good laying condition, as, it gives them the necessary stimulus without producing fat. It is a complete food. Nothing else need be given them but grit and occasional green cut bone. It will also help the fertility during the cold months.

Price, ro lbs., $\$ 1.50$; I co lbs., $\$ 2.25$.

\section{Bowker's Animal Meal}

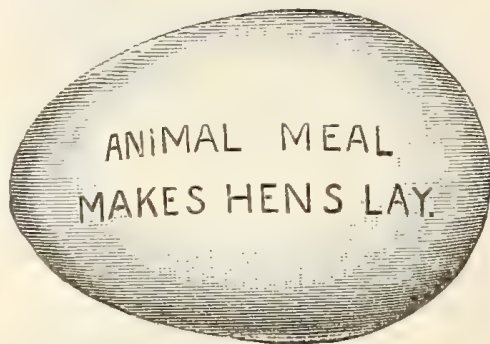

The richest part of the egg is the albumen. The laying hen a ud grow. ing chicks should be fed upon food ricli in aibumen and easily

digested. "Animal Meal"' contains a large amount of albumen, as well as material for the shell.

It is a well-balanced animal food, and contains less than 5 per cent water, while scraps contain 20 to 30 , and fresh meat 75 to 80 per cent. It will therefore go farther, and, being thoroughly cooked, is more easily digested.

Price, per 5-1b. carton, 20c.; 25 lbs., $75 \mathrm{c}$.; 50 lbs., $\$ 1.35$; roo lbs., $\$ 2.50$. Special prices by the ton.

\section{Ground Dried Blood}

Two Ounces of Ground Dried Blood Represent One Quart of Raw Blood

BLOOD MEAL is greatly relished by fowls, and an increase in the number of eggs is quickly noticed wher it is fed. Poultrymen must feed more or less meat scraps in winter to make hens lay; this is generally acknowledged. BLOOD MEAL is merely a meat in a highly concentrated form, rich in albuminoids and ash, both of which enter largely into the composition of the egg.

As to the advantages gained by feeding BLOOD MEAL to young chicks, ducks, and turkeys, we can say that there is positively nothing better for them. Those raising chicks hatched in incubators tell us that the loss from weakness, or "breaking down," as they term it, is enormous. If BLOOD MEAL is mixed with their ration of feed at the rate of one part cf blood to twenty of meal or shorts, no chick will die from the cause mentioned.

Price, 5 lbs., 25 c. ; 50 lbs., $\$ 2.00$; per roo lbs., $\$ 3.50$. 


\section{CHICK FOODS}

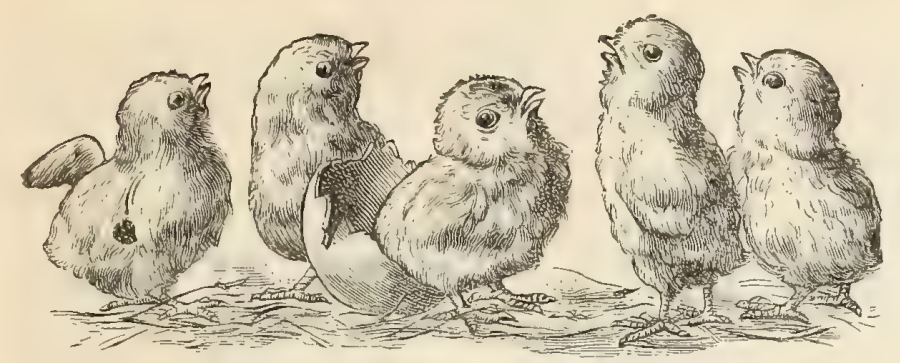

SINGING CHICK MANNA'S PRAISES

For the first day or two little chicks require but little food; brooder chicks particularly should not be fed for 36 to 48 hours after hatching, as their bowels are not perfectly formed, and, if overfed, dysentery or stoppage of the bowels ensues, and both are fatal. The first food should he Chick Manna and a little grit. Feed this for a week or ten days, and then begin with our "Vigor" Chick Food, and they will grow and feather "like a green bay tree." For the first week feed five times a day; second week, four times a day; and after that three times a day will do. Never feed what they will eat without moving out of their tracks; you must make them scratch for what they eat, and keep them hungry enough so that they will enjoy their feed. Give them water only after feeding them.

\section{F. P. C. CHICK MANNA}

\section{A Health Food for Little Chicks}

Chick Manna is a health food for little chicks, and with it you can raise every chick hatched. It promotes Health, Quick Growth, and Strong Development. Especially valuable for raising chicks in winter and early spring. Chick Manna should be the first food, and exclusively fed for ten days or more, after which time other food may be given, but should contain a portion of Manna for at least a few days longer. In feeding Chick Ilanna to chicks that have been fed on other feed, let Chick Manna be a part only of the feed for the first day.

Price of Chick Manna, I-lb. package, Ioc.; by mail, 25c. ; 48 1bs. to case. 5-1b. package, 40c. ; ro packages to case. I5-1b. package, \$I. Io; 5 packages to case; $60-1 \mathrm{~b}$. case (bulk), $\$ 4.20$.

\section{CYPHERS CHICK FOOD}

\section{A Complete Food for Young Chicks}

Cyphers Chick Food is a mixture of eleven (II) different grains and seeds, proportioned so as to meet all the needs of growing chicks, and to fully nourish them. By the term "fully nourished" we mean a great deal. Chick foods, as a rule, contain too much fat-forming, and not enough bone-forming elements; and, in consequence, the chick develops indigestion and diarrhcea-which ultimately means no digestion at all-and quickly starves to death. Or, if partially nourished, leg weakness develops, and the chick drags out a miserable existence for a greater or lesser length of time. If you feed Cy phers Chick Food, you are relieved of all concern, as the food is a complete and properly-balanced food, ready for use.

In compounding Cyphers Chick Food, the protein, or flesh-and muscle-forming element, is maintained higher, the carbohydrate; or fatforming element, is reduced to its proper proportion, and the ash, or mineral elements are in sufficient amount to supply the needs of the rapidlygrowing bird. If chicks are to be developed into breeders, no other food is required for the first eight weeks.

For the first three or four days spread the food on a board or bare floor four or five times a day. As soon as the chick begins to eat rapidly and scratch for food, scatter it in chaff or cut hay several times each day in sufficient amount to keep the chicks continually working. It should

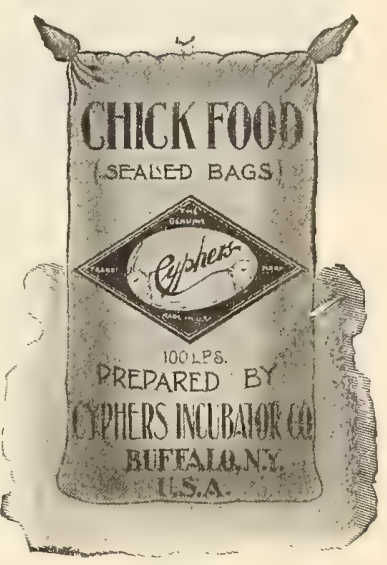
not be fed in any other manner. A dish of fresh water is kept before them at all times. About the fifth week a dish of High Protein Beef Scrap is put before them, and is replenished as fast as eaten. Continue feeding chick food until the eighth or ninth week. The chickens are then placed in colony houses on grass runs, and given a dish of cracked corn and one of beef scrap. Before the chickens are let out in the morning, a mash composed of Cyphers Forcing Food is fed. This is the only food they get through the day, except the cracked corn and beef scrap. A dish of fresh water is kept before them. On the above ration they make a quick, strong growth and mature early.

For broilers or roasters, the chick food and beef scrap are supplemented by adding Cyphers Forcing Food to the diet after the third or fourth week.

Put up only in sealed bags, bearing manufacturer's trade mark.

Price, 50-1b. bag, $\$ 1.50$; 10o-1b. bag, $\$ 2.50 ; 500.1 \mathrm{~b}$. 1ot, $\$ 12.00$.

\section{"Vigor" Chick Food}

This is our own brand of food for chicks, and is a carefully-prepared mixture of sound grains and seeds, with a little grit to give just such food as they would pick up on a large farm during the spring and summer months. It will give the chicks quick growth and keep them in good health. It contains all the meat and bone that is required, and anything extra that you give in this line will cause trouble. Always to be fed dry; never wet it.

Price, per lb., 8c. ; ro 1bs., 50c.; $501 \mathrm{bs}$., $\$ 1.75$; I00 lbs., $\$ 3.00$. 


\section{CLOVER PRODUCTS}

The value of clover as a portion of the regular diet of fowls can hardly be overestimated. Its value has long been recognized by poultrymen, as it furnishes protein, lime, and other material salts in an easily-digested form. Fowls relish it greatly in either dry or green form.

Clover is the best green food for winter use, as there is no waste, as in vegetables, and it is in a form to be fed with a very small amount of labor.

Feeding clover will insure a large percentage of fertile eggs and strong germs. It will do much to keep laying fowls and breeding stock in good health and vigor, adds luster to the plumage, and thus assists in putting choice birds in exhibition condition.

These clover products are put up in strong 50 and Ioo-lb. sealed bags, bearing the Cyphers registered trade mark, and labeled to comply with the various State food laws.

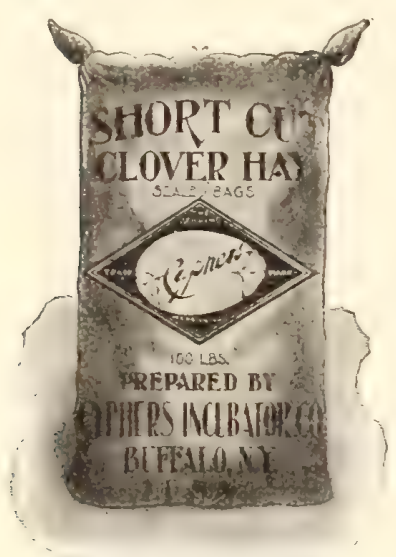

\section{Short=Cut Clover Hay}

This is Clover Hay cut into short lengths, and free from waste in the form of long stalks, weedś, etc. Fed either in a mash or scalded and fed in a trough by itself.

Put up in 50 and roo pounds.

\section{PRICE}

5o-1b. bag

$\$ 1.10$

Ioo-1b. bag

$500 \mathrm{lbs}$.

2.00

.

\section{Shredded Clover}

This article is finer cut than Short-Cut Clover and not so fine as Mealed Clover. For use in the daily mash.

Put up in 50 and Ioo-1b. sealed bags. Directions for feeding in each bag.

50-1b. bag

\section{PRICE}

I oo-1b. bag

$500 \mathrm{lbs}$.

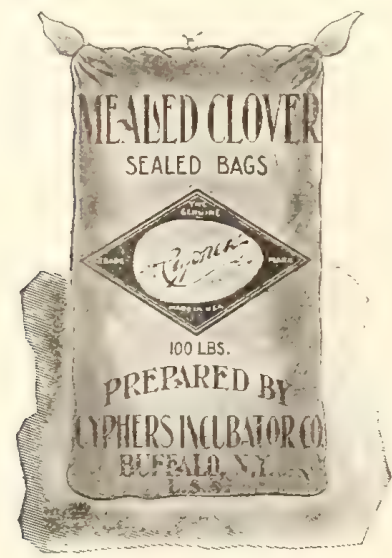

$5001 \mathrm{bs}$.

\section{Mealed Clover}

\$I. 10

2.00

8.75
Mealed Clover is Shredded Clover reduced to a meal. It contains the entire product-stalks, leaves, and blossoms. Best form for use in mash food for chicks, the meal being ground. sufficiently coarse to give bulk to the mash, thus making it easily digested.

Put up in 50 and roo-lb. sealed bags. Directions for feeding in each bag.

\section{PRICE}

5o-1b. bag

\$1. IO

10o-lb. bag

2.00

9.00 


\section{Cyphers Laying Food}

Cyphers Laying Food is the result of much study to produce a balanced ration, and is a highly nutritious and palatable food. It is a blending of several different food materials in such proportions as to best furnish the elements necessary to fully nourish the body and promote egg production. It is to be mixed with warm water, and daily-night or morning - is eaten by the fowls with relish.

A feed of mixed hard grains, such as Cyphers Scratching Food, should be scattered in litter on the floor of the pen to promote exercise, and a dish of cracked oyster shells and grit should be kept in the pens. This food induces the production of eggs, and will nourish and develop the embryos into strong, robust chicks.

Cyphers Laying Food is the best and only successfully-balanced ration from which to make the morning mash, whether for chickens, pullets, hens, cockerels, capons, ducks, turkeys, or geese. It is made from the best-selected grains, and contains no oat hulls or gluten meal, which analysis shows to be the base of three-quarters of the prepared poultry foods on the market. The manufacturers of this food make no cereal foods, and consequently have no bi-products, as is the case with most manufacturers who offer poultry foods. It is especially valuable as a food for breeding ducks.

This food is put up in sealed bags bearing manufacturer's trade mark.

Price, 50 pounds, $\$ 1.15 ;$ I 00 pounds, $\$ 2.00$.

\section{Cyphers Forcing Food}

Where very rapid growth is required, as in growing broilers or roasters, a highly-concentrated food can be fed, and for this work we offer Cyphers Forcing Food. This should be fed according to the results desired. That is, if a broiler is required, the chick should be fed up to the limit, so as to make the growth in the shortest possible time. If a roaster is wanted, it should not be forced so rapidly, as it has longer to live, its digestive organs have more work to do, and, therefore, they should not be taxed to the uttermost in the earlier stages. Price, 50 pounds, $\$ 1.25 ;$ Ioo pounds, $\$ 2.25$.

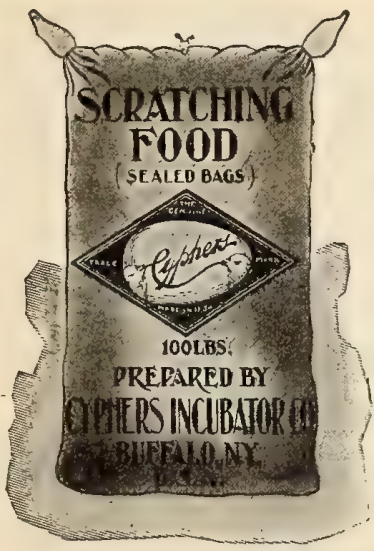

\section{Cyphers Scratching Food}

In combining grains to be used as an exercise food and to be scattered in the pens to make the hens work for what they get, it will not do to make up a random assortment of any available material.

As the Scratching Food is not supposed to be scattered before halffamished birds that will gladly eat most anything, it must be composed of material that will be considered with special favor by the hens, something, in fact, that their system craves. There must be a strong inducement for a well-fed hen to work for every morsel of this food, and at the same time it must be composed of such material as will not defeat the purposes of the balanced foods they get in their regular ration. In this Scratching Food we have exactly filled these requirements. A little of this food scattered in the litter will quickly start the dust flying, which means healthy fowls, full of vigor and vitality, and a full egg basket of hatchable eggs.

Put up in sealed bags bearing manufacturer's trade mark.

Price, 50 pounds, \$I. Io ; I00 pounds, $\$ 2.00$.

\section{Midland Poultry Foods}

Are composed of the very best material obtainable, and as carefully and accurately mixed as it is possible to make them. They are a complete food, and will produce specific results, each for its purpose, and no other.

\section{MIDLAND BRANDS.}

No. 1-Nursery Chick Food.

No. 4-Egg and Feather Producing Food.

No. 6-Duckling Food.

Price per original sack (about 2 bushels), $\$ 2 . \mathrm{co}$; 5-sack lots at $\$$ I. 85 per sack.

\section{MIDLAND GRENADIER MEAL}

\section{A Forcing Food for Broiler:}

The advantage of a cramming machine over the trough for fattening a chicken is that the bird can digest and assimilate much more feed than it will consume if left to its own inclinations. It is vitally essential that the food furnished in this way be scientifically prepared for this specific purpose, and the Midland Grenadier Meal is guaranteed to be just what is needed, and, if fed as directed, will open the eyes of those unaccustomed to this work.

Price, $5 \mathrm{c}$. a pound; per 25 pounds, $90 \mathrm{c}_{\text {, }}$; per 50 pounds, $\$ 1.75$; per Ioo pounds, $\$ 3.00$. 


\section{CURES FOR ROUP}

Roup is a disease of the air passages produced by colds. There is a discharge from the nose and eyes which becomes thick and offensive. It is very contagious in this stage, and the bird should be separated from the rest of the flock at once. If the kead is swollen or eyes closed, rub them with a mixture composed of one tablespoonful each of melted vaseline and Johnson's Anodyne Liniment (see this page) Then use any of the following preparations, carefully following directions on the package.

\section{Cyphers Roup Cure}

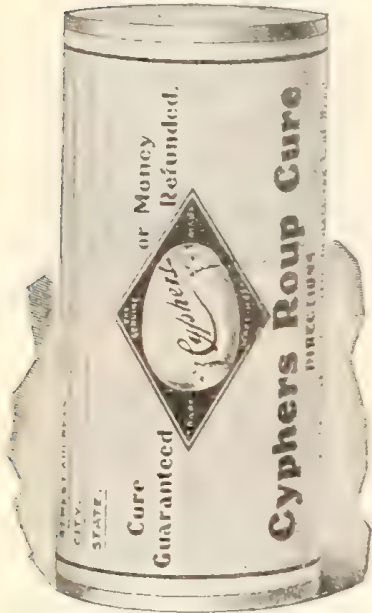

A positive guaranteed remedy for the cure and prevention of this dreaded dis. ease. Also prevents colds a nd is urequaled for canker. especially in pigeons

Roup is one of the most common and most deadly diseases affecting poultry. Al poultrymen should take great precaution against it. Roup is a contagious catar thal disease, and ust: ally follows simply neglected colds.

Symptoms: Froth and bubbles in the corners of the eyes, sneezing, and a foul

smelling watery discharge from nostrils, followed by swelling of the head.

Taken in time, this disease may be conquered with a good remedy; hence, all should have a supply of Cyphers Koup Cure on hand. One $50 \mathrm{c}$. package makes 25 gallons of medicine. One \$1.00 package makes 75 gallons of medicine. Directions on each package.
PRICE-Small size
Large
$\$ 0.50$ postpaid
I.00

\section{HAVENS' ROUP PILLS}

For the Cure of

Roup, Catarrh, Cold and Distemper

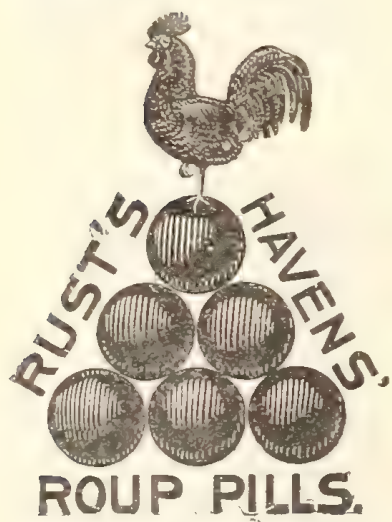

It was former 1 y the habit of fanciers, farmers and others, whenever roup appeared in a flock, to kill the fowls affected and remore them immediately, to prevent the spread of the disease. The practice is, happily, no longer necessary since the introduction of Havens' Roup Pills Price, per box, 25c. by mail, 28c.; per doz., by express, $\$ 2.50$. Box of 250 pills, \$I.

They entirely cured my fowls of Roup.-ABRAM WOLFE, Lebanon. N. J.

Havens' Roup Pills are simply wonderful,-C. TRUEX, harness dealer, Freehold, N. J.

$I$ found them a perfect success in Roup.-PETER $H$. DOACKenbosh, Manalapan, N.J.

\section{CONKEY'S \\ ROUP CURE}

Conkey's Roup Cure will positively cure roup in all its forms. It is simply put in drinking water and the chicken takes its own medicine. It prevents colds and is unequaled for canker, especially in pigeons.

One 5oc. package makes 25 gallons of medicine; \$I packages make 75 gallons of medicine.

So it is the best and cheapest cure of its kind in the market.

\section{JOHNSON'S}

\section{ANODYNE}

\section{LINIMENT}

for the cure of Internal and External Inflammation. An old and universal household remedy for colds, coughs, cramps, cholera, rheumatism, dysentery, burns, wounds, sprains, and bruises. Also valuable in the Poultry Yard for roup, cholera, and wounds. Price, per bottle, 25c. and 5oc.

\section{F. P. C. "Multum in Parvo" Poultry Powder}

\section{A Purely Medical Preparation for Cholera, Roup, "etc.}

Multum in Parvo is a cure for cholera. A customer writes: "I find it an excellent remedy; it is the only medicine $I$ have ever found that will cure what we call turkey cholera." It is also a valuable remedy for roup disease in its various forms. However, we recommend the use of the Roup Preparation in connection with Multum in Parve when the rattling in the throat is noticed; also for sore and cankered mouth. Poultry keepers do well to have these two preparations constantly on hand to meet cholera and roup. Much is gained in meeting disease promptly. I/2-1b. package, 20c.; by mail, 28c.; 1-1b. package, 35c.; by mail, $50 \mathrm{c}$. 


\section{Lambert's "Death to Lice"}

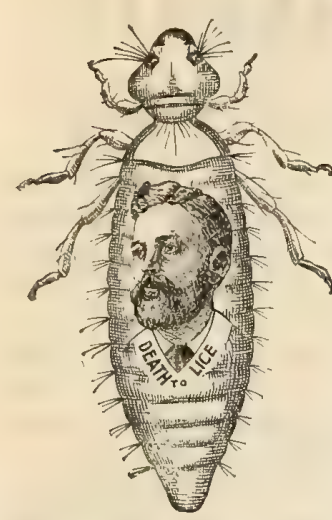

In any well-conducted poultry establishment Lice have to be fought all the time.

Lambert's preparations for this purpose are standard, reliable goods, well-known and largely used by the best poultrymen the country over.

For sitting hens it has no equal, keeping them clean, sweet and comfortable, without injury to the hen, eggs, or chickens, should they hatch in it. No trouble to apply; no detriment to the person handling it. Also invaluable for lice on HORSES, CATTLE, SWINE, or plants, fleas on DOGS, ticks on SHEEP, moths under carpets or in furs. Always harmless to animals when used according to directions. It acts as a disinfectant and purifier, warding off distemper and contagious diseases. A liberal use of this powder should answer for all ordinary purposes. It can be mixed with sawdust as a litter for chicken coops or nest boxes. It can be sprinkled on the dropping boards under the roosts after cleaning. It can be used on show birds in their pens with good effect. Laying fowls or large chicks can be dusted at night; they will be clean in the motning. Sitting hens well dusted twice during incubation will never leave their nests on account of lice, and it is perfectly safe to use. It your hens are near your stable, sprinkle the horse-brush before using with Death to Lice, and ycur horses will be safe.

We are general agents for D. J. Lambert's Preparations for Lice, and can give you dealers discount in case lots.

\section{5-oz. box (trial size). \\ Postpaid
I 5-oz. box (regular size)
Postpaid . .

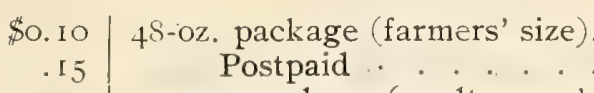 \\ .25 \\ .40 \\ roo-oz. package (poultrymen's size) \\ Express paid \\ Lambert's "Death to Lice" Ointment}

$\$ 0.50$

1.00
1.00
2.00

For Head Lice on Little Chicks. Harmless and efficient. I-oz. size, IOc.; 3-oz., $25 \mathrm{c}$

Lambert's "Death to Lice" Special

Dissolve the "Special" in kerosene, and you have an efficient Liquid Lice Paint. 4-oz. size, IOc.; 16-oz. size, 25c., ot postpaid, 40c:

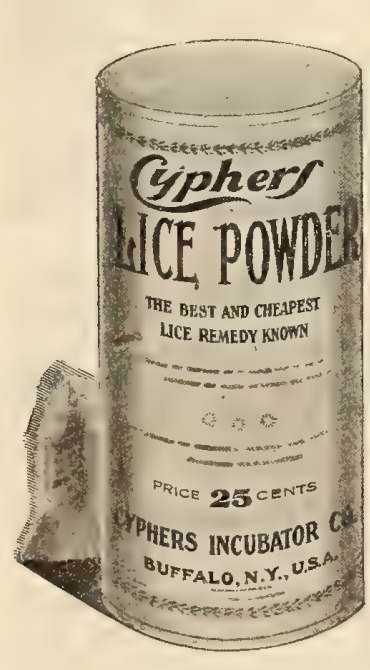

\section{Cyphers Lice Powder}

Is c a re f u 11 y compounded, and contains no carbolic acid or other chemicals which will injure the fertility of the eggs. It is clean to handle, easy to apply, sure in effect, and can be used in the nests of sitting hens without fear of in juring young chickens. For lice on cattle and horses, ticks on sheep, and fleas on dogs, Cyphers Lice Powder is a most effective remedy. It can also be used on plants and bushes as a protection against bugs and lice. As an insecticide it is without a peer.

\section{PRICES}

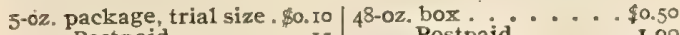

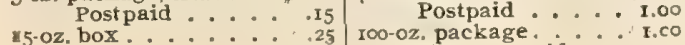

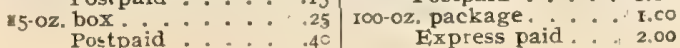

\section{trade VERO mark}

\section{RELIABLE INSECT POWDER}

For the Destruction of Chicken Lice, etc. One of the Most Effective Remedies

to Relieve Chickens, Pigeons, and

Canary Birds from Lice, Dogs and Cats from Fleas

Places infested with roaches, ants, moth, silverfish and bedbugs can be cleansed by placing the powder in crevices, holes, and other places infected.

$1 / 4=1 b$. can, 16c.; by mail, $25 \mathrm{c}$.

$x / 2=1 b$. can, 30c.; by mail, $40 c$.

\section{PURE PERSIAN INSECT POWDER}

We import an absolutely unadulterated article, and it can be relied upon to kill the insect pests of all kinds.

Price, 1/4 lb., I5c.; by mail, 20c.; I 1b., 40c.; by mail, $58 \mathrm{c}$. 


\section{GRIT! GRIT!! GRIT!!!}

\section{BIRDS NEED GRIT !}

It is well known that the feathered tribe have no teeth and that the food is masticated in the gizzard; but the gizzard itself is a feeble agent, and cannot perform its functions without the aid of some substance that is hard and sharp. Nature, therefore, prompts the hens to pick up and swallow gravel, glass, small shells, and other substances; but it may be noticed that they prefer such as are sharp and irregular.

Round bits of gravel do not serve the purpose, though better than nothing, and the gizzard is not injured, no matter if the sharpest and keenest glass be swallowed. The food and hard substances are kept in coustant motion while in the gizzard, and the entire contents are ground into an impalpable powder and passed into the stomach.

Common sense, therefore, teaches us, and all authorities on poultry unite in the statement, that something of this kind is absolutely essential to the good health and egg producing qualities of the fowl.

In summer, when the birds have farm range, they can look out for themselves in this respect; but where they have to be confined, or in winter when everything is frozen up tight or covered with snow, this necessary grit must be supplied to them freely or they will languish for its want.

\section{CRUSHED OYSTER SHELL}

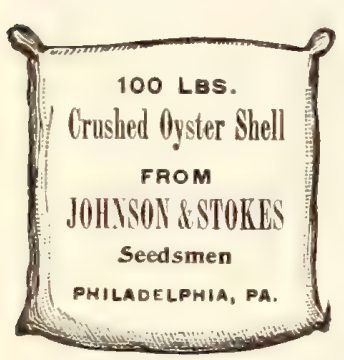

This is a most im. portant article for the poultry yard through the winter, and should be liberally supplied to the fowls. It is also advisable to keep it before them during the entire year, as experience has proven they will eat it in the middle of summer. Our shell is made entirely of OYSTER SHELI, NOT CLAM, as much is that is offered, and is thoroughly screened from all dust and dirt.

It is now offered so cheap that it does not pay to try and grind or break up your own shell. We have it fine for young chicks and for mashes, and coarser for regular use.

\section{PRICE}

Put up in 5 lb. fancy lithograph cartons, each, 15c. Per case of 20 cartons, 100 lbs. in all, \$I.5O. In bulk, 25 lbs., 30c.; 50 lbs., 50c.; I00 1b. bag, 65c.; 500 lbs., \$2.50.

Special prices by the ton or carload.

\section{GROUND CHARCOAL}

A little ground charcoal, mixed with the soft feed in the morning, once or twice a week, is an excellent corrective for the fowls, and keeps them healthy.

Price, I 1b., 8c.; 5 lbs., 35c.; ro lbs., 6oc.; 25 lbs., \$1.25; IOo lbs., \$4.
SOFT SEA SHELLS

\section{LARGELY USED ON DUCK RANCHES}

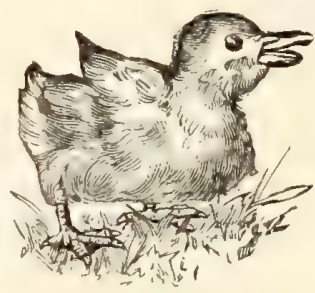

These are selected shells, and are used by duck and poultry raisers extensively, especially for ducks.

No grinding, no pounding, no trouble, but all ready to feed.

Eigg shells formed by feeding Sea Shells prove far superior to other eggs for hatching, by actual results.

Some poultrymen state their value double to other shells; where this is doubted, one fair trial has convinced all of the trutb of the statement.

The shells are best when damp (because they contain chloride of sodium in just the necessary quantity) and are so shipped.

Price, 5 lbs., 20c.; 25 lbs., 50c.; per bushel, 75c.; 2 bushel sack, \$I.35; per barrel, \$2.

\section{GRANULATED BONE}

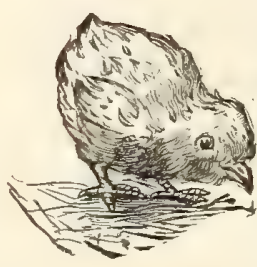

is about the size of wheat, and can be fed like any other food in grain, about one handful for every five fowls daily, or every other day. In either manner it furnishes a valuable food for poultry at all seasons of the year. Price, 5 lbs., 25 c.; Io lbs., 40c.; 50 lbs., \$I. 50 ; IOO lbs., \$2.50. 


\section{BEE \\ KEEPERS'

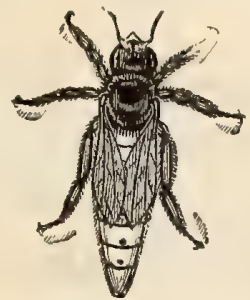 \\ BEE SUPPLIES}

The growing demand for bee keeper's supplies has caused us to put in a full line of articles wanted in the apiary, and can get, at short notice, anything not found listed here

\section{The Dovetailed Hive}

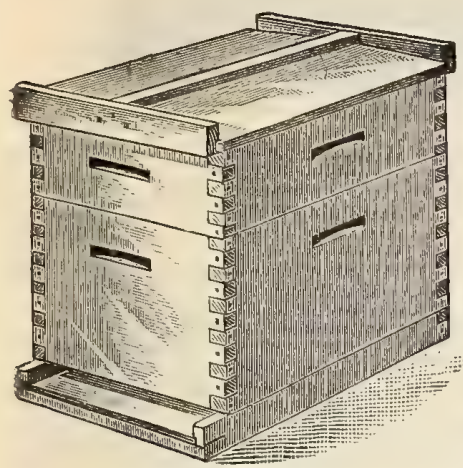

The Dove tailed Hive is taking the lead of the singlewalled hives, as it contains many of the most desirable features of the various hives for rapid handling of bees, and is one of the cheapest hives manufactured.

It is dovetailed together, as shown in cut, and that is what gives it its name.

\section{Price List of Hives}

No. I Dovetailed Hive, eight frame, complete, a one-and-a-half-story hive for comb honey, includes a body with eight improved Hoffman thick-top frames and plain division board, one super, with a follower and wedge, six section holders, with separators, section, and starters. Each, set up, \$2.85. In the flat, each, $\$ 2.15$; five hives, $\$ 9.75$; Io hives, $\$ 18$.0o.

No. 2 Ten Frame Hive is the same as No I, except that it has ten frames instead of eight.

Price, set up, each, $\$ 3.00$; in flat, each, $\$ 2.30$; lots of 5 in flat, $\$ 10.50$; lots of $10, \$ 19.50$.

No. 5 Dovetailed Hive, eight frames, complete, is a two-story hive for extracting ; includes two bodies, with sixteen thick-top Hoffman frames and two division boards. Each, set up, $\$ 3.00$; in the flat; each, $\$ 2.30 ; 5$ hives, $\$ 10.50$; Io hives, 19.50 .

No. 6 is the same as No. I, except that it has four $D$ cases, with twenty-four sections and starters for same (no separators) instead of section holders. Each, set up, \$3.00.

\section{Dovetailed Chaff Hive}

Dovetailed Chaff Hive is a one-and-a-half story, double-walled, eight-frame hive for wintering bees. It has a space of two inches between the walls, with a tray, of five inches deep, for packing chaff, and a seven-inch-deep telescope cover, which prevents the rain from beating in. It also has a double bottom. It will take the same super and upper story that are used on a regular dovetailed hive. Each, set up, \$4.00; \$3.00 in flat.

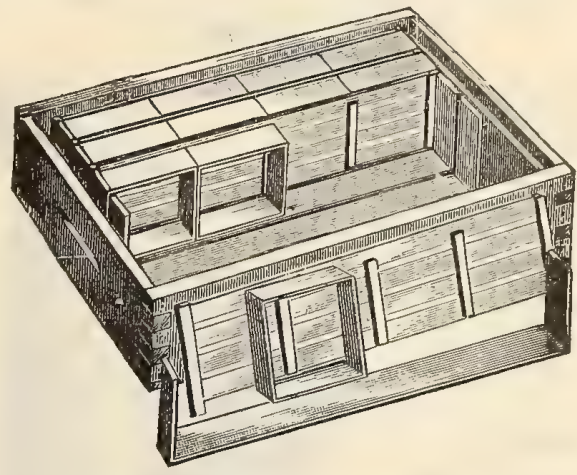

Dovetailed Super

With Plain Section and Fence

Each, complete . . . . . 95c., nailed 7oc. in flat.

\section{Section Boxes}

Our No. I sections are made up of the choicest white basswood, and are all perfect in finish and free from defects.

Price, per $25 \ldots . . . . . . . .30 .30$

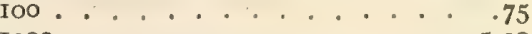

1000 . . . . . . 5.00

Write for special price on large quantities.

No. 2 Section Boxes, made of basswood, but not finished as perfectly as the No. I.

Price, per 100.......... . \$o.65 $1000 \ldots . . . . .450$

\section{Hoffman Frames}

The Hoffman thick-top, self-spacing frames have been the leader for years, as they are self-spacing, and with them kees can be handled very rapidly.

Price, per 25, put up . . . . . . . \$1.50

$$
\begin{aligned}
& \text { " } 100 \text { " . . . . . . . } 4.00 \\
& \text { 25, in flat .......... I.00 }
\end{aligned}
$$

\section{Simplicity Frames}

Lighter in weight than the Hoffman, and used where care can be exercised in handling.

Price, put up, per $25 \ldots . . . . \$ 1.00$

"6 " $100,3.00$

" in the flat" roo....... . . 2.00

Price List of Hive Parts

Empty Body . . . . . . . . . each, \$0.50

Bottom Board . . . . . . . . . " 35

Cover . . . . . . . . . . " " 45

Plain Division Board, roc. in flat; set up, " $\quad$ I5

Section Holders . . . . . . . per 25, 75

" ". . . . . . " 100, 2.00

Fences . . . . . . . " 25, 60

Tinc 


\section{Comb Foundation}

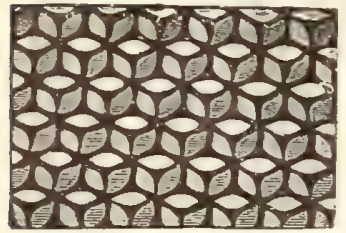

All our Comb Foundation is the New Weed Process, made from fure bright yellow beeswax. It is beyond a doubt tougher, more easily worked by the bees and more transparent than any foundation ever before made.

Price, Medium Broad,

“. Light Surplus,

\section{Smokers}

The Corneil sinoker is just the this $x$ for those who want a first class, reliable smoker at a medium price. It is of good capacity, 3\% inch barrel. strongly made and well finished.

\section{Price $85 \mathrm{c}$.}

\section{Crane}

\section{Smoker}

This is made on the same general line as the Corneil. The size of the cup is $3 \frac{1}{4}$ inches, has

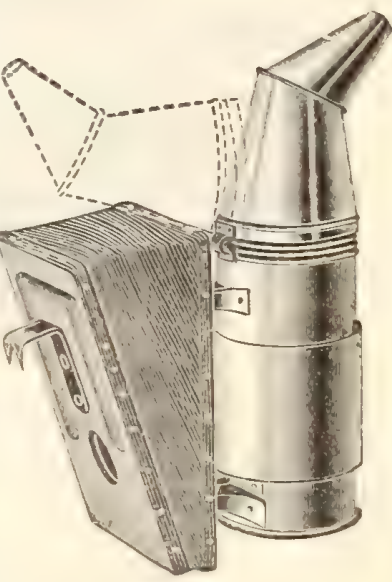

curved nozzle hinged so as to swing back for re. plenishing. It has the strongest blast of any smoker in the market. Price, \$1.25

\section{Clark's Cold Blast Smoker}

The Clark Cold Blast Smoker is cheap in price. It is a breech loader, therefore easily replenished by simply revolving the sliding door. Price, $55 \mathrm{c}$.

\section{Foundation Fasteners}

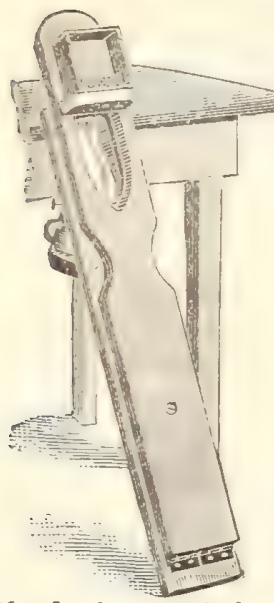

The Daisy Foundation Fastener is for putting starters into sections. Nothing could be more simple of easily operated.

\section{PRICE}

Daisy, with Lamp . . 1.25 Parker

\section{Manum's Swarm Catcher} jar the latter off the limb, and close the lid. This device will reach a swarm twenty feet from the ground. It is light and easily handled.

Price, \$I each, without pole.

Complete with pole, $\$$ I.25

\section{Porter Bee Escape}

One of the most essential things in the apiary is a bee escape, as it aids the apiarist in removing his honey crop. We recommend the Porter Escape as one of the best made, and no well regulated apiary can afford to be without it. Full directions for use. Price, 25c. each; with board, $35 \mathrm{c}$.

\section{Alley's Queen and Drone Trap}

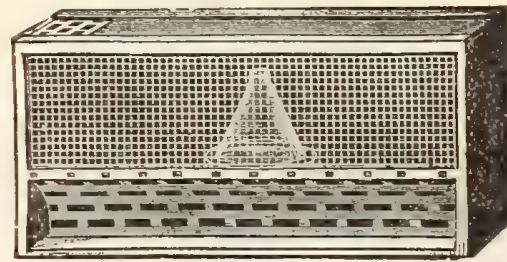

This will automatically catch and cage the drones in an apartment by themselves. The trap will also catch the queen when the swarm issues, and hold her confined until the apiarist can give her his attention. The bees will cluster ahout the queen, and may then be hived.

Price, 5oc.; by mail, $75 \mathrm{c}$.

\section{Bee Entrance Guards}

These are to admit workers, but exclude drones, After the drones are all out, fix the guard over the entrance, and at night the drones can be destroyed.

Price, Tinker Zinc, I3c, each; I.00, for Io Root " IOC. "SOc." IO

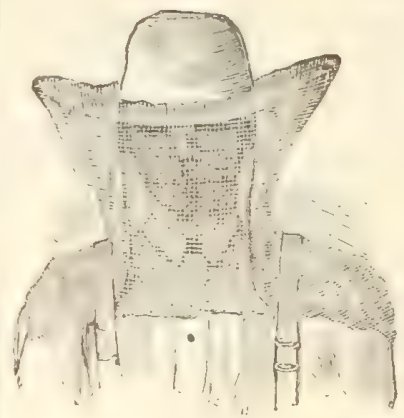

Veils to Protect the Face

Our veils each contain $I 1 / 4$ yards of the best material for the purpose They are well made with rubber cords in the top to fit around the hat, and lower edge is bound to prevent fraying.

Price List of Veils and Hats

No. I, Made entirely of Silk Tulle... 8oc No, 2. Cotton Tulle, with Silk Face. . . 5oc No. 3. " " throughout ....40c Bee Hats, flexible rim, fit any head, 3oc.

\section{Rubber Gloves}

We sell large quantities of these for handling bees. We canfurnish a good article well worth the money.

\section{Price List of Rubber Gloves}

Ladies' Size, Nos, 6, 7, 8 and 9.... \$1.35 Men's " " IO, II and I2.... I.45

\section{Cogshall Bee Brush}

This is a whisk broom specially made for brushing bees from combs by being made much thinner and longer. With it the bees can be removed from combs very gently.

Price, 2oc, each; by mail, 25c. 


\section{TENTS \\ For Setting Over a Hive}

These are for the purpose of enabling us to go on with such work as introducing queens, transferring, etc., when robbers get so troublesome that we could not go on with work otherwise. Dimensions of tent, $5 \mathrm{ft}$. long, $5 \mathrm{ft}$. wide and $5 \mathrm{ft}$. high. Price, \$1.50.

\section{HONEY KNIVES}

These knives are used for uncapping, scraping propolis off bottom boards, covers, etc.; for transferring and cutting chunk honey generally.

\section{Price List of Knives}

Novice... . . . each, $75 \mathrm{C}$

Bingham. . . . . . . " " 70c.

Quimby . . . . . . . " " 90c.

Muty.......... " 5 . . .

\section{SPUR WIRE IMBEDDER}

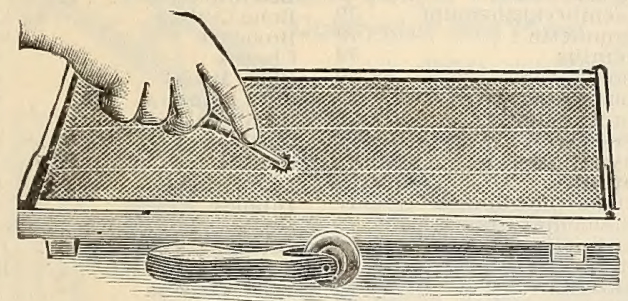

This is a little tool like a tracing wheel, with teeth set in such a way as to straddle the wire while it is in the act of imbedding. Price, I5c, each.

\section{HONEY EXTRACTORS}

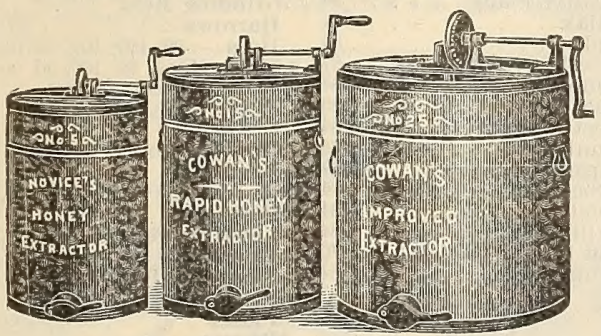

SHOWING THE RELATIVE SIZES

The above cut will show the relative sizes of Honey Extractors. These are excellent machines when rapid work is required. They are strong and well made.

\section{Price List of Extractors}

No. 5, Novice, for L Frames or Simplicity.

Weight, $45 \mathrm{lbs}$. . . . . . \$8.50

No. I5, Two Frame Cowan, for L Frames.

Weight, 70 lbs. . ... . . II.50

No. 25, Four Frame Cowan, for L Frames.

$28 \mathrm{in}$. in diameter. Weight, I50 lbs. . 23.00

\section{FEEDERS}

Bees are fed for two purposes-to stimulate brood rearing or to supply them with the necessary stores for winter.

\section{Price List of Feeders}

Simplicity Feeder..... each, 8c.; Io for $\$ 0.65$ Gray's Cover Feeder . . " I5c. Boardman Feeder. . . . " 25c.; Miller's Feeder . . . . . " 35c.;

\section{CAGES FOR QUEENS}

\section{For the Purpose of Mailing Queens to all Parts of the Country}

\section{PRICE LIST OF QUEEN CAGES}

Benton Cage . . . . . each, 5c.; Io for $\$ 0.40$ Export Benton, complete. " $25 \mathrm{c}$.; " 2.00 Miller's Introducing Cage. " IOc.; “ $\quad .80$ West's Spiral Cage . . . " " ror.; " West's Cell Protector. .. " " 5c.; " 50

\section{TINNED WIRE}

We sell No. 30 Tinned Wire, which is the most suitable for wiring frames.

\section{Price List of Tinned Wire}

3/4 oz. Spools . . . each, 3c.; doz., \$o.3o

$1 / 4$ lb. " ... " " I2c.; "

$1 / 2 \mathrm{oz}$. "... " " $20 \mathrm{c}$.; " 2.25

I

30c.; s6

3.30

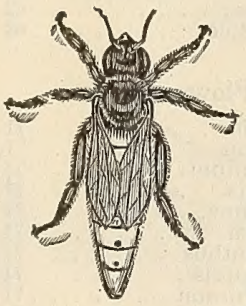

\section{BEES QUEEN BEES}

We have imported this past season some of the finest colonies of Golden Italian Bees ever brought to this country, and insure a pure strain by having secured coutrol of ali the bees within flying distance of our apiary. We find, after giving the subject careful study, that the best strains of bees for gathering honey are the Imported Italians. We have also secured some of the best Five Banded Italians we could secure, bred in this country, and we cross these directly with the imported mother, making our queens beautiful golden to the tip, and her bees the best honey gatherers in the world. They enter the sections readily, are quiet and not inclined to swarm. We offer them at the following prices, which are very low, considering the quality of bees we produce:

\section{FRICES OF BEES}

Fis: Colony of Bees with Queen . \$10.00 Mated Queens ......... . . .00 Selected Untested Queens .... I.25 Tested Queen . . . . . . . . I.5O Select Tested Queen . . . . . 2.50 Fine Breeding Queen . . . . . 5.00

NoTE.-The price of Colony does not include the hive, which will be additional, and prices will be found on page 39 .

\section{The A B C of Bee Culture}

Fifty-second thousand now out. A cyclopædia of everything pertaining to the care of the honey bee. By A. I. Root. This is a cyclopædia of over 400 pages, and is beautifully illustrated by 300 original engravings, many of them full page. Some of the latter embrace a view of the apiaries of the largest and most successful bee men. The whole work is elegantly bound in cloth, 7 inches wide by Io $1 / 2$ inches long, and embossed on side and back in gilt. Price, $\$ 1.25$. 


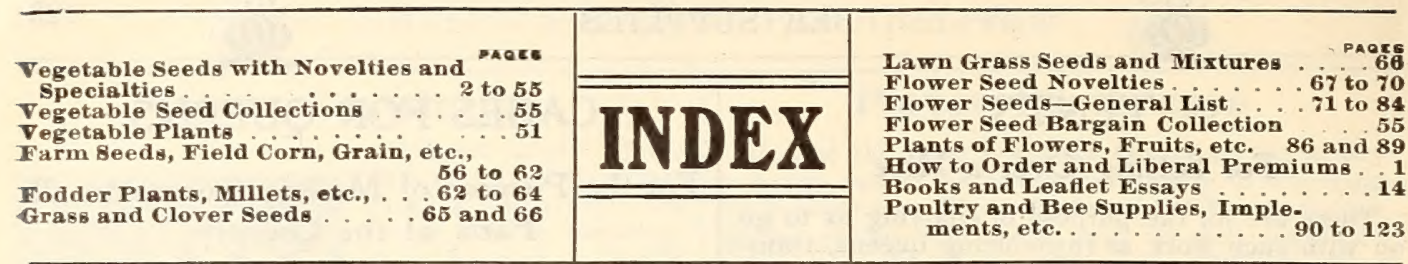

\begin{tabular}{|c|c|c|}
\hline Vegetable Seeds, & Farm Seeds-Con. & $\begin{array}{l}\text { Flower Seeds-Con. } \\
\text { PAGK }\end{array}$ \\
\hline Artichoke ...... 15 & Beans, Field & . 30,77 \\
\hline if Roots, . . 63 & Broom Corn ....6. 63 & Grasses . : : \\
\hline Asparagus & $\begin{array}{l}\text { Buckwheat } \therefore .59 \\
\text { Chufas }\end{array}$ & Grevillea : \\
\hline Beans, Bush, Girej - & Clovers & Helianthus. see sun: \\
\hline Beans, Bush, Wax-Pod- & Fruit Tree Seeds $\cdots \cdots$ & Heliotrope $: \cdots .78$ \\
\hline Beans, Bush Varieties for 2,16 & $\begin{array}{l}\text { Frut Iree seeds } \ldots .59 \\
\text { Ginseng } \ldots . .\end{array}$ & $\begin{array}{l}\text { Hollyhocks }: \cdots: \cdots: 78 \\
\text { Humulus. }\end{array}$ \\
\hline $\begin{array}{l}\text { Shelling } \cdots: 17 \\
\text { Beans, Limas }: \cdots \\
17\end{array}$ & $\begin{array}{l}\text { Grasses : . : : : } 65,66 \\
\text { Millets } \\
\text { Millo Maize. }: 64 \\
\end{array}$ & $\begin{array}{r}\text { Ipomoea. See Moonflower, } \\
\text { Kenilworth Iry } \quad 68,79\end{array}$ \\
\hline Beets, Garden : : 3,19 & Oats $: \div 0$ & Lantana .... \\
\hline $\begin{array}{l}\text { "Sugar } \\
\text { ". Mangel Wurzels : } .20 \\
20\end{array}$ & $\begin{array}{l}\text { Osage Orange } \\
\text { Peas, Cow and Field: }: .59\end{array}$ & $\begin{array}{l}\text { Larkspur } \cdots 78 \\
\text { Lathyrus }\end{array}$ \\
\hline Borecole. See Kale . 30 & Rape, Dwarf Essex. . . 62 & Lobelias $\quad . \quad .78$ \\
\hline $\begin{array}{l}\text { Broccoli } \\
\text { Brussels sprouts } \ldots .25\end{array}$ & $\begin{array}{l}\text { Speltz or Emmer. } \\
\text { Spring Rye. }\end{array}$ & $\begin{array}{l}\text { Lychnis } \\
\text { Marigolds }\end{array}$ \\
\hline Sabbage, $\quad 4,5,21,22,23,24$ & Spring Wheat . . . & Marvel of Peru \\
\hline Carrots & Sugar Cane..... & Mesembryanthemum \\
\hline $\begin{array}{l}\text { Cauliflower, }, \cdots, 7,27,25 \\
\text { Celery }\end{array}$ & Sunflower .... & Mignonette..... \\
\hline 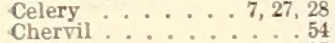 & $\begin{array}{l}\text { Teosinte }: \cdots \\
\text { Tobacco }\end{array}$ & 68.79 \\
\hline 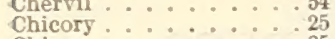 & Vetehes. : : : & $\begin{array}{l}\text { ntlowers : . } \\
\text { lordicas : }\end{array}$ \\
\hline Chives . . . . 25 & Wild Rice . . . . . 6 & Morning Glories : \\
\hline $\begin{array}{l}\text { Collards } \\
\text { Corn Salad }: \cdots\end{array}$ & & Myosotis ..... \\
\hline Corn Salad . . . 6,28 & Flower Seeds. & $\begin{array}{l}\text { Nasturtiums } \cdots 67 \text { to } 70 \\
\text { Novelties } \therefore 60\end{array}$ \\
\hline 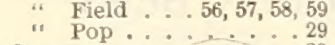 & Abronia & $\begin{array}{l}\text { Ornamental Gourds } \\
\text { Ornamental Grasses }\end{array} \quad 77,78$ \\
\hline Cress $: \therefore \ldots 29$ & Abutilon .... & Pansies....... \\
\hline Cucumber. . & $\begin{array}{l}\text { Acroclinum. . : } \\
\text { Adlumia }\end{array}$ & Petunias : \\
\hline $\begin{array}{l}\text { Dandelion } \\
\text { Egg-Plant }\end{array}$ & $\begin{array}{l}\text { Adlumia . . } \\
\text { Ageratum : }\end{array}$ & Phloxes. \\
\hline $\begin{array}{l}\text { Egg-Plant : } \\
\text { Endive. . }\end{array}$ & Alyssum .... & $\begin{array}{l}\cdot 68,76 \\
81\end{array}$ \\
\hline Garlic ....... 3 & $\begin{array}{l}\text { Amaranthus . } \\
\text { Ampelopsis... }\end{array}$ & Portulaca : : : 82 \\
\hline $\begin{array}{l}\text { Gourds } \ldots .80,77 \\
\text { Herbs }\end{array}$ & Antirrhinum : & $\begin{array}{l}\text { Primula } \\
\text { Pyrethrum }\end{array}$ \\
\hline Horse Radish : & $\begin{array}{l}\text { Aquilegia. } \\
\text { Arctotis Grandis : }\end{array}$ & Ricinus \\
\hline $\begin{array}{l}\text { Kale or Borecole. } \\
\text { Kohl-Rabi . . . }\end{array}$ & Asparagus Fern & Salpiglossis . \\
\hline Leek . . . : & $\begin{array}{l}\text { Asters } \\
\text { Balloon Vine : }\end{array}$ & Sensitive Plant: \\
\hline $\begin{array}{l}\text { Lettuce : sweet: } \\
\text { Marjoram, }\end{array}$ & Balsams & $\begin{array}{l}\text { Smilax .... } \\
\text { Stocks }\end{array}$ \\
\hline Martynia & $\begin{array}{l}\text { Balsam Appleand Pear } \\
\text { Begonia }\end{array}$ & Stokesia Cyanes \\
\hline Melons, $\underset{\text { Wusk }}{\text { Water }} \cdot 8,35,36,37$ & Bellis. See Daisy & $\begin{array}{l}\text { Sunflowers ... } \\
\text { Sweet Peas }\end{array}$ \\
\hline Jushropms & $\begin{array}{l}\text { Calceolaria } \\
\text { Calendula }\end{array}$ & Sweet William \\
\hline ustard & $\begin{array}{l}\text { Calendula }: \text { : } \\
\text { Campanula }\end{array}$ & Thunbergia . \\
\hline $\begin{array}{l}\text { Nasturtium } \\
\text { Okra or Gombo : : }\end{array}$ & Canary-Bird Flower & $\begin{array}{l}\text { Tropæolum } \\
\text { Verbenas. }\end{array}$ \\
\hline Onion, Pedigree Seed $: 9$, & $\begin{array}{l}\text { Candytuft. . } \\
\text { Cannas. . }\end{array}$ & Violet : : \\
\hline " American, 38, 39, 40,41 & Carnations & Wallflower \\
\hline 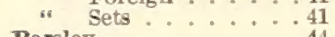 & Castor-Oil Plant. & $\begin{array}{l}\text { Wild Flower Garden } \\
\text { Zinnias........... }\end{array}$ \\
\hline & & \\
\hline
\end{tabular}

\section{Miscellaneous-Con.}

Grapes . Hot Bed Mats and cloth, 92 Incubators ...... 10 Insecticides . . . . 990 Mastica. . . . . . 103 Nut Trees Paper, Celery and Wax 99 Poultry Foods ... 114 to 117 Poultry Supplies (General)

Small Fruits $\quad 107,120$ Twine, Raphia, ete. $\cdots 9$

\section{Implements}

Asparagus Buncher ... 96 Baskets Implements. 121 to 101 Bee Implements ... 121 to 123 $\underset{\text { Brooders }}{\text { Bone Cutters . . 9 96, } 110}$ Churns

Cider Mills

Corn Planters

Corn Shellers

Cortivators, 99, 100, 3 d cover Cutters . 96, 101, 103, 107, 110 Dairy Supplies . . . 94, 95 Dibbles ... 100, 3 d cover Drinking Fountains ....112 Drinking Fountains . . 112 Feed Cookers … Feed Cookers ..... 97 Flower Pots $\because \therefore \because 997$ Forks . . . . . 997

Fumigators .... . 98

Glazing Points : : 92,98

Grass Catchers : . 102

Grindstones $\because \cdots 98$

Grinding Mills $\ldots$

Harrows . . . 99, 100

Hoes . 99, 100, 101, 3d cover

Horse Hoes, 99, 100, 3d cover Horse Radish Graters . . 101 Hose ....... 101 Iron Age Toois $\ldots \ldots 100$ Jardineres . . . . 101 Knives . . 95,98, 101 Labels $\cdots .92$ Lawn Mowers $\therefore \therefore 102$ Mole Traps $\cdots \because 105$ Planet Jr. Tools, 99, 3d cover Plant Stands . 103 Plows ... 103, 3d cover Presses

Centaurea......7

Chrysanthemums $\ldots 67,74$

Cineraria

Clarkia

Clematis

Cobrea Scandens

Cockscomb

Coreopsis :

Cosmos

Crotolaria

Cuphea

Cyclamen.

Cypress Vine

Dahlias

Daisy

Datura Delphinium

Dianthus

Digitalis

Dolichos

Eschscholtzis

$\begin{aligned} & \text { Eschscholtzia } \\ & \text { Everlasting Flowers }\end{aligned} \cdots: 77$

Forget-me-nots . . . 79

Forget-me-nots ' See Mar-
Four-O'Clocks. vel of Peru

\section{Plants.}

Cornflower

Roones

Stokesia Cyanea

Strawberries

\section{Bulbs.}

Begonias, Tuberous Rooted 85 Caladiums Caladiums $\cdots . .85$
Cannas Cannas

Gladioli.

Gloxinias

Iris

Oxalis.

Tritoma Pfitzerii ... . 70

Tuberoses. . . . . . 85

\section{Miscellaneous.}

Bee Supplies . . 121 to 123 Books. $: \because \ldots 108$ Dairy Supplies : $: \ldots 94,95$ Disinfectants . . . . . .99 Fencing $\ldots \ldots \ldots 113$ Fruit Trees .....
Pumps

Putty Buib * . $\quad \begin{array}{r}90 \\ 92,103\end{array}$

Rakes . . . . 103

Reels and Lines . . . . 98

Rollers Hot Bed … 101 Scissors and Shears 104,105 Scythes . . 104 Seed Sowers . . . . 104 Seed Tryers . . . 103
Shovels Sieves ...... 105 Sprinklers .... 92, 105 Sprayers ...... 90 Stakes ...... 105 Trellis $: 105$ Thermometers, 92, 95, 106, 111
Torch, Asbestos

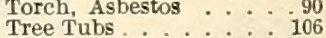
Traps . . . . 106 Water Pots 106 Weeders .....97, 106 Wheelbarrows 106 Wheel Hoes . 100, 3 d cover Wine and Berry Presses, 103 POULTRY SUPPLIES in
great assortment in specisl catalogue. Syringes ...... 105 Water Barrel and Truck, 106

Geranium

Godetia.
Australian Salt Bush Barley 


\section{Planet Jr. Farm and Garden Tools}

PLANET JR. No. 3 Hill and Drill Seeder

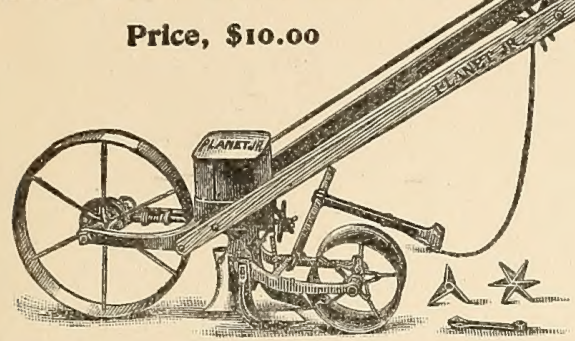

Planting in rows and thinning afterwards is a terrible time-waste. The No. 3 Seeder puts the seed right on ble time-waste. the hill is wanted. Plants 4, 6, 8, 12 or 24 the spot where the hintinuous row as desired. Changed inches apart, or in a continuous row as desired. Chate drill in a moment. Holds 3 quarts. Th

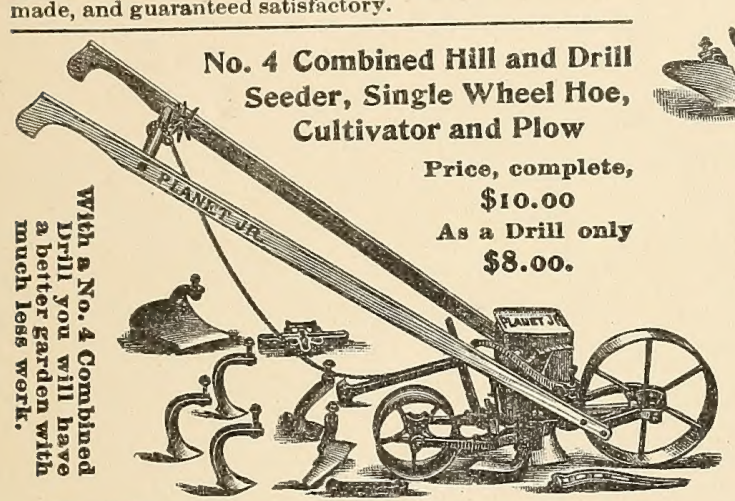

The Drill is the same as the No. 3 Seeder but gmaller. By moving only one bolt the drill is taken off and the tool frame attached, making it one of the best of the Planet Jr. Single Wheel Hoes. This gives you the "whole business" in one tool.

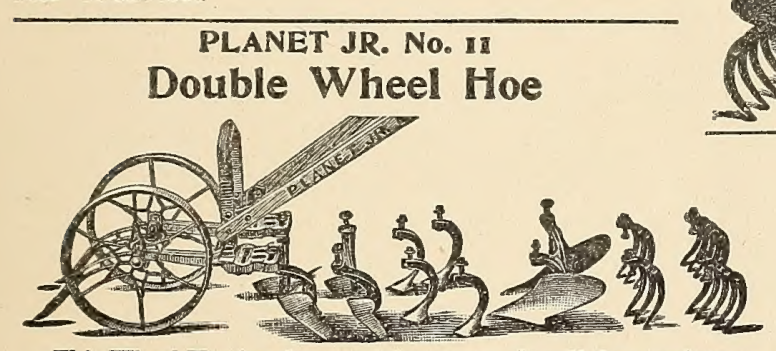

This Wheel Hoe is a famous labor-saver. It will do a varlety of work that is almost incredible, and it is changed and adjusted with marvelous ease and quickness. The wheels can be set to four different width and the frume at three heights. The tools are changed without removing a siligle nut. Nolhing like it for are changed without removing a siligle
onion growerg.

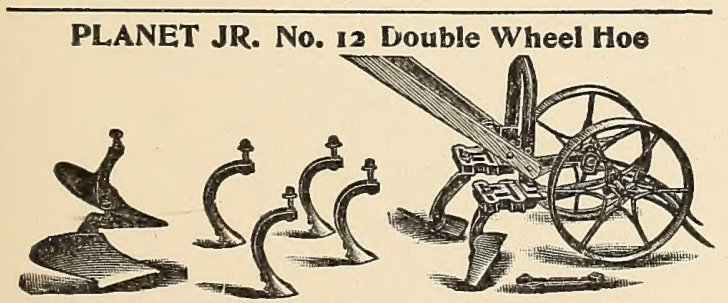

This tool is fdentical with No. 11 Wheel Hoe, except that it has fewer attachments, and is sold at a correspondingly les price. The tools shown and sold with No.12 are what gardeners use most, and the others can he added as wanted. Price, \$6.50.

PLANET JR. No. I3 Double Wheel Hoe Same as No. 12, but with 6-inch hoes only. Price, \$4.50.
PLANET JR. No. 25

Combined Hill and Drill Seeder and

Double Wheel Hoe. Price, \$13.50

This new combined machine is intended for a class of gardeners who have a large enough acreage in crops for a Double Wheel Hoe to be used to good advantage, and yet. prefer not to buy a separate Wheel Hoe. It holds $2 \frac{1}{2}$ quarts (or about 5 lbs. of onion seed).

A g Drilt it is almost identical with the Planet $\mathrm{Jx}$. No. 4 Drill; will sow in drills or hills, $4,6,8,12$ or 24

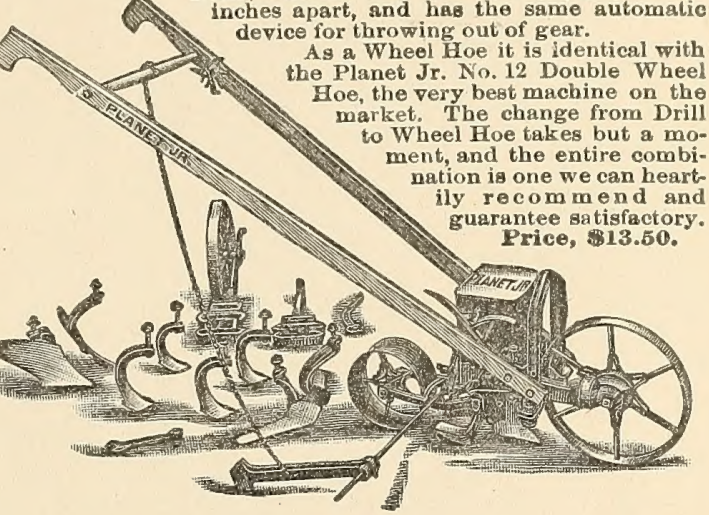

PLANET JR. No: 16 Single Wheel Hoe

A light inexpensive and extremely efficient tool. Frame and handes are adjustable, snd wheels can bo changed to the other side of the frame, when both side of the row can be hoed at one passage.

Prioo, 85.50.

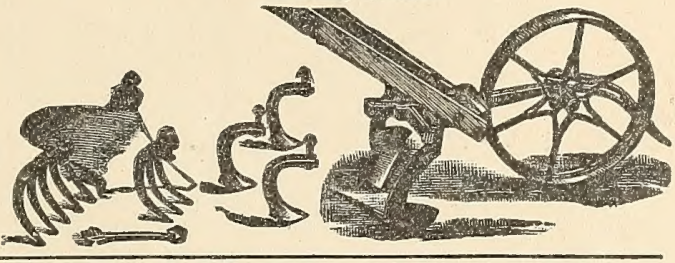

PLANET JR. No.17

\section{Single Wheel Hoe}

This tool is identical with No. 16, but has only a pair of 6-inch hoes, a plow, and a get of cultivator teeth-an outfit sufficient for most garden work. The other attachments can be added at any time.
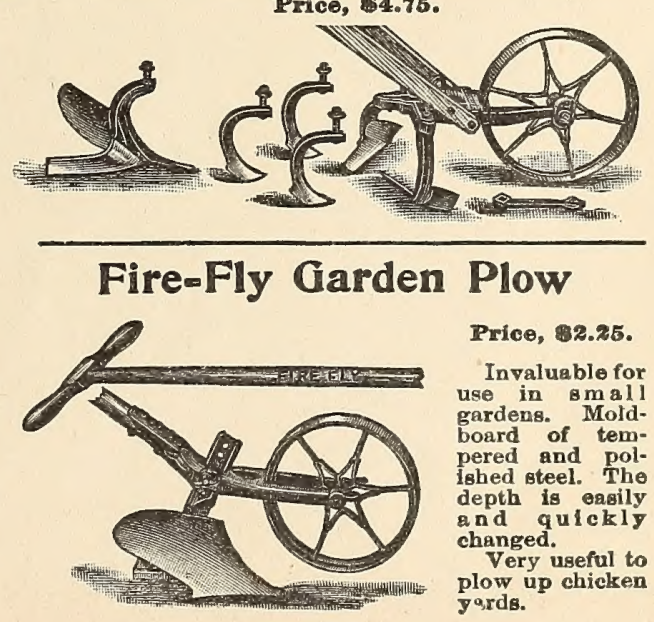


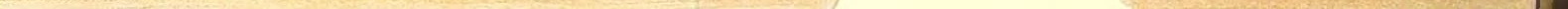

